МIНICTЕРСТВО ОСВІТИ I НАУКИ УКРАЇНИ

КИЇВСЬКИЙ НАЦІОНАЛЬНИЙ УНІВЕРСИТЕТУ

ТЕХНОЛОГІЙ ТА ДИЗАЙНУ

МІЖНАРОДНЕ ЕЛЕКТРОХІМІЧНЕ ТОВАРИСТВО

НАЦІОНАЛЬНИЙ ТЕХНІЧНИЙ УНІВЕРСИТЕТ УКРАЇНИ «КИЇВСЬКИЙ

ПОЛІТЕХНІЧНИЙ ІНСТИТУТ ІМЕНІ ІГОРЯ СІКОРСЬКОГО»

\title{
ПЕРСПЕКТИВНІ МАТЕРІАЛИ ТА ПРОЦЕСИ В ПРИКЛАДНІЙ ЕЛЕКТРОХІМІЇ - 2018
}

Монографрія

Рекомендовано Вченою радою Київського національного університету технологій та дизайну

Київ 2018 
Колектив укладачів:

В. 3. Барсуков - д-р хім. наук, проф., зав. кафедри КНУТД; член МЕТ;

Ю. В. Борисенко - канд. техн. наук, доцент КНУТД;

В. Г. Хоменко - канд. техн. наук, докторант КНУТД;

О. В. Лінючева - д-р техн. наук, проф. зав. кафредри НТУУ «КПІ ім. Ігоря Сікорського», член МЕT.

\section{Рецензенти:}

Є. В. Кузьмінський - д-р хім. наук, проф., завідувач кафредри Національного технічного університета України «Київський політехнічний інститут імені Ігоря Сікорського»;

В. П. Плаван - д-р техн. наук, профр., завідувач кафредри Київського національного університету технологій та дизайну.

Рекомендовано Вченою радою Київського національного університету технологій та дизайну для широкого кола викладачів, науковців, аспірантів, магістрів та студентів профрільних вищих навчальних закладів, інженерно-технічних працівників електрохімічних виробництв

(Протокол № 4 від 28.11.2018)

П 26 Перспективні матеріали та процеси в прикладній електрохімії - 2018: монографрія / В. З. Барсуков, Ю.В.Борисенко, В. Г. Хоменко, О.В.Лінючева; за заг. ред. В. 3. Барсукова. - Київ: КНУТД, 2018. - 290 с.

ISBN 978-617-7506-24-8

Розглянуті перспективні процеси та матеріали в таких пріоритетних напрямках прикладної електрохімії, як електрохімічні джерела струму, гальванотехніка, захист від корозії, електрохімічні сенсори, сучасні електрохімічні та споріднені технології. Стан досліджень в цих пріоритетних напрямах електрохімії в значній мірі визначає прогрес у загальному розвитку науки і техніки XXI століття та сприяє створенню принципово нових видів продукції та технологій. Монографія рекомендована для науковців, викладачів, аспірантів, студентів профрільних ВН3, інженерно-технічних працівників електрохімічних виробництв.

(C) В. З. Барсуков, Ю. В.Борисенко, В. Г. Хоменко, О. В. Лінючева, 2018 (C) КНУТД, 2018 
MINISTRY OF EDUCATION AND SCIENCE OF UKRAINE KYIV NATIONAL UNIVERSITY OF TECHNOLOGIES AND DESIGN

INTERNATIONAL SOCIETY OF ELECTROCHEMISTRY

IGOR SIKORSKY KYIV POLYTECHNIC INSTITUTE

\section{PROMISING MATERIALS \\ AND PROCESSES IN \\ APPLIED ELECTROCHEMISTRY - 2018}

Monograph

The monograph was recommended for publication by the Scientific Council of

Kyiv National University of Technologies and Design

Kyiv 2018 
Editor's Board:

V. Z. Barsukov - Prof.Dr., head of department for KNUTD, ISE member;

Yu. V. Borysenko - PhD, senior lecturer for KNUTD;

V. G. Khomenko - PhD, Postdoc for KNUTD;

O. V. Linyucheva - Prof.Dr., head of department for Igor Sikorsky Kyiv Polytechnic Institute, ISE member.

Reviewers:

Ye. V. Kuzminskiy - Prof.Dr., head of department for Igor Sikorsky Kyiv Polytechnic Institute;

V. P. Plavan - Prof. Dr., head of department for Kyiv National University of Technologies and Design.

Monograph has been recommended by the Scientific Council of Kyiv National University of Technologies and Design (KNUTD) for the wide range of lectors, scientists, PhD students, holders of a master's degree and students of Universities, engineers and technicians of various electrochemical enterprises

(Protocol No 4 of 28.11.2018)

P 26 Promising Materials and Processes in Applied Electrochemistry 2018: Monograph / V. Z. Barsukov, Yu. V. Borysenko, V. G. Khomenko, O. V. Linyucheva; editor-in-chief V.Z. Barsukov. - Kyiv: KNUTD, 2018. 290 pages.

ISBN 978-617-7506-24-8

The promising processes and materials have been considered in such key directions of applied electrochemistry as electrochemical power sources, electroplating, corrosion protection, electrochemical sensors, modern electrochemical and related technologies during the last years. A state of art in these key directions of electrochemistry determines a progress in general development of science and engineering of XXI century and promotes to creation of essentially new types of production and technologies. Monograph has been recommended for scientists, lectors, PhD students, engineers and technicians.

UDC 621.35

ISBN 978-617-7506-24-8

(C) V. Z. Barsukov, Yu. V. Borysenko,

V. G. Khomenko, O. V. Linyucheva, 2018

(C) KNUTD, 2018 


\section{CONTENT}

\section{INTRODUCTION - 9}

\section{COLLECTIVE MONOGRAPH AUTHORS - 11}

\section{ELECTROCHEMICAL POWER SOURCES - 13}

1.1 Behavior of Non-Graphitic Carbon Electrodes of LithiumIon Batteries in Electrolytes based on Ionic Liquids

Khomenko V. G. - 14

1.2 Optimization of electrode structure for symmetric supercapacitors with high specific energy intensity Izotov V., Gogotsi O., Havrykov D., Chufarov M., Zozulya Yu., Linyucheva O., Zahorodna V. - 22

1.3 Conductivity and electrochemical stability of non-aqueous electrolytes for magnesium power sources Kirsanova I. V., Polishchuk Yu. V., Shembel E M., Lysytsya I. S., Savchenko A. S. - 34

1.4 Estimation of the Primary Batteries State of Charge and State of Art by Frequency Characteristics of Electrochemical Impedance Spectra Riabokin O.L., Bojchuk O.V., Pershina K.D. - 48

1.5 Influence of amorphous carbon on the electrochemical characteristics of battery graphite Suslov M. M., Muhin V. V. - 56

1.6 Toward bifunctional doped $\mathrm{MnO}_{2}$ oxygen electrocatalyst Sokolsky G., Zudina L., Boldyrev E., Gauk N., Ivanov S. - 64

\section{ELECTRODEPOSITION - 71}

2.1 Electrode materials in the oxidation of rhodanide Kosohin O., Kushmyruk A., Linyucheva O. - 72

2.2 Justification of the choice of electrode material for the electrochemical synthesis of peroxyacetic acid Bilous T.A., Tulsky G.G., Tulskaya A.G., Muratova H.M. - 79 
2.3 Electrodeposition of $\mathrm{Cr}$ coatings from a trivalent chromium plating bath based on deep eutectic solvent Bobrova L.S., Protsenko V.S. - 86

2.4 Electrochemical coating based on tin-nickel alloy with antibacterial properties

Pyanko A.V., Chernik A.A., Alisienok O.A., Sergievich D.S. - 102

2.5 Electrodeposition and characterization of $\mathrm{Ni}^{-\mathrm{TiO}_{2}}$ composite coatings

Zaverach Ie.M., Yermak N.V. - 113

\section{CORROSION PROTECTION - 123}

3.1 4-Hydroxy-3,5-dimethoxybenzaldehyde as "green" corrosion inhibitor for copper: Experimental and theoretical approaches

Vorobyova V.I., Skiba M.I., Zhuk T.S. - 124

3.2 Carbon Steel (St.3) Corrosion Caused by the Circulating Water Flow

Pilipenko A., Pancheva H., Khrystych O., Smirnova O. - 143

3.3 Investigation of corrosion process in the alloy AA6060 containing anodic-oxide coatings of vanadium

Keshin A.V., Matsius M.Y., Chernik A.A. - 151

3.4 Stress-corrosion cracking of gas pipelines:

the reasons of appearance and factors

Nyrkova L.I., Prokopchuk S. N., Lisovoy P.E. - 156

3.5 Rape grist extract (Brassica napus) as a green corrosion inhibitor of mild steel in hot tap water Vasyliev G., Vorobiova V. - 163

3.6 Marking of titanium passive film breakdowns as a function of their appearance time and to increase the contrast of SEM images

Buket O.I., Chernysh D.M., Leonova O.I. - 185

3.7 Adsorption model of organic compounds on metals, based on complex formation conception with charge transfer, and its application for corrosion inhibitors selection Pogrebova I.S. - 195 
3.8 Chemical and potentiostatic formation of conversion molybadatic coatings on mild steel's surface

Frolenkova S.V., Motronyuk T.I., Overchenko T.A., Ushchapovskiy D.Yu., Nahorniy A. - 215

\section{ELECTROCHEMICAL SENSORS - 222}

4.1 Influence of corrosion on percolation of current and mechanical integrity of anodes in oxygen sensors Buket O.I., Vashchenko O.M. - 223

\section{MODERN ELECTROCHEMICAL AND RELATED TECHNOLOGIES - 228}

5.1 Inversion of metal oxide composites structural matrixes Sakhnenko N.D., Ved' M.V., Karakurkchi A.V., Mayba M.V. - 229

5.2 Features of properties of PVC compositions filled by graphite

Shariko Ye., Novak D., Plavan V., Bereznenko N. - 237

5.3 Recent developments and perspectives of development of microbial fuel cells in Ukraine

Shchurska K. O., Zubchenko L. S., Galkin O. Yu., Kuzminskiy Ye. V. - 242

5.4 Diffused multi-layer coatings with titanium, chrome, aluminium, carbon, nitrogen on $\mathrm{Y8A}$ steel Khyzhnyak V. G. , Loskutova T.V., Kalashnikov T.Y., Arshuk M.V., Pogrebova I.S. - 248

5.5 The structure of functional coatings of tin-lead alloy on foil glass fiber deposited from the melt

Ushchapovskiy D.Yu., Linyucheva O.V., Motronyuk T.I., Pidvashetsky G.Yu., Zabaluev A.S., Aksonova O.V. - 265

5.6 Electrochemical reduction of benzaldehyde at platinum single crystal surfaces

Bolielyi O. S. - 273

5.7 Thermally synthesized Mn2O3, Mn3O4 oxides for anodes of Mg-battery with Mg-perchlorate electrolyte based on dimethylformamid Apostolova R.D., Savchenko A.S. - 281 


\section{MICT}

ВСТУП - 10

АВТОРИ КОЛЕКТИВНОЇ МОНОГРАФЇ̈ - 11

\section{Розділ 1. ЕЛЕКТРОХІМІЧНІ ДЖЕРЕЛА СТРУМУ - 13}

1.1 Поведінка вуглецевих неграфітових електродів літійіонних акумуляторів в електролітах на основі іонних рідин Хоменко В.Г. -14

1.2 Оптимізація структури електродів симетричних суперконденсаторів 3 високою питомою енергосмністю Ізотов В., Гогоци А., Гавриков Д.,, Чуфаров М., Лінючева О., Зозуля Ю., Загородна В. - 22

1.3 Провідність та електрохімічна стабільність неводних електролітів для магнієвих джерел струму Кірсанова І. В., Поліщук Ю. В., Шембель Е. М., Лисиця І. С., Савченко А. С. - 34

1.4 Встановлення ступеню заряду та стану первинних джерел струму з використанням частотних характеристик спектрів електрохімічного імпедансу Рябокінь О.Л., Бойчук О.В., Першина К.Д. - 48

1.5 Вплив аморфного вуглецю на електрохімічні характеристики акумуляторного графіту Суслов М.М., Мухін В.В. - 56

1.6 Біфункціональний допований діоксид мангану як каталізатор електровідновлення кисню Сокольський Г., Зудіна Л., Болдирєв Е., Гаюк Н., Іванов С. - 64

\section{Розділ 2. ГАЛЬВАНОТЕХНІКА - 71}

2.1 Електродні матеріали для окислення роданіду Косогін О., Кушмирук А., Лінючева О. - 72

2.2 Обгрунтування вибору електродного матеріалу для електрохімічного синтезу пероксиоцтової кислоти Білоус Т. А., Тульський Г. Г., Тульська А. Г., Муратова О. М. - 79 
2.3 Електроосадження $\mathrm{Cr}$ покриттів із електроліту хромування на основі низькотемпературного евтектичного розчинника, що містить сполуки тривалентного хрому Боброва Л.С., Проценко В.С. - 86

2.4 Електрохімічне покриття на основі сплаву олово-нікель 3 антибактеріальними властивостями

Пянко А.В., Черник О.О., Алісіенок О.А., Сергієвич Д.С. - 102

2.5 Електроосадження та визначення властивостей Ni-TiO2 композиційних покриттів Заверач Є.М., Срмак Н.В. - 113

\section{Розділ З. ЗАХИСТ МЕТАЛІВ ВІД КОРОЗЇ̈ - 123}

3.1 4-гідрокси-3,5-диметоксибензальдегід як "зелений" інгібітор корозії для міді: експериментальні та теоретичні підходи

Воробйова В.І., Скиба М.І., Жук Т.С. - 124

3.2 Корозія вуглецевої сталі у потоці оборотної води Пилипенко О.І., Панчева Г.М., Христич О.В., Смірнова О.Л. - 143

3.3 Дослідження протікання корозії анодно-оксидних покриттів на сплаві АА6060, що містять ванадій Кешин А.В., Мацюсь М.Ю., Черник О.О. - 151

3.4 Стрес-корозійне розтріскування магістральних газопроводів: причини виникнення та фактори Ниркова Л.І., Прокопчук С.М., Лісовий П.Е. - 156

3.5 Екстракт шроту ріпаку (Brassica napus) як «зелений» інгібітор корозії сталі в гарячій воді Васильєв Г.С., Воробйова В.І. - 163

3.6 Маркування пробоїв пасивної плівки титану в залежності від часу їх появи з метою підвищення контрасту СЕМзнімків

Букет О.І., Черниш Д.М., Леонова О.I. - 185

3.7 Модель адсорбції органічних сполук на металах, що основана на концепції утворення комплексів 3 переносом заряду, та її використання при підборі інгібіторів корозії Погребова І.С. - 195 
3.8 Хімічне та потенціостатичне формування конверсійних молібдатних покриттів на маловуглецевій сталі Фроленкова С.В., Мотронюк Т.І., Оверченко Т.А., Ущаповський Д.Ю., Нагорний А. - 215

\section{Розділ 4. ЕЛЕКТРОХІМІЧНІ СЕНСОРИ - 222}

4.1 В Вллив корозії на перколяцію струму і механічну цілісність анодів сенсорів кисню

Букет O.I., Ващенко О.М. - 223

\section{РоздіЛ 5. СУЧАСНІ ЕЛЕКТРОХІМІЧНІ ТА СПОРІДНЕНІ ТЕХНОЛОГЇ̈ - 228}

5.1 Інверсія структурних матриць металоксидних композитів Сахненко М.Д., Ведь М.В., Каракуркчі Г.В., Майба М.В. - 229

5.2 Особливості властивостей ПВХ композиції, наповненої графітом

Шарико Є.М., Новак Д.С., Плаван В.П., Березненко Н.М. -271

5.3 Сучасні розробки та перспективи розвитку мікробних паливних елементів в Україні

Щурська К.О., Зубченко Л.С., Галкін О.Ю., Кузьмінський Є.В. - 242

5.4 Дифузійні багатошарові покриття за участю титану, хрому, алюмінію, вуглецю, азоту на сталі У8А Хижняк В.Г., Лоскутова Т.В., Калашніков Г.Ю., Аршук М.В., Погребова I.С. - 248

5.5 Структура функціональних покриттів зі сплаву оловосвинець на фольгованому склотекстоліті, нанесених із розплаву

Ущаповський Д.Ю., Лінючева О.В., Мотронюк Т.I., Підвашецький Г.Ю., Забалуєв А.С., Аксьонова О.В. - 265

5.6 Електровідновлення бензальдегіду на поверхні монокристала платини Болелий О. С. - 273

5.7 Термічно синтезовані оксиди Mn203, Mn3O4 для анодів Mg-батареї з Mg-перхлоратним електролітом на основі диметилформаміду Апостолова Р.Д., Савченко А.С. - 281 


\section{INTRODUCTION}

In May 2016, on the eve of Science Day in Ukraine, a remarkable tradition was established in the framework of cooperation with International Society of Electrochemistry (ISE). Under the auspices and sponsorship of this Society the ISE Satellite Student Regional Symposium on Electrochemistry - $1^{\text {st }}$ ISE Regional Student Meeting in Ukraine was organized. In May 2017 and April 2018 this excellent tradition was further developed: $2^{\text {nd }}$ and $3^{\text {rd }}$ ISE Regional Student Meetings in Ukraine "Promising Materials and Processes in Applied Electrochemistry" were organized.

An important feature of the 3rd Regional Student Meetings in Ukraine "Promising Materials and Processes in Applied Electrochemistry" is that some material science presentations will be published in the Journal "Materials Today. Proceedings" in 2019. Papers, which have mainly pure scientific or technological nature, are published in this collective monograph.

Such increasing creative activity of young Ukrainian electrochemists has stimulated the preparation of this collective monograph, which considers some modern problems and promising ways of solving them in the following key directions of applied electrochemistry: Electrochemical power sources (part 1), Electroplating (part 2), Corrosion protection (part 3), Electrochemical sensors (part 4), Modern electrochemical and related technologies (part 5).

The monograph could be useful for a wide range of lecturers, scientists, PhD students, holders of a master's degree and students of universities, engineers and technicians of various electrochemical enterprises.

Prof.Dr. V. Barsukov. 


\section{ВСТУП}

У травні 2016 року, напередодні Дня науки в Україні, в рамках співпраці з Міжнародним електрохімічним товариством (MET) була заснована чудова традиція. Під егідою та спонсорством цього товариства був організований Перший Регіональний Сателітний студентський симпозіум MET з електрохімії в Україні.

У травні 2017 р. та в квітні 2018 р. ця чудова традиція була продовжена організацією 2-го та 3-го Регіональних Сателітних студентських симпозіумів MET з електрохімії в Україні "Перспективні матеріали та процеси в прикладній електрохімії". Вагомою особливостю 3-го Симпозіума є те, що частина доповідей матеріалознавчого характеру буде опублікована в журналі "Materials Today. Proceedings" в 2019 році. Матеріали суто наукового і технологічного характеру публікуються в даній колективній монографії.

Така зростаюча творча активність молодих українських електрохіміків стимулювала підготовку цієї колективної монографрії, в якій розглядаються деякі сучасні проблеми та перспективні шляхи їх вирішення за наступними ключовими напрямками прикладної електрохімії: електрохімічні джерела струму (частина 1), гальванотехніка (частина 2), захист металів від корозії (частина 3), електрохімічні сенсори (частина 4), сучасні електрохімічні та споріднені технології (частина 5).

Монографрія може бути корисною для широкого кола лекторів, науковців, аспірантів, магістрів та студентів університетів, інженерів та техніків різних електрохімічних виробництв.

Д-р хімічних наук, профр. Барсуков В.З. 


\section{AUTHORS COLLECTIVE MONOGRAPH АВТОРИ КОЛЕКТИВНОЇ МОНОГРАФІЇ}

\section{Surname}

Aksonova O.V.

Alisienok O.A.

Apostolova R.D.

Arshuk M.V.

Barsukov V.Z.

Bereznenko N.

Bilous T.A.

Bobrova L.S.

Bojchuk O.V.

Boldyrev E.

Bolielyi O. S.

Borysenko Yu.V.

Buket O.I.

Chernik A.A.

Chernysh D.M.

Chufarov M.

Frolenkova S.V.

Galkin O. Yu.

Gauk N.

Gogotsi O.

Havrykov D.

Ivanov S.

Izotov V.

Kalashnikov T.Y.

Karakurkchi A.V.

Keshin A.V.

Khomenko V. G.

Khrystych O.

Khyzhnyak V. G.

Kirsanova I. V.

Kosohin O.

Kushmyruk A.

Kuzminskiy Ye. V.

Leonova O.I.

Linyucheva O.V.

Lisovoy P.E.

Loskutova T.V.

Lysytsya I. S.

Matsius M.Y.

Mayba M.V.

Motronyuk T.I.
Прізвище

Аксьонова О.В.

Алісіенок О.А.

Апостолова Р.Д.

Аршук М.В.

Барсуков В.3.

Березненко Н.M.

Білоус Т. А.

Боброва Л.С.

Бойчук О.В.

Болдирєв Е.

Болелий О. С.

Борисенко Ю.В.

Букет O.I.

Черник O.O.

Черниш Д.М.

Чуфаров М.

Фроленкова С.В.

Галкін О.Ю.

Гаюк Н.

Гогоци А.

Гавриков Д.

Іванов C.

Ізотов B.

Калашніков Г. Ю. $\quad \mathbf{5 . 4}$

Каракуркчі Г.В.

Кешин А.B.

Хоменко В.Г.

Христич О.В.

Хижняк В. Г.

Кірсанова I. В.

Косогін О.

Кузьмінський Є.В. $\quad 5.3$

Кушмирук А.

Леонова O.I.

Лінючева О.В.

Лісовий П.Е.

1.2; 2.1; 5.5; укладач

Лоскутова Т. В.

Лисиця I. C.

Мацюсь М.Ю.

Майба М.В.

Мотронюк T.I.
2.1

3.6

3.4

5.4

1.3

№ статті

5.5

2.4

5.7

5.4

укладач

2.2

2.3

1.4

1.6

5.6

укладач

3.6; 4.1

2.4; 3.3

3.6

1.2

3.8

5.3

1.6

1.2

1.2

1.6

1.2

5.1

3.3

1.1; укладач

3.2

5.4

1.3

2.1

3

3.3

5.1

3.8; 5.5 
Surname

Muhin V. V.

Muratova H.M.

Nahorniy A.

Novak D.

Nyrkova L.I.

Overchenko T.A.

Pancheva H.

Pershina K.D.

Pilipenko A.

Pidvashetsky G.Yu.

Plavan V.

Pogrebova I.S.

Polishchuk Yu. V.

Prokopchuk S. N.

Protsenko V.S.

Pyanko A.V.

Riabokin O.L.

Sakhnenko N.D.

Savchenko A. S.

Sergievich D.S.

Shariko Ye.

Shchurska K. O.

Shembel E M.

Skiba M.I.

Smirnova O.

Sokolsky G.

Suslov M. M.

Tulskaya A.G.

Tulsky G.G.

Ushchapovskiy D.Yu.

Vashchenko O.M.

Vasyliev G.

Ved'M.V.

Vorobyova V.I.

Yermak N.V.

Zabaluev A.S.

Zahorodna V.

Zaverach Ie.M.

Zhuk T.S.

Zozulya Yu.

Zubchenko L. S.

Zudina L.
Прізвище

Мухін B.B.

№ статті

Муратова О. М.

1.5

Нагорний А.

2.2

Новак Д.С.

3.8

Ниркова Л.І.

5.2

Оверченко Т.А., $\quad \mathbf{3 . 8}$

Панчева Г.М. $\quad 3.2$

Першина К.Д. $\quad \mathbf{1 . 4}$

Пилипенко O.I. $\quad \mathbf{3 . 2}$

Підвашецький Г.Ю. $\mathbf{5 . 5}$

Плаван В.П.

5.2

Погребова I.C.

$3.7 ; 5.4$

Поліщук Ю. В.

1.3

Прокопчук С.M. $\quad \mathbf{3 . 4}$

Проценко В.С. $\quad \mathbf{2 . 3}$

Пянко А.В. $\quad \mathbf{2 . 4}$

Рябокінь О.Л. $\quad \mathbf{1 . 4}$

Сахненко М.Д. $\quad \mathbf{5 . 1}$

Савченко А. С. $\quad \mathbf{1 . 3}$

Сергієвич Д.С. $\quad \mathbf{2 . 4}$

Шарико Є.М. $\quad \mathbf{5 . 2}$

Щурська К.О. $\quad \mathbf{5 . 3}$

Шембель О. М. $\quad 1.3$

Скиба M.I. $\quad 3.1$

Смірнова О.Л. $\quad \mathbf{3 . 2}$

Сокольський $Г$. $\quad \mathbf{1 . 6}$

Суслов М.М. $\quad \mathbf{1 . 5}$

Тульська А. Г. $\quad \mathbf{2 . 2}$

Тульський Г. Г. $\quad \mathbf{2 . 2}$

Ущаповський Д.Ю. $\quad \mathbf{3 . 8 ; 5 . 5}$

Ващенко О.М. $\quad \mathbf{4 . 1}$

Васильєв Г.С. $\quad 3.5$

Ведь М.В. $\quad \mathbf{5 . 1}$

Воробйова В.І. $\quad \mathbf{3 . 1} ; 3.5$

Срмак Н.В. $\quad \mathbf{2 . 5}$

Забалуєв А.С. $\quad \mathbf{5 . 5}$

Загородна В. $\quad \mathbf{1 . 2}$

Заверач C.M. $\quad \mathbf{2 . 5}$

Жук Т.С. $\quad 3.1$

Зозуля Ю. $\quad \mathbf{1 . 2}$

Зубченко Л.С. $\quad \mathbf{5 . 3}$

Зудіна Л. $\quad \mathbf{1 . 6}$ 


\title{
Part 1
}

\section{ELECTROCHEMICAL POWER SOURCES}

\author{
Розділ 1
}

ЕЛЕКТРОХІМІЧНІ ДЖЕРЕЛА СТРУМУ 


\title{
Behavior of Non-Graphitic Carbon Electrodes of Lithium-Ion Batteries in Electrolytes based on Ionic Liquids
}

\author{
Khomenko V. G. \\ Department for Electrochemical Power Engineering \& Chemistry \\ Kyiv National University of Technologies and Design \\ 2, Nemirovich-Danchenka str., Kyiv 01011 Ukraine
}

\section{Introduction}

Lithium-ion battery (LIB) has been one of the most promising electrochemical energy storage technologies $[1,2]$. LIB works are based on the movement of lithium ions between two battery electrodes, the anode and cathode. The ions are stored in the anode which is often graphite. When they discharge, the ions move to the cathode. One advantage of a graphite anode is the small volume change that occurs when the ions enter it. Lithium-ion batteries (LIB) generally use electrolyte solutions based on organic solvents and $\mathrm{LIPF}_{6}$ salt because they have high ionic conductivity, and can form an effective solid electrolyte interface (SEI) that helps intercalation of lithium ion into graphite anode. However, organic electrolytes involve safety issues because of their low thermal stability and flammability. Ionic liquids (ILs) are molten salts with melting points well below $100{ }^{\circ} \mathrm{C}$. ILs have many useful properties, including low vapor pressure, high chemical and thermal stability, wide electrochemical voltage window, non-flammability and high ionic conductivity [3, 4]. However, incompatibility of typical ILs with graphite anode has also been recognized as a serious problem for lithium-ion battery application $[5,6]$. Non-graphitic carbons such as hard carbon have an advantage that they can be intercalated/deintercalated in a different types of electrolyte [7, 8]. Besides, hard carbons show very small changes of volume during the charge/discharge. The anode based on hard carbon may be quite promising for the new generations of LIB with ILs. In this work, the behavior of nongraphitic carbons electrodes in solutions based on ILs was investigated. 


\section{Experimental}

The hard carbon was prepared from table sugar by the method described in Ref. [9]. Sugar precursor ("sulfuric acid washed" sugar) was pyrolyzed from $600-1000$ ${ }^{\circ} \mathrm{C}$ for $3 \mathrm{~h}$ in a high-purity argon atmosphere.

The active materials were mixed with the amount of 7-9 wt\% polyvinylidene fluoride (PVDF) in N-methylpyrrolidine (NMP) solution. The resulting slurry was cast onto a coper foil, and a doctor blade with a gap opening of $200 \mu \mathrm{m}$ was used to define the maximum thickness of the freshly coated layer. The resulting film was dried at $120^{\circ} \mathrm{C}$ in order to evaporate the NMP. The electrodes were compacted to the desired density by calendering. The thicknesses of the active layers of electrodes were in the range $0.08-0.10 \mathrm{~mm}$. The disc electrodes having a diameter of $16 \mathrm{~mm}$ were cut out of the coating film cast onto metal foil current collector using a punch. Before assembling the cell the electrodes were dried under a primary vacuum at $120^{\circ} \mathrm{C}$ in the time frame of $12 \mathrm{~h}$. The coin cells (CR2016 standard size) were assembled in an argon-filled glove box (Unilab model, MBraun, USA). The TEKLON ${ }^{\mathrm{TM}}$ EDEX separator (manufactured by ENTEK Membranes LLC, USA). The electrolyte $1 \mathrm{M} \mathrm{LiPF}_{6}$ in $\mathrm{EC}: \mathrm{DEC}: \mathrm{DMC}=1: 1: 1 \mathrm{w} / \mathrm{w}$ electrolyte (conventional electrolyte), as well as the electrolytes based on the following ILs from ENEA (Rome/Casaccia, Italy): N-methyl-N-propyl pyrrolidinium bis(fluorosulfonyl)imide (PYR13FSI) and N-methyl-N-buthylpyrrolidinium bis(trifluoromethansulfonyl)imide (PYR14TFSI) were used for assembling the coin cells. Electrochemical investigations were performed using a 32-channel battery cycler MSTAT 32 from Arbin Instruments, USA and multi-channel potentiostat VMP3 from Princeton Applied Research, UK.

\section{Result and discussion}

Herein, we report a hard carbon synthesized via carbonization of table sugar. The apparatus for carbonization is a simple horizontal furnace with a homogeneous heating zone of $150 \mathrm{~mm}$ and a quartz tube $(20 \mathrm{~mm}$ diameter) presented schematically in the Figure 1. A thin layer of the precursor powder is spread uniformly on ceramic plate which is introduced in the quartz tube reactor. For example hard carbon is 
obtained from the pyrolysis of sugar at different temperatures ranging from 600 to $1000^{\circ} \mathrm{C}$. The selected temperature was reached with a heating ramp of $10^{\circ} \mathrm{C} / \mathrm{min}$ and using an argon flow. Finally, the system is cooled down at $5^{\circ} \mathrm{C} / \mathrm{min}$ under argon flow. In some cases, additional thermal treatments were also performed on the purified carbon materials.

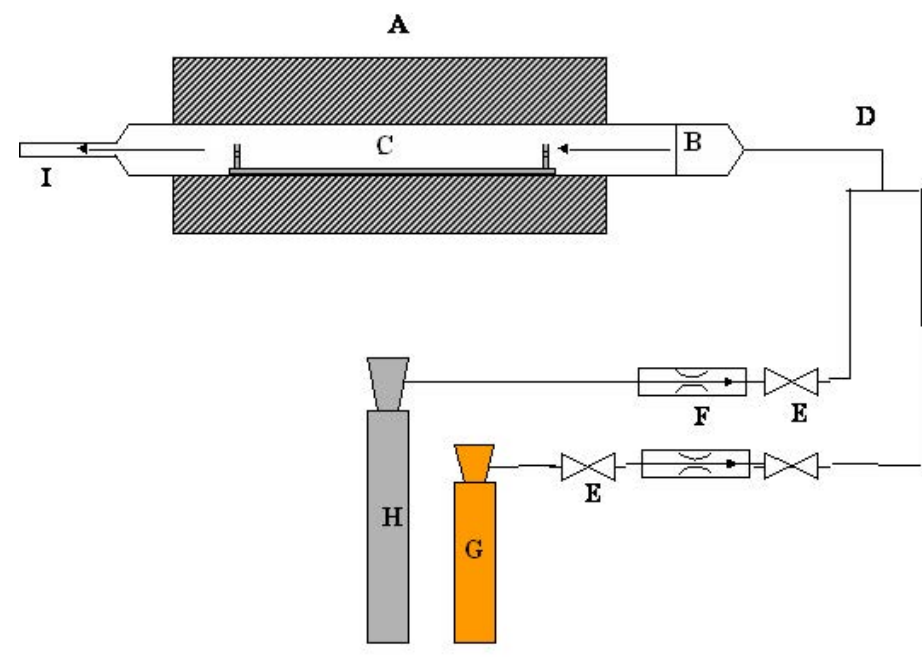

A - Furnace $\left(\operatorname{Tmax}=1100^{\circ} \mathrm{C}\right)$

B - Quartz tube

C - Quartz plate

D - Gas inlet

E - Valves

F - Flow meters

$\mathrm{G}, \mathrm{H}-\mathrm{Gases}\left(\mathrm{Ar}\right.$ and $\mathrm{Ar}+\mathrm{H}_{2}$ )

Fig. 1. Schematic representation of the unit used for synthesis of anodic materials

A scanning electron microscope (SEM) was used to examine the powder morphology of hard carbon obtained from the pyrolysis of table sugar. The SEM is represented by Fig 2. Hard carbon has small particles which come in particle sizes lower $20 \mu \mathrm{m}$.
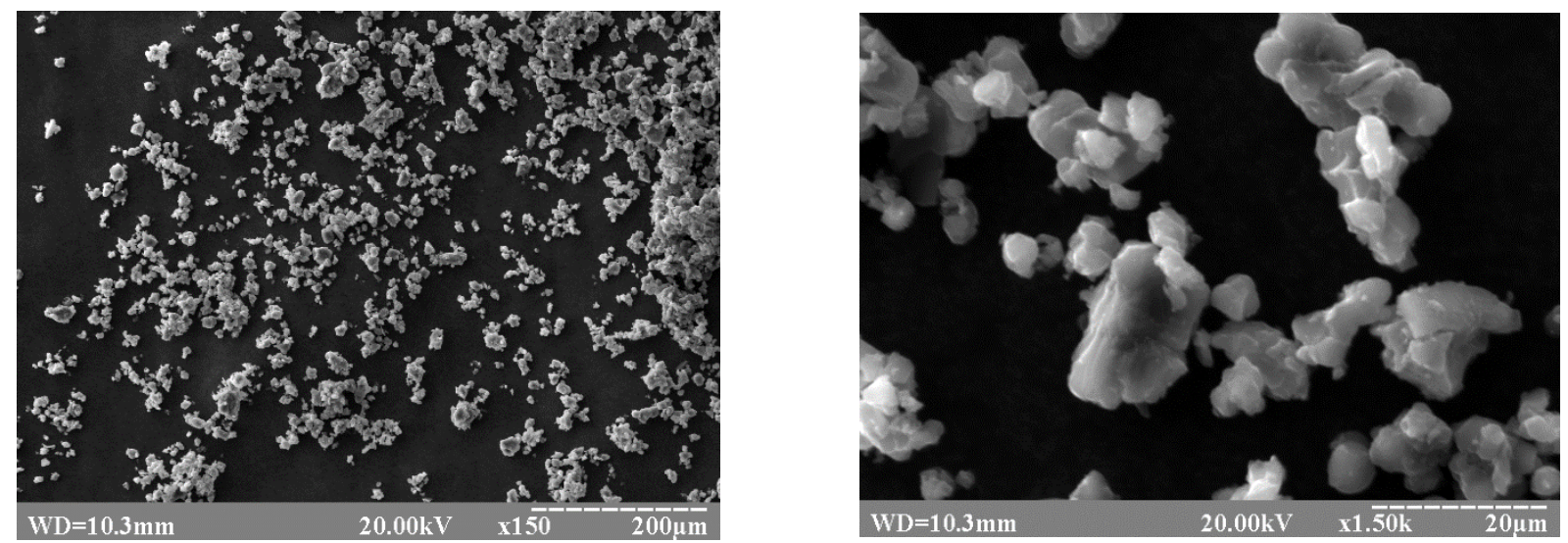

Fig. 2. SEM of hard carbon obtained from the pyrolysis of table sugar at $1000{ }^{\circ} \mathrm{C}$

The electrochemical performance of hard carbon anode has been evaluated using 
different electrolyte mixtures. Figure 3 (red line) shows potential vs. capacity for lithium insertion/extraction from conventional electrolyte and Fig. 3 (blue line) shows the corresponding results for lithium insertion/extraction in IL based electrolyte (PYR13FSI). The reversible part of the potential profiles for both cell and lithium insertion and extraction has a similar shape with some differences in potential values. The focus of this work was reversible capacities, it should be note that the irreversible capacities of cell using IL based electrolyte was higher than that for the cell with conventional electrolyte.

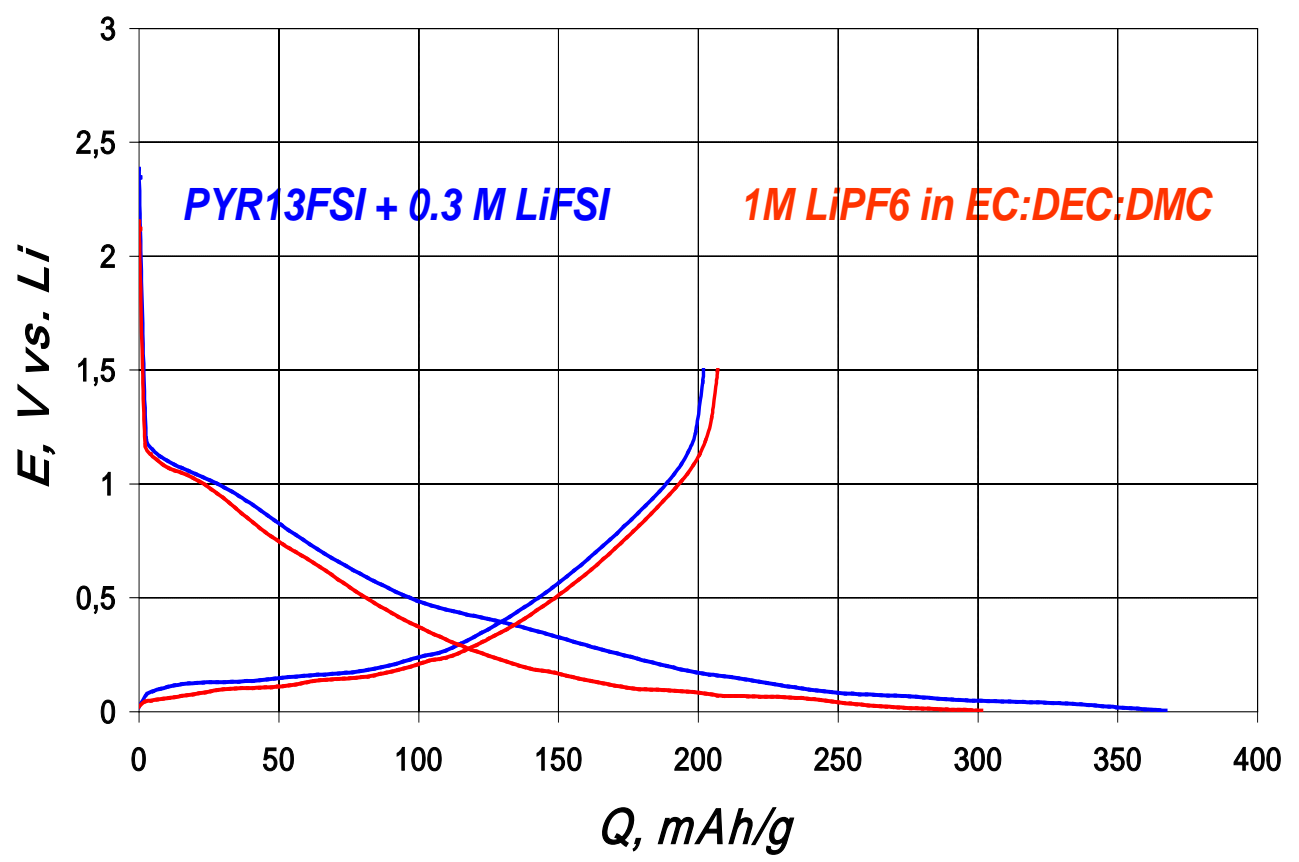

Fig. 3. Profiles of charge/discharge potentials of the hard carbon at current density $30 \mathrm{~mA} / \mathrm{g}$ into organic (red line) and IL based electrolyte (blue line)

Thus, the lithium insertion/ removal process is not completely reversible in the case IL based electrolyte. The initial capacity of hard carbon in lithium deintercalation was found to be of $208 \mathrm{~A} \cdot \mathrm{h} \cdot \mathrm{g}^{-1}$ within the range of cut-off potentials from 0.0 to $2.0 \mathrm{~V}$. The irreversible capacity was about $94 \mathrm{~mA} \cdot \mathrm{h} \cdot \mathrm{g}^{-1}$, which is less than in the case of IL based electrolyte. Table 1 shows electrochemical characteristics for the sugar samples pyrolyzed at different temperature. The difference in capacity between the first discharge and the first charge ( $Q$ rev.) gives the irreversible capacity (Q irr.). Table 1 shows that the samples have different irreversible Li 
insertion capacities. The carbonization temperature significantly influenced on the irreversible capacity for lithium storage. The difference of reversible capacity is small for all samples. The irreversible capacity is small for samples obtained at higher temperature. The irreversible capacity is not only a measure of the amount of SEl, but can also relate to the reduction of surface species on the carbon [10]. Thus, there are no interests to use lower temperature treated samples for further investigation.

Table 1. The electrochemical properties of hard carbon obtained at different temperature

\begin{tabular}{|c|c|l|c|c|c|c|}
\hline$\#$ & T, ${ }^{\circ} \mathrm{C}$ & Electrolyte & $\begin{array}{c}\text { Qrev, } \\
\mathrm{mA} \cdot \mathrm{h} \cdot \mathrm{g}^{-1}\end{array}$ & $\begin{array}{c}\text { Qirr, } \\
\mathrm{mA} \cdot \mathrm{h}^{-1}\end{array}$ & $\begin{array}{c}\text { Efficiency } \\
\text { on } 1 \text { st cycle, \% }\end{array}$ & $\begin{array}{c}\text { Efficiency } \\
\text { on } \text { 1 }^{\text {st }} \text { cycle, } \%\end{array}$ \\
\hline 1 & 600 & LP71 & 195 & 341 & 36 & 89 \\
\hline 2 & 700 & LP71 & 191 & 223 & 46 & 93 \\
\hline 3 & 800 & LP71 & 203 & 156 & 57 & 96 \\
\hline 4 & 900 & LP71 & 206 & 115 & 64 & 98 \\
\hline 5 & 1000 & LP71 & 208 & 94 & 69 & 98 \\
\hline 6 & 1000 & PYR13FSI & 202 & 167 & 55 & 91 \\
\hline 7 & 1000 & PYR14TFSI & 32 & 98 & - & - \\
\hline 8 & 1000 & $\begin{array}{l}\text { PYR13FSI+5 } \\
\text { \% LP71 }\end{array}$ & 199 & 106 & 65 & 96 \\
\hline 9 & 1000 & $\begin{array}{l}\text { PYR14TFSI+ } \\
5 \% \text { LP71 }\end{array}$ & 174 & 120 & 59 & 93 \\
\hline
\end{tabular}

LP71:1M LiPF6 in EC:DEC:DMC=1:1:1 w/w

PYR13FSI: $0.3 \mathrm{M}$ LITFSI in N-methyl-N-propyl pyrrolidinium bis(fluorosulfonyl)imide

PYR14TFSI: 0.3 M LITFSI in N-methyl-N-buthylpyrrolidinium bis(trifluoromethansulfonyl)imide

In order to investigate the electrochemical behavior of hard carbon, in our studies mixture conventional electrolyte and IL-based electrolytes have been tested. Our findings are presented in the table 1 for the sugar sample pyrolyzed to $1000^{\circ} \mathrm{C}$. It can be seen from the table that organic electrolyte content in the IL based electrolyte causes increasing the capacity and decreasing the irreversible capacity. Thus the organic additives may improve electrochemical performance materials in IL based electrolyte.

For all electrochemical test results described in this section, we used one grade of graphitized carbon materials. This is PUREBLACK ${ }^{\circledR} 205$ Carbon received from 
Superior graphite Co (USA). A transmission electron microscope (TEM) and a scanning electron microscope (SEM) were used to examine the powder morphology of PUREBLACK ${ }^{\circledR} 205$ Carbon. The SEM and TEM are represented by Fig 4. Similar to Carbon Black Pureblack has spherical particles which come in particle sizes lower $20 \mu \mathrm{m}$ (see Fig. 4 left picture). We would like to note very unusual appearance of the graphitic structures shown in TEM (Fig. 4 right picture). Noting their graphite-like composition (at a given particle size of below $100 \mathrm{~nm}$ ), one should expect to see them as being more conductive than hard carbon.
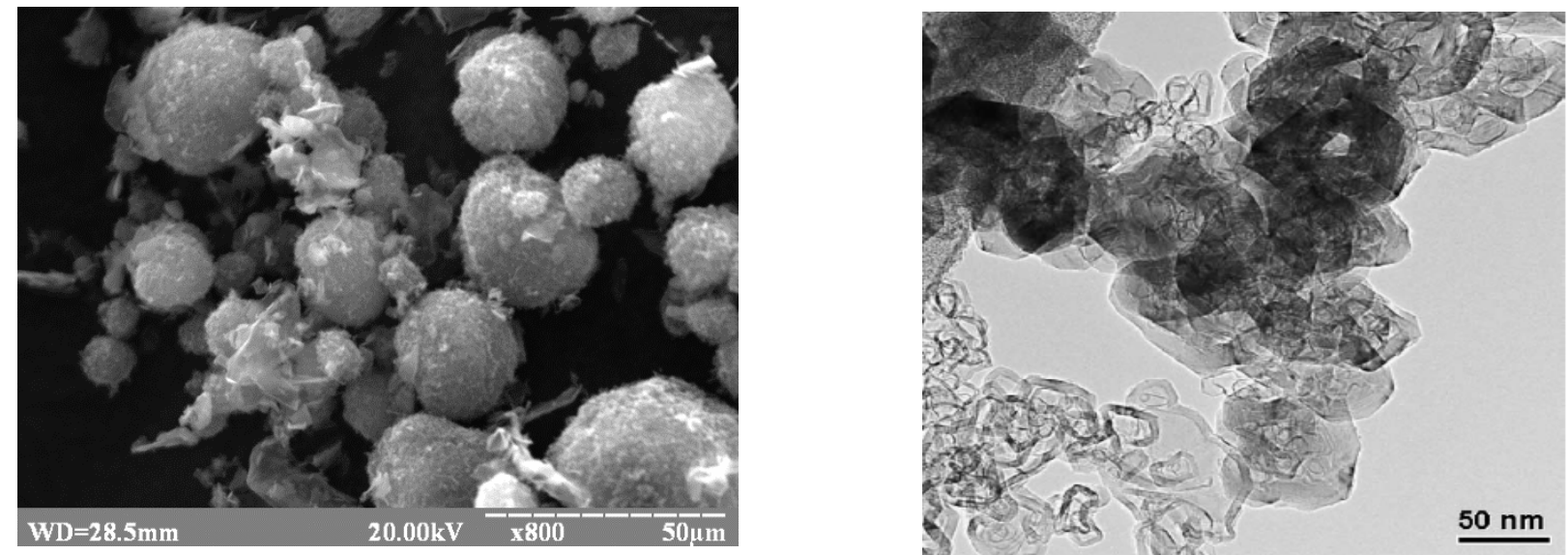

Fig. 4. SEM (left picture) and TEM (right picture) of PUREBLACK ${ }^{\circledR} 205$ Carbon.

Thus the graphitized carbon black (Pureblack), being an ultra pure partially graphitized carbon black with properties exceeding those of battery grade acetylene blacks have higher conductivity than carbon black and feature higher packing density. The PUREBLACK Carbon is quite an interesting material for development of LIB.

Figure 5 shows the voltage profiles of PUREBLACK ${ }^{\circledR} 205$ Carbon at the current density of $30 \mathrm{~mA} / \mathrm{g}$. The experiment was conducted in the CR2016 coin cells with a Li metal counter electrode. The initial capacity of PUREBLACK in deintercalation of lithium was seen to be $192 \mathrm{~mA} \cdot \mathrm{h} / \mathrm{g}$ within the range of cut-off potentials between 0.0 and $2.0 \mathrm{~V}$. The capacity that cannot be recovered (the "irreversible capacity loss") is observed in the first charge/discharge cycle. It is clear from Fig. 5 that the irreversible capacity in the first cycle is very high (up to $215 \mathrm{~mA} \cdot \mathrm{h} / \mathrm{g}$ ). The irreversible capacity exists mainly due to the growth of solid-electrolyte interface (SEI) film. Such types 
of materials are characterized by presence of a large potential plateau at the potentials of about $0.8 \mathrm{~V}$ in their intercalation profiles in the first cycle (Fig. 5). The formation of SEI film is related to a surface area. As for the PUREBLACK, it has a large specific surface area (of about $50 \mathrm{~m}^{2} \cdot \mathrm{g}^{-1}$ ). Therefore, the formation of SEI film would certainly lead to a high irreversible capacity in the PUREBLACK.

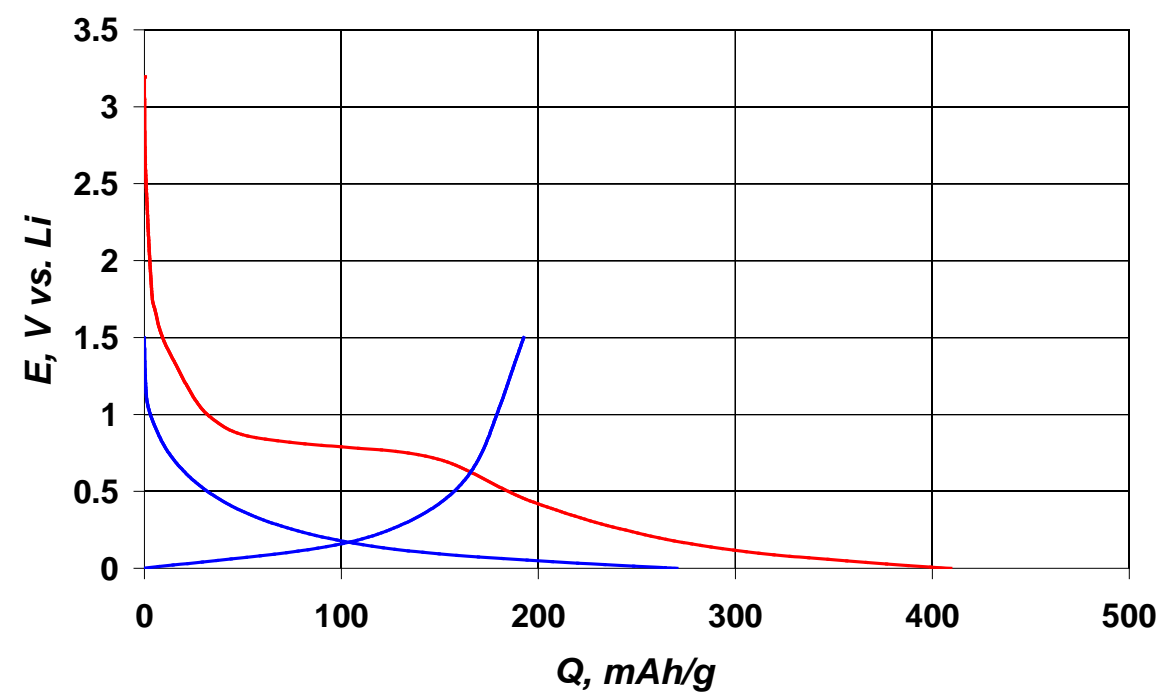

Fig. 5. The profiles of charge/discharge potentials for PUREBLACK ${ }^{\circledR} 205$ Carbon at the current density of $30 \mathrm{~mA} / \mathrm{g}$. Electrolyte: LP71

The data presented in table 2 shows that the difference in capacity between the first discharge and the first charge was higher than for cell with conventional electrolyte. The organic additive of organic electrolyte (LP-71) improved electrochemical performance of PUREBLACK in IL based electrolyte but that effect was lower than for hard carbon materials (see table 1).

Table 2. The electrochemical performance of PUREBLACK ${ }^{\circledR} 205$ Carbon in the IL based electrolytes

\begin{tabular}{|l|c|c|c|c|}
\hline Electrolyte & $\begin{array}{c}\text { Qrev, } \\
\mathrm{mA} \cdot \mathrm{h} \cdot \mathrm{g}^{-1}\end{array}$ & $\begin{array}{c}\text { Qirr, } \\
\mathrm{mA} \cdot \mathrm{h} \cdot \mathrm{g}^{-1}\end{array}$ & $\begin{array}{c}\text { Efficiency } \\
\text { on 1st cycle, } \\
\%\end{array}$ & $\begin{array}{c}\text { Efficiency } \\
\text { on } 10^{\text {st cycle, }} \\
\%\end{array}$ \\
\hline PYR13FSI & 98 & 245 & 29 & 88 \\
\hline PYR14TFSI & 22 & 116 & 16 & 76 \\
\hline PYR13FSI+5\%LP71 & 115 & 267 & 30 & 93 \\
\hline PYR14TFSI+5\%LP71 & 103 & 272 & 27 & 89 \\
\hline
\end{tabular}




\section{Conclusion}

The non-graphitic carbon materials were prepared. Their electrochemical properties in the commercial electrolyte and IL were studied by the constant current charge-discharge test. The carbon anode exhibited lower reversible capacity in IL electrolytes than that in conventional electrolyte. In order to overcome this problem and to improve electrochemical property anodes, in the current work mixed electrolytes containing non-flammable IL were prepared and investigated. The organic additive of organic electrolyte (LP-71) improved electrochemical performance of non-graphitic carbon materials in IL based electrolyte but still characteristics of materials were lower than in conventional electrolyte. Thus, further optimization materials and composition of IL based electrolyte are required.

\section{Reference}

[1] M. Hu, X. L. Pang, Z. Zhou, J. Power Sources, 237 (2013) 229

[2] J. B. Goodenough, Y. Kim, Chem. Mater, 22 (2010) 587

[3] G. A. Elia, U. Ulissi, F. Mueller, J. Reiter, N. Tsiouvaras, Y. K. Sun, B. Scrosati, S. Passerini, J. Chem. Eur., 22 (2016) 6808-6814

[4]. L. Lombardo, S. Brutti, M. Navarra, S. Panero, P. Reale, J. Power Sources, 227 (2013) 8-14

[5] Y. Katayama, M. Yukumoto, T. Miura, Electrochem. Solid-State Lett. 6 (2003), A96-A97

[6] H. Zheng, K. Jiang, T. Abe, Z. Ogumi, Carbon, 44 (2006) 203-210

[7] L. Zubizarreta, M. Gil-Agustí, V. Khomenko, V. Barsukov, J. of Solid State Electrochemistry, 21 (2017) 3557-3566

[8] H. Fujimoto, K. Tokumitsu, A. Mabuchi, N. Chinnasamy, T. Kasuh, J. Power Sources, 195 (2010) 7452-7456

[9] O. Mao, R.L. Turner, I.A. Courtney, B.D. Fredericksen, M.I. Buckett, L.J. Krause, J.R. Dahn, Electrochem. Solid-state Lett. 2 (1999) 3

[10] F. Béguin, F. Chevallier, C. Vix-Guterl, S. Saadallah, V. Bertagna, J. N. Rouzaud and E. Frackowiak, Carbon, 43 (2005) 2160-2167 


\title{
Optimization of electrode structure for symmetric supercapacitors with high specific energy intensity
}

\author{
Izotov V..$^{\mathrm{a}, \mathrm{b}}$, Gogotsi O. ${ }^{\mathrm{c}}$, Havrykov D. ${ }^{\mathrm{a}, \mathrm{b}}$, Chufarov M ${ }^{\mathrm{a}}$, Zozulya Yu. ${ }^{\mathrm{c}}$, \\ Linyucheva O. ${ }^{\mathrm{b}}$, Zahorodna V. ${ }^{\mathrm{c}}$ \\ ${ }^{a}$ Key Laboratory of Physics and Technology for Advanced Batteries (Ministry of \\ Education), College of Physics, Jilin University, Changchun 130012, P.R. China \\ ${ }^{b}$ National Technical University of Ukraine "Igor Sikorsky Kyiv Polytechnic \\ Institute”, Peremogi Ave., 37, Kiev, 03056, Ukraine \\ ${ }^{c}$ Materials Research Center, Kiev 03680, Ukraine
}

\begin{abstract}
One of the main disadvantages of symmetric supercapacitors is their low specific energy capacity. Primarily, the low energy density of supercapacitors due to a low amount of active material in the device. To eliminate this drawback, recently, a new promising direction has been developed, which associated with the creation of thicker electrodes with a high concentration of activated carbon material. One of the main issues in the manufacture of high-capacitance supercapacitors based on thick electrodes is the thickness of the carbon-containing component of the electrodes, which will ensure the maximum density intensity of the device. In this paper, the authors proposed an approach to calculate the optimal thickness of the carboncontaining component of the electrodes for supercapacitors with high specific capacity.
\end{abstract}

Key words: supercapacitor, porous carbon material, the specific capacity. thickness of the carbon-containing component of the electrodes.

\section{Оптимизация структуры электродов симметричных суперконденсаторов с высокой удельной энергоемкостью}

Изотов В. ${ }^{\mathrm{a}, \mathrm{b}}$, Гогоци А. ${ }^{\mathrm{c}}$, Гавриков Д., ${ }^{\mathrm{a}, \mathrm{b}}$, Чуфаров М. ${ }^{\mathrm{a}}$, Линючева О. ${ }^{\mathrm{b}}$, Зозуля Ю. ${ }^{\mathrm{c}}$, Загородна В. ${ }^{\mathrm{c}}$ 
${ }^{a}$ Ключевая лаборатория физики и технологии современных накопителей энергии (Министерства образования), Институт физики, Цзилинский Университет, Чанчунь 130012, Китай

${ }^{b}$ Национальный технический университет Украиньл "Киевский политехнический институт имени Игоря Сикорского", пр-т Перемоги, 37, Киев, 03056, Украина

${ }^{c}$ Материаловедческий Исследовательский Центр, Киев 03680, Украина

В последнее время появился повышенный интерес к перезаряжаемым источникам энергии, которые обладают высокой удельной мощностью, способные работать в широком температурном интервале и не меняющие свои параметры в течение длительного периода эксплуатации[1,2]. Техническое решение этой задачи связывают с использованием суперконденсаторов. Электрохимические конденсаторы двойного электрического слоя или суперконденсаторы - перезаряжаемые источники энергии, которые способны выдерживать $10^{6}$ циклов заряд/разряд практически без изменения своих параметров. Их КПД приближается к 95\%, а температурный диапазон лежит в интервале от $-50{ }^{\circ} \mathrm{C}$ до $+80{ }^{\circ} \mathrm{C}[3]$.

Следует отметить, что наряду с высокой удельной мощностью до 15 кВт/кг, их удельная энергоемкость не превышает 6 Вт*час/кг[4]. Работы по увеличению удельной энергоемкости суперконденсаторов интенсивно ведутся во всех ведущих фирмах производителях суперконденсаторов. Традиционно работы по созданию суперконденсаторов с высокой удельной энергоемкостью сосредотачивались на синтезе новых материалов с высокой площадью поверхности и заданным распределением пор по размерам[5-7]. Наряду с традиционными направлениями появились работы, в которых авторы предлагают увеличить концентрацию активного углеродного материала в суперконденсаторах[8]. Это направление представляется достаточно перспективным если учесть, что содержание пористого углеродного материала в промышленных суперконденсаторах колеблется в пределах от 20\% до 30\%[9]. 
Увеличение концентрации активного углеродного вещества предлагается осуществлять за счет увеличения концентрации активированного углерода в электродах и за счет увеличения толщины электродов. При таком подходе актуальным становится вопрос, какой толщины должна быть углеродсодержащая составляющая электродов, чтобы конечное изделие имело максимальную удельную энергоемкость.

Настоящая работа посвящена изучению зависимости удельной энергоемкости суперконденсатора от толщины углеродсодержащей составляющей его электродов.

\section{1. Теоретическая модель}

Удельная емкость суперконденсатора (емкость суперконденсатора, отнесенная к его весу $\left.C\left(h_{e}\right)\right)$, как функция от толщины углеродсодержащей составляющей электродов $\left(h_{e}\right)$ описывается уравнением:

$$
C\left(h_{e}\right)=\frac{c\left(h_{e}\right) * V_{e}}{P_{a l}+P_{\text {sep }}+P_{e}+P_{\text {cap }}+P_{\text {int }}+P_{\text {ext }}}
$$

где $c\left(h_{e}\right)$ - удельная объемная емкость пористого углеродного материала, $P_{a l}$ вес алюминиевых коллекторов; $P_{\text {sep }}$ - вес сепаратора, пропитанного электролитом; $P_{e}$ - вес двух углеродных составляющих электродов пропитанных электролитом; $P_{\text {сар }}$ - вес корпуса $P_{\text {int }}$ - вес внутренних коммутирующих соединений $P_{\text {ext }}$ - вес внешних токовыводов; $V_{e}$ - объем двух углеродных составляющих электродов.

На удельную емкость суперконденсатора с ростом толщины углеродсодержащей составляющей его электродов оказывают влияние два фактора. Первый - уменьшение удельной емкости активного углеродного материала, связанное с эффектом насыщения. Второй фактор - увеличение активного углеродного материала в суперконденсаторе. Если первый фактор ведет к уменьшению емкости суперконденсатора то второй, наоборот, к увеличению емкости. 
При построении модели зависимости удельной объемной емкости активированного материала от толщины углеродсодержащей составляющей электродов, предполагаем, что в некоторой области толщин от $h_{0}$ до $h_{m}$ удельная объемная емкость убывает линейно за счет эффекта насыщения. В линейном приближении уравнение, описывающее зависимость $c\left(h_{e}\right)$ будет иметь вид:

$$
\begin{aligned}
& c\left(h_{e}\right)=c\left(h_{0}\right)\left(1-2 \alpha h_{e}\right) \\
& \alpha=\frac{c\left(h_{0}\right)-c\left(h_{m}\right)}{2 c\left(h_{0}\right)\left(h_{m}-h_{0}\right)}
\end{aligned}
$$

С учетом уравнения (2) уравнение (1) для удельной энергоемкости суперконденсатора $C\left(h_{e}\right)$ удобно представить в виде:

$$
\begin{aligned}
& C\left(h_{e}\right)=\frac{2 c\left(h_{0}\right)\left(1-2 \alpha h_{e}\right) h_{e}}{2 h_{e}\left(\rho_{e}+P / V\right)+h_{a l}\left(\rho_{a l}+P / V\right)+h_{\text {sep }}\left(\rho_{\text {sep }}+P / V\right)} ; \\
& P=P_{\text {cap }}+P_{\text {int }}+P_{\text {ext }} ; \\
& V=S\left(2 h_{e}+h_{a l}+h_{\text {sep }}\right)
\end{aligned}
$$

где $\rho_{e}$ - удельный вес углеродсодержащей составляющей электродов, пропитанных электролитом; $\rho_{a l}$ удельный вес алюминия; $\rho_{s e p}$ - удельный вес сепаратора пропитанного электролитом; $h_{a l}$ и $h_{\text {sep }}$ - толщины алюминиевого коллектора и сепаратора соответственно; $V$ - объем, который занимает электрохимическая система в суперконденсаторе, а $S$ - площадь поверхности электродов суперконденсатора.

Исследуем $C\left(h_{e}\right)$ как функцию $h_{e}$ на экстремум. После проведения вычислений получаем значение для оптимальной толщины углеродсодержащей составляющей электродов $h_{e}$ при которой значение $C\left(h_{e}\right)$ будет максимальным. 


$$
\begin{aligned}
& h_{e}=Y\left(\sqrt{1+\frac{1}{2 Y} h_{0}+\frac{1}{Y \alpha}}-1\right) \\
& Y=\frac{h_{A l}\left(\rho_{A l}+P / V\right)+h_{s}\left(\rho_{s}+P / V\right)}{\left(\rho_{e}+P / V\right)}
\end{aligned}
$$

При выводе уравнения (4) было сделано предположение, что концентрация активированного углеродного материала в углеродсодержащей составляющей электродов не зависит от толщины электродов. При постановке экспериментов необходимо следить за выполнением этого требования.

\section{2. Постановка эксперимента}

\section{1 Подготовка электродов}

Для экспериментальной проверки правильности полученных выше результатов были изготовлены макеты суперконденсаторов с электродами с различной толщиной углеродсодержащей составляющей. Толщина углеродсодержащей составляющей изменялась в пределах от 100 мкм до 800 мкм.

Электроды для макетов суперконденсаторов изготавливались размером 20 мм *20 мм (видимая площадь поверхности $4 \mathrm{~cm}^{2}$ ). Углеродсодержащий композитный материал для электродов изготавливался из активированного углерода материала YP-50F фирмы Kuraray Chemical (Япония) (91 весовых \%). Размер гранул углеродного материала был менее 20 мкм. В качестве связующего использовался политетрафторэтилен (PVDF) фирмы «Sigma Aldrich» (6 весовых \%), а в качестве токопроводящей добавки использовалась сажа Super-P фирмы «Nippon Kodoshi Со»., (Япония) - (3 весовых \%). Изготовление углеродсодержащей составляющей электродов толщиной 100 , 200, 400, 600 и 800 мкм осуществлялось методом вальцевания.

Коллекторы тока в макетах изготавливались из алюминиевой фольги толщиной 20 мкм. Для того, чтобы уменьшить контактное сопротивление между углеродсодержащей составляющей электрода и алюминиевым 
коллектором тока поверхность коллектора модифицировалась электроискровым методом [10].

Углеродсодержащая составляющая электрода соединялась с алюминиевым коллектором при помощи токопроводящего термоклея.

Процесс приклеивания состоял из двух стадий. На первой стадии на поверхности коллектора формировалась клеящая пленка. Для этого на поверхность коллектора наносилась суспензия, состоящая из смеси 1,29 мас.\% политетрафторэтилена (PVDF) и 1,93 мас.\%, сажи Super-P фирмы «Nippon Kodoshi Co»., (Япония) в 96,78 мас.\% N-метил-2-пирролидона (NMP), фирмы «Sigma Aldrich». Смесь наносилась при помощи устройства «Доктор Блейд». Толщина нанесенного слоя составляла 10 мкм. Затем коллектор с нанесенной на него смесью помещали в сушильный шкаф и сушили в течение 3 часов при температуре $120{ }^{0} \mathrm{C}$. После высушивания на поверхности коллектора оставалась клеящая пленка толщиной $<3$ мкм.

На последней стадии изготовления электродов углеродсодержащая составляющая прижималась к алюминиевому коллектору тока, помещалась в сушильный шкаф и выдерживалась в течение часа при температуре $170{ }^{0} \mathrm{C}$. Для увеличения контакта между алюминиевым коллектором и углеродсодержащей составляющей изготовленные электроды дополнительно пропускались через подогреваемые вальцы, разогретые до температуры $180{ }^{0} \mathrm{C}$.

Для удаления влаги из пор углеродсодержащей составляющей электродов электроды выдерживали в течении 72 часов в вакуумном сушильном шкафу при давлении 1 кПа и температуре $150{ }^{\circ} \mathrm{C}$.

\section{2 Изготовление макетов суперконденсаторов}

Сборку макетов суперконденсаторов проводили в боксе в атмосфере аргона. Содержание кислорода и воды в боксе было ниже 1 ppm. Электроды разделялись при помощи пористого сепаратора TF48-40 фирмы Nippon Kodoshi Corporation, Япония толщиной 40 мкм. В качестве электролита использовался 1,5 M раствор тетрафторборат тетраэтиламмония $\left((\mathrm{Et})_{4} \mathrm{NBF}_{4}\right)$ в ацетонитриле. Корпуса макетов суперконденсаторов изготавливались из ламинированной 
алюминиевой фольги марки DNPe1-40h производства Nippon Printing Co., Ltd. (Япония).

\section{3 Электрохимические измерения}

Электрохимические измерения проводились электрохимическим измерительным комплексом IviumStat (Ivium Technologies, Эйндховен, Голландия). При измерениях методом циклической вольтамперометрии менялась скорость развертки в пределах от 1 мB/сек до 1000 мB/сек. При гальваностатических измерениях плотность тока менялась от $5 \mathrm{~mA} / \mathrm{cm}^{2}$ до 50 мА/см² видимой площади поверхности.

\section{3. Обсуждение результатов}

На удельные энергетические параметры суперконденсаторов влияет не только распределение пор по размерам и удельная емкость пористого углеродного материала, но и концентрация активированного углеродного материала в углеродсодержащей составляющей электрода. В свою очередь концентрация активированного углеродного материала в углеродсодержащей составляющей электрода зависит как от размера гранул активированного углеродного порошка, так и технологии изготовления электродов[1].

В настоящей работе авторы стремились получить одинаковую высокую концентрацию активированного углеродного порошка в электродах толщиной от 100 мкм до 800 мкм. Для получения высокой концентрации активированного порошка в электродах использовался порошок с размером гранул менее, 20 мкм, а применённая, в данной работе, методика горячего вальцевания позволила получить электроды различной толщины с одинаковой концентрацией активированного порошка в углеродсодержащей составляющей электродов (Таблица 1).

Как отмечалось выше последнее обстоятельство важно для проверки справедливости теоретических выкладок.

Циклические вольтамперограммы, приведенные на рис.1а и 1b, показывают, как меняются значения удельной емкости с изменением скорости развертки. 


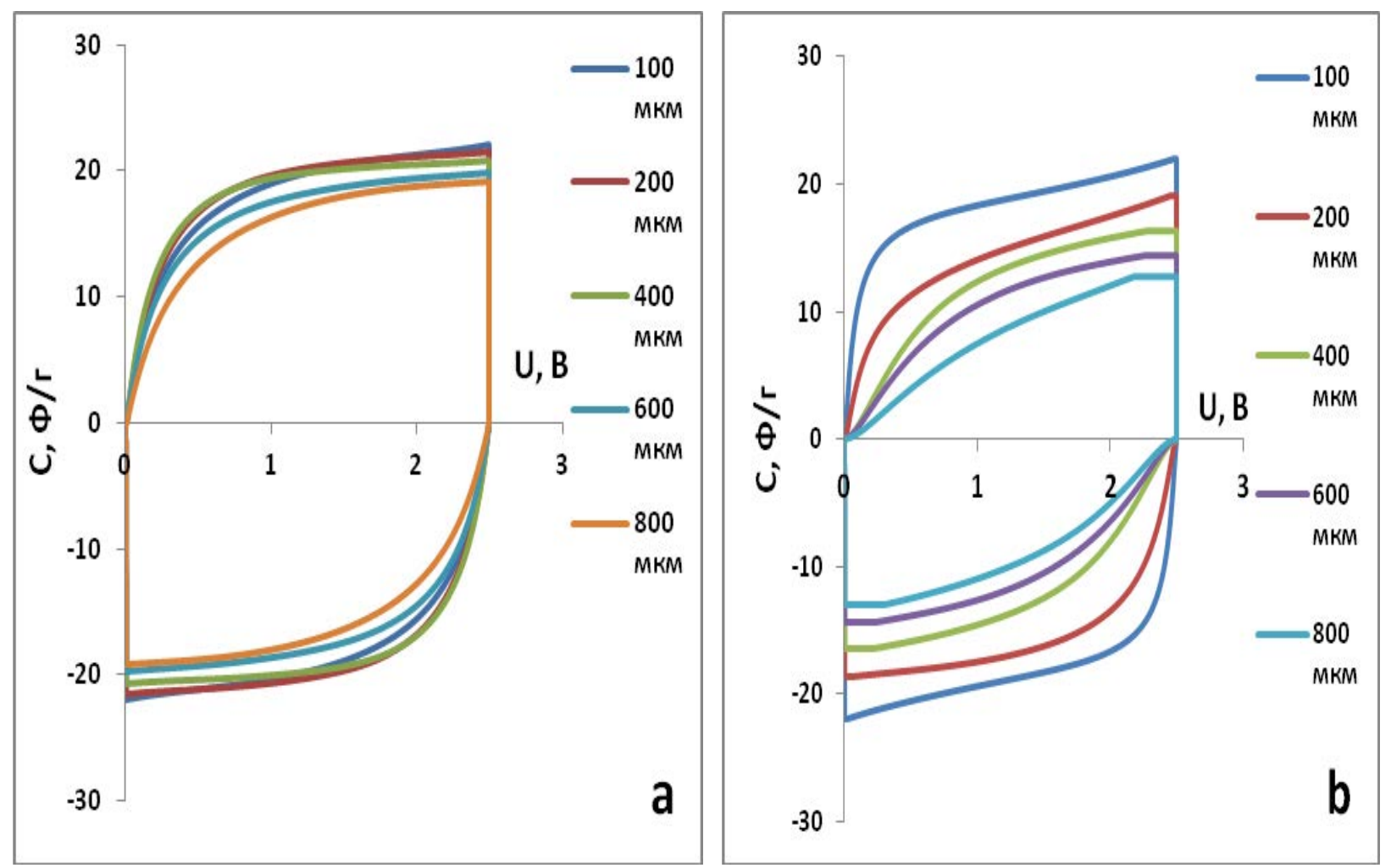

Рис. 1. Циклические вольтамперограммы со скоростью развертки 4 мB/сек (1a) и $20 \mathrm{MB} /$ сек. (1b) макетов суперконденсаторов с различной толщиной углеродсодержащих составляющих электродов

На рис. 1а видно, что при малых скоростях развертки эффект насыщения практически не сказывается и удельные емкости активированного углеродного материала практически не зависят от скорости разверти. Однако, с увеличением скорости разверти до 20 мВ/сек влияние эффекта насыщения становится ощутимым (рис 1b). Удельная емкость углеродного материала уменьшилась для всех толщин электродов, исключение составляли только электроды с толщиной углеродсодержащей составляющей равной 100 мкм. Для электродов с толщиной углеродсодержащей составляющей равной 100 мкм удельная емкость углеродного материала осталась практически неизменной.

С другой стороны, в более толстых электродах масса активного углеродного материала больше, чем в электродах $\mathrm{c}$ толщиной углеродсодержащей составляющей более 100 мкм и следовательно, их емкость больше. Это наглядно показано на рис. 2. 


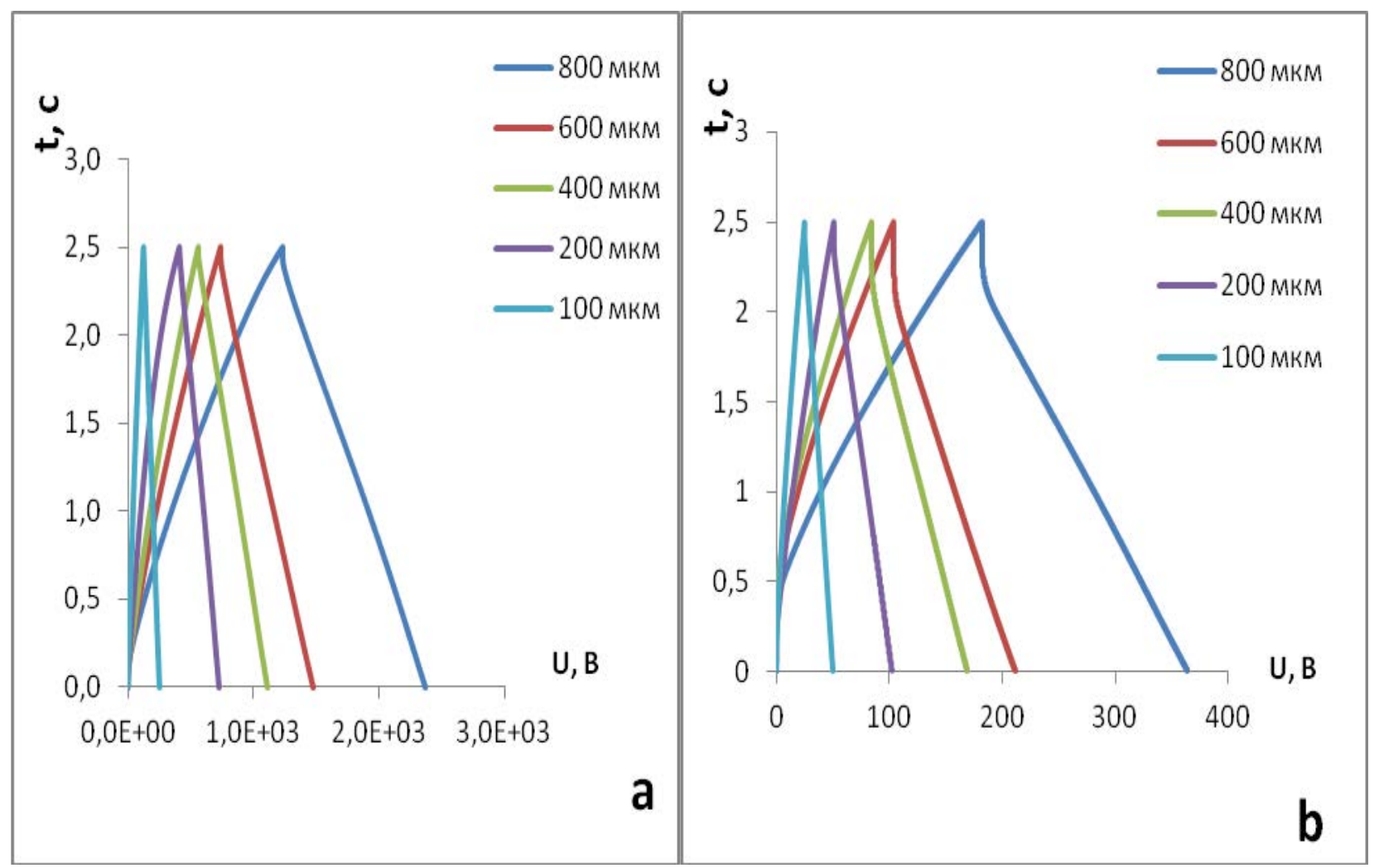

Рис. 2. Зависимость емкости макетов суперконденсаторов с различной толщиной углеродсодержащих составляющих электродов, измеренные в гальваностатическом режиме при плотностях токов 5 мА/см² $(2 \mathrm{a})$ и $25 \mathrm{MA} / \mathrm{cm}^{2}(2 \mathrm{~b})$.

Если учесть, что в суперконденсаторе значительную часть веса составляет пассивный материал то остается открытым вопрос, какая толщина углеродсодержащей составляющей электрода обеспечит максимальную удельную емкость изделия. Также следует учесть режим эксплуатации суперконденсатора. В данной работе авторы рассматривают режим заряда/разряда суперконденсатора малыми токами, т. е. величина плотности тока не превышает $5 \mathrm{~mA} / \mathrm{cm}^{2}$.

Для проверки правильности сделанных в работе предположений был изготовлен макет суперконденсатора в мягком корпусе (рис. 3).

Как видно из приведенных выше экспериментальных данных, конструкция электродов, определяющая удельную емкость суперконденсатора, существенно зависит от режима эксплуатации изделия. 


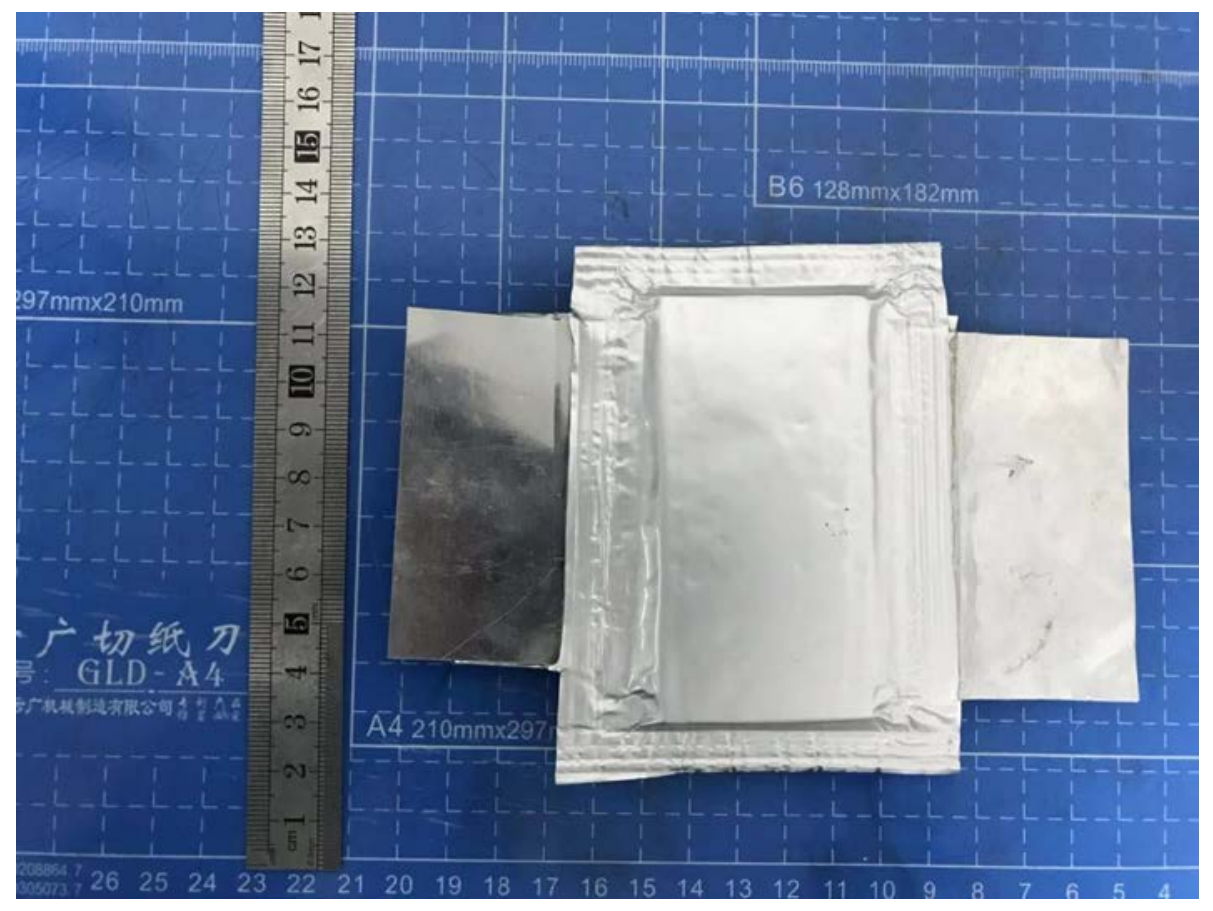

Рис. 3. Макет суперконденсатора в мягком корпусе.

В настоящей работе авторы рассматривают ситуацию, при которой суперконденсатор будет работать с плотностью тока заряд/разряда не более 5 $\mathrm{MA} / \mathrm{cm}^{2}$. В таблице 1 приведены значения для удельной объемной емкости, полученные из гальваностатических измерений. Гальваностатические измерения проводились при плотности тока 5 мА/см² .

Таблица 1. Содержание активного вещества и удельная объемная емкость в электродах различной толщины углеродсодержащей составляющей.

\begin{tabular}{|l|c|c|c|c|c|}
\hline $\begin{array}{l}\text { Толщина углеродсодержащей } \\
\text { составляющей электродов (см) }\end{array}$ & 0,01 & 0,02 & 0,04 & 0,06 & 0,08 \\
\hline $\begin{array}{l}\text { Вес активного вещества в } \\
\text { углеродсодержащей составляющей двух } \\
\text { электродов (г) }\end{array}$ & 0,106 & 0,203 & 0,2893 & 0,289 & 0,377 \\
\hline $\begin{array}{l}\text { Удельная объемная емкость пористого } \\
\text { углеродного материала (Ф/см }\end{array}$ & 16,74 & 15,97 & 14,14 & 12,64 & 11,58 \\
\hline
\end{tabular}


Значение коэффициента $\alpha$, рассчитанное по формуле (2) на основании данных приведенных в таблице 1 равно $2,2 \mathrm{~cm}^{-1}$. Объем, который занимает электрохимическая система в макете суперконденсатора (рис. 3), составил $36 \mathrm{~cm}^{3}$. Вес корпуса вместе с термоклеем и внешними токовыводами равнялся 5,28 г.

Остальные параметры необходимые для расчета оптимальной толщины углеродсодержащей составляющей электрода равны: удельный вес алюминиевого коллектора $-2,7$ г/см³ , а его толщина - 0,002 см; удельный вес углеродсодержащей составляющей электрода пропитанной электролитом -

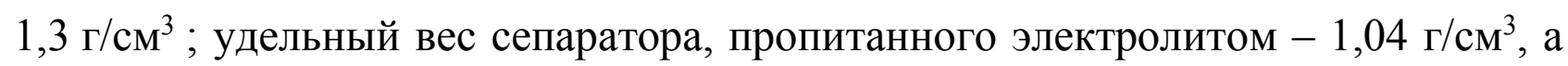
его толщина - 0,003 см.

После подстановки приведенных выше значений в уравнение (4) получаем оптимальную толщину углеродсодержащей составляющей электрода равной 0,048 см. При изготовлении макета суперконденсатора, приведенного на рис. 3, толщина углеродсодержащей составляющей электрода равнялась 0,045 см. Емкость макета суперконденсатора получилась равной 480 Ф, а вес изделия составил 33,5 г.

Удельная энергоемкость такого суперконденсатора составляет $14,5 \mathrm{BT}^{*}$ час/кг, что в 2,4 раза больше чем у лучших современных промышленных суперконденсаторов. Как показали испытания суперконденсатора, несмотря на низкую удельную плотность тока (всего $5 \mathrm{~mA} / \mathrm{cm}^{2}$ ) суперконденсатор способен разряжаться и заряжаться токами до $2 \mathrm{~A}$ без потери емкости.

\section{4. Выводы}

Разработка и применение электродов $\mathrm{c}$ высокой концентрацией активированного углеродного материала в углеродсодержащей составляющей электродов с толщиной более 100 мкм позволяет создать суперконденсаторы с высокой удельной емкостью. Развитие научных исследований и инженерноконструкторских работ в этом направлении позволит в ближайшем будущем 
создать новое поколение симметричных суперконденсаторов с высокой энергоемкостью, которые будут способны заменить аккумуляторы.

\section{Благодарность}

Авторы выражают глубокую благодарность профессору Юрию Гогоци за обсуждение результатов работы и критические замечания, а также Министерство образования и науки Украины за финансирование темы №2920 «Наукові основи та закономірності електрохімічних процесів формування упорядкованих нанорозмірних та мікрорівневих матеріалів хемотроніки» в рамках которой была выполнена данная работа.

\section{Литература}

[1] P. Simon, Y. Gogotsi, Materials for electrochemical capacitors, Nat. Mater. 7 (2008) $845-854$.

[2] J.R. Miller, Valuing reversible energy storage, Science 335 (2012) 1312-1313.

[3] X. Wang, H. Zhou, E. Sheridan, J.C. Walmsley, D. Ren, D. Chen, Geometrically confined favourable ion packing for high gravimetric capacitance in carbon-ionic liquid supercapacitors, Energy Environ. Sci. 9 (2016) 232-239.

[4] F. Beguin, V. Presser, A. Balducci, E. Frackowiak, Adv. Mater. 26 (14) (2014) 2219-2251

[5] J. Chmiola, G. Yushin, Y. Gogotsi, C. Portet, P. Simon, P.-L. Taberna, Anomalous increase in carbon capacitance at pore sizes less than 1 nanometer, Science 313 (2006) 1760-1763.

[6] C. Largeot, C. Portet, J. Chmiola, P.-L. Taberna, Y. Gogotsi, P. Simon, Relation between the ion size and pore size for an electric double-layer capacitor, J. Am. Chem. Soc. 130 (2008) 2730-2731.

[7] X. Wang, H. Zhou, F. Lou, Y. Li, M.E. Buan, X. Duan, J.C. Walmsley, E. Sheridan, D. Chen, Boosted Supercapacitive Energy with High Rate Capability of aCarbon Framework with Hierarchical Pore Structure in an Ionic Liquid, ChemSusChem 9 (2016) 3093-3101.

[8] B. Dyatkin, O. Gogotsi, B. Malinovskiy, Y. Zozulya, P. Simon, Y. Gogotsi, High capacitance of coarse-grained carbide derived carbon electrodes, J. Power Sources 306 (2016) 32-41.

[9] Y. Zhu, S. Murali, M.D. Stoller, K. Ganesh, W. Cai, P.J. Ferreira, A. Pirkle, R.M. Wallace, K.A. Cychosz, M. Thommes, Carbon-based supercapacitors produced by activation of graphene, Science 332 (2011) 1537-1541.

[10] Малєтін Ю.А., Стрижакова Н.Г., Ізотов В.Ю., Миронова А.А., Подмогильний С.Н., Шембель О.М., Новак П., Данилін В.В. Спосіб виготовлення електродів 3 низьким контактним опором для батарей та конденсаторів подвійного електричного шару.// Патент України 2005/90448 2010. 


\title{
Conductivity and electrochemical stability of non-aqueous electrolytes for magnesium power sources
}

\author{
Kirsanova I. V., Polishchuk Yu. V., Shembel E M., \\ Lysytsya I. S., Savchenko A. S. \\ Ukrainian State University of Chemical Technology (USUCT)
}

In order to optimize the characteristics of current sources with magnesium anode, non-aqueous electrolytes based on magnesium perchlorate, mixtures of magnesium and lithium perchlorates in solvents of a series of glycols of dimethyl ethers (glymes) have been investigated. The values of specific ionic conductivity of these electrolytes were determined in the temperature range $-25 \ldots+60{ }^{\circ} \mathrm{C}$. The ionic conductivity of the electrolyte is increasing when $\mathrm{LiClO}_{4}$ is introduced in composition with $\mathrm{Mg}$ $\left(\mathrm{ClO}_{4}\right)_{2}$. The range of electrochemical stability on the platinum electrode of the proposed non-aqueous electrolytes containing $\mathrm{Mg}\left(\mathrm{ClO}_{4}\right)_{2}$ has been established and ranges from 0.5 up to $3.8 \mathrm{~V}$ regarding magnesium reference electrode.

Keywords: magnesium anode, current sources, non-aqueous electrolytes, ionic conductivity, electrochemical stability, glymes, magnesium perchlorate, lithium perchlorate.

\section{Проводимость и электрохимическая стабильность неводных электролитов для магниевых источников тока}

Кирсанова И. В., Полищук Ю. В., Шембель Е. М., Лисица И. С., Савченко А. С.

Государственное высшее учебное заведение «Украинский государственный химико-технологический университет», научно-исследовательская лаборатория химических источников тока, Днепр, пр. Гагарина 8, 49005

Химические источники тока с магниевым анодом и неводным электролитом активно разрабатывают как альтернативу литиевым аккумуляторным системам $[1-4]$. Одной из проблем при разработке магниевых источников тока является 
подбор электролитов [5-11]. Электролиты должны удовлетворять следующим критериям: кулоновская эффективность процесса осаждения/растворения магния - $\quad 100 \%$; кулоновская эффективность процессов интеркаляции/деинтеркаляции ионов магния в катодный материал - 100\%; широкое окно электрохимической стабильности, не ниже 4.0 В относительно магниевого электрода сравнения; обеспечение высокой коррозионной стойкости конструкционных материалов; совместимость с катодным материалом. Авторы [12] разработали карту, по которой можно выбрать необходимый электролит для определенного катода. Однако, однозначного подхода при выборе компонентов электролита не существует, а данные по проводимости и стабильности электролитов на основе солей магния не систематизированы.

\section{1. Экспериментальная часть}

Используемые химические соединения: перхлорат магния $\left(\mathrm{Mg}\left(\mathrm{ClO}_{4}\right)_{2}\right.$; перхлорат лития $\left(\mathrm{LiClO}_{4}\right)$; глимы общей формулы $\mathrm{CH}_{3} \mathrm{O}\left(\mathrm{C}_{2} \mathrm{H}_{4} \mathrm{O}\right)_{n} \mathrm{CH}_{3}$, где $\mathrm{n}-1$, 2, 3, 4 (моноэтиленгликольдиметиловый эфир (диметоксиэтан) $\mathrm{CH}_{3} \mathrm{OC}_{2} \mathrm{H}_{4} \mathrm{OCH}_{3}$ (глим (G1), Aldrich, безводный, 99,9\%), диэтиленгликольдиметиловый эфир $\mathrm{CH}_{3} \mathrm{O}\left(\mathrm{C}_{2} \mathrm{H}_{4} \mathrm{O}\right)_{2} \mathrm{CH}_{3}$ (диглим (G2), Aldrich, безводный, 99,5\%), триэтиленгликольдиметиловый эфир $\mathrm{CH}_{3} \mathrm{O}\left(\mathrm{C}_{2} \mathrm{H}_{4} \mathrm{O}\right)_{3} \mathrm{CH}_{3}$ (триглим (G3), Aldrich, 99,0\%), тетраэтиленгликольдиметиловый эфир $\mathrm{CH}_{3} \mathrm{O}\left(\mathrm{C}_{2} \mathrm{H}_{4} \mathrm{O}\right)_{4} \mathrm{CH}_{3}$ (тетраглим (G4), Aldrich, >99,0\%). Для удаления остаточных следов влаги все электролиты после приготовления выдерживали 2 недели над молекулярными ситами (тип $\mathrm{Na}_{\mathrm{x}}$ ) с размером пор $4 \AA$. Предварительно молекулярные сита тщательно промывали ацетоном и дистиллированной водой, затем прокаливали в камерной электропечи СНОЛ-7,2/12,5 И4Пр при температуре $500{ }^{\circ} \mathrm{C}$ в течении 5 часов.

Измерения ионной проводимости проводили в двухэлектродной стеклянной ячейке с платиновыми электродами в диапазоне температур от -20 до $+60{ }^{\circ} \mathrm{C}$.

Для вычисления удельной ионной проводимости растворов электролитов была определена постоянная ячейки (К), как отношение величины ионной 
проводимости 0,1 н водного раствора $\mathrm{KCl}$, измеренного при температуре $25^{\circ} \mathrm{C}$, к величине его удельной ионной проводимости при данной температуре. Величину удельной ионной проводимости растворов электролитов, используемых в данной работе, определяли по формуле:

$$
\chi=\frac{1}{R K},
$$

где $\chi$ - величина удельной ионной проводимости электролита, $\mathrm{OM}^{-1} \cdot \mathrm{cm}^{-1} ; \mathrm{R}-$ комплексное сопротивление электролита, определенное из годографов импеданса, Ом; К - постоянная ячейки, см.

Комплексное сопротивление электролита определяли как отрезок на оси активных сопротивлений, полученный экстраполяцией импедансного спектра в область высоких частот. Диапазон частот, в котором был получен импедансный спектр, составляет 100 кГц - 100 Гц. Амплитуда напряжения 10 мВ. Для регистрации импедансных спектров использован аналитический радиометр Voltalab-40.

Электрохимическую стабильность неводных электролитов на основе солей магния исследовали в трех-электродной ячейке, где рабочий электрод представлял собой платиновую проволоку $\left(\mathrm{S}=0,0079 \mathrm{~cm}^{2}\right)$. Вспомогательный и электрод сравнения изготавливали из металлического магния (фольга толщиной 100 мкм). Вольтамперные зависимости в диапазоне потенциалов 0,5 4,0 В снимали при скорости развертки потенциала $2 \mathrm{MB} / \mathrm{c}$ и регистрировали при помощи аналитического радиометра Voltalab-40.

\section{2. Результаты и их обсуждение}

\section{1. Ионная проводимость электролитов.}

В работе исследовали растворы перхлората магния и смеси перхлоратов магния и лития в индивидуальных растворителях на основе глимов и смесей глимов. Проводимость электролита определяет макрокинетику электрохимического процесса в пористом электроде: чем выше ионная проводимость электролита, тем глубже ионы магния проходят в порах электрода. Полученные значения ионной проводимости исследуемых электролитов, приведенные в таблице 1 , имеют один порядок. 
Таблица 1. Ионная проводимость используемых электролитов при $25{ }^{\circ} \mathrm{C}$

\begin{tabular}{|c|c|}
\hline Состав электролита & $\chi, \mathrm{MCM}^{*} \mathrm{CM}^{-1}$ \\
\hline $1,0 \mathrm{M} \mathrm{Mg}\left(\mathrm{ClO}_{4}\right)_{2}$ в $\mathrm{G} 1$ & 7,23 \\
\hline $1,0 \mathrm{M} \mathrm{Mg}\left(\mathrm{ClO}_{4}\right)_{2}$ в $\mathrm{G} 2$ & 3,72 \\
\hline $1,0 \mathrm{M} \mathrm{Mg}\left(\mathrm{ClO}_{4}\right)_{2}$ в $\mathrm{G} 3$ & 2,60 \\
\hline $1,0 \mathrm{M} \mathrm{Mg}\left(\mathrm{ClO}_{4}\right)_{2}$ в $\mathrm{G} 4$ & 0,98 \\
\hline $0,25 \mathrm{M} \mathrm{Mg}\left(\mathrm{ClO}_{4}\right)_{2}+0,25 \mathrm{M} \mathrm{LiClO}_{4}$ в G1 & 2,23 \\
\hline $0,5 \mathrm{M} \mathrm{Mg}\left(\mathrm{ClO}_{4}\right)_{2}+0,5 \mathrm{M} \mathrm{LiClO}_{4}$ в G1 & 6,80 \\
\hline $0,5 \mathrm{M} \mathrm{Mg}\left(\mathrm{ClO}_{4}\right)_{2}+0,5 \mathrm{M} \mathrm{LiClO}_{4}$ в G4 & 1,57 \\
\hline $0,5 \mathrm{M} \mathrm{Mg}\left(\mathrm{ClO}_{4}\right)_{2}$ в смеси G1:G4 (1:1) & 2,05 \\
\hline $0,25 \mathrm{M} \mathrm{Mg}\left(\mathrm{ClO}_{4}\right)_{2}$ в $\mathrm{G} 1: \mathrm{G} 4(1: 1)$ & 1,29 \\
\hline
\end{tabular}

Очевидно, что вязкость и донорное число используемых растворителей (табл. 2) влияют на ионную проводимость исследуемых электролитов.

Таблица 2. Значение вязкости и донорных чисел используемых растворителей при $20^{\circ} \mathrm{C}[13,14]$

\begin{tabular}{|c|c|c|}
\hline Растворитель & $\begin{array}{c}\text { Вязкость, } \\
\text { мПасс }\end{array}$ & $\begin{array}{c}\text { Донорное } \\
\text { число }\end{array}$ \\
\hline G1 & 0.40 & $19 \pm 1$ \\
\hline G2 & 0.99 & $18 \pm 1$ \\
\hline G3 & & \\
\hline G4 & 3.60 & $12 \pm 4$ \\
\hline
\end{tabular}

При снижении температуры вязкость увеличивается, что приводит к смещению годографа импеданса системы $\mathrm{Pt} /$ электролит / Pt в область более высоких значений сопротивления (рис. 1). 


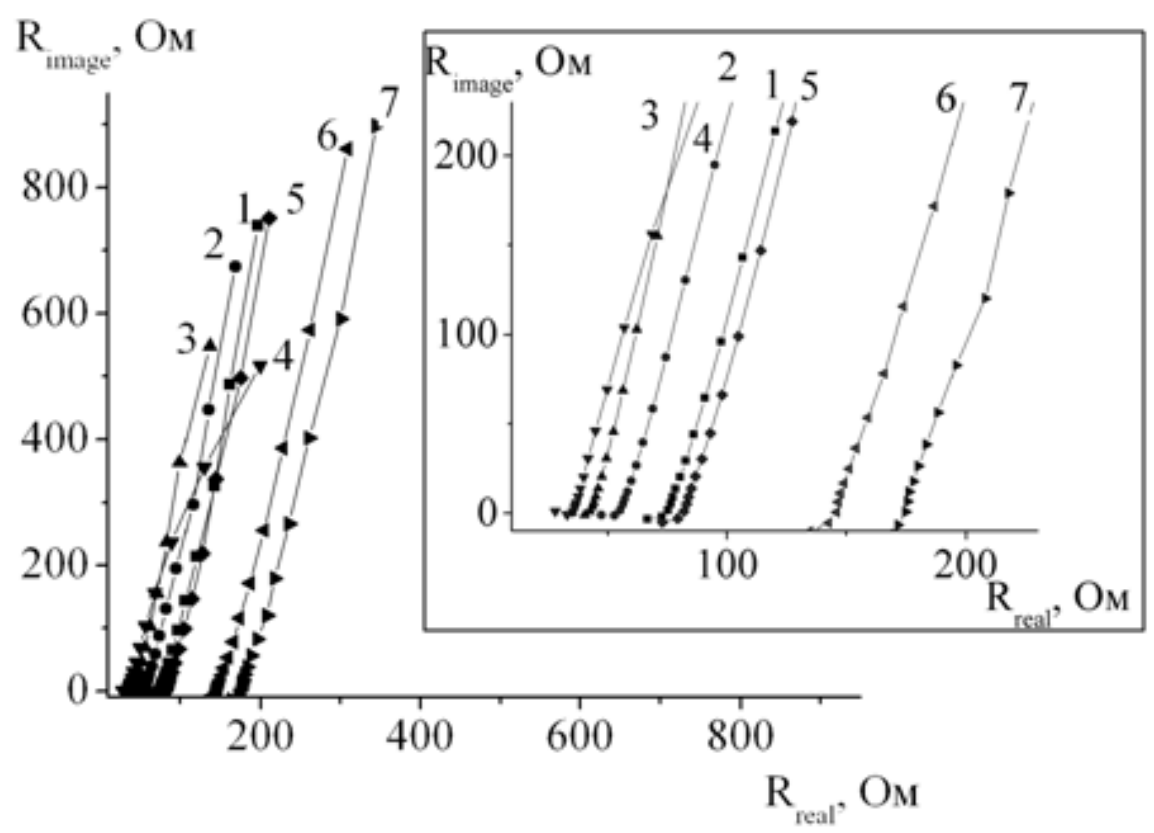

Температура, ${ }^{\circ} \mathrm{C}: 1-+5 ; 2-+20 ; 3-+40 ; 4-+60 ; 5-+0 ; 6--15 ; 7--25$

Рис. 1. Годограф импеданса системы $\mathrm{Pt} / 1,0 \mathrm{M} \mathrm{Mg}\left(\mathrm{ClO}_{4}\right)_{2}+\mathrm{Gl} / \mathrm{Pt}$ в температурном ряду $-25 \div+60{ }^{\circ} \mathrm{C}$

Влияние природы растворителя на ионную проводимость электролитов на основе солей магния с концентрацией 1,0 М показано на рисунке 2. На температурных зависимостях проводимости можно выделить участки линейной зависимости для всех электролитов (рис. 3). Значение ионной проводимости снижается в ряду электролитов на основе следующих растворителей $\mathrm{G} 1>\mathrm{G} 2>\mathrm{G} 3=\mathrm{G} 4$. Для G2 и G3 значения проводимости практически не отличаются.

Уменьшение концентрации солей приводит к уменьшению ионной проводимости электролита (табл. 1). Более значимым оказывается влияние температуры на электролит с большей концентрацией солей: 0,5 $\mathrm{M} \mathrm{Mg}\left(\mathrm{ClO}_{4}\right)_{2}+0,5 \mathrm{M} \mathrm{LiClO}_{4}+\mathrm{G} 1$. На проводимость электролита $[0,25 \mathrm{M}$ $\left.\mathrm{Mg}\left(\mathrm{ClO}_{4}\right)_{2}+0,25 \mathrm{M} \mathrm{LiClO}_{4}+\mathrm{G} 1\right]$ температура влияет значительно меньше.

Влияние температуры на ионную проводимость электролитов на основе смеси солей с различными растворителями имеет один характер: с увеличением температуры ионная проводимость растет. Ионная проводимость электролита 
на основе G4 в 2-3 раз меньше, чем электролита на основе G1 (рис. 4) в диапазоне температур от -20 до $+60{ }^{\circ} \mathrm{C}$.

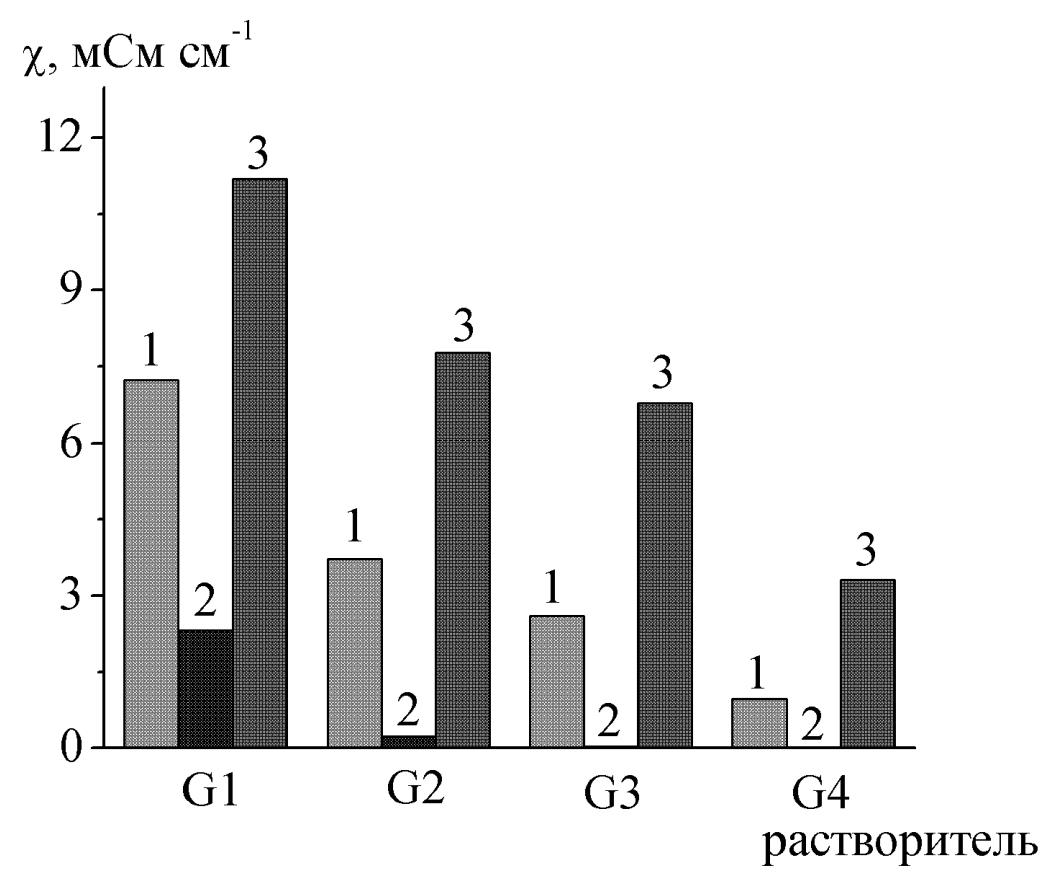

Температура, ${ }^{\circ} \mathrm{C}: 1-+25 ; 2--25 ; 3-+60$

Рис. 2. Влияние природы растворителя на удельную ионную проводимость электролитов на основе магниевых солей с концентрацией $1,0 \mathrm{M}$

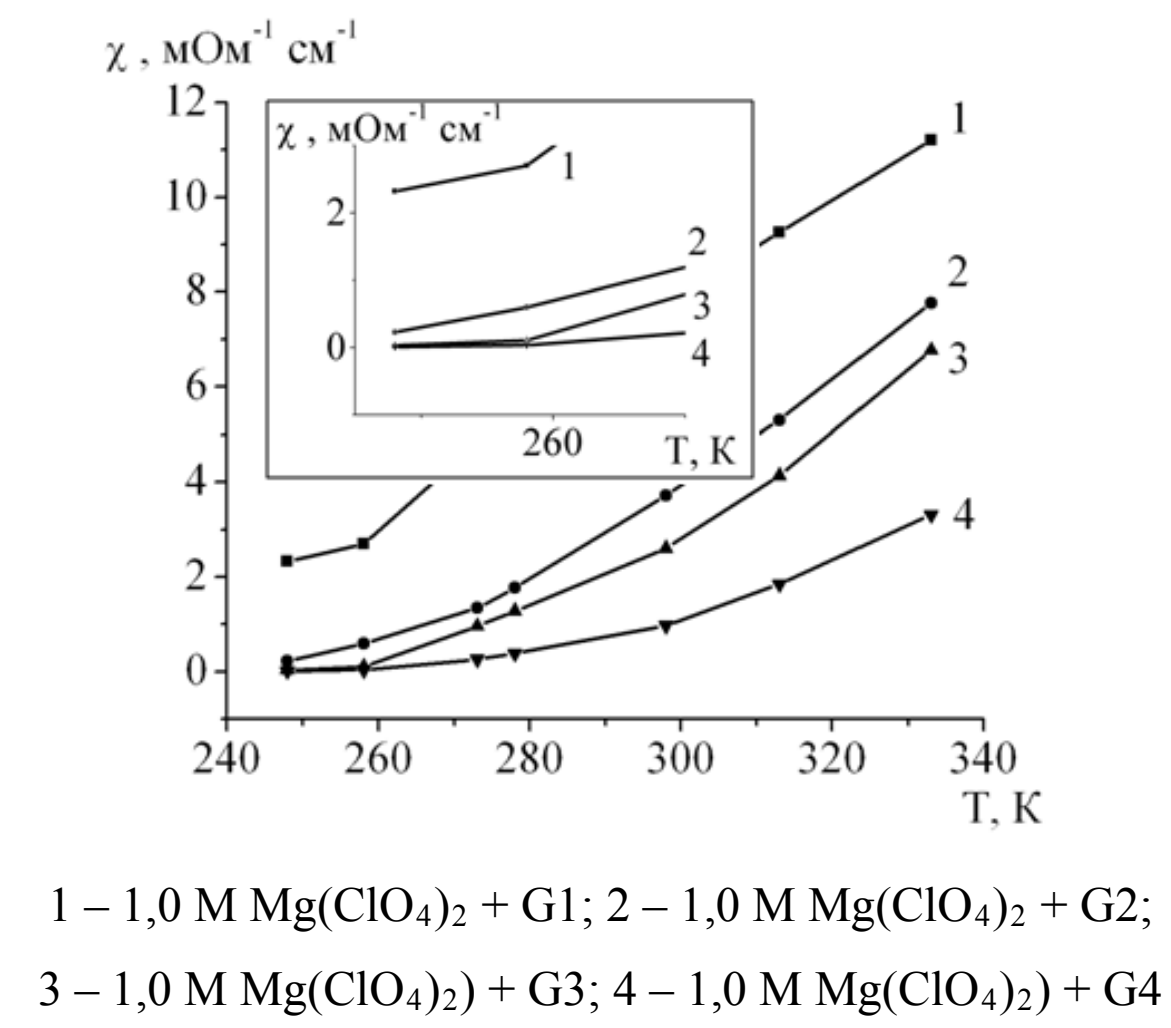

Рис. 3. Температурная зависимость ионной проводимости электролита в зависимости от природы растворителя 


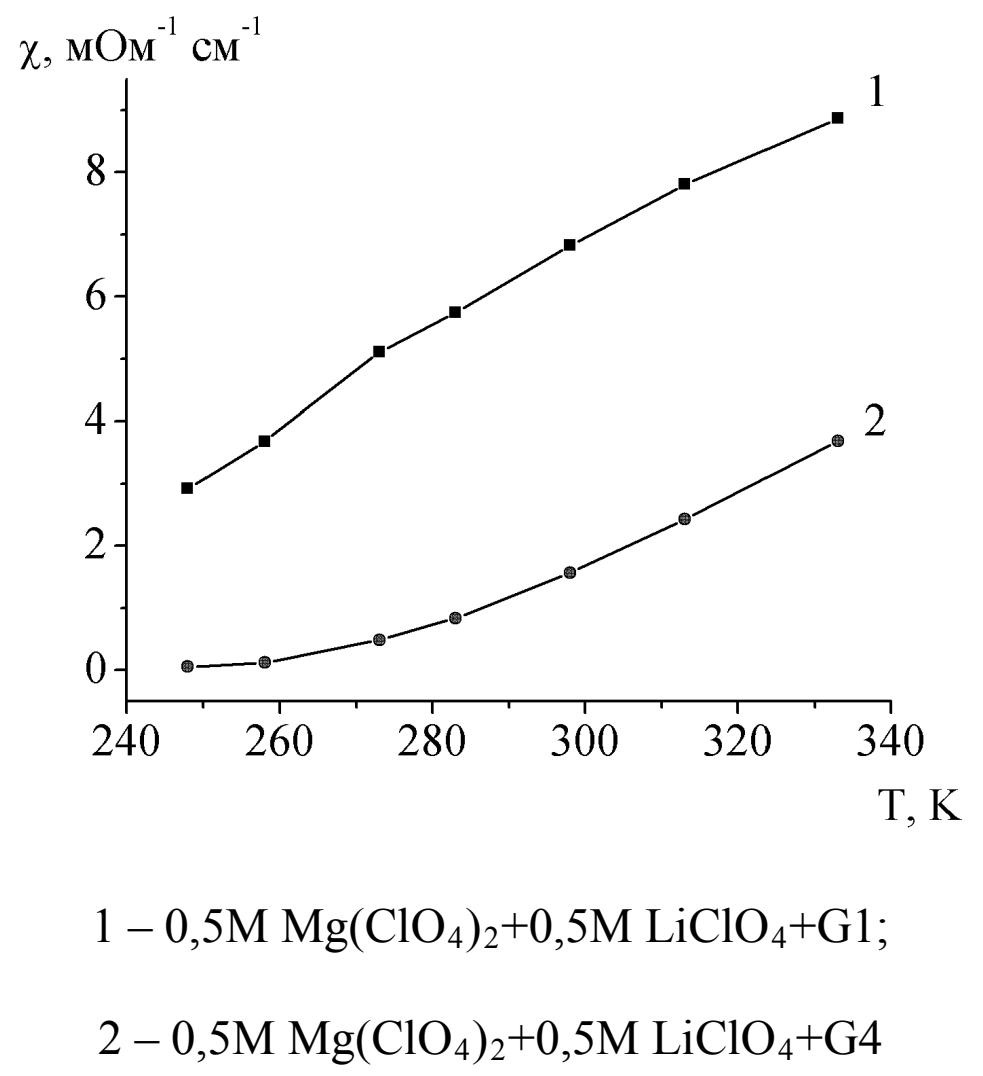

Рис. 4. Температурная зависимость ионной проводимости электролита на основе смеси солей в зависимости от природы растворителя

Введение в электролит соли лития позволяет снижать концентрацию ионов магния в растворе практически без потери проводимости (табл. 1, рис. 5).

Влияние температуры на характер зависимости ионной проводимости электролитов на основе смесей растворителей показано на рис. 6 . Проводимость электролитов в смеси глимов с высоким и низким донорным числом и разной вязкостью G1 и G4 зависит от концентрации соли: для $0,5 \mathrm{M}$ раствора $\mathrm{Mg}\left(\mathrm{ClO}_{4}\right)_{2}$ при высоких температурах проводимость увеличивается в 1,5 раза по сравнению с $0,25 \mathrm{M}$ раствором $\mathrm{Mg}\left(\mathrm{ClO}_{4}\right)_{2}$.

Таким образом, для оптимизации состава электролита на основе солей магния с точки зрения ионной проводимости необходимо учитывать природу (донорное число, вязкость) растворителя и концентрацию соли. 


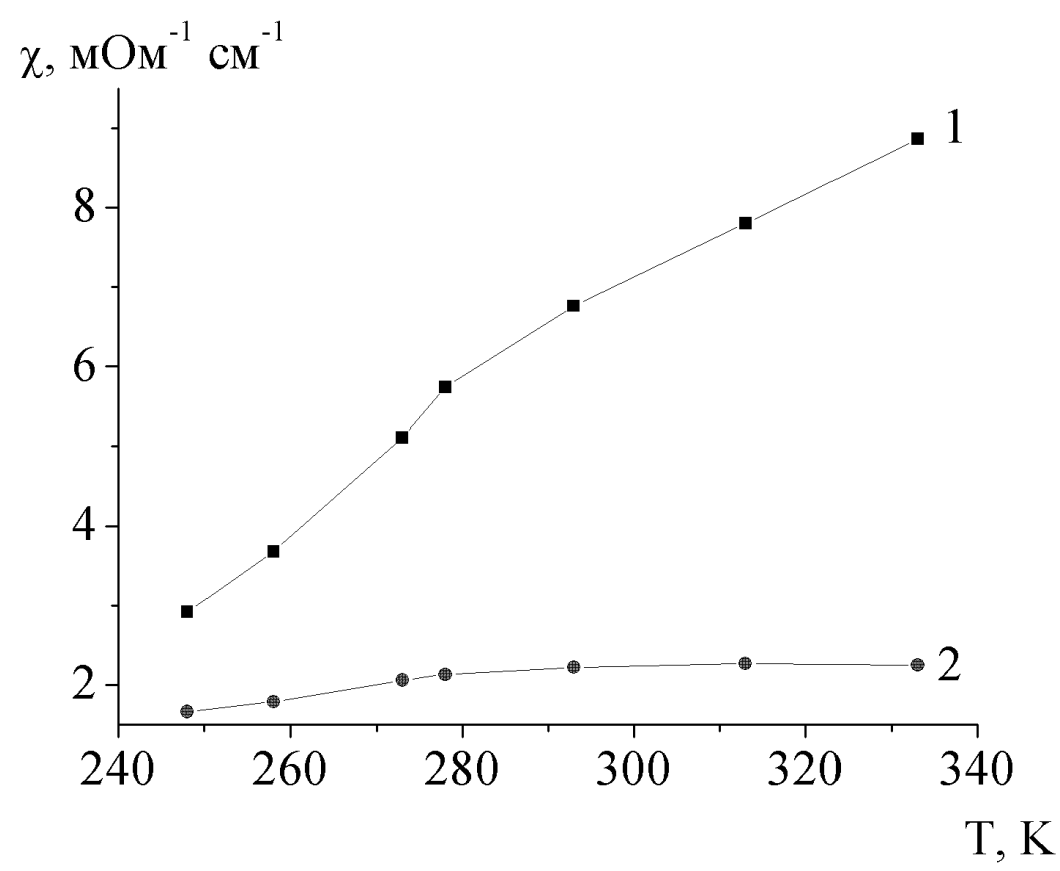

$$
\begin{gathered}
1-0,5 \mathrm{M} \mathrm{Mg}\left(\mathrm{ClO}_{4}\right)_{2}+0,5 \mathrm{M} \mathrm{LiClO}_{4}+\mathrm{G} 1 ; \\
2-0,25 \mathrm{M} \mathrm{Mg}\left(\mathrm{ClO}_{4}\right)_{2}+0,25 \mathrm{M} \mathrm{LiClO}_{4}+\mathrm{G} 1
\end{gathered}
$$

Рис. 5. Температурная зависимость ионной проводимости электролита на основе смеси солей в зависимости от концентрации соли

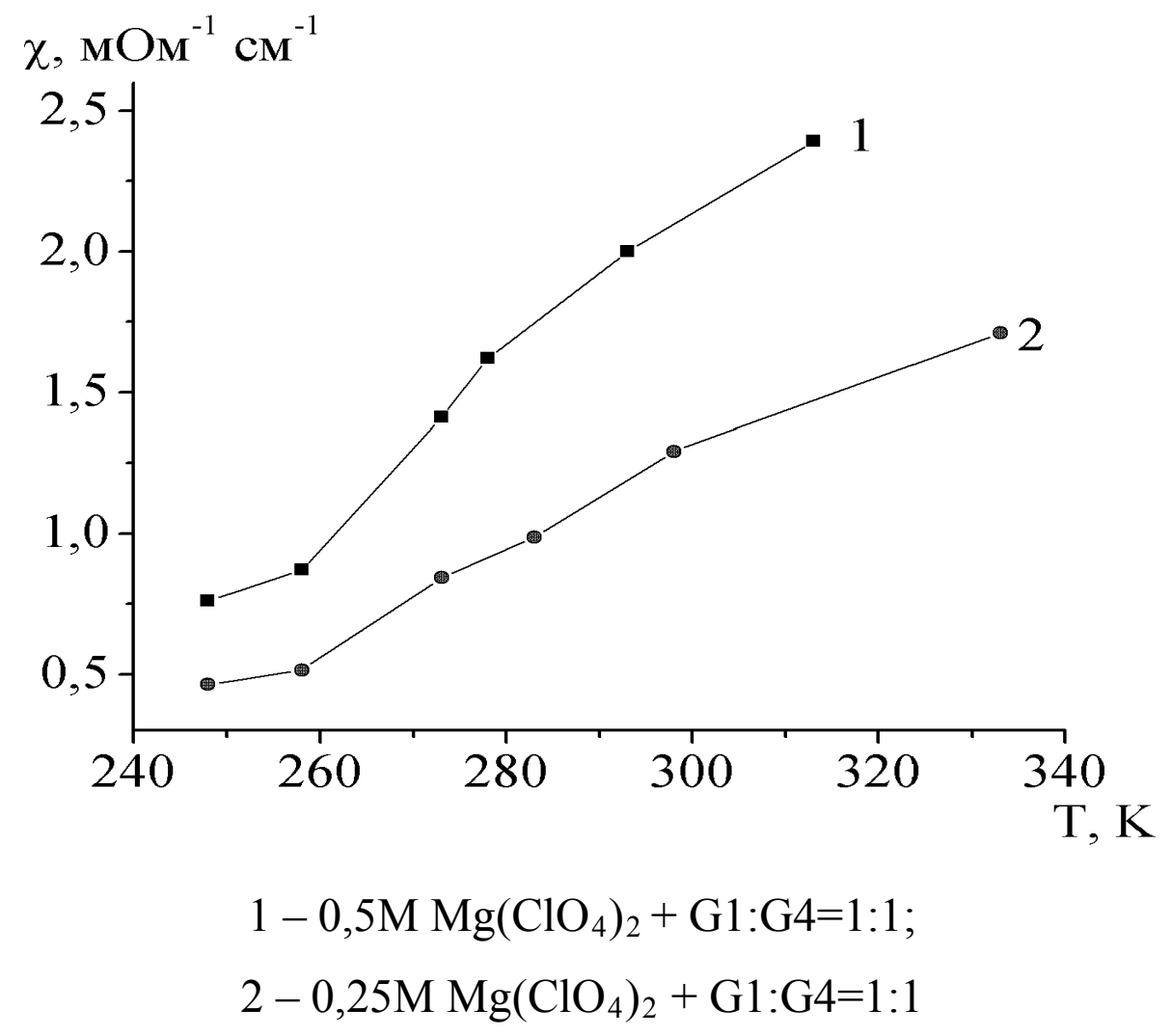

Рис. 6. Температурная зависимость ионной проводимости электролитов в смеси растворителей 


\section{2. Эектрохимическая стабильность неводных электролитов.}

Для обеспечения эффективной работы источника тока в процессе циклирования, электролит должен обладать электрохимической стабильностью в рабочем диапазоне потенциалов катода и анода источника тока $\mathrm{Mg}-\mathrm{MnO}_{2}$. Электрохимическую стабильность электролитов, составы которых указаны в таблице 1 , определяли на платиновом электроде. Электрод сравнения и вспомогательный электрод изготовлены из магниевой фольги.

Напряжение разомкнутой цепи составляло около 2,0 $\mathrm{B}$. Развертку потенциала проводили в диапазоне от 0.5 В до высоких потенциалов, при которых начиналось окисление компонентов электролита.

Следует отметить, что наличие воды, даже в небольших количествах отражается на форме фоновых кривых. На рисунке 6 показана фоновая характеристика на платиновом электроде электролита $1 \mathrm{M} \mathrm{Mg}\left(\mathrm{ClO}_{4}\right)_{2}$ в $\mathrm{G} 1$, который сушили над молеукулярными ситами в течении недели. Видно, что на катодной ветви присутствует пик при потенциале около $1,3 \mathrm{~B}$, который отвечает за восстановление воды. Обратный процесс характеризуется анодным пиком при потенциале 2,7 В. Таким образом, необходимо тщательное удаление остатков воды из предложенных электролитов.

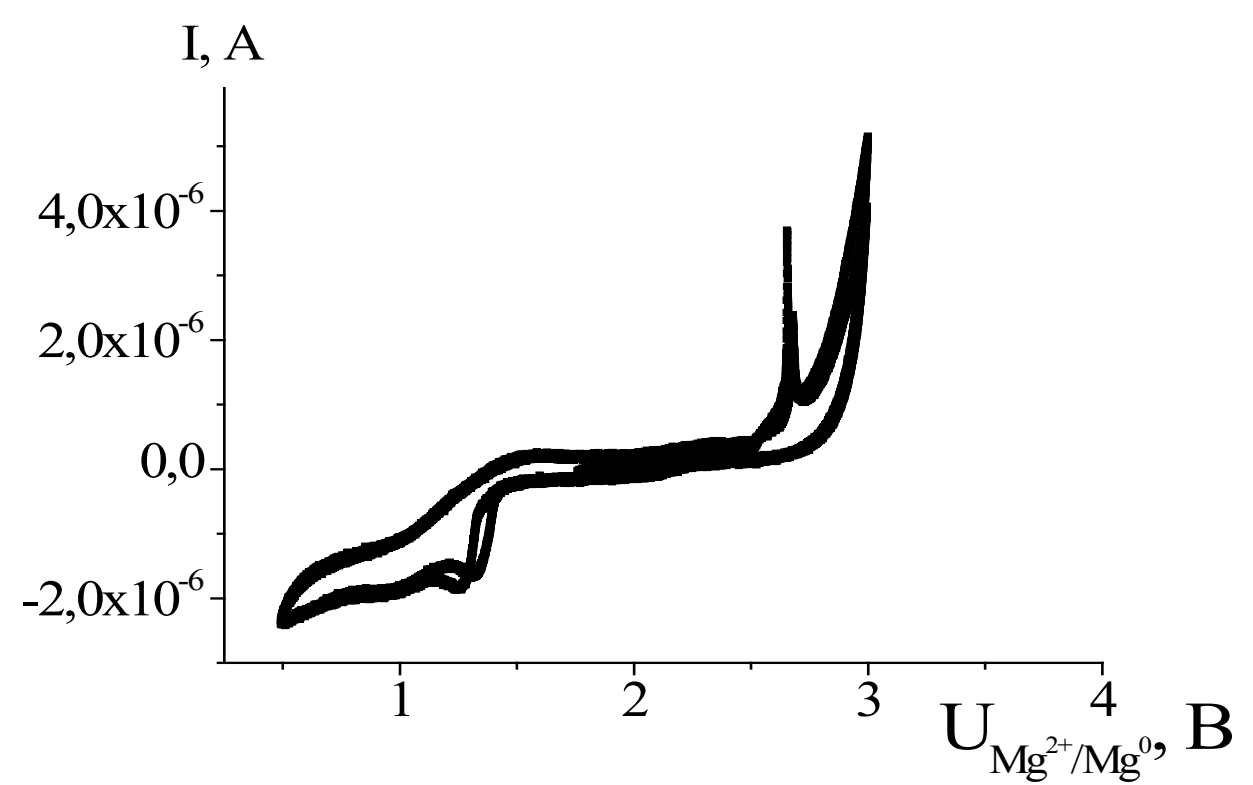

Рис. 6. Вольтамперные характеристики электролитов на основе 1,0 M $\mathrm{Mg}\left(\mathrm{ClO}_{4}\right)_{2}$ на платиновом электроде. Скорость развертки потенциала $2 \mathrm{mB} / \mathrm{c}$ 
На рисунке 7 представлены фоновые характеристики для электролитов на основе глимов, содержащих $1,0 \mathrm{M} \mathrm{Mg}\left(\mathrm{ClO}_{4}\right)_{2}$. Для каждого состава электролита снимали 3 цикла.

Из представленных кривых видно отсутствие гистерезиса на кривых прямого и обратного хода. В диапазоне потенциалов от 0,5 до 3,5 В фоновая характеристика имеет горизонтальное плато.
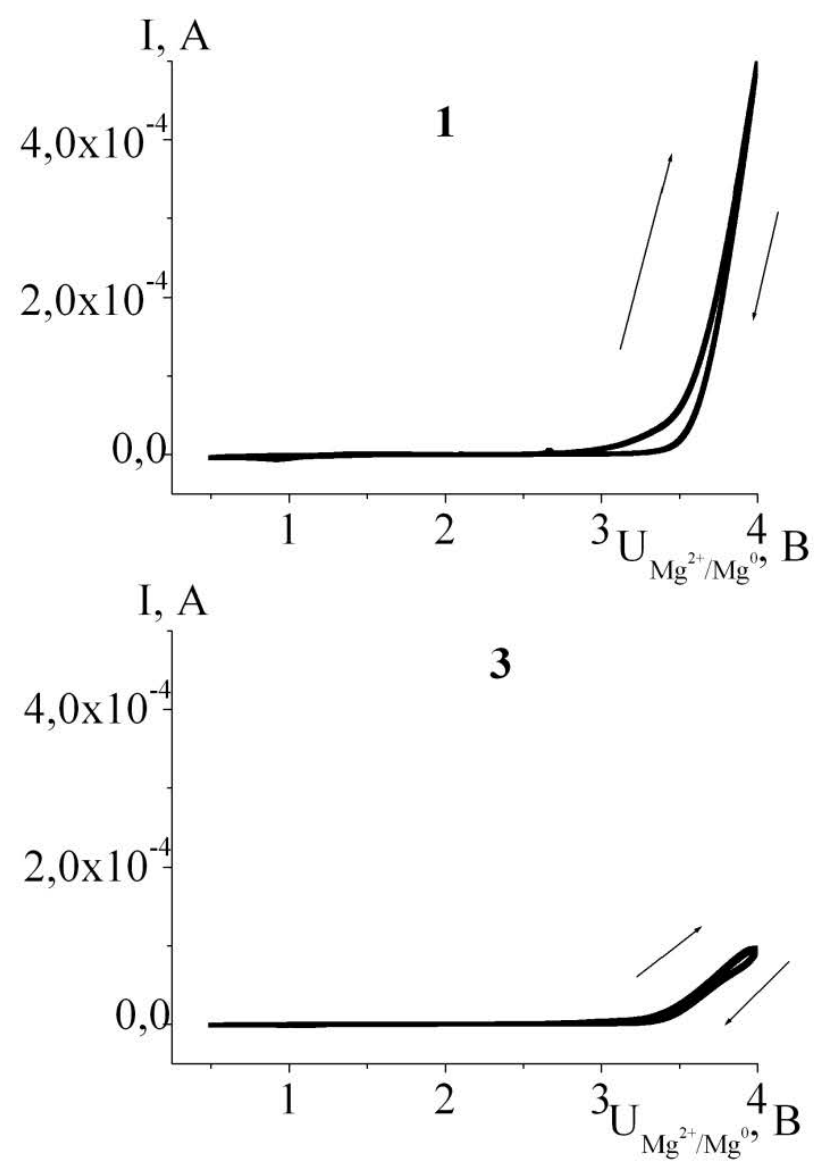

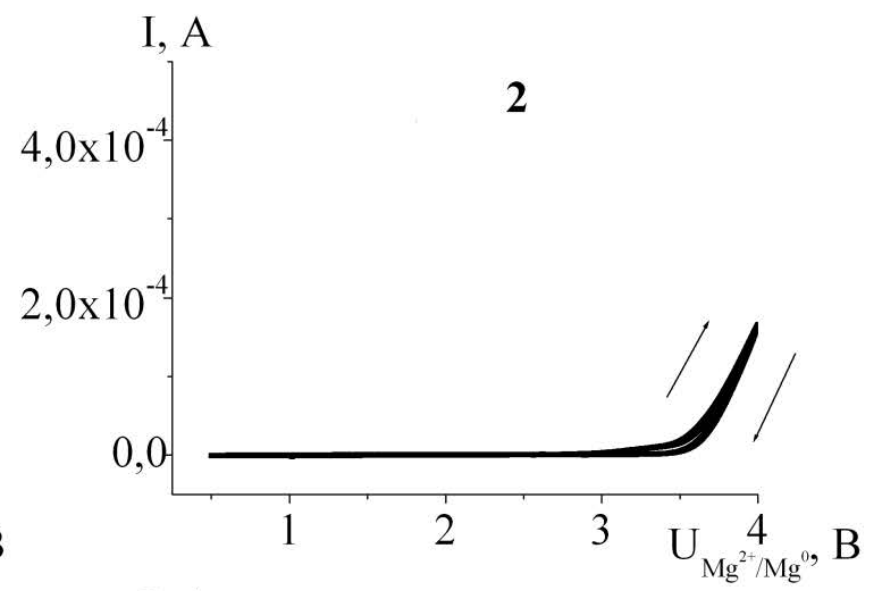

I, A

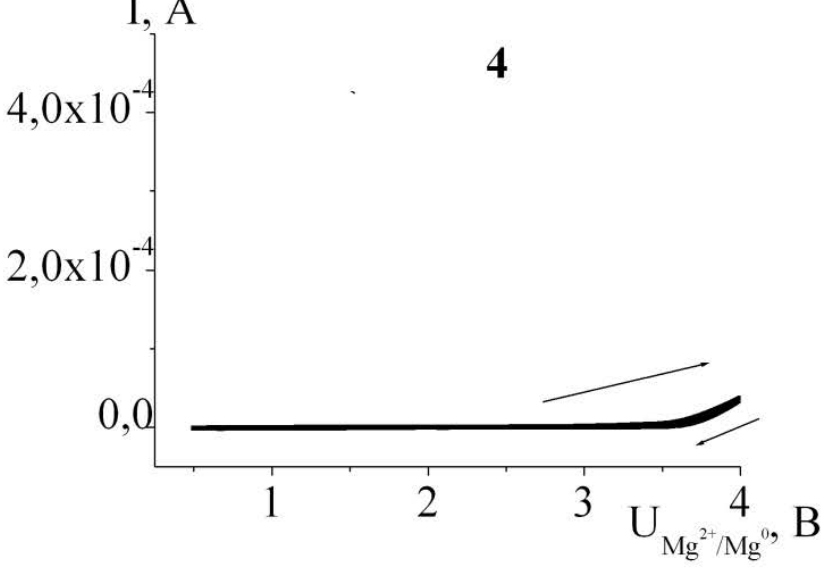

$$
\begin{aligned}
& 1-1,0 \mathrm{M} \mathrm{Mg}\left(\mathrm{ClO}_{4}\right)_{2}+\mathrm{G} 1 ; 2-1,0 \mathrm{M} \mathrm{Mg}\left(\mathrm{ClO}_{4}\right)_{2}+\mathrm{G} 2 \\
& \left.\left.3-1,0 \mathrm{M} \mathrm{Mg}\left(\mathrm{ClO}_{4}\right)_{2}\right)+\mathrm{G} 3 ; 4-1,0 \mathrm{M} \mathrm{Mg}\left(\mathrm{ClO}_{4}\right)_{2}\right)+\mathrm{G} 4
\end{aligned}
$$

Рис.7. Вольтамперные характеристики электролитов на основе 1,0 M $\mathrm{Mg}\left(\mathrm{ClO}_{4}\right)_{2}$ на платиновом электроде. Скорость развертки потенциала 2 мB/c.

Выше потенциала 3,5 В наблюдается возрастание тока, связанное с началом процесса разложения компонентов электролита (рис. 8). Из представленных результатов видно, что величина анодного тока в области потенциалов более 
положительных, чем 3.5.В уменьшается от $4,9 \times 10^{-4}$ до $8 \times 10^{-5}$ А в ряду G1 > G2 $>\mathrm{G} 3>\mathrm{G} 4$.
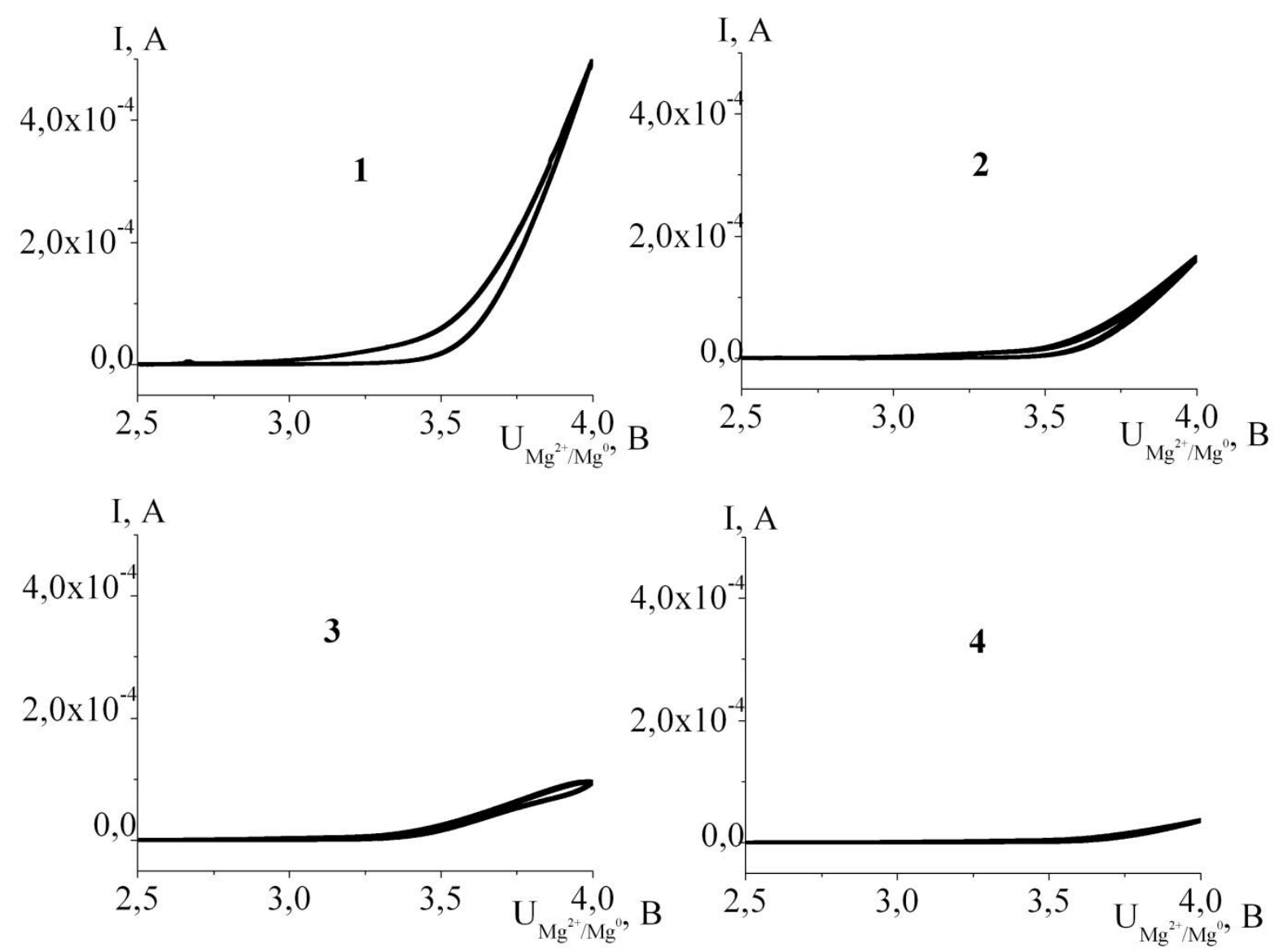

$$
\begin{aligned}
& 1-1,0 \mathrm{M} \mathrm{Mg}\left(\mathrm{ClO}_{4}\right)_{2}+\mathrm{G} 1 ; 2-1,0 \mathrm{M} \mathrm{Mg}\left(\mathrm{ClO}_{4}\right)_{2}+\mathrm{G} 2 \\
& \left.\left.3-1,0 \mathrm{M} \mathrm{Mg}\left(\mathrm{ClO}_{4}\right)_{2}\right)+\mathrm{G} 3 ; 4-1,0 \mathrm{M} \mathrm{Mg}\left(\mathrm{ClO}_{4}\right)_{2}\right)+\mathrm{G} 4
\end{aligned}
$$

Рис. 8. Вольтамперные характеристики электролитов на основе 1,0 M $\mathrm{Mg}\left(\mathrm{ClO}_{4}\right)_{2}$ на платиновом электроде. Скорость развертки потенциала $2 \mathrm{mB} / \mathrm{c}$

Введение в состав электролита дополнительно перхлората лития $\mathrm{LiClO}_{4}$ (рис. 9) или использование смесей глимов (рис.10) не приводит к существенному изменению формы фоновой характеристики. Увеличение концентрации солей значительно увеличивает значение тока в анодной области. 

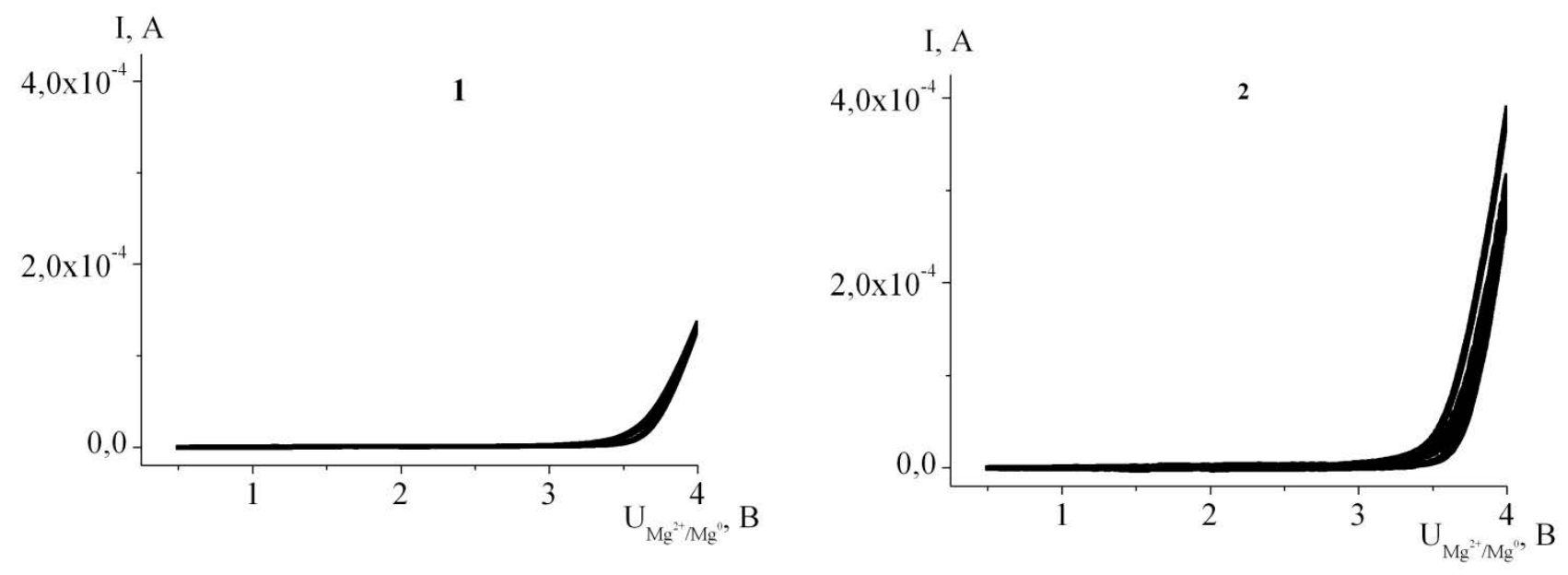

$$
\begin{gathered}
1-0,25 \mathrm{M} \mathrm{Mg}\left(\mathrm{ClO}_{4}\right)_{2}+0,25 \mathrm{M} \mathrm{LiClO}_{4}+\mathrm{G} 1 ; \\
2-0,5 \mathrm{M} \mathrm{Mg}\left(\mathrm{ClO}_{4}\right)_{2}+0,5 \mathrm{M} \mathrm{LiClO}_{4}+\mathrm{G} 1
\end{gathered}
$$

Рис. 9. Вольтамперные характеристики электролитов на основе моноглима G1 на платиновом электроде. Скорость развертки потенциала 2 мB/c.

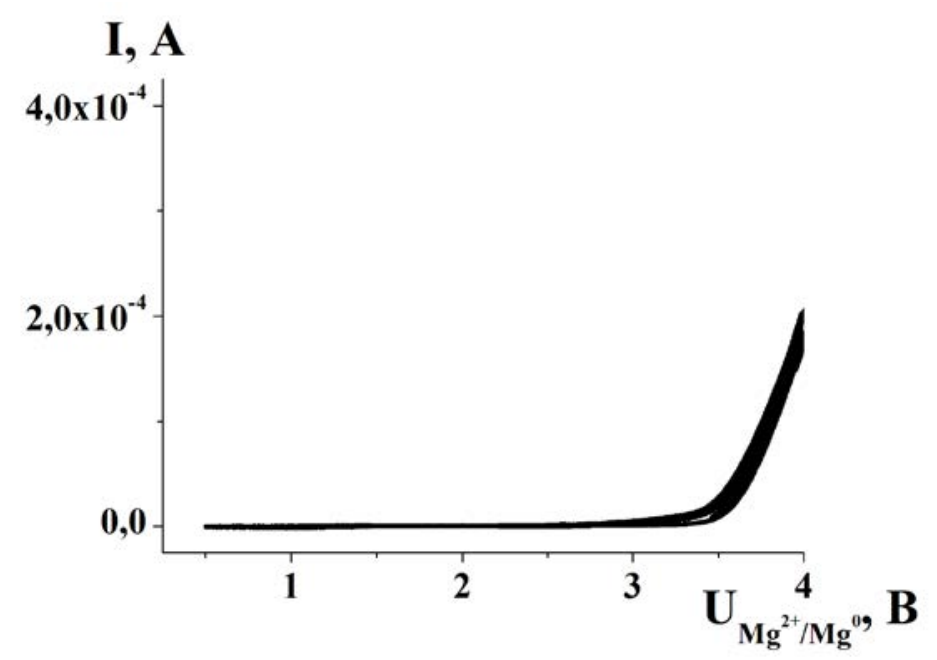

Рис. 10. Вольтамперные характеристики электролита состава $0,5 \mathrm{M} \mathrm{Mg}\left(\mathrm{ClO}_{4}\right)_{2}$ + G1:G4=1:1 на платиновом электроде. Скорость развертки потенциала 2 мB/с

Bсе электролиты, составы которых приведены в таблице 1, являются электрохимически стабильными в диапазоне потенциалов от 0,5 до 3,5 В и могут быть успешно использованы в источниках тока системы $\mathrm{Mg}-\mathrm{MnO}_{2}$. При этом преимущества имеют электролиты с более высокой проводимостью. 
Дальнейшие исследования направлены на исследование влияния состава неводного электролита на кинетику электрохимических процессов.

\section{3. Выводы}

1. Исследованные электролиты на основе глимов и их смесей могут быть рекомендованы для использования в источнике тока системы $\mathrm{Mg}-\mathrm{MnO}_{2}$.

2. Электролиты на основе $1 \mathrm{M}$ раствора $\mathrm{Mg}\left(\mathrm{ClO}_{4}\right)_{2}$ имеют значение проводимости порядка $10^{-3} \mathrm{CM}^{\cdot} \mathrm{cm}^{-1}$. Значение ионной проводимости $1 \mathrm{M}$ раствора $\mathrm{Mg}\left(\mathrm{ClO}_{4}\right)_{2}$ в глимах с общей формулой $\mathrm{CH}_{3} \mathrm{O}\left(\mathrm{C}_{2} \mathrm{H}_{4} \mathrm{O}\right)_{n} \mathrm{CH}_{3}$ снижается в ряду G1 > G2 > G3 > G4. Это обусловлено увеличением вязкости растворитея и уменьшением его донорного числа.

3. Введение в электролит $0,5 \mathrm{M} \mathrm{LiClO}_{4}$ позволяет снизить концентрацию ионов магния в электролите при сохранении высоких значении проводимости на уровне $710^{-3} \mathrm{CM}^{\cdot} \mathrm{cm}^{-1}$ при $25^{\circ} \mathrm{C}$.

4. Увеличение температуры -20 до $+60{ }^{\circ} \mathrm{C}$ приводит к неаддитивному увеличению проводимости. Например, для электролита $1 \mathrm{M} \mathrm{Mg}\left(\mathrm{ClO}_{4}\right)_{2}$, G1 проводимость увеличивается в 6 раз, а в электролите $1 \mathrm{M} \mathrm{Mg}\left(\mathrm{ClO}_{4}\right)_{2}$, $\mathrm{G} 4$ - в 3 pasa.

5. В диапазоне 0,5 - 3,5 В исследуемые электролиты обладают электрохимической стабильностью и могут быть успешно использованы в источниках тока системы $\mathrm{Mg}-\mathrm{MnO}_{2}$.

\section{Благодарность}

Данная работа выполнена в рамках проекта Министерства образования и науки Украины № 42170790 «Розробка високоенергоємних джерел струму на основі українських магнієвих i марганцевих сировинних матеріалів для інноваційного приладобудування». Исследования поддерживались в рамках проекта NATO SPS 985148 "Development of New Cathodes for Stable and Safer Lithium-Sulfur Batteries”. Магниевый анод может быть перспективным для источников тока с катодом на основе серы. Заведующая и научный руководитель научно-исследовательской лаборатории химических источников 
тока, научный руководитель проекта МОН и проекта НАТО в ДВНЗ УДХТУ д.х.н., проф. Шембель Е.М.

\section{Литература}

[1] Zhang, R., Ling, Ch., Arbor, A. 2016. MRS Energy \& Sustainability : A Review Journal. 3, 1. DOI:10.1557/mre.2016.2.

[2] Canepa, P., Gautam, G.S., Hannah, D.C., Malik, R., Liu, M., Gallagher, K.G., Persson, K.A., Cede, G. 2017. Chem. Rev. 117, 5, 4287. DOI: 10.1021/acs.chemrev.6b00614.

[3] Mizuno Fuminori, Singh Nikhilendra, Arthur Timothy S., Fanson Paul T., Ramanathan Mayandi, Benmayza Aadil, Prakash Jai, Liu Yi-Sheng, Glans PerAnders, Guo Jinghua. 2014. Front energy Reseach. 2, 1.

[4] Kim Ju-Sik, Chang Won-Seok, Kim Ryoung-Hee, Kim Dong-Young, Han Dong-Wook, Lee Kyu-Hyoung, Lee Seok-Soo, Doo Seok-Gwang. 2014. J. Power Sourcesю, 273, 210.

[5] Timothy S. Arthur, Per-Anders Glans, Nikhilendra Singh, Oscar Tutusaus, Kaiqi Nie, Yi-Sheng Liu, Fuminori Mizuno, Jinghua Guo, Daan Hein Alsem, Norman J. Salmon, Rana Mohtadi. 2017. Chem. Mater. 29, 7183. DOI: 10.1021/acs.chemmater.7b01189.

[6] Jake, T. Herb, Carl, A. Nist-Lund, Craig B. Arnold. 2016. ACS Energy Lett. 1, 1227. DOI: 10.1021 /acsenergylett.6b00356.

[7] Adam J Crowe, John L DiMeglio, Kyle K Stringham, Bart M Bartlett. 2017. J. Phys. Chem. C. 121, 38, 20613. DOI: 10.1021/acs.jpcc.7b06068.

[8] Se-Young Ha, Yong-Won Lee, Sang Won Woo, Bonjae Koo, Jeom-Soo Kim, Jaephil Cho, Kyu Tae Lee, Nam-Soon Choi. 2014. ACS Appl. Mater. Interfaces. 6, 4063. dx.doi.org/10.1021/am405619v.

[9] Dong Young Kim, Younhee Lim, Basab Roy, Young-Gyoon Ryub, Seok-Soo Lee. 2014. Phys. Chem. Chem. Phys. 16, 25789. DOI: 10.1039/c4cp01259c.

[10] Niya Sa, Nav Nidhi Rajput, Hao Wang, Baris Key, Magali Ferrandon, Venkat Srinivasan, Kristin A. Persson, Anthony K. Burrell, John T. Vaughey. 2016. RSC Adv. 6, 113663. DOI: 10.1039/c6ra22816j.

[11] Tao Gao, Xiao Ji, Singyuk Hou, Xiulin Fan, Xiaogang Li, Chongying Yang, Fudong Han, Fei Wang, Jianjun Jiang, Kang Xu, Chunsheng Wang. 2017. Adv. Mater. 1704313. DOI: 10.1002/adma.201704313.

[12] Song Jaehle, Sahadeo Emily, Noked Malachi, Lee Sang Bok. 2016. Journal Physical Chemistry Letters. 7, 1736.

[13] Tang, S. 2014. RSC Adv. 4, 22, 11251.

[14] Lutz, L., Yin, W., Grimaud, A., Alves Dalla Corte, D., Tang, M., Johnson, L. 2016. The Journal of Physical Chemistry. 120, 36, 20068. 


\title{
Estimation of the Primary Batteries State of Charge and State of Art by Frequency Characteristics of Electrochemical Impedance Spectra
}

\author{
Riabokin O.L., Bojchuk O.V., Pershina K.D.
}

Joint Department of Electrochemical Energy Systems NAS of Ukraine, Kiev, Vernadsky ave. 38-A, 03142

Electrochemical Impedance Spectroscopy (EIS) is widely used for measurement and study of the electrode materials and electrochemical properties of electrochemical devices [1-5]. There are many methods for obtaining various electrochemical parameters using EIS [1-5]. Moreover, the intercalation of ions into battery electrodes could be fixed by EIS spectra using their ability to response the solid-state transport of charge carriers in the active material at low frequencies [6]. It is well known that the transport of charge carriers is limited by ionic diffusion in many battery materials due to the high mobility of electrons $[7,8]$. Traditionally the diffusion in battery electrodes with large particle sizes is described by Warburg-type diffusion impedance, which draws a $45^{\circ}$ line in the complex plane representation (Nyquist plot), and is widely reported at low frequencies. Such response is well described by a linearized diffusion model [9]. But in primary batteries the electrode process consumes zincate ions and produces hydroxyl ions during charge in the zinc electrode compartment; inversely, during discharge it produces zincate ions and consumes hydroxyl ions [10]. In this case the transport of zinc material leads to a reduction of capacity and service life of a battery due to formation of zinc species which entrain zinc, such as $\mathrm{Zn}, \mathrm{ZnO}, \mathrm{Zn}(\mathrm{OH})_{2}, \mathrm{~K}_{2} \mathrm{Zn}(\mathrm{OH})_{4}, \mathrm{Zn}(\mathrm{OH})_{4}{ }^{2-}$ or polymeric zinc species, and decreases the size of particles on the electrode/electrolyte boundary [11]. Such processes lead to a significant deviation from linearity and can't be described by the linearized diffusion model, because the penetration depth of diffusion can reach the impermeable current collector of a thin electrode film or the 
reflective center of a nanoparticle at accessible low frequencies, due to short diffusion lengths in the thin film and nanoparticles [7, 12 - 14]. Therefore, it's the reason to apply parameters that describe the nonlinear behavior of diffusion, in particular, the model of anomalous diffusion. This model gives relatively simple equations in the frequency domain based on frequency dependence of the differential capacitance from capacitance fractional derivatives and estimates the intensity of the ions motion, depending on the frequency change [15]. So, the purpose of the work is to apply the required frequency dependent parameters of the EIS to estimate the primary batteries state of charge and state of art.

\section{Experimental}

Alkaline zinc manganese primary batteries (Duracell) in AAA gross geometry (MN 2400) with a voltage of $1.5 \mathrm{~V}$ were chosen as the samples of test. The discharge of this batteries was carried out at the potentiostat in galvanostatic mode under DC $10,20,30,40,50,60 \mathrm{~mA} / \mathrm{cm}^{2}$ at a temperature of $(20 \pm 5)^{\circ} \mathrm{C}$ within 80 minutes in accordance to international standards [16]. Before the discharging, the samples were stood at $1.5 \pm 0.2 \mathrm{~h}$. for obtaining the temperature equilibrium in the electrochemical system. The value of discharge currents based on the nominal capacity of the batteries in $\mathrm{A} \bullet \mathrm{h}$ was calculated. Internal resistance at constant current was calculated by the formula:

$$
R=\frac{U_{\mathrm{i}}-U_{\mathrm{f}}}{I_{2}-I_{1}}
$$

$I_{2}=0,2 \cdot I_{1}, I_{1}$ - discharge currents.

The EIS spectra were recorded using an Autolab-30 electrochemical module (Ekochemie BV, Netherlands) equipped with a Frequency Response Analyzer module. The measurements were performed according to a standard procedure in the frequency range of $0.01 \mathrm{~Hz}$ to $1.0 \mathrm{MHz}$ with a single pulse amplitude of $\pm 5 \mathrm{mV}$ into two electrode cell. The module was controlled using Autolab 4.7 software with the subsequent processing using the Zview 2.0 software package via the complex amplitude method.

\section{Results and discussion}

Impedance spectra of samples after various current external loads have established 
a significant difference of their form (Fig. 1a, 2a). The typical displacements in the middle-frequency $\left(10^{2}-10^{3} \mathrm{~Hz}\right)$ and the low-frequency $\left(10^{-1}-10^{1} \mathrm{~Hz}\right)$ regions of the spectrum have been fixed too (Fig. 1b, 2b). So the Warburg-type diffusion impedance, which draws a $45^{\circ}$ line in the complex plane representation, which has been widely reported at low frequencies, can't be applied, because in all the cases the line in the complex plane representation is below $45^{\circ}$. Such dependencies have been well described by anomalous diffusion model under the conditions of the adsorption limitation on the electrode/electrolyte interface [15]. In compliance with the model it is able to partition of the diffusion flows into two parts: the diffusion between the macro grains of the electrode materials:

$$
J=-D \frac{\partial^{1-\gamma}}{\partial t^{1-\gamma}} \frac{\partial c}{\partial x}
$$

and diffusion between the microparticles:

$$
\frac{\partial^{2-\gamma} C}{\partial t^{2-\gamma}}=D \frac{\partial^{2} C}{\partial x^{2}}
$$

The first type of diffusion could be described by Fick's second law because in most active materials the mobility of electrons is much higher than that of ions. As electrons become freely available in the system, the mean electric field quickly relaxes, resulting in local charge neutrality in the bulk. Under such conditions ionic diffusion limits transport of the charge carriers, and a neutral diffusion equation, Fick's law, can be recovered for the ion material balance in the system. In this case the electrochemical double layer develops at the interface due to the potential drop across it. The double layer charging process can be modeled with the ideal capacitor equation [7]. Taking into account the potential drop of the dense part of the DL the capacitance is described by the equation:

$$
C=q / c_{1}+q / c_{2}+q / c_{3}
$$

$c_{1}, c_{2}, c_{3}$ - differential capacitance of the various parts of DL

Thus the macroscopic capacitance can be calculated as:

$$
C_{\max }=3 R_{\max } \omega_{\max }
$$

Microscopic capacity corresponding to the degree of destruction of the electrode can be calculated by macroscopic capacitance fractional derivative: 


$$
C_{\min }=\frac{1}{3 R_{\max } \omega_{\max }^{2-\gamma}}
$$

So, it can get a visual picture of the battery electrode/electrolyte interface changes using a three-dimensional coordinate system (frequency, differential capacitance and capacitance fractional derivatives). The performance of the graphical integration demonstrates significant differences in the structure of electrode/electrolyte interface under different current loads (Fig. 1a, b, c, d), i.e. battery state of art. Such behavior of the batteries made it possible to assume the state of charge by simple calculation using the maximum shift of phase angle values and values of frequencies near this maximum (Fig. 1b, 2b).

$$
f_{r}(t)=\frac{f_{0}}{\sqrt{1-\frac{t}{T_{D}}}}
$$

$f_{0}$ - the frequency of the maximum shift of phase angle of the charged element, $t$ time, $T_{D}$ - time of shift when discharged [2]. Then, taking into account the shift of the frequency range of the:

$$
\mathrm{SOC}=\frac{f_{T D}}{f_{0}} \times 100 \%
$$

Also, the linear dependence has the ratio of absolute values of the phase angle shift:

$$
\mathrm{SOC}=\frac{\theta_{\mathrm{TD}}}{\theta_{0}} \times 100 \%
$$

Batteries state of charge calculations by different methods (Table 1) show constitutive differences in charge values and mistakes of measurements, especially under high current density. Using of eq. 7 significantly increased batteries SOC values. This allows us to suppose that this method of calculation is incorrect. The SOC calculation by maximum phase angle shift gave more correct results. That allowed us to offer it as an express test of the battery SOC. 


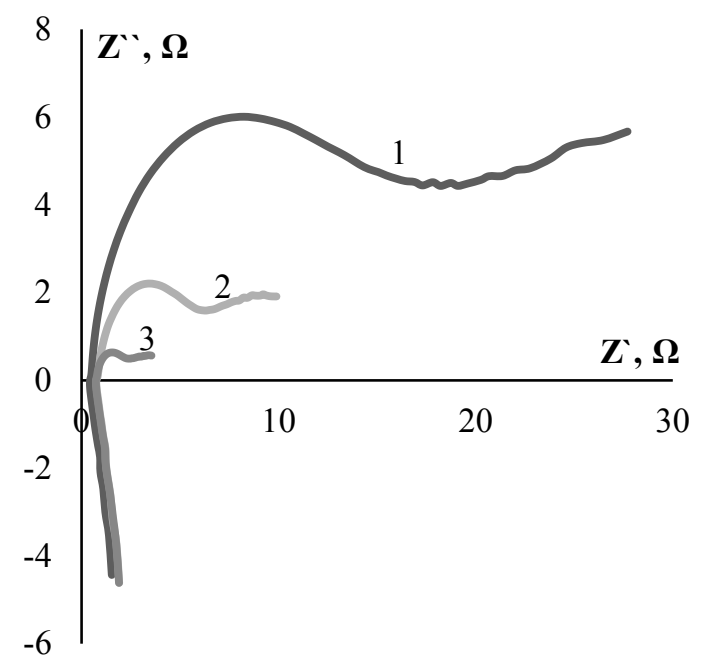

(a)

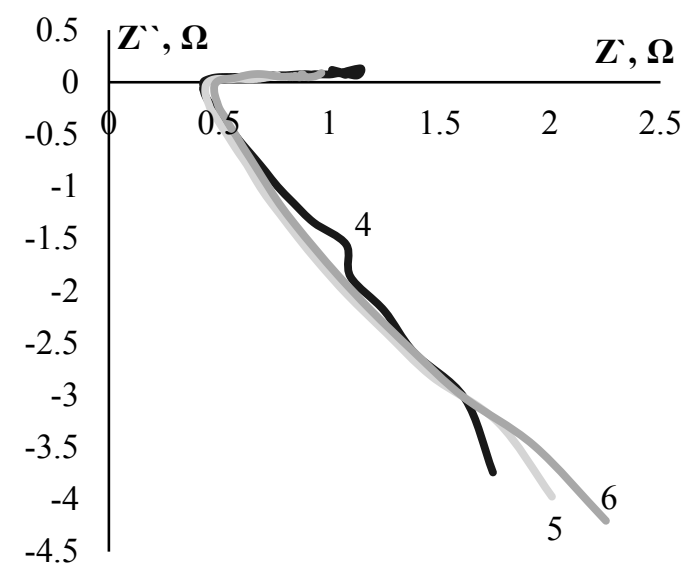

(c)

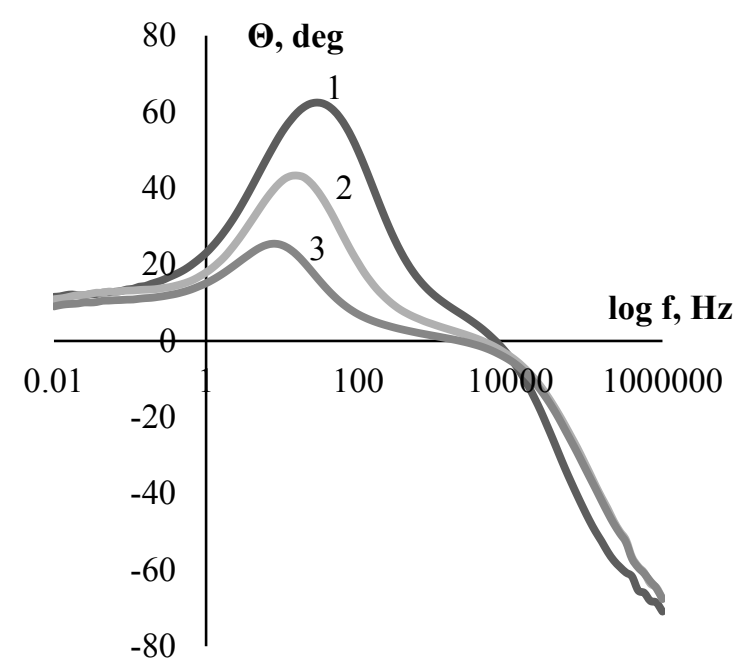

(b)

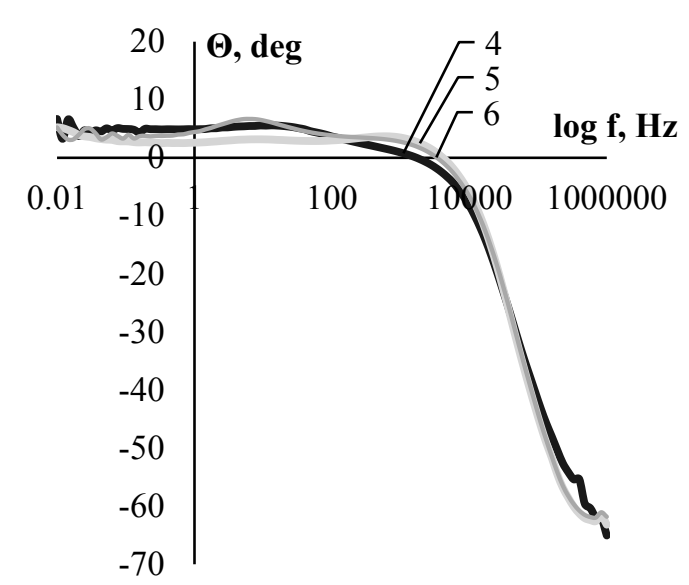

(d)

Fig. 1. EIS of batteries after discharge in Nyquist coordinates (a) $1-10 \mathrm{~mA} / \mathrm{cm}^{2}, 2$ $20 \mathrm{~mA} / \mathrm{cm}^{2}, 3-30 \mathrm{~mA} / \mathrm{cm} 2$; (c) $4-40 \mathrm{~mA} / \mathrm{cm}^{2}, 5-50 \mathrm{~mA} / \mathrm{cm}^{2}, 6-60 \mathrm{~mA} / \mathrm{cm}^{2}$. In Bode coordinates after discharge: (b) $1-10 \mathrm{~mA} / \mathrm{cm}^{2} ; 2-20 \mathrm{~mA} / \mathrm{cm}^{2}, 3-30 \mathrm{~mA} / \mathrm{cm} 2$, (d) $4-40 \mathrm{~mA} / \mathrm{cm}^{2}, 5-50 \mathrm{~mA} / \mathrm{cm}^{2}, 6-60 \mathrm{~mA} / \mathrm{cm}^{2}$ 


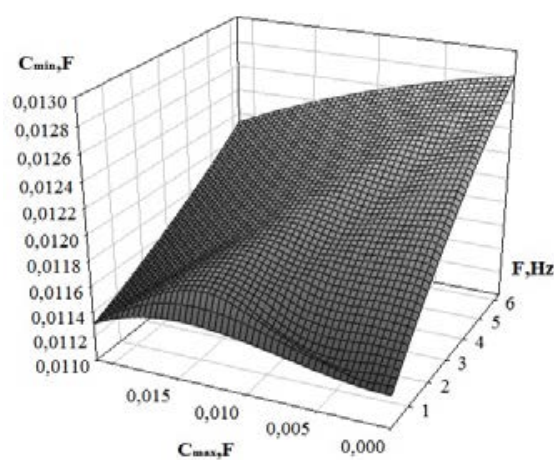

(a)

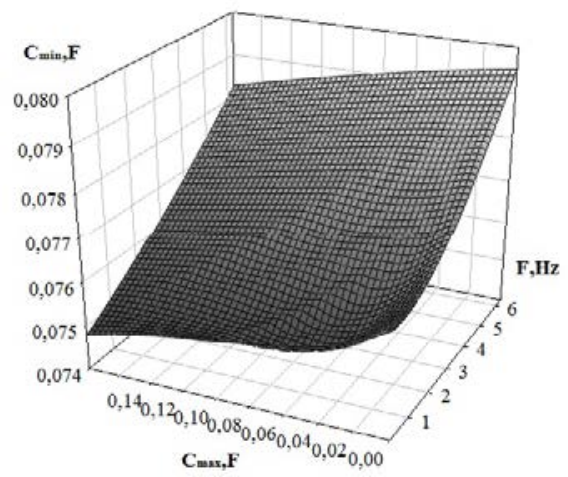

(c)

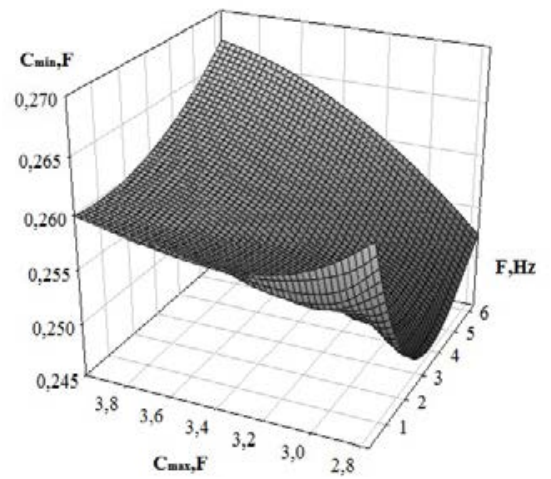

(e)

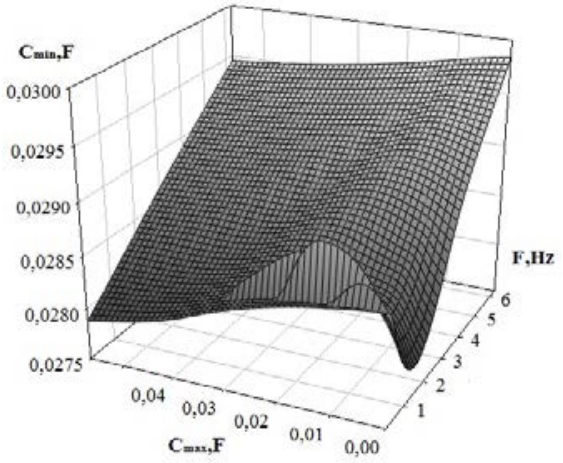

(b)

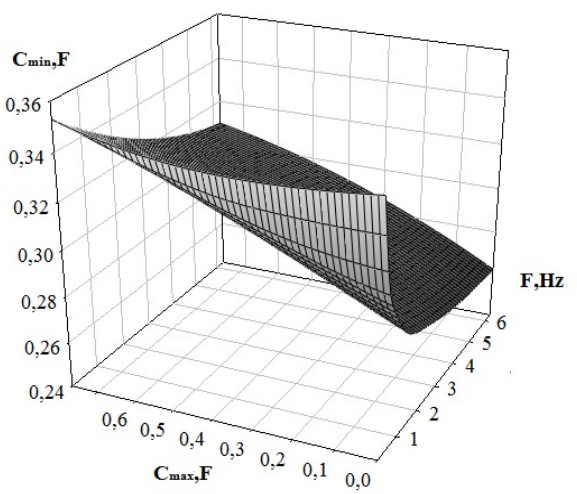

(d)

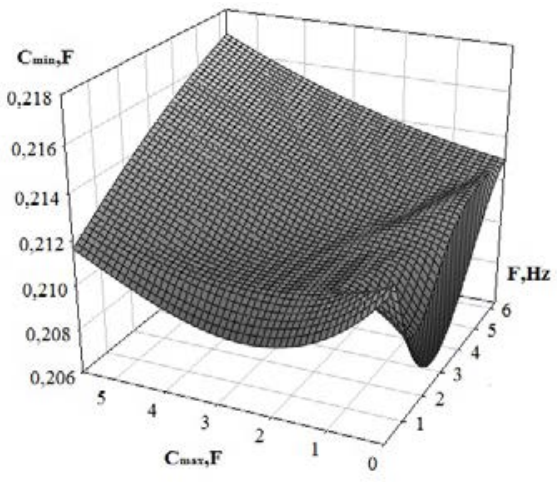

(f)

Fig. 2. 3D discharge diagram at (a) $10 \mathrm{~mA} / \mathrm{cm}^{2}$, (b) $2-20 \mathrm{~mA} / \mathrm{cm}^{2}$, (c) $3-30$ $\mathrm{mA} / \mathrm{cm} 2$, (d) $4-40 \mathrm{~mA} / \mathrm{cm}^{2}$, (e) $5-50 \mathrm{~mA} / \mathrm{cm}^{2}$, (f) $6-60 \mathrm{~mA} / \mathrm{cm}^{2}$ in the low frequency range 
Table 1 . Results of battery charge measurements by different methods

\begin{tabular}{ccccccc}
\hline $\begin{array}{l}\text { Density of } \\
\text { discharge } \\
\text { current, } \\
\mathrm{mA} / \mathrm{cm}^{2}\end{array}$ & $\begin{array}{l}\text { Maximum } \\
\text { of initial } \\
\text { frequency } \\
f_{0}, \mathrm{~Hz}\end{array}$ & $\begin{array}{l}\text { Maximum of } \\
\text { frequency } \\
\text { after } \\
\text { discharging } \\
f_{T D}, \mathrm{~Hz}\end{array}$ & $\begin{array}{l}\text { The value } \\
\text { of the } \\
\text { phase } \\
\text { angle shift } \\
\Theta, \text { deg }\end{array}$ & $\begin{array}{l}\text { Calculated } \\
\text { SOC by } \\
\text { eq.7, } \%\end{array}$ & $\begin{array}{l}\text { Calculated } \\
\text { SOC by } \\
\text { eq.9, \% }\end{array}$ & $\begin{array}{l}\text { SOC according to } \\
\text { standard } \\
\text { measurements, } \\
\%\end{array}$ \\
\hline 0 & 57,50 & 57,50 & 76,22 & 0 & 0 & 0 \\
10 & 57,50 & 33,11 & 62,33 & $42 \pm 2,7$ & $18 \pm 0,5$ & $12 \pm 1,5$ \\
20 & 57,50 & 19,05 & 42,94 & $67 \pm 2,4$ & $44 \pm 0,5$ & $44 \pm 1.5$ \\
30 & 57,50 & 10,97 & 24,76 & $81 \pm 7,6$ & $68 \pm 0,5$ & $68 \pm 1,5$ \\
40 & 57,50 & 10,97 & 5,50 & $89 \pm 9,5$ & $93 \pm 0,7$ & $60 \pm 5,5$ \\
50 & 57,50 & 10,97 & 3,17 & $89 \pm 10,5$ & $96 \pm 0,7$ & $52 \pm 10,4$ \\
\hline
\end{tabular}

\section{Conclusion}

The application of the frequency dependent EIS parameters in low frequency range estimates the primary batteries state of charge and state of art. Data application of three-dimensional coordinate system (frequency, differential capacitance and fractional derivatives from this capacitance) makes it possible to perform a graphical integration procedure. This procedure demonstrates significant differences in the structure of electrode/electrolyte interface under different current loads, and gives an opportunity for battery state of art estimation. The state of batteries charge estimated by different methods has shown constitutive differences in charge values, especially under high current density. Method based on the ratio of frequencies near maximum shift of phase angle has the highest deviation relative to the standard method of the battery SOC estimation. The SOC calculation by maximum phase angle shift has given more correct results and minimal mistakes during measurements. The ratio of maximum phase angle shift has been proposed as express test of the battery SOC.

\section{References}

[1] J.P. Christophersen, C.G. Motloch, J.L. Morrison, W. Albrecht, , U.S. Patent, No. US 2007/0257681 (2007).

[2] H.J. Daniel, A.K. Baert, A. Vervaeta, IEICE Trans. Commun., INTELEC'03, E87-B (12) (2004) 3478-3484. 
[3] B. Hirschorn, M. E. Orazem, B. Tribollet, V. Vivier, I. Frateur, M. Musiani, Electrochim. Acta 55 (2010) 6218-6227.

[4] Shih, T.-C. Lo, Electrochemical impedance spectroscopy for battery research and development, Tech. rep., Solartron Instruments (1996) .

[5] Troltzsch, O. Kanoun, H.-R. Trankler, , Electrochimica Acta 51 (89) (2006) $1664-1672$

[6] E. Karden, S. Buller, R. W. Doncker, Journal of Power Sources, 85(1), (2000)72-78

[7] W. Lai, F. Ciucci, J. Electrochem. Soc., 158(2) (2011) A115-A121.

[8] J. Song, M.Z. Bazant, J. Electrochem. Soc., 160(1) (2013) A15-A24.

[9] B.A. Baukamp, Electrochim. Acta, 169(1-4) (2004) 65-73.

[10] M.D. Levi and D., Electrochim. Acta, 45(1-2) (1999) 167-185.

[11] R.E.F. Einerhand, W. Visscher, J. Electrochem. Soc., 138(1) (1991) 7-17.

[12] J.P. Meyers, M. Doyle, R. M. Darling, and J. Newman, J. Electrochem. Soc., 147(8) (2000) 2930-2940.

[13] D.R. Franceschetti, J.R. Macdonald, and R.P. Buck, J. Electrochem. Soc., 138(1991) 1368-1371.

[14] J. Xie, N. Imanishi, T. Zhang, A. Hirano, Y. Takeda, and O. Yamamoto, Mater. Chem. Phys., 120(2-3) (2010) 421-425.

[15] J. Bisquert, A. Compte, J. Electroanalytical Chemistry, 499 (2001) 112-120.

[16] International Standard IEC 61960:2003, Secondary cells and batteries containing alkaline or other non-acid electrolytes. Edition 2.0, 2011-06. 


\title{
Influence of amorphous carbon on the electrochemical characteristics of battery graphite
}

\author{
Suslov M. M., Muhin V. V. \\ Kiev National University of Technology and Design
}

\begin{abstract}
A flake natural graphite is most widely used today as an anode material for lithium-ion battery (LIA).
\end{abstract}

For these purposes a high-ordered graphite used that has a high purity, determined by the shape, structure and size of the particles. Such graphite is an ideal matrix for reversible intercalation of lithium ion. One of the largest sources of graphite raw materials in Europe is the Zavalivsky deposit of Kirovograd region (Ukraine), where the content of graphite in the original ore reaches $5-7 \%$. Some manufacturers prefer a synthetic graphite due to its excellent consistency and a high degree of purity compared with a natural one. In this work, the study of the amount of amorphous carbon on the electrochemical characteristics of GAK graphite grade from the Zavlivsky deposit was carried out. Amorphous carbon was formed by pyrolysis of a mixture with glucose in a microwave oven. The ratio of graphite and glucose was 1:1 and 1: 0.5 (by mass).

Adding an amorphous carbon and a carbon black in a small amounts makes it possible to stabilize the capacity, especially when working at higher densities of current. Nevertheless, a significant increase in these components leads to increasing in irreversible capacity and deterioration of graphite stability.

Key words: graphite, microwave irradiation, glucose, irreversible capacity, electrochemical characteristics.

\section{Вплив аморфного вуглецю на електрохімічні характеристики акумуляторного графіту}

Суслов М.М., Мухін В.В.

\section{Київський наиіональний університет технологій та дизайну}

На сьогоднішній день лусковий природний графіт найбільш широко використовується як анодний матеріал для літій-іонного акумулятора (ЛІА). Для цих цілей використовуються високо-впорядковані графіти, що володіють високою чистотою, визначеною формою, структурою і розмірами частинок. 
Такі графіти є ідеальною матрицею для оборотної інтеркаляції літію. Одним 3 найбільших джерел графітової сировини в Європі є Заваллівське родовище Кіровоградської області (Україна), де вміст графіту в вихідній руді сягає 5-7\%. Деякі виробники віддають перевагу синтетичному графіту через його чудову консистенцію і високий ступень чистоти в порівнянні з природним. Але вже існують сучасні методи очищення, які дозволяють домогтися чистоти природного графіту на рівні 99,9\% [1], тоді як синтетичний графіт має значно більш високу собівартість.

\section{1. Экспериментальна частина}

\section{1. Методи виготовлення та аналіз}

У даній роботі було скомбіновано та використано різні методики підготовки та очистки для досягнення кращого результату досліджень:

1. Механічна підготовка;

2. Механічна, хімічна підготовка;

3. Механічна, хімічна підготовка, СВЧ-опромінення.

«Механічна» підготовка полягала у розподілі фракцій по їх розмірах, ця операція проводилася за допомогою сит з різними діаметрами отворів $(25,35$, 45 мкм).

Хімічна підготовка включала в себе очищення графіту від домішок (металів, органічних частин, мінералів). Спосіб включав кислотну обробку графіту 3 наступною промивкою водою та сушінням, причому кислотну обробку графіту проводили в суміші двух концентрованих кислот - азотної, соляної [2]. Азотнута соляну брали у співвідношенні 1:3 (так звана "царська водка"), обробку здійснювали протягом 3-5 годин (в реакторі та нутч-фільтрі, виконаних 3 кислотостійких матеріалів). Після промивки водою продукти реакції фільтровали за допомогою водоструйного насосу та колби Бюхнера до $\mathrm{pH} 7$, далі - за допомогою дистильованої води - до досягнення промивною водою електропровідності вихідної дистильованої води, а перед сушінням обезводнювали, переважно за допомогою центрифуги.

Вихідна зольність Заваллєвського графіту після якісної флотаційної обробки становить 5-6 \%, а обробка в суміші двох кислот при середньому співвідношенні $\mathrm{HNO}_{3}: \mathrm{HCl}=1: 3$ дозволяє навіть за одну стадію отримати кінцеву зольність $\sim 0,02 \%$ [2].

Відомі принципи підвищення питомої ємності графітових електродів за рахунок використання в якості модифікаторів поверхні графіту таких високо енергоємних матеріалів, як аморфний вуглець [3].Для цього використовують вуглецевмісні речовини, які змішують 3 графітом і піддають піролізу 3 виділенням аморфного вуглецю. Вуглецевмісної речовини не повинно бути 
дуже багато (до 10\%). Аморфний вуглець повинен бути розподілений по поверхні графітових частинок якнайбільш рівномірно і в дрібнодисперсному стані.

Для покращення електрохімічних характеристик графіту нами було застосовано СВЧ-опромінення. До графіту додавали лимонну кислоту або глюкозу. Приготування суміші відбувалося наступним чином: графіт після механічної та кислотної очистки змішується 3 глюкозою та піддається ультразвуковій диспергації (УЗД) у дистильованій воді по 20 хвилин. Після УЗД матеріал ставиться на сушку на 6-9 годин з утриманням температурного режиму 100-110 ${ }^{\circ} \mathrm{C}$. Наступна операція-опромінення в СВЧ - пічці, режим 800 Вт, час опромінення - 15 хвилин, перерва 5-10 хвилин.Обробка в СВЧ - пічці повторювалася 4 цикли. При першому циклі опромінення у печі відбувається процес випаровування залишків води. У табл. 1 можна бачити зниження температури при СВЧ-опроміненні графіту від циклу до циклу.

Таблиця1. Різниця температур при СВЧ-опромінюванні природного графіту Заваллівського родовища

\begin{tabular}{|c|c|c|}
\hline № циклу & Температура, $\mathrm{t}^{\circ} \mathrm{C}$ & Час, хв. \\
\hline 1 & 820 & 15 \\
\hline 2 & 610 & 15 \\
\hline 3 & 540 & 15 \\
\hline 4 & 520 & 15 \\
\hline
\end{tabular}

Головним недоліком графіту є відносно низька питома ємність, оскільки навіть теоретичне значення $\mathrm{Q}_{\mathrm{C}}=372 \mathrm{MA} \cdot$ год / г.

$\mathrm{Si}, \mathrm{Sn}, \mathrm{Al}$, тверде вугілля та деякі інші матеріали активно досліджуються як альтернативні матеріали для літій-іонних батарей.

У даній роботі було проведено дослідження впливу кількості аморфного вуглецю на електрохімічні характеристики графіту (ГАК) Заваллівского родовища. Аморфний вуглець утворювався при піролізі суміші ГАК і глюкози в СВЧ печі. Співвідношення графіту і глюкози становило 1:1 та 1:0,5 (по масі). У таблиці 2 перелічені графіти 3 аморфним вуглецем, які були виготовлені за допомогою СВЧ-опромінення та піддавалися електрохімічним дослідженням. 
Таблиця 2. Перелік вуглецевих матеріалів, досліджених у роботі

\begin{tabular}{|c|c|c|}
\hline № & Марка графіту/маркування & $\begin{array}{c}\text { Співвідношення графіт/аморфний } \\
\text { вуглець (по масі) }\end{array}$ \\
\hline 1 & ГАК «вихідний» & - \\
\hline 2 & ГАК «1» & $1: 1$ \\
\hline 3 & ГАК «2» & $1: 0.5$ \\
\hline 4 & ГАК «3» & $1: 0.5+10 \%$ сажі \\
\hline
\end{tabular}

\section{2. Приготування електродної маси і макету}

Суспензії різного складу (табл. 3) на основі активної речовини - графіту виробництва Заваллівського графітового комбінату ГАК, було приготовлено у високообертовій мішалці (IKA RW 20). Перемішування компонентів тривало 20 хвилин при швидкості обертання мішалки 2000 об/хв. Потім було проведено обробку сумішей ультразвуковим диспергатором (УЗД) для дезагрегації i рівномірного розподілення складових суспензій. Отримані таким методом суміші було нанесено на заздалегідь підготовлену мідну фольгу за допомогою аплікатора з певним визначеним зазором. Фольгу з нанесеною катодною масою було висушено під інфрачервоною лампою.

Таблиця 3. Склад досліджених композитних матеріалів

\begin{tabular}{|c|c|c|c|c|}
\hline $\begin{array}{c}\text { Марка графіту/ } \\
\text { маркування }\end{array}$ & $\begin{array}{c}\text { Активна } \\
\text { речовина, } \\
\%\end{array}$ & $\begin{array}{c}\text { PVDFв } \\
\text { NMP, \% }\end{array}$ & $\begin{array}{c}\text { CB } \\
\text { (carbon } \\
\text { black), \% }\end{array}$ & $\begin{array}{c}\text { графіт/аморф } \\
\text { ний вуглець } \\
\text { (по масі) }\end{array}$ \\
\hline ГАК «1» & 92 & 8 & & $1: 1$ \\
\hline ГАК «2» & 92 & 8 & & $1: 0.5$ \\
\hline ГАК «3» & 82 & 8 & 10 & $1: 0.5$ \\
\hline
\end{tabular}

При збиранні елементів у аргоновому боксі за допомогою шприца в кожен робочий напівелемент було введено електроліт. Для дослідження була застосована електролітна система розчин $1 \mathrm{M} \mathrm{LiClO}_{4}$ в суміші розчинників етіленкарбонат: диметилкарбонат $=1: 1$ по масі. Напівелемент було витримано 5 хвилин перед збиранням для просочення електродної маси. На електрод було накладено сепаратор та кільце-ущільнювач. Зверху було вкладено кришку елемента з літієвим анодом, що служив у дослідженні електродом порівняння. 
Макети 3 укладеною кришкою було завальцьовано для герметизації за допомогою пневматичного пресу в іншому сухому аргоновому боксі, який сполучався форкамерою з боксом для заливки електроліту.

\section{2. Основні результати і їх обговорення}

\section{1. Структурні дослідження графітів}

Було проведено дослідження структурних характеристик досліджених типів графітів за допомогою сканувальної електронної мікроскопії (прилад JSM6700F, JEOL, Японія). 3 отриманих мікрофотографій розраховували розподіл часток за розмірами та визначали середній розмір часток для кожного типу графіту(рис. 1).

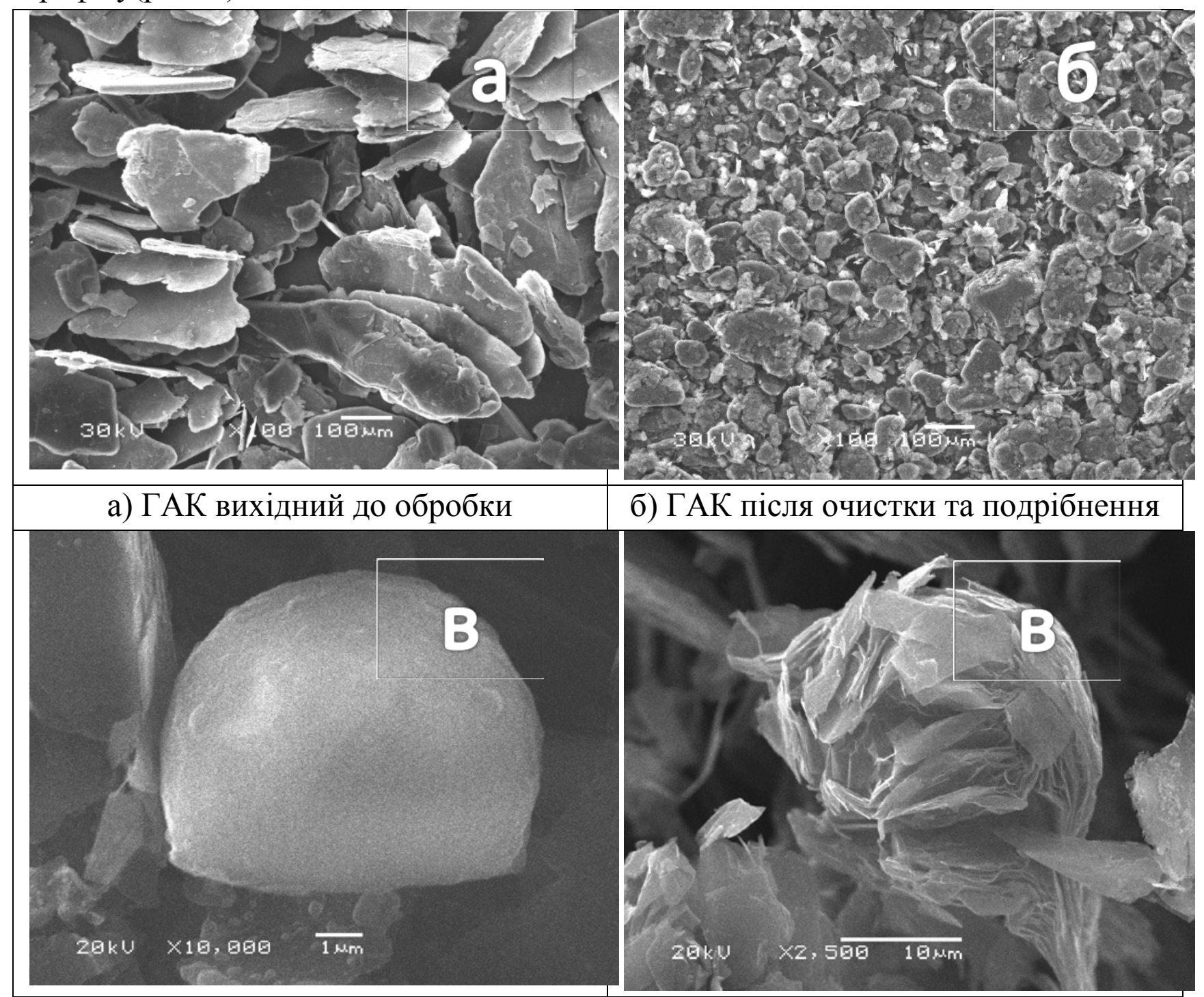

в) ГАК після СВЧ опромінення з утвореним аморфним вуглецем

Рис.1. Результати сканувальної електронної мікроскопії графітів 
Аналіз мікрофотографій вказує, що середні повздовжні розміри просіяних частинок графіту становлять відповідно від 40 до 200 мкм, в той же час оброблений графіт стає більш однорідний за розмірами частинок.СВЧопромінений матеріал відрізняється від двох вище наведених своєю структурою за рахунок утвореного аморфного вуглецю (за допомогою піролізу у СВЧ печі) та розірваних лусок (за рахунок термоудару внаслідок випаровування залишків $\mathrm{H}_{2} \mathrm{O}$ ).

\section{2. Електрохімічні дослідження та їх обговорення}

Результати електрохімічних досліджень ємності на першому циклі (Табл. 4, Рис. 2а) показують зменшення величини незворотної ємності зі зменшенням кількості аморфного вуглецю в складі електродного матеріалу.

Таблиця 4. Ємність на першому циклі

\begin{tabular}{|c|c|c|c|c|}
\hline $\begin{array}{c}\text { Модифікація } \\
\text { графіту }\end{array}$ & $\begin{array}{c}\text { Відношення } \\
\text { ГАК до } \\
\text { глюкози }\end{array}$ & $\begin{array}{c}\text { Смність на } \\
\text { першому циклі, } \\
\text { мА·год/г }\end{array}$ & $\begin{array}{c}\text { Незворотна } \\
\text { ємність, } \\
\text { мА·год/г }\end{array}$ & $\begin{array}{c}\text { Остаточна } \\
\text { ємність, } \\
\text { мА·год/г }\end{array}$ \\
\hline ГАК «1» & $1: 1$ & 376 & 83 & 290 \\
\hline ГАК «2» & $1: 0,5$ & 352 & 75 & 277 \\
\hline ГАК «3» & $\begin{array}{c}1: 0,5+10 \% \\
\text { СВ }\end{array}$ & 311 & 49 & 262 \\
\hline
\end{tabular}

В той же час, остаточна розрядна ємність після першого циклу спостерігається для варіанту ГАК «1» 3 урахуванням збільшення сумарної ємності за рахунок введення аморфного вуглецю, що також чітко видно з Рис. 2a.

Вже після 10 циклу графіт ГАК «1»дещо втрачає свою ємність, а навпаки ГАК «3» 3 домішками аморфного вуглецю і $10 \%$ сажі розформовується i виходить в лідери. Цей варіант зберігає найбільшу ємність і стабільність також при збільшенні струму розряду до $1 \mathrm{C}$, на що вказують результати циклювання композитів, наведені на рис. 3. 


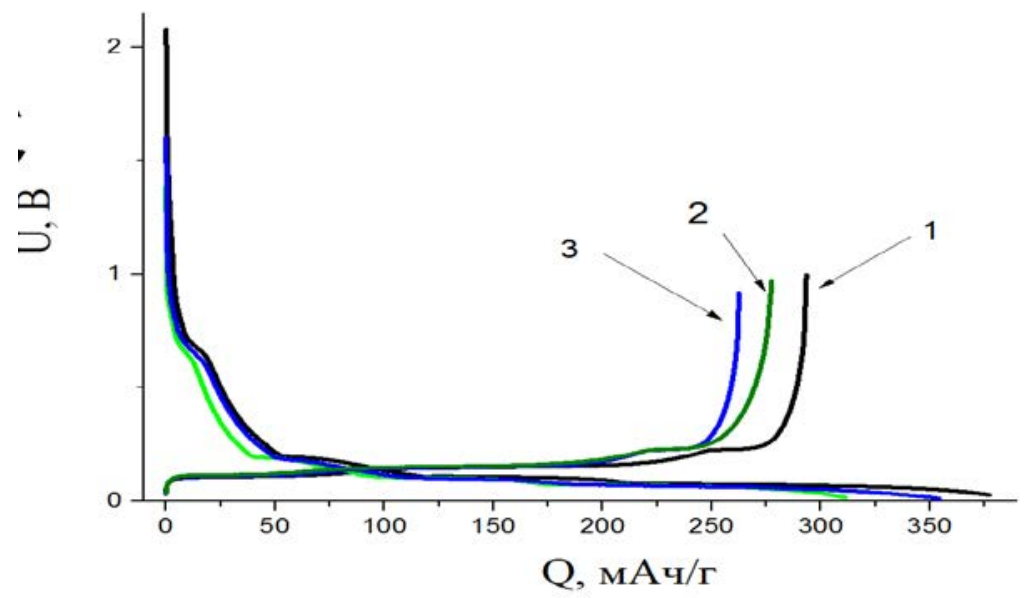

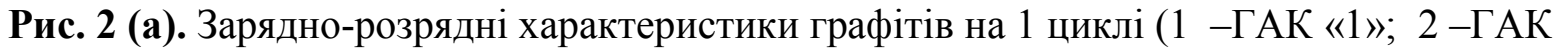
$\ll 2 » ; 3-\Gamma A K \ll 3 »)$

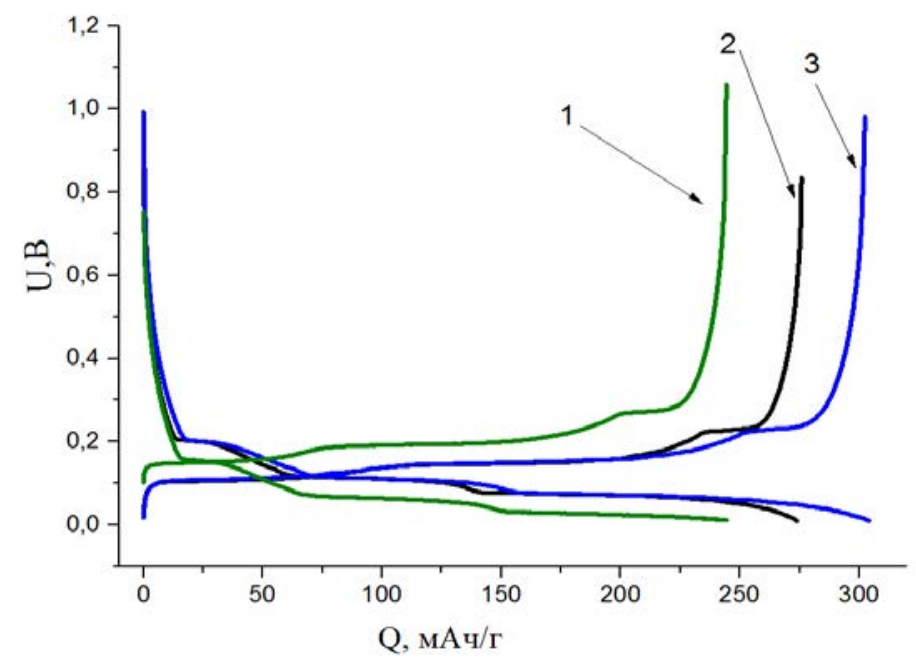

Рис. 2(б). Зарядно-розрядні характеристики графітів на 10 циклі (1 - ГАК «1»; 2 - ГАК $\ll 2 » ; 3-\Gamma A K \ll 3 »)$

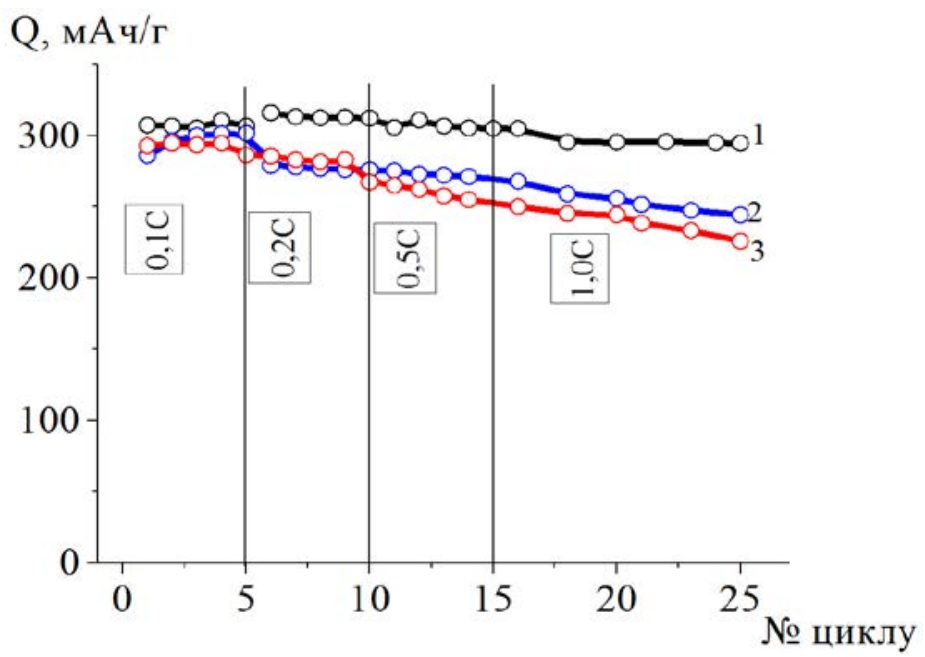

Рис. 3. Залежність питомої розрядної ємності від режиму розряду і кількості заряднорозрядних циклів для різних графітів: $1-$ ГАК «3»; $2-\Gamma A K \ll 1 » ; 3-\Gamma A K \ll 2 »$. 
3 наведених даних можна зробити наступні висновки щодо впливу досліджених факторів на стабільність електрохімічних властивостей графіту при тривалому циклуванні. Основним механізмом поступової деградації характеристик навіть умовно «ідеально-чистого» графітового електрода в процесі циклювання $є$ поступове «розхитування» його структури в результаті інтеркаляції-деінтеркаляції літію в графіт і пов'язаних з цим об'ємних змін системи "частинки графіту - полімерне сполучення"[1]. Звичайно, інтеркаляція літію в графіт не призводить до настільки великих змін об'єму, як при його інтеркаляції в кремній або олово (понад 300\%). Однак, навіть значно менші зміни об'єму також здатні поступово "розхитати" систему "частинки графіта тонка плівка полімеру". В результаті такого "розхитування" суцільність електрода поступово знижується, контакти між частинками графіту слабшають, зростає поляризація електрода і знижується ємність.

\section{Висновок}

Удосконалення структури природного графіту шляхом додавання до нього аморфного вуглецю (у співвідношенні 1:0,5) і сажі (до 10\%) дає можливість стабілізувати ємність, особливо при роботі на більш високих густинах струму. Разом з цим, значне збільшення цих компонентів призводить до збільшення незворотної ємності і погіршення стабільності графітових електродів.

\section{Література}

[1] Использование графитов Завальевского месторождения в качестве активних материалов для литий-ионных аккумуляторов/ В.З. Барсуков, Е.А. Ильин, К.В. Лихницкий и др.//Эектрохимия (2008), т.44, №5, с. 624-630.

[2] Спосіб хімічної очистки графіту /В.3. Барсуков, В.І. Лисін, В.Г. Хоменкотаін. // Патент України на винахід 98691(2012). - Бюл. № 11.

[3] Amorphous Carbon-Coated Tin Anode Material for Lithium Secondary Battery/M. Noh, Y.Kwon, H.Lee, et al.//Chem. Mater. (2005), v.17, p. 1926-1929. 


\title{
Toward bifunctional doped $\mathrm{MnO}_{2}$ oxygen electrocatalyst
}

\author{
Sokolsky G. ${ }^{1,2}$, Zudina L. ${ }^{2}$, Boldyrev E. ${ }^{3}$, Gauk N. ${ }^{2}$ Ivanov S. ${ }^{4}$
}

National Technical University of Ukraine «Igor Sikorsky Kyiv Polytechnic

\author{
Institute» \\ ${ }^{2}$ National Aviation University, Kyiv, Ukraine \\ ${ }^{3}$ Institute of General and Inorganic Chemistry of National Academy of Science \\ of Ukraine, Kyiv, Ukraine \\ ${ }^{4}$ National Academy of Culture and Arts Management, Kyiv, Ukraine
}

Processes of oxygen electroevolution (OEER) and electroreduction (OERR) is supposed to be important constituent part of water splitting technologies, sustainable energy generation such as fuel cells, metal-air batteries or regenerative fuel cells. Despite the excellent prospectives and theoretical electrical performance of them new findings and developments are still necessary. The example where improvements are crucial to make it practically available is the Lithium-air battery (LAB) technology $[1,2,3]$.

Oxides of transition metals with tailor-made properties are good candidates for LAB-applications as alternative to noble metals materials. Manganese dioxide has many advantages among other transition metals. It has high ORR activity, it is one of the best $\mathrm{H}_{2} \mathrm{O}_{2}$ decomposition catalysts, it found practical application in $\mathrm{Zn}$-air batteries for decades in addition to low cost and environmental friendliness [4].

On the other hand, electrocatalytic activity in both reduction and oxidation processes of a single compound is rare. Therefore, special bifunctional catalysts have been developed for LAB technologies. The bifunctionality is well-known in chemistry. For instance, many bifunctional catalysts in organic chemistry possess either Lewis or Brønsted basic functionality. Compared to single functional group catalysts, the cooperative effect of the two complementary functional groups can lead to new reactivity and stereocontrol in reactions that were previously challenging or 
unprecedented [5].

There are generally two strategies to improve the activity (or reaction rate) of an electrocatalyst system: (i) increasing the number of active sites on a given electrode (e.g. through increased loading or improved catalyst structuring to expose more active sites per gram), or (ii) increasing the intrinsic activity of each active site [6]. At the same time, there are physical limits to how much catalyst material can be loaded onto an electrode without affecting other important processes such as charge and mass transport. The difference between a good catalyst and a poor catalyst can be more than 10 orders of magnitude apart, whereas the difference between a high loading and a low loading catalyst might only be 1 to 3 orders of magnitude [7].

The electrolytic doping procedure has been developed in our research group [8, 9]. As shown recently, phase and chemical composition of electrocrystallisation product is dependent on dopant additive nature and concentration in an electrolyte. The electrochemical properties in this case are subjected to changes that otherwise are difficult to achieve. Enhanced electrocatalytic activity of Fe-doped $\mathrm{MnO}_{2}$ in phenol and VOC degradation was shown in [9], the peculiarities of electrocatalytic activity of doped $\mathrm{MnO}_{2}$ samples in oxygen electroreduction are also under consideration [10].

Manganese(IV) oxides are among the most effective non-precious (electro)catalysts of both oxidation and reduction processes, nevertheless there is a necessity to develop bifunctional catalysts that activate simultaneously oxidation and reduction. The phase composition and structure defects have profound influence on this material activity. The purpose of this work was to study influence of induced by dopant ions changes on ability of manganese(IV) oxides to be oxygen electrocatalyst.

\section{Experimental}

Manganese(IV) oxide samples were electrodeposited galvanostatically $\quad(i=$ $10 \mathrm{~A} / \mathrm{dm}^{2}$ ) at the platinum plate anode and the vitreous carbon plate as an auxiliary electrode. The pristine fluorine-containing electrolyte consisted of $0.1 \mathrm{M} \mathrm{HF}+0.7 \mathrm{M}$ $\mathrm{MnSO}_{4}$ and the dopant additives in the electrolyte were sulfates of the following concentration: $1.5 \mathrm{M} \mathrm{NH}_{4}{ }^{+}, 0.01 \mathrm{M} \mathrm{Fe}^{2+}, 0.01 \mathrm{M} \mathrm{Cr}^{3+}, 0.01 \mathrm{M} \mathrm{Co}^{2+}$. Some samples 
were prepared using trinary electrolytes by ions of metals. They contained besides manganese sulfate and hydrofluoric acid HF additives of cobalt sulfate and lithium hydroxide. The dopant ions were introduced by the addition of $0.03-1 \mathrm{M}$ of CoSO 4 and $0.1-4 \mathrm{M} \mathrm{LiOH}$. The concentration of manganese ions was also varied in the range $0.1-0.7 \mathrm{M}$. XRD study was performed on a DRON 4 instrument (Mo and $\mathrm{CuK \alpha} \alpha$-radiation).

The cyclic voltammetry (CVA) experiment was carried out in a standard three electrode cell and $0.3 \mathrm{M} \mathrm{LiOH}$ electrolyte saturated with $\mathrm{O}_{2}$ on IPC-PRO potentiostat - galvanostat at the potential scan rate to within 0.001-0.5 V/s. Carbon paste electrode (CPE) was assembled to study manganese dioxide samples electrocatalytic activity in ORR. CPE was a thoroughly grounded mixture of doped manganese oxide: graphite in the ratio 70:30 and polytetrafluoroethylene (PTFE) emulsion loaded into PTFE-tube.

\section{Results and discussion}

The XRD phase analysis showed the following main phase components depending on dopants added (Table 1). These results are in agreement with thermodynamics of hollandite phase since foreign ions like $\mathrm{NH}_{4}{ }^{+}$in structure channels decrease its free energy significantly [4] as a result of influence of entropic factor. The template doping effects of $\mathrm{M}^{+}$-ions on hollandite or $\alpha-\mathrm{MnO}_{2}$ stabilisation allow realization of electrocatalyst with structure tunnel size available for small molecules of water and organics. Ramsdellite or $\gamma-\mathrm{MnO}_{2}$ is crystallised with additives of transition metals $\left(\mathrm{Fe}^{2+}, \mathrm{Co}^{2+}\right)$ and at the presence of $\mathrm{Cu}^{2+}$ both effects take place. The low concentrations of $\mathrm{Cu}^{2+}$ additive (0.001-0.002 M) stabilize hollandite structure but the increase its content by the order of magnitude changes hollandite to semiamorphous ramsdellite phase and $\beta-\mathrm{MnO}_{2}$. The layered birnessite structure is formed at the presence of $\mathrm{Cr}^{3+}$ additives. 
Table 1. Chemical and phase composition of doped manganese dioxide samples obtained by anode electrodeposition at the presence of ionic additives from fluorinecontaining electrolytes.

\begin{tabular}{|c|c|c|c|c|}
\hline $\begin{array}{c}\text { Samples } \\
\text { Origin/dopant }\end{array}$ & 1 & 2 & 3 & 4 \\
\cline { 2 - 5 } & $\mathrm{NH}_{4}^{+}$ & $\mathrm{Cr}^{3+}$ & $\mathrm{Fe}^{2+}$ & $\mathrm{Co}^{2+}$ \\
\hline $\begin{array}{c}\text { Dopant ion concentration in } \\
\text { electrolyte, mol/L }\end{array}$ & 1.5 & 0.001 & 0.01 & 0.01 \\
\hline $\begin{array}{c}\text { Mn (total), mas. \% } \\
\begin{array}{c}\text { Dopant ion content in samples, } \\
\text { mas. \% }\end{array}\end{array}$ & - & 3.9 & 0.26 & 0.012 \\
\hline Phase components & $\alpha+\gamma$ & $\delta+\alpha$ & $\gamma+\beta$ & $\Gamma$ \\
\hline
\end{tabular}

As shown by XRD-data, significant additional broadening of (110) ramsdellite main XRD-pattern peak is observed at the presence of $0.001-0.01 \mathrm{M} \mathrm{Co}^{2+}$. The same tendency is less distinctive for $\mathrm{Fe}^{2+}$ due to its reducing activity in an electrolyte. These features are the results of the heterovalent substitution of transition metals that occupy Mn position in crystal lattice. Crystal chemistry gives the evidences in favour of this behavior of dopant additives. Isostructural to ramsdellite structure compounds exist (Pnma with orthorhombic symmetry of heterogenite $\mathrm{CoOOH}-$ groutite $\beta$ $\mathrm{MnOOH}$ - ramsdellite $\gamma-\mathrm{MnO}_{2}$ - goethite, $\left.\alpha-\mathrm{FeOOH}\right)$. Therefore, the simultaneous presence of these metals in an electrolyte gives prerequisites of solid solutions formation. Conditions of their preparation require further investigations. The results of XRD study of heavy doped by Co-samples in comparison with heterogenite XRD pattern are shown in Fig. 1. To summate mentioned above facts, the prospective of active site concentration increase is realized in case of $\mathrm{Mn}^{4+}$ sites heterovalent substitution by $\mathrm{Fe}^{2+}, \mathrm{Co}^{2+}$ and etc.

CVAs of doped $\mathrm{MnO}_{2} \mathrm{CPE}$ in $0.30 \mathrm{M} \mathrm{LiOH}$ solution saturated with oxygen were studied at $\mathrm{V}=20 \mathrm{mV} \cdot \mathrm{s}^{-1}$. Peaks of ORR become visible in $\mathrm{mA}$ range of currents in our CVA experiments after electrolyte saturation by oxygen or prolonged anode polarisation at potentials higher than $1 \mathrm{~V}(\mathrm{vs} \mathrm{Ag} / \mathrm{AgCl})$ at oxygen evolution. The 
weak two steps of ORR can be seen in the range of potentials -0.2 and $0.7 \mathrm{~V}$ and are the charge transfer controlled with the Tafel slopes $b$ that are in agreement with 60 and $120 \mathrm{mV}$ of ORR detected on Pt electrode correspondingly [11]. OER peaks are observed at the reverse direction of CVA scan after about $1.0 \mathrm{~V}$.

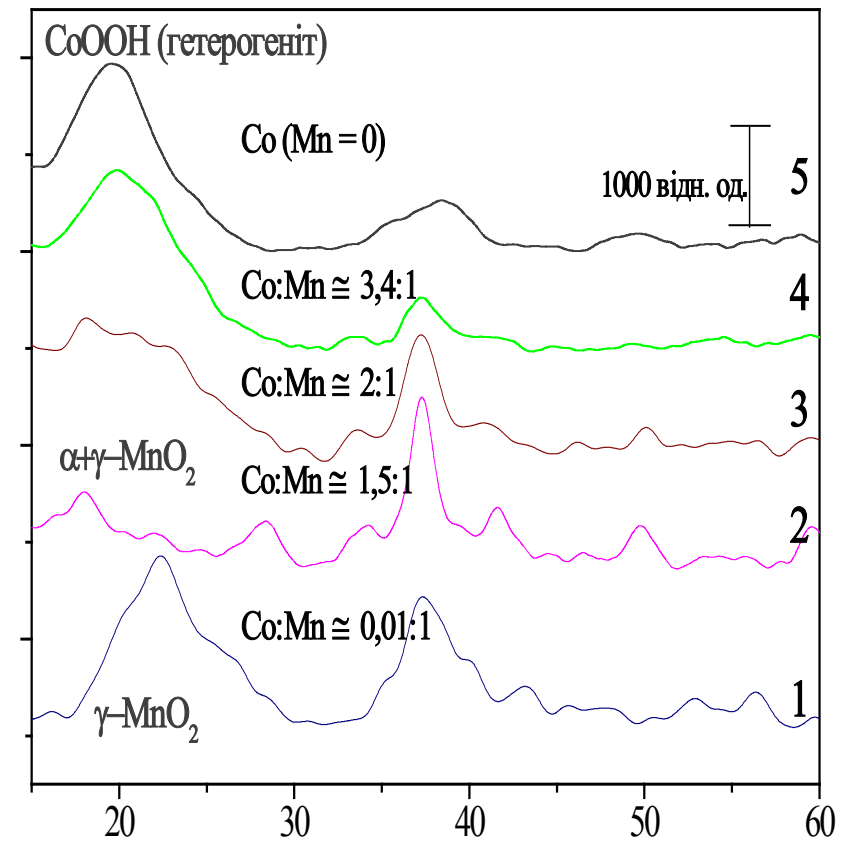

$2 \theta\left(\mathrm{Cu} K_{\alpha}\right)$
Fig. 1. XRD patterns of doped by Co and $\mathrm{Li}$ samples with different ration $\mathrm{Co:Mn}$ in an electrolyte in comparison with Co containing electrolyte

Analysis of ORR activity of investigated samples is shown in Table 2. $\mathrm{Fe}^{2+}$, and $\mathrm{Co}^{2+}$ doped samples display similar behaviour with two weak peaks of ORR currents. These samples have two well-defined $2 \mathrm{e}^{-}$steps of ORR with maximal current unlike Samples 1-3. $\Delta \mathrm{E}\left(\mathrm{E}_{\mathrm{OER}}-\mathrm{E}_{\mathrm{ORR}}\right)$ is close to $1.0 \mathrm{~V}$ which is in agreement with published data [12]. The anode current of OER makes up $56 \mathrm{~mA} / \mathrm{cm}^{2}$ for sample 1 which is evaluated from steady state polarisation curve and it is by about 40 times larger than ORR currents on this sample.

The electrolytic doping procedure improves the prospective of practical application of electrodeposited manganese(IV) oxides as electrocatalyst. The high activity of $\mathrm{Fe}^{2+}$-doped $\mathrm{MnO}_{2}$ indicates the positive role of $\mathrm{Fe}^{3+} / \mathrm{Fe}^{2+}$ redox pairs as active sites of surface states. Doped by $\mathrm{Co}^{2+}$ samples display high activity and some unique features in ORR(OER) also. It is proposed that combination of $\mathrm{Co}^{2+}$ and $\mathrm{Fe}^{2+}$ additives could be prospective as a bifunctional catalyst for LAB cathode application. 
Table 2. ORR electrochemical parameters of samples $1-4(\mathrm{~V}=0.02 \mathrm{~V} / \mathrm{s})$

\begin{tabular}{|c|c|c|c|c|}
\hline Sample & 1 & 2 & 3 & 4 \\
\cline { 2 - 5 } & $\mathrm{NH}_{4}^{+}$ & $\mathrm{Cr}^{3+}$ & $\mathrm{Fe}^{2+}$ & $\mathrm{Co}^{2+}$ \\
\hline ORR E $_{1}, \mathrm{~V}$ & - & - & 0.547 & 0.544 \\
\hline $\mathrm{I}_{1}, \mathrm{~mA} / \mathrm{cm}^{2}$ & - & - & 1.18 & 1.38 \\
\hline $\mathrm{ORR} \mathrm{E}_{2}, \mathrm{~V}$ & -0.028 & -0.111 & 0.023 & -0.015 \\
\hline $\mathrm{I}_{2}, \mathrm{~mA} / \mathrm{cm}^{2}$ & 1.24 & 0.56 & 0.29 & 0.33 \\
\hline
\end{tabular}

\section{Conclusion}

The electrolytic doping procedure developed in our research group obeys both strategy principles in improving electrocatalyst efficiency, i.e. increasing the number of active sites and intrinsic activity. The directed changes of phase composition increase intrinsic activity of surface sites comparing with conventional electrodeposition methods. The prospective of active site concentration increase is realized in case of heterovalent substitution by $\mathrm{Fe}^{2+}, \mathrm{Co}^{2+}$ and etc.

The electrolytic doping procedure expands practical application of electrochemical manganese dioxide due to the control of chemical and phase compositions. The ionic dopant additives of $\mathrm{NH}_{4}{ }^{+}, \mathrm{Fe}^{2+}, \mathrm{Co}^{2+}$ have different mechanisms of their influence upon electrocrystallisation process. The electrolytic doping procedure improves the prospective of practical application of electrodeposited manganese(IV) oxides as electrocatalyst. Both doped by $\mathrm{Co}^{2+}$ and $\mathrm{Fe}^{2+}$ ions samples display the best activity and some unique features in ORR(OER). It is proposed that combination of $\mathrm{Co}^{2+}$ and $\mathrm{Fe}^{2+}$ additives could be prospective as a bifunctional catalyst for $\mathrm{LAB}$ cathode application. The high activity of $\mathrm{Fe}^{2+}$-doped $\mathrm{MnO}_{2}$ indicates the positive role of $\mathrm{Fe}^{3+} / \mathrm{Fe}^{2+}$ redox pairs as active sites of surface states. 


\section{References}

[1] Z. Zhang, J. Liu, J.Gu, L. Su, L. Cheng, Energy Environ. Sci., 2014, 7, 2535.

[2] C. Fangyi, C. Jun, Chem. Soc. Rev., 2012, 41, 2172.

[3] J.W.D. Ng, Y. Gorlin, T. Hatsukade, F.T. Jaramillo, Adv. Energy Mater., 2013, 3, 1545.

[4] K.A. Stoerzinger, M. Risch, B. Han, Y. Shao-Horn, ACS Catal., 2015, 5 (10), 6021-6031.

[5] Dixon, D. J. Beilstein J. Org. Chem. 2016, 12, 1079-1080.

[6] Seh, Z. W., Kibsgaard, J., Dickens, C. F., Chorkendorff, I. B., Nørskov, J. K., \& Jaramillo, T. F. (2017). Science, 355(6321), eaad4998

[7] J. D. Benck, T. R. Hellstern, J. Kibsgaard, P. Chakthranont, T. F. Jaramillo, Catalyzing the Hydrogen Evolution Reaction (HER) with Molybdenum Sulfide Nanomaterials. ACS Catal. (2014) 4, 3957-3971.

[8] Sokolsky, G. V., Ivanov, S. V., Boldyrev, E. I., Ivanova, N. D., \& Lobunets, T. F. Solid State Phenomena (2015) 230, 85-92.

[9] Sokol'skii, G. V., Ivanova, S. V., Ivanova, N. D., Boldyrev, E. I., Lobunets, T. F., \& Tomila, T. V. (2012). Journal of Water Chemistry and Technology, 34(5), 227233.

[10] Sokolsky, G., Zudina, L., Boldyrev, E., Miroshnikov, O., Gauk, N., \& Kiporenko, O. (2018). Acta Physica Polonica A, 133(4), 1097-1102.

[11] C.Song, and J.Zhang, Eds J.Zhang, in: PEM Fuel Cell Electrocatalysts and Catalyst Layers: Fundamentals and Applications, Springer, London 2008, p. 89.

[12] Chung-Hao Kuo, I.M.Mosa, S.Thanneeru, V.Sharma, Lichun Zhang, et al. Chem. Commun. 51,5951 (2015). 


\section{Part 2 \\ ELECTRODEPOSITION}

Розділ 2

ГАЛЬВАНОТЕХНІКА 


\title{
Electrode materials in the oxidation of rhodanide
}

\author{
Kosohin O., Kushmyruk A., Linyucheva O.
}

Igor Sikorsky Kyiv Polytechnic Institute, Kyiv, Peremohy prosp., 37, 03056

Rodanides (thiocyanates, salts of thiocyanate acids) are widely used in industry, in particular, for the synthesis of thiourea, in analytical chemistry, in agriculture as toxic chemicals. However, during the oxidation of rhodanides, the formation of cyanide (hydrocyanic) acid is possible, that requires monitoring the implementation of the processes of using rhodanides. However, controlled oxidation reaction [1]

$$
\mathrm{SCN}^{-}+4 \mathrm{H}_{2} \mathrm{O} \rightarrow \mathrm{SO}_{4}^{2-}+\mathrm{HCN}+7 \mathrm{H}^{+}+6 \bar{e},
$$

can be a source of trace amounts of hydrogen cyanide and can be used to test diagnostic tools for cyanide in environmental monitoring systems in industries, which related to the possible release of hydrocyanic acid into the air of the working area. These include, first of all, the production of acrylonitrile, the extraction of precious metals from raw materials, galvanic processes. However, any diagnostic tools (gas analyzers) require periodic testing, which requires the availability of means of calibration - metering devices of standard gas mixtures. Such mixtures of hydrogen cyanide in Ukraine are not produced, and their transportation is potentially dangerous, given the significant toxicity and explosion hazard. That is why the creation of a air-gas generator that would allow controlled generation of the required amount of hydrogen cyanide at the time of testing gas analyzers is of considerable interest.

\section{Experimental}

In work as an electrode material and conductive base is used titanium in the form of a PTEM grade powder with a dispersity of $0.05 \ldots 0.10 \mathrm{~mm}$; wire with a diameter of $1.5 \mathrm{~mm}$ and foil with a thickness of $0.1 \mathrm{~mm}$ (titanium grade VT1-0). The preparation of titanium consisted in etching with a $30 \%$ solution of $\mathrm{H}_{2} \mathrm{SO}_{4}$ to remove impurities of heavy metals, followed by washing with running and distilled water. 
A catalytic platinum coating on a titanium base was obtained by thermal decomposition of hexachloroplatinic acid, the calculated amount of which was applied to the surface of titanium and evaporated, after which it was calcined for an hour in a muffle furnace at an acid decomposition temperature [2]:

$$
\mathrm{H}_{2} \mathrm{PtCl}_{6}+2 \mathrm{H}_{2} \mathrm{O} \stackrel{400^{\circ} \mathrm{C}}{\longrightarrow} \mathrm{Pt}+6 \mathrm{HCl}+\mathrm{O}_{2} \text {. }
$$

The calculated amount of platinum was $30 \mathrm{mg}$ of catalyst per $1 \mathrm{~g}$ of Ti.

Electrodes based on powdered titanium were made in the form of discs with a diameter of $18 \mathrm{~mm}$ and a thickness of $0.25 \mathrm{~mm}$ by pressing. To the electrodes were pressed into the current lead of tantalum wire. The final pressing pressure was $360 \mathrm{MPa}$, which exceeds the yield strength of titanium. We used molds from tool steel U-8, and as a press, an IP-100 type machine with an electronic control unit.

The study of the effect of $\mathrm{pH}$ on the behavior of electrode materials in solutions of rhodanide was carried out at a constant $\mathrm{pH}$ value, which was set by adding the calculated amount of sulfuric acid to a solution of potassium rhodanide. The $\mathrm{pH}$ of the solutions was determined using an I-150 ion-meter.

The study of the behavior of titanium and electrodes based on it in potassium rhodanide solutions was carried out in a potentiodynamic mode using a standard three-electrode cell with separated cathode and anode spaces. $\mathrm{An} \mathrm{Ag} / \mathrm{AgCl}$ electrode filled with a saturated $\mathrm{KCl}$ solution was used as a reference electrode, its potential relative to the standard hydrogen electrode was $0.225 \mathrm{~V}$. The auxiliary electrode was made of $0.2 \mathrm{~g}$ of titanium powder, activated by platinum, and pressed onto a disk of $2 \mathrm{~g}$ of titanium. The electrodes were connected by current leads with the corresponding contacts of the potentiostat PI-50-1.1 with the programmer PR-8 and the two-coordinate potentiometer PDA 1-01. The potential sweep rate in the potentiodynamic mode was $2 \cdot 10^{-3} \mathrm{~V} / \mathrm{s}$.

\section{Results and discussion}

Titanium, despite the strongly negative potential for ion formation reactions, is characterized by high corrosion resistance in many corrosive environments, which is explained by significant passivation [3]. In solutions of sulfuric acid with a $\mathrm{pH} 0.1 \ldots 3.0$, a current-free potential of $+0.1 \ldots+0.4 \mathrm{~V}$ is set on the surface of titanium 
for flat and wire electrodes and $+0.3 \ldots+0.5 \mathrm{~V}$ for powder titanium electrodes. The magnitude of the potential is due to the processes of ionization of oxygen dissolved in the electrolyte on the surface of titanium.

$$
2 \mathrm{H}_{2} \mathrm{O}=\mathrm{O}_{2}+4 \mathrm{H}^{+}+4 e, \quad \mathrm{E}=1,23-0,059 \mathrm{pH} .
$$

and a change in the thickness of the oxide film with a simultaneous change in the phase composition of the oxide layers

$$
\mathrm{Ti}_{2} \mathrm{O}_{3}+\mathrm{H}_{2} \mathrm{O}=2 \mathrm{TiO}_{2}+2 \mathrm{H}^{+}+2 \bar{e}, \quad E=-0,091-0,059 \mathrm{pH} .
$$

A higher potential value for electrodes made from titanium powder is associated with a higher concentration of oxygen, which remains deep in the pores of the electrode when it is impregnated. In solutions with a lower $\mathrm{pH}$ value, a slower steadystate establishment of the potential was generally observed.

The anodic polarization of titanium (Fig. 1) leads to the appearance of currents associated with an increase in the thickness of the oxide layers according to reaction (3). The degree of surface extension practically does not affect the current density, which is calculated on the apparent geometric surface. This indicates an insignificant contribution of the deeper electrode layers to the current-forming processes.

In solutions with a lower $\mathrm{pH}$ value, the anode currents had a greater value, but did not exceed $2.5 \cdot 10^{-5} \mathrm{~A} / \mathrm{cm}^{2}$, which indicates a high stability of titanium in the investigated $\mathrm{pH}$ range in solutions of sulfuric acid.

In a solution of potassium rhodanide with a concentration of $1 \mathrm{M}(\mathrm{pH}$ 6), the current-free potentials of $+0.1 \ldots+0.3 \mathrm{~V}$ are set on titanium, which indicates the occurrence of conjugate reactions (2) and (3). The type of anodic polarization curves up to a potential of $0.75 \mathrm{~V}$ indicates the inertness of titanium in this solution (Fig. 2, a). The potential for the appearance of current corresponds to the reaction of formation of cyanogen [4]

$$
2 S C N^{-} \rightarrow(S C N)_{2}+2 \bar{e}, \quad E^{0}=0,77 \mathrm{~B},
$$

which in the aquatic environment quickly hydrolyzes

$$
3(\mathrm{SCN})_{2}+4 \mathrm{H}_{2} \mathrm{O} \rightarrow 5 \mathrm{SCN}^{-}+\mathrm{HCN}+7 \mathrm{H}^{+}+\mathrm{SO}_{4}^{2-} .
$$




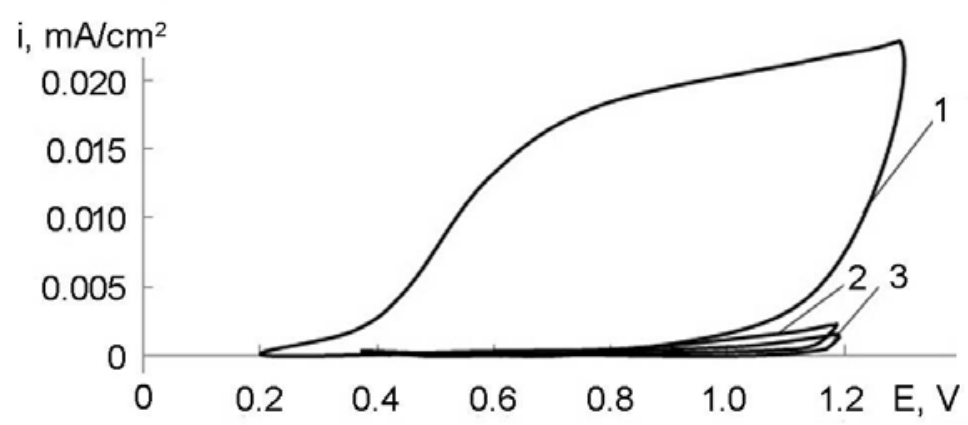

Fig. 1. Polarization curves in a solution of $\mathrm{H}_{2} \mathrm{SO}_{4}, \mathrm{pH} 1$, on titanium electrodes of various types: 1 -wire; 2 -porous; 3 - plate.

However, the current density did not exceed $0.25 \mathrm{~mA} / \mathrm{cm}^{2}$ at a potential of $1.0 \mathrm{~V}$, regardless of the extension of the electrode surface.

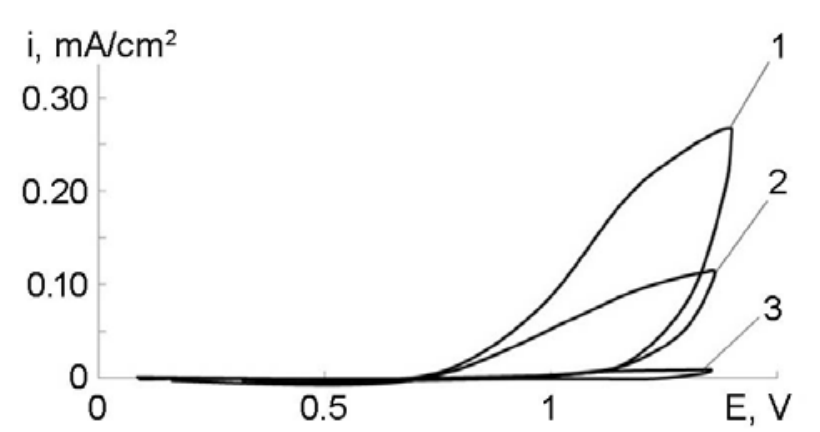

a

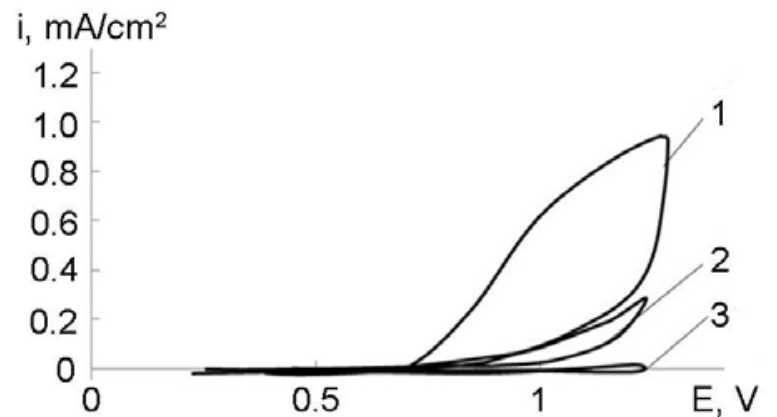

b

Fig. 2. Polarization curves in $1 \mathrm{M} \mathrm{KSCN}$ with $\mathrm{pH} 6$ (a) and $\mathrm{pH} 1$ (b) on various types of titanium electrodes: 1 - wire; 2 - porous; 3 - plate.

In solution of potassium rhodanide with $\mathrm{pH} \mathrm{1,} \mathrm{the} \mathrm{anodic} \mathrm{currents,} \mathrm{which} \mathrm{may}$ caused of the oxidation of the products of the conversion of thiocyanate, are several times higher than at $\mathrm{pH} 6$ (Fig. 2, b), which is associated with the greater completeness of the reactions (1), (4) and (5). However, the values of these currents do not exceed $1 \mathrm{~mA} / \mathrm{cm}^{2}$, which confirms the suitability of titanium as a conductive electrode base for the oxidation of rhodanide to $+1.0 \mathrm{~V}$.

The data of the Fig. 1 and 2 show that the currents on the electrodes of various types increase in the following sequence: plate - porous - wire. The ratio of two quantities was calculated - the area of the electrode in contact with the solution and on which all processes actually take place, to the volume of the electrode (see table). 
There is a correlation between the obtained parameter and the direction of the increase in currents. The smallest value of this parameter, which actually represents the length of the passage of electrons from the reaction zone to the point of the collector, is observed on the wire electrode. Thus, the smaller the current path, the more equipotential the electrode surface is, and consequently, large values of current can be achieved.

Table. The influence of the type of electrode on the ratio of the electrogenerating area to the volume of the electrode

\begin{tabular}{|l|c|c|c|}
\hline \multirow{2}{*}{\multicolumn{1}{|c|}{ Parametr }} & \multicolumn{3}{|c|}{ Type of electrode } \\
\cline { 2 - 4 } & wire & porous & plate \\
\hline Area, $\mathrm{S}, \mathrm{cm}^{2}$ & 9.4 & 10.2 & 2 \\
\hline Volume $\mathrm{V}, \mathrm{cm}^{3}$ & 3.5 & 2.5 & 0.2 \\
\hline Ratio S/V & 2.7 & 4 & 10 \\
\hline
\end{tabular}

On titanium, activated by platinum, in solutions of sulfuric acid, current-free potentials of $0.7 \ldots 0.75 \mathrm{~V}$ are established, which are close to the potential of the reaction

$$
\mathrm{Pt}+\mathrm{H}_{2} \mathrm{O}=\mathrm{PtO}+2 \mathrm{H}^{+}+2 e, \quad \mathrm{E}=0.76-0.059 \mathrm{pH} .
$$

The anodic polarization of such an electrode leads to the appearance of anodic currents (Fig. 3) associated with filling the surface with adsorbed oxygen and the formation of platinum oxides of greater stoichiometry:

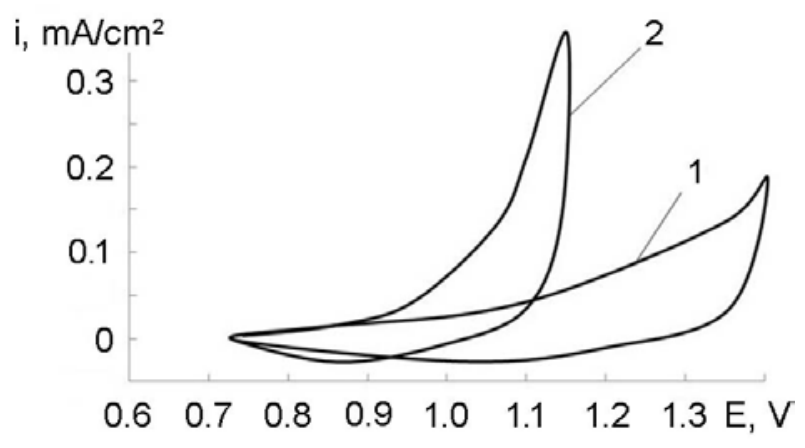

Fig. 3. Polarization curves on titanium, activated by platinum, in a solution of $\mathrm{H}_{2} \mathrm{SO}_{4}$ (pH 1): 1 - porous electrode; 2 - wire electrode.

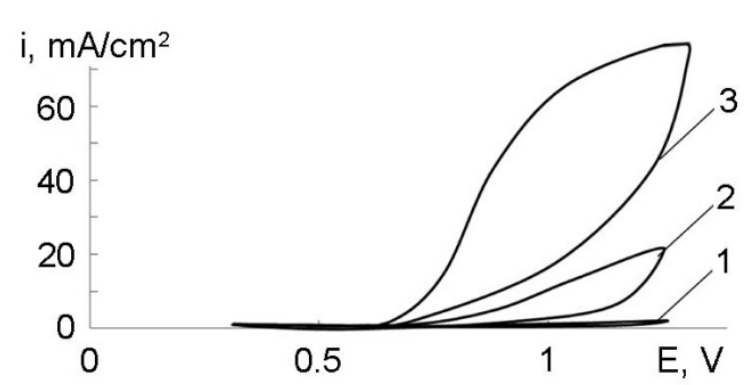

Fig. 4. Polarization curves on a platinumactivated titanium electrode in a solution with a $\mathrm{pH} 1$ and a $\mathrm{KSCN}$ concentration, M: $1-0 ; 2-0.1 ; 3-1$. 


$$
\begin{aligned}
& \mathrm{Pt}+2 \mathrm{H}_{2} \mathrm{O}=\mathrm{Pt}(\mathrm{OH})_{2}+2 \mathrm{H}^{+}+2 e, \quad E=0.98-0.059 \mathrm{pH}, \\
& \mathrm{Pt}(\mathrm{OH})_{2}=\mathrm{PtO}_{2}+2 \mathrm{H}^{+}+2 e, \quad E=1.018-0.059 \mathrm{pH} .
\end{aligned}
$$

In this case, as for titanium, the use of a wire electrode makes it possible to achieve large values of anodic currents (curve 2, Fig. 3).

The introduction of potassium rhodanide into the solution of sulfuric acid leads to the appearance of currents of rhodanide and adsorbed sulfur on the anodic curve at a potential of $+0.65 \mathrm{~V}$ (Fig. 4)

$$
\mathrm{S}_{\text {ads }}+4 \mathrm{H}_{2} \mathrm{O} \rightarrow \mathrm{SO}_{4}^{2-}+8 \mathrm{H}^{+}+6 \bar{e},
$$

which is formed as a result of the decomposition of the acidic form of thiocyanate acid:

$$
S C N^{-}+H^{+} \rightarrow H S C N \rightarrow S_{a d s}+H C N .
$$

Increasing the concentration of potassium rhodanide allows to obtain high values of currents under conditions of anodic polarization. It should be noted that the behavior of platinized titanium is similar to the behavior of pure platinum (Fig. 5), with the exception of smaller values of anode currents.

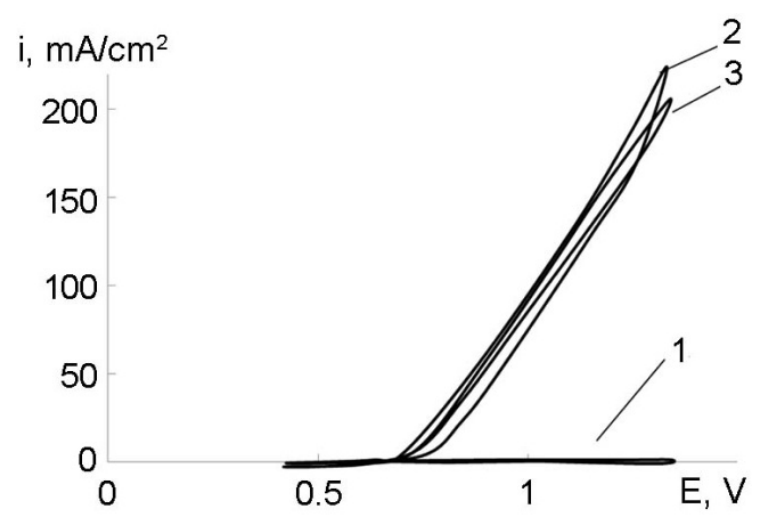

Fig. 5. Polarization curves on platinum electrode in a solution $1-\mathrm{H}_{2} \mathrm{SO}_{4}(\mathrm{pH} 1)$;

$$
\text { 2-1 M KSCN (pH 1); 3-1 M KSCN (pH 6). }
$$

\section{Conclusion}

Titanium exhibits significant inertness in solutions of sulfuric acid with a $\mathrm{pH} 0.1 \ldots 3$. In equilibrium, conjugated processes of ionization of dissolved oxygen and an increase in the stoichiometry of titanium oxides occur on the surface of titanium. Anodic polarization of titanium in a solution of sulfuric acid led to the 
appearance of currents of no more than $5 \cdot 10^{-5} \mathrm{~A} / \mathrm{m}^{2}$, which indicates the absence of its anodic activity.

The introduction of potassium rhodanide into a solution of sulfuric acid leads to the appearance of anodic currents at potentials above $0.75 \mathrm{~V}$, which indicates a slight activity of titanium in the reactions of oxidation of rhodanide. The shape and degree of extension of the electrode surface are of great importance for the choice of the type of electrode - large current values are achieved on wire electrodes due to a more uniform distribution of potential.

The surface activation of titanium with platinum made it possible to obtain electrodes stable in acidic solutions with a low overvoltage of the oxidation reaction of rhodanide, which in their electrocatalytic properties are almost as good as platinum.

Thus, it has been shown that titanium activated platinum can be used as the anode material of an electrochemical generator of "hydrogen cyanide - air" mixture.

\section{References}

[1] Z. Tocksteinová, F. Opekar, The electrochemical generation of small amounts of hydrogen cyanide // 1986. Talanta 33 (8), 688-690 pp.

[2] A. E. Schweizer, G. T. Kerr, Thermal Decomposition of Hexachloroplatinic Acid, Inorg. Chem. 17 (1978), 2326-2327 pp.

[3] M.N. Fokin, Yu.S. Ruskol, A.V. Mosolov, Titan and its alloys in the chemical industry: reference book, Leningrad, Chemistry, 1978, $200 \mathrm{p}$.

[4] O. Barbosa-Filho, J. Monhemius, Leaching of gold in thiocyanate solutions. Part 1: Chemistry and thermodynamics, Transactions Institution of Mining\&Metallurgy 103 (1994), 105-110 pp. 


\title{
Justification of the choice of electrode material for the electrochemical synthesis of peroxyacetic acid
}

\author{
Bilous T.A., Tulsky G.G., Tulskaya A.G., Muratova H.M. \\ National Technical University "Kharkiv Polytechnic Institute”, Kharkiv, Kyrpychova \\ Str. 2, 61002
}

The kinetics of anodic processes in water solutions of acetic acid has been studied applying the $\mathrm{Pt} / \mathrm{PtO}$ and $\mathrm{PbO}_{2}$ anodes. The choice of promoters of peroxide-particles formation has been proved. Addition $\mathrm{F}^{-}, \mathrm{Cl}^{-}, \mathrm{Br}^{-}$, I into electrolyte slows down the combined process of oxygen release. $\mathrm{Cl}^{-}, \mathrm{I}^{-}$(Current output is $1,75 \ldots 2,10 \%$ ) particles have been defined as the most effective for platinum anode and $\mathrm{F}^{-}, \mathrm{I}^{-}$ (Current output 2,28..2,32\%) have been defined as the most effective for leaddioxide anode. Electrochemical synthesis of peroxyacetic acid should be performed on lead dioxide which corresponds to the maximum current output.

Keywords: peroxyacetic acid; acetic acid; platinum anode; lead-dioxide anode; promoter.

\section{Обгрунтування вибору електродного матеріалу для електрохімічного синтезу пероксиоцтової кислоти}

Білоус Т. А., Тульський Г. Г., Тульська А. Г., Муратова О. М.

Наџіональний Технічний Університет «Харківський Політехнічний Інститут», Харків, вул. Кирпичова 2, 61002

Пероксиоцтова кислота (ПООК) - це сильний дезінфектант 3 широким спектром антимікробної активності. Використовується як дезінфікуючий i протимікробний засіб в медицині ( $\approx 0,1 \%$ по ПООК) та харчовій промисловості $(0,015 \ldots 0,03$ \% по ПООК), для дезінфекції стічних вод, як пастеризатор на пивоварнях та винних заводах, як вибілювальний агент в целюлознопаперовому та текстильному виробництві, в промисловості для синтезу епоксидних з'єднань і т.п. Переваги ПООК: відсутні стійкі токсичні похідні, 
незначна залежність від $\mathrm{pH}$, ефективність та короткий час контакту. Широкому розповсюдженню перешкоджає висока вартість ПООК пов'язана з обмеженим виробництвом та нетривалим терміном зберігання. Як відомо, в промислових масштабах ПООК одержують хімічним синтезом, шляхом взаємодії концентрованої оцтової кислоти 3 концентрованим пероксидом водню в присутності кислотного каталізатору $\left(\mathrm{H}_{2} \mathrm{SO}_{4}\right)$. Застосування електрохімічного синтезу ПООК, безпосередньо на місцях використання, виключає витрати пов'язані 3 хімічним синтезом, транспортуванням та зберіганням, кислота виробляється у кількості, необхідній для споживання [1 - 4].

Актуальною проблемою для електрохімічного синтезу ПООК є пошук промоторів утворення пероксо-груп та як наслідок цього збільшення виходу за струмом цільового продукту. Відомо, що аніони, адсорбовані на поверхні платини, впливають на селективність анодного процесу та швидкість виділення кисню. Тому великий інтерес викликає дослідження впливу добавок галогеніонів на кінетику анодних процесів в водних розчинах оцтової кислоти. Тим більш, що $\mathrm{F}^{-}$та $\mathrm{Cl}^{-}$являються промоторами при електрохімічному синтезі пероксидисульфатної кислоти та її солей.

Мета роботи: Дослідити вплив матеріалу аноду на кінетику анодних процесів в водному 3 моль/дм ${ }^{3}$ розчині оцтової кислоти. Обгрунтувати вибір промоторів утворення пероксо-груп для електрохімічного синтезу ПООК.

\section{1. Методика експерименту}

Електроліти готували з концентрованої оцтової та сульфатної кислот марки «Хप

Вольтамперні залежності отримували за допомогою потенціостату Р-45X. Швидкість розгортки потенціалу $10 \mathrm{MB} / \mathrm{c}$.

Поляризаційні виміри проводили в електрохімічній комірці при температурі $284 \ldots 287$ К. В якості аноду використовували: 1) платиновий диск з робочою поверхнею $1,13 \mathrm{~cm}^{2}$; 2) $\mathrm{PbO}_{2}$ нанесений на титановий струмопідвід з підшаром $\mathrm{RuO}_{2} 3$ робочою поверхнею 1,1 cм$^{2}$. Допоміжний електрод - платина. Електрод 
порівняння - хлорид-срібний, підведений до поверхні аноду за допомогою скляного ключа. Всі значення потенціалів перераховані відносно водневого електроду.

Електроліз проводили в електролізері з розділенням катодного та анодного простору діафрагмою з полівінілхлориду. Товщина шару електроліту складала 10 мм. Задану температуру електроліту підтримували шляхом пропускання проточної води $(278 \ldots 281 \mathrm{~K})$ через охолоджуючу камеру електролізеру. Джерело живлення постійного струму Б5-46. Анод: 1) платина, 3 робочою поверхнею $17,5 \mathrm{~cm}^{2}$; 2) $\mathrm{PbO}_{2}$ на титановому струмопідводі 3 підшаром $\mathrm{RuO}_{2} 3$ робочою поверхнею 17,8 см². Допоміжний електрод - 12X18Н10Т.

Концентрацію напрацьованої ПООК визначали методом йодометричного титрування.

\section{2. Результати експерименту та їх обговорення}

Практично не можливе проведення електрохімічного синтезу цільового продукту (ПООК) без участі побічних суміщених процесів [1-4]. Маючи за мету гальмування виділення кисню доцільно: проводити процес електролізу 3 використанням анодних матеріалів з високою перенапругою виділення кисню $\left(\mathrm{Pt} / \mathrm{PtO}, \mathrm{PbO}_{2}\right)$, в концентрованих водних розчинах оцтової кислоти, 3 добавками промоторів утворення пероксо-груп [1 - 4].

На рисунку 1 наведено поляризаційні залежності для 3 моль/дм ${ }^{3} \mathrm{CH}_{3} \mathrm{COOH}$ на $\mathrm{Pt} / \mathrm{PtO}$ (а) та $\mathrm{PbO}_{2}$ (б).

Підйом струму на платині (рис. 1, a) починається при потенціалах $1,40 \ldots 1,45$ В та супроводжується процесом виділення кисню (перша прямолінійна ділянка в діапазоні 1,45...1,60 В):

$$
2 \mathrm{H}_{2} \mathrm{O}=\mathrm{O}_{2}+4 \mathrm{H}^{+}+4 \mathrm{e}^{-} ; \mathrm{E}^{0}=1,228 \mathrm{~B} .
$$

При потенціалах вище 1,6 В (рис. 1, а) спостерігається перехідна ділянка. Друга прямолінійна ділянка в діапазоні потенціалів 1,7...2,0 В (рис. 1, а) 
супроводжується протіканням суміщених процесів утворення пероксиду водню та ПООК:

$$
\begin{gathered}
2 \mathrm{H}_{2} \mathrm{O}=\mathrm{H}_{2} \mathrm{O}_{2}+2 \mathrm{H}^{+}+2 \mathrm{e}^{-} ; \mathrm{E}^{0}=1,776 \mathrm{~B} \\
\mathrm{CH}_{3} \mathrm{COOH}+\mathrm{H}_{2} \mathrm{O}=\mathrm{CH}_{3} \mathrm{COOOH}+2 \mathrm{H}^{+}+2 \mathrm{e}^{-} ; \mathrm{E}^{0}=1,819 \mathrm{~B} .
\end{gathered}
$$

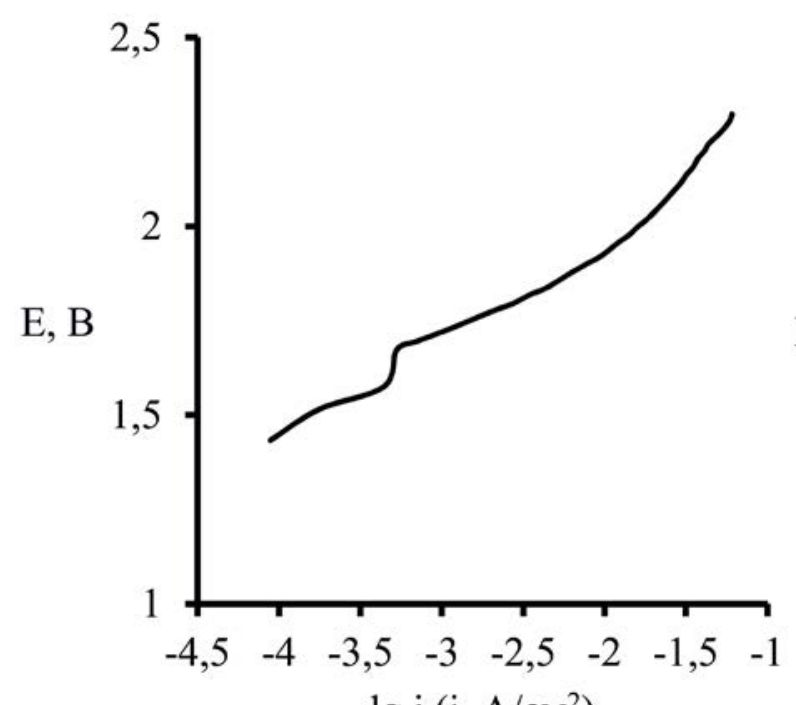

$\lg \mathrm{j}\left(\mathrm{j}, \mathrm{A} / \mathrm{cm}^{2}\right)$

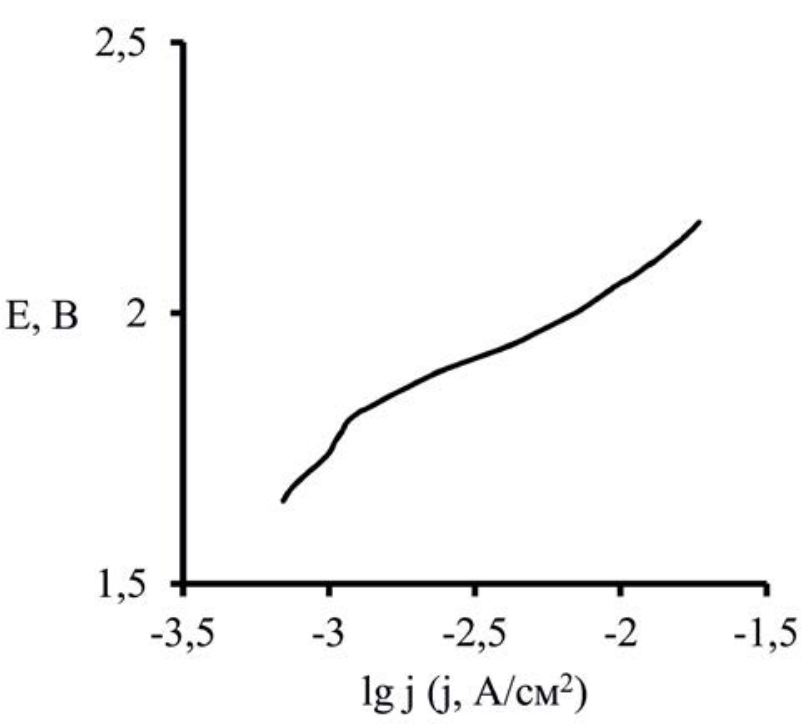

б

Рис. 1. Вольтамперні залежності отримані у водному розчині 3 моль/дм $\mathrm{CH}_{3} \mathrm{COOH}$ : a - на $\mathrm{Pt} / \mathrm{PtO}$ електроді; b - на $\mathrm{PbO}_{2}$ електроді

Підйом струму на $\mathrm{PbO}_{2}$ (рис. 1, б) починається при потенціалах 1,60...1,65 В та супроводжується процесом виділення кисню (перша прямолінійна ділянка в діапазоні 1,65...1,75 B).

При потенціалах вище 1,75 В (рис. 1, б) спостерігається перехідна ділянка. Друга прямолінійна ділянка в діапазоні потенціалів 1,8...2,0 В (рис. 1, б) супроводжується протіканням суміщених процесів утворення пероксиду водню та ПООК.

Подальший зсув потенціалу (рис. 1) в більш електропозитивну область (вище 2,2...2,3 В) призводить до протікання наступних суміщених процесів: реакція Кольбе, реакції анодного приєднання та заміщення, деструктивне окислення оцтової кислоти. 
Використання в якості анодного матеріалу $\mathrm{PbO}_{2}$ призводить до збільшення перенапруги виділення кисню в порівняні з $\mathrm{Pt} / \mathrm{PtO}$. Електрохімічний синтез ПООК доцільно проводити в діапазоні потенціалів $1,8 \ldots 2,0$ В та при густині струму $50 \ldots 150 \mathrm{~A} / \mathrm{cm}^{2}$.

Високий питомий опір електроліту (к $=1,55 \cdot 10^{-3} \mathrm{CM} / \mathrm{cm}$ при $\left.288 \mathrm{~K}\right)$ являється однією з основних проблем електролізу водних розчинів оцтової кислоти, що заважає досягненню потенціалів утворення ПООК. На основі попередніх досліджень ця проблема була вирішена введенням до складу електроліту електропровідної добавки $\mathrm{H}_{2} \mathrm{SO}_{4}$ в кількості 0,5 моль/см ${ }^{3}$ [4].

Для інтенсифікації анодного процесу утворення ПООК доцільно в склад електроліту ввести промотори утворення пероксо-груп. Поляризаційні залежності отримані для 3 моль/дм ${ }^{3} \mathrm{CH}_{3} \mathrm{COOH}+0,5$ моль/дм ${ }^{3} \mathrm{H}_{2} \mathrm{SO}_{4} 3$ добавками іонів: $\mathrm{F}^{-}, \mathrm{Cl}^{-}, \mathrm{Br}^{-}, \mathrm{I}^{-}$. Добавка іонів здійснювалась шляхом введення в електроліт відповідних солей лужних металів.

Введення до складу електроліту добавок іонів $\mathrm{F}^{-}, \mathrm{Cl}^{-}, \mathrm{Br}^{-}, \mathrm{I}^{-}$призводить до гальмування суміщеного анодного процесу - виділення кисню. Збільшення анодного потенціалу відбувається за рахунок адсорбції на поверхні платинового аноду введених аніонів та зменшення числа активних центрів виділення кисню. Слід зауважити, що збільшення концентрації добавок $\left(\mathrm{F}^{-}, \mathrm{Cl}^{-}\right.$, $\mathrm{Br}^{-}, \mathrm{I}^{-}$) в діапазоні $0,001 \ldots 0,1$ моль/дм³ призводить до переважної адсорбції введених іонів на поверхні електроду.

На рисунку 2 та 3 наведено діаграму виходу за струмом ПООК та пероксиду водню для $\mathrm{Pt} / \mathrm{PtO}$ та $\mathrm{PbO}_{2}$ анодів. 


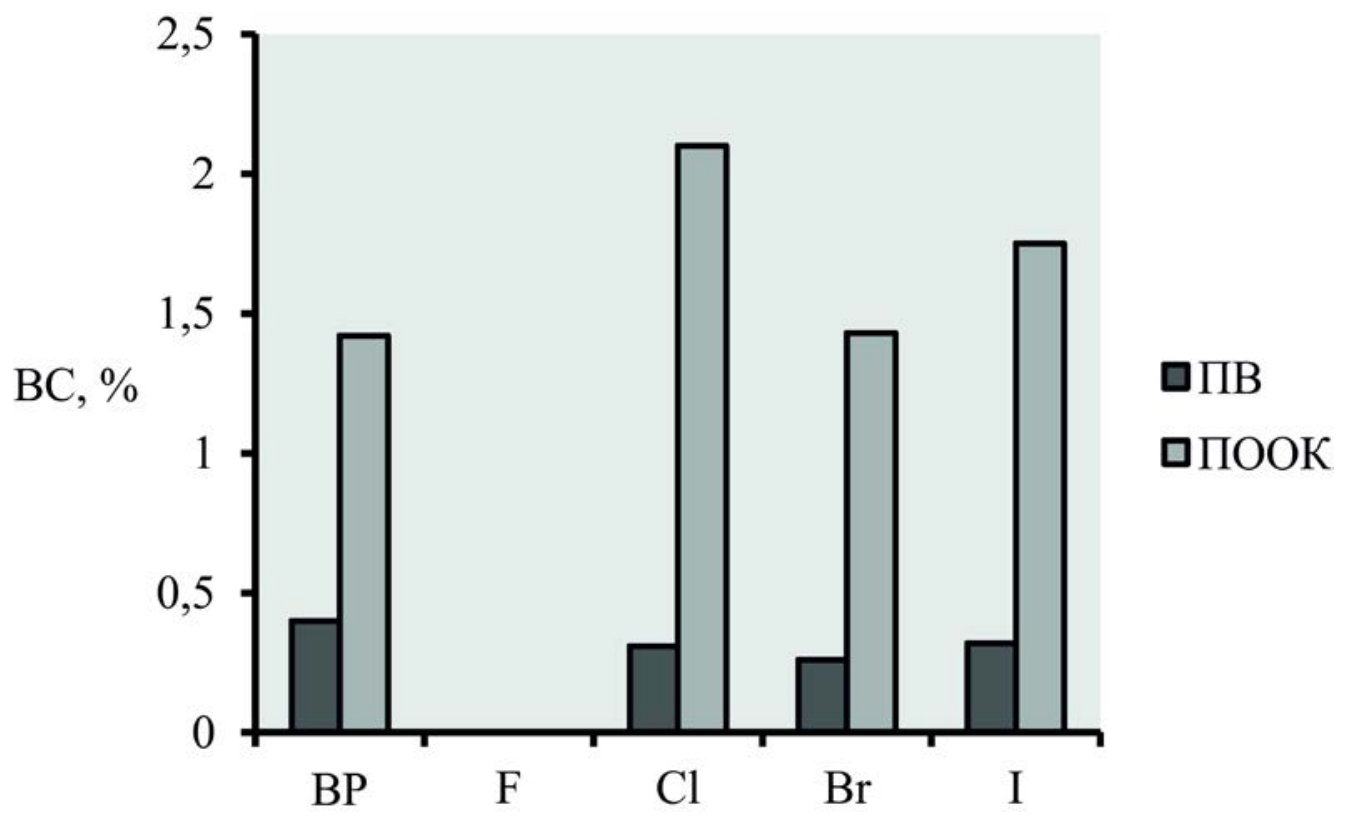

Рис. 2. Діаграма виходу за струмом ПООК та пероксиду водню (ПВ) для

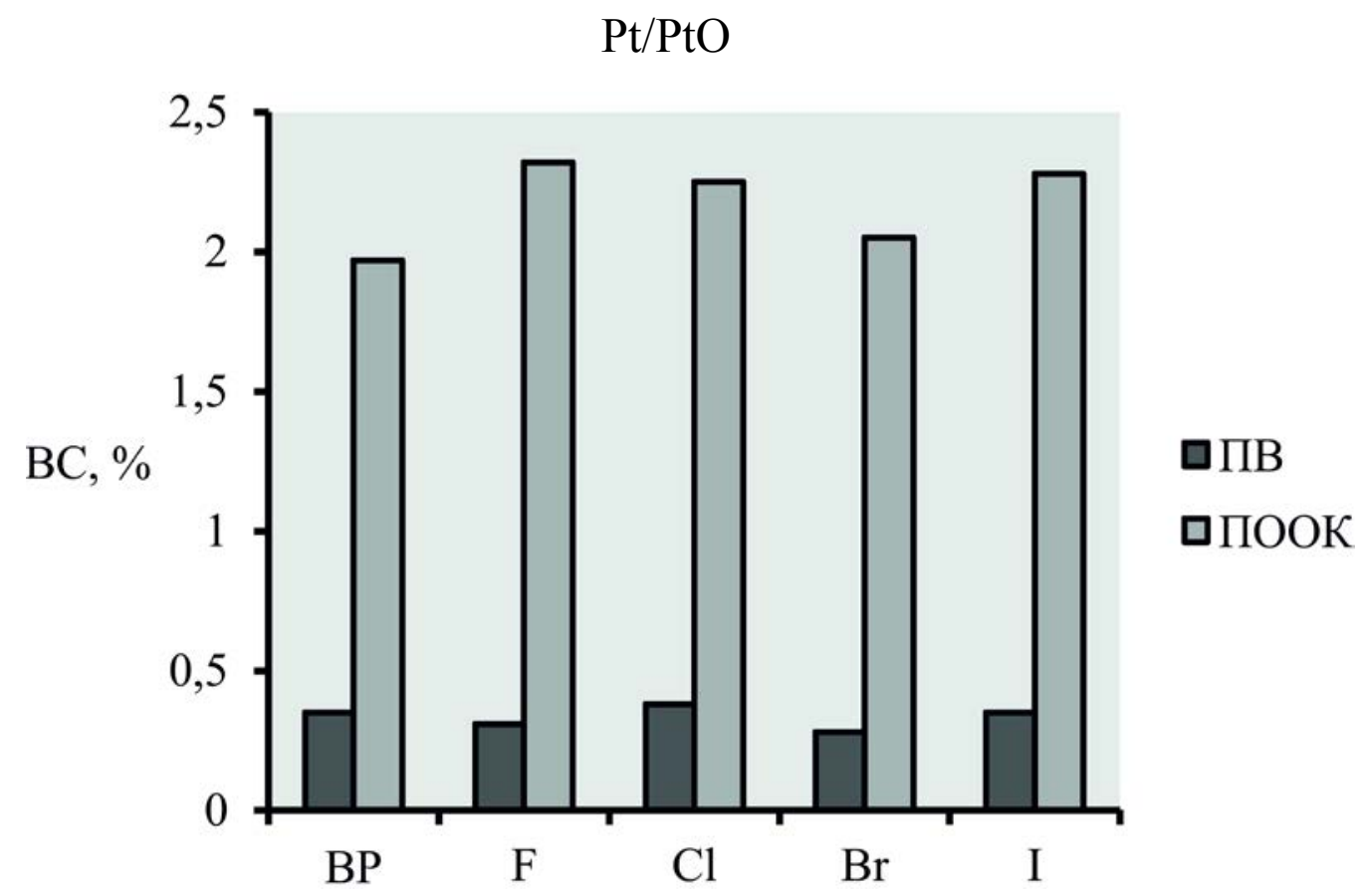

Рис. 3. Діаграма виходу за струмом ПООК та пероксиду водню (ПВ) для $\mathrm{PbO}_{2}$

На основі наведених діаграм (рис. 2 та 3) можна стверджувати, що введення до складу електроліту добавок іонів $\mathrm{F}^{-}, \mathrm{Cl}^{-}, \mathrm{Br}^{-}, \mathrm{I}^{-}$призводить до збільшення виходу за струмом ПООК в порівнянні з даними для вихідного електроліту без добавок. 
Для $\mathrm{Pt} / \mathrm{PtO}$ найбільш ефективними виявилися $\mathrm{Cl}^{-}, \mathrm{I}^{-}$іони $\left(\mathrm{BC}_{\text {поок }}=\right.$ $1,75 \ldots 2,10$ \%). Для $\mathrm{PbO}_{2}$ найбільш ефективними виявилися $\mathrm{F}^{-}, \mathrm{I}^{-}$іони $\left(\mathrm{BC}_{\text {поок }}=\right.$ $2,28 \ldots 2,32 \%)$.

На основі вище сказаного можна стверджувати, що більш доцільно використовувати при електрохімічному синтезі ПООК в якості електродного матеріалу $\mathrm{PbO}_{2}$ (більш висока перенапруга виділення кисню та вищий вихід за струмом ПООК в порівнянні з платиновим електродом).

\section{3. Висновки}

Показано, що при електрохімічному синтезі ПООК в якості електродного матеріалу більш доцільно використовувати $\mathrm{PbO}_{2}$. На даному електродному матеріалі спостерігається більш висока перенапруга виділення кисню та вищий вихід за струмом ПООК в порівнянні з платиновим електродом.

Добавки іонів $\mathrm{F}^{-}, \mathrm{Cl}^{-}, \mathrm{Br}^{-}, \mathrm{I}^{-}$призводять до гальмування суміщеного анодного процесу виділення кисню. Для $\mathrm{Pt} / \mathrm{PtO}$ найбільш ефективними виявилися $\mathrm{Cl}^{-}, \mathrm{I}^{-}$ іони $\left(\mathrm{BC}_{\text {поок }}=1,75 \ldots 2,10\right.$ \%). Для $\mathrm{PbO}_{2}$ найбільш ефективними виявилися $\mathrm{F}^{-}, \mathrm{I}^{-}$ іони $\left(\mathrm{BC}_{\text {поок }}=2,28 \ldots 2,32 \%\right)$.

\section{Література}

[1] T.A. Bilous, G.G. Tulsky, Promising Materials and Processes in Technical Electrochemistry: monograph. Kyiv: KNUTD, 2016, pp. $244-248$.

[2] T.A. Bilous, A.G. Tulskaya, O.L. Matrunchyk, Promising Materials and Processes in Applied Electrochemistry: monograph. Kyiv: KNUTD, 2017, pp. $230-$ 234.

[3] T.A. Bilous, G.G. Tulsky, A.M. Korohodska, M.O. Podustov, Visnyk NTU "KhPI" [Bulletin of the National Technical University "KhPI"] 48 (2017) 24 28.

[4] T.A Bilous, G.G. Tulsky, O.L. Matrunchyk, Visnyk NTU "KhPI" [Bulletin of the National Technical University "KhPI"] 49 (2017) 10 - 14. 


\title{
Electrodeposition of $\mathrm{Cr}$ coatings from a trivalent chromium plating bath based on deep eutectic solvent
}

\begin{abstract}
Bobrova L.S., Protsenko V.S.
Ukrainian State University of Chemical Technology, Gagarin Ave., 8, Dnipro, 49005 Ukraine
\end{abstract}

The electrodeposition of coatings from a trivalent chromium plating bath based on deep eutectic solvent was characterized in this work. The electrolyte contained chromium (III) chloride, choline chloride and the additive of extra water. The plating bath allowed electrodepositing chromium coatings with an amorphous type of microstructure, which contain some carbon and oxygen. The influence of the coatings thickness on a surface morphology was established by means of SEM technique. The polarization measurements confirmed the stepwise reduction of $\mathrm{Cr}(\mathrm{III})$ to $\mathrm{Cr}(0)$. The current efficiency of chromium electrodeposition reaction was stated to increase with increasing current density and decreasing temperature. The microhardness of deposits reached ca. 550-600 HV. The coatings obtained using plating bath based on DES showed electrocatalytic activity towards the hydrogen evolution reaction in acidic medium.

\section{Introduction}

Chromium coatings are widely used in up-to-date industry, because they ensure high microhardness, wear and corrosion resistance, attractive surface appearance, etc. [1]. Commonly, chromium coatings are electrodeposited from aqueous plating baths containing compounds of hexavalent chromium, which are extremely dangerous to the environment and people's health. It is known that EU adopted Regulation No $1907 / 2006$ which forbade or severely limited the use of $\mathrm{Cr}(\mathrm{VI})$ compounds in functional and decorative electroplating. Therefore, the development of effective alternatives to hexavalent chromium electroplating is considered as a very important problem in the surface engineering and applied electrochemistry [2]. Trivalent 
chromium electrodeposition is a possible and attractive option to resolve this problem [2-9]. Although some attempts have been made to replace $\mathrm{Cr}(\mathrm{VI})$ plating processes by trivalent chromium ones, there are still a number of problems which are mainly related to a very intricate solution chemistry of $\mathrm{Cr}$ (III) complexes in aqueous solutions [10]. In this context, chromium electroplating baths on the basis of deep eutectic solvents seem to be a promising alternative to "common" technologies.

Deep eutectic solvents (DESs) are fluids consisting of a eutectic mixture of some organic and inorganic components [11]. The melting point of a DES is lower than those of individual constituents due to the formation of hydrogen bonds between molecules and ions in the liquid mixture. DESs have an ionic character with respect to their transport properties [12-15]. The physicochemical and service properties of DESs are similar to those of "common" ionic liquids, while DESs are cheaper, more available and environmentally friendlier [11].

DESs can be successfully used in various electrochemical processes, especially in electrodeposition and electroplating [16-19].

A number of works have been published to date, in which some aspects of chromium electrodeposition from DESs based electrolytes were considered [20-27]. Nevertheless, some important questions remain practically unrevealed. For instance, published works reported the physicochemical properties of Cr(III)-containing DESs $[21,24,27]$, electrocrystallization behavior [23] and electrochemical mechanism of $\mathrm{Cr}$ (III) electroreduction [21, 23, 25, 26]. However, the effect of electrodeposition conditions on current efficiency has not been systematically investigated. In addition, some properties of the coatings obtained from DESs based electrolytes are poorly studied. For example, the effects of electrolysis duration on the current efficiency and surface morphology of deposits have not been described yet. The microhardness of coatings deposited from choline chloride based Cr(III) plating bath has not been determined.

This work was aimed to summarize the main results of our study on the electrodeposition of chromium coatings prepared from a deep eutectic solvent with the addition of extra water. We characterized the surface morphology of $\mathrm{Cr}$ coatings 
with different thickness, determined the microstructure and composition of deposits, defined voltammetry responses in the $\mathrm{Cr}$ (III) electrolyte based on DES and established the effects of current density and bath temperature on the current efficiency of chromium deposition. In addition, we measured the microhardness values of deposits and evaluated the electrochemical behavior of $\mathrm{Cr}$ coatings in an acidic medium in a wide range of electrode potentials.

The main results of this work have been published in our previous paper [28].

\section{Experimental}

Chromium coatings were electrodeposited using an electrolyte prepared from choline chloride (Aldrich, purity $>98 \%$ ), which was recrystallized from isopropanol, filtered and dried under vacuum, and chromium (III) chloride hexahydrate (Aldrich, purity $>98 \%$ ), which was used as received. The deep eutectic solvent was synthesized by mixing choline chloride $(\mathrm{ChCl})$ and $\mathrm{CrCl}_{3} \cdot 6 \mathrm{H}_{2} \mathrm{O}$ in the molar ratio of 2.5:1, respectively [29]. The mixture was kept in a thermostatic heater at the temperature of $70{ }^{\circ} \mathrm{C}$ and continuously stirred until a homogenous, dark green fluid had formed. A required amount of bidistillate water was further added to the DES and the mixture was stirred at the same temperature to obtain a homogenous fluid.

Thus, the ionic liquid containing $\mathrm{CrCl}_{3}+2.5 \mathrm{ChCl}+15 \mathrm{H}_{2} \mathrm{O}$ was under consideration, where numbers denotes the molar proportions between the components.

It should be noted that extra water was introduced into ionic fluids containing $\mathrm{CrCl}_{3}$ and $\mathrm{ChCl}$ to increase their electrical conductivity and decrease viscosity to the values which are acceptable to perform electrolysis under laboratory conditions [2729]. Table 1 gives literature data on the effect of extra water on the viscosity and conductivity. Note that the value $x=6$ in Table 1 is related to the liquid system without the addition of extra water (all water originates from hexahydrate salt $\left.\mathrm{CrCl}_{3} \cdot 6 \mathrm{H}_{2} \mathrm{O}\right)$. 
Table 1. The influence of water content on conductivity and viscosity of the $\mathrm{CrCl}_{3}+2.5 \mathrm{ChCl}+x \mathrm{H}_{2} \mathrm{O}$ liquid mixtures at $40{ }^{\circ} \mathrm{C}[28,29]$.

\begin{tabular}{lll}
\hline$x$ & Conductivity $\left(\Omega^{-1} \mathrm{~m}^{-1}\right)$ & Viscosity $(\mathrm{mPa} \mathrm{s})$ \\
\hline 6 & 0.058 & 1958.7 \\
15 & 1.301 & 77.2 \\
\hline
\end{tabular}

In electrodeposition experiments, a thermostatted two-electrode cell was used. Chromium was deposited on a disk-shaped sample of copper foil $\left(S=1.77 \mathrm{~cm}^{2}\right)$ placed in a plastic holder. Prior to each experiment, the surface of $\mathrm{Cu}$ foil was polished using $0.05 \mu \mathrm{m}$ alumina slurry and then rinsed with hydrochloric acid solution (1:1 vol.) and distillate water. Platinized titanium was used as an anode without separation of anodic and cathodic compartments.

Voltammetric responses were recorded by means of Potentiostat Reference 3000 (Gamry). The ohmic potential drop was measured and automatically compensated using the built-in IR-compensator of the potentiostat. Electrochemical measurements were carried out in a common glass three-electrode cell. The electrochemical cell was thermostatted with an accuracy of $\pm 0.01^{\circ} \mathrm{C}$. A platinum disk $(\varnothing 5 \mathrm{~mm})$ in a glass holder was used as a working electrode in these experiments. A Pt wire was used as a counter electrode and the electrode potentials were measured relative to Ag pseudoreference electrode.

The surface morphology of coatings was characterized by scanning electron microscopy (Zeiss EVO 40XVP) in secondary electron regimes. The chemical composition of the surface layers was determined by energy dispersive X-ray spectroscopy (EDX) coupled with the SEM microscope (Oxford INCA Energy 350).

The composition of coatings has been also evaluated by means of chemical analysis. In these experiments, a weighed electrodeposited coating was completely dissolved from the substrate in aqueous solution of $\mathrm{HCl}$ (1:1 vol.). A further complexation of $\mathrm{Cr}(\mathrm{III})$ ions with EDTA yielded stable colored complex, the concentration of which was determined by UV-vis spectroscopy technique (UV/vis spectrophotometer SF-46, $\lambda=540 \mathrm{~nm}$ ). 
X-ray diffraction analysis was performed by means of an X-ray diffractometer DRON-3.0 in the monochromatized $\mathrm{Co}-\mathrm{K}_{\alpha}$ radiation.

Vickers microhardness test was conducted using PMT-3 device at a $100 \mathrm{~g}$ load, and the coatings thickness was not less than $20 \mu \mathrm{m}$. The average microhardness of the deposits was calculated based on five separate measurements.

To estimate the corrosion-electrochemical behavior of obtained chromium coatings, the potentiodynamic polarization curves were recorded. An aqueous solution of $0.5 \mathrm{M} \mathrm{H}_{2} \mathrm{SO}_{4}$ was used as a corrosive medium. Dissolved atmospheric oxygen was removed by purging purified electrolytic hydrogen. The coatings were electrodeposited on the gold disc electrode. The counter electrode was made of porous graphite. The potentials were measured towards the saturated $\mathrm{Ag} / \mathrm{AgCl}$ reference electrode. The scan rate was $50 \mathrm{mV} \mathrm{s}^{-1}$.

\section{Results and discussion}

3.1. Surface morphology, microstructure and chemical composition of coatings

Figure 1 shows typical SEM images characterizing the surface morphology of coatings deposited from the plating bath based on DES. As can be seen, the surface morphology appreciably changes with thickness of coatings. At relatively small thickness (ca. $2.5 \mu \mathrm{m}$ ), the surface is smooth and there are some defects (micropores and microcracks). When the thickness of coatings increases, the cracks on the surface grow and crateriform cavities appear. The depth of these cavities seems to be increased with deposits thickness. Such evolution of the surface morphology is typical of chromium coatings obtained from plating baths on the basis of $\mathrm{Cr}$ (III) salts $[5,30]$. 


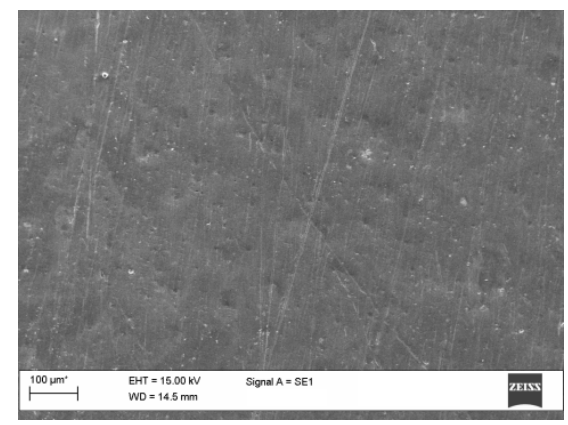

a

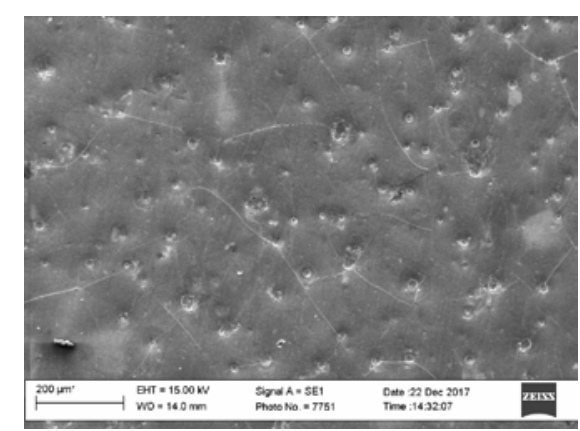

C

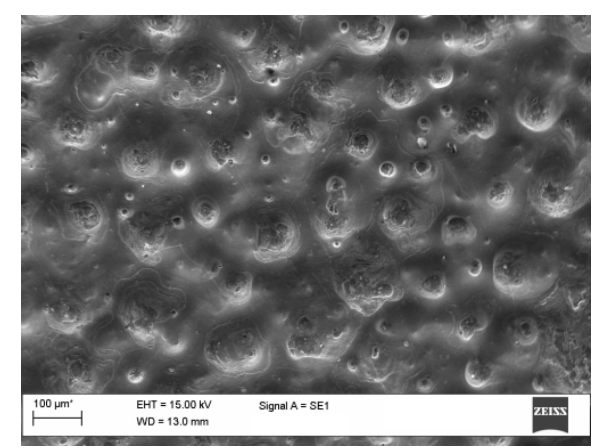

e

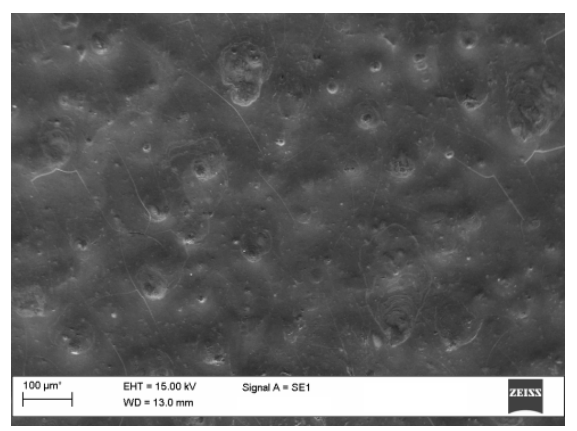

b

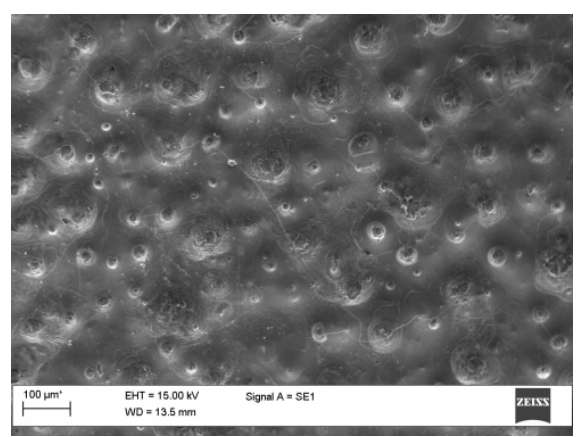

d

Fig. 1. SEM images of the surface of coatings deposited from the electrolyte based on DES with different average thickness ( $\mu \mathrm{m}$ ): (a) 2.5, (b) 5, (c) 10, (d) 15 and (e) 20 [28].

It is known that the electrodeposition of chromium is accompanied by simultaneous hydrogen evolution reaction (HER) both in aqueous electrolytes and in those prepared using DESs $[5,27]$. The bubbles of hydrogen evolved remain on the surface for some time and partially block it. When chromium layers are grown around a hydrogen bubble attached to the surface, a cavity is formed. The plating electrolytes on the basis of DES are relatively viscous, therefore, the withdrawal of hydrogen gas bubbles is hindered in this case. Evidently, the longer the electrolysis 
duration (that means an increase in average deposits thickness), the deeper are the cavities formed on the surface.

The X-ray diffraction patterns revealed the amorphous structure of the coatings (Fig. 2). The formation of X-ray amorphous or nanocrystalline structures of deposited coatings is commonly observed for $\mathrm{Cr}(\mathrm{III})$ electroplating baths [4, 5, 30, 31].

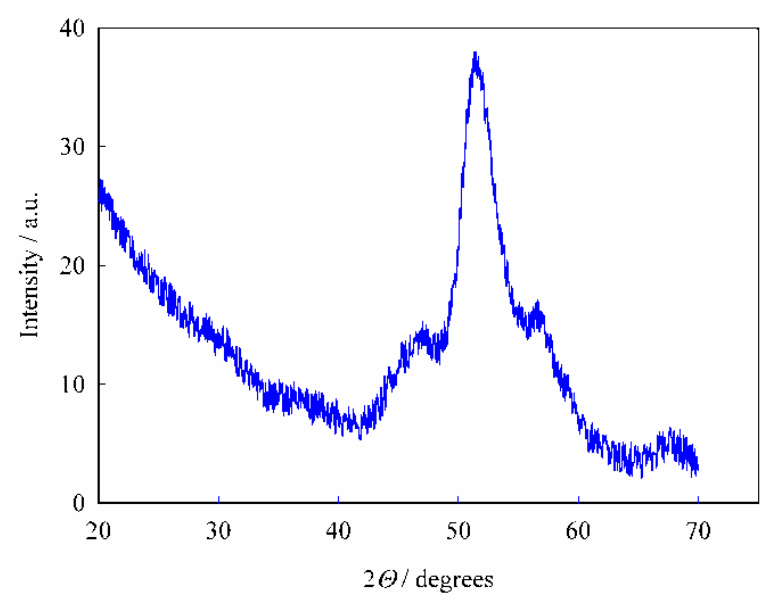

Fig. 2. Typical X-ray diffraction pattern of a coating deposited from the bath containing $\mathrm{CrCl}_{3}+2.5 \mathrm{ChCl}+15 \mathrm{H}_{2} \mathrm{O}$ at $7 \mathrm{~A} \mathrm{dm}^{-2}$ and $40{ }^{\circ} \mathrm{C}[28]$.

The results of EDX analysis showed the presence of such elements as $\mathrm{Cr}, \mathrm{C}, \mathrm{Cl}$ and $\mathrm{O}$ on the coatings surface (Fig. 3, Table 2). As expected, chromium is a dominant element. The oxygen spectra may be originated as a result of the formation of a thin oxide passive film on a chromium surface. Additionally, oxygen can be incorporated into coatings in the form of poorly soluble hydroxide compounds of $\mathrm{Cr}(\mathrm{III})$, which are always formed in the near-electrode layer during chromium electrodeposition [3]. Chlorine (a very weak signal) may be detected due to the capture of some chloride ions from the plating electrolyte. As concerns the presence of carbon in coatings, it can be explained by interaction of a part of active chromium ad-atoms with adsorbed organic bath constituents by the so-called "chemical" mechanism [32]. The incorporation of carbon into the electrodeposits hinders surface diffusion of chromium ad-atoms that ensures the formation of amorphous or nanocrystalline structure, and chromium can exist as nanocrystalline phases of chromium carbides $[4,7,31,32]$. The identification of the phases of chromium carbides in the obtained 
X-ray diffraction patterns (Fig. 2) is complicated by the fact that the diffraction peaks of amorphous chromium is relatively broad, and they can overlap the responses from other phases.

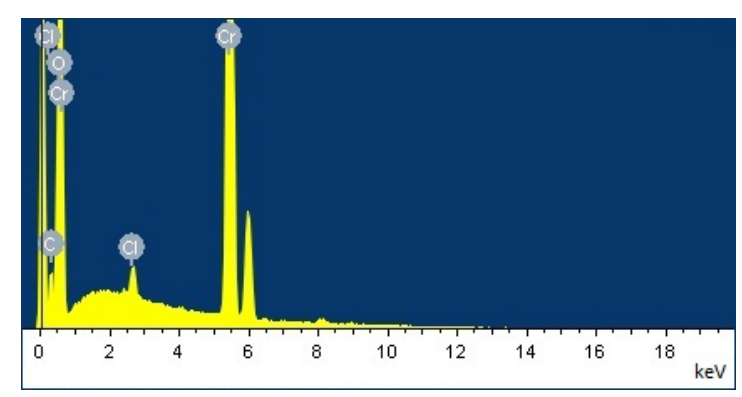

Fig. 3. Typical EDX spectrum of the surface of a coating deposited from the bath containing $\mathrm{CrCl}_{3}+2.5 \mathrm{ChCl}+12 \mathrm{H}_{2} \mathrm{O}$ at $7 \mathrm{~A} \mathrm{dm}^{-2}$ and $40{ }^{\circ} \mathrm{C}[28]$.

Table 2. Chemical composition of the coating surface according to the results of EDX analysis [28].

\begin{tabular}{ll}
\hline Element & Content (wt.\%) \\
\hline $\mathrm{Cr}$ & 83.04 \\
$\mathrm{O}$ & 10.52 \\
$\mathrm{Cl}$ & 0.97 \\
$\mathrm{C}$ & 5.74 \\
\hline
\end{tabular}

It should be observed that EDX may provide ambiguous and uncertain information on the content of light elements (like $\mathrm{O}$ and $\mathrm{C}$ ). In order to confirm the presence of carbon in electrodeposits obtained from the DES based plating bath, we annealed the coatings and perform the X-ray diffraction analysis of the heat-treated material. Earlier, Zeng et al. [33] and Huang et al. [34] have stated that the annealing of amorphous $\mathrm{Cr}-\mathrm{C}$ layers at the temperatures of $400-600{ }^{\circ} \mathrm{C}$ leads to the their crystallization and the peaks originated from chromium carbide can be easily observed in XRD patterns.

As follows from the data shown in Fig. 4, pronounced diffraction peaks corresponding to $\mathrm{Cr}_{2} \mathrm{O}_{3}$ and $\mathrm{Cr}_{23} \mathrm{C}_{6}$ are seen in the XRD patterns of the coatings annealed at $500{ }^{\circ} \mathrm{C}$. This confirms the presence of carbon in as-deposited coatings. 
Figure 5 shows the content of chromium in coatings, these values being determined by chemical analysis after full dissolving the electrodeposits in $\mathrm{HCl}$ solution. In a first approximation, the content of chromium is practically independent of current density and bath temperature, and it is equal to ca. $80 \mathrm{wt} . \%$. As can be clearly seen, these results are in good agreement with those obtained by means of EDX method.

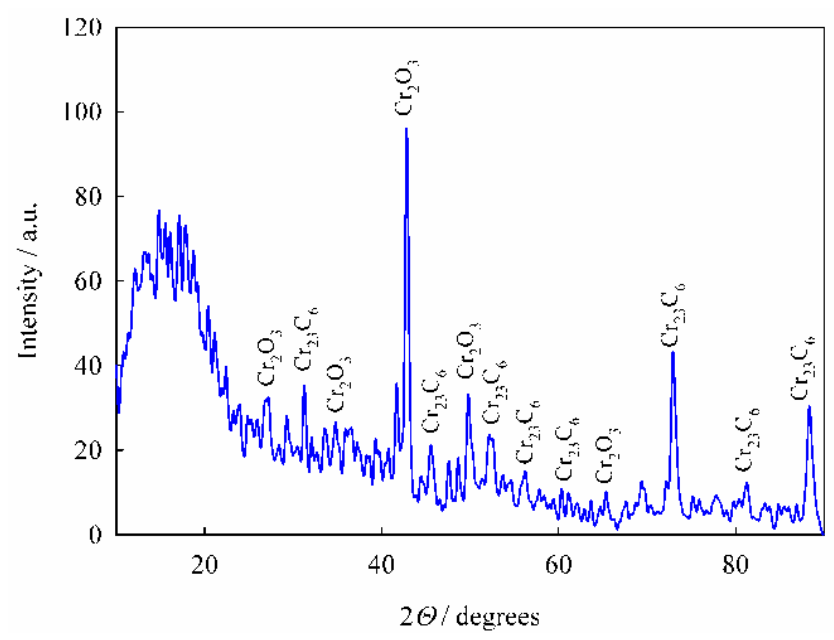

Fig. 4. X-ray diffraction pattern of a coating after annealing at $500{ }^{\circ} \mathrm{C}(1 \mathrm{~h}$, free air). The coating was deposited from the bath containing $\mathrm{CrCl}_{3}+2.5 \mathrm{ChCl}+15 \mathrm{H}_{2} \mathrm{O}$ at $7 \mathrm{~A} \mathrm{dm}^{-2}$ and $40{ }^{\circ} \mathrm{C}[28]$.

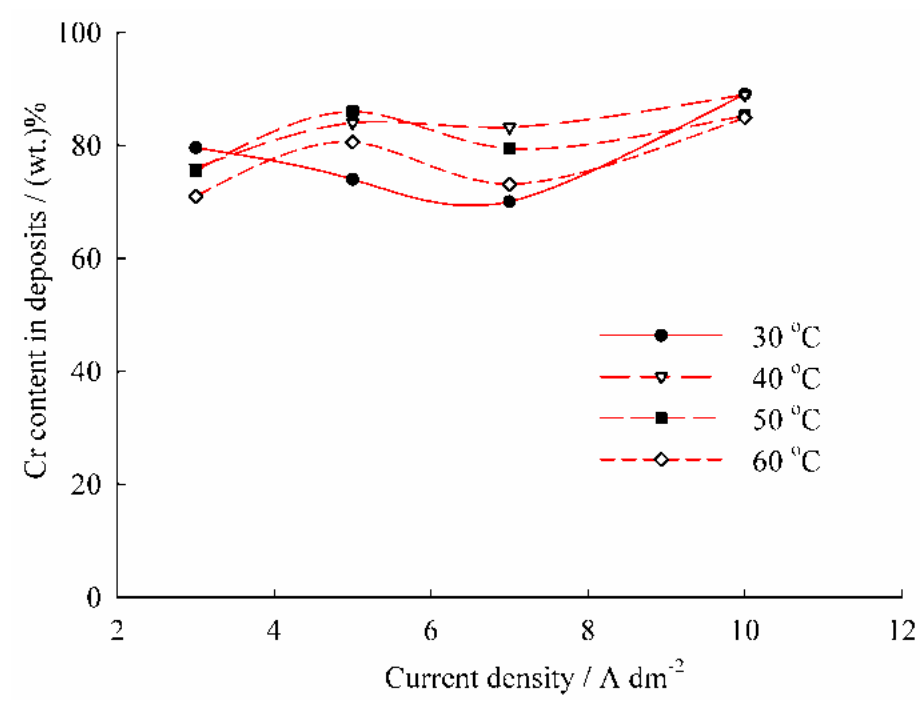

Fig. 5. The effect of current density and electrolyte temperature on the content of chromium in deposits prepared from the bath containing $\mathrm{CrCl}_{3}+2.5 \mathrm{ChCl}+15 \mathrm{H}_{2} \mathrm{O}$ [28]. 


\subsection{Potentiodynamic polarization study and current efficiency of chromium}

electrodeposition reaction

Figure 6 shows the cyclic voltammetry curve recorded on a Pt electrode in the chromium (III) plating electrolyte based on DES. The polarization curve looks like those described earlier for similar electrochemical systems [24-26]. In the cathodic branch, the reduction peak $C_{l}$ corresponds to the electrochemical reaction $\mathrm{Cr}(\mathrm{III})+\mathrm{e}^{-}$ $\rightarrow \mathrm{Cr}(\mathrm{II})$. At a further increase of cathode polarization, the current density starts to steeply rise (peak $C_{2}$ ) which can be attributed to both the formation of metallic chromium according to the reaction $\mathrm{Cr}(\mathrm{II})+2 \mathrm{e}^{-} \rightarrow \mathrm{Cr}(0)$ and the hydrogen evolution reaction. The formation of metallic chromium as well as the evolution of $\mathrm{H}_{2}$ bubbles in this range of electrode potential can be visually detected.

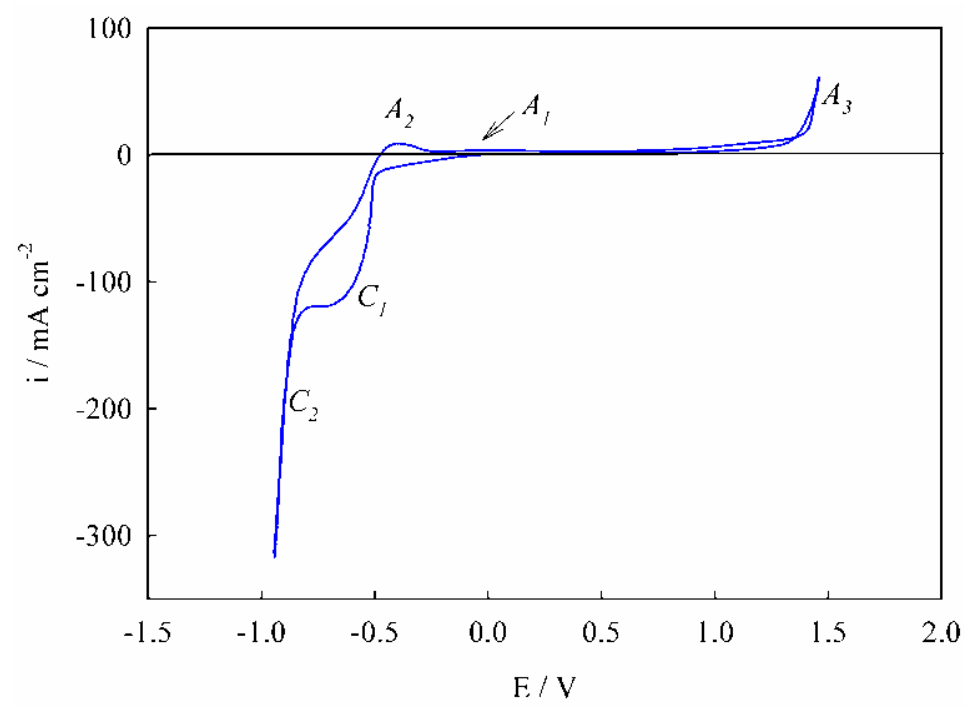

Fig. 6. Cyclic voltammetry curve recorded on platinum electrode in the electrolyte containing $\mathrm{CrCl}_{3}+2.5 \mathrm{ChCl}+15 \mathrm{H}_{2} \mathrm{O}$. The scan rate was $125 \mathrm{mV} \mathrm{s}^{-1}$ and the temperature was $70^{\circ} \mathrm{C}[28]$.

In the reverse anodic scan, three current peaks are observed. The current peak $A_{2}$ is associated with the oxidation of $\operatorname{Cr}(0)$ to $\mathrm{Cr}$ (II) (electrochemical dissolution of chromium). The peak $A_{1}$ (a weak signal) can be assigned to the oxidation of $\mathrm{Cr}$ (II) to $\mathrm{Cr}$ (III). The current peak $A_{3}$ corresponds to the anodic evolution of gaseous chlorine. In general, the results of cyclic voltammetry study are in good agreement with the 
concept of stepwise reduction of $\mathrm{Cr}$ (III) with the participation of $\mathrm{Cr}$ (II) complexes as intermediates $[3,35,36]$.

The current efficiency of the partial reaction of chromium deposition reaction $(\mathrm{Cr}(\mathrm{III}) \rightarrow \mathrm{Cr}(0))$ was calculated by comparing the weight gain of the cathode placed in the plating bath with that of a copper coulometer connected in series. The correction for the content of metallic chromium in the coatings (Fig. 5) was applied in these calculations. The current efficiency of chromium electrodeposition reaction increases with increasing current density and decreasing bath temperature (Table 3). Such behavior is typical of trivalent chromium electroplating baths $[1,2,5]$. It should be noted that the bath temperature has no effect on the surface appearance of coatings and semi-bright and uniform layers with a good adhesion to the substrate are obtained in the temperature range of 30 to $60^{\circ} \mathrm{C}$. The current density has more pronounced effect upon the surface appearance of coatings: the surface of deposits becomes relatively rough and not bright enough if the current density exceeds the value of about $10 \mathrm{~A} \mathrm{dm}^{-2}$. Therefore, we think that the most suitable current density is close to 3-7 $\mathrm{A} \mathrm{dm}^{-2}$.

Table 3. The effects of temperature and current density on the current efficiency of chromium electrodeposition reaction in the plating bath containing $\mathrm{CrCl}_{3}+2.5 \mathrm{ChCl}+15 \mathrm{H}_{2} \mathrm{O}$. Electrolysis duration was $20 \min [28]$.

\begin{tabular}{lll}
\hline Temperature $\left({ }^{\circ} \mathrm{C}\right)$ & Current density $\left(\mathrm{A} \mathrm{dm}^{-2}\right)$ & Current efficiency $(\%)$ \\
\hline 30 & & 24.6 \\
40 & 3 & 12.7 \\
50 & & 6.7 \\
60 & & 2.5 \\
\hline & 5 & 11.7 \\
50 & 7 & 15.6 \\
& 10 & 24.1 \\
\hline
\end{tabular}


It is important that the current efficiency only slightly diminishes with electrolysis time (by ca. 1-2\% during several tens of minutes of electrolysis) which can be associated with a gradual development of the surface area in the course of electrodeposition process (see Fig. 1). However, thick layers can be obtained from the chromium plating bath under consideration, and hence these coatings can be used not only as thin "decorative" $\mathrm{Cr}$ (with a thickness of ca. $1 \mu \mathrm{m}$ ) but also in "hard" chromium electroplating where the thickness of deposits reaches several tens micrometers [1].

\subsection{Microhardness and corrosion-electrochemical behavior of coatings}

Microhardness is a very important characteristic of industrials chromium electrodeposits [1]. The measured values of microhardness of chromium coatings deposited from the DES based plating bath are shown in Fig. 7. Abbott et al. [21] established that soft chromium coatings with a microhardness of $242 \mathrm{HV}$ are deposited from ionic liquids based on the mixture of choline chloride and $\mathrm{CrCl}_{3}$ (without extra water addition). The use of special additives to the electrolyte allowed increasing the microhardness to ca. $600 \mathrm{HV}$.

It can be seen from the data given in Fig. 7 that the coatings with the microhardness of about 550-600 HV can be deposited using the deep eutectic solvent containing the addition of extra water, without any other special organic or inorganic additives. It should be observed that the microhardness of as-deposited coatings prepared in this work is close to that typical of industrial hard chrome (from hexavalent chromium bath) $[1,2]$. 


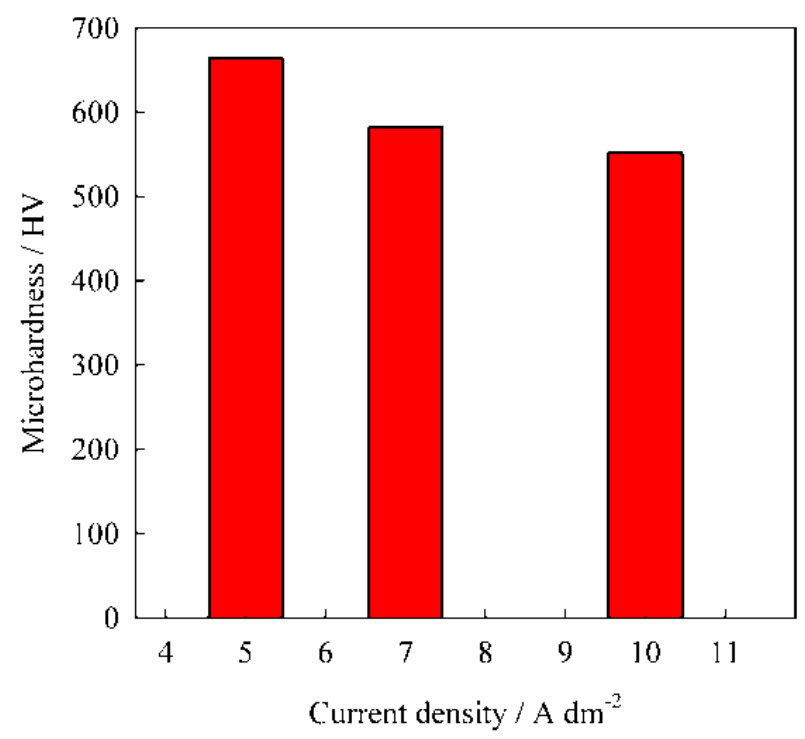

Fig. 7. Microhardness of deposits prepared from the bath containing $\mathrm{CrCl}_{3}+2.5 \mathrm{ChCl}+15 \mathrm{H}_{2} \mathrm{O}$ at different current densities. The electrolyte temperature was $40^{\circ} \mathrm{C}$.

The corrosion-electrochemical behavior of the coatings was evaluated by the potentiodynamic polarization technique (Fig. 8). The polarization curve of "pure" chromium (obtained from common hexavalent chromium plating baths) is given for the sake of comparison (Fig. 8, curve 1). This curve exhibits all specific features typical of chromium in an acidic medium: the region of hydrogen evolution reaction, the active dissolution peak and the regions of passive and transpassive states [37]. However, the coating prepared from the DES shows quite a different electrochemical behavior: the active dissolution region disappears, and the open circuit potential increases (Fig. 8, curve 2).

The transpassive region shifts towards more negative potentials. It should be observed that the cathodic branch of the polarization curve corresponding to the HER shifts in the direction of more positive potentials indicating the electrocatalytic properties of the coatings deposited from the plating bath containing DES.

We think that the particular corrosive and electrochemical behavior of $\mathrm{Cr}$-deposits obtained in this work (an anomalous shape of polarization curves recorded in an acidic medium) can be presumably associated with the presence of some carbon in the coatings. Carbon incorporated into the film structure provides the formation of a 
protective film on the surface of the coatings [4]. Edigaryan et al. [38] attributed a special electrochemical behavior of the chromium carbide electrodeposits obtained from a trivalent Cr-bath to the presence of chromium carbides in them. Chromium carbides can be peculiar "cathodic agents" that shift the open circuit potential to the passivity region. Apparently, these considerations can be extended to the electrodeposits prepared in this work. It should also be noted that the electrocatalytic activity of chromium carbides in the reaction of hydrogen evolution reaction has been detected in a number of works [39-41].

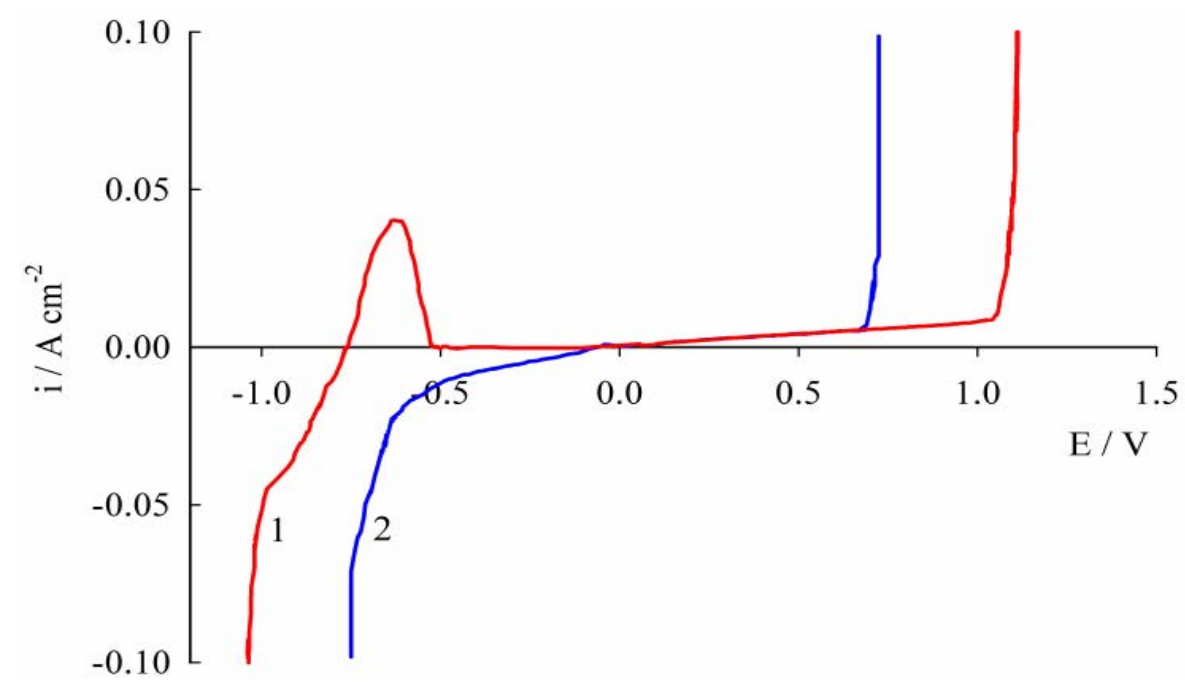

Fig. 8. Potentiodynamic polarization curves recorded on chromium deposits in $0.5 \mathrm{M} \mathrm{H}_{2} \mathrm{SO}_{4}$ at

$25^{\circ} \mathrm{C}$. The coatings were electrodeposited from the bath containing $250 \mathrm{~g} \mathrm{dm}^{-3} \mathrm{CrO}_{3}$ and 0.025 $\mathrm{g} \mathrm{dm}^{-3} \mathrm{H}_{2} \mathrm{SO}_{4}$ at $40 \mathrm{~A} \mathrm{dm}^{-2}$ and $45{ }^{\circ} \mathrm{C}$ (1) and from the bath containing $\mathrm{CrCl}_{3}+2.5 \mathrm{ChCl}+15 \mathrm{H}_{2} \mathrm{O}$ at $5 \mathrm{~A} \mathrm{dm}^{-2}$ and $40{ }^{\circ} \mathrm{C}(2)$. The scan rate was $50 \mathrm{mV} \mathrm{s}^{-1}$ [28].

\section{Conclusions}

We reported in this work the electrodeposition of chromium coatings using environmentally friendly trivalent chromium plating bath on the basis of a deep eutectic solvent. The electrolyte contains the mixture of $\mathrm{CrCl}_{3}$, choline chloride and some extra water. The obtained coatings have an amorphous type of microstructure which crystallized after the thermal treatment showing the presence of chromium carbide. Thus, as-deposited coatings included some carbon which was also confirmed by the results of EDX analysis. The polarization measurements displayed stepwise electroreduction of $\mathrm{Cr}$ (III) that is typical of chromium deposition from $\mathrm{Cr}$ (III) electrolytes. The electrodeposition is accompanied by the hydrogen evolution 
reaction which affects the surface morphology (the formation of cavities on the surface) and results in the fact that the current efficiency of chromium deposition reaction is not more than $25 \%$. The current efficiency grows both when increasing current density and decreasing electrolyte temperature. The microhardness of asdeposited $\mathrm{Cr}$ coatings prepared in this work is about 550-600 HV. The polarization curve characterizing the electrochemical behavior of the obtained coatings in $0.5 \mathrm{M}$ $\mathrm{H}_{2} \mathrm{SO}_{4}$ differs from that of "usual" chromium: there is no region of active dissolution and the region corresponding to the HER shifts towards more positive potentials, indicating the electrocatalytic properties of the synthesized electrodeposits.

\section{Acknowledgements}

We thank Prof. F.I. Danilov for valuable discussions of the obtained results. We also thank Dr. A.S. Baskevich for performing the XRD investigation and Dr. S.A. Korniy for the preparation of SEM images.

\section{References}

[1] J.K. Dennis, T.E. Such, Nickel and Chromium Plating, Elsevier Science, 2015.

[2] Protsenko, V.S., Danilov, F.I., 2014, Clean Technol. Environ. Policy 16, 1201.

[3] Protsenko, V., Danilov, F., 2009, Electrochim. Acta 54, 5666.

[4] Danilov, F.I., Protsenko, V.S., Gordiienko, V.O., Kwon, S.C., Lee, J.Y., Kim, M., 2011, Appl. Surf. Sci. 257, 8048.

[5] Protsenko, V.S., Gordiienko, V.O., Danilov, F.I., Kwon, S.C., 2011, Met. Finish. 109, 33.

[6] Protsenko, V.S., Gordiienko, V.O., Danilov, F.I., Kwon, S.C., Kim, M., Lee, J.Y., 2011, Surf. Eng. 27, 690.

[7] Protsenko, V.S., Danilov, F.I., Gordiienko, V.O., Kwon, S.C., Kim, M., Lee, J.Y., 2011, Thin Solid Films 520, 380.

[8] Bikulčius, G., Češunienè, A., Selskienè, A., Pakštas, V., Matijošius, T., 2017, Surf. Coat. Technol. 315, 130.

[9] Liang, A., Li, Y., Liang, H., Ni, L., Zhang, J., 2017, Mater. Lett. 189, 221.

[10] Surviliené, S., Nivinskiené, O., Češūniené, A., Selskis, A., 2006, J. Appl. Electrochem. 36, 649.

[11] Smith, E.L., Abbott, A.P., Ryder, K.S., 2014, Chem. Rev. 114, 11060.

[12] Abbott, A.P., Harris, R.C., Ryder, K.S., 2007, J. Phys. Chem. B 111, 4910.

[13] Abbott, A.P., Capper, G., Davies, D.L., Rasheed, R.K., Tambyrajah, V., 2003, Chem. Commun. 70.

[14] Abbott, A.P., Capper, G., Davies, D.L., Rasheed, R., 2004, Inorg. Chem. 43, 3447. 
[15] Abbott, A.P., Boothby, D., Capper, G., Davies, D.L., Rasheed, R.K., 2004, J. Am. Chem. Soc. 126, 9142.

[16] Abo-Hamad, A., Hayyan, M., AlSaadi, M.A., Hashim, M.A., 2015, Chem. Eng. J. 273, 551.

[17] Abbott, A.P., McKenzie, K.J., 2006, Phys. Chem. Chem. Phys. 8, 4265.

[18] Abbott, A.P., Ryder, K.S., König, U., 2008, Trans. Inst. Met. Finish. 86, 196.

[19] Abbott, A.P., Frisch, G., Ryder, K.S., 2013, Annu. Rev. Mater. Res. 43, 335.

[20] Abbott, A.P., Capper, G., Davies, D.L., Rasheed, R.K., 2004, Chem. A Europ. J. 10,3769 .

[21] Abbott, A.P., Al-Barzinjy, A.A., Abbott, P.D., Frish, G., Harris, R.C., Hartley, J., Ryder, K.S., 2014, Phys. Chem. Chem. Phys. 16, 9047.

[22] Maharaja, J., Raja, M., Mohan, S., 2014, Surf. Eng. 30, 722.

[23] Ferreira, E.S.C., Pereira, C.M., Silva, A.F., 2013, J. Electroanal. Chem. 707, 52.

[24] McCalman, D.C., Sun, L., Zhang, Y., Brennecke, J.F., Maginn, E.J., Schneider, W.F., 2015, J. Phys. Chem. B 119, 6018.

[25] Sun, L., Brennecke, J.F., 2015, Ind. Eng. Chem. Res. 54, 4879.

[26] Zhang, J., Gu, C., Tong, Y., Gou, J., Wang, X., Tu, J., 2015, RSC Adv. 5, 71268.

[27] Bobrova, L.S., Danilov, F.I., Protsenko, V.S., 2016, J. Mol. Liq. 223, 48.

[28] Protsenko, V., Bobrova, L., Danilov, F., 2018, Anti-Corros. Methods Mater. $65,499$.

[29] Protsenko, V.S., Bobrova, L.S., Danilov, F.I., 2017, Ionics 23, 637.

[30] Danilov, F.I., Protsenko, V.S., Butyrina, T.E., Vasil'eva, E.A., Baskevich, A.S., 2006, Prot. Met. 42, 560.

[31] Protsenko, V.S., Danilov, F.I., Gordiienko, V.O., Baskevich, A.S., Artemchuk, V.V., 2012, Int. J. Refract. Met. Hard Mater. 31, 281.

[32] Protsenko, V.S., Gordiienko, V.O., Danilov, F.I., 2012, Electrochem. Commun. 17, 85.

[33] Zeng, Z., Wang, L., Liang, A., Chen, L., Zhang, J., 2007, Mater. Lett. 61, 4107.

[34] Huang, C.A., Liu, Y.W., Yu, C., Yang, C.-C., 2011, Surf. Coat. Technol. 205, 3461.

[35] Danilov, F.I., Protsenko, V.S., 2001, Prot. Met. 37, 223.

[36] Danilov, F.I., Protsenko, V.S., Butyrina, T.E., 2001, Russ. J. Electrochem. 37, 704.

[37] Huang, C.-A., Lin, W., Liao, M.J., 2006, Corros. Sci. 48, 460.

[38] Edigaryan, A.A., Safonov, V.A., Lubnin, E.N., Vykhodtseva, L.N., Chusova, G.E., Polukarov, Yu.M., 2002, Electrochim. Acta 47, 2775.

[39] Tsirlina, G.A., Petrii, O.A., 1987, Electrochim. Acta 32, 649.

[40] Tomás-García, A.L., Jensen, J.O., Bjerrum, N.J., Li, Q., 2014, Electrochim. Acta 137, 639.

[41] Schmuecker, S.M., Clouser, D., Kraus, T.J., Leonard, B.M., 2017, Dalton Trans. 46, 13524. 


\title{
Electrochemical coating based on tin-nickel alloy with antibacterial properties
}

\author{
Pyanko A.V., Chernik A.A., Alisienok O.A., Sergievich D.S. \\ Belarusian State Technological University, Minsk, Sverdlov Str. 13a, 220006
}

Hygiene/antimicrobial issues in public places eg. hospitals, schools, hotels, public transportation etc. are of a crucial importance as its ignorance could lead to spread of viral diseases or epidemics and consequently to deaths. A typical example of that are hospital acquired infections (HAI). According to The European Centre for Disease Prevention and Control (ECDC) in the EU, about 3 million people are infected annually with HAI and about 25,000 patients die from HAI-related reasons. Such infections also arise extra healthcare costs and result in annual productivity losses of at least $€ 1.5$ billion. It is estimated that $15 \%$ of these infections are due to the transmission through inanimate objects. Although sanitization and disinfection of surfaces using chemical liquids such as chloride or alcohol-based detergents is a common practice to prevent transmission of diseases, frequently such procedures are skipped, skimped or in the case of public transportation not practically feasible.

Since 1985, when Matsunaga et al. [1] reported about photochemical sterilization of Saccharomyces cerevisiae (yeast), Lactobacillus acidophilus and Escherichia coli (bacteria), and Chlorella vulgaris in water using $\mathrm{Pt}-\mathrm{TiO}_{2}$ photocatalyst under metal halide lamp irradiation, much research has been performed on the photocatalytic antimicrobial effect of $\mathrm{TiO}_{2}[2]$.

A lot of studies [6-12] have demonstrated that $\mathrm{TiO}_{2}$-mediated photooxidation shows much promise for the elimination of microorganisms in many applications especially in the areas where the use of chemical cleaning agents or biocides has proven to be ineffective or is restricted by regulations, e.g., in the pharmaceutical or food industry. The photobiocide properties of $\mathrm{TiO}_{2}$ also open the possibility of developing highly effective self-cleaning and selfsterilizing materials. 
In this work, bactericidal activities of samples $\mathrm{Sn}-\mathrm{Ni}$ films modified $\mathrm{TiO}_{2}$, are investigated in killing of both gram-positive and gram-negative bacteria with the special reference on the role of the photoproduced reactive oxygen species of different types in the cell inactivation.

\section{Experimental}

The most suitable matrix for antibacterial composite electrochemical coatings is a tin-nickel alloy containing $65 \%$ of tin and $35 \%$ of nickel. This coating has enhanced decorative properties, microhardness, corrosion- and wear resistance. Electrolytes for the electrodeposition of the tin-nickel alloy are aqueous solutions of nickel and tin salts. The concentration of tin salt determines the range of permissible cathode current densities [3].

Such composite coatings consist of $\mathrm{Sn}-\mathrm{Ni}$ matrix and are doped with $\mathrm{TiO}_{2}$ nanoparticles as a reinforcing mean. Doped- $\mathrm{TiO}_{2}$ nanoparticles, having the ability to absorb visible light, can be activated indoors and thus present enhanced photocatalytic activity. The incorporation of such doped- $\mathrm{TiO}_{2}$ nanoparticles in the $\mathrm{Sn}-\mathrm{Ni}$ matrix will provide its self-cleaning and antibacterial properties. The percentage of the incorporated nanoparticles is of crucial importance. In order to increase the co-deposition rate and consequently the photocatalytic activity, pulse current plating could be utilized. By this method, higher co-deposition rate of nanoparticles can be achieved compared to the conventional direct current plating. These kind of coating is able to be operated under indoor light irradiation and can be applied to common touched objects (knobs, taps, handles) reducing the risk of infection's transmission by $50-100 \%$.

Nanodisperse titanium dioxide, obtained by sol-gel technology, has the ability to absorb visible light and has increased photocatalytic properties [5]. The technology provides a stable particle size of the hydrosol in the range of 10-20 $\mathrm{nm}$. As a peptizing acid, it is possible to use strong mono-basic inorganic acids: nitric and hydrochloric acids. The content of the solid phase can vary for the hydrosol from 1.5 to $6 \%$ by weight (in terms of $\mathrm{TiO}_{2}$ ), for xerogels derived from this hydrosol - up to $70 \%$ by weight, while xerogels retain the ability to peptize in aqueous solutions 
without addition additional components. Titanium dioxide, which is part of the xerogel, contains up to $70-75 \%$ of the crystalline phase. These properties can be used to create antibacterial metal coatings. Nanoparticles of the $\mathrm{sol} \mathrm{TiO}_{2}$ are introduced in the tin-nickel alloy electrolyte.

\section{Results and discussion}

In the course of this research work, the composition and characteristics of the process were optimized. The optimal range of current densities for alloy electrodeposition was defined using the Hull cell (Fig. 1). It is recommended to use low current values $\left(0.5 \mathrm{~A} / \mathrm{dm}^{2}\right)$ to obtain a $\mathrm{Sn}-\mathrm{Ni}-\mathrm{TiO}_{2}$ composite coating.

c) $0,5 \mathrm{~A} / \mathrm{dm} 2$
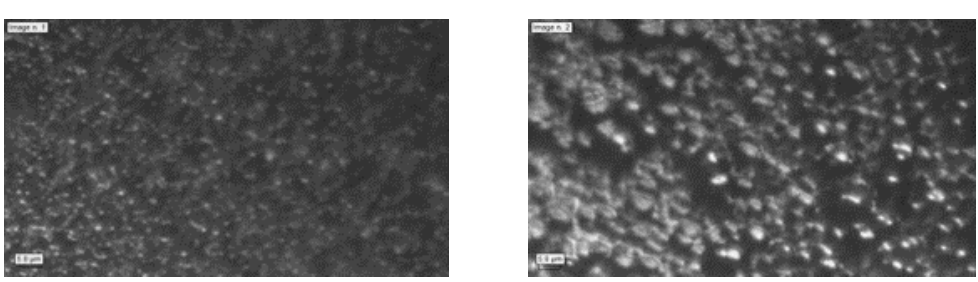

a)

$\mathrm{A} / \mathrm{dm}^{2}$

b) 0,8 $\mathrm{A} / \mathrm{dm}^{2}$

Fig. 1. Microphotographs of the surface of metal coatings obtained at different current densities

At high current densities dark, opaque coatings are deposited, current density of $0,8 \mathrm{~A} / \mathrm{dm}^{2}$ allows to form - semimatous alloys and, at low current densities coatings are shiny.

Figure 2 shows potentiostatic anodic polarization curve of the tin-nickel alloy with titanium dioxide deposition onto copper.

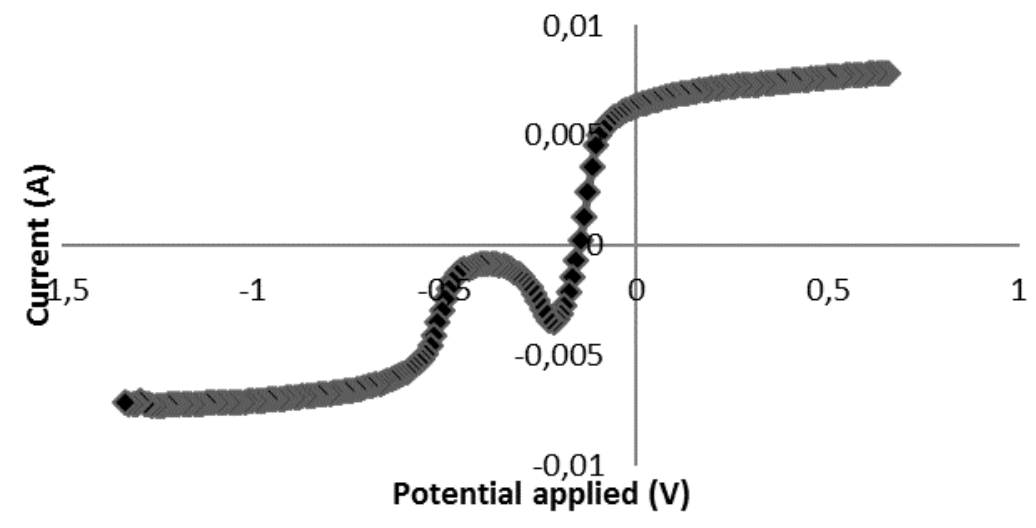


Fig. 2. Potentiostatic anodic polarization curve of the tin-nickel alloy with titanium dioxide deposition process

From the anodic polarization curve it is seen that at a potential values from -0.60 to $-0.20 \mathrm{~V}$ a peak appears. This peak is characteristic for the process of electrodeposition of titanium dioxide. Therefore, during the electrochemical deposition of the composite coating, a co-precipitation of $\mathrm{Sn}-\mathrm{Ni}-\mathrm{TiO}_{2}$. The chemical modification (doping) of $\mathrm{TiO}_{2}$ nanoparticles aims to achieve lower band gap and thus become capable of operating in indoor light.

Development of pulse plating process in order to achieve high incorporation rate and uniform distribution of reinforcing nanoparticles on the surface of metal/alloy matrix leads to an effective immobilization of photocalalytic particles. Optimization of the pulse plating process in order to be sustainable in terms of saving energy, time and raw materials.

The antimicrobial activity of the samples was determined using gram-negative bacterium Escherichia coli and grampositive bacterium Staphylococcus aureus as the testcultures. The overnight cultures in the nutrient broth were diluted with sterile physiological solution $(0.15 \mathrm{M} \mathrm{NaCl})$, then $100 \mathrm{ml}$ of bacteria suspension was placed on the samples; the control samples have no photocatalyst coating. All samples were exposed to UV light for 60 min (Fig. 3).

Fig. 3. Samples after

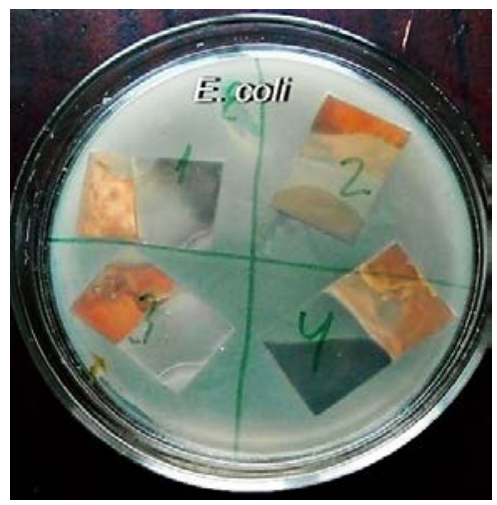

the antibacterial test: 1 - control

sample (Sn-Ni),

$$
2 \text { - Sn-Ni-0,5g/1 TiO } 2,3 \text { - Sn-Ni-1g/1 TiO } 2,4 \text { - Sn-Ni-2g/1 TiO } 2
$$


From the results in control sample (Fig. 3, 1) and in sample with Sn-Ni-1g/1 TiO (Fig. 3, 3) electrochemical coating, when UV light was not applied, no inactivation of microorganisms was observed. It is means that the bacteria on the surface of the samples could be distributed unevenly, and the recommended concentration of titanium dioxide synthesized from the sol is $1 \mathrm{~g} / \mathrm{l}$ in the composition of the coating. Samples 2 and 4 (Fig. 3) also have antibacterial properties, but they are less active $(50 \%)$.

\section{Discussion and Conclusion}

The result of the work is the development of a sol-gel mass production method of doped-TiO2 nanoparticles, realization of robust process parameters, enhancement of functional properties of obtained coating exhibiting high adhesion with the substrate, testing the antibacterial character of the coating under different relevant light conditions. Such coatings will be able to work with room lighting and can be applied to general facilities (pens, cranes, handrails and etc.), which will reduce the risk of transmission of infection in 50-100\%.

\section{References}

[1] T. Matsunaga, R. Tomoda, T. Nakajima, H. Wake, Photoelectrochemical sterilization of microbial cells by semiconductor powders, FEMS Microbiol. Lett. 29 (1985) 211-214.

[2] H.M. Yadav, S.V. Otari, R.A. Bohara, S.S. Mali, S.H. Pawar, S.D. Delekar, Synthesis and visible light photocatalytic antibacterial activity of nickelndashdoped $\mathrm{TiO}_{2}$ nanoparticles against gramndashpositive and gramndashnegative bacteria, Journal of Photochemistry and Photobiology A: Chemistry (2014), http://dx.doi.org/10.1016/j.jphotochem.2014.07.024

[3] Spiridonov BA, Berezina NN Electrodeposition and structure of tin-nickel coatings, Protection of metals, 2004. T. 40. №1.

[4] Liana Anicaia, Aurora Peticab, Stefania Costovicic Electrodeposition of Sn and Ni-Sn alloys coatings using choline chloride based ionic liquids-evaluation of corrosion behavior Electrochimica Acta,, 2013, V. 114. P. 868-877.

[5] Zhao Y, Li C., Liu X., Gu F., Jiang H., Shao W., Zhang L., He Y. Synthesis and optical properties of $\mathrm{TiO}_{2}$ nanoparticles, Materials Letters. 2007. V.61. №1. P. 79-83.

[6] A.N. Murashkevich, OA Alisienok, I.M. Zharskiy Physicochemical and phocurrental properties of nano-sized titanium dioxide precipitated on silica microspheres // Kinetics and catalysis. - 2011. - T. 52. № 6. - C. 830-837.

[7] A.N. Murashkevich, AS Lavitskaya, TI Barannikova, I.M. Zharskiy Infrared absorption spectra and structure of $\mathrm{TiO}_{2}-\mathrm{SiO}_{2}$ composites // ZhPS. 2008. T.75. № 5 . P. 724-728. 


\title{
Electrochemical coating based on tin-nickel alloy with antibacterial properties
}

\author{
Pyanko A.V., Chernik A.A., Alisienok O.A., Sergievich D.S. \\ Belarusian State Technological University, Minsk, Sverdlov Str. 13a, 220006
}

Hygiene/antimicrobial issues in public places eg. hospitals, schools, hotels, public transportation etc. are of a crucial importance as its ignorance could lead to spread of viral diseases or epidemics and consequently to deaths. A typical example of that are hospital acquired infections (HAI). According to The European Centre for Disease Prevention and Control (ECDC) in the EU, about 3 million people are infected annually with HAI and about 25,000 patients die from HAI-related reasons. Such infections also arise extra healthcare costs and result in annual productivity losses of at least $€ 1.5$ billion. It is estimated that $15 \%$ of these infections are due to the transmission through inanimate objects. Although sanitization and disinfection of surfaces using chemical liquids such as chloride or alcohol-based detergents is a common practice to prevent transmission of diseases, frequently such procedures are skipped, skimped or in the case of public transportation not practically feasible.

Since 1985, when Matsunaga et al. [1] reported about photochemical sterilization of Saccharomyces cerevisiae (yeast), Lactobacillus acidophilus and Escherichia coli (bacteria), and Chlorella vulgaris in water using $\mathrm{Pt}-\mathrm{TiO}_{2}$ photocatalyst under metal halide lamp irradiation, much research has been performed on the photocatalytic antimicrobial effect of $\mathrm{TiO}_{2}[2]$.

A lot of studies [6-12] have demonstrated that $\mathrm{TiO}_{2}$-mediated photooxidation shows much promise for the elimination of microorganisms in many applications especially in the areas where the use of chemical cleaning agents or biocides has proven to be ineffective or is restricted by regulations, e.g., in the pharmaceutical or food industry. The photobiocide properties of $\mathrm{TiO}_{2}$ also open the possibility of developing highly effective self-cleaning and selfsterilizing materials. 
In this work, bactericidal activities of samples $\mathrm{Sn}-\mathrm{Ni}$ films modified $\mathrm{TiO}_{2}$, are investigated in killing of both gram-positive and gram-negative bacteria with the special reference on the role of the photoproduced reactive oxygen species of different types in the cell inactivation.

\section{Experimental}

The most suitable matrix for antibacterial composite electrochemical coatings is a tin-nickel alloy containing $65 \%$ of tin and $35 \%$ of nickel. This coating has enhanced decorative properties, microhardness, corrosion- and wear resistance. Electrolytes for the electrodeposition of the tin-nickel alloy are aqueous solutions of nickel and tin salts. The concentration of tin salt determines the range of permissible cathode current densities [3].

Such composite coatings consist of $\mathrm{Sn}-\mathrm{Ni}$ matrix and are doped with $\mathrm{TiO}_{2}$ nanoparticles as a reinforcing mean. Doped- $\mathrm{TiO}_{2}$ nanoparticles, having the ability to absorb visible light, can be activated indoors and thus present enhanced photocatalytic activity. The incorporation of such doped- $\mathrm{TiO}_{2}$ nanoparticles in the $\mathrm{Sn}-\mathrm{Ni}$ matrix will provide its self-cleaning and antibacterial properties. The percentage of the incorporated nanoparticles is of crucial importance. In order to increase the co-deposition rate and consequently the photocatalytic activity, pulse current plating could be utilized. By this method, higher co-deposition rate of nanoparticles can be achieved compared to the conventional direct current plating. These kind of coating is able to be operated under indoor light irradiation and can be applied to common touched objects (knobs, taps, handles) reducing the risk of infection's transmission by $50-100 \%$.

Nanodisperse titanium dioxide, obtained by sol-gel technology, has the ability to absorb visible light and has increased photocatalytic properties [5]. The technology provides a stable particle size of the hydrosol in the range of 10-20 $\mathrm{nm}$. As a peptizing acid, it is possible to use strong mono-basic inorganic acids: nitric and hydrochloric acids. The content of the solid phase can vary for the hydrosol from 1.5 to $6 \%$ by weight (in terms of $\mathrm{TiO}_{2}$ ), for xerogels derived from this hydrosol - up to $70 \%$ by weight, while xerogels retain the ability to peptize in aqueous solutions 
without addition additional components. Titanium dioxide, which is part of the xerogel, contains up to $70-75 \%$ of the crystalline phase. These properties can be used to create antibacterial metal coatings. Nanoparticles of the sol $\mathrm{TiO}_{2}$ are introduced in the tin-nickel alloy electrolyte.

\section{Results and discussion}

In the course of this research work, the composition and characteristics of the process were optimized. The optimal range of current densities for alloy electrodeposition was defined using the Hull cell (Fig. 1). It is recommended to use low current values $\left(0.5 \mathrm{~A} / \mathrm{dm}^{2}\right)$ to obtain a $\mathrm{Sn}-\mathrm{Ni}-\mathrm{TiO}_{2}$ composite coating.

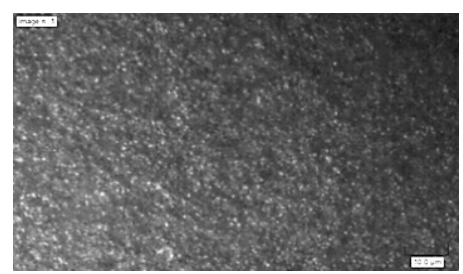

a) $1 \mathrm{~A} / \mathrm{dm}^{2}$

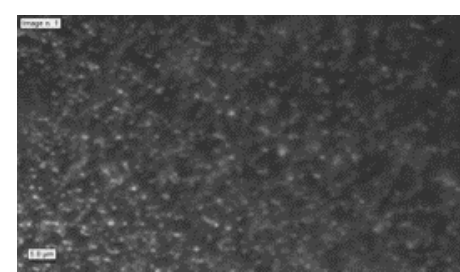

b) $0,8 \mathrm{~A} / \mathrm{dm}^{2}$

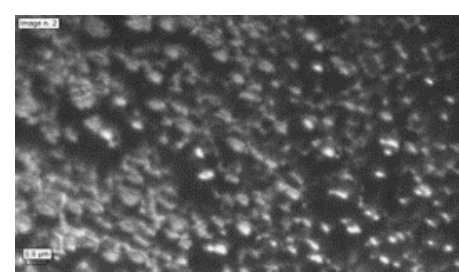

c) $0,5 \mathrm{~A} / \mathrm{dm} 2$

Fig. 1. Microphotographs of the surface of metal coatings obtained at different current densities

At high current densities dark, opaque coatings are deposited, current density of $0,8 \mathrm{~A} / \mathrm{dm}^{2}$ allows to form - semimatous alloys and, at low current densities coatings are shiny.

Figure 2 shows potentiostatic anodic polarization curve of the tin-nickel alloy with titanium dioxide deposition onto copper. 


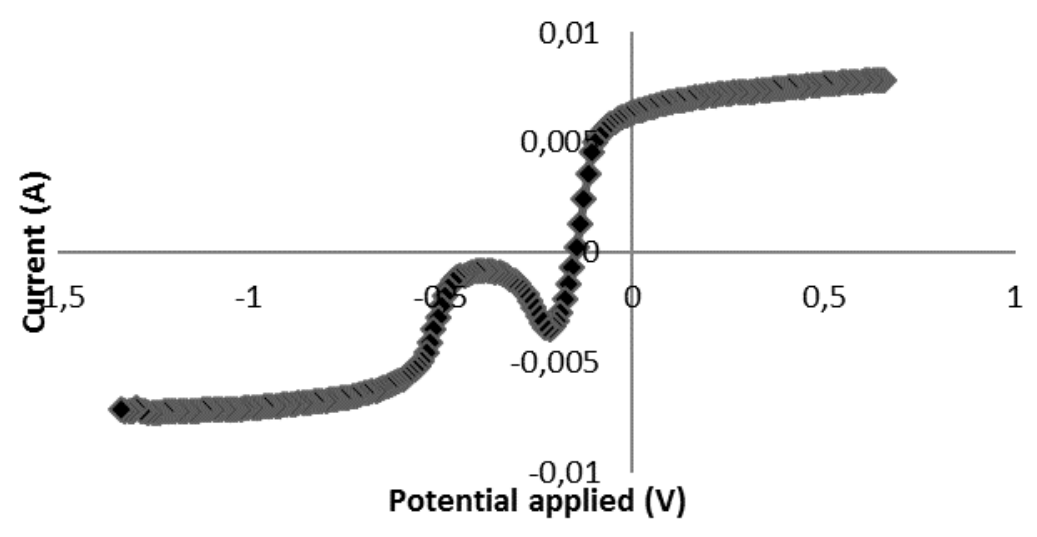

Fig. 2. Potentiostatic anodic polarization curve of the tin-nickel alloy with titanium dioxide deposition process

From the anodic polarization curve it is seen that at a potential values from -0.60 to $-0.20 \mathrm{~V}$ a peak appears. This peak is characteristic for the process of electrodeposition of titanium dioxide. Therefore, during the electrochemical deposition of the composite coating, a co-precipitation of $\mathrm{Sn}-\mathrm{Ni}-\mathrm{TiO}_{2}$. The chemical modification (doping) of $\mathrm{TiO}_{2}$ nanoparticles aims to achieve lower band gap and thus become capable of operating in indoor light.

Development of pulse plating process in order to achieve high incorporation rate and uniform distribution of reinforcing nanoparticles on the surface of metal/alloy matrix leads to an effective immobilization of photocalalytic particles. Optimization of the pulse plating process in order to be sustainable in terms of saving energy, time and raw materials.

The antimicrobial activity of the samples was determined using gram-negative bacterium Escherichia coli and grampositive bacterium Staphylococcus aureus as the testcultures. The overnight cultures in the nutrient broth were diluted with sterile physiological solution $(0.15 \mathrm{M} \mathrm{NaCl})$, then $100 \mathrm{ml}$ of bacteria suspension was placed on the samples; the control samples have no photocatalyst coating. All samples were exposed to UV light for 60 min (Fig. 3). 


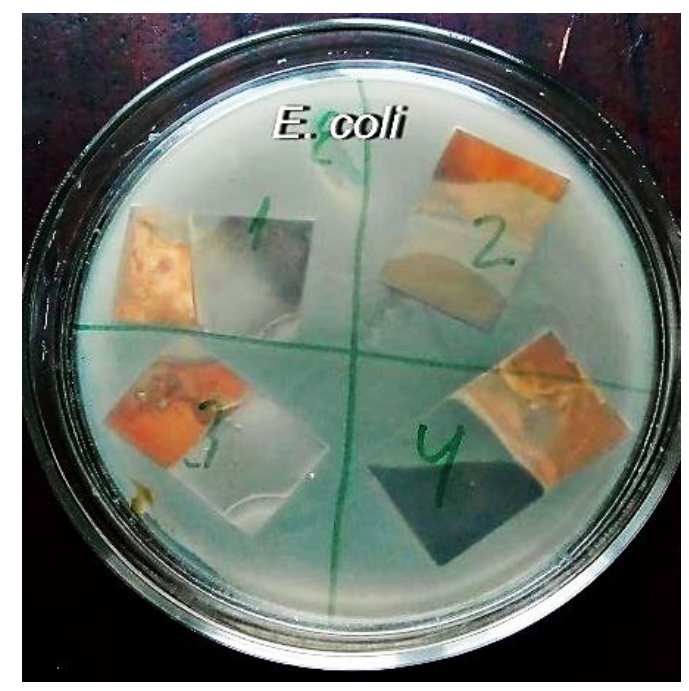

Fig. 3. Samples after the antibacterial test: 1 - control sample (Sn-Ni), 2 - Sn-Ni-0,5g/1 TiO 2,3 - Sn-Ni-1g/1 TiO 2,4 - Sn-Ni-2g/1 TiO 2

From the results in control sample (Fig. 3,1 ) and in sample with Sn-Ni-1g/1 TiO (Fig. 3, 3) electrochemical coating, when UV light was not applied, no inactivation of microorganisms was observed. It is means that the bacteria on the surface of the samples could be distributed unevenly, and the recommended concentration of titanium dioxide synthesized from the sol is $1 \mathrm{~g} / 1$ in the composition of the coating. Samples 2 and 4 (Fig. 3) also have antibacterial properties, but they are less active $(50 \%)$.

\section{Discussion and Conclusion}

The result of the work is the development of a sol-gel mass production method of doped-TiO2 nanoparticles, realization of robust process parameters, enhancement of functional properties of obtained coating exhibiting high adhesion with the substrate, testing the antibacterial character of the coating under different relevant light conditions. Such coatings will be able to work with room lighting and can be applied to general facilities (pens, cranes, handrails and etc.), which will reduce the risk of transmission of infection in 50-100\%. 


\section{References}

[1] T. Matsunaga, R. Tomoda, T. Nakajima, H. Wake, Photoelectrochemical sterilization of microbial cells by semiconductor powders, FEMS Microbiol. Lett. 29 (1985) 211-214.

[2] H.M. Yadav, S.V. Otari, R.A. Bohara, S.S. Mali, S.H. Pawar, S.D. Delekar, Synthesis and visible light photocatalytic antibacterial activity of nickelndashdoped $\mathrm{TiO}_{2}$ nanoparticles against gramndashpositive and gramndashnegative bacteria, Journal of Photochemistry and Photobiology A: Chemistry (2014), http://dx.doi.org/10.1016/j.jphotochem.2014.07.024

[3] Spiridonov BA, Berezina NN Electrodeposition and structure of tin-nickel coatings, Protection of metals, 2004. T. 40. №1.

[4] Liana Anicaia, Aurora Peticab, Stefania Costovicic Electrodeposition of Sn and $\mathrm{Ni}-\mathrm{Sn}$ alloys coatings using choline chloride based ionic liquids-evaluation of corrosion behavior Electrochimica Acta,, 2013, V. 114. P. 868-877.

[5] Zhao Y, Li C., Liu X., Gu F., Jiang H., Shao W., Zhang L., He Y. Synthesis and optical properties of $\mathrm{TiO}_{2}$ nanoparticles, Materials Letters. 2007. V.61. №1. P. 79-83.

[6] A.N. Murashkevich, OA Alisienok, I.M. Zharskiy Physicochemical and phocurrental properties of nano-sized titanium dioxide precipitated on silica microspheres // Kinetics and catalysis. - 2011. - T. 52. № 6. - C. 830-837.

[7] A.N. Murashkevich, AS Lavitskaya, TI Barannikova, I.M. Zharskiy Infrared absorption spectra and structure of $\mathrm{TiO}_{2}-\mathrm{SiO}_{2}$ composites // ZhPS. 2008. T.75. № 5. P. 724-728.

[8] A.N. Murashkevich, O.A. Alisienok, I.M. Zharskiy, E.K. Yukhno Nanoscale composite materials in the system $\mathrm{SiO}_{2}-\mathrm{TiO}_{2} / /$ Sol. Gel. Sci. and Tech. 2013. V.65. №3, P.367-373.

[9] S. Ito, T. Deguchi, K. Imai, M. Iwasaki, H. Tada, Preparation of Highly Photocatalytic Nanocomposite Films Consisting of $\mathrm{TiO}_{2}$ Particles and $\mathrm{Zn}$ Electrodeposited on Steel, Electrochem. Solid-State Lett. 2 (1999) 440-442.

[10] T. Deguchi, K. Imai, H. Matsui, M. Iwasaki, H. Tada, S. Ito, Rapid electroplating of photocatalytically highly active $\mathrm{TiO}_{2}-\mathrm{Zn}$ nanocomposite films on steel, J. Mater. Sci. 36 (2001) 4723-4729.

[11] S. Spanou, E. a. Pavlatou, N. Spyrellis, Ni/nano-TiO 2 composite electrodeposits: Textural and structural modifications, Electrochim. Acta

54 (2009) 2547-2555.

[12] A. Gomes, M.I. Pereira, M.H. Mendonça, F.M. Costa, $\mathrm{Zn}-\mathrm{TiO}_{2}$ composite films prepared by pulsed electrodeposition, J. Solid State Electrochem.9 (2004) 190196. 


\title{
Electrodeposition and characterization of $\mathrm{Ni}-\mathrm{TiO}_{2}$ composite coatings
}

\author{
Zaverach Ie.M., Yermak N.V. \\ Khmelnytskyi National University, Khmelnytskyi, Instytutska Str. 11, 29016 \\ evgzaverach@ukr.net
}

Electrodeposition of nickel-titania $\left(\mathrm{Ni}-\mathrm{TiO}_{2}\right)$ composite coatings was carried out from an additive-free Watts solution containing 10 and $20 \mathrm{~g} / 1$ dispersed $\mathrm{TiO}_{2}$ particles (size $2-3 \mu \mathrm{m}$ ). The influences of current density, bath temperature, $\mathrm{TiO}_{2}$ concentration in the bath were studied. The corrosion performance, wear behavior and electrocatalytic properties of $\mathrm{Ni}-\mathrm{TiO}_{2}$ composite coatings were investigated. The results indicated that $\mathrm{Ni}-\mathrm{TiO}_{2}$ composite coatings with $\mathrm{TiO}_{2}$ content $8-10$ wt.\% exhibited higher corrosion and wear resistance than $\mathrm{Ni}$ coatings. $\mathrm{Ni}-\mathrm{TiO}_{2}$ composites showed electrocatalytic activity for the methanol oxidation.

\section{Introduction}

Electrodeposition is one of the most important techniques for producing metal matrix composites, owing to many merits, such as low cost, low operating temperature, ease of fabrication and high quality deposits. The metal matrix composites are materials in which the properties of a metallic host material are modified with addition of the second dispersed phase (micro, submicron- or nanosized particles) by electrodeposition process. Nickel is commonly used as continuous metallic matrix phase of composite coatings because of the high rates of deposition; nickel has excellent mechanical properties and high corrosion resistance; the appearance and other properties of electrodeposited nickel can be varied over wide ranges by controlling the composition and operating parameters of the plating solution $[1,2]$. The dispersed phase can be hard oxides $\left(\mathrm{Al}_{2} \mathrm{O}_{3}, \mathrm{TiO}_{2}, \mathrm{SiO}_{2}\right)[3-5]$, carbides (SiC, WC) [6 - 8], nitrides (BN, AlN) $[9,10]$ or polymers (PE, PTFE) [11, 12]. Many types of composite coatings have been developed to enhance corrosion 
resistance, microhardness, wear resistance, self-lubrication, etc. The percentage and distribution of dispersed particles in metal matrix of composite coatings determine their mechanical and physicochemical properties. Moreover, the rate of particles' incorporation depends on the nature of particles (size, shape, charge) and the deposition conditions (current density, temperature, $\mathrm{pH}$ ) $[1-4,8-10,11]$.

Nickel based electrodes can be used as catalyst due to its surface oxidation properties. Their electrocatalytic activity depends mainly on the catalytic role of $\mathrm{Ni}(\mathrm{OH})_{2} / \mathrm{NiOOH}$ redox couple. Nickel displays potential catalytic properties in a wide number of processes: hydrogen evolution reaction, oxygen evolution reaction, hydrogenation reactions, electrosynthesis of amines, electrooxidation of small organic molecules (alcohols, aldehydes, amino acids, sugars) [13 - 19]. Electrooxidation of small organic molecules gives a promising way for direct converting the chemical energy of a fuel and an oxidant into electric energy in fuel cells. Nickel composite coatings show a higher catalytic activity than pure $\mathrm{Ni}$ coatings towards the electrochemical oxidation of methanol due to smaller grain size and larger actual surface area [17 - 19].

Thus, nickel based composite coatings are becoming important for different engineering applications: corrosion protection, hardening of machinery, increasing wear resistance, tool production, electrocatalysis. The aim of this work is to investigate the influence of deposition conditions on the incorporation of micro-sized $\mathrm{TiO}_{2}$ particles in nickel matrix and to study corrosion and electrocatalytic properties, wear behavior of $\mathrm{Ni}^{-\mathrm{TiO}_{2}}$ composites.

\section{Experimental details}

Nickel coatings and composite $\mathrm{Ni}-\mathrm{TiO}_{2}$ coatings were electrodeposited from an additive-free Watts solution with a composition (in $\mathrm{g} / \mathrm{l}$ ): $\mathrm{NiSO}_{4} \cdot 7 \mathrm{H}_{2} \mathrm{O} 240$ - 260; $\mathrm{NiCl}_{2} \cdot 6 \mathrm{H}_{2} \mathrm{O} 40-60 ; \mathrm{H}_{3} \mathrm{BO}_{3} 30-40$. The deposition conditions were cathode current density, i, $0,8-2,5 \mathrm{~A} / \mathrm{dm}^{2}$, $\mathrm{pH} 4-5$, bath temperature, $\mathrm{t}, 20$ and $50{ }^{\circ} \mathrm{C}$, concentration of $\mathrm{TiO}_{2}$ powder (size $2-3 \mu \mathrm{m}$ ) in bath, $\mathrm{C}_{\mathrm{TiO} 2}, 10$ and $20 \mathrm{~g} / \mathrm{l}$; metallurgical nickel anodes. The electrolyte was stirred by a magnetic stirrer in the electrodeposition process in order to maintain the uniform particles concentration and prevent 
sedimentation in solution. Plain carbon steel and tool steel samples were the cathodes. The thickness of coatings was 20 and $30 \mu \mathrm{m}$.

Before the electrodeposition, the samples were degreased in alkaline solution, dipped in acid solution (10\% $\mathrm{HCl}$ with $5 \mathrm{~g} / 1$ urotropine) and finally washed with distilled water. After electrodeposition, the samples were rinsed by distilled water and dried with air at room temperature. $\mathrm{TiO}_{2}$ content (wt.\%) in the deposits was determined by gravimetric measurements.

Electrochemical studies were carried out in a conventional three-electrode cell powered by potentiostat/ galvanostat PI-50-1.1. An Ag/AgCl-Saturated $\mathrm{KCl}$, a Pt wire and a sample $\left(\mathrm{S}=1 \mathrm{~cm}^{2}\right)$ with electrodeposited coating were used, respectively, as the reference, counter and working electrodes,. The corrosion performance of electrodeposited coatings was investigated by potentiodynamic (potential sweep rate, $\mathrm{v}$, was $5 \mathrm{mV} / \mathrm{s}$ ) and potentiostatic polarization. A model corrosion medium of $5 \%$ $\mathrm{NaCl}$ solution with $\mathrm{pH} \sim 6$ at temperature $15-20{ }^{\circ} \mathrm{C}$ was used. The investigations of methanol oxidation reaction were performed by using cyclic voltammetry at $\mathrm{v}=10$ $\mathrm{mV} / \mathrm{s}$. Measurements were carried out at temperature $15-20{ }^{\circ} \mathrm{C}$ in $1 \mathrm{M} \mathrm{NaOH}$ solution in the absence and the presence of $1 \mathrm{M}$ of methanol. Prior to performing the polarization measurements, all investigated samples were maintained for a definite period in the solution. Potentials are presented in a standard hydrogen scale. The corrosion potential $\left(\mathrm{E}_{\mathrm{cor}}\right)$ and corrosion current density $\left(\mathrm{i}_{\mathrm{cor}}\right)$ were obtained using the Tafel exploration method. Corrosion rate K (mm/year) was calculated from the following equation

$$
K=8,76 \cdot \frac{i_{c o r} \cdot q_{N i}}{\rho_{N i}}
$$

where $\mathrm{i}_{\text {cor }}$ is corrosion current density in $\mathrm{A} / \mathrm{m}^{2}, \mathrm{q}_{\mathrm{Ni}}$ is electrochemical equivalent in $\mathrm{g} /(\mathrm{A} \cdot \mathrm{h}), \rho_{\mathrm{Ni}}$ is the density in $\mathrm{g} / \mathrm{cm}^{3}$.

For measuring the wear resistance, dry sliding wear tests were carried out by using a pin on disk type machine on cylindrical samples against a steel wheel. The changes of linear size of sample due to wear of the pin was measured by differential 
capacitance sensor. The sliding parameters were rotation speed of the disc $40 \mathrm{~m} / \mathrm{min}$, the applied load $60 \mathrm{~N}$, the sliding distance $1000 \mathrm{~m}$.

\section{Results and discussion}

The effect of deposition conditions on $\mathrm{Ni}-\mathrm{TiO}_{2}$ coatings composition is shown in Table 1. According to the obtained data, the content of $\mathrm{TiO}_{2}$ particles in the coatings grows considerably due to the increase of concentration of dispersed phase in electrolyte. Apparent influence of current density and bath temperature on incorporation of $\mathrm{TiO}_{2}$ particles in nickel matrix was observed.

Table 1. Effect of deposition conditions on

$\mathrm{Ni}-\mathrm{TiO}_{2}$ coatings composition

\begin{tabular}{l|l|l|l|l}
\hline $\mathrm{i}, \mathrm{A} / \mathrm{dm}^{2}$ & $\mathrm{C}_{\mathrm{TiO} 2}, \mathrm{~g} / \mathrm{l}$ & $\mathrm{t},{ }^{\circ} \mathrm{C}$ & $\mathrm{Ni}(\mathrm{wt} . \%)$ & $\mathrm{TiO}_{2}$ (wt.\%) \\
\hline 0,8 & 10 & 20 & $95-97$ & $3-5$ \\
\hline 1,0 & 10 & 20 & $98-99$ & $1-2$ \\
\hline 1,0 & 10 & 50 & $86-88$ & $13-15$ \\
\hline 1,5 & 10 & 50 & $90-92$ & $8-10$ \\
\hline 1,5 & 20 & 50 & $75-78$ & $22-25$ \\
\hline 2,5 & 10 & 50 & $97-99$ & $1-3$ \\
\hline 2,5 & 20 & 50 & $82-85$ & $15-18$ \\
\hline
\end{tabular}

These results may be explained by the adsorption mechanism of dispersed particles and metal codeposition $[1,11,18]$. These phenomena play a considerable role in particle codeposition with nickel, due to the high adsorption affinity of nickel for the solid particles. According to this mechanism, the rate of codeposition is determined by initiation of real contact between the metal ions adsorbed on dispersed particles and the cathode surface. Once the particles are absorbed on the cathode surface, they will be imbedded into metal of coatings. With increased amount of $\mathrm{TiO}_{2}$ dispersed particles in the electrolyte, nickel will be deposited with a higher amount of dispersed particles and a large area of the cathode surface will be covered by them.

It is known, that the increase of current density increases the Coulombic force between $\mathrm{Ni}^{2+}$ absorbed on dispersed particles and the cathode. Thus, the rate of 
movement of $\mathrm{TiO}_{2}$ particles from bulk solution to the cathode surface increases, agglomeration of dispersed particles in the solution near the cathode may happen. Big agglomerates were not encapsulated and incorporated in metal matrix. Effect of bath temperature is conditioned on better efficiency of nickel deposition.

Fig. 1a presents potentiodynamic anodic polarization curves of galvanic nickel and $\mathrm{Ni}-\mathrm{TiO}_{2}$ composite coatings deposited at $\mathrm{i}=1,5 \mathrm{~A} / \mathrm{dm}^{2}$ and $\mathrm{C}_{\mathrm{TiO} 2} 10$ and $20 \mathrm{~g} / \mathrm{l}$. Potentiostatic polarization curves (Fig. 1b) were obtained to evaluate corrosion data. The $\mathrm{E}_{\text {cor }}, \mathrm{i}_{\text {cor }}$ and $\mathrm{K}$ values were calculated using the Tafel extrapolation method and equation (1) and they are given in Table 2.

Table 2. Corrosion data of $\mathrm{Ni}$ and $\mathrm{Ni}-\mathrm{TiO}_{2}$ coatings

\begin{tabular}{l|l|l|l}
\hline Coating & $\mathrm{E}_{\text {cor, }} \mathrm{V}$ & $\mathrm{i}_{\text {cor }}, \mathrm{A} / \mathrm{m}^{2}$ & $\mathrm{~K}, \mathrm{~mm} /$ year \\
\hline $\mathrm{Ni}$ & $-0,175$ & 0,141 & 0,15 \\
\hline $\mathrm{Ni}-\mathrm{TiO}_{2}$, & $-0,085$ & 0,076 & 0,08 \\
$\mathrm{TiO}_{2}$ content $8-10$ wt. $\%$ & & & \\
\hline
\end{tabular}

It was found, that incorporation in nickel matrix of dispersed $\mathrm{TiO}_{2}$ particles results in shift of corrosion potentials to more positive values, decreases currents of anodic dissolution and corrosion currents in comparison with the pure Ni coatings. One should note here that anodic currents were higher for $\mathrm{Ni}^{-\mathrm{TiO}_{2}}$ coatings deposited at $\mathrm{C}_{\mathrm{TiO} 2} 10 \mathrm{~g} / \mathrm{l}\left(\mathrm{TiO}_{2}\right.$ content $\left.22-25 \mathrm{wt} . \%\right)$ at $\mathrm{E}>0,2 \mathrm{~V}$ than for nickel coatings (curve 1,3 Fig. 1a). It can be attributed to the high content of $\mathrm{TiO}_{2}$ in deposits which enhances their surface roughness.

The improvement of corrosion behavior of $\mathrm{Ni}^{-\mathrm{TiO}_{2}}$ composite coatings can be connected with screening effect of metal matrix by dispersed particles with low electric conductivity and decrease in pitting at incorporation of dispersed particles. Besides, incorporation of $\mathrm{TiO}_{2}$ into nickel coatings may reduce the size of Ni grains, due to the distribution of $\mathrm{TiO}_{2}$ particles on the boundaries of $\mathrm{Ni}$ grains in the electrodeposition [18]. 

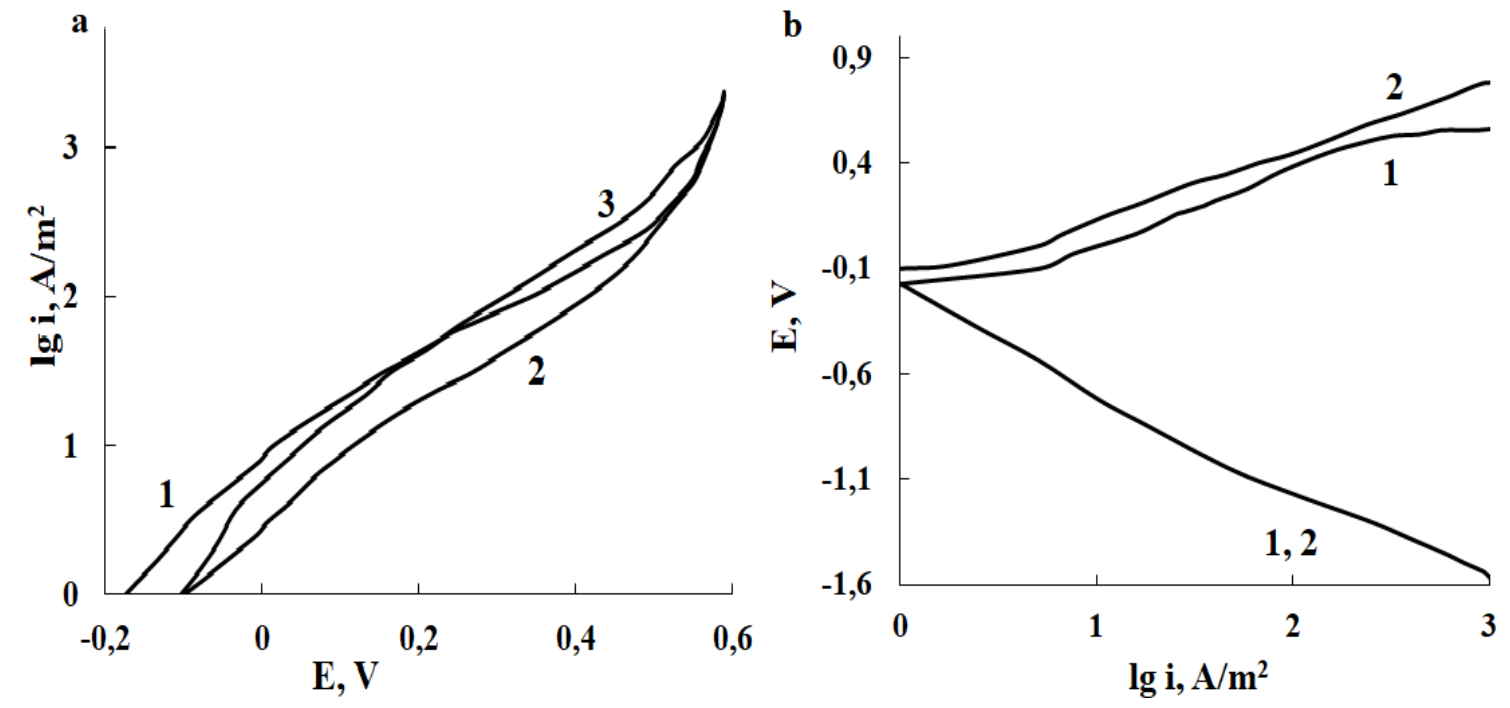

Fig. 1. Potentiodynamic anodic polarization curves, $v=5 \mathrm{mV} / \mathrm{s}$; (b) potentiostatic polarization curves in $5 \% \mathrm{NaCl}$. $\mathrm{Ni}$ coatings $(1)$ and $\mathrm{Ni}-\mathrm{TiO}_{2}$ coatings $(2,3)$ deposited at $\mathrm{i}=1,5 \mathrm{~A} / \mathrm{dm}^{2}$ and $\mathrm{C}_{\mathrm{TiO} 2}: 10 \mathrm{~g} / 1$ (2) and $20 \mathrm{~g} / 1$ (3)

The relations between sliding distance and wear of samples with $\mathrm{Ni}$ and $\mathrm{Ni}-\mathrm{TiO}_{2}$ coatings is drawn in Fig.2. The results indicate that the wear of the coated surface increases with sliding distance. On the other hand, the wear of some $\mathrm{Ni}^{-\mathrm{TiO}_{2}}$ composite coatings is lower than Ni coatings (curve 3 Fig. 2a; curve 3 Fig. 2b). At sliding distance $1000 \mathrm{~m} \mathrm{Ni}$ coatings show the wear around $0,150 \mathrm{~mm}$, but the $\mathrm{Ni}$ $\mathrm{TiO}_{2}$ composite coating deposited at $\mathrm{t}=20{ }^{\circ} \mathrm{C}$ and current density $1 \mathrm{~A} / \mathrm{dm}^{2}\left(\mathrm{TiO}_{2}\right.$ content $1-2$ wt.\%) show the wear $0,058-0,060 \mathrm{~mm}$ and $\mathrm{Ni}^{-\mathrm{TiO}_{2}}$ composite coating deposited at $\mathrm{t}=50{ }^{\circ} \mathrm{C}$ and $\mathrm{i}=1,5 \mathrm{~A} / \mathrm{dm}^{2}\left(\mathrm{TiO}_{2}\right.$ content $8-10$ wt. $\left.\%\right)$ show the wear $0,065-0,070 \mathrm{~mm}$. By comparison, wear of uncoated samples was 0,450$0,495 \mathrm{~mm}$. 

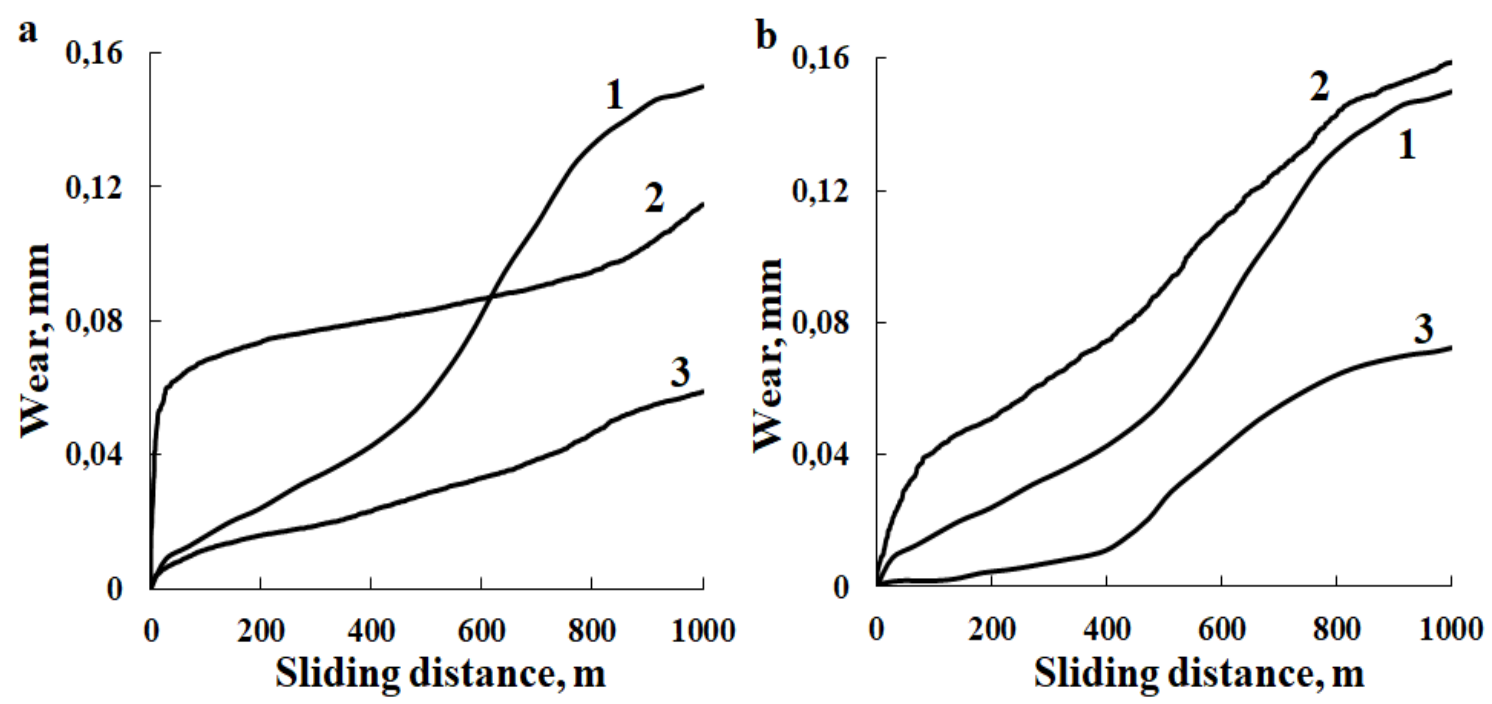

Fig. 2. Relations between sliding distance and wear of samples with Ni coating (1) and with $\mathrm{Ni}-\mathrm{TiO}_{2}$ coating $(2,3)$. (a) $\mathrm{Ni}-\mathrm{TiO}_{2}$ coating deposited at $\mathrm{t}=20^{\circ} \mathrm{C}$ and $\mathrm{i}: 0,8$ $\mathrm{A} / \mathrm{dm}^{2}$ (2), $1 \mathrm{~A} / \mathrm{dm}^{2}$ (3); (b) $\mathrm{Ni}_{-} \mathrm{TiO}_{2}$ composite coating deposited at $\mathrm{t}=50^{\circ} \mathrm{C}$ and $\mathrm{i}: 1$ $\mathrm{A} / \mathrm{dm}^{2}(2), 1,5 \mathrm{~A} / \mathrm{dm}^{2}(3)$

It was established, that wear behavior of $\mathrm{Ni}^{-\mathrm{TiO}_{2}}$ composites depends on deposition conditions which determinate $\mathrm{TiO}_{2}$ content into deposits and size of $\mathrm{Ni}$ grains $[1,2]$. The improvement of wear behavior for some $\mathrm{Ni}^{-\mathrm{TiO}_{2}}$ composites with $\mathrm{TiO}_{2}$ content $1-10$ wt.\% may result from optimum number and distribution of dispersed particles in $\mathrm{Ni}$ matrix. $\mathrm{TiO}_{2}$ particles with high hardness are barriers for shift of coating microlayers that lead to changing the friction conditions in sliding couple.

Fig. 3 shows cyclic voltammograms of $\mathrm{Ni}$ and $\mathrm{Ni}-\mathrm{TiO}_{2}$ coatings in $1 \mathrm{M} \mathrm{NaOH}$ in the absence and presence of methanol. Two small peaks are observed in the voltammograms of $\mathrm{Ni}$ and $\mathrm{Ni}-\mathrm{TiO}_{2}$ coatings in $1 \mathrm{M} \mathrm{NaOH}$ in anodic direction. One at about $0,10-0,12 \mathrm{~V}$ due to formation of $\mathrm{NiO}$ and $\mathrm{Ni}(\mathrm{OH})_{2}$ and the other - at about $0,65-0,7 \mathrm{~V}$ due to conversion of $\mathrm{Ni}(\mathrm{OH})_{2}$ to $\mathrm{NiOOH}$ and enrichment of $\mathrm{Ni}^{3+}$ species on the electrode surface. 

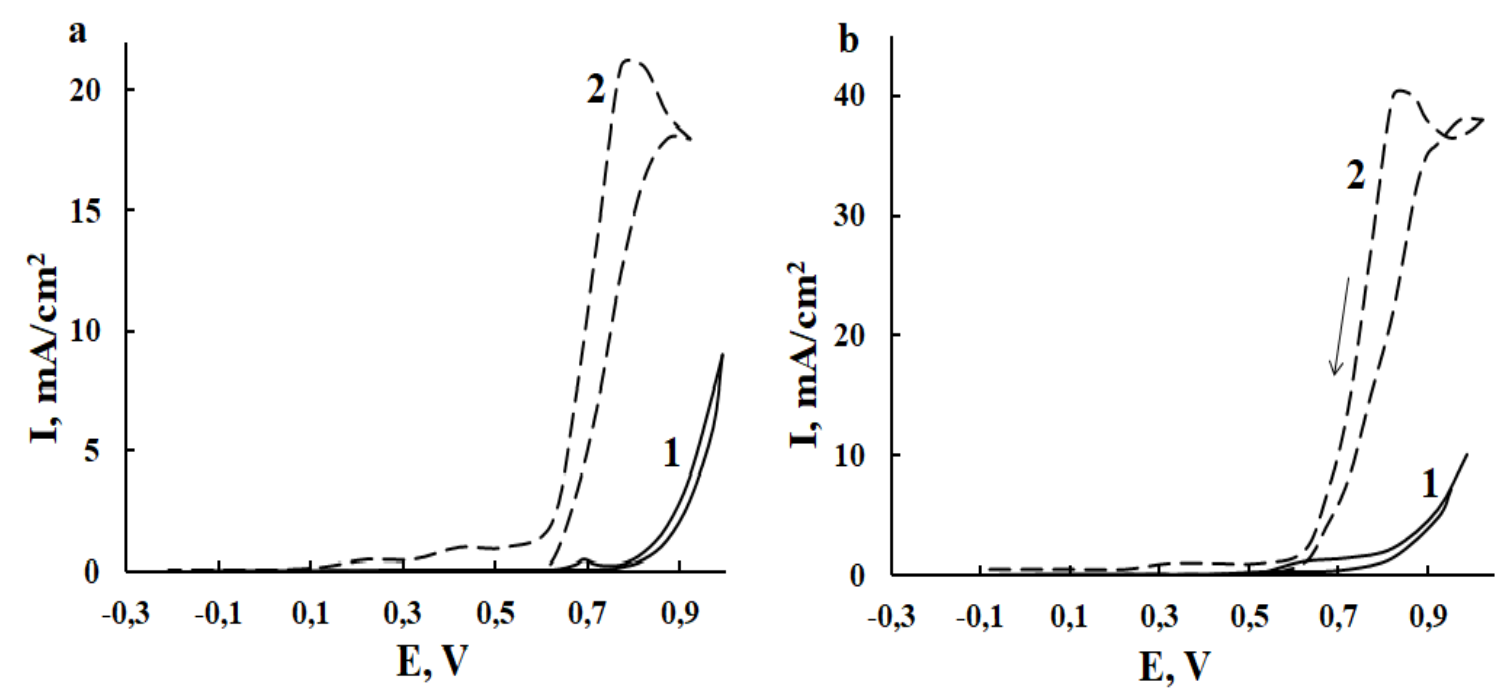

Fig. 3. Cyclic voltammograms in the absence (1) and the presence of $1 \mathrm{M}$ of methanol (2). (a) $\mathrm{Ni}$ coating; (b) $\mathrm{Ni}-\mathrm{TiO}_{2}$ coating; deposition conditions were $\mathrm{i}$

$$
=1,5 \mathrm{~A} / \mathrm{dm}^{2}, \mathrm{t}=50{ }^{\circ} \mathrm{C}, \mathrm{C}_{\mathrm{TiO} 2}=10 \mathrm{~g} / \mathrm{l}, \mathrm{v}=10 \mathrm{mV} / \mathrm{s}
$$

The electro-oxidation of methanol on pure $\mathrm{Ni}$ and $\mathrm{Ni}^{-\mathrm{TiO}_{2}}$ coatings starts at about $0,65 \mathrm{~V}$ when the electrode surface is covered with formed $\mathrm{NiOOH}$ species, then the current density reaches its maximum values at around $0,87-0,9 \mathrm{~V}$ in anodic direction. The response of methanol electro-oxidation at $\mathrm{Ni}^{-\mathrm{TiO}_{2}}$ composite coatings is larger than the response obtained for pure electrodeposited nickel. Thus the oxidation current density of $\mathrm{CH}_{3} \mathrm{OH}$ at $0,87 \mathrm{~V}$ was $18 \mathrm{~mA} / \mathrm{cm}^{2}$ on $\mathrm{Ni}$ coating and 35 $\mathrm{mA} / \mathrm{cm}^{2}$ on $\mathrm{Ni}^{-\mathrm{TiO}_{2}}$ coatings (curve $2 \mathrm{Fig}$. $3 \mathrm{a}$ and $3 \mathrm{~b}$ ).

It is seen from Fig. 3 that another reoxidation peak appeared in the reverse scan at about $0,8 \mathrm{~V}$. This peak was, probably, due to the reoxidation of $\mathrm{CH}_{3} \mathrm{OH}$ or the intermediate products generated during methanol oxidation. Formate and $\mathrm{CO}_{2}$ were identified as the main reaction products in alkaline solutions [18], but it is possible that formation of absorbed $\mathrm{CO}$ may occur. Absorbed $\mathrm{CO}$ causes deactivation and blocking of the active sites of electrode surface during oxidation process. In the reversible half cycle absorbed intermediates and products are removed and the oxidation of $\mathrm{CH}_{3} \mathrm{OH}$ continues at the initial stage of the cathodic half cycle. The rate of methanol oxidation in the reverse scan drops as the unfavorable potentials $(\mathrm{E}<0,5$ V) are reached. 
It was suggested that methanol is oxidized on $\mathrm{Ni}$ and $\mathrm{Ni}-\mathrm{TiO}_{2}$ coatings through the reaction with $\mathrm{NiOOH}$ to form $\mathrm{Ni}(\mathrm{OH})_{2}$, that is $\mathrm{NiOOH}$ acts as electron transfer mediator for the oxidation process [16-18]

$$
\mathrm{NiOOH}+\text { methanol } \leftrightarrow \mathrm{Ni}(\mathrm{OH})_{2}+\text { products }
$$

The enhancement of the catalytic activity of $\mathrm{Ni}-\mathrm{TiO}_{2}$ composite coatings was probably attributed to the presence of the mixed oxides (the nickel oxides and titanium oxides) which can be good electron transfer mediators for the oxidation process of organic molecules $[18,19]$. In addition, the presence of $\mathrm{TiO}_{2}$ dispersed particles can reduce the grain size of $\mathrm{Ni}$ and increase the actual surface area of electrodes that lead to formation of the great amount of active sites.

\section{Conclusions}

Composite coatings consisting of nickel matrix and $\mathrm{TiO}_{2}$ particles were obtained by means of electrodeposition. The content of $\mathrm{TiO}_{2}$ particles in the coatings depends on current density, bath temperature, $\mathrm{TiO}_{2}$ concentration in the bath. From results of electrochemical studies and wear tests, a conclusion can be drawn that $\mathrm{Ni}^{-\mathrm{TiO}_{2}}$ composite coatings with $\mathrm{TiO}_{2}$ content of $8-10$ wt. $\%$ have improved corrosion and wear behavior. These composite coatings were deposited at current density of 1,5 $\mathrm{A} / \mathrm{dm}^{2}$, bath temperature of $50{ }^{\circ} \mathrm{C}$ and concentration of dispersed particles of $10 \mathrm{~g} / \mathrm{l}$.

$\mathrm{Ni}-\mathrm{TiO}_{2}$ composite coatings showed a higher catalytic activity than pure $\mathrm{Ni}$ coatings towards the electro-oxidation of methanol. The process of methanol oxidation occurs at $\mathrm{E}=0,65-0,9 \mathrm{~V}$ in anodic direction and continues in the initial stage of the cathodic half cycle of voltammograms. 


\section{References}

[1] L.I. Antropov, Yu.N. Lebedinskii, Kompozitsionnyie pokrytiia i matierialy, Kyiv: Technika, 1986, 200 c.

[2] A.M.A. Mohamed, T.D. Golden (Eds.), Electrodeposition of Composite Materials, Publisher: InTech, 2016, 282 p. [Online]. Available: https://www.intechopen.com/books/electrodeposition-of-composite-materials. [Accessed: 27-Feb-2018].

[3] R.K. Saha, T.I. Khan, Surf. Coat. Technol. 205 (2010) 890 - 895.

[4] P. Baghery, M. Farzam, A.B.Mousavi, M. Hosseini, Surf. Coat. Technol. 204 (2010) $3804-3810$.

[5] W.-Y. Tu, B.-S. Xu, Sh.-Y. Dong, H.-D. Wang, Mat. Lett. 60 (2006) 1247 1250.

[6] E. Garcia-Lecina, I. Garcia-Urrutia, I.A. Diez, M. Salvo, F. Smeacetto, G. Gautier, R. Seddon, R. Martin, Electrochim. Acta 54 (2009) 2556 - 2562.

[7] F. Bratu, L. Benea, J.-P. Celis, Surf. Coat. Technol. 201 (2007) 6940 - 6946.

[8] M. Stroumbouli, P.Gyftou, E.A. Pavlatou, N. Spyrellis, Surf. Coat. Technol. 195 (2005) $325-332$.

[9] E. Pompei, L. Magagnin, N. Lecis, P.L. Cavalotti, Electrochim. Acta 54 (2009) $2571-2574$.

[10] A.A. Aal, M. Bahgat, M. Radwan, Surf. Coat. Technol. 201 (2006) 2910 2918.

[11] Z.A. Hamid, I.M. Ghayad, Mat. Lett. 53 (2002) 238 - 243.

[12] Q. Zhao, Y. Liu, Surf. Coat. Technol. 200 (2005) 2510 - 2514.

[13] R. Solmaz, A. Döner, G. Kardaş, Electrochem. Commun. 10 (2008) 1909 1911.

[14] J. Kubisztal, A. Budniok, Int. J. Hydrogen Energy 33 (2008) 4488 - 4494.

[15] I. Danaee, M. Jafarian, F. Forouzandeh, F. Gobal, M.G. Mahjani, Electrochim. Acta 53 (2008) $6602-6609$.

[16] I. Danaee, M. Jafarian, F. Forouzandeh, F. Gobal, M.G. Mahjani, Int. J. Hydrogen Energy 33 (2008) 4367 - 4376.

[17] A.A. Aal, H.B. Hassan, M.A.A. Rahim, J. Electroanal. Chem. 619-620 (2008) $17-25$.

[18] A.A. Aal, H.B. Hassan, J. Alloys Compd. 477 (2009) 652 - 656.

[19] H.B. Hassan, Z.A. Hamid, R.M. El-Sherif, Chinese J. Cat. 37 (2016) 616 627. 


\title{
Part 3 \\ CORROSION PROTECTION
}

\author{
Розділ 3 \\ ЗАХИСТ МЕТАЛІВ ВІД КОРОЗЇ̈
}




\title{
4-Hydroxy-3,5-dimethoxybenzaldehyde as "green” corrosion inhibitor for copper: Experimental and theoretical approaches
}

\author{
Vorobyova V.I. ${ }^{a}$, Skiba M.I. ${ }^{\mathrm{b}}$, Zhuk T.S. ${ }^{\mathrm{a}}$ \\ ${ }^{a}$ National Technical University of Ukraine «Igor Sikorsky Kyiv Polytechnic \\ Institute», Kyiv, Ukraine; \\ ${ }^{b}$ Ukrainian State University of Chemical Technology, Dnipro, Ukraine
}

As one of the simplest, convenient for applications, and efficient methods of the corrosion protection of the metal products under the conditions of atmospheric corrosion (AC), we can mention the application of volatile inhibitors [1-3]. Due to the more strict environmental regulations that have been implemented in recent years, corrosion inhibitors are required to have an environmentally friendly profile. Due to these concerns, green coatings have been a new trend in corrosion protection and extensive study is necessary to understand the mechanism of the coatings. In view of the ecological requirements and the lack of the major part of high-performance VIAC, it was decided [3] that natural compounds of vegetable origin can be regarded as promising raw materials for the production of inhibitors of this kind. The increasing trend of number of published papers regarding copper corrosion inhibitors in recent years shows the importance of this issue for researchers [3, 4]. As one of these sources, we can use the rapeseed oil cake (from the Brássica Nápus family) [5, 6]. As shown in [7], the 2-propanol extract of volatile compounds of the rapeseed oil cake provides an efficient protection of cooper against AC under the conditions of periodic condensation of moisture for 20 days. In analyzing the chemical composition of the 2-propanol extract with the help of gas-chromatography-mass spectrometry, it was shown that its main constituents is syringaldehyde (4-Hydroxy-3,5dimethoxybenzaldehyde). Was shown in the course of AC, the adsorption of organic compounds of extract takes place both on the surface of the metal and on the products of its oxidation and, in order to explain the mechanism of protective action of the 
organic compounds, one can use the concept of resonance potentials [7]. The comparison of the resonance potentials of copper and its main compounds with the ionization potentials of the main organic components of the extract shows that syringaldehyde (4-Hydroxy-3,5-dimethoxybenzaldehyde) is characterized by higher adsorption activities to the oxidized surfaces. Then, in view of the ability of copper to form chemical compounds, adsorption transforms into chemisorption. Also organic compounds containing conjugated double bonds, several heteroatoms (i.e. sulfur, nitrogen, oxygen) and/or polar functional groups generally exhibit favorable inhibitive properties, so they can always be employed as inhibitor for corrosion of copper [7]. Quantum theoretical calculations have been used by many researchers to establish the mechanistic information on corrosion and inhibition process [4-6]. Despite that in our previous work we have already theoretical explored some adsorption phenomenon of the main components as inhibitors through principle the calculated ionization potentials [7,8]. However, information about the inhibition mechanism of syringaldehyde from the theory aspect remains unanswered. The application of the concept of resonance potentials is most rigorously substantiated for the interpretation of the chemisorption of surface-active substances (SAS) for which physical adsorption have a minor significance. If adsorption is caused by the electrostatic forces, especially in the case of adsorption of SAS on the metals with high negative corrosion potentials, then this concept does not explain the efficiency of action of the SAS. Therefore, it is expedient to study theoretically adsorption ability of a substance, both physical and chemical, using quantum chemical calculations. Considering the above information and with the purpose of attaining an effective eco-friendly corrosion inhibition treatment avoiding the addition of the inhibitor to the surrounding environment, the evaluation of syringaldehyde is reported here. Syringaldehyde is aromatic aldehyde derivative component of different types of plant raw materials. Thus, the aim of this work is to elucidate inhibitory effect of syringaldehyde as a green volatile corrosion inhibitor copper and protective characteristics of the layers formed on copper. 


\section{Experimental}

\subsection{Materials and Apparatus}

To study the efficiency of its action upon the corrosion-electrochemical behavior of copper, we used specimens made of M0 copper ( $99.95 \% \mathrm{Cu}$ ). Syringaldehyde which chemical structure is shown in Fig. 1 was used in the experiments. The inhibitor used was syringaldehyde (4-Hydroxy-3,5-dimethoxybenzaldehyde) with the concentration range from 50 to $300 \mathrm{mg} / \mathrm{L}$.

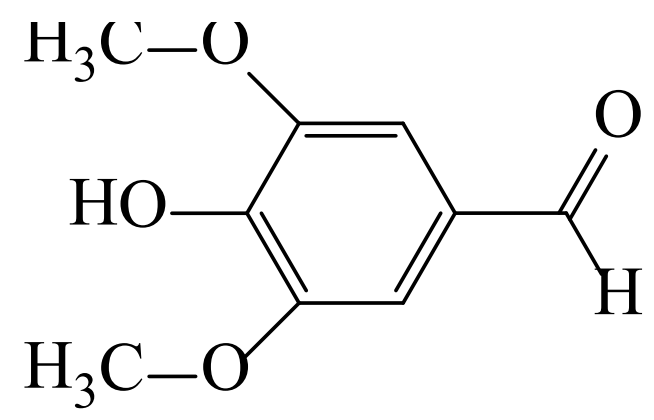

Fig. 1. Chemical structures of syringaldehyde (4-Hydroxy-3,5-

dimethoxybenzaldehyde).

The purity is $99.0 \%$ on dries basis dissolution of syringaldehyde was directly carried out in solution 2-propanol at room temperature and used as volatile corrosion inhibitor in all the experiments.

\subsection{Gravimetric measurements}

Volatile inhibiting sieve test were applied to evaluate the inhibition effect of the VIAC. To obtain reproducible results three samples were used in each test simultaneously. There was a hole in each plate drilled to suspend the sample by a nylon thread. The samples were grinded with $\mathrm{SiC}$ paper to 1000 mesh and were then cleaned in alcohol and rinsed before drying at room temperature. The final geometrical area was $25 \mathrm{~cm}^{2}$. The gravimetric measurement was conducted by suspending the samples in a $250 \mathrm{~cm}^{3}$ conical flask with a tight-fitting rubber cork containing a small dish. The VIAC were dispersed in the dish. The samples with freshly prepared surface were mounted on the flask with and without $1.0 \mathrm{~g}$ inhibitor, respectively. After inhibitor film-forming period of 3 days, $15 \mathrm{~cm}^{3} 0.01 \mathrm{M} \mathrm{NaCl}$ was added. The test process included cyclic warming and cooling of the samples in a corrosion testing chamber of varying humidity. One cycle included an $8 \mathrm{~h}$ exposure 
in the thermostat $\left(50 \pm 1^{\circ} \mathrm{C}\right)$, and $16 \mathrm{~h}$ exposure at room temperature. The total duration of the tests was 21 days. The efficiency of inhibitors was estimated according to the degree of protection against corrosion (IE) $[7,8]$.

\subsection{Electrochemical measurements}

To determine the influence of protective surface films on the cathodic and anodic electrode AC processes for copper, we plotted the potentiodynamic polarization curves for a three-electrode electrochemical cell in air by separating the anolyte from the catholyte (the volume of working solution was $60 \mathrm{~cm}^{3}$ ). We used a cylindrical copper electrode pressed into a Teflon holder and a platinum plate as an auxiliary electrode. The disk end face of the copper electrode $0.385 \mathrm{~cm}^{2}$ in area served as the working surface. We plotted the polarization curves in a $0.01 \mathrm{M} \mathrm{NaCl}$ solution used to model the aggressive medium of the $\mathrm{AC}$ of metals [2]. As a specific feature of our electrochemical investigations, we can mention the following fact: the disk-shaped surface of the end face of the working electrode was immersed in surface layers of the working solution by at most $1-2 \mathrm{~mm}$. This enabled us to perform more exact modeling of the AC running on the metal surface in thin layers of condensed moisture. A capillary from the reference electrode was placed near the surface of the working electrode from below. Prior to processing in the VIAC vapor, the working electrode was polished and degreased with acetone. The VIAC film on the surface was preliminarily formed in vapors of the syringaldehyde. The polarization investigations were performed by using a PI-50-1.1 potentiostat and a PR-8 programmer. The potential of copper was measured relative to the silver-chloride reference electrode. The induced electrode potentials were recalculated relative to the normal hydrogen electrode.

The electrochemical impedance spectroscopy (EIS) was measured atopen circuit potential with a $10 \mathrm{mV} \mathrm{AC} \mathrm{perturbation} \mathrm{at} \mathrm{frequency} \mathrm{ranging} \mathrm{from} 100 \mathrm{kHz}$ to 0,05 $\mathrm{mHz}$ with 10 points per decade. The testdevice and the cell configuration for the EIS measurements werethe same as those for the polarization curve tests.To prove reproducibility, the polarization curve tests and the EIS measurements were repeated three times. 


\subsection{Scanning electron microscope (SEM)}

The morphologies of the metal surfaces of the specimens without films and after the formation of the VIAC film and corrosion tests were studied with the help of a by FEI E-SEM XL 30. For SEM images, $1 \mathrm{~cm}^{2}$ specimen sample were taken.

\subsection{Quantum chemical calculations}

According to the literature data [4-6,9-10], the adsorption activity of organic molecules and, hence, their susceptibility to chemisorption can be estimated by the reactivity indices, various electronic structure parameters obtained as a result of quantum-chemical calculations with regard for the electronic and energy characteristics of the inhibitor and the metal. Therefore, a prognostic estimate of the adsorption capacity based on the electronic characteristics of molecules such as the energy of the higher occupied molecular orbital (E HOMO) and the energy of the lower vacant molecular orbital (E LUMO), the energy of the molecular gap $(\Delta \varepsilon=\mathrm{E}($ номо $)-\mathrm{E}($ LUMO $))$ was carried out, electronegativity and chemical hardnessof a molecule based on the theory of functional density. It has been established that corrosion inhibitors usually promote the formation of a chelate on the metal surface, which include the transfer of electrons from the organic compounds to the metal, forming a donor-acceptor bond during the chemical adsorption process. According to Koopman's theorem [4-6], the frontier orbital energies $\mathrm{E}_{\text {Номо }}$ and $\mathrm{E}_{L U M O}$ are related to the ionization potential, I, and the electron affinity, A, of iron and the inhibitor molecule by the following relations: $\mathrm{A}=-\mathrm{E}_{L U M O}, \mathrm{I}=-\mathrm{E}_{\text {HOMO }}$.

In this adsorption, the metal acts as an electrophile while the inhibitor acts as a nucleophile. Considering the charge transfer characteristics of the adsorption, the wide use of quantum chemical calculations to study this process is justified. Calculated electron charges on the atoms of molecules were determined by their ability to chemical interaction and by the wave function of the HOMO and the LUMO, the most probable adsorption centre and the predictive adsorption capacity of the compounds were determined. In addition, it is known that the more a negative charge on a heteroatom, the better the transfer of electrons from the donor occurs. Taking into account the characteristics of the transfer of charge of adsorption, the 
literature substantiates the widespread use of quantum-chemical calculations for the study of this process [4-6, 9-10]. Pearson and Parr were presented definitions using the finite differences method depending on electron affinity (A) and ionization energy (I) of any chemical species (atom, ion or molecule) for chemical hardness ( $\eta$ ), and chemical potential $(\chi)$ According to the theory of functional density, the absolute electronegativity $(\chi)$, chemical potential $(\mu)$ are the main parameters that characterize the ability of molecules to chemically interact. The chemical potential, electronegativity, chemical hardness of an electronic system is defined as detailed in the works [4-6,9-10].

$$
\begin{gathered}
\chi=-\mu=\frac{1}{2}(I+A) \\
\eta=\frac{1}{2}(\mathrm{I}-\mathrm{A})
\end{gathered}
$$

The global electrophilicity index $(\omega)$ was introduced by Parr et al. [8, 9] and is given by:

$$
\omega=\frac{(\mathrm{I}+\mathrm{A})^{2}}{8(\mathrm{I}+\mathrm{A})}
$$

In considering the adsorption process from the point of view of the acid-basic interaction, the important quantitative parameters characterizing this process are the degree of charge transfer $\Delta \mathrm{N}$, that is, the interaction strength of acid-acceptor molecules (iron surface) and the donor base (investigated substances of the vapor phase of the extract) and the magnitude of the energy change that accompanies the formation of the complex. The electron charge transfer, $\Delta \mathrm{N}$, from base $\mathrm{B}$ to acid $\mathrm{A}$, and the associated energy change $\Delta \mathrm{E}$ is given as:

$$
\begin{gathered}
\Delta \mathrm{N}=\frac{\mu_{\mathrm{B}}-\mu_{\mathrm{A}}}{2\left(\eta_{\mathrm{A}}+\eta_{\mathrm{B}}\right)} \\
\Delta \mathrm{E}=\frac{\left(\mu_{\mathrm{B}}-\mu_{\mathrm{A}}\right)^{2}}{2\left(\eta_{\mathrm{A}}-\eta_{\mathrm{B}}\right)}
\end{gathered}
$$


$\chi=-\mu-$ electronegativity, $\mathrm{eV}$

$\eta$ - chemical hardness, $\mathrm{eV}$;

A, B - Indices in formulas $(4,5)$;

A - characteristics of the molecule of the test substance;

B - characteristics of the elemental lattice of the surface of iron.

The electronegativity of metal surface is replaced by the work function for Fe (110) surface, theoretically equals $4.82 \mathrm{eV}$ and the hardness metal which equals $0 \mathrm{eV}$ for bulk metals $[8,9]$.

Quantum chemical calculations have been performed by the HyperChem 7 package. The geometry optimization was obtained by application of the restricted Hartree-Fock method (RHF) using MNDO approach with PM3 parameterization.

These parameters will provide insights into the mechanism of the interaction of the extract components with mild steel surface.

\section{Results and discussion}

Corrosion rate and inhibition effectiveness for the test samples are shown in Tabl. 1.

Table 1. Calculated corrosion rates and inhibition efficiency for volatile corrosion inhibition test VIAC (Period of film-forming, $48 \mathrm{~h}$, conditions of periodic condensation of moisture ( $0.01 \mathrm{M} \mathrm{NaCl}$ for 21 Days).

\begin{tabular}{|c|c|c|}
\hline $\begin{array}{c}\text { Concentration inhibitor, } \\
\mathrm{mg} / \mathrm{L}\end{array}$ & $\begin{array}{c}\text { Corrosion rates, } \mathrm{g} / \mathrm{m}^{-2} \\
\mathrm{~h}^{-1}\end{array}$ & $\begin{array}{c}\text { Inhibition } \\
\text { efficiency (IE), } \%\end{array}$ \\
\hline 50 & 0.001514 & 48.14 \\
\hline 100 & 0.000429 & 85.30 \\
\hline 150 & 0.000327 & 88.79 \\
\hline 200 & 0.000202 & 93.08 \\
\hline 250 & 0.000105 & 96.41 \\
\hline 300 & 0.000049 & - \\
\hline without inhibitor & 0.002920 & 98.33 \\
\hline
\end{tabular}

The analysis of the results of accelerated corrosion tests shows that the syringaldehyde protect copper from corrosion under the conditions of periodic 
moisture condensation. The corrosion rate and inhibition effectiveness for the syringaldehyde film-forming specimens were and $98.33 \%$, respectively. It should be noted that the treatment of specimens in the vapor phase of individual 2-propanol does not improve the corrosion resistance of the metal.

It was investigated the effect of exposure time of the metal on the vapour phase of syringaldehyde on corrosion effect under the conditions of periodic moisture condensation. The exposure time was varied between 5 and $72 \mathrm{~h}$ (Fig. 2). It should be noted that the corrosion rate to decreases with increasing the time film formation [1, 6-7]. The inhibition efficiency (IE) increases in the range 37.06-98.25\%. The corrosion inhibition efficiency values for syringaldehyde corrosion inhibitors after 5, $12,24,48,72 \mathrm{~h}$ are obtained $37.91 \%, 84.29 \%, 87.84 \%, 97.24 \%$ and $98.25 \%$, respectively are shown in Figure 2.

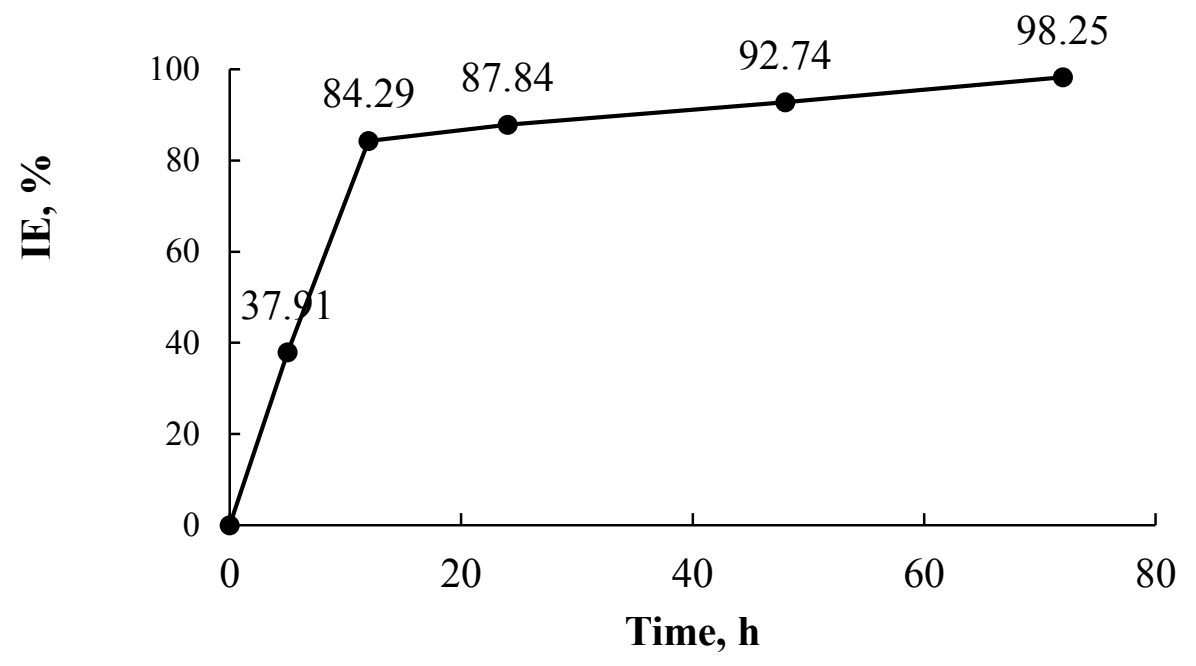

Fig. 2. Inhibition efficiencies for copper under the conditions of periodic moisture condensation $0,01 \mathrm{M} \mathrm{NaCl}$ solution with different time film-forming.

\subsection{Electrochemical Investigations of the Partial Electrode Processe.}

In analyzing the influence of VIAC films on the rate of the partial electrode processes of anodic oxidation of copper and cathodic reduction of the molecular atmospheric oxygen in a $0.01 \mathrm{M} \mathrm{NaCl}$ solution with and without protective films (Fig. 3). 
If the VIAC films are present on the copper surface causes a considerable decrease in electrochemical reactions the rate of the anodic and cathodic processes, although their effects on decreasing anodic dissolution of copper are more dominant. In the presence of a VIAC film on the copper surface, the anode current density sharply decreases, especially under the potential equal to $0.35 \mathrm{~V}$. Almost equal anode current densities in the course of passivation of copper under a potential of $0.8 \mathrm{~V}$ in the no matter how long the film is formed on the surface are usually explained by the fact that, under these conditions, the rate of dissolution of the metal is determined not by the protective characteristics of the film but by the properties of the layer of products of the dissolution of copper. It may happen that, for high degrees of polarization, the film may lose its integrity or disappear from the surface. As the time of treatment of the metal by the volatile compounds of syringaldehyde increases to $48 \mathrm{~h}$, the increase in the inhibiting efficiency becomes especially pronounced, which corresponds to the saturation of the surface with the inhibitor and the formation of the strongest bonds between the inhibitor and the metal.

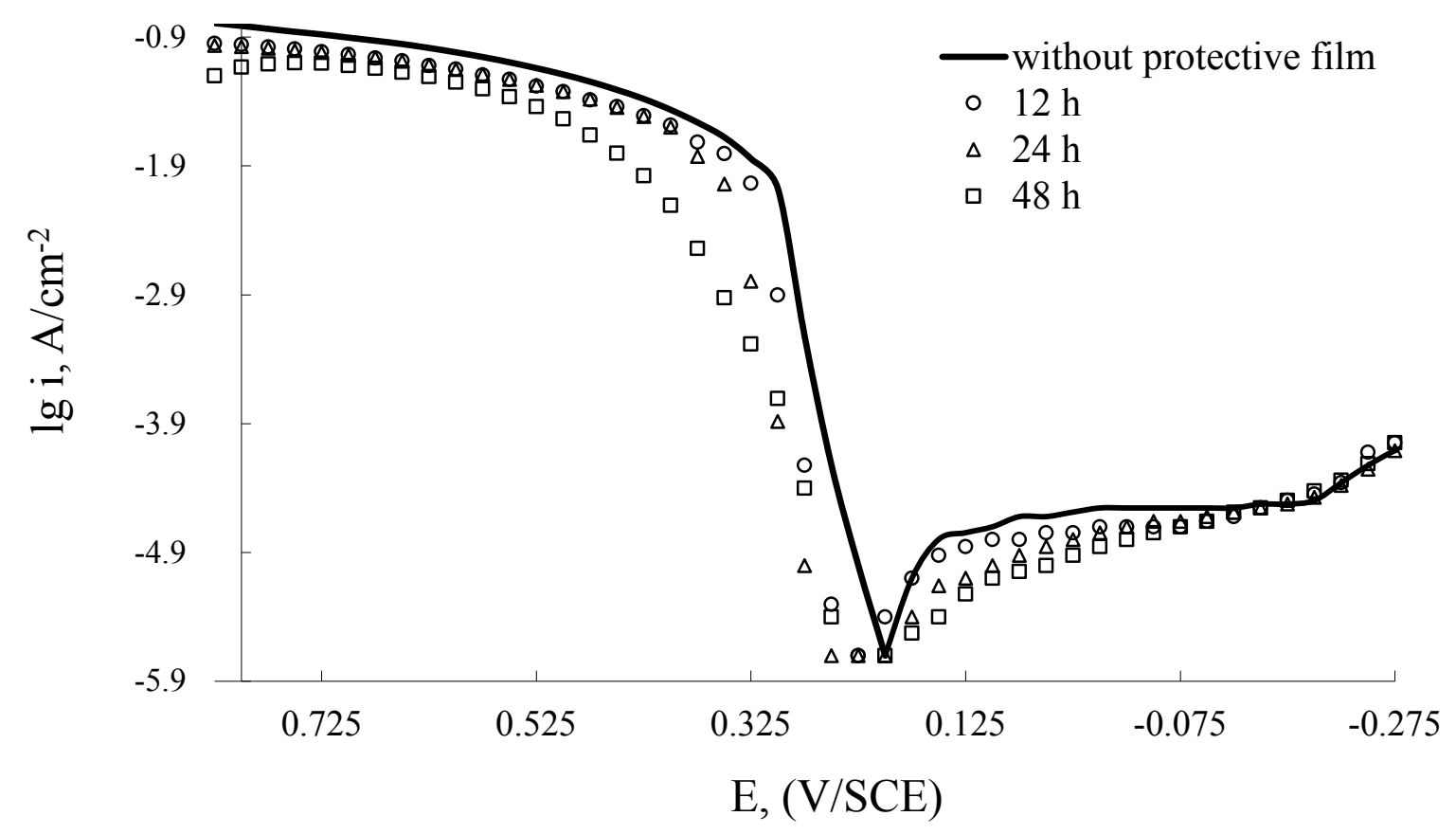

Fig. 3. Polarization cathodic and anodic curves of copper in a $0.01 \mathrm{M} \mathrm{NaCl}$ solution without (1) and with (2) the films of volatile inhibitors of atmospheric corrosion formed for $12,24,48 \mathrm{~h}$ in the vapor phase of the syringaldehyde. 
The changes in the slopes of the curves of anodic polarization after $48 \mathrm{~h}$ filmforming within the range of potentials between the maxima of anode current densities show that the formation of surface compounds is controlled by different stages. Moreover, the nature of controlling stage most clearly changes in the presence of a film on the surface. Since the rate of anodic processes of the dissolution of copper both in the absence and in the presence of the surface film is much higher than the rate of cathodic processes, it is possible to assert that the film does not change the nature of the controlling partial process of the corrosion of copper in thin interlayers of the $0.01 \mathrm{M} \mathrm{NaCl}$ solution. In other words, under the conditions of $\mathrm{AC}$, the dissolution of copper is controlled by the cathodic process.

The effect of corrosion inhibitor on both anodic and cathodic branches implies to mix nature of corrosion inhibitor, although anodic reaction is more influenced.

The Nyquist diagrams (Fig. 4) obtained without inhibitor (blank) and with the film that obtained after period of film-formed $(12,24,48 \mathrm{~h})$ in vapor phase of inhibitor shows a depressed semicircle in the high frequency region. This high frequency semicircle is mainly due to the charge transfer and double-layer capacitance [9]. For time film-forming of 12 and $24 \mathrm{~h}$, and more particularly for $12 \mathrm{~h}$, the shape of the diagram in the high frequency region differs and appears to involve two overlapping semi-circles. The second semi-circle may correspond to the film of corrosion products. For time film-forming $48 \mathrm{~h}$, a slight inductive behavior is observed at low frequency. It could be linked to a non-stationarity of the system. However, the evolution of open-circuit potential (OCP) was followed with time (results not shown) and it was observed that in any case, the OCP was stable after less than 15 minutes. Consequently, such a behavior may rather be due to adsorption phenomena and thus may point out the chemosorption of the inhibitor on the copper surface.

This inductive behavior was neglected, i.e. the data corresponding to the highest frequencies of this peculiar impedance diagram were excluded for the modelling. Actually it is masked by a stronger effect at the higher time film-forming 12 and $24 \mathrm{~h}$. For these two period of film-formed and for the blank as well, the curves deviate from their semicircular shape at low frequency, which may be related to a diffusion 
phenomenon, more likely that of dissolved $\mathrm{O}_{2}$. From the analysis of the potentiostatic polarization curves, it was deduced that $\mathrm{O}_{2}$ reduction was under mixed activationdiffusion control after 12 and $24 \mathrm{~h}$ period of film-forming and mainly under activation control after $48 \mathrm{~h}$. In the case of the blank solution, both situations were met and the Nyquist plot shown here corresponds to a case where the cathodic reaction was partially controlled by diffusion. In accordance with this preliminary description of the EIS results, the analysis of impedance data were performed with the various equivalent circuits presented in Figure 5.

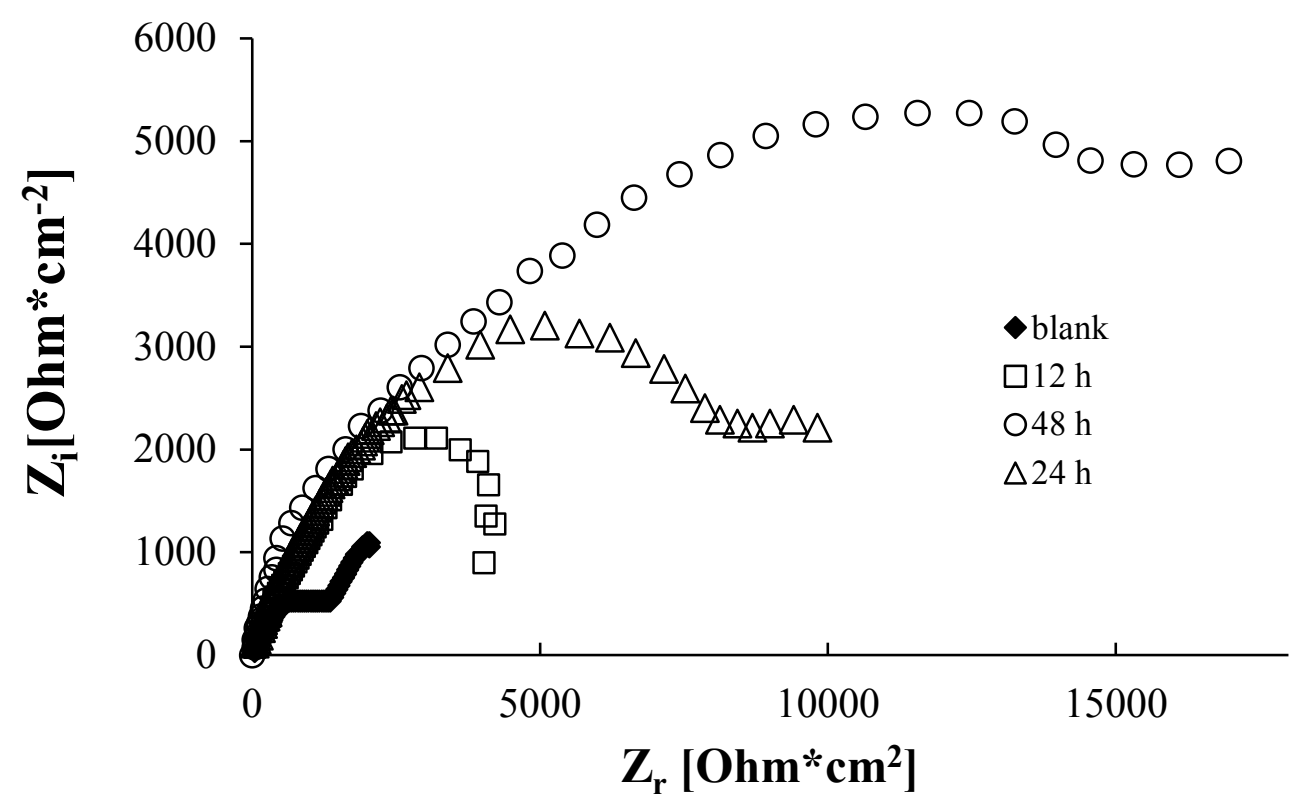

Fig. 4. Nyquist plots for copper electrode immersion in $0.01 \mathrm{M} \mathrm{HCl}$ solutions without (blank) and with various time of film-forming $(12,24,48 \mathrm{~h})$ of syringaldehyde.

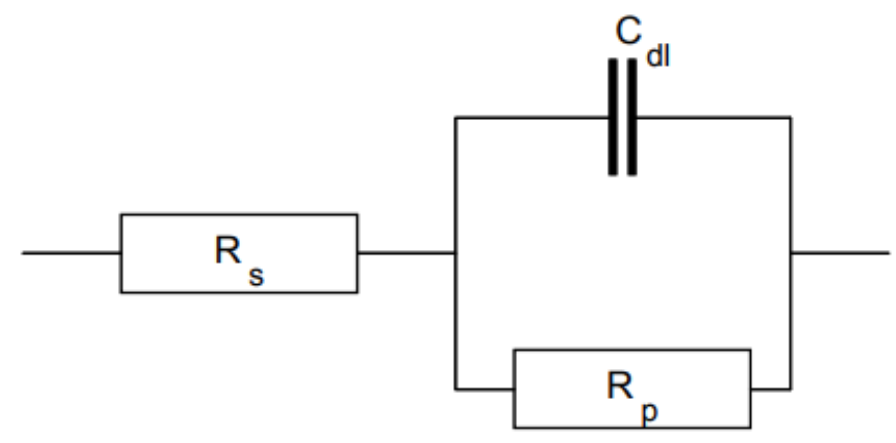

Fig. 5. Equivalent circuits for test copper 
Table 2. Electrochemical impedance parameters obtained for concentration 300 $\mathrm{mg} / \mathrm{L}$ after various times compared to those obtained without inhibitor

\begin{tabular}{|c|c|c|c|c|c|c|}
\hline \multicolumn{2}{|r|}{ Time (h) } & $\mathrm{R}_{\mathrm{s}}$ & $\mathrm{R}_{\mathrm{p}}$ & $\begin{array}{c}\mathrm{Q}_{\mathrm{dl}} \\
10^{-3}\end{array}$ & W & IE \\
\hline \multicolumn{2}{|c|}{$\begin{array}{c}\text { Blank (after } 24 \mathrm{~h} \text { of exposure in } \\
\text { the air) }\end{array}$} & 8.5 & 2500 & 0.15 & $\begin{array}{l}21 \\
6\end{array}$ & - \\
\hline \multirow{3}{*}{ 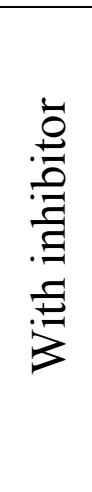 } & 12 & 8.4 & 8940 & $\begin{array}{l}0.1 \\
4\end{array}$ & $\begin{array}{l}43 \\
4\end{array}$ & $\begin{array}{l}73 \\
2\end{array}$ \\
\hline & 24 & 7.8 & $\begin{array}{l}1330 \\
0\end{array}$ & $\begin{array}{l}0.1 \\
1\end{array}$ & $\begin{array}{l}11 \\
0\end{array}$ & $\begin{array}{l}72 \\
8\end{array}$ \\
\hline & 48 & 6.6 & $\begin{array}{l}2200 \\
0\end{array}$ & $\begin{array}{l}0.0 \\
7\end{array}$ & $\begin{array}{l}33 \\
4\end{array}$ & 91 \\
\hline
\end{tabular}

* $\mathrm{W}$ - resistance of Warburg, which is connected with diffusion limitation (resistance of electrolyte in pores)

These models were used in various studies to describe the behavior of copper or copper alloys in chloride containing solutions, with or without adsorption inhibitors $[8,9]$. That of Figure 4proved suitable for the Nyquist plot of copper in the blank solution. In this model, $\mathrm{Rs}$ is the solution resistance, $\mathrm{R}_{\mathrm{p}}$ is the charge transfer resistance, $\mathrm{Q}_{\mathrm{dl}}$ corresponds to the capacitance of the double layer and $\mathrm{W}$ is the Warburg impedance related to the diffusion processes in the low frequency region. This shows that the contribution of the film of corrosion products formed on the metal surface is negligible.

\subsection{Scanning electron microscope (SEM) surface examination}

The adsorption process due to the action of syringaldehyde was monitored with an SEM while varying the exposure time. The investigations of the morphology of copper surface prior to and after corrosion tests performed under the conditions of $\mathrm{AC}$ show that, on the surfaces of specimen without films, one can detect only traces of the mechanical processing of the surface (Figure 6 a). The following images (Figure $6 \mathrm{~b}, \mathrm{c}$ ) are of the copper surface after 24, 35, $48 \mathrm{~h}$ of exposure for the filmforming of the syringaldehyde. It shows a thin and covering surface film. After 
holding of the specimens for $24 \mathrm{~h}$ in the vapor of syringaldehyde, a protective film (containing spherical inclusions whose diameter is several times larger than the thickness of the film) appears on the surface (Figure $6 \mathrm{~b}$ ). Most likely, the formation of inclusions is connected with the fact that the syringaldehyde is primarily adsorbed in the oxidized domains (active centers).

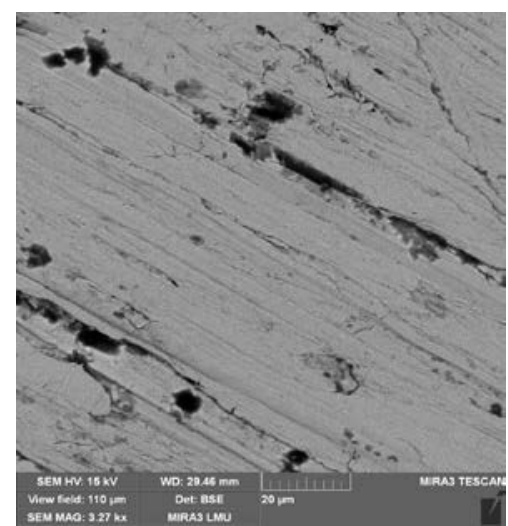

$\mathrm{a}$

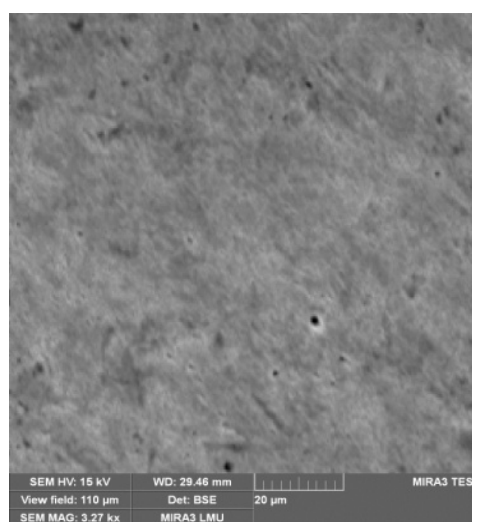

b

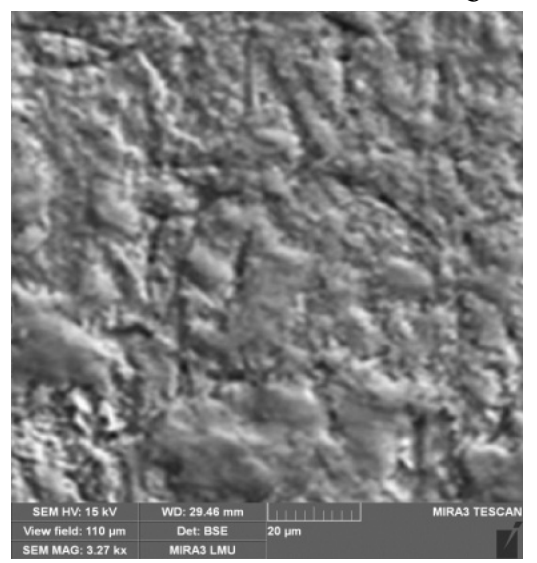

d

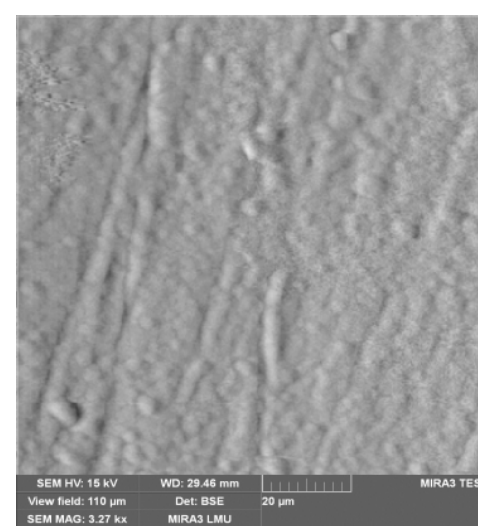

c

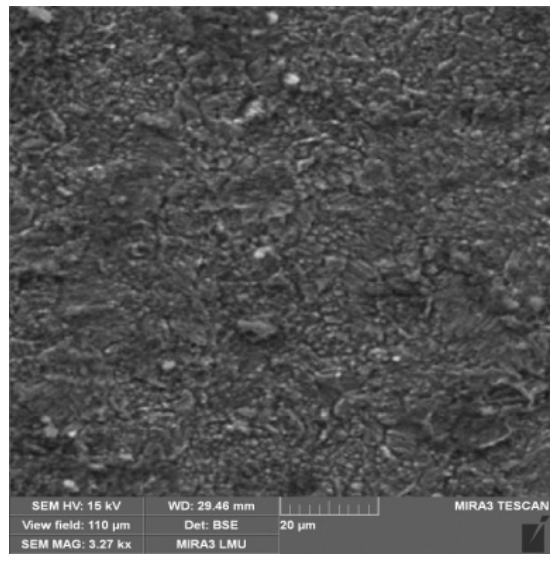

e

Fig. 6. Morphology of the surface of copper specimens: (a) after mechanical processing, after the formation of a film for $24,35,48 \mathrm{~h}(\mathrm{~b}, \mathrm{c}, \mathrm{d})$ in the gas-vapor atmosphere in the presence of syringaldehyde, after cyclic tests for 21 days under the conditions of condensation of moisture (e) $(0.01 \mathrm{M} \mathrm{NaCl})$.

This organic compound is gradually transformed into chemisorbed compounds with copper ions responsible for the adsorption of the other compounds. Syringaldehyde adsorb on the copper surface with the contribution of both chemisorption and physisorption, although, chemical adsorption play more dominant role on corrosion inhibition. The presence of protective film considerably reduces the corrosion attacks through the formation of a protective layer which acts as a physical 
barrier against aggressive ions. The bare copper in a corrosive medium showed a severe attack, whereas the layer formed copper showed a homogeneous and smooth surface without corrosion products. From the SEM image, it can be concluded that the films effectively protect the copper surface from corrosion. It was investigated the changes in the morphology of the surface films after the course of cyclic corrosion tests when the analyzed film is periodically wetted and dried. In the course of formation films after 48 hours, we observe the hydration of the film and its volume increases, i.e., the film swells. As temperature increases, the film gets dry, shrinks, and possibly, partially loses its integrity forming a film of the «shagreen type» (Figure $6 \mathrm{~d}$ ), which results in worsening of its protective properties. This effect was observed and studied of the mechanism of action of the 2-propanol extract of Rapeseed oil cake on the atmospheric corrosion of copper [5].

\subsection{Quantum theoretical studies}

Accordingly, quantum chemical calculations are performed to investigates the structural parameters affect the inhibition efficiency of inhibitors; study their adsorption mechanisms on the surface and film forming process. The adsorption study regarding large size inhibitors are still relying on conventional molecular mechanics method (Fig. 7). The HOMO energy reflects the capacity of a molecule to donate electrons, whereas the LUMO energy corresponds to a tendency for electron acceptance [15-27]. The HOMO/LUMO energy gap $(\Delta \varepsilon)$ for syringaldehyde was derived from the values $\mathrm{E}_{\text {Номо }}=(-9.44 \mathrm{eV})$ and $\mathrm{E}_{\text {LUмо }}(-0.686 \mathrm{Ev})$ to be $8.75 \mathrm{eV}$. Low values of $\Delta \varepsilon$ imply that minimal energy will be required to remove an electron from the last occupied orbital, corresponding to an increase in metal/inhibitor chemisorptive (covalent) interactions, hence improved inhibition efficiencies.

Table 3. Calculated quantum chemical properties for the syringaldehyde.

\begin{tabular}{|c|c|c|c|c|}
\hline Molecule & $\begin{array}{c}\mathrm{E}_{\text {HOMO }} \\
(\mathrm{eV})\end{array}$ & $\begin{array}{c}\mathrm{E}_{\text {LUMO }} \\
(\mathrm{eV})\end{array}$ & $\begin{array}{c}\Delta \varepsilon \\
(\mathrm{eV})\end{array}$ & $\begin{array}{c}\text { dipole moment } \\
(\mu)\end{array}$ \\
\hline $\begin{array}{c}\text { Syringaldeh } \\
\text { yde }\end{array}$ & -9.440 & -0.686 & 8.754 & 5.4882 \\
\hline
\end{tabular}


Figure 7 shows the electric/orbital density distribution of HOMO and LUMO for syringaldehyde. It is found that the electron density of the frontier orbital is well proportioned (Fig. 7). Such results indicate syringaldehyde could be both the acceptor of the electron and the donor of the electron. That is, there is electron transferring in the interaction between the inhibitor molecule and metal surface. Hence, the electrons might be inclined to transfer from the HOMO orbitals of syringaldehyde like molecules to copper surface. This has been further validated by the $\Delta \mathrm{N}$ descriptor, since all the $\Delta \mathrm{N}$ values listed in Table 4 are positive.

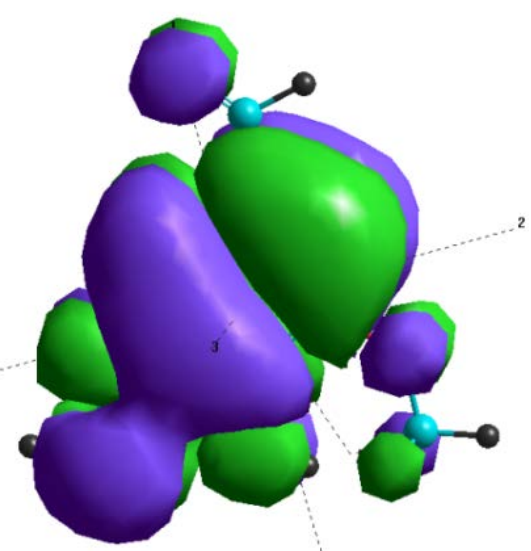

a

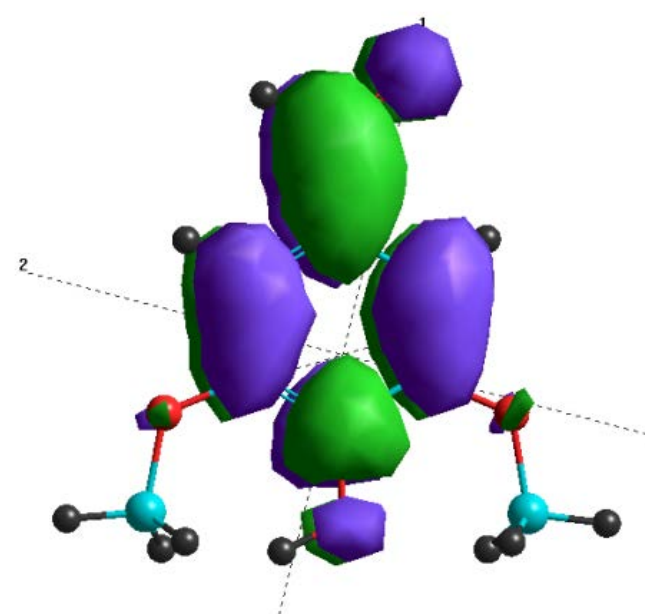

b

Fig. 7. The frontier molecular orbital density distribution of syringaldehyde (a) HOMO and (b) LUMO.

We should declare that $\Delta \mathrm{N}$ values do not represent accurately the number of electrons transferring between the donor and acceptor. Therefore, another expression "electron-donating ability" (abbreviated as EDA) may be more appropriate than "number of transferred electrons". The $\Delta \mathrm{N}$ values determine the EDA of inhibitors (Table 4), and the bigger the $\Delta \mathrm{N}$ value, the greater the EDA for one inhibitor molecule. Based on Lukovits's study [15-27], when $\Delta \mathrm{N}<3.6$, the inhibition performance improves with higher EDA. 
Table 4. Calculated quantum chemical properties for the syringaldehyde

\begin{tabular}{|c|c|c|c|c|c|c|c|c|}
\hline$\frac{\frac{0}{J}}{\frac{0}{0}}$ & 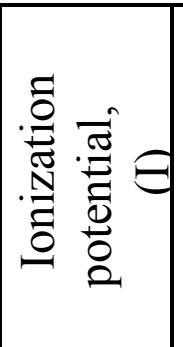 & 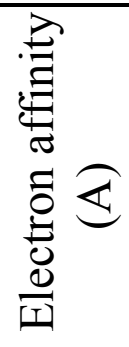 & 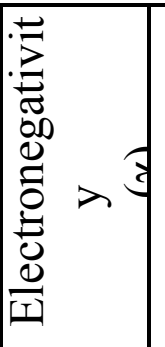 & 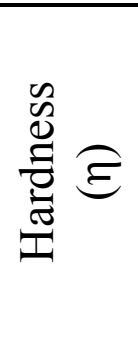 & $\begin{array}{l}\tilde{\omega}_{0} \\
\sum_{0} \\
\tilde{n}\end{array}$ & 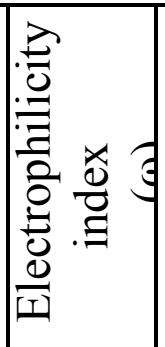 & 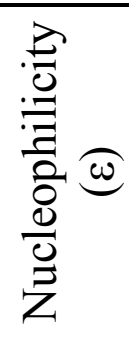 & 乙 \\
\hline $\begin{array}{l}\text { Syringaldehy } \\
\text { de }\end{array}$ & 9.44 & $\begin{array}{l}0.6 \\
86\end{array}$ & $\begin{array}{l}5.0 \\
63\end{array}$ & $\begin{array}{l}4.37 \\
7\end{array}$ & $\begin{array}{c}0.2 \\
28\end{array}$ & $\begin{array}{l}1.2 \\
5\end{array}$ & 0.8 & $\begin{array}{l}0.2 \\
21\end{array}$ \\
\hline
\end{tabular}

We can also find that the optimized inhibitor molecules almost all show planar structures, and their frontier molecular orbitals are $\pi$-type, which suggest a parallel adsorption mode for the inhibitors on iron surface.

The reactive centers and the high electron density regions of molecules can be determined with the help of molecular ESP maps (Fig. 8b).

As is shown in Figure 3a, the electrostatic potential have been characterized with different colors, purple and green colors stand for the regions of the negative and positive electrostatic potential, respectively. It is evident from Figure 3 that the oxygen atom Carbonyl group has the majority of the negative charges. Therefore, it can be concluded that the aldehyde molecule can be absorbed physically by electrostatic forces.

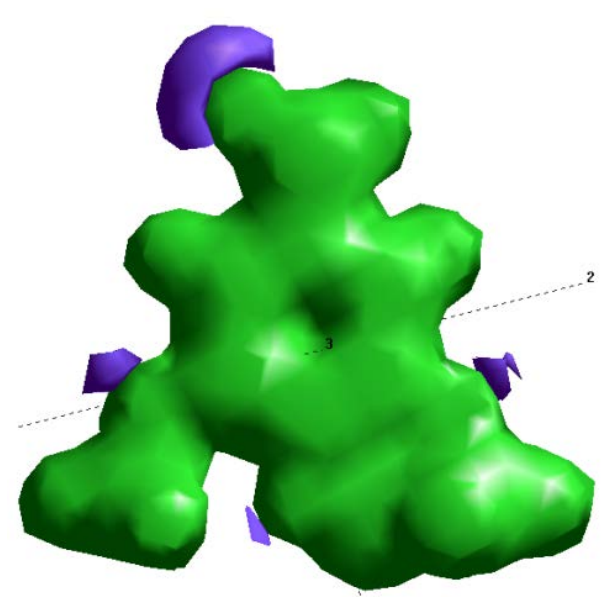

a

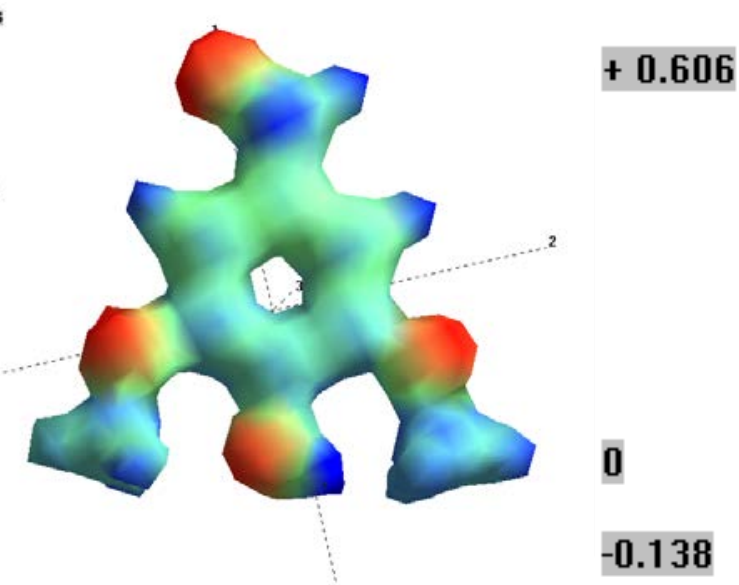

$\mathrm{b}$

Fig. 8. Electrostatic potential (a) and $3 d$ isosurface (b) representation of electrostatic potential structure for syringaldehyde. 
Inspection of the data in Table 2 shows that the $\Delta \mathrm{E}$ value of syringaldehyde is lower, which can facilitate its adsorption on the metal surface so it has higher inhibition efficiency. To obtain a clear picture of the interaction between the molecular of syringaldehyde and mild steel surface, intermolecular parameters such as a charge transfer descriptors and the associated energy change should be taken into account. Corrosion inhibition of mild steel syringaldehyde is a complex process and is mainly influenced by charge transport. Electrophilicity is an index which measures the propensity of chemical specie to accept electrons. The higher the value of $\omega$, the higher the capacity of the molecule to accept electrons. Thus, a good nucleophile is characterized by low values of $\mu$ and $\omega$; whereas a good electrophile is characterized by high values of $\mu$ and $\omega$. It is clear in Table 2 that the molecules have low electrophilicity index values and are good nucleophiles. Electrophilicity may be stated as the measure of reactivity to-wards attracting electrons from a nucleophile of a chemical species. Nucleophilicity $(\varepsilon)$ is physically in verse of electrophilicity $(1 / \omega)$. For this reason, it should be stated that a molecule that have large electrophilicity value is ineffective against corrosion while a molecule that have large nucleophilicity value is a good corrosion inhibitor.

\subsection{Mechanism of inhibition of syringaldehyde on copper corrosion}

Thus, on the basis of experimental data and quantum chemical calculations the adsorption of organic molecules was not considered only as a physisorption adsorption or as a chemisorption adsorption. Due to the fact that syringaldehyde at interacted with the metal surface to inhibit the corrosion reaction, we can assume that the adsorption of syringaldehyde molecules was preferential chemisorption on the surface in combination with physisorption.

At the first stage occurs the physical adsorption of the vanillin due то electrostatic potential of molecule. In the second stage reaction centers are unshared electron pairs of heteroatoms and $\pi$-electrons of aromatic/heterocyclic ring. The organic molecules may adsorb on the metal/solution interface by one and/or more of the following ways: (1) donor-acceptor interactions between the $\pi$-electrons of aromatic rings and vacant d-orbital of surface copper atoms, and (2) interaction between unshared electron pairs 
of hetero atoms and vacant d-orbital of copper surface atoms.These processes stipulate formation of aprotective film and drastically reduce the transport of aggressive ions to the metal surface thereby controlling the corrosion of the copper. Evaluation of adsorption activity of molecule syringaldehyde according to indexes of reactivity and the study of the surface morphology of samples enable us to assume that the effectiveness of syringaldehyde at final stage is due to chemisorption of volatile organic components, which then interact and are transformed into the surface phase film that contains copper ions (corrosion products).

\section{Conclusions}

The syringaldehyde was found to be an effective inhibitor the copper in simulated atmospheric water. The inhibition efficiency was found to increase with time during the 48 hour of pre-treatment performed in this study, and reached $\sim 98 \%$ for the largest considered inhibitor concentration. The presence of protective film considerably reduces the corrosion attacks through the formation of a protective layer which acts as a physical barrier against aggressive ions. Polarization curves indicated that syringaldehyde acted essentially as mixed type inhibitor, it suppresses both anodic and cathodic reactions for copper in simulated atmospheric water, retarding the dissolution of copper by blocking of metal surface. The results of EIS measurements indicated that the corrosion of steel is mainly controlled by the diffusion process. The morphology study elucidated the development of film on the specimen immersed in vapor phase of syringaldehyde. The inhibition of syringaldehyde is attributed to its interaction with surface of cooper and formed a chemisorption thin protective film. Quantum structure-activity relationships have been used to study the effect of molecular structure on inhibition efficiency of the

syringaldehyde. High value of E HOMO is likely to indicate a tendency of the inhibitor to donate electrons to appropriate acceptor molecule, $\mathrm{Cu}$ surface, of low empty molecular orbital energy. Quantum-chemical calculations confirm that the syringaldehyde can be adsorbed both by electrostatic potential, forming a physically adsorbed layer and blocking the surface due to chemically adsorbed molecules. 


\section{References}

[1] Zhang D-Q., Gao L-X., Zhou G-D.: Surf. Coat. Technol., 2010, 204, 1646. https://doi.org/10.1016/j.surfcoat.2009.10.054

[2] Zhang D-Q., An Z-X., Pan Q-Y. et al.: Corros. Sci., 2006, 48, 1437. https://doi.org/10.1016/j.corsci.2005.06.007

[3] Sudheer A., Quraishi E., Eno E., Natesan M.: Int. J. Electrochem. Sci., 2012, 7, 7463.

[4] Quraishi M., Jamal D.: Corrosion, 2002, 58, 5, 387. https://doi.org/10.5006/1.3277627

[5] Montemor M.: Act. Protect. Coat., 2016, 233, 107. https://doi.org/10.1007/978-94017-7540-3_6

[6] Chygyrynets’ E., Vorobyova V.: Chem. Chem. Technol., 2014, 8, 235.

[7] Vorob’iova V., Chyhyrynets' O., Vasyl'kevych O.: Mater. Sci., 2015, 50, 726. https://doi.org/10.1007/s11003-015-9778-z

[8] Chyhyrynets O.,Vorob'iova V.: Mater. Sci., 2013, 49, 318. https://doi.org/10.1007/s11003-013-9617-z

[9] Poongothai N., Rajendran P., Natesan M. et al.: Indian J. Chem. Technol., 2005, 12, 641.

[10] Premkumar P., Kannan K., Natesan M.: Asian J. Chem., 2008, 20, 445.

[11] Premkumar P., Kannan K., Natesan M.: J. Metall. Mater. Sci., 2008, 50, 227.

[12] Li X., Deng S., Fu H., Xie X.: Corros. Sci., 2014, 78, 29. https://doi.org/10.1016/j.corsci.2013.08.025

[13] Leygraf C., Wallinder I.,Tidblad J., Graedel T.: Atmospheric Corrosion. John Wiley \& Sons, Inc., Hoboken 2016.

[14] Kaya S., Tüzün B., Kaya C., Obot I.: J. Taiwan Inst. Chem. Eng., 2016, 58, 528. https://doi.org/10.1016/j.jtice.2015.06.009

[15] Gece G.: Corros. Sci., 2008, 50, 11, 2981. https://doi.org/10.1016/j.jtice.2015.06.009

[16] Koopmans T.: Physica, 1934, 1, 104. https://doi.org/10.1016/S0031-8914(34)90011-2

[17] Kovacevic N., Kokalj A.: Corros. Sci., 2011, 53, 3, 909. https://doi.org/10.1016/j.corsci.2010.11.016

[18] Parr R., Pearson R.: J. Am. Chem. Soc., 1983, 105, 7512. https://doi.org/10.1021/ja00364a005

[19] Parr R., Donnelly R., Lewy M., Palke W.: J. Chem. Phys., 1978, 68, 3801. https://doi.org/10.1063/1.436185

[20] Pearson R.: Proc. Nats. Acad. Sci. USA, 1986, 83, 8440.

[21] Chattaraj P., Sarkar R., Roy D.: Chem. Rev., 2006, 106, 2065. https://doi.org/10.1021/cr040109f

[22] Parr R., von Szentpaly L., Liu S.: J. Am. Chem. Soc. 1999, 121, 1922. https://doi.org/10.1021/ja983494x

[23] Kaya S., Kaya C.: Comput. Theor. Chem., 2015, 1052, 42. https://doi.org/10.1016/j.comptc.2014.11.017

[24] HyperChemTM, Hypercube, Inc., 1994

[25] Rosliza R. et al.: J. Appl. Electrochem., 2010, 40, 833. https://doi.org/10.1007/s10800-009-0066-1

[26] Ferreira M., Varela H., Torresi R., Tremiliosi-Filho G.: Electrochim. Acta, 2006, 52, 434. https://doi.org/10.1016/j.electacta.2006.05.025

[27] Lukovits I., Kálmán E., Zucchi F.: Corrosion. 2001, 57, 3. https://doi.org/10.5006/1.3290328 


\title{
Carbon Steel (St.3) Corrosion Caused by the Circulating Water Flow
}

\author{
Pilipenko A. ${ }^{\text {a }}$ Pancheva H. ${ }^{\text {a }}$, Khrystych O. ${ }^{\text {b }}$, Smirnova O. ${ }^{\text {a }}$ \\ a Department of Technical electrochemistry, National Technical University "Kharkiv \\ Polytechnic Institute”, \\ Kyrpyhova str. 2, Kharkiv, 61002, Ukraine \\ ${ }^{\mathrm{b}}$ National University of Civil Protection of Ukraine, Chernyshevska str., 94, Kharkiv, \\ 61023, Ukraine
}

\section{Introduction}

The main factors that define the material corrosion rate in the circulating water are the chemical composition of it, the mineralization, and the amount of dissolved gases, and also the temperature, the $\mathrm{pH}$ factor, the metal surface condition and the fluid velocity [1-6]. The latter factor defines directly the running time of industrial equipment, because it is in charge of specific features of the delivery of depolarizer to the metal surface.

The corrosion rate is not a simple function of the flow rate. It also depends on some other factors that have influence on the oxygen diffusion rate. The water flow rate has an essential influence on the corrosion process due to a change in the diffusion layer thickness caused by the formation of a thin layer of corrosion products on the metal surface or by their low density. If the layer of corrosion products has a considerable thickness or high density, then its contribution to the diffusion resistance value is increased to such an extent that the diffusion layer produces no significant influence on the corrosion process.

This statement is very important; because it enables the detection of the mechanism of influence the protective layers have on the diffusion section of preelectrode layer of the solution. It allows us to establish the reason for the complicated character displayed by the relationship of the corrosion rate of steels with an increase in the flow rate (a decrease in the double layer diffusion section). 


\section{Methods of Experimental Studies}

A device with the rotating disk electrode was used to study the influence the circulating water flow rate has on the electrode processes that occur on the carbon steel surface. The studies were carried out using the polished specimens made of carbon steel (St.3) with the diameter $d=20 \mathrm{~mm}$ and $\delta=3 \mathrm{~mm}$. The solution temperature was equal to $22{ }^{\circ} \mathrm{C}$, and the $\mathrm{pH}$ factor of the solution was checked up every 24 hours and it was adjusted in the case of need. Electrochemical tests were carried out recording polarization relationships using the potentiostat PI-50-1. Platinum was used as an additional electrode. Electrode potentials were measured and compared with those of saturated chloride silver reference electrode and then these were converted to the normal hydrogen electrode scale.

The investigations were carried out for liquid and air contact conditions when the air was passing through the solution or purged through the nitrogen solution. To carry out an experiment we used the circulating water with $c(\mathrm{NaCl})=0.02$ mole $\cdot \mathrm{L}^{-1}$ and $\mathrm{pH}$ $=7$ and the circulating water with 0.1 mole $\cdot \mathrm{L}^{-1}$ and $\mathrm{pH}=12$. The electrode rotation rate was changed stepwise in the range of 408 to $3930 \mathrm{rp} \cdot \mathrm{m}^{-1}$. To convert the linear velocity of the fluid flow in the tube to the equivalent velocity of disk rotation we used the equation [7]:

$$
v=10.3 P_{t}^{1 / 4} \sqrt{\frac{2}{R_{f}}} P_{l}^{1 / 2} \sqrt{v \cdot \omega}
$$

where $v$ is the linear velocity, $\mathrm{m} \cdot \mathrm{s}^{-1} ; P_{t}$ and $P_{l}$ are the Prandtl numbers for laminar and turbulent fluid flows, accordingly; $R_{f}$ is the friction coefficient; $v$ is the kinematic viscosity, $\mathrm{cm}^{2} \cdot \mathrm{c}^{-1} ; \omega$ is the disk rotational speed, $\mathrm{rp} \cdot \mathrm{m}^{-1}$. After substitution of the constants in the equation (1) we obtained the wanted relation (Table 1).

The disk rotational speed was selected to correspond to real velocities of the fluid flow in circulating water supply systems $\left(0.04-0.14 \mathrm{~m} \cdot \mathrm{s}^{-1}\right)$. 
Table 1. The relationship between the flow rate in the tube and the disk rotational speed

\begin{tabular}{|c|c|c|}
\hline & $v, \mathrm{~m} \cdot \mathrm{s}^{-1}$ & $\omega, \mathrm{rp} \cdot \mathrm{m}^{-1}$ \\
\hline 1 & 0.040 & 408 \\
\hline 2 & 0.060 & 840 \\
\hline 3 & 0.085 & 1500 \\
\hline 4 & 0.118 & 2880 \\
\hline 5 & 0.140 & 3930 \\
\hline
\end{tabular}

\section{Experimental Data}

Fig. Fig. 1 to 6 give electrochemical research data. The anode curve shows the passive state domain (Fig. 4, 5) for alkaline solutions when the oxygen is present in the system [8]. For alkaline $\mathrm{pH}$ values this domain is observed for all stirring rates and it is reduced with an increase in $\omega$. The passive state domain is unavailable on anode polarization curves for neutral $\mathrm{pH}$ values (Fig. 1-3), independently of the stirring rate.

The corrosion rate depends to a great extent on the rotational speed. During the rotation with $408 \mathrm{rp} \cdot \mathrm{m}^{-1}$ the corrosion current is approximately 2 to 3 times higher in comparison to that in the solution (that was not subjected to) without stirring at $\mathrm{pH}=$ 12 and it is 3 to 5 times higher at $\mathrm{pH}=7$. The passive state domain is reduced significantly during the nitrogen purging of the system. It happens due to the participation of oxygen in the protective film formation [9].

The three domains can provisionally be outlined on cathode polarization curves, in particular, the domain with the electrochemical process defining phase (from $E$ to ($0.5)-(-0.6) \mathrm{V})$, the mixed kinetics domain $((-0.5)-(-0.7) \mathrm{V})$ and the diffusion kinetics domain $((-0.6)-(-1.0) \mathrm{V})$. 


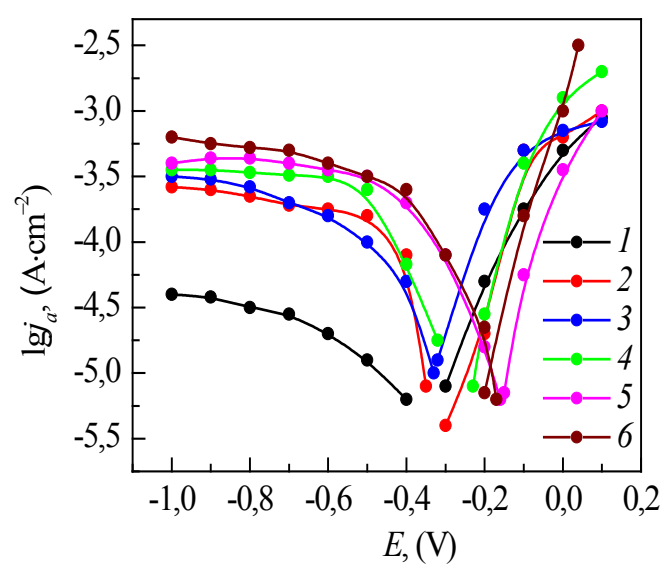

Fig. 1. Influence of the rotation frequency of the disk electrode on polarization relationships obtained for the circulating water in the ambient air. $c(\mathrm{NaCl})=0.02$ mole $\cdot \mathrm{L}^{-1}, \mathrm{pH}=7 . \omega, \mathrm{rp} \cdot \mathrm{s}^{-1}: 1-0 ; 2-6.8 ; 3-14 ; 4-25 ; 5-48.3 ; 6-65.5$.

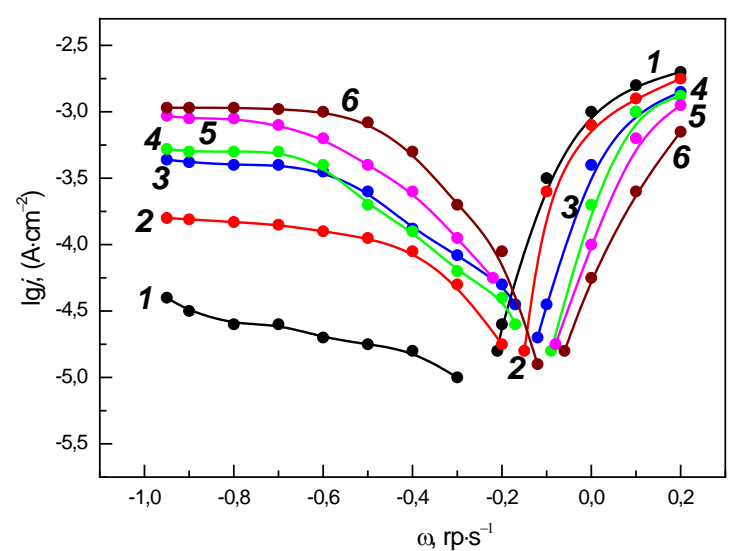

Fig. 2. Influence of the rotation frequency of the disk electrode on polarization relationships obtained for the air-purged circulating water. $c(\mathrm{NaCl})=0.02 \mathrm{~mole} \cdot \mathrm{L}^{-1}$, $\mathrm{pH}=7 . \omega, \mathrm{rp} \cdot \mathrm{s}^{-1}: 1-0 ; 2-6.8 ; 3-14 ; 4-25 ; 5-48.3 ; 6-65.5$.

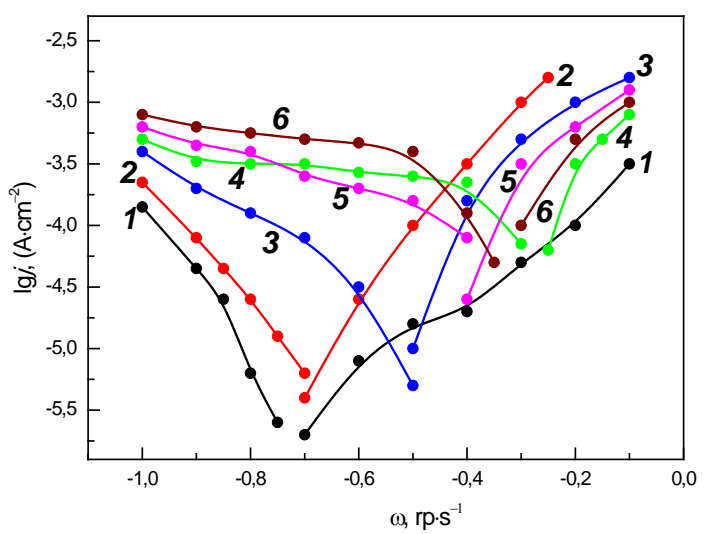

Fig. 3. Influence of the rotation frequency of the disk electrode on polarization relationships obtained for the nitrogen-purged circulating water. $c(\mathrm{NaCl})=0.02$ mole $\cdot \mathrm{L}^{-1}, \mathrm{pH}=7 . \omega, \mathrm{rp} \cdot \mathrm{s}^{-1}: 1-0 ; 2-6.8 ; 3-14 ; 4-25 ; 5-48.3 ; 6-65.5$. 


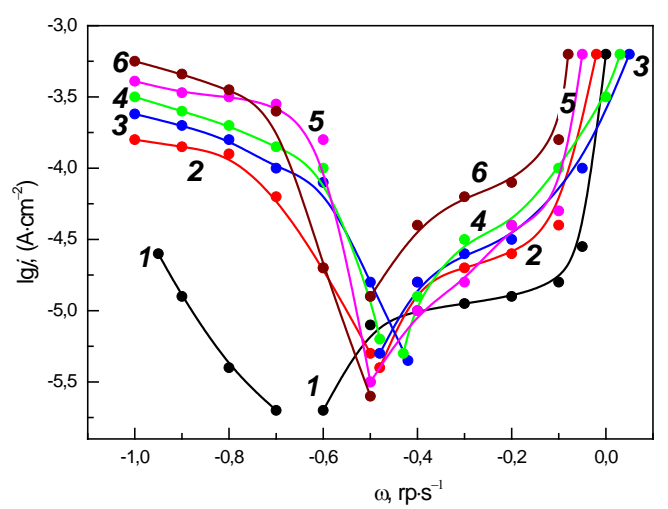

Fig. 4. Influence of the rotation frequency of the disk electrode on polarization relationships obtained for the circulating water in the ambient air. $c(\mathrm{NaCl})=0.1$ mole $\cdot \mathrm{L}^{-1}, \mathrm{pH}=12 . \omega, \mathrm{rp} \cdot \mathrm{s}^{-1}: 1-0 ; 2-6.8 ; 3-14 ; 4-25 ; 5-48.3 ; 6-65.5$.

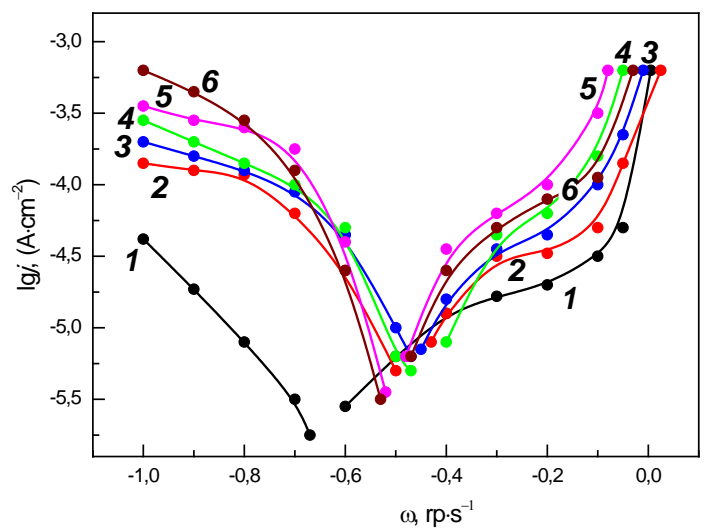

Fig. 5. Influence of the rotation frequency of the disk electrode on polarization relationships obtained for the air-purged circulating water. $c(\mathrm{NaCl})=0.1$ mole $\cdot \mathrm{L}^{-1}$, $\mathrm{pH}=12 . \omega, \mathrm{rp} \cdot \mathrm{s}^{-1}: 1-0 ; 2-6.8 ; 3-14 ; 4-25 ; 5-48.3 ; 6-65.5$.

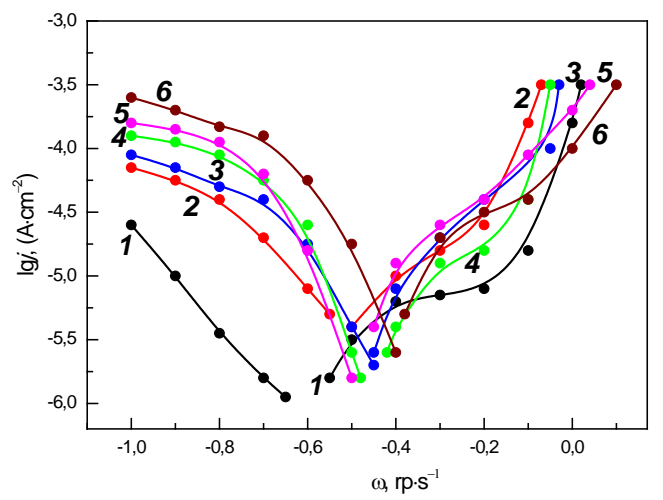

Fig. 6. Influence of the rotation frequency of the disk electrode on polarization relationships obtained for the nitrogen-purged circulating water. $c(\mathrm{NaCl})=0.1$ mole $\cdot \mathrm{L}^{-1}, \mathrm{pH}=12 . \omega, \mathrm{rp} \cdot \mathrm{s}^{-1}: 1-0 ; 2-6.8 ; 3-14 ; 4-25 ; 5-48.3 ; 6-65.5$. 
The potentiometric measurements that were carried out for the polarization potential of $-0.7 \mathrm{~V}$ (Fig. 7, a; 8, a) showed that the nitrogen purging of the system at $\mathrm{pH}=7$ considerably hampers the cathode process (Fig. 7, a, curve 3). This is indicative of that the oxygen supply to the place of reaction is the defining phase for the circulating water at $\mathrm{pH}=7$. The relationship $j_{k}=\sqrt{\omega}$ is linear and its angle of slope is defined by the oxygen concentration (Fig. 8, a, the curves 1,2).

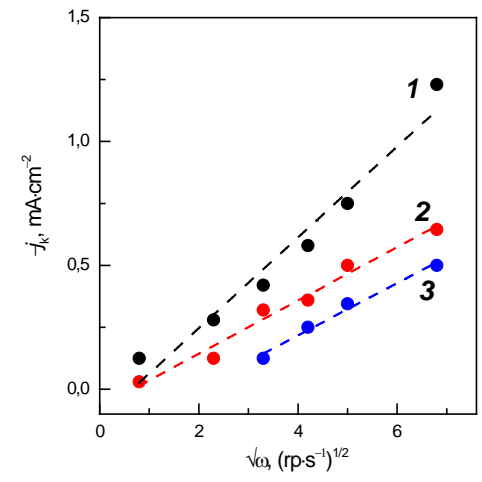

a

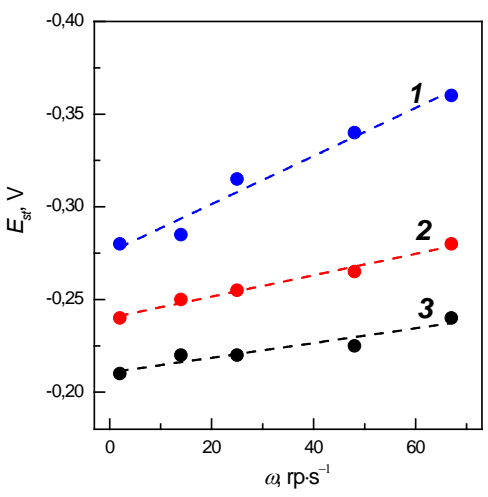

b

Fig. 7. Relationships $j_{k}=\sqrt{\omega}$ and $\mathrm{E}_{\mathrm{st}}=\omega$ for the circulating water: 1 - air-purged system; 2 - equilibrium with air; 3 - nitrogen-purged system. $c(\mathrm{NaCl})=0.02 \mathrm{~mole} \cdot \mathrm{L}^{-}$

$$
1, \mathrm{pH}=7 \text {. }
$$

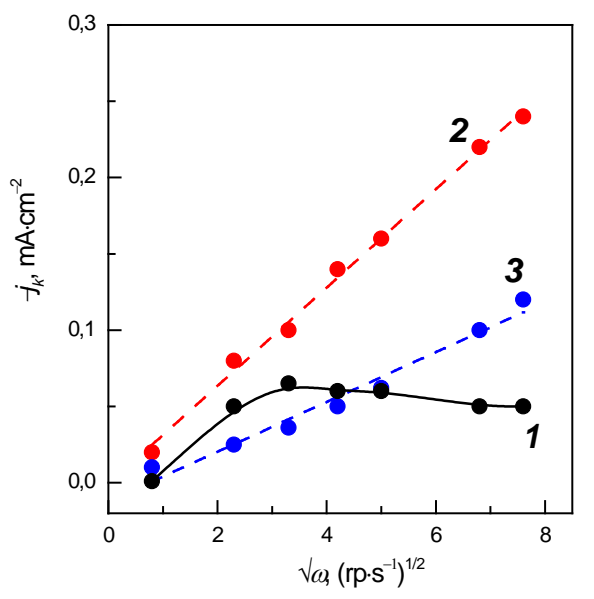

a

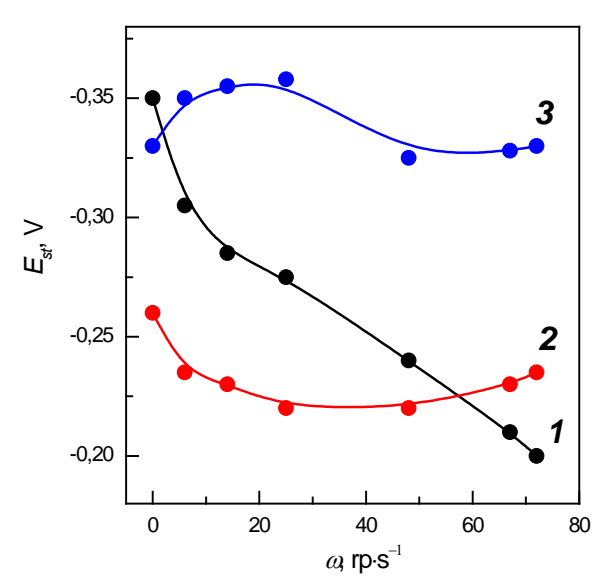

b

Fig. 8. Relationships $j_{k}=\sqrt{\omega}$ and $\mathrm{E}_{\mathrm{st}}=\omega$ for the circulating water: $1-$ air-purged system; 2 - equilibrium with air; 3 - nitrogen-purged system. $c(\mathrm{NaCl})=0.1 \mathrm{~mole} \cdot \mathrm{L}^{-1}$, $\mathrm{pH}=12$. 
When the system is saturated with the air oxygen and $\mathrm{pH}=7$ the cathode process rate is increased (Fig. 7, a, curve 1). This phenomenon is also observed for the working conditions of circulating water supply system when the water is saturated with oxygen in the cooling tower. Saturation of the system with the air oxygen at $\mathrm{pH}$ $=12$ results in the deceleration of cathode process (Fig. 8, a, curve 1 ). The sodium hydroxide develops the properties of the cathode-anode inhibitor at $\mathrm{pH}=12$ [8]. The value of cathode current in the solution with $c(\mathrm{NaCl})=0.1 \mathrm{~mole} \cdot \mathrm{L}^{-1}$ and $\mathrm{pH}=12$ is 1 to 2 orders of magnitude lower than the value of cathode current in the solution with $c(\mathrm{NaCl})=0.2$ mole $\cdot \mathrm{L}^{-1}$ and $\mathrm{pH}=7$. It is explained by the complicated transfer of oxygen through the protective film formed on the metal and also by a reduced solubility of it (Table 2).

Table 2. The influence of $\mathrm{pH}$, temperature and $\mathrm{NaCl}$ concentration on the oxygen solubility in the circulating water

\begin{tabular}{|c|c|c|c|}
\hline$c(\mathrm{NaCl}), \mathrm{g} \cdot \mathrm{L}^{-1}$ & $t,{ }^{\circ} \mathrm{C}$ & $\mathrm{pH}$ & $c\left(\mathrm{O}_{2}\right), \mathrm{mg} \cdot \mathrm{L}^{-1}$ \\
\hline 1 & $20-22$ & 7 & 13.3 \\
\hline 1 & $40-45$ & 7 & 11.4 \\
\hline 1 & $20-22$ & 12 & 12.1 \\
\hline 10 & $20-22$ & 7 & 13.4 \\
\hline 10 & $20-22$ & 12 & 9.28 \\
\hline 10 & $40-45$ & 12 & 8.27 \\
\hline
\end{tabular}

The influence the rotating disk has on the value of $E_{s t}$ (Fig. 7, b; 8, b) has been studied. With an increase in the rotational speed the value of $E_{s t}$ shifts to the domain of low values (Fig. 7, b). It confirms the fact that the corrosion rate of circulating water supply systems is increased with an increase in the flow rate at $\mathrm{pH}=7$.

For the solution with $c(\mathrm{NaCl})=0.1 \mathrm{~mole} \cdot \mathrm{L}^{-1}$ and $\mathrm{pH}=12$ an increase in the rotational speed of electrode results in the shift of Est to the positive domain. It is conditioned by the fact that an increase in the stirring rate results in that the cathode process is facilitated to a greater extent and the anode process is facilitated to a lesser extent. Therefore, to preserve the rate equilibrium of anode and cathode reactions the 
metal potential is shifted to the positive domain $[8,9]$. The corrosion currents in the solution with $c(\mathrm{NaCl})=0.1 \mathrm{~mole} \cdot \mathrm{L}^{-1}$ and $\mathrm{pH}=12$ are lower approximately by one order of magnitude than the corrosion currents in the solution with $c(\mathrm{NaCl})=0.2$ mole $\cdot \mathrm{L}^{-1}$ and $\mathrm{pH}=7$ at similar electrode rotation velocities.

\section{Conclusion}

It has been established that the carbon steel (St.3) is inclined to the transition into the passive state when the anode is polarized in alkaline solutions.

The passivity is observed in alkaline solutions for all disk rotational speeds and the tendency to the passivation is decreased with an increase in the rotational speed. For neutral solutions, the St.3 steel passive state domain is unavailable for all disk rotational speeds. The nitrogen purging of alkaline solutions results in a considerable reduction of the domain of the passive state of steel and it is explained by a decreased content of oxygen that participates in formation of the protective film. It has been established that an increase of $\omega$ for the water with $\mathrm{pH}=7$ results in the shift of $E_{s t}$ of the steel to the domain of negative values and the corrosion rate is increased.

For the water with $\mathrm{pH}=12$, an increase in $\omega$ results in the shift of $E_{s t}$ to the domain of positive values and the corrosion rate is decreased. The investigations carried out showed that the water with $c(\mathrm{NaCl})=0.1 \mathrm{~mole} \cdot \mathrm{L}^{-1}$ and $\mathrm{pH}=12$ is more acceptable for circulating water supply systems than the water with $c(\mathrm{NaCl})=0.2$ mole $\cdot \mathrm{L}^{-1}$ and $\mathrm{pH}=7$ when the flow rate varies in the range of 0.04 to $0.14 \mathrm{~m} \cdot \mathrm{s}^{-1}$.

\section{References}

[1] H. Fang, B. Brown, and S. Nesic, Corrosion. 67 (2010) 015001-1.

[2] E. M. Chinwko, B. O. Odio, J. L. Chukwuneke, and J. E. Sinebe, IJSTR. 3 (2014) 306.

[3] M. A. Deyab and S. T. Keera, Egyp. J. Petrol. 21 (2012) 31.

[4] M. D. Asaduzzaman, C. M. Mustafa, and M. Islam, Chem. Ind. \& Chem. Eng. Q. 17, (2011) 477.

[5] G. S. Frankel, J. Electrochem. Soc. 145, (1998) 2186.

[6] J. Soltis, Corros. Sci. 90, (2015) 5.

[7] V. M. Novakovskij, S. N. Fishman, Trudy Ural'skogo himicheskogo instituta, Vyp. 9 (1961) 71.

[8] A. Pilipenko, H. Pancheva, G. Reznichenko, O. Mirgorod, N. Miroshnichenko, and A. Sincheskul, EEJET. 2 (2017) 21.

[9] H. Pancheva, G. Reznichenko, N. Miroshnichenko, A. Sincheskul, A. Pilipenko, and V. Loboichenko, EEJET. 4 (2017) 59. 


\title{
Investigation of corrosion process in the alloy AA6060 containing anodic-oxide coatings of vanadium
}

\author{
Keshin A.V., Matsius M.Y., Chernik A.A.
}

Belarusian State Technological University, Minsk, Sverdlov Str. 13a, 220006

Electrochemical frequency modulation (EFM) was used to study the corrosion behavior of anodic-oxide coatings of aluminum alloy grade AA6060. Which was exposed to $0.03 \mathrm{M} \mathrm{NaCl}$ solution, as a non-destructive method of analysis [1, 2]. Investigated coatings were obtained during the anodizing process in sulfuric acid in the presence of vanadium oxoanions. Corrosion behavior of oxide films was evaluated based on the corrosion rates and corrosion currents obtained during the EFM analysis.

A comparison of the results shows that the addition of vanadium oxoanions to the anodizing electrolyte provides greater corrosion resistance of the coatings, compared to the oxide films obtained in a similar way in sulfuric acid.

Anodised aluminium is widely used for industrial purposes. Aluminum alloy grade AA6060 is used: for building structures, such as windows, facade structures. fences, handrails, heat-dissipating elements of electronic devices, including computers, flexible assembly systems, elements of machine-building equipment, truck body parts, domestic equipment of passenger cars, furniture and office equipment, sports equipment.

Due to wide industrial application, corrosion research of the given alloy and increase of its anticorrosive properties are actual problem [3].

\section{Experimental}

Composition AA6060 ( $\mathrm{Si}-0,20-0,60 ; \mathrm{Fe}$ - to 0,$5 ; \mathrm{Cu}$ - to 0,$10 ; \mathrm{Mn}-0.1 ; \mathrm{Mg}$ $0,45-0,90 ; \mathrm{Zn}-0.2$; Ti - to 0,15 ; Al - rest) samples stamped plate diameter $40 \mathrm{~mm}$. Were previously subjected to grinding step by means of abrasive tape P180 - P280, followed by etching in a solution of sodium hydroxide. The final treatment consisted 
in mechanical polishing, the components of the polishing paste were removed from the surface of the samples by means of ultrasonic treatment in a Stoddard solvent.

Anodic oxide films were prepared in a solution of sulfuric acid $\left(150 \mathrm{~g} / \mathrm{dm}^{3}\right)$ with a different content of ammonium metavanadate $(0.001-0.1 \mathrm{M})$. Solutions were prepared using chemical compounds of the class "chemically pure" and "pure, for analysis" and distilled water.

Anodizing process was carried out at $25{ }^{\circ} \mathrm{C}$ and anode current density of $1 \mathrm{~A} / \mathrm{dm}^{2}$ for one hour. Measurement of the parameters of the corrosion process was carried out in a $0.03 \mathrm{M}$ sodium chloride solution at a temperature of $25{ }^{\circ} \mathrm{C}$ in a three-electrode cell, and $\mathrm{Ag} / \mathrm{AgCl}$ reference electrodes glassy carbon electrode were used as an auxiliary electrode.

The experiment was carried out using the potentiostat/galvanostat Autolab PGSTAT302N with the FRA $32 \mathrm{~N}$ removal module by the controlled software Metrohm Autolab B.V. «Nova 2.1», EFM study data were collected at an open circuit potential during exposure to corrosive media for 8 hours.

\section{Results and discussion}

Corrosion behavior of samples of anodic oxide, on the AA6060 alloy, obtained during anodization in sulfuric acid in the presence of vanadium oxoanions, was studied in a $0.03 \mathrm{M}$ solution of $\mathrm{NaCl}$. The results of the study are presented in the form of numerical values, parameters of the corrosion process obtained by electrochemical frequency modulation (EFM). Numerical values represent the average values obtained during 8 hours of continuous research in the working environment, each of the samples considered in this paper.

Vanadat ion $\left(\mathrm{VO}_{3}^{-}\right)$with high mobility characteristics was used as a modifying additive in a solution in the form of an ammonium metavanadate salt, to improve the corrosion resistance of the oxide film [4,5]. Ammonium metavanadate was added to the electrochemical oxidation solution in small amounts, gradually increasing the concentration from $0.001 \mathrm{M}$ to $0.1 \mathrm{M}$. 


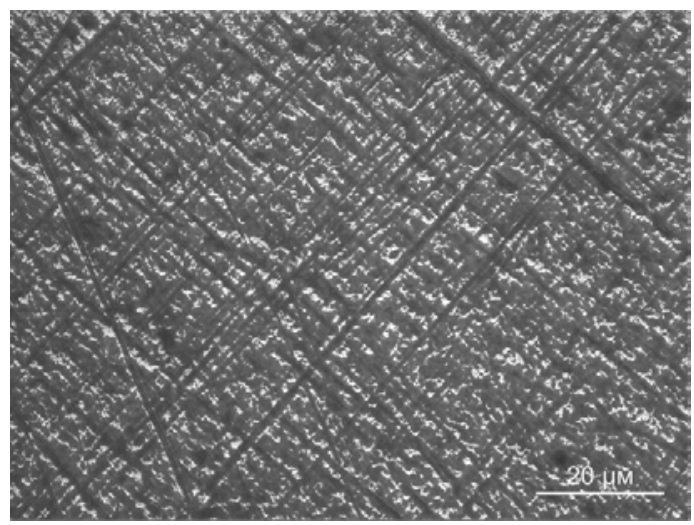

a

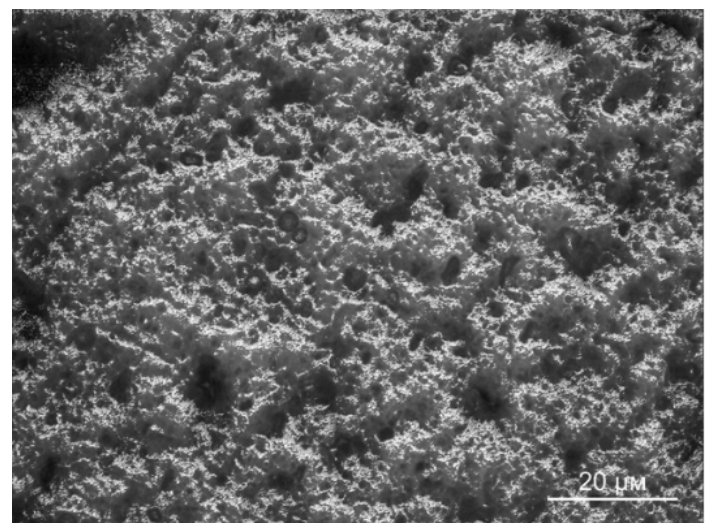

b

Fig. 1. The surface structure of the test sample: $a$ - after mechanical treatment; b after electrochemical oxidation.

During the formation of the anodic oxide film on the aluminum surface, as you can see in Fig. 1, significant change in the microrelief of the surface is noticeable. This is due to the different of the formation rate of the oxide film on the surface of the AA6060 alloy caused by the adsorption of vanadate anions having a high oxidizing ability.

\subsection{Corrosion research}

Considering the values of the corrosion rates shown in the figure 2 , the cycling of the process of passivation/depassivation of the surface of the investigated alloy is noticeable.

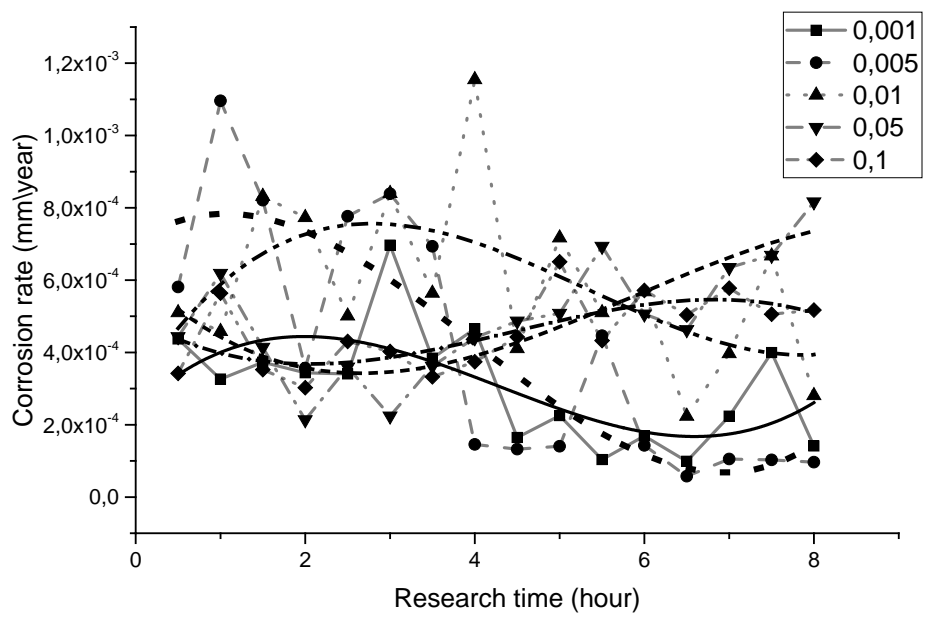

Fig. 2. Graph of the change in corrosion rate from the time in a corrosive environment 


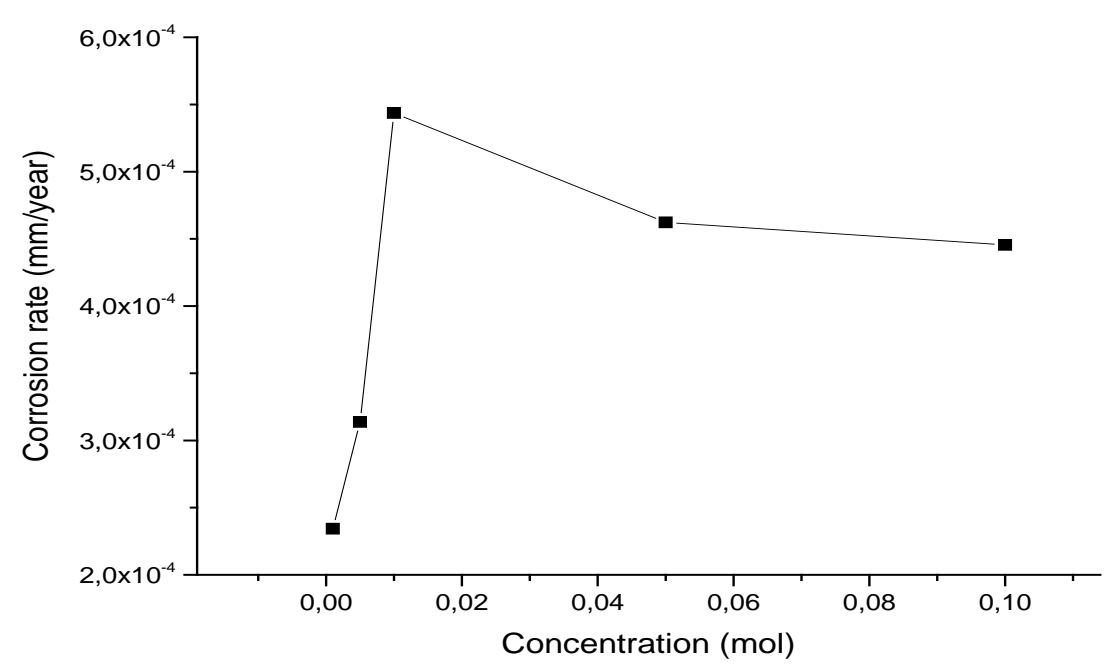

Fig. 3. Graph of corrosion rate from concentration of ammonium metavanadate in anodizing electrolyte

Throughout the span of the corrosion observation, it is evident that the coatings obtained in the presence of 0.001 and $0.005 \mathrm{M}$ metavanadate show the lowest rates and corrosion currents in the time interval under consideration and range from 1.84 to $2.9 \cdot 10^{-4} \mathrm{~mm} /$ year.

The introduction of vanadium axoanions into the anodizing electrolyte at a higher concentration leads to a slight increase in corrosion rates (Fig. 2.), the maximum of which is observed at a concentration of $0.01 \mathrm{M}$. Further introduction of vanadium compounds in the electrolyte composition does not significantly affect the rate of corrosion damage of the anodic oxide coating [6].

Such behavior of the resulting coatings is due primarily to the anions included in the oxide film, which begin to oxidize the base metal during the course of the corrosion process. So low concentrations of metavanadate promote "healing" of the coating, that is, accelerate the progress of the passivation reaction. Coatings obtained at high concentrations of the modifying additive have an increased amount of $\mathrm{VO}_{3}^{-}-$ ions included in the anode oxide composition, which more actively oxidizes the surface of the test sample, increasing the average rate of corrosion process.

\subsection{Mechanism.}

The corrosive behavior of the AA6060 alloy with treatment in an anodizing electrolyte containing $\mathrm{VO}_{3}^{-}$ions can be explained by the effect of vanadium 
oxoanions at the metal/oxide interface during anodization. These anions act as passivators when adsorbed on active sites or defective areas of the surface. Adsorbed anions participate in the ongoing oxidation-reduction reactions and are include into the barrier layer of the anodic oxide. Ion $\mathrm{VO}_{3}{ }^{-}$has a high oxidizing ability, which promotes the healing and strengthening of the oxide film, hence, increasing corrosion resistance.

\section{Conclusion}

The corrosion resistance of AA6060 alloy samples anodized in sulfuric acid in the presence of vanadium oxoanions in a $0.03 \mathrm{M} \mathrm{NaCl}$ solution using the EFM method is considered. The results show that the addition of vanadium compounds in an amount of 0.001-0.005 $\mathrm{M}$ to the electrolyte greatly reduces the rate of corrosion process. The corrosion rate, at given concentrations, varies in the range of $2.34-3.14 \cdot 10^{-4}$ $\mathrm{mm} / \mathrm{year}$, for anodized without metavanadate of the alloy AA6060 it is 0.002307 $\mathrm{mm} / \mathrm{year}$. The further increase in the content of vanadium oxoanions in the anodizing electrolyte shifts the parameters of the corrosion process into the region of high corrosion rates, which is associated with a more active oxidation of the metal with $\mathrm{VO}_{3}{ }^{-}$ions.

\section{References}

[1] W. Lee, S.-J. Park, Porous anodic aluminum oxide: anodization and templated synthesis of functional nanostructures, Chemical Review 114 (2014) 7487.

[2] G.D. Sulka, Highly ordered anodic porous alumina formation by self-organized anodizing, in: A. Eftekhari (Ed.), Nanostructured Materials in Electrochemistry, Wiley-VCH, 2008, 2015, pp. p. 1.

[3] Khaled, K.F., 2009. J. Appl. Electrochem. 39, 429.

[4] Amin, M.A., Khaled, K.F., 2010. Corros. Sci. 52, 1762.

[5] Amin, M.A., Khaled, K.F., 2010. Corros. Sci. 52, 1194.

[6] L. Zaraska, W.J. Stepniowski, G.D. Sulka, E. Ciepiela, M. Jaskuła, Analysis of nanopore arrangement and structural features of anodic alumina layers formed by two-step anodizing in oxalic acid using the dedicated executable software, Applied Physics A 114 (2014) 571. 


\title{
Stress-corrosion cracking of gas pipelines: the reasons of appearance and factors
}

\author{
Nyrkova L.I., Prokopchuk S. N., Lisovoy P.E. \\ E.O. Paton Electric Welding Institute of the National Academy of Sciences of \\ Ukraine, Kyiv
}

The article provides a brief overview of the reasons and the factors resulting in one of the most dangerous types of damages to main pipelines - stress corrosion cracking (SCC). It is noted that the SCC is due to the presence of a complex of several factors at the same time on the region, among which are: a corrosive-active medium with specific corrosive properties; stress-strain state of the pipeline; passive and active protection. It is noted that despite the similarity of the external appearance of SCC on the surface of pipes, two types of SCC has been recognizing: SCC at high pH, which is carrying on intergranular mechanism, and SCC at near neutral $\mathrm{pH}$, which characterizing by transgranular failure. It was emphasized that in order to provide undangerous working life of gas pipelines, it is necessary to analyze all complex of factors contributing to the occurrence of SCC extremely full, during design and, especially, during operation.

Key words: gas pipeline, stress-corrosion cracking, near-neutral pH SCC, high pH SCC

\section{Стресс-коррозионное растрескивание магистральных}

газопроводов: причины возникновения и факторы

Ныркова Л.И., Прокопчук С.Н., Лисовой П.Э.

Институт электросварки имени Е. О. Патона НАН Украинь

Киев, ул. К. Малевича, 11, 03150

Коррозионное растрескивание под напряжением (КРН) подземных магистральных газопроводов (МГ) относится к числу наиболее актуальных проблем их эксплуатации $[1,2]$. Анализ причин отказов и результатов диагностических обследований участков МГ показали, что стресскоррозионному растрескиванию подвержены газопроводы, пролегающие в 
различных природно-климатических районах, сооруженные из труб разного производства, отличающиеся по конструкции и размерам [3]. Доля коррозионных дефектов на внутренней поверхности не превышает 6\% от доли коррозионных дефектов, которые выявляются на внешней катоднозащищаемой поверхности, 31,7\% из которых составляют коррозионные язвы и питтинги, 68,3\% - стресс-коррозионные трещины [4].

С начала 1990-х годов по настоящее время отмечается негативная тенденция увеличения доли аварий, вызванных стресс-коррозионным растрескиванием, от 25 до 60 \% [3]. За последние годы случаи стресс-коррозионного растрескивания зарегистрированы в США, Австралии, Канаде [5-6], России [7], Украине.

Несмотря на то, что большое количество работ посвящено изучению КРН магистральных газопроводов, проблема предупреждения такого вида разрушения по-прежнему остается актуальной. Это связано с тем, что большинство из них эксплуатируется в течение длительного времени в условиях воздействия нагрузок при совместном влиянии коррозионноактивных сред и катодной защиты.

Понятие КРН. Коррозионное растрескивание металла труб под напряжением, или стресс-коррозия, представляет собой особый вид разрушений, проявляющийся в виде образования на внешней поверхности колонии трещин в горизонтальном направлении, развивающиеся во времени и приводящие, в конечном итоге, к разрыву трубы, рис. 1 [1]. Опасность стресскоррозионных дефектов характеризуется непредсказуемостью возникновения и внезапностью наступления аварийной ситуации.

Возникновение КРН, как правило, обусловлено присутствием на участке одновременно нескольких факторов $[6,8]$, к числу которых относятся:

- наличие околотрубной среды, обладающей специфическими коррозионными свойствами; 


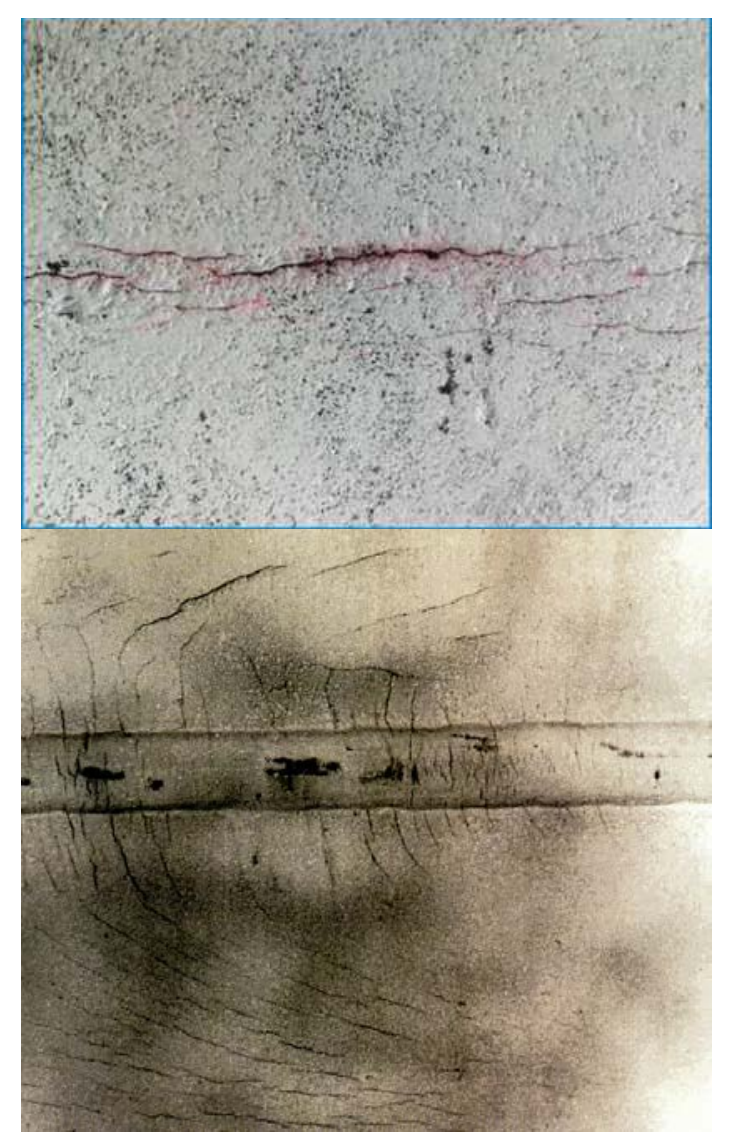

Рис. 1. Стресс-коррозионные повреждения металла [4]

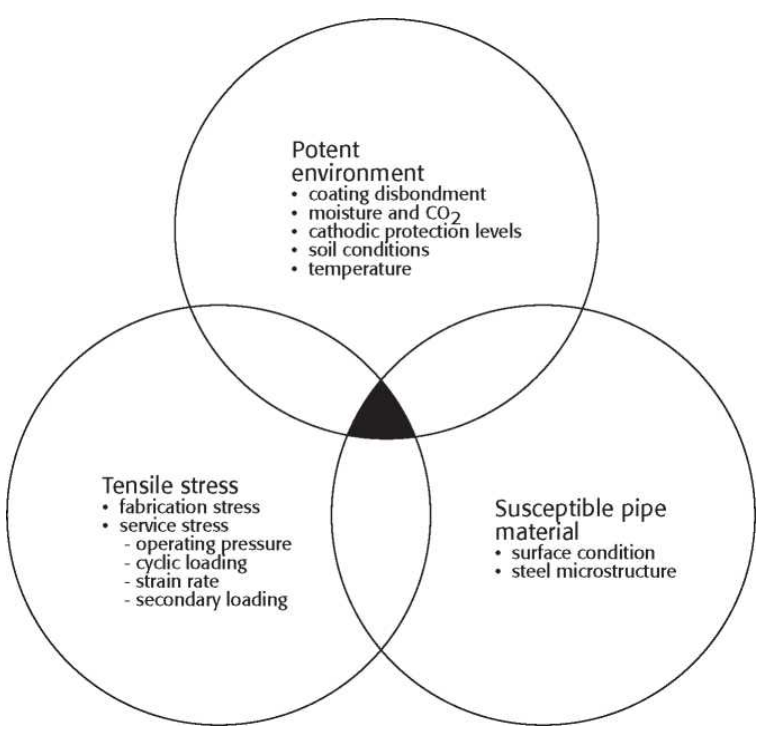

Рис. 2. Факторы стресскоррозионного растрескивания [6]

- материал труб, склонный к коррозионному растрескиванию в условиях длительного взаимодействия с околотрубной средой (металлургические и особенности материала, технология производства и параметры качества стали, состав, загрязненность неметаллическими включениями, структурные характеристики деформационная микроструктура, которые определяют чувствительность металла труб к растрескиванию;

- напряженно-деформированное состояние трубы, обусловленное особенностями режимов эксплуатации газопровода (давление, циклические нагрузки и т.д.), технологического передела в цепочке производства труб (зоны концентрации напряжений в местах отклонения геометрии от теоретической окружности, остаточные напряжения и деформации, особые свойства поверхностных слоев металла). Этот фактор рассматривают как контролирующий кинетику растрескивания. 
Cmaдии процесса. Процесс КРН протекает в несколько стадий. Первая стадия - инкубационный период, в течение которого в металле труб происходят существенные изменения: рост внутренних напряжений, структурные изменения в кристаллах, образование зародышевых дефектов, сопровождающееся возникновением микротрещин. Вторая стадия зарождение микротрещин, их рост и объединение в макротрещины. Этому способствуют напряжения, вызванные рабочим давлением и эксплуатационными факторами. Одна из составляющих таких факторов влияние грунта, что особенно существенно проявляется на участках со сложным рельефом. Третья стадия - рост макротрещин до критической величины, по достижении которой происходит механическое разрушение (долом) трубопровода. До завершения первой стадии не могут происходить остальные стадии.

Tunbl КРН. В настоящее время различают два типа КРН магистральных трубопроводов: при высоком значении $\mathrm{pH}$ (более 9) и при $\mathrm{pH}$, близких к нейтральным (7,5-8,2) [9-17]. Первыми были зарегистрированы случаи так называемого «классического» КРН, вызванного присутствием карбонатбикарбонат ионов, или КРН при высоких рН [9-12]. Благодаря интенсивным исследованиям, механизм этого вида КРН трубных сталей изучен достаточно хорошо. В настоящее время считается, что превалирующим механизмом развития КРН магистральных газопроводов в грунтовых электролитах с высоким рН является локальное анодное растворение металла.

Второй, «неклассический», вид КРН зарегистрирован при авариях магистральных газопроводов сравнительно недавно, последние 10-15 лет [1317]. Большинство исследователей сходятся во мнении, что КРН в средах с $\mathrm{pH}$, близких к нейтральным, обусловлено синергетическим действием механической нагрузки, наводороживания и локального растворения металла. Указанные факторы оказывают на КРН взаимосвязанное воздействие, и многие авторы считают, что нельзя однозначно выделить доминирующий фактор роста трещины. Однако некоторые исследователи все же полагают, что в 
растрескивании трубной стали в электролитах, близких к нейтральным существенную роль играет водород [18-19]. По мнению других исследователей, основное влияние на рост трещины в трубной стали в слабокислых и нейтральных электролитах оказывает локальное анодное растворение металла [20-22]. При этом ученые полностью не исключают влияния на КРН при рН, близких к нейтральным, атоммарного водорода, который в зависимости от потенциала металла, $\mathrm{pH}$ раствора и его ионного состава может замедлять или ускорять растворение металла.

Случаи «классического» КРН при высоких $\mathrm{pH}$ зафиксированы в США, Австралии, Иране, Аргентине, Саудовской Аравии [6]. В странах бывшего СССР «классический» тип растрескивания наблюдался на МГ, проложенных в пустынных и полупустынных районах Средней Азии и Казахстана [3]. Второй тип КРН трубных сталей в средах с рН, близких к нейтральным отмечался в Канаде, Италии, Западной Сибири, Урала и северных областей европейской части России.

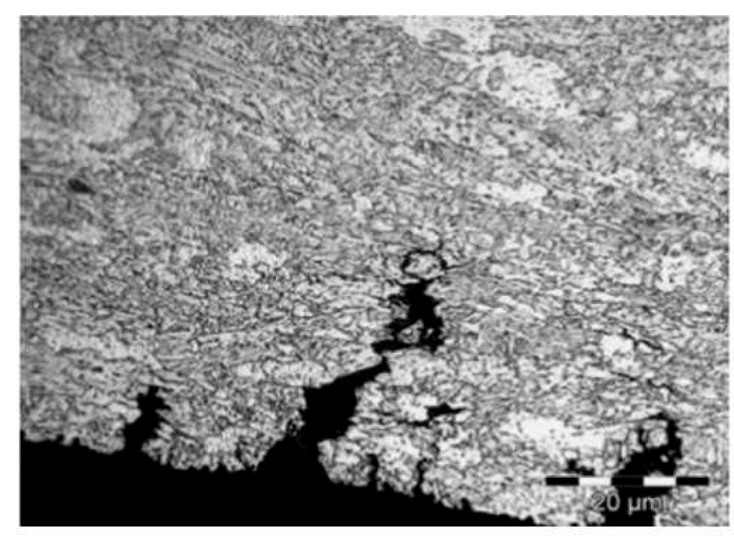

$a$

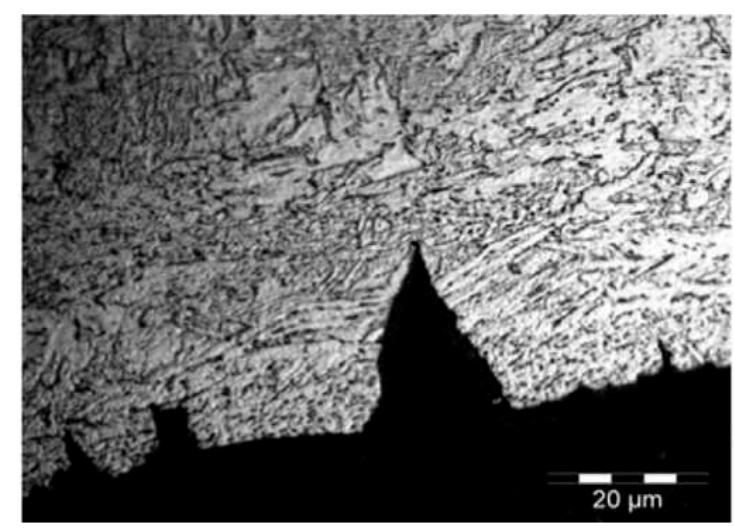

$\sigma$

Рис. 2. Вид стресс-коррозионных трещин при высоких $\mathrm{pH}$ (а) и $\mathrm{pH}$, близких к нейтральным (б)

Внешний признак обоих типов КРН - группы или колонии трещин вблизи очагов разрушений, ориентированных, преимущественно, вдоль оси трубы. Однако, при классическом КРН развитие трещин протекает межкристаллитно, рис. 2, a, а при неклассическом, определяемом диффузией водорода в стенку 
трубопровода и возникновением огромных (в сотни мегапаскалей) разрушающих давлений, транскристаллитно, рис. 2, б.

Трещина, развиваясь в ширину и глубину может привести к разрушению газопровода. Кинетика классического КРН определяется, в значительной степени, условиями пассивации, обусловленными спецификой образования защитных коррозионных пленок.

В трещине, заполненной электролитом, создаются оптимальные условия для возникновения гальванопары, при этом дно выступает в роли анода, а берега являются катодом. В процессе коррозии на анодном участке образуется тонкая защитная оксидная пленка. Если пленка сохраняет целостность, то она является барьером для воздействия окружающей среды и стресс-коррозия не развивается. Однако пленка является хрупкой и при пластической деформации разрушается, что дает возможность развития стресс-коррозии. Следовательно, скорость пластической деформации, т.е величина напряженнодеформированного состояния является главным условием развития данного вида КРН.

\section{Выводы}

Коррозионное растрескивание под напряжением особый вид разрушений, проявляющийся в виде поверхностных трещин, инициируемых в условиях применения защитного покрытия и катодной защиты при одновременном длительном воздействии специфического коррозионно-активной среды и механических растягивающих напряжений. Опасность этого вида разрушений обусловлена непредсказуемостью возникновения и внезапностью развития аварийной ситуации. Для обеспечения надежной эксплуатации магистральных газопроводов необходимо максимально полно анализировать комплекс факторов, способствующих возникновению КРН, при проектировании и, особенно, при эксплуатации. 


\section{Литература}

[1] В. Г. Антонов, А. Г. Арабей, В. Н. Воронин, И. А. Долгов, М. М. Кантор, Кношински, Ю. П. Сурков. Коррозионное растрескивание под напряжением труб магистральных газопроводов. $-2006,105$ с.

[2] Y. Frank Cheng Stress Corrosion Cracking of Pipelines. - Hoboken: John Willey\&Sons Publishing. - 2013, 257 P.

[3] Т.К. Сергеева, Е.П. Турковская, Н.П. Михайлов и др. Состояние проблемы стресс- коррозии в странах СНГ и за рубежом. $-1998,98$ с.

[4] Хижняков В.И. Развитие научных основ, разработка и реализация новых критериев эффективности электрохимической защиты трубопроводов от коррозии. Дисс. докт. дехн. наук. - 2010.

[5] Baker M. Stress corrosion cracking study: final report OPS TTO8. Integrity Management Program. - 2005.

[6] Public Jnquiry Concerning Stress Corrosion Cracking on Canadion Oil and Gas Pipelines. Report of NEB. - 1996.

[7] Ю.Г. Лапынин, С.Н. Савеня, А.А. Савеня. Альманах Волгоградского отделения международной академии авторов научных открытий и изобретений, Волгоградское изд. Госуниверситета. - 2007, С. 180-185.

[8] С.А. Сильвестров, А.К. Гумеров. Строительство и эксплуатация нефтегазопроводов, баз и хранилищ. Проблемы сбора, подготовки и транспорта нефти и нефтепродуктов. - № 3 (113), с. 95-113.

[9] A. Egbewande, W. Chen, R. Eadie, R. Kania, G. Van Boven, R.Worthingham, J. Been. Corrosion Science. - 2014, v. 83, p. 343-354.

[10] Song F.M. Corrosion Science. - 2009, v. 51, p. 2563-2657.

[11] Wang Q. Corrosion Science. - 2010, v. 52, p. 4064-4072.

[13] W. Chen, S.-H. Wang, F. King, T. R. Jack, R. R. Fessler. Corrosion. - 2004, v. 60, № 3, p. 275-283.

[14] R. N. Parkins, W. K. Blanchard, B. S. Delanty // Corrosion. - 1994, v. 50, p. 394-408.

[15] Arafin M.A., Szpunar J.A. Corrosion Science. --2009, v. 51, p. 119-128.

[16] Zang C., Cheng Y.F. Journal of Materials Engineering and Performance. 2010, v.19, № 9, p.1284-1289.

[17] Parkins R.N. Corrosion. - 1987, v. 43, № 5, p. 130.

[18] Lu B.T. Acta Materialia. - 2009, v. 57, p. 41-49.

[19] Мазель, А. Г. Строительство трубопроводов. - 1992, № 9, с. 23-26.

[20] A.I. Marshakov, V.E. Ignatenko, R.I. Bogdanov, A.B.Arabey. Corrosion Science. - 2014, v. 83, p. 209-216.

[21] Р.И. Богданов, А.И. Маршаков, Э. Игнатенко. Коррозия: материалы, защита. - 2011, № 11, с. 30-38.

[22] А.Б. Арабей, Р.И. Богданов, В.Э. Игнатенко и др. Физикохимия поверхности и защита материалов. - 2011, т. 47, № 2, с. 208-217. 


\title{
Rape grist extract (Brassica napus) as a green corrosion inhibitor of mild steel in
}

\section{hot tap water}

\author{
Vasyliev G., Vorobiova V. \\ National technical university of Ukraine "Igor Sikorsky Kyiv Polytechnic Institute", \\ 37, Prospect Peremohy, Kyiv-56, 03056,Ukraine
}

Rape grist extract (Brassica napus) was produced by macerating rape grist in 2propanol alcohol and tested as a mild steel corrosion inhibitor in hot tap water. The extraction process was intensified with ultrasound. The experiment was conducted in a laboratory installation modelling the working conditions of closed hot water supply system. The tap water was filled into the installation, heated and circulated by the water pump. The 3 LPR probes were inserted into the installation as well as coupons were placed for weight loss corrosion rate determination. The weight loss and polarization techniques showed at least 2,5 times corrosion rate reduction in $400 \mathrm{~h}$. LPR measurements revealed that better inhibition efficiency occurs after the removal of corrosion products from the steel surface. The GC-MS technique was used to analyze the composition of extract and quantum chemical calculations were performed to analyze adsorption abilities of the main extract compounds.

Keywords: mild steel; weight loss, polarization resistance; oxygen reduction, green inhibitor

\section{Екстракт шроту ріпаку (Brassica napus) як «зелений» інгібітор корозії сталі в гарячій воді}

\author{
Васильєв Г.С., Воробйова В.I.
}

Національний технічний університет Украӥни «Київський політехнічний інститут імені Ігоря Сікорського», Київ, пр-т. Перемоги 37, 03056

На сьогоднішній день суттєва частина корозійних пошкоджень сталевих трубопроводів припадає на інженерні системи, що експлуатуються 3 використанням природних вод (системи холодного або гарячого водопостачання, цикли охолодження та нагрівання підприємств, системи 
водовідведення та каналізації та ін.)у практично всіх галузях промисловості та соціальної сфери. Корозія сталевого обладнання, крім зменшення терміну експлуатації і збільшення витрат на ремонт, може завдати серйозної шкоди навколишньому середовищу. Аварії призводять до перебоїв у подачі води i тепла, спричиняють підтоплення територій та вимагають капіталовкладень на їх ліквідацію. Погіршення якості води призводить до погіршення стану здоров’я населення, що споживає таку воду.

Одним із методів протикорозійного захисту металів $\epsilon$ використання інгібіторів корозії - хімічних сполук або їх композицій, введення яких в корозійне середовище у невеликих кількостях (0,01-3,0 г/дм³) значно зменшує швидкість корозії [1]. Останнім часом для створення засобів протикорозійного захисту все більше використовують органічні компоненти рослинної сировини. Ця тенденція спостерігається як в Україні, так і за кордоном.

Перспективність і привабливість використання органічних речовин рослинного походження в замкнених теплообмінних системах та водопровідній воді показана в роботах [2]. Встановлено, що водні екстракти евкаліпту, квітів гібіскусу та печериці проявляють інгібуючі властивості в вище зазначених корозійних середовищах. Рослинний танін екстрагується iз природньої сировини певного виду, i містить сполуки ароматичного типу i iнших 3 активними функціональними групами, що забезпечує так само можливість ефективного його використання в якості інгібітору корозії деяких металів [3-5]. У роботі [6] досліджується вплив екстракту материнки майорану на корозійний процес маловуглецевої сталі в нейтральному середовищі. Процес гальмування корозійного процесу досліджувався за допомогою поляризаційних кривих. 3 даного дослідження було встановлено, що екстракт листя материнки майорану може бути використаний в якості інгібітора корозії для маловуглецевої сталі. Ефективність гальмування корозії склала близько 90\%.

Що стосується використання органічних сполук рослинної сировини для інгібування корозійного процесу металів у хлорвмісних водних розчинах, то авторами [7] було досліджено процес інгібування корозії вуглецевої сталі 
етанольним екстрактом Мірмекодіїв (Myrmecodia Pendans) в розчині 3,5\% $\mathrm{NaCl}$. Електрохімічними методами дослідження встановлено, рослинний екстракт $€$ інгібітором змішаної дії гальмує, як анодну, так і катодну реакції корозійного процесу. Отримані результати показують, що в залежності від концентрації екстракту він може себе проявляти як інгібітор катодного, анодного або змішаного типу. Найбільша протикорозійна ефективність відбувається при концентрації інгібітору 400 мг/л. За допомогою ІЧ-Фур'є - спектрометрії авторами встановлено, що в результаті витримки в інгібованому розчині $3,5 \%$ $\mathrm{NaCl}$, на поверхні сталі ідентифікуються типи зв'язків, що характерні основним компонентам екстракту $(\mathrm{N}-\mathrm{H} ; \mathrm{C}=\mathrm{C}-\mathrm{H} ; \equiv \mathrm{C}-\mathrm{H} ;-\mathrm{OH} ; \mathrm{C} \equiv \mathrm{N} ; \mathrm{C}=\mathrm{O} ; \mathrm{C}-\mathrm{C}=\mathrm{C} ; \mathrm{N}=\mathrm{O} ; \mathrm{H}-$ $\mathrm{C}-\mathrm{H}$; C-O), однак диференційні та ковалентні типи ОН зв'язку дещо зміщені, а також спостерігається утворення зв'язку Fe-O та Fe-N-H с при утриманні 675 $\mathrm{cm}^{-1}$ та $882 \mathrm{~cm}^{-1}$ відповідно. На думку авторів це пов'язано з формуванням нових сполук, через зв'язування активних сполука екстракту з іонами $\mathrm{Fe}^{2+}$ i адсорбції ïх на поверхні металу. Тобто інгібування корозійного процесу відбувається за рахунок формування адсорбційного шару на поверхні металу, та утворення комплексних сполук.

В роботі інших дослідників [8] також оцінена протикорозійна ефективність Капсаїци́ну (Capsaicin) у водному середовищі $3,5 \% \quad \mathrm{NaCl}$. Інгібуюча ефективність рослинного екстракту пов'язана з адсорбціїю молекул 8-метил-Nваніліл-6-нонаміду на поверхні зразка і блокуванням активних центрів, або осадження сполук продуктів корозії на поверхні міді.

Авторами досліджено інгібуючу ефективність Тютюну справжнього (Nicotianaglauca) на корозію сталі у нейтральному водному середовищі. Показано, що рослинний екстракт є інгібіторам анодного типу, а основними діючими компонентами є амінокислоти [9].

Так при оцінці захисної ефективності етанольного екстракту Achyranthesasperaна корозію сталів середовищі індустріальної води авторами встановлено, що перщі 10-15 годин відбувається поступове збільшення інгібуючої дії. При подальшому збільшенні часу витримки зразка в 
інгібованому водному розчині до 40 годин призводить до стабілізації захисної ефективності (Ступінь захисту 80\%). На думку авторів, це пов'язано 3 формуванням 3 часом адсорбційної плівки 3 більшими захисними властивостями. [10]. На основі електрохімних методів дослідження, автори стверджують, що екстракт є інгібітором змішаної дії, гальмує як анодну, так i катодну реакції корозійного процесу. Механізм захисної дії обумовлено, як фізичним так, частково і хімічним типом адсорбції молекул на поверхні сталі.

Для зменшення швидкості корозії міді в нейтральному водному розчині $(0,5$ $\mathrm{M}$ розчин $\mathrm{NaCl}$ ) запропоновано використовувати екстракт оливкового листя Olive [11]. На основі електрохімічних методів дослідження встановлено, що досліджуваний екстракт є інгібітор катодного типу, а плівка, яка утворюється на поверхні металу, слугує бар'єром, для гальмування доступу кисню до катодних ділянок поверхні міді. При цьому фізично адсорбована плівка формується впродовж 6 - 24 годин. Авторами встановлено, що впродовж 1 - 6 годин інгібуюча ефективність збільшується до 70\%, більш високий рівень інгібуючої ефективності на рівні 90\% можна досягти лише за 24 години експонування зразка в інгібованому розчині. На думку авторів, це обумовлено впливом інгібітору на продукти корозії, оскільки плівка продуктів корозії за 24 години в основному була сформована лише на деяких ділянках поверхні сталі, в той час як ефективність гальмування залишалась достатньо високою (86\%). Ймовірно органічні молекули адсорбувались саме на шарі продуктів корозії. Інгібуюча ефективність обумовлена адсорбцією фенольних сполук оливкової олії на поверхні міді.

Таким чином можна зробити висновок, що ефективність захисту металів рослинними екстрактами в різних агресивних середовищах залежить від багатьох факторів, зокрема від часу формування захисної плівки, що може відбуватися протягом деякого часу. При цьому швидкість процесу формування плівки і ії захисні властивості будуть залежати від хімічної природи складових рослинного екстракту так і стану поверхні. 
Метою роботи було визначення принципової можливості використання природних речовин рослинного походження із значною сировинною базою, а саме екстракту ріпаку, як інгібітору корозії сталі для нейтральних водних середовищ. Встановлення складу рослинного екстракту, визначення основних компонентів, що сходять до складу захисного шару та дослідження процесів формування захисного шару.

\section{1. Методика експериментів}

Для корозійних досліджень як інгібітор корозії було використано етиловий екстракт шроту ріпаку.Шрот ріпаку представляє собою шматки пресованоподрібненої маси насіння після холодного віджиму. Для екстрагування до заздалегідь подрібненої рослинної сировини додавали етиловий спирт (співвідношення 1 г сухої маси на 10 мл розчинника). 3 метою інтенсифікації процес екстрагування проводили в ультразвуковій ванні (частота ультразвуку 27 кГц, потужність 100 Вт) впродовж 2 годин, 3 подальшою фільтрацією при кімнатній температурі.

Компонентний склад речовин рослинного екстракту вивчали методом хромато-мас-спектрометрії на газовому хроматографі "FINIGAN FOCUS" 3 мас-селективним детектором фірми TermoElectronics. Умови хроматографувания такі: капілярна кварцова колонка HP-5MS 3 діаметром 0,25 мм і довжиною 30 м, товщина плівки фази 0,25 мкм. Газ-носій - гелій, потік газу-носія в колонці 1,2 мл/хв. Режим Spleet 3 діленням потоку 1:10. Температура інжектора $250{ }^{\circ} \mathrm{C}$, температура інтерфейсу $\mathrm{MSD}-280{ }^{\circ} \mathrm{C}$, температура термостату хроматографа програмована: початкова температура $50^{\circ} \mathrm{C}$ з утриманням 0,5 хв, далі зі швидкістю $25{ }^{\circ} \mathrm{C} / \mathrm{xв}$ до $125{ }^{\circ} \mathrm{C}$; далі зі швидкістю $10{ }^{\circ} \mathrm{C} / \mathrm{xв}$ до $255{ }^{\circ} \mathrm{C}$; далі зі швидкістю $25{ }^{\circ} \mathrm{C} / \mathrm{xв}$ до $300{ }^{\circ} \mathrm{C} 3$ утримуванням протягом 10 хв. Іонізація електронним ударом 3 енергією електронів 70 еB. Режим роботи MSD: повне сканування іонів від 29 до 450 атомних мас (режим SCAN). Ідентифікували компоненти, зіставляючи час утримування піків на хроматограмі і повних мас-спектрів окремих компонентів 3 відповідними результатами для чистих сполук у бібліотеці мас-спектрів 
“NIST-5” та також з використанням лінійних індексів утримування. Відносний кількісний вміст хімічних компонентів екстракту розраховували методом внутрішньої нормалізації площ піків без коригувальних коефіцієнтів чутливості. Встановлення кількісного вмісту екстрагованих сполук, проводили газовим хромато-мас-спектральним методом, при кількісному визначенні за зовнішнім стандартом [1].

Корозійній дослідження проводили на сталі Ст3, яка $\epsilon$ найбільш розповсюдженим матеріалом трубопроводів та обладнання інженерних мереж. Для масометричного методу використовували дискові зразки діаметром 36 мм, товщиною 1,5 мм. Поверхню зразків перед випробуваннями шліфували наждаковим папером різної зернистості, знежирювали спиртом, травили в розчині 200г/л $\mathrm{HCl}$, промивали та сушили в потоці теплого повітря. Підготовлені зразки зважували на аналітичних терезах з точністю до 0,0001 г. Аналогічна підготовка проводилася для стальних електродів датчиків корозії ДК-1 на яких проводили визначення швидкості корозії методом поляризаційного опору.

Зразки розміщували в лабораторній установці, що моделює систему оборотного водопостачання. Установка являє собою закритий циркуляційний контур об'ємом 6 дм³, зібраний з поліпропіленових труб діаметром 50 мм. В контурі розміщується відцентровий насос продуктивністю $1,5 \mathrm{~m}^{3} /$ год та трубчастий електронагрівач потужність 1,5 кВт. Установка заповнювалась водопровідною водою, температура води в процесі експерименту $50{ }^{\circ} \mathrm{C}$. В нічні години установка вимикалася, температура знижувалася до $15{ }^{\circ} \mathrm{C}$, потік води відсутній.

По закінченню терміну експозиції зразки вилучали зустановки, рихлі продукти корозії видаляли м'якою гумкою, а тверді - катодним травленням в розчині 100 г/л лимонної кислоти при катодній густині струму $\mathrm{i}=100 \mathrm{MA} / \mathrm{cm}^{2}$. Після видалення продуктів корозії зразки промивали проточною водою, краплі вологи видаляли фільтрувальним папером, висушували в потоці теплого повітря і повторно зважували. 
Для неперервного визначення швидкості корозії в ході експерименту в установці було розміщено 3 датчики корозії ДК-1, підключені до системи автоматизованого корозійного моніторингу (САКМ-1). Система дозволяє автоматизувати збір даних з датчиків корозії в режимі реального часу, архівування даних та їх перенесення на комп'ютер для подальшої обробки. Вимірювання швидкості корозії за методом поляризаційного опору проводили корозиметром СІК-3, що працює за гальваностатичним принципом вимірювання. В приладі реалізовано двоступінчатий метод вимірювання, що дозоляє визначати швидкість корозії за наявності на електродах датчика значних електродних ємностей.

Використання інгібіторів корозії в системах водопостачання практично ніколи не проводиться 3 початку експлуатації системи, а тому на момент початку використання інгібітору на внутрішній поверхні труб вже накопичений багаторічний осад продуктів корозії, солей твердості води, а часто і продуктів життєдіяльності мікроорганізмів. В даній роботі також було змодельована система 3 сформованим осадом продуктів корозії і ефективність інгібітору перевіряли на прокородованій поверхні. Також, перевіряли можливість видалення продуктів корозії з поверхні металу хімічним травленням, для чого використовували 4\% розчин засобу для видалення відкладень ЛВХ 4.2 (ТОВ «Лабораторія водної хімії», м. Черкаси). Послідовність експерименту наведена на рис. 1.

Адсорбційні властивості компонентів екстракту визначали за квантовохімічними розрахунками. Для квантово-хімічних розрахунків (КХР) використовували метод молекулярної механіки $\mathrm{MM}+\mathrm{i}$ напівемпіричний метод MP3 при повній оптимізації геометрії молекул. По розрахованих електронних зарядах на атомах молекул визначали їх здатність до хімічної взаємодії, а по хвильовій функції вищої зайнятої молекулярної орбіталі $\left(E_{B 3 м о}\right)$ та нижчої вільної молекулярної орбіталі встановлювали $\left(E_{H в м о}\right)$ найбільш вірогідні адсорбційні центри та енергетичний зазор $\Delta E$ (енергію щілини між $\left(E_{B з м O}\right)$ та $\left.\left(E_{H B M O}\right)\right)$. 
Дослід №1

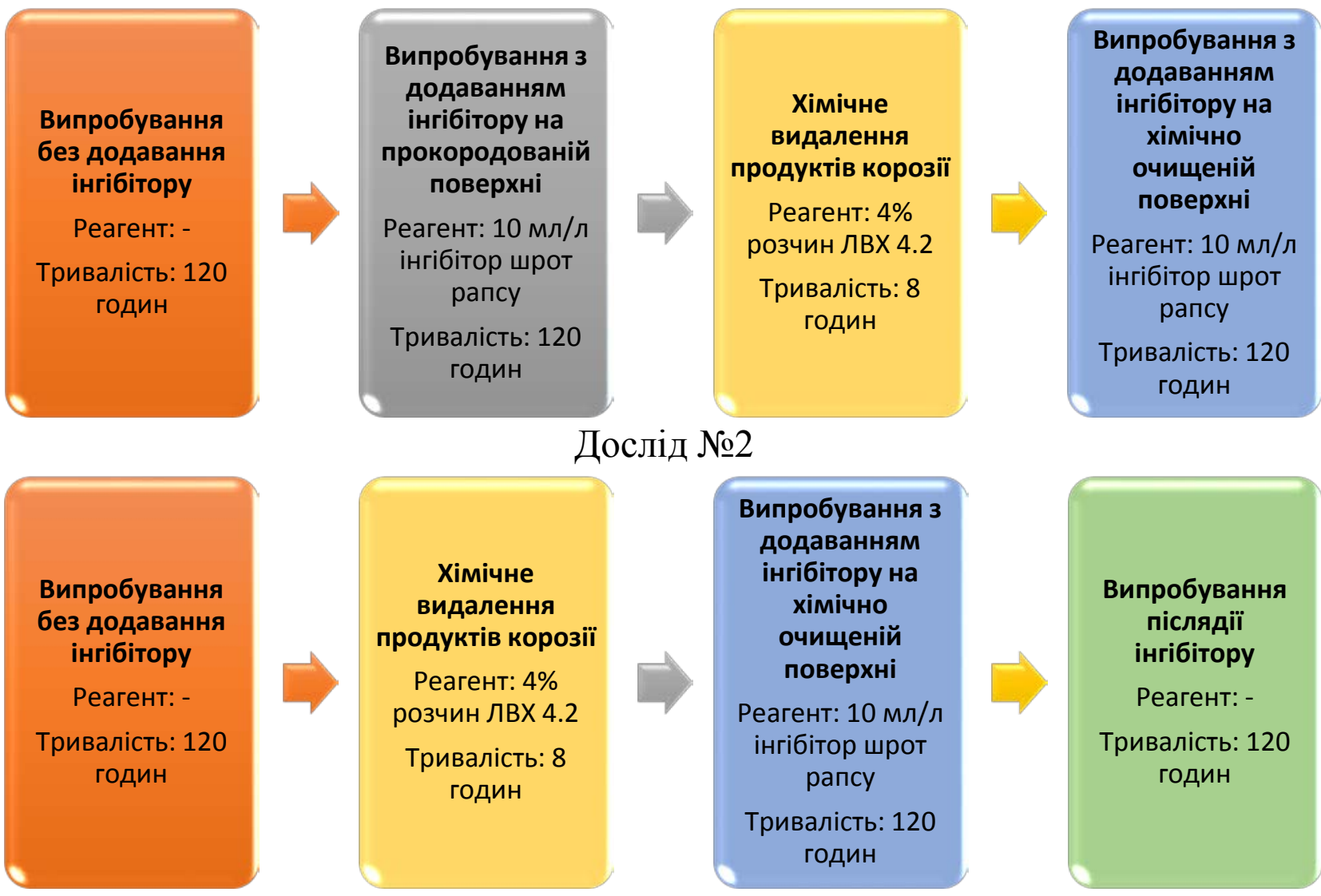

Рис. 1. Хід досліджень протикорозійних властивостей екстракту шроту ріпаку у гарячій водопровідній воді.

\section{2. Результати досліджень}

\section{1. Аналіз складу екстракту шроту ріпаку}

При дослідженні компонентного складу екстракту шроту ріпаку в індивідуальному стані виділено та ідентифіковано близько 20 сполук (табл.1). Хроматограмма ізопропанольного екстракту представлена на рисунку 2.

Серед них домінують глікозиди (29\%): сахароза, гуанозин, ксантозин; бузковий альдегід (13,5\%), кетон - 3,5-диметоксиацетофенон $(17,3 \%)$, фітостерини ( $\beta$ і $\gamma$-ситостерол, кампестерол) $(4,6 \%)$, а також насичені i ненасичені жирні кислоти, представлені пальмітиновою (гексадеканова), олеїновою (цис-9-октадеценова кислота), лінолевою (октадекадієнова) i оцтовою кислотами (21\%). 


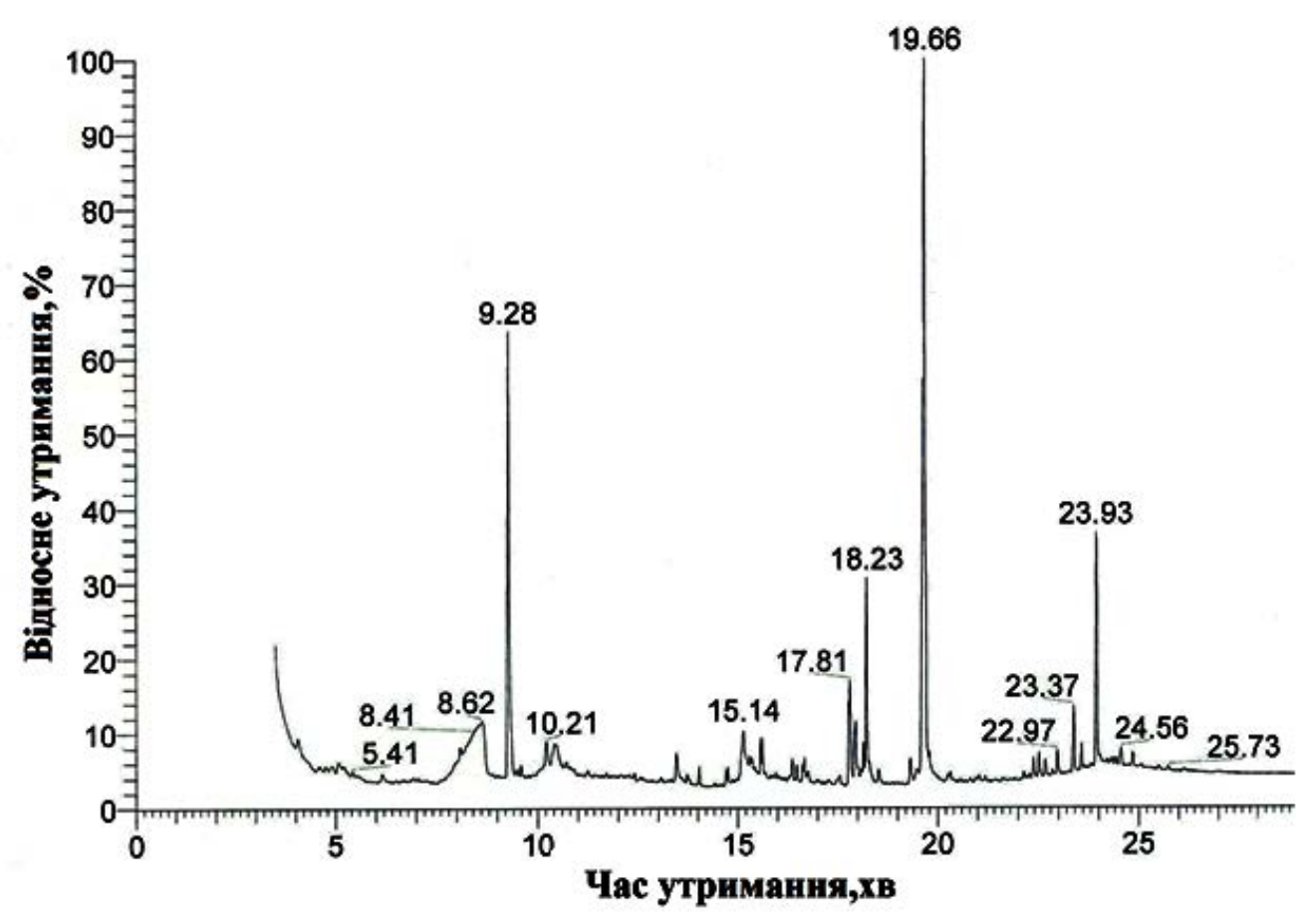

Рис. 2. Хроматограма ізопропанольного екстракту шроту ріпаку

В несуттєвій кількості присутні алкалоїди, а саме піролідин,1-(1-оксо-7,10гексадекадієнілу) та 2-піролідин, 1-(9-октадеценілу), а також терпени: ергоста5,22-дієн-3-ол та стігмастан-3,5-дієн.

Аналіз складу показав, що у складі екстрактивної частини під дію ультразвуку, основними компонентами також $є$ глікозиди: сахароза, гуанозин, ксантонозін; бузковий альдегід, кетон - 3,5-діметоксіацетофенон, стероїди ( $\beta$ і $\gamma$ - сітостерол, кампестерол і ін.), а також насичені і ненасичені жирні кислоти, представлені пальмітинової, олеїнової, лінолевої і оцтової кислоти. Однак збільшується вміст бузкового альдегіду, 3,5-діметоксиацетофенона і деяких насичених і ненасичених жирних кислот.

\section{2. Корозійні випробування}

Криві залежності миттєвої швидкості корозії від часу у гарячій воді в умовах досліду №1 наведені на рис. 2. На першому етапі (до 120 годин) швидкість корозії у гарячій воді знаходиться на високому рівні 0,7-1,2 мм/рік. Зниження швидкості корозії відбувається внаслідок формування на поверхні осаду продуктів корозії та солей твердості води. При подальшому введенні у воду інгібітору корозії швидкість корозії на прокородаваній поверхні датчиків дещо 
знижується, до 0,5 мм/рік. Ймовірно, товстий та рихлий шар продуктів корозії перешкоджає доступу інгібітору до поверхні металу, тому захисний ефект не значний.

Таблиця 1. Компонентний склад та відносна кількість сполук екстракту шроту ріпаку за результатами газової хромато-мас-спектрометрії

\begin{tabular}{|l|c|c|}
\hline \multicolumn{1}{|c|}{ Назва компоненту } & $\begin{array}{c}\text { Час } \\
\text { витримки } \\
\text { t хв }\end{array}$ & $\begin{array}{c}\text { Кількісний } \\
\text { склад, } \%\end{array}$ \\
\hline гуанозин & 8,41 & 10,4 \\
\hline сахароза & 8,57 & 1,2 \\
\hline ксантозин & 8,62 & 4,3 \\
\hline 3,5 -диметоксиацетофенон & 9,28 & 28,3 \\
\hline бузковий альдегід & 10,21 & 20,5 \\
\hline оцтова кислота & 10,56 & 1,6 \\
\hline n-циклогексил-4-гідроксибутирамід & 15,14 & 1,6 \\
\hline піролідин, 1 - (1-оксо-7,10- & 16,63 & 0,8 \\
\hline гексадекадиеніл) & 16,67 & 0,9 \\
\hline 2-піролідин, 1 - (9-октадеценіл) & 17,81 & 4,8 \\
\hline Гексадеканова кислота & 18,23 & 4,1 \\
\hline Октадекадієновая кислота & 19,66 & 12,2 \\
\hline Цис-9-октадеценовая кислота & 19,75 & 2 \\
\hline Стеаринова кислота & 22,97 & 0,8 \\
\hline Етанамін, 2,2'-оксибіс [N,N-диметил]- & 23,01 & 2 \\
\hline 7-дигідродиосгенін & 23,37 & 1 \\
\hline Кампестерол & 23,93 & 1 \\
\hline$\gamma$ - ситостерол & 24,56 & 1,1 \\
\hline$\beta$-ситостерол & 2,58 & 2,4 \\
\hline ергоста-5,22-діен-3-ол & \\
\hline
\end{tabular}

Для видалення шару продуктів корозії систему було промито 4\%-им розчином для зняття відкладень ЛВХ 4.2. Даний розчин має кислу реакцію, 
утворений сумішшю органічних кислот. Процес видалення продуктів корозії тривав 8 годин, після чого систему промили водопровідною водою, промивний розчин злили та заповнили водопровідною водою з інгібітором.

Швидкість корозії з інгібітором після видалення продуктів корозії швидко знижується до 0,3 мм/рік, що у 2 рази нижче, ніж при додаванні інгібітору коли поверхня металу містить продукти корозії. Таким чином, екстракт шроту ріпаку виявився ефективним інгібітором корозії маловуглецевої сталі у гарячій воді при його застосуванні на попередньо очищеній від продуктів корозії поверхні.

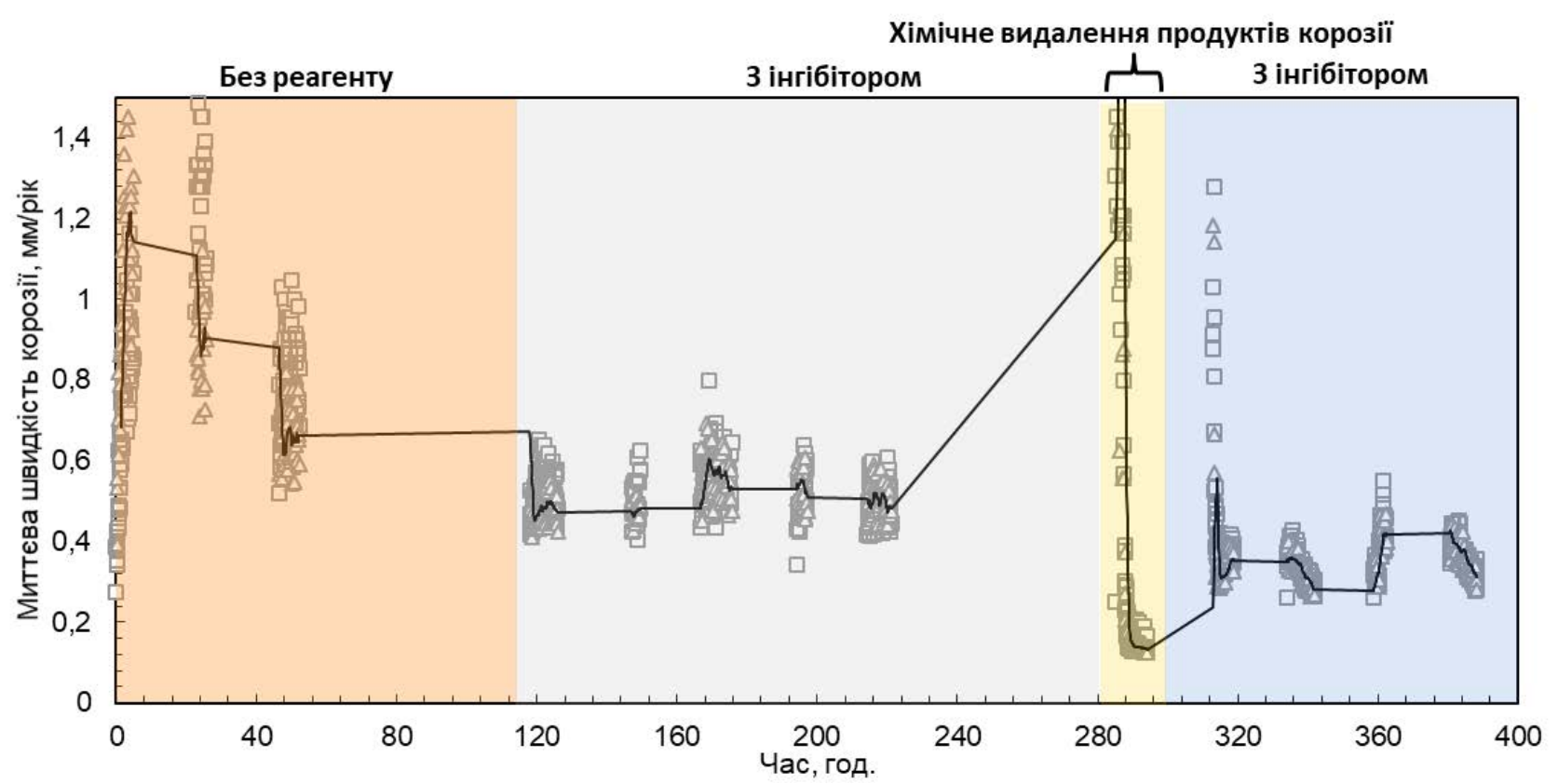

Рис. 3. Залежність миттєвої швидкості корозії сталі Ст3 від часу у гарячій воді $\left(50^{\circ}\right)$ при додаванні інгібітору корозії - екстракту шроту ріпаку (10 мл/л), дослід №1.

В наступному досліді перевіряли післядію інгібітору. Крива залежності миттєвої швидкості корозії від часу для досліду №2 наведена на рисунку 3.

У другому досліді хід кривих подібний до досліду №1. Введення інгібітору після видалення осадів 3 поверхні електродів дозволяє знизити швидкість корозії до 0,2 мм/рік і нижче. В подальшому плівка інгібітору проявляє ефект післядії, швидкість корозії сталі залишається на низькому рівні - 0,1 мм/рік впродовж 100 годин після заміни води в системі. Дані методу поляризаційного опору добре узгоджуються із результатами масометрії, наведеними на рисунку 
4. Так, за даними масометрії швидкість корозії сталі після видалення продуктів корозії знижується у 2,5 рази в присутності екстракту шроту ріпаку.

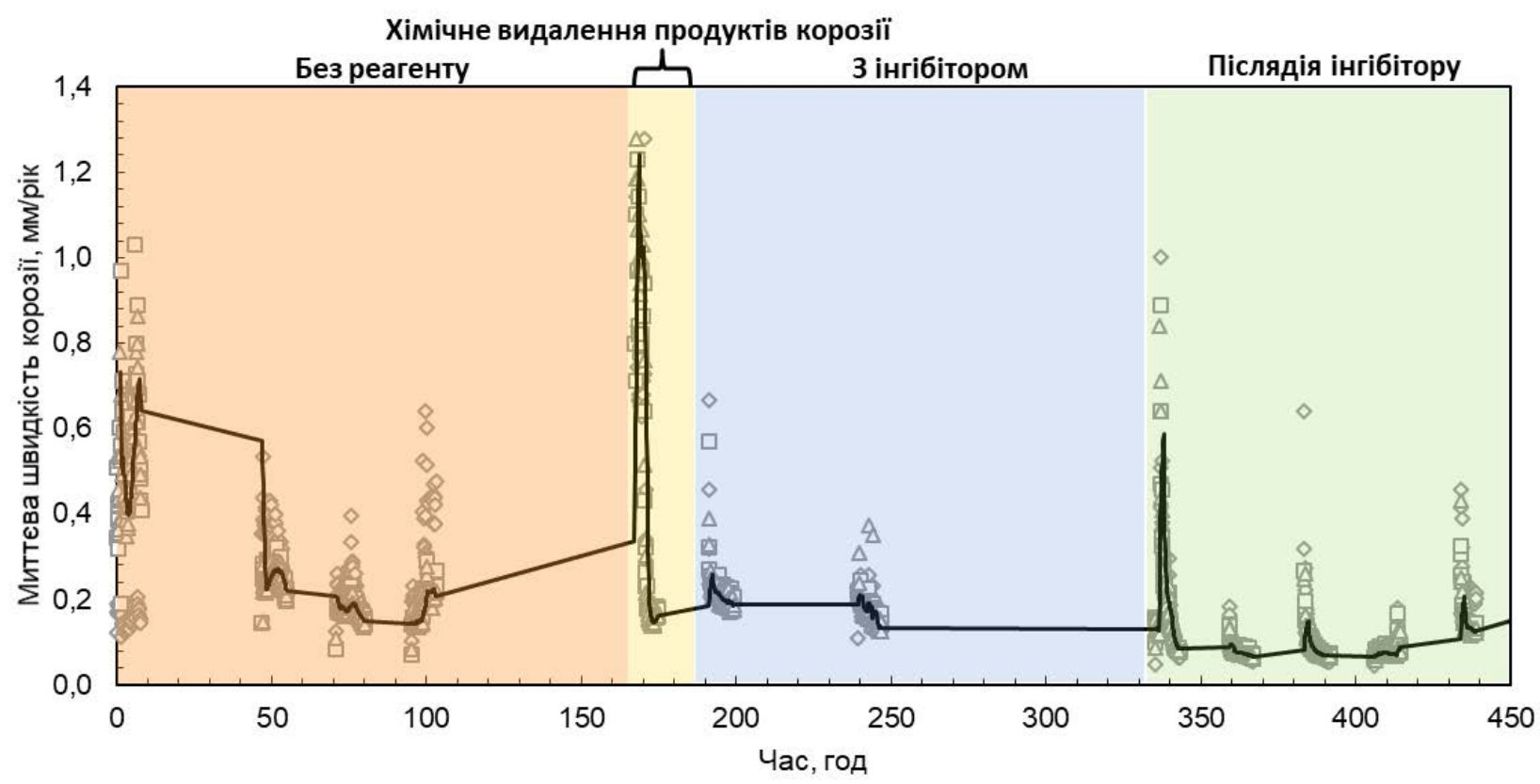

Рис. 4. Залежність миттєвої швидкості корозії сталі Ст3 від часу у гарячій воді $\left(50^{\circ}\right)$ при додаванні інгібітору корозії - екстракту шроту ріпаку (10 мл/л), дослід №2.

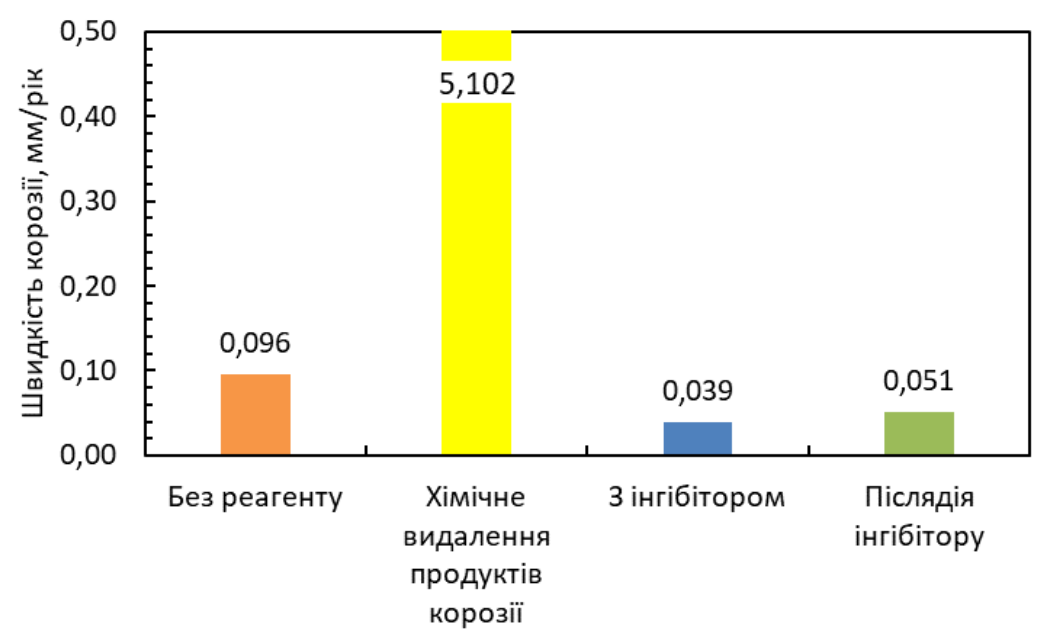

Рис. 5. Швидкість корозії сталі Ст3 у гарячій водопровідній воді, визначена масометрични методом

Таким чином, екстракт шроту ріпаку є ефективним інгібітором корозії маловуглецевої сталі у гарячій водогінній воді. Сформована плівка на поверхні металу дозволяє знизити швидкість корозії до 0,1 мм/рік і нижче і зберігає захисні властивості впродовж 100 годин після заміни води. 


\section{3. Оцінка адсорбційної здатності основних компонентів екстракту на основі квантово-хімічних розрахунків}

При дослідженні протикорозійної ефективності будь якого рослинного екстракту важко передбачити основні інгібуючі сполуки, в першу чергу, за рахунок багатокомпонентного складу. Тому залишається не відомим, які із сполук, що входять до складу екстракту, вносять найбільший внесок у його інгібуючу ефективність [12-19]. Адсорбційну активність органічних молекул, а отже, здатність до хемосорбції згідно з літературними даними $[17,18]$ можна оцінити за індексами реакційної здатності тобто за різними параметрами електронної структури, отриманими квантово-хімічними розрахунками (КХР), коли враховують електронні і енергетичні характеристики як інгібітора, так $\mathrm{i}$ металу. Тому в роботі проведена прогнозна оцінка адсорбційної здатності на основі електронних характеристик молекул, таких як енергія вищої зайнятої молекулярної орбіталі $\left(\mathrm{E}_{\text {взмо }}\right)$ та енергії нижчої вакантної молекулярної орбіталі $\left(\mathrm{E}_{H в м о}\right)$, енергії щілини молекул $(\Delta \varepsilon=\mathrm{E}(\mathrm{B} 3 \mathrm{MO})$ - $\mathrm{E}(\mathrm{HBMO}))$, абсолютна електронегативність, жорсткість молекули, що базуються на теорії функціональної щільності. При цьому вважається, що адсорбція органічних речовин відбувається на частково заповнену d-орбіталь Феруму реакційними центрами молекул. При подібному механізмі адсорбції електронна взаємодія, як правило, має донорно-акцепторний характер, в результаті чого на поверхні утворюються хімічні комплекси органічних речовин з металом.

3 іншого боку доцільно оцінити адсорбційну здатність молекул на основі принципу теорії ЖМКО Пірсона. Згідно теорії Koopman's [19] значення енергії вищої зайнятої молекулярної орбіталі $\left(\mathrm{E}_{B 3 м о}\right)$ та нижньої вакантної молекулярної орбіталі (Е $\mathrm{E}_{\text {нвмо }}$ пов'язані з потенціалом іонізації (I) та ядерною подібністю до електронів (А) наступним співвідношенням: $\mathrm{A}=-\mathrm{E}_{\text {нвмо }}$, $\mathrm{I}=-\mathrm{E}_{B 3 м O}$.

По розрахованих електронних зарядах на атомах молекул визначали їх

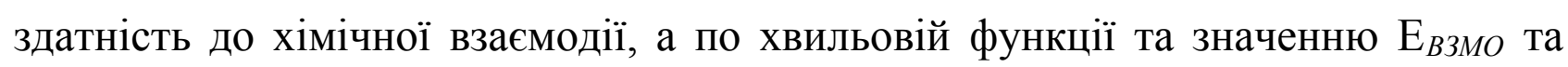

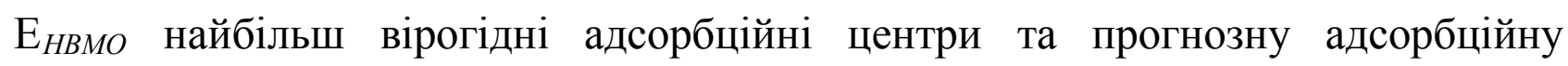


здатність сполук. Чим більш негативний заряд на гетероатомі, тим краще відбувається передача електронів від донора. Враховуючи характеристики переносу заряду адсорбції, в літературі обгрунтовано широке використання квантово-хімічних розрахунків для вивчення цього процесу.

При якісному описі кислотно-основної взаємодії необхідно розглядати величини ВЗМО донора та НВМО акцептора. До того ж відомо, що при адсорбції поверхня металу виступає як електрофіл, в той час як інгібітор діє як нуклеофіл. Тобто на основі розрахунків електронних зарядів можна прогнозувати, що взаємодія з поверхнею металу буде відбуватися по атомах, де сконцентрована найбільша електрона густина, оскільки на них розташовані найбільш електронегативні заряди. Внаслідок цього саме ці атоми володіють надлишковим зарядом, тобто мають неподілену електронну пару та можуть виступати в якості нуклеофільного агенту $[17,18]$.

Pearson and Parr були представлені визначення, використовуючи метод кінцевих відмінностей залежно від ядерної подібності до електронів (А) та енергії іонізації (I) будь-яких хімічних видів (атомів, іонів або молекул) для жорсткості молекули ( $)$ та хімічного потенціалу $(\mu)$.

Відповідно до теорії функціональної щільності абсолютна електронегативність $(\chi)$, хімічний потенціал $(\mu) \epsilon$ основними параметрами, що характеризують здатність молекул до хімічної взаємодії [20]. Хімічний потенціал, абсолютну електронегативність та жорсткість розраховували за наступними формулами:

$$
\begin{aligned}
& \chi=-\mu=\frac{1}{2}(I+A) \\
& \eta=\frac{1}{2}(I-A),
\end{aligned}
$$

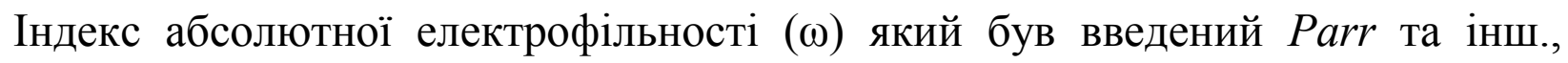
розраховували за наступною формулою:

$$
\omega=\frac{(I+A)^{2}}{8(I+A)}
$$

При розгляданні процесу адсорбції з точки зору кислото-основної взаємодії важливим кількісними параметрами, що характеризують цей процес, є ступінь 
переносу заряду $\Delta \mathrm{N}$, тобто сила взаємодії молекул кислоти - акцептора (поверхня заліза) і основи - донора (досліджувані речовини парової фази екстракту гребнів винограду) та величина зміни енергії, що супровод-жують утворення комплексу. При описі кислотно-основної взаємодії, розрахо-вана сила взаємодії $(\Delta N)$ молекул з поверхнею $\alpha$-Fe та зміна енергії $(\Delta E)$ :

$$
\begin{array}{r}
\Delta N=\frac{\mu_{B}-\mu_{A}}{2\left(\eta_{A}+\eta_{B}\right)} \\
\Delta E=\frac{\left(\mu_{B}-\mu_{A}\right)^{2}}{2\left(\eta_{A}-\eta_{B}\right)}
\end{array}
$$

де $\chi=-\mu-$ абсолютна електронегативність, еВ;

$\eta$ - абсолютна жорсткість, еВ;

$A$ - характеристики молекули досліджуваної речовини;

$B$ - характеристики елементарної решітки поверхні заліза.

Згідно з роботою авторів за абсолютну електронегативність поверхні заліза теоретично можна прийняти 4,82 еВ, а абсолютну жорсткість 0 еВ.

Вище зазначені параметри дадуть змогу з'ясувати механізм взаємодії компонентів екстракту з поверхнею легкої сталі.

Згідно з літературними даними [16] адсорбція органічних речовин відбувається на частково заповнену d-орбіталь Феруму, реакційними центрами молекул. При подібному механізмі адсорбції електронна взаємодія, як правило, має донорно-акцепторний характер, в результаті чого на поверхневі утворюються хімічні комплекси органічних речовин 3 металом. В реакції донора електронів з акцептором електронів відбуваються парні взаємодії між всіма орбіталями донора та акцептора, які підходять один до одного по симетрії. Але головний вклад в загальну енергію вносить взаємодія між граничними орбіталями, а саме ВЗМО донора (основи) та НВМО акцептора (кислоти). При якісному описі кислотно-основної взаємодії необхідно розглядати величини ВЗМО донора та НВМО акцептора. До того ж відомо, що при адсорбції поверхня металу виступає як електрофіл, в той час як інгібітор діє як нуклеофіл. При якісному описі кислотно-основної взаємодії необхідно 
розглядати величини ВЗМО донора та НВМО акцептора. На основі розрахунків електронних зарядів можна прогнозувати, що взаємодія з поверхнею металу буде відбуватися по атомах, де сконцентрована найбільша електрона густина, оскільки на них розташовані найбільш електронегативні заряди. Внаслідок цього саме ці атоми володіють надлишковим зарядом, тобто мають неподілену електронну пару та можуть виступати в якості нуклеофільного агенту. До того ж відомо, що чим більш негативний заряд на гетероатомі, тим краще відбувається передача електронів від донора.

Оскільки хвильова функція розташована, здебільшого, на атомах вуглецю і двох атомах кисню, то адсорбція, ймовірно, буде йти саме через ці центри.

Базуючись на квантово-хімічних розрахунках електронних зарядів та 3 урахуванням розміщення електронної густини ВЗМО, можна прогнозувати, що взаємодія з поверхнею металу відбувається: для бузкового альдегіду по атомах кисню метокси групи із зарядами $-0,282 \mathrm{eB},-0,287 \mathrm{eB}$ та атому кисню гідроксильної групи із зарядом $-0,270 \mathrm{eB}$, а також частково за атомами вуглецю ароматичного ядра. Взаємодія гуанозину з поверхнею металу, ймовірно, буде відбуватись за атомами нітрогену азотної основи гуаніну та найближчому атому кисню (-0,347 еВ). Скупчення електронної густини у молекули ксантозину здебільшого знаходиться на пуриновій основі (атомах азоту 3 зарядами -0,305, -0,089 еВ) та найближчих атомах кисню $(-0,331,-0,368$ еВ) рибози. Тому найвірогідніше адсорбція буде відбуватися саме через ці атоми.

Результати отриманих розрахунків свідчать, що молекули нуклеозидів, вірогідніше за все, будуть мати декілька реакційних центрів, що вказує на відносну міцність адсорбційного зв'язку «метал -інгібітор». Оскільки відомо, що захисна дія інгібітора збільшується, якщо в його молекулі є кілька функціональних груп - центрів адсорбції. Наявність декількох ефективних центрів адсорбції може призвести до утворення поверхневих хелатних комплексів, що забезпечить високий ступінь захисту від корозії. 


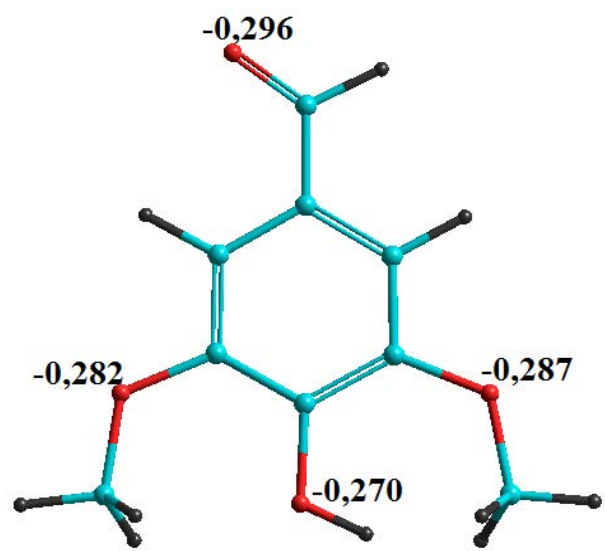

Бузковий адьдегід

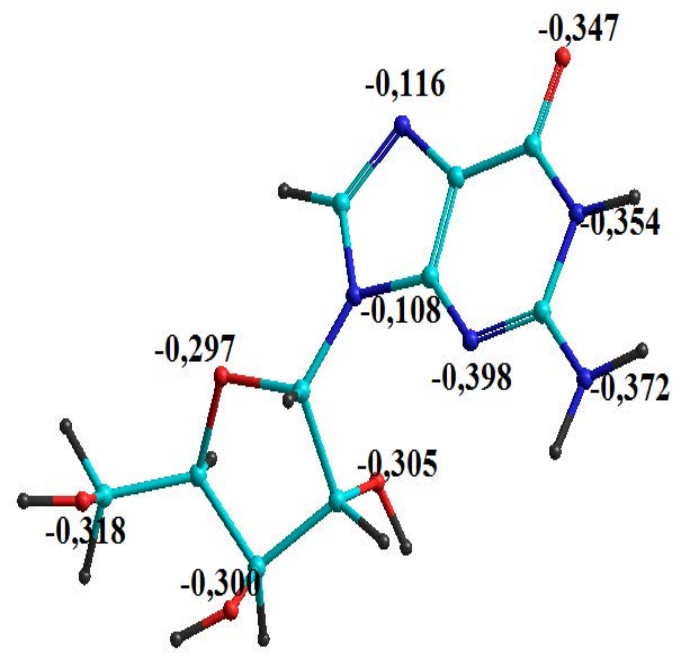

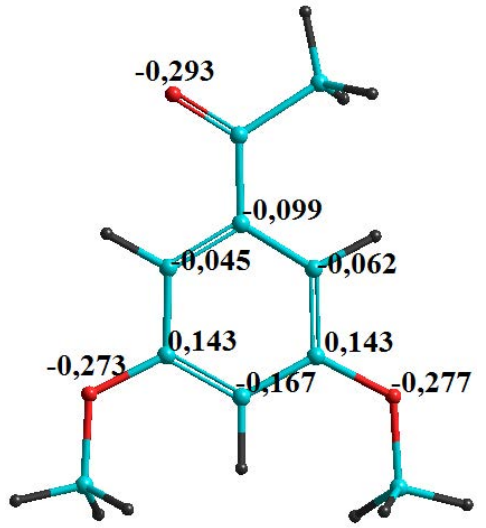

3,5 - диметоксиацетофенон

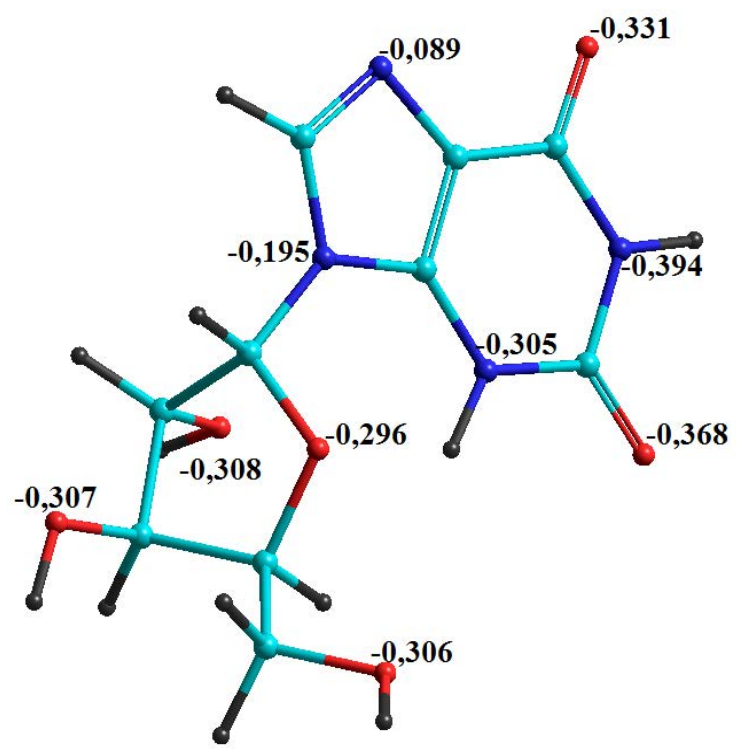

Гуанозин

Ксантозин

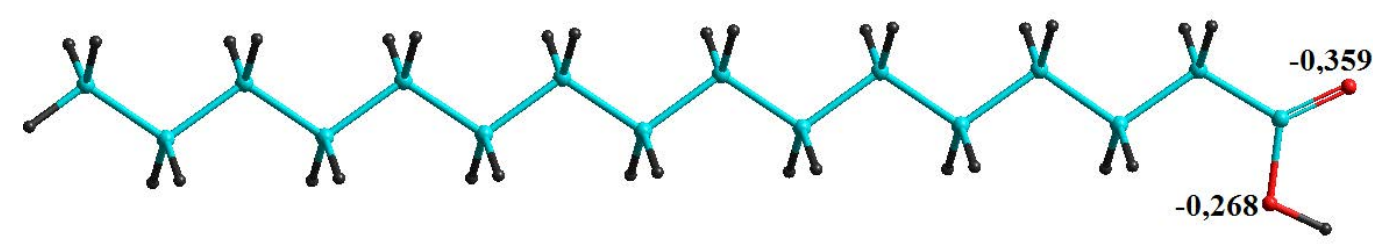

Пальмітінова кислота

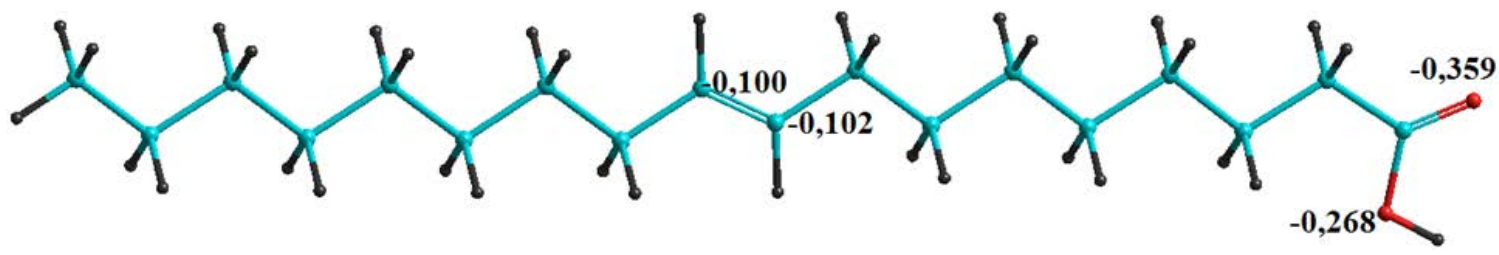

Олеїнова кислота

Рис. 6. Електронні заряди на атомах в молекулах компонентів ізопропанольного екстракту шроту ріпаку 


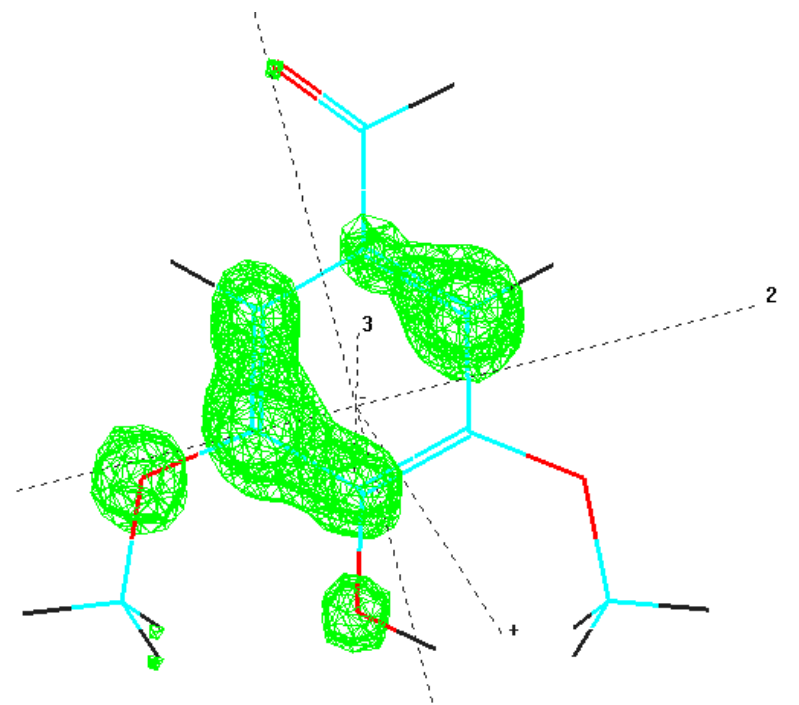

Бузковий альдегід

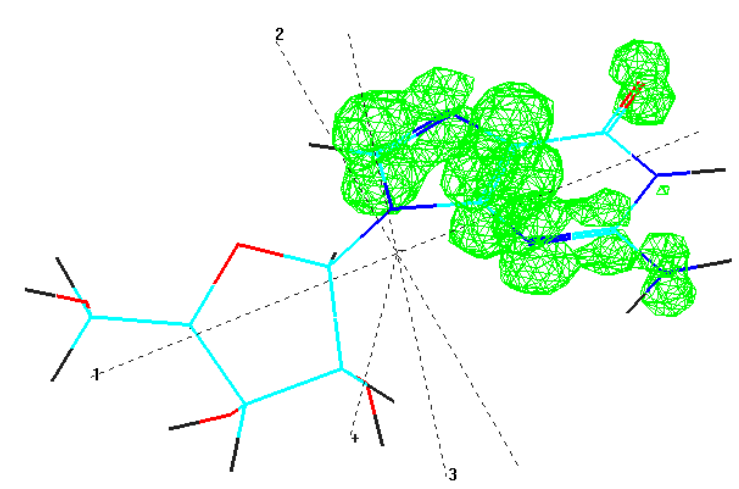

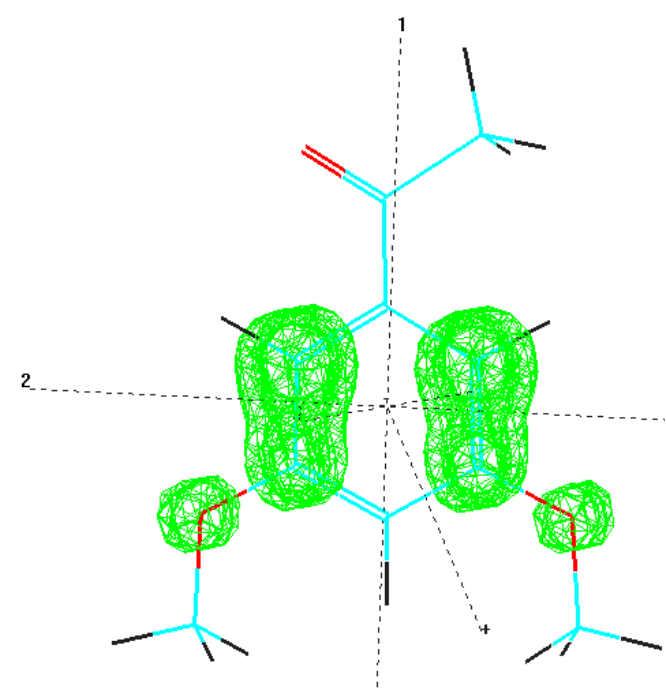

3,5-диметоксиацетофенон

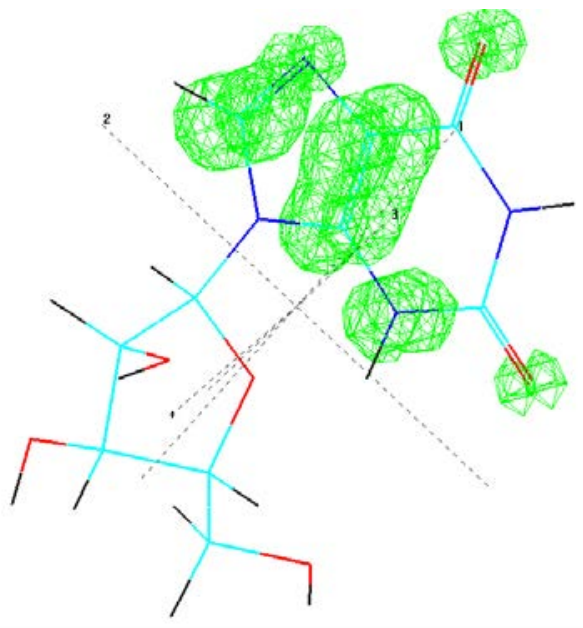

Гуанозин

Ксантозин

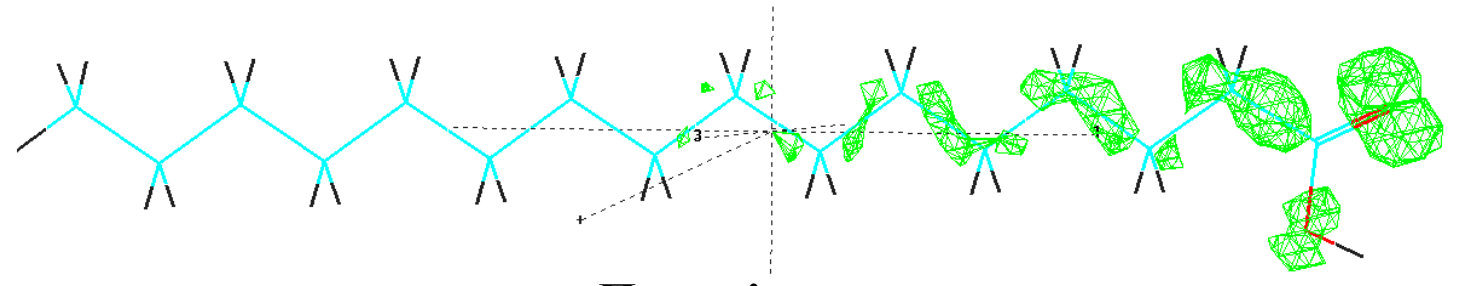

\section{Пальмітинова кислота}

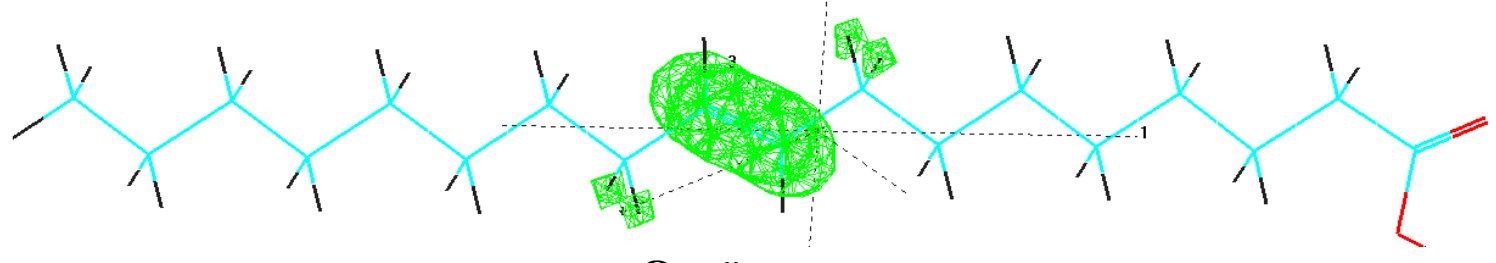

Олеїнова кислота

Рис.7. Оптимізована структура молекул. Щільність вищої зайнятої молекулярної орбіталі (орбітальне значення щільності 0,005). 
В молекулі досліджуваної пальмітинової кислоти активними центрами для хімічної взаємодії $є$ атоми кисню карбоксильної групи -СООН, тому найбільш вірогідна адсорбція відбуватиметься саме через цю групу (рис. 6, 7).В той час, як найбільш електронегативні заряди молекули олеїнової кислоти також знаходяться на атомах кисню, хвильова функція ВЗМО розташована на подвійному вуглецевому зв'язку $\mathrm{C}=\mathrm{C}$ через високу рухливість електронної хмари кратних зв’язків. Ймовірно, адсорбція молекул кислот на поверхні заліза буде проходити саме через ці атоми.Для досліджуваних молекул з урахуванням значення енергії ВЗМО адсорбційна активність збільшується в ряду: пальмітинова кислота $<$ олеїнова кислота $<$ гуанозин $<$ бузковий альдегід $<$ 3',5'диметоксиацетофенон <ксантозин.

Таблиця 3. Квантово-хімічні характеристики молекул речовин, що входять до ізопропанольного екстракту шроту ріпаку

\begin{tabular}{|l|c|c|c|}
\hline \multicolumn{1}{|c|}{ Молекула } & $E_{B 3 м O,} \mathrm{eB}$ & $E_{H в M O}, \mathrm{eB}$ & $\Delta \varepsilon($ в-н $) \mathrm{eB}$ \\
\hline Ксантозин & $-8,973$ & 0,217 & 9,19 \\
\hline Гуанозин & $-9,620$ & 0,461 & 10,08 \\
\hline 3,5 - диметоксиацетофенон & $-9,081$ & 0,211 & 9,292 \\
\hline Бузковий альдегід & $-9,440$ & 0,686 & 8,754 \\
\hline Олеїнова кислота & $-9,883$ & 0,907 & 10,79 \\
\hline Пальмітинова кислота & $-11,183$ & 1,066 & 12,25 \\
\hline
\end{tabular}

Аналіз результатів квантово-хімічних розрахунків показує (табл. 3), що ксантозин та 3,5-диметоксиацетофенон, порівняно 3 іншими компонентами екстракту, є більш адсорбційно активними сполуками, енергія ВЗМО дорівнює $-8,97$ еВ та $-9,08$ еВ.

В таблиці 3 представлені розраховані значення енергії щілини досліджуваних молекул. Відомо, що високі значення цієї енергії молекули ( $\Delta \varepsilon=$ $E(B 3 M O)$ - $E(H B M O))$ свідчать про збільшення електронної стабільності та зменшення реакційної здатності, в той час, як більш низькі параметри цього значення вказують на більшу реакційну здатність, а отже і високу інгібуючу ефективність, оскільки енергія для видалення електрону з останньої зайнятої 
молекулярної орбіталі буде низькою [17-22]. Так, значення енергії щілини для досліджуваних молекул збільшується в ряду: бузковий альдегід < ксантозин < 3,5 - диметоксиацетофенон < Гуанозин $<$ Олеїнова кислота $<$ Пальмітинова кислота.

Отже, перші речовини ряду вірогідно є більш сильними інгібіторами. Розраховані значення абсолютної жорсткості $\chi$ aбсолютної електронегативності $\eta$, абсолютної м'якості $\sigma$, сили взаємодії молекул 3 поверхнею $\alpha-\mathrm{Fe} \Delta \mathrm{N}$, зміни енергії при взаємодії та абсолютної електрофільності для досліджуваних молекул представлені в таблиці 4.

Отримані результати розрахунку електрофільності, що вважають індексом, який визначає схильність приймати електрони, представлено в таблиці 4. Чим вище значення електрофільності, тим вище здатність молекули приймати електрони. Таким чином, органічні сполуки 3 кращими нукліофільними властивостями характеризується низьким значенням $\mu$ та $\omega$; в той час як хороший електрофіл характеризується високим значенням $\mu$ та $\omega$. Отримані результати свідчать, що всі розглянуті молекули мають низькі значення електрофільності, а отже виступають в якості нукліофілів. При розгляданні процесу адсорбції з точки зору кислото-основної взаємодії важливим кількісними параметрами, що характеризують цей процес, є ступінь переносу заряду $\Delta \mathrm{N}$, тобто сила взаємодії молекул кислоти - акцептора (поверхня заліза) і основи - донора (досліджувані речовини парової фази екстракту шроту ріпаку) та величина зміни енергії, що супроводжують утворення комплексу.

Ступінь переносу заряду $\Delta N_{F e}$ найбільша у ксантозину і 3,5 диметоксиацетофенон (табл. 4). Значення $\Delta N<3,6$ [18] означає, що молекули мають здатність до передачі заряду до поверхні металу. При цьому гальмування процесу корозії збільшується за рахунок підвищення електрон-донорної здатності молекул до поверхні металу, що узгоджується 3 дослідженнями Lukovitsma інш. Розраховані від'ємні значення зміни енергії $(\Delta E)$, пов'язані 3 
процесом переносу заряду, вказують на екзотермічність процесу, що сприяє процесу передачі заряду з органічних молекул до поверхні сталі.

Таблиця 4. Абсолютна електронегативність $(\chi)$, абсолютна жорсткість $(\eta)$, абсолютна м’якість $(\mathrm{S})$ ступінь перенесення заряду $(\Delta \mathrm{N})$, зміна енергії $(\Delta \mathrm{E})$ та абсолютна електрофільність ( $\omega)$ молекул ізопропанольного екстракту шроту ріпаку

\begin{tabular}{|l|c|c|c|c|c|c|c|c|}
\hline \multicolumn{1}{|c|}{ Молекула } & $\mathrm{I}$ & $\mathrm{A}$ & $\chi,(\mathrm{eV})$ & $\eta,(\mathrm{eV})$ & $\mathrm{S},(\mathrm{eV})$ & $\Delta \mathrm{N}$ & $\Delta \mathrm{E}$ & $\omega$ \\
\hline Ксантозин & 8,973 & $-0,217$ & 4,38 & 4,6 & 0,217 & 0,285 & $-0,0106$ & 1,09 \\
\hline Гуанозин & 9,620 & $-0,461$ & 4,58 & 5,04 & 0,198 & 0,240 & $-0,0028$ & 1,14 \\
\hline $\begin{array}{l}3,5 \text { - } \\
\text { диметоксиацетоф } \\
\text { енон }\end{array}$ & 9,081 & $-0,211$ & 4,44 & 4,65 & 0,215 & 0,276 & $-0,0076$ & 1,10 \\
\hline $\begin{array}{l}\text { Бузковий } \\
\text { альдегід }\end{array}$ & 9,440 & $-0,686$ & 5,06 & 4,37 & 0,228 & 0,221 & $-0,0033$ & 1,26 \\
\hline Олеїнова кислота & 9,883 & $-0,907$ & 4,5 & 5,4 & 0,185 & 0,232 & 0,0051 & 1,12 \\
\hline $\begin{array}{l}\text { Пальмітинова } \\
\text { кислота }\end{array}$ & 11,183 & $-1,066$ & 5,1 & 6,1 & 0,163 & 0,158 & 0,0023 & 1,26 \\
\hline
\end{tabular}

Отримані результати свідчать, щоадсорбція досліджуваних органічних сполук на поверхні сталі, вірогідно, обумовлена наявністю атомів кисню та $\pi$ електронів $\mathrm{C}=\mathrm{C}$ зв'язку. Вклад в інгібуючу ефективність вносять як основні сполуки рослинного екстракту, так сполуки, що утворюються.Із компонентів рослинного екстракту максимальний вклад в інгібуючу ефективність вносять альдегіди та кетони та продути їх поліконденсації.

Таким чином, узагальнюючи результати масометричних, електрохімічних та спектральних досліджень, можна зробити висновок, що ймовірно, проміжні продукти поліконденсації беруть участь в полімерних перетвореннях, що призводять до утворення захисної плівки.

\section{3. Висновки}


Дослідження складу екстракту шроту ріпаку при інтенсифікації екстракції дією ультразвуку показало, що в ньому міститься близько 20 індивідуальних компонентів, серед яких домінують альдегіди і кетони. Серед основних компонентів відзначено високий вміст бузкового альдегіду та 3,5диметоксиацетофенон. Отримані дані істотно доповнюють і розширюють дані досліджень хімічного складу складових промислових відходів переробки ріпаку, що дозволяє розширити сировинну базу для отримання екологічно безпечних інгібіторів корозії.

Встановлено, що формування захисної плівки відбувається за 40-48 годин від початку експонування металу в інгібованому водному розчині і складає високу (до $60,0 \%$ ) протикорозійну ефективність. Досліджуваний рослинний екстракт гальмує переважно катодну реакцію корозійного процесу.

\section{Література}

[1] Розенфельд И. Л.: Ингибиторы коррозии. 1977, Химия, 350 с.

[2] Badiea A.M., Mohana K.N..: J.of Mat. Engin. and Perform, 2009, 18, 9, 1264.

[3] Sathiyanathan R. A, Maruthamuthu, L. S. Selvanayagam, M. Mohanan.: Indian Journal of Chemical Technology, 2005, 12, 3, 356.

[4] Radojčića I., Berkovića K., Kovač S., Vorkapić-Furač J..: Corrosion Science. 2008, 50, 5, 1498.

[5] Badiea A.M., Mohana K.N.: J.of Mat. Engin. and Perform, 2009, 18, 9. 1264.

[6] Rani B. E., J. Basu B. B.: International Journal of Corrosion, 2011, 2012.

[7] Pradityana A.: International Journal of Corrosion, 2016.

[8] Wang P. et al.: Corrosion Science, 2014, 80, 366.

[9] Abd-El-Khalek D. E.: Portugaliae Electrochimica Acta, 2012, 30, 4, 247.

[10] Kumar B. P., Mohana K. N. // ISRN Corrosion, 2013, 2013.

[11] Rahal C., Masmoudi M., Abdelhedi R.: Journal of Electroanalytical Chemistry, 2016, 769, 53.

[12]Kovacevic N., Kokalj A.: Corros. Sci., 2011, 53, 3, 909.

[13] Parr R., Pearson R.: J. Am. Chem. Soc., 1983, 105, 7512.

[14] Parr R., Donnelly R., Lewy M., Palke W.: J. Chem. Phys., 1978, 68, 3801.

[15] Pearson R.: Proc. Nats. Acad. Sci. USA, 1986, 83, 8440.

[16] Chattaraj P., Sarkar R., Roy D.: Chem. Rev., 2006, 106, 2065.

[17] Parr R., von Szentpaly L., Liu S.: J. Am. Chem. Soc. 1999, 121, 1922.

[18] Kaya S., Kaya C.: Comput. Theor. Chem., 2015, 1052, 42.

[19] Koopmans T.: Physica, 1934, 1, 104.

[20] Gece G.: Corros. Sci., 2008, 50, 11, 2981.

[21] HyperChemTM, Hypercube, Inc., 1994 


\title{
Marking of titanium passive film breakdowns as a function of their appearance time and to increase the contrast of SEM images
}

\author{
Buket O.I., Chernysh D.M., Leonova O.I. \\ National Technical University of Ukraine "Igor Sikorsky Kyiv \\ PolytechnicInstitute”,Peremogy pr.,37,03056, Kyiv, Ukraine
}

The problem of determining the breakdown location of a passive titanium film is very difficult for SEM microscopy. The reason is that there are no significant differences in the interaction of the electron in SEM with both titanium dioxide in the passive film and with metatitanic acid, which fills new places of breakdowns. It has been shown that metatitanic acid can be marked more contrast with heavy metal ions due to the formation of insoluble metatitanates. The breakdowns of the titanium passive film are marked in such a way that the contrast chemical composition of the breakdown places depends on breakdowns appearance time due to the consistent change of the marker-ions composition in the experimental solution over time.

\section{Introduction}

Investigation of the properties of passive oxide layers on the surface of metals and alloys often involves the obtaining SEM images. One of the goals of obtaining such images is to study the size and location of breakdowns of the passive oxide film. At the same time, the use of SEM is associated with some difficulties, which are related to the features of its physical principles and using methods.

The main difficulty is the continuous preparation of SEM for investigations with a limited area of samples that SEM investigates at a time. At the same time, the higher the maximum possible increase in the image, the longer it takes to create an appropriate vacuum in the microscope. Consequently, the study of a large amount of metal samples can take an unacceptably long time because of the relatively long preparation of SEM for the study of each new batch of samples (or each single sample, the size of which is large). 
The second difficulty is characteristic for pure titanium samples and is associated with the absence of any contrast in SEM images between the passive film of titanium dioxide and the breakdown places, which are almost immediately delayed by metatitanic acid. The interaction with the electron flux is practically identical for metatitanic acid and for titanium dioxide because their chemical composition is identical for the SEM and even the condition of the electron shells of the corresponding atoms does not differ significantly. Consequently, the presence, location, and form of breakdowns can sometimes be guessed only by the contrast of the areas irradiated by the electron areas of the protrusions and valleys in comparison with the "shadow" behind them.

This work is aimed at to solving the problem of increasing the contrast of the breakdown places of the passive titanium film, when the breakdowns are investigated using SEM. At the same time, it is also necessary to solve the problem of contrast marking of breakdowns, which are obtained on one sample at different times. Including breakdowns, which are obtained with a consistent change in the electrochemical surface treatment of a titanium sample. Solving these problems will help increase the amount of information that can be obtained from one sample. It will also be possible to reduce significantly the number of SEM experiments, which is especially important for extensive studies of the breakdown processes development or pitting of a passive film over time.

\section{Theoretical justification}

The ability of heavy metal ions to emit intensively secondary electrons at SEM in comparison with the ions of light metals and other lighter elements is well known. If the determined surface area, which is covered with titanium dioxide, is attached with heavy metal ions, then such places in SEM images will look bright and contrast. Based on the known properties of titanium, it can be assumed that this metal in the places of passive film breakdowns should react actively with the water-oxygen medium. It is generally known that the pores in the oxide film on aluminum are first filled with gel-like aluminum hydroxide. Therefore, it is known that the first product of the interaction of titanium with water should be metatitanic acid, which is slightly 
soluble and exists as a gel. Solid polymeric acids are capable of ion exchange with heavy metal salts [1] and often form insoluble compounds. The tendency of metatitanic acid to form insoluble salts with lead ions is known.

It is generally known that, other equal conditions, ions of heavy metals with a large charge (+3) are inclined to form less soluble compounds with solid polymeric acids than ions with a smaller charge. Though it is possible that after the interaction of $\mathrm{Fe}^{3+}$ ions with metatitanic acid, this acid will be incapable to interact with $\mathrm{Pb}^{2+}$ ions. And only newly formed metatitanic acid will be able to exchange hydrogen ions for $\mathrm{Pb}^{2+}$ ions from the solution.

Thus, it is possible to mark gelled metatitanic acid with various heavy metal ions if these ions are introduced in order to increase the solubility equilibrium of their salts. It is possible that the kinetics of ion exchange in this case will allow to ignore the differences in solubility of salts. However, each subsequent ion will be unable to displace the precursor from the metatitanate due to the slowing down of the corresponding stages of the replacement reaction.

In principle, this can be prevented by the unexpectedly large ion-exchange capacity of the titanium dioxide surface outside the breakdown places. This ability exists in some non-stoichiometric oxides [1].

It is known that gel-like corrosion products are capable of dehydration and recrystallization. For example, for the corrosion of iron and steel, it was shown that the electrochemical activity of iron hydroxides is responsible for the significant discrepancy between the results of gravimetry and measurement of the polarization resistance [2]. Obviously, this discrepancy is due to the ability of these compounds to oxidation-reduction reactions. These reactions would not be possible if there was no ability to ion exchange with the solution. Since it has been found that the electrochemical activity of iron corrosion products decreases with time [3], similar behavior can be expected from metatitanic acid.

Thus, if metatitanic acid crystallizes into titanium dioxide too quickly, this can prevent marking. If the time of phase transformations is optimal, recrystallization of metatitanates of heavy metals can promote reliable fixation of marker ions. After this, 
this metatitanate will not be able to interact with the following solutions. Therefore, the chemical analysis of specific heavy metals in metatitanates on the surface will determine the time of their appearance from the time of contact of the titanium sample with a solution of a certain salt. Only an experiment can give further refinement.

\section{Method}

Samples of pure titanium of grade VT1-00 in the form of a foil $0.1 \mathrm{~mm}$ thick were made in the size $40 \times 4 \mathrm{~mm}$. Electrochemical surface treatment was carried out in an aqueous solution of $6 \mathrm{M}$ lithium chloride by an impulse potentiostat. A standard three-electrode polarization scheme with a platinum auxiliary electrode was used, which is separated from the working electrode by a porous glass partition and a silver chloride reference electrode. The electrolyte for the silver chloride electrode was a 6 $\mathrm{M}$ solution of lithium chloride, in which the potential of the reference electrode was $0.16 \mathrm{~V}$. Before the polarization, the titanium electrodes were handled and degreased with a paste of crystalline soda and distilled water. The polarization mode of the electrodes consisted of alternating anode (up to $+4.0 \mathrm{~V}$ ) and cathode $(-0.05 \mathrm{~V})$ impulses duration $1 \cdot 10^{-5} \mathrm{~s}$ for 2 seconds.

After electrochemical treatment of titanium electrodes, they were removed from a glass three-electrode cell and washed with a solution of heavy metal salts in distilled water. The first was an aqueous solution of iron (III) chloride with a concentration of $1 \cdot 10^{-5} \mathrm{M}$, and the second one was an aqueous solution of lead (II) nitrate with a concentration of $1 \cdot 10^{-3} \mathrm{M}$ in a complex with polyhexamethyleneguanidine (PGMG) concentration $1 \cdot 10^{-2} \mathrm{M}$. Complex with PGMG was used because of the assumption about the need to reduce the activity of lead ions in the exchange reactions.

Titanium samples were contacted with a solution of heavy metal salts not more than 15 seconds. After this, preparations were made for SEM or the following electrochemical treatment, followed by washing with a solution of lead salt. Preparation for SEM was carried out by washing titanium electrodes in 50-ml noncondensing distilled water for two days. In the first day, water was changed 20 times, and on the second day three times. Samples were dried in air without heating for 24 
hours and sent to SEM.

\section{Results}

Metatitanic acid showed high ability to sorb ions of even one-one valence electrolyte like lithium chloride. After drying, the breakdowns can be identified by tree-like crystals of salts, which crystallize and contain chlorides shown at point 2 in Fig. 1. Washing with distilled water for half an hour does not eliminate the electrolyte from the breakdown places. The content of the elements at point 2 is averaged for Fig. 1(b) and Fig. 1(c) and confirms that this object is a chloride crystal (probably lithium). The base of the crystal at point 1 in Fig. 1(b) and the recess at point 1 in Fig. 1(c) contains few chlorides.

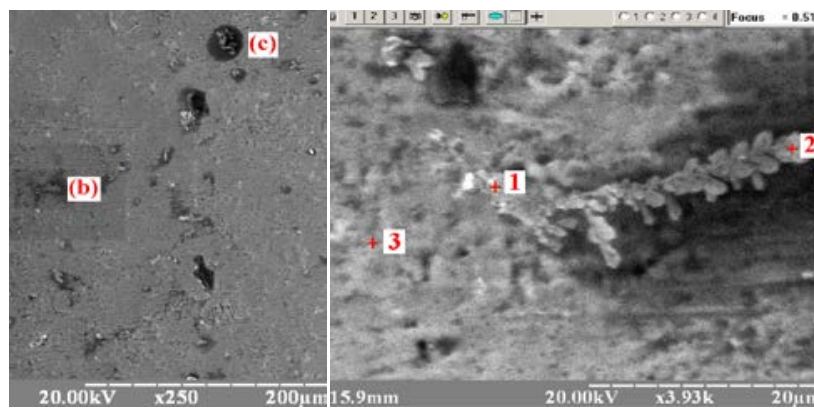

(a)

(b)

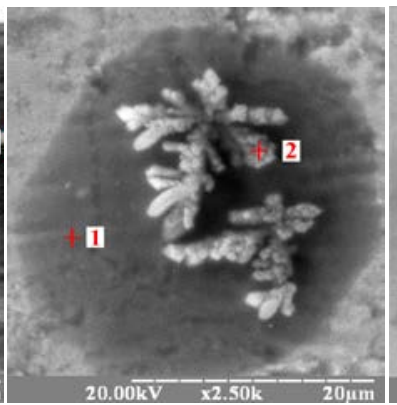

(c)

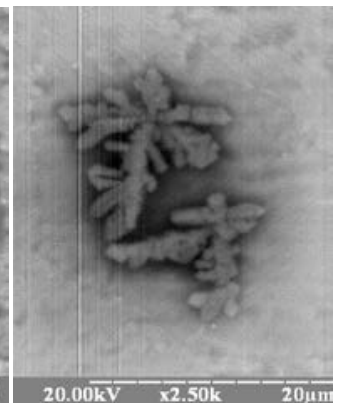

(d)

Fig. 1. The surface of titanium after electrochemical treatment in $6 \mathrm{M} \mathrm{LiCl}$. SEM images in the secondary (a, b, c) and reflected (d) electrons with an analysis of the chemical composition at the points:

$$
\text { 1. } 99.88 \% \mathrm{Ti}+0.12 \% \mathrm{Cl} ; 2.94 \% \mathrm{Ti}+6 \% \mathrm{Cl} ; 3.100 \% \mathrm{Ti} \text {. }
$$

It is probably a metatitanic acid from which the ions of the electrolyte diffused into the crystallization zone. The remaining surface of the titanium is completely free of chlorides, as indicated by the chemical analysis at point 3 in Fig. 1. The result obtained suggested that it is possible to treat metatitanic acid with heavy metal salts after more thorough washing, as described in the method. The measured content of titanium in the surface oxide layers is $100 \%$ because SEM does not define light elements.

The points 1 and 2 in Fig. 2 contrasts stand out against the background of the rest of the titanium surface after treatment with salts of iron and lead. 


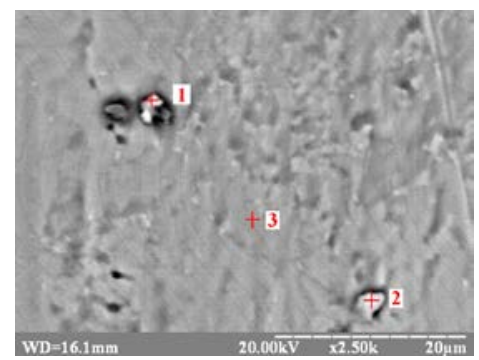

(a)

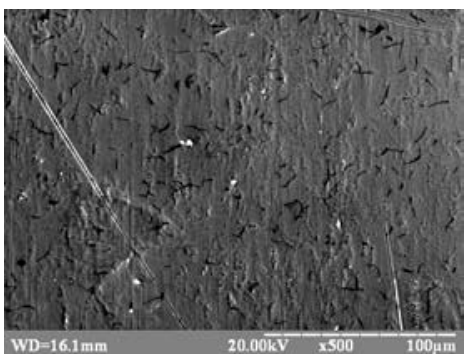

(b)

Fig. 2. The surface of titanium after electrochemical treatment and successive immersion in solutions of iron salts and lead (II) complex with PGMG. SEM images

in the reflected (a) and secondary (b) electrons with the analysis of chemical composition at the points: $1.49 .90 \% \mathrm{Ti}$ (IV) $+49.99 \% \mathrm{Fe}$ (II) $+0.11 \% \mathrm{~Pb}$ (IV);

$2.70 .29 \% \mathrm{Ti}(\mathrm{IV})+29.63 \% \mathrm{Fe}(\mathrm{II})+0.08 \% \mathrm{~Pb}(\mathrm{IV}) ; 3.100 \% \mathrm{Ti}(\mathrm{IV})$.

Moreover, the content of lead in them does not exceed the measurement error precisely because metatitanic acid has already reacted with iron (III) salts. The chemical analysis at these points shows the product of the $\mathrm{Fe}^{2+}$ ions exchange with metatitanic acid. Probably $\mathrm{Fe}^{3+}$ ions were reduced by titanium to $\mathrm{Fe}^{2+}$ ions, in the same way as metallic iron is oxidized by corrosion products $[2,3]$. The valence of lead (IV) in Fig. 2 can be considered wrong due to extremely low concentration. The rest of the titanium surface does not associate heavy metal ions, seen from the chemical analysis at point 3 (Fig. 2). The black strokes of a complex shape in Fig. 3(a) have a chemical composition of $100 \%$ Ti according to the SEM data. They are probably the remnants of polymer molecules PGMG, which are almost completely transparent in reflected electrons and almost do not form secondary electrons.

One should also pay attention to the smaller size of the degeneration zones of the passive film from titanium dioxide to metatitanic acid in Fig. 2 in comparison with Fig. 1. This is probably due to the presence of lithium chloride in the places of breakdowns in Fig. 1. This electrolyte is well known for its hygroscopicity. The presence of lithium chloride and moisture for a long time in the places of breakdowns caused more extensive damage to the surface of titanium during air drying in comparison with the experimental conditions for Fig. 2, where the electrolyte was eliminated by a longer and thorough rinsing. 


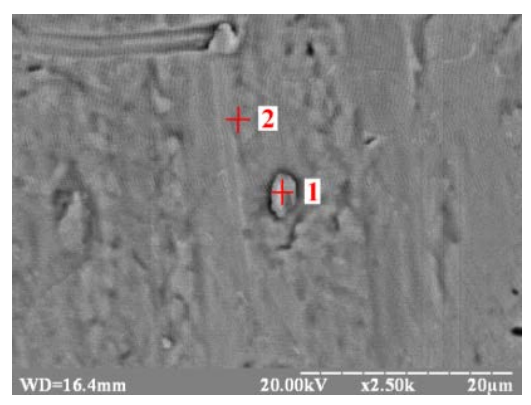

Fig. 3. The surface of titanium after electrochemical treatment and immersion in a solution of lead (II) complex with PGMG. SEM images with the analysis of the chemical composition at the points: $1.94 .12 \% \mathrm{Ti}$ (IV) $+5.88 \% \mathrm{~Pb}$ (II); $2.100 \% \mathrm{Ti}$ (IV).

If the titanium electrode after electrochemical treatment was immersed in a solution of lead (II) salt with PGMG, then the passive film breakdown places were bound by lead ions. This is indicated by the chemical analysis at point 1 in Fig. 3 .

If the titanium electrode after electrochemical treatment is rinsed for 5 hours in distilled water, the result of the interaction with iron and lead salts reveals a substantially lower concentration of heavy metal ions at the breakdown points (Fig. 4). This indicates the course of aging and dehydration of metatitanic acid, during which this acid gradually loses its ability to ion exchange. Such a phenomenon will contribute to an increase in the irreversibility of fixing heavy metal ions in the breakdown areas, if ion exchange is carried out immediately after the formation of the breakdown.

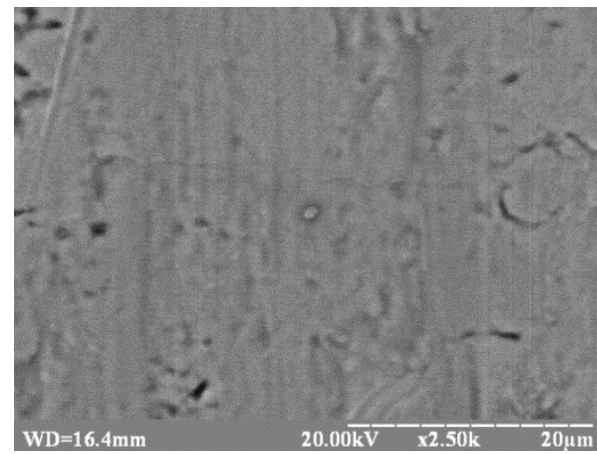

(a)

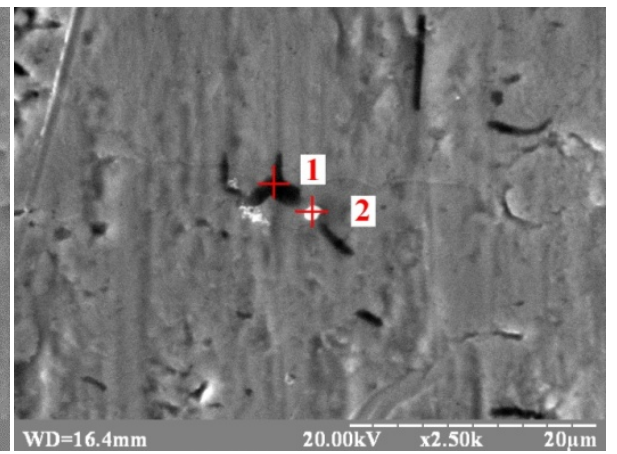

(b)

Fig. 4. The surface of titanium after electrochemical treatment, washing for 5 hours and immersion in a solution of an iron salt and lead (II) complex with PGMG. SEM images in the reflected (a) and secondary (b) electrons with an analysis of the chemical composition at the points:

1. $100 \%$ Ti (IV); 2. 89.18\% Ti (IV) + 9.86\% Fe (II) + 0.96\% Pb (IV). 


\section{Discussion and Conclusion}

This work shows the possibility of contrast (for SEM) marking of breakdowns of a passive titanium film in such a way that it is possible to determine the time interval for the appearance of specific breakdowns. In this case, the breakdowns can be caused either by the development of the current corrosion process over time, or caused by a change in the corrosion conditions over time. It is established that the places of breakdowns of the passive titanium film are tightened with metatitanic acid. This gelatinous acid loses its ability for ion exchange for several hours and therefore it is capable of fixing heavy metal ions irreversibly if interaction with them occurred immediately after the breakdown. Heavy metal ions contrast in SEM images in both reflected and secondary electrons against the background of titanium oxygen compounds. It is possible to carry out experiments in such a way so as to pump the solution through a three-electrode cell to conduct polarization of the electrodes. In this case, the background solution can be periodically replaced with a solution with a certain marker ion. Thus, it is possible to increase the informativity of a single titanium sample and to reduce the number of SEM preparations for work, which is especially important in the study of many samples with a strong increase in a deep vacuum.

\section{Acknowledgment}

The authors would like to thank the staff of the Physical Engineering Faculty of the National Technical University of Ukraine "Igor Sikorsky Kyiv Polytechnic Institute" for the opportunity to obtain SEM images.

\section{References}

[1] V. Chviruk, A. Kushmiruk. Behavior of manganese dioxide electrodes in system containing a solid protonic electrolyte // Russian Journal of Electrochemistry, 2000, Volume 36, Issue 5, pp. 539-544.

[2] G. Vasyliev, A. Brovchenko, Y. Herasymenko, Comparative assessment of corrosion behaviour of mild steels 3, 20 and 08KP in tap water, Chem. Chem. Technol. 7 (2013) 477-482.

[3] G. Vasyliev, Polarization Resistance Measurement in Tap Water: The Influence of Rust Electrochemical Activity, J. Mater. Eng. Perform. (2017). doi:10.1007/s11665-017-2813-5. 


\title{
Adsorption model of organic compounds on metals, based on complex formation conception with charge transfer, and its application for corrosion inhibitors selection
}

\author{
Pogrebova I.S. \\ National Technical University of Ukraine «Igor Sikorsky Kyiv Polytechnic \\ Institute»,37 Peremohy Av., 03056 Kyiv, Ukraine
}

The adsorption model of organic compounds on metals is proposed based on the representations about the formation of charge transfer complexes and their stabilization by means of charge and electronic interaction. The series of equations were obtained that establish the relations between the activation energies of adsorption processes, the conditions for the adsorption equilibrium on the metal and the physical and chemical properties of the reagents. The expediency of using the proposed model in the interpretation of various types of adsorption occurring on metals is shown. It has been established that in predicting adsorption, in addition to such fundamental properties as the potentials of ionization of organic compounds and the work of the electron output from the metal, it is necessary to take into account the electrical nature of substances and the $\varphi$-potential of the metal in the Antropov scale. The prospect of creating effective corrosion inhibitors of metals with the proposed model is shown taking into account the ways of the influence of adsorbed compounds on the kinetics of corrosion processes.

Keywords: adsorption, organic compounds, ionization potentials, metal potential, charge transfer

\section{Модель адсорбції органічних сполук на металах, що основана на концепції утворення комплексів 3 переносом заряду, та її використання при підборі інгібіторів корозії}

\author{
Погребова I.C.
}

Національний технічний університет Украӥни «Київський політехнічний інститут імені Ігоря Сікорського», Київ, пр.Перемоги, 37, корп.№9, 01056

Захисна дія органічних інгібіторів корозії обумовлена їх адсорбцією на поверхні кородуючого металу і впливом адсорбованих частинок на парціальні реакції корозійного процесу [1-7]. У зв'язку з цим при підборі адсорбційних 
інгібіторів корозії особливого значення набувають наукові підходи, які дають змогу прогнозувати адсорбцію і враховувати вплив на ї протікання різних фізико-хімічних властивостей органічних сполук та металів.

Серед наукових підходів, які використовують нині при прогнозуванні

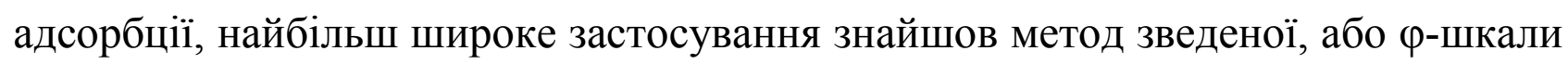
потенціалів Л.І. Антропова [8-9], заснований на врахуванні стаціонарного потенціалу кородуючого металу $\left(\mathrm{E}_{\mathrm{c}}\right)$ та його нульової точки $\left(\mathrm{E}_{\mathrm{N}}\right)$. У зведеній шкалі $\varphi$-потенціал електрода, який визначається як $\varphi_{\mathrm{c}}=\mathrm{E}_{\mathrm{c}}-\mathrm{E}_{\mathrm{N}}, \epsilon$ мірою заряду його поверхні відносно до даного розчину. Це дозволяє прогнозувати електростатичну взаємодію органічних сполук 3 поверхнею кородуючого металу, враховувати їхні електричні властивості і вести раціональний підбір адсорбційних інгібіторів корозії для кожного конкретного корозійного процесу. Але поряд із електростатичною на поверхні металів протікає специфічна адсорбція, яка супроводжується частковим або повним переносом заряду (частіше від органічної сполуки до металу) та утворенням орбітальних (ковалентних або координаційних) зв'язків між адсорбатом та адсорбентом. Таке припущення підтверджується чисельними корелятивними залежностями між захисною дією інгібіторів корозії металів та їх різноманітними фізикохімічними властивостями $[1,2,6]$, найбільше використання серед яких знайшов перший потенціал іонізації органічних сполук (I), який є однією із основних їх фундаментальних характеристик.

Так, ще у роботах Н. Хаккермана були встановлені лінійні залежності між інгібуючою дією та потенціалами іонізації різних класів органічних сполук, що виявилось доцільним при розробці органічних інгібіторів корозії металів. Пізніше у роботах Е.А. Нечаєва [12-14] було показано, що на залежностях параметрів адсорбції від потенціалів іонізації органічних сполук часто спостерігаються максимуми (названі авторами «резонансними потенціалами», $\mathrm{I}_{\mathrm{p}}$ ), що свідчить про вибіркову адсорбцію на поверхні металів. Застосування резонансного потенціалу як критерію адсорбційної активності металів виявилось корисним при підборі органічних добавок до електролітів 
знежирення та електроосадження металів, виборі деяких інгібіторів корозії металів та ін. Але використання лише одного $\mathrm{I}_{\mathrm{p}}$-потенціалу не дозволяє враховувати потенціал кородуючого металу, природу агресивного середовища, електричну природу органічних сполук, що адсорбуються, будову подвійного електричного шару на межі розподілу метал-електроліт - фактори, які відіграють значну роль при інгібуванні корозії металів.

У дійсній роботі розглянута модель адсорбції органічних сполук на металах, основана на уявленнях про утворення комплексів 3 переносом заряду та їх стабілізації за рахунок зарядної (електростатичної) та електронної (орбітальної) взаємодії між адсорбатом та адсорбентом. Показано необхідність комплексного використання при прогнозуванні адсорбції потенціалу іонізації та зарядного числа органічних сполук, роботи виходу електрона та $\varphi$-потенціала металу. Встановлена користь застосування цієї моделі, та врахування шляхів впливу адсорбційних частинок на реакції корозійного процесу, при розробці ефективних інгібіторів корозії металів у водних агресивних середовищах.

1. Модель адсорбції органічних сполук на металах, основана на концепції утворення комплексів 3 переносом заряду

В рамках адсорбційної моделі, основаної на уявленнях про утворення поверхневих комплексів 3 частковим переносом заряду [15-20], процес адсорбції молекули ПАР (SAS) із розчинника (L) на металі (M) може бути представлений обмінною реакцією:

$$
?_{A} \cdot S A S \cdot L+?_{B} \cdot L \cdot[M] \rightarrow ?_{C} \cdot S A S \cdot[M]+?_{D} L \cdot L,
$$

а зміна стандартної вільної енергії адсорбції $\operatorname{SAS}$ на металі $\left(-\Delta G_{A}^{0}\right)-$ рівнянням:

$$
-\Delta G_{A}^{0}=?_{A} \cdot \Delta G_{S A S-L}^{0}+?_{B} \cdot \Delta G_{L-M}^{0}-?_{C} \cdot \Delta G_{S A S-M}^{0},
$$

де $\Delta G_{S A S-L}^{0}, \Delta G_{L-M}^{0}, \Delta G_{S A S-M}^{0}-$ відповідно стандартні енергії утворення комплексів SAS-L, L-M, SAS-M, а $?_{A}$, ? ${ }_{B}, ?_{C}, ?_{D}-$ стехіометричні коефіцієнти, які характеризують повноту їх утворення.

Стандартна вільна енергія утворення поверхневого комплексу у рамках такого підходу може бути визначена із співвідношення: 


$$
-\Delta G_{S A S-M}^{0}=\Delta \vec{G}_{*}^{0}-K_{c h} \cdot \Delta G_{S A S-M(c h)}^{0}-K_{S p} \cdot \Delta G_{S A S-M(s p)}^{0},
$$

в якому $\Delta \vec{G}_{*}^{0}-$ стандартна енергія переносу заряду (електрону) від донора (частіше SAS) до акцептора (частіше M); $\Delta G_{S A S-M(c h)}^{0}, \Delta G_{S A S-M(s p)}^{0}$ - стандартні енергії стабілізації цих комплексів відповідно за рахунок електростатичної (зарядної) та специфічної (орбітальної або ковалентної) взаємодії, а $K_{c h}, K_{s p}-$ коефіцієнти, які враховують їхню частку в адсорбційному процесі.

У більш загальному випадку 3 використанням такого підходу у ці рівняння повинні бути введені додаткові складові, які враховують енергії взаємодії між молекулами SAS та розчинником $\left(\Delta G_{S A S-L}^{0}\right)$ i молекулами розчинника та металом $\left(\Delta G_{L-M}^{0}\right)$. Введення цих складових у рівняння (2) дозволяє враховувати внесок у протікання загального адсорбційного процесу фізичної адсорбції, обумовленої виштовхуванням молекул води 3 поверхні металу адсорбованими сполуками.

Отже, стандартна вільна енергія адсорбції органічної сполуки (SAS) на металі (М) формально може бути представлена рівнянням:

$$
\begin{aligned}
& -\Delta G_{A}^{0}=\gamma_{A} \cdot \Delta G_{S A S-L}^{0}+Y_{B} \cdot \Delta G_{L-M}^{0}+\Upsilon_{C} \cdot \Delta \vec{G}_{*}^{0}-\gamma_{C} K_{c h} \cdot \Delta G_{S A S-M(c h)}^{0}- \\
& -\gamma_{C} \cdot K_{s p} \cdot \Delta G_{S A S-M(s p)}^{0},
\end{aligned}
$$

яке враховує основні види адсорбції органічних сполук на металах $[5,20]$ : фізичну, обумовлену електростатичною взаємодією між адсорбатом i адсорбентом та виштовхуванням молекул води молекулами SAS 3 поверхні металу (1, 2, 4 члени правої частини рівняння (4)); специфічну першого роду, яка визначається в значній мірі зарядною взаємодією між адсорбатом та адсорбентом (3 і 4 члени частини рівняння (4)); специфічну другого роду, обумовлену насамперед хімічною природою реагентів (3 і 5 члени правої частини цього рівняння).

Із енергетичного циклу, який відображає утворення на поверхні металу адсорбційного комплексу (рис. 1), витікає, що при $\mathrm{E}=\mathrm{E}_{\mathrm{N}}$ стандартна енергія 
переносу заряду $\Delta \vec{G}_{*}^{0}$ від незарядженої молекули SAS до металу визначається наступними рівняннями:

$$
\begin{gathered}
\Delta \vec{G}_{*}^{0}=\alpha_{1} \cdot\left(I_{(L)}-\omega_{(L)}^{\overline{\mathrm{e}}}\right), \\
\Delta \vec{G}_{*}^{0}=\alpha_{1} \cdot\left(I_{(L)}-A_{\Gamma(\mathrm{P})}^{\bar{e}}+A_{\Gamma(P)}^{\bar{e}}+V_{M / L}^{0} \cdot F-A_{\Gamma(X)}^{S A S}+Z_{1} \cdot \chi_{V / F} \cdot F+A_{\Gamma(X)}^{S A S}\right), \\
\Delta \vec{G}_{*}^{0}=\alpha_{1} \cdot\left(I-\omega^{\bar{e}}+V_{M / L}^{0} \cdot F+Z_{1} \cdot \chi_{V / L} \cdot F\right),
\end{gathered}
$$

в яких відповідно $I_{(L)}$ і $I$ - перші потенціали іонізації молекули SAS у воді й у вакуумі, $\omega_{M(L)}^{\bar{e}}$ i $\omega_{M}^{\bar{e}}-$ роботи виходу електрона 3 металу в цих же середовищах; $V_{M / L}^{0}$ - вольт-потенціал на межі поділу M/L при $\mathrm{E}_{\mathrm{N}} ; Z_{1}$ - зарядне число іонізованої (окисненої) частинки; $A_{\Gamma(\mathrm{P})}^{\bar{e}}-$ реальна енергія гідратації електрона; $A_{\mathrm{p}(X)}^{\overline{\overline{\mathrm{e}}}}$ - хімічна енергія гідратації іонізованої частинки; $\chi_{V / L}-$ поверхневий потенціал на межі вакуум-розчинник; $F$ - число Фарадея; $\alpha_{1}-$ коефіцієнт переносу заряду від SAS до металу (від 0 до 1), або частка енергії, яка йде на цей процес (вважається, що окиснення - прямий процес, тоді як у кінетиці - зворотний). При цьому $\omega_{M(L)}^{\bar{e}}$ i $\omega_{M}^{\bar{e}}$ пов'язані між собою співвідношенням: $\omega_{M(L)}^{\bar{e}}=\omega_{M}^{\bar{e}}+V_{M / L}^{0} \cdot F-A_{\Gamma(\mathrm{P})}^{\bar{e}}$.

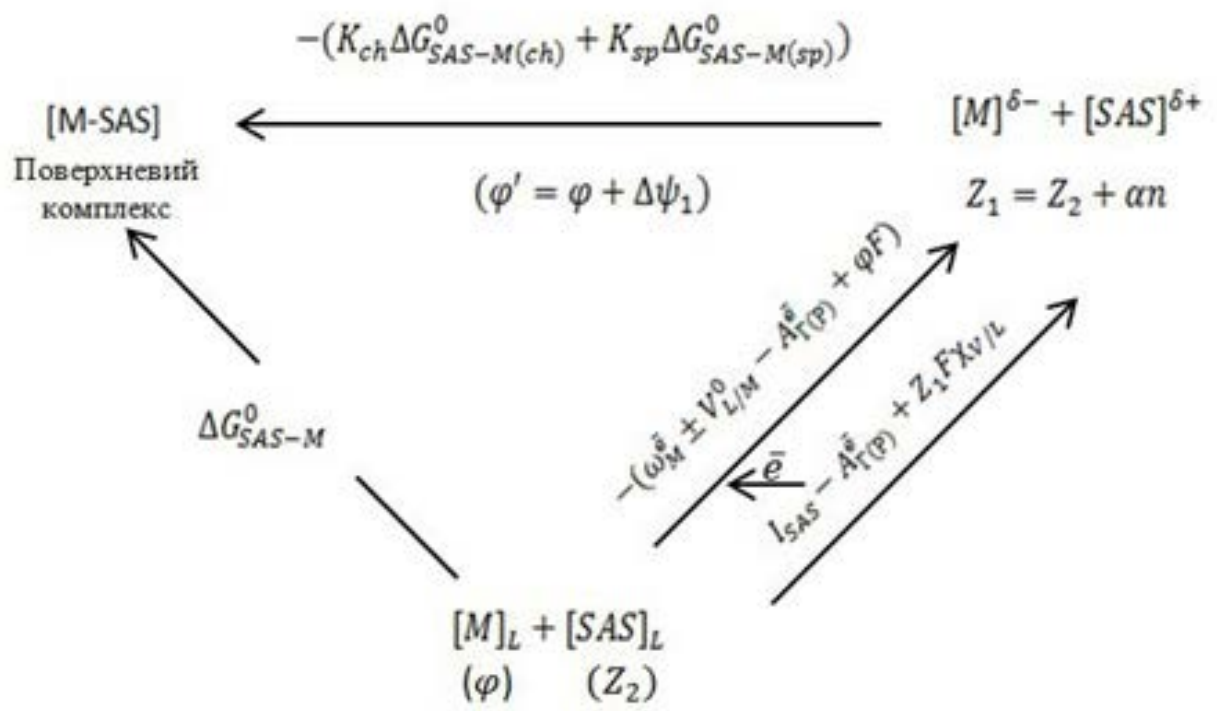

Рис. 1. Енергетичний цикл утворення поверхневого комплексу при адсорбції SAS на М з донорною функцією SAS і акцепторною металу 
При $\mathrm{E} \neq \mathrm{E}_{\mathrm{N}}$, тобто при відхиленні потенціалу металу від його нульової точки, в рівняння (7) має бути внесена поправка $\Delta V_{M / L}$, яка враховує відповідну зміну вольта-потенціалу і в першому наближенні відповідає $\varphi$-потенціалу металу в шкалі Антропова: $\left|\Delta V_{M / L}\right|=|\varphi|$. Останнє витікає із наступних співвідношень:

$$
\begin{gathered}
\Delta V_{M / L}=g_{M / L_{(q)}}+g_{M / L_{(d i p)}}+g_{M / L_{(a d s)}}-g_{M / L_{(d i p)}}^{0}-\left(\chi_{M / L}-\chi_{M / L}^{0}\right), \\
\varphi=E-E_{N}=g_{M / L_{(q)}}+g_{M / L_{(d i p)}}+g_{M / L_{(a d s)}}-g_{M / L_{(d i p)}}^{0},
\end{gathered}
$$

де $g_{M / L}, g_{M / L}^{0}, \chi_{M / L}, \chi_{M / L}^{0}$ - гальвані і поверхневі стрибки потенціалу при Е та $\mathrm{E}_{\mathrm{N}}$ відповідно; $g_{M / L(q)}, g_{M / L(d i p)}, \quad g_{M / L(a d s)}-$ іонний, дипольний та адсорбційний стрибки $g_{L / M}$ - потенціалу при даному потенціалі $\mathrm{E}, g_{L / M_{(d i p)}}^{0}$ дипольний стрибок гальвані-потенціалу при $\mathrm{E}_{\mathrm{N}}$, різницею $\left(\chi_{M / L}-\chi_{M / L}^{0}\right)$ в першому приближенні можна знехтувати.

Таким чином, для донорної функції SAS та акцепторної металу стандартна енергія переносу заряду повинна дорівнювати:

$$
\Delta \vec{G}_{*}^{0}=\alpha_{1} \cdot\left(I-\omega_{M}^{\bar{e}}+V_{M / L}^{0} \cdot F+Z_{1} \cdot \chi_{V / L}-\varphi \cdot F\right),
$$

a для зворотнього процесу переносу заряду від металу (донор) до молекули SAS (акцептор):

$$
\Delta \vec{G}_{*}^{0}=\alpha_{2} \cdot\left(\omega_{M}^{\bar{e}} \pm V_{M / L}^{0} \cdot F+Z_{2} \cdot \chi_{V / L} \cdot F-F_{a f}+\varphi \cdot F\right),
$$

де $\left(F_{a f}\right)$ - спорідненість органічної сполуки до електрона, $\left(Z_{2}\right)$ - зарядне число реагуючих частинок, $\alpha_{2}$ - коефіцієнт переносу заряду від металу до молекули SAS.

Оскільки відомо, що $\varphi=E-E_{N}$, а $E_{N}=\frac{\omega_{\mathrm{M}}^{\mathrm{e}}}{F}-$ const [21], вираз (10) можна також подати як: $\Delta \vec{G}_{*}^{0}=\alpha_{1} \cdot\left(I+\Delta V_{M / L} \cdot F+Z_{1} \cdot \chi_{V / L} \cdot F-E+\right.$ const $)$; або $\Delta \vec{G}_{*}^{0}=\alpha_{1} \cdot\left(\Delta \vec{G}_{*(x)}^{0}-E \cdot F\right)$, де $\Delta \vec{G}_{*(x)}^{0}-$ хімічна складова енергії $\Delta \vec{G}_{*}^{0}$, яка не залежить від потенціалу електрода. Аналогічно можна навести вираз для зворотного процесу переносу заряду. 
Отже, вирази енергії активації корозійних процесів, отримані у дійсній моделі (10), (11), знаходяться у відповідності з основними положеннями теорії акту переносу заряду, згідно з якою основною змінною, що впливає на перенос заряду, $є$ потенціал електроду [21]. Різниця знаків у виразах $\pm \varphi F$ цих рівнянь показує, що енергія електричного поля прискорює перенос заряду від металу до молекули SAS i сповільнює процес, який протікає в зворотньому напрямі (аналогічно впливу енергії поля на процеси відновлення та окислення).

Використання рівнянь (10), (11), дозволяє визначити умови встановлення на поверхні металу адсорбційної рівноваги, яка може бути обумовлена як зарядною (електростатичною), так із електронною (ковалентною або орбітальною) взаємодією між реагентами. При адсорбції незаряджених органічних сполук (ПАР молекулярного типу) та $E=E_{N}$ умовами встановлення адсорбційної рівноваги на металі є співвідношення:

$$
I \approx 2\left(\omega_{\mathrm{M}}^{\overline{\mathrm{e}}}+V_{M / L}^{0} F\right)
$$

якщо вважати, що: $z_{1}=0, z_{2}=0, \alpha_{1}=\alpha_{2}=0,5$ а $I \gg F_{\text {ср }}$ в зв'язку із невисокою спорідненістю сполук до електрона та послабленням iï за рахунок екрануючої дії молекул води [12].

Така обмінна електронна взаємодія між молекулою SAS i металом формально не супроводжується переносом заряду, а стабілізація поверхневого комплексу обумовлена утворенням ковалентних зв'язків між адсорбатом та адсорбентом за рахунок їх електронної (орбітальної) взаємодії. При умові $\alpha_{1}=$ 1 співвідношення (12) відповідає безбар'єрному механізму переносу електрона і встановленню більш міцного адсорбційного зв'язку між реагентами.

Слід відмітити, що співвідношення (12), що витікає 3 дійсної моделі, формально збігається 3 виразом для резонансного потенціалу, вперше запропонованим в роботах Е. А. Нечаєва і В. П. Куприна [12-14] на основі деяких інших міркувань і знайшов експериментальне підтвердження при дослідженні адсорбції різних класів органічних сполук на поверхні ряду металів: $\mathrm{Bi}, \mathrm{Sn}, \mathrm{Pb}, \mathrm{Cu}, \mathrm{Cd}, \mathrm{Ag}, \mathrm{Cr}, \mathrm{Fe}$ та ін []. Авторами також було показано, що 
виникнення резонансних потенціалів - максимумів на залежностях адсорбції від потенціалів іонізації органічних сполук, обумовлено або перекривання хвильових функцій реагентів, або тунелювання неподіленної пари електронів 3 молекули органічної сполуки на валентній орбіталі металу.

Але при адсорбції нейтральних органічних сполук в області $E \neq E_{N}$ необхідно враховувати також вплив на акт переносу заряда $\varphi$-потенціалу метала та електростатичну взаємодію між реагентами, яка обумовлена виникненням (внаслідок переносу електрона) у молекул SAS частково позитивного $\left(\delta^{+}\right)$або частково негативного $\left(\delta^{-}\right)$заряду. У випадку донорної функції органічних сполук, які набувають надлишковий позитивний заряд $\left(\delta^{+}\right)$, такий перенос електрона буде призводити до їх електростатичної взаємодії із негативно зарядженою поверхнею металу $(\varphi<0)$, при їх акцепторній функції i виникненні у сполук частково негативного заряду $\left(\delta^{-}\right)$- до електростатичної взаємодії з металом, у якого $\varphi>0$. Значне відхилення потенціалу електрода від його нульової точки в область негативних $\varphi$-потенціалів, згідно 3 рівнянням (10), повинно ускладнювати акт переносу заряда при адсорбції SAS iз донорною функцією. Аналогічна картина буде спостерігатись для молекул SAS 3 акцепторною функцією при зміщенні потенціалу електрода від його нульової точки в область більш позитивних значень $\varphi$-потенціалу (рівняння 11).

Такі уявлення в рамках дійсної моделі дозволяють пояснити найбільшу адсорбцію молекулярних ПАР поблизу нульових точок металів та десорбцією цих ПАР при відхилені від неї (рис.2). Можливість такої специфічної взаємодії при $E \neq E_{N}$ підтверджується зростанням в декілька разів адсорбції багатьох органічних сполук при переході від межі розподілу повітря-розчин до межіртуть-розчин $E=E_{N}$. Але значне зростання адсорбції цих сполук на обох межах розподілу, яке спостерігається при збільшенні іх молекулярної маси, свідчить про накладання фізичної адсорбції на специфічну у вказаних умовах протікання адсорбції[5,22]. 
Таким чином, із урахуванням викладеного для молекулярних органічних сполук при $E \neq E_{N}$ умови становлення адсорбційної рівноваги можна можна показати рівнянням:

$$
I=2\left(\omega_{M}^{\bar{e}}+V_{M / L}^{0}+\varphi F\right)+\sum \alpha n \cdot \varphi,
$$

в якому складова $\left(\sum \alpha n \varphi\right)$ враховує зарядну взаємодію між металом і органічною сполукою, з частковим надлишковими зарядоми.

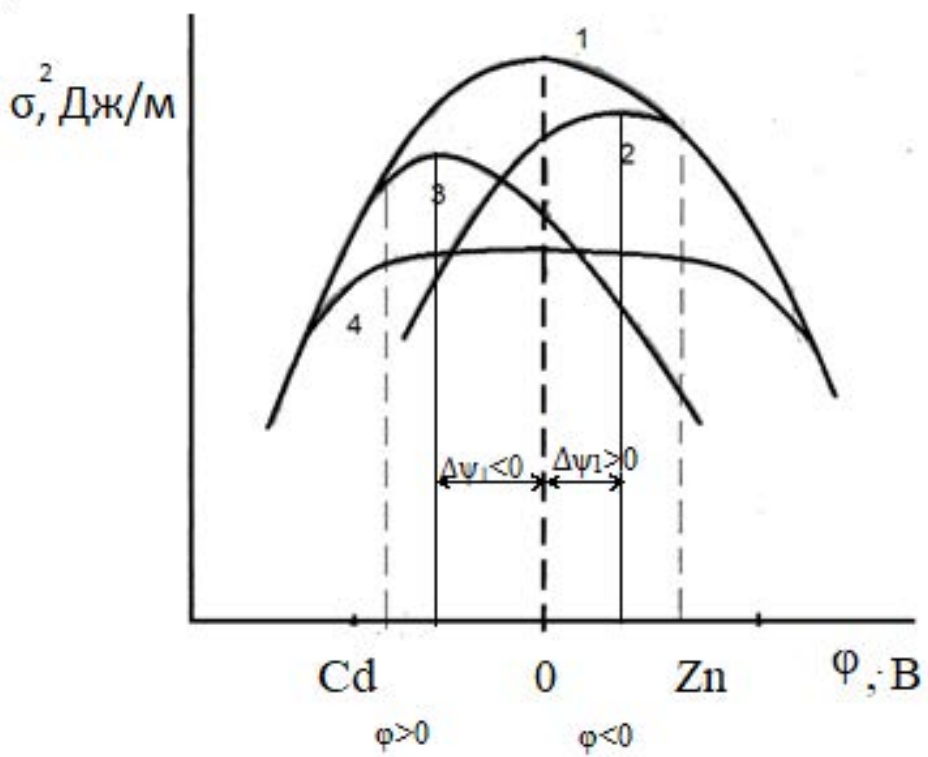

Рис.2. Типові електрокапілярні криві, , зняті на ртуті в фоновому розчині

(1) та в розчинах, де $\epsilon$ поверхневоактивні аніони (2), катіони (3)

$$
\text { і молекулярні речовини (4) }
$$

Більш складний вигляд набуває вираз для умов адсорбційної рівноваги при адсорбції заряджених органічних сполук в області $E \neq E_{N}$. Дійсно, при адсорбції заряджених частинок у рівнянні стандартних енергій переносу заряду (10), (11) необхідно ввести додаткову складову, що враховує вплив $\Delta \psi_{1}$ потенціалу, який виникає при адсорбції ПАР (рис.2), на акт переносу заряду. Так при адсорбції ПАР катіонного типу виникає позитивний $\Delta \psi_{1}$ потенціал $[21,22]$, який буде загальмовувати перенос заряду від молекули органічної сполуки на метал. Навпаки негативний $\Delta \psi_{1}$-потенціал, що виникає при адсорбції аніоноактивних ПАР, буде гальмувати зворотній процес переносу заряду. Крім того, у рівняння адсорбційної рівноваги (12) необхідно ввести додаткову складову, яка враховує енергію електростатичної взаємодії між 
зарядженою частинкою та протилежно зарядженою поверхнею металу. Тоді умови адсорбційної рівноваги у при адсорбції монофункціональних органічних сполук з донорною функцією можуть бути подані рівнянням:

$$
\alpha_{1}\left(I \omega_{M}^{\bar{e}}+V_{M / L}^{0} \cdot F+Z_{1} \cdot \chi_{V / L}-\left(\varphi-\Delta \psi_{1}\right) F\left(z+\alpha_{1} n\right)\left(\varphi-\Delta \psi_{1} F\right)\right)=0
$$

де $Z$ - зарядне число частинки, що адсорбується, а $\Delta \psi_{1}$ - адсорбційний стрибок потенціалу, що виникає на межі розподілу метал-електроліт.

У більш загальному випадку, при адсорбції поліфункціональних органічних сполук, які мають декілька адсорбційних центрів і схильних як до електронної, так і для зарядної взаємодії, вираз умов адсорбційної рівноваги набуває наступного вигляду:

$I=2\left[\left(\omega_{M}^{\bar{e}}+\Delta V_{M-L}\right) \cdot F+\left(\varphi-\Delta \psi_{1}\right) \cdot F\right]-\sum(z+\alpha n)\left(\varphi-\Delta \psi_{1}\right) F$,

в якому складова $\sum(z+\alpha n)\left(\varphi-\Delta \psi_{1}\right) F$ враховує зарядну взаємодію усіх адсорбційних центрів сполук та перерозподіл їхнього зарядного числа внаслідок частинного переносу заряду. При цьому при негативних значеннях $\varphi$ потенціалу повинна спостерігатися переважно адсорбція катіоноактивних органічних сполук, при позитивних значеннях - аніоноактивних, що знаходиться у відповідності 3 даними електрокапілярних вимірювань на ртуті[22], відомими ще з часів Гуї (рис 2).

Із аналізу рівняння (15) неважко показати, що специфічна адсорбція заряджених органічних сполук на металі визначається не тільки фундаментальними властивостями реагентів $\left(I_{S A S}, \Delta \omega_{M}^{\overline{\mathrm{e}}}\right)$, але й зарядним числом органічних сполук(z) та $\varphi$-потенціалом металів, що залежать як від їхньої природи так i від середовища. Це дозволяє пояснити появу на залежностях адсорбції від потенціалів іонізації органічних сполук декількох максимумів $\left(\mathrm{I}_{\mathrm{p}}\right)$, вплив на резонансні потенціали деяких металів (олова, срібла, наприклад) електродного потенціалу [12,14], відсутність для багатьох органічних сполук прямого взаємозв’язку між антикорозійними властивостями та їх $\mathrm{I}_{\mathrm{p}}$-потенціалами [23], наведеними в вище названих роботах, та ін. 
Таким чином, із вище наведеного матеріалу витікає, що фізична адсорбція органічних сполук та їхня специфічна адсорбція першого роду повинні у більшій мірі залежати від $\varphi$-потенціалу електрода, ніж від хімічної природи металу. При кожному ф-потенціалі металу поверхнева концентрація органічних сполук у цьому випадку визначається як результат накладання специфічних сил адсорбції на електростатичні. Такий вид специфічної взаємодії спостерігається, наприклад, при адсорбції органічних сполук, які містять л-електронні зв'язки на різних металах: $\mathrm{Hg}, \mathrm{Bi}, \mathrm{Zn}, \mathrm{Cd}, \mathrm{Pb}, \mathrm{Fe}$, інгібуванні кислотної корозії чорних та кольорових металів нітрогенвмісними органічними сполуками, схильними до $\pi$-електронної взаємодії та ін [5]. Якщо $\varphi$-потенціал одного металу дорівнює $\varphi$-потенціалу другого, електростатична взаємодія між ними і адсорбованими частинками буде приблизно однакова. Це дає можливість застосовування метода $\varphi$-шкали потенціалів Антропова при прогнозуванні процесів адсорбції та застосування ртутного електроду як модельного для опису адсорбційних процесів на металах, які мають схожу зі ртуттю електронну будову атомів.

Специфічна адсорбція другого роду також залежить від $\varphi$-потенціалу металу, однак стабілізація поверхневих комплексів у цьому випадку визначається, в основному, можливістю адсорбата і адсорбента утворювати електронні (ковалентних або координаційних) зв’язки. Такий вид адсорбційної взаємодії спостерігається для багатьох органічних сполук 3 ненасиченими зв’язками, атомами N, O, S, Р, що мають неподілені пари електронів та деяких інших сполук, які широко застосовують при інгібуванні корозії металів. Механізми адсорбції таких органічних сполук на ртуті i на поверхні d-металів внаслідок різної будови атомів, суттєво різняться. Останнє значно обмежує можливість використання «модельного» ртутного електроду для опису таких адсорбційних процесів на d-металах і потребує застосування інших сучасних методів адсорбційних досліджень. 


\section{2. Використання моделі адсорбції, основаної на концепції утворення}

комплексів 3 переносом заряду, при розробці інгібіторів корозії.

Аналіз значної кількісті результатів корозійних випробувань, які були присвячені розробці інгібіторів корозії металів, свідчать, що адсорбція і захисна дія органічних сполук залежать від низки факторів, які стають домінуючими в тих чи інших умовах протікання корозійного процесу.

При інгібуванні корозії цинку, у якого $\varphi<0$, в розчинах сульфатної кислоти, найбільшу ефективність мають органічні речовини катіонного типу: четвертичні солі амонію, нітрогеновмісткі органічні сполуки, схильні до $\pi$ електронної взаємодії та ін. Органічні сполуки аніонного типу суттєво не впливають на кислотну корозію цинку або, навіть, стимулюють іiі [5]. Навпаки при кислотній корозії кадмію, у якого $\varphi>0$, вказані нітрогеновмісткої органічної сполуки мають невисоку захисну дію, а найбільшу ефективність виявляють органічні речовини аніонного типу. Корелятивні залежності, між захисною дією та адсорбційними властивостями таких інгібіторів, визначеними на ртуті при відповідних $\varphi$-потенціалах, свідчать про їх фізичну адсорбцію і специфічну адсорбцію першого роду, які залежать від $\varphi$-потенціалу.

На залежності коефіцієнтів гальмування кислотної корозії цинку $(\gamma)$ від потенціалів іонізації органічних сполук (рис. 3а) спостерігаються два максимуми $\left(\mathrm{I}_{\max }\right)$, що відповідають потенціалам іонізації його найбільш ефективних інгібіторів корозії, і відносяться до ПАР катіонного типу: катапіну (параалкілпіридиній хлориду), у якого $\mathrm{I}_{\max }=8,4 \mathrm{eB}$ (перший максимум на залежностях $\gamma$-I) та піридину, у якого $\mathrm{I}_{\max }=9,4$ eB (другий максимум на залежностях $\gamma-\mathrm{I}$ ). Тіосечовина, у якої потенціал іонізації I дорівнює 8,3 еB, та ії похідні (монометилолтіосечовина (ММТС), диметилолтіосечовина (ДМТС)), анілін та його похідні, у яких $\mathrm{I}<8,4 \mathrm{eB}$, практично не впливають на його кислотну корозію або навіть стимулюють їі. Високу ефективність при його кислотній корозії цинку мають також інші четвертинні солі піридину: Nдецилхлоридпіридиній хлорид (ДПХ), КПИ-1, СПХ та ін. 

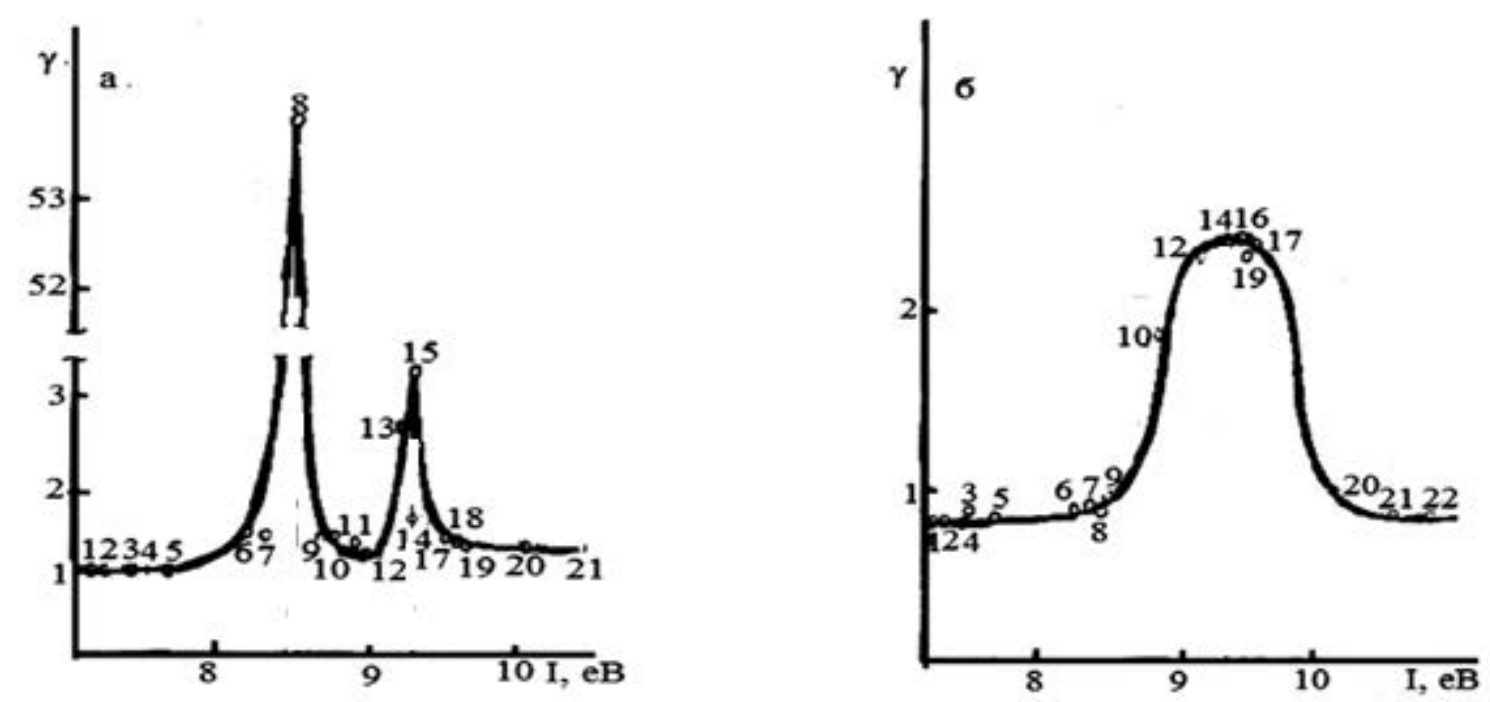

1 - n-толуідин, 2 - дифеніламін, 3 - о-толуідин, 4 - m-толуідин, 5 - анілін, 6 тіосечовина, 7 - бензиламін, 8 - катапін (параалкілбензилпіридиній хлорид), 9 фенол, 10 - бензотріазол, 11 - тіофен, 12 - 2,4-лутідин, 13 - 2-піколін, 14 - феноксол ВІС-15, 15 - піридин, 16 - ліноліва кислота, 17 - лаурілсульфат натрію, 18 - сечовина, 19 - ацетамід, 20 - пропанол, 21 - етанол, 22 - метанол (концентрація добавок $1 \cdot 10^{-2}$ моль $\left.\cdot \pi^{-1}\right)[18]$.

Рис. 3. Залежності коефіцієнтів гальмування $(\gamma)$ корозії цинку в 0,5 M $\mathrm{H}_{2} \mathrm{SO}_{4}$ (a) і 10 М КОН (б) від потенціалів іонізації сполук

На залежностях коефіцієнтів гальмування кислотної корозії кадмію від потенціалів іонізації органічних сполук (рис. 4), спостерігається один максимум, що відповідає потенціалу іонізації тіосечовини $\left(\mathrm{I}_{\max }=8,3 \mathrm{eB}\right)$. Більш високу захисну дію, ніж тіосечовина виявляють при його кислотній корозії ММТС, ДМТС - добавки аніонного типу. Катапін, потенціал іонізації якого приблизно такий, як й у тіосечовини, несуттєво впливає на кислотну корозію кадмію, а протоновані похідні аналіну, піридину прискорюють їі.

При корозії заліза та вуглецевих сталей, які також, як цинк, мають негативний заряд поверхні $(\varphi<0)$, в розчинах сульфатної кислоти найбільшу ефективність при кімнатній температурі виявляють катапін, ДПХ, КПІ-1, СПХ, СП та інші четвертичні піридинієві солі, які здатні адсорбуватись за рахунок зарядної та л-електронної взаємодії. Тіосечовина, ММТС, ДМТС при кімнатній температурі і досліджених концентраціях мають невисоку захисну 
дію при корозії заліза та сталі в розчинах відповідних реагентів. На залежності $\gamma-\mathrm{I}$, отриманій для сталі 08Кп (рис. 4) у розчині $0,5 \mathrm{M}$ сульфатної кислоти, спостерігають два максимума, які відповідають найбільшої захисної дії органічних сполук катіонного типу: катапіну $\left(\mathrm{I}_{\max }=8,4 \mathrm{eB}\right)$ та 8-оксипіридину $\left(\mathrm{I}_{\max }=9,4 \mathrm{eB}\right)$. Органічні сполуки аніонного типу, які мають близькі потенціали іонізації, такі як фенол ( $\mathrm{I}=8,4 \mathrm{eB})$, тіосечовина $(\mathrm{I}=8,3 \mathrm{eB})$, фенаксол ВЧС-15 (I = 9,4 eB), саліцилова кислота $(\mathrm{I}=9,4 \mathrm{eB})$, ДС-10 (I = 9,4 eB) при досліджених концентраціях мають невисоку захисну дію при їі кислотній корозії.

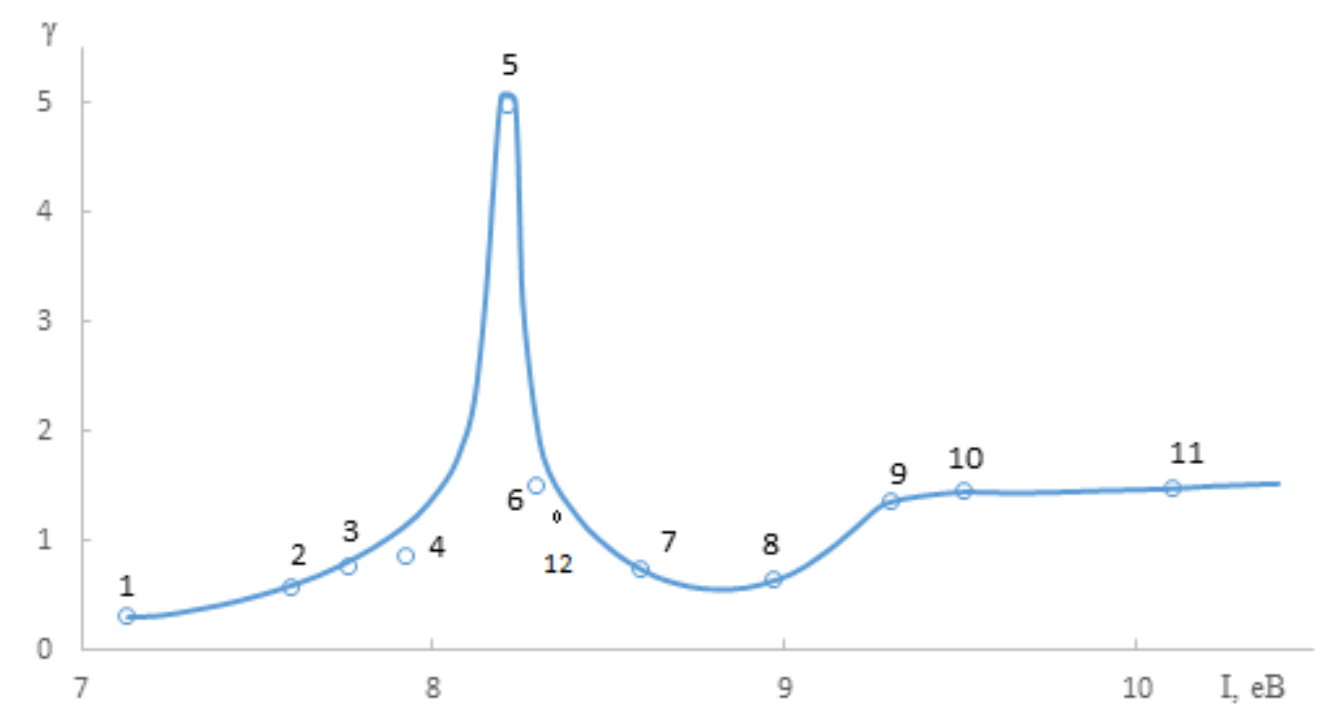

1 - диметиланілін, 2 - о-толуідин, 3 - анілін, 4 - нафталін, 5 - тіосечовина, 6 бензотриазол, 7 - сульфосаліцилова кислота, 8 - сечовина, 9 - пропіловий спирт, 10 етиловий спирт, 11 - метиловий спирт (концентрація інгібіторів $1 \cdot 10^{-2}$ моль Л $^{-1}$ ), 12 катапин

Рис. 4. Залежність коефіцієнтів гальмування корозії кадмію в $3 \mathrm{M} \mathrm{H}_{2} \mathrm{SO}_{4}$ від потенціалів іонізації органічних сполук

Таким чином, наведені дані свідчать про значну роль електростатичної взаємодії, електричної природи адсорбованих сполук та $\varphi$-потенціалів електроду при підборі органічних інгібіторів корозії. При кислотній корозії цинку, заліза і вуглецевої сталі, які мають негативний заряд поверхні $(\varphi<0)$, найбільшу ефективність виявляють органічні сполуки катіонного типу, при кислотній корозії кадмію, у якого $\varphi>0$,- органічні сполуки аніонного типу. 
Потенціали максимумів $\left(\mathrm{I}_{\max }\right)$, які виникають на залежностях $\gamma-\mathrm{I}$ для цинку, $\epsilon$ достатньо близькими до резонансних потенціалів $\left(\mathrm{I}_{\mathrm{p}}\right)$, що були отримані в роботах $[12,14]$ для цинкового порошку в сірчанокислому електроліті (табл.). Для кадмію і вуглецевої сталі максимуми, які виникають на залежностях $\gamma-\mathrm{I}$, відрізняються від $\mathrm{I}_{\mathrm{p}}$-потенціалів, отриманих у роботах цих авторів, і у більшій мірі близькі до потенціалів розрахованих за рівнянням (15) для кадмію і за рівнянням (15) - для сталі. Отримані результати свідчать про вплив $\varphi$ потенціалу металу і зарядного числа $\Delta \psi_{1}$-потенціалу адсорбованих сполук на їх адсорбцію та захисну дію.

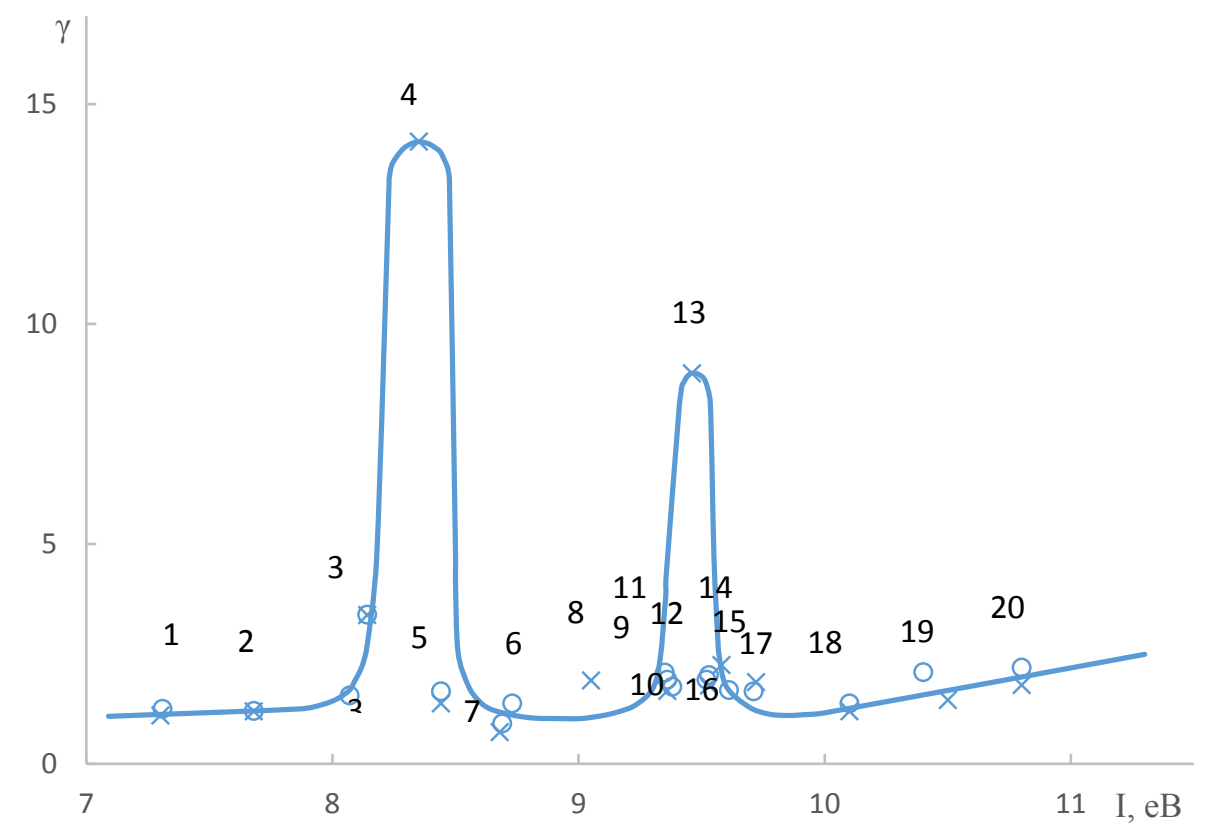

1 - дифеніламін, 2 - анілін, 3 - тіосечовина, 4 - катапін, 5 - фенол, 6 - бензиламін, 7 бензотриазол, 8 - 2-піколін, 9 - синтанол, 10 - піридин, 11 - феноксол ВЧС-15, 12 - 4амінопіридин,13 - 8-оксіхінолін, 14 - ДС-10, 15 - саліцилова кислота, 16 лаурилсульфат натрію, 17 - сечовина, 18 - ізопропіловий спирт, 19 - етанол, 20 метанол (концентрація добавок $1 \cdot 10^{-2}$ моль $\cdot \pi^{-1}$ )

Рис. 5. Залежність коефіцієнтів гальмування корозії сталі 08 КП в $0,5 \mathrm{M}$ $\mathrm{H}_{2} \mathrm{SO}_{4}$ від потенціалів іонізації сполук 
Таблиця. Порівняння потенціалів іонізації найбільш ефективних інгібіторів корозії металів $\left(\mathrm{I}_{\max }\right)$, потенціалів іонізації, розрахованих за рівняннями моделі $\left(\mathrm{I}_{\mathrm{M}(1)}, \mathrm{I}_{\mathrm{M}(2)}, \mathrm{I}_{\mathrm{M}(3)}\right)$ і і резонансних потенціалів $\left(\mathrm{I}_{\mathrm{p}}\right)$, отриманих авторами [12]*

\begin{tabular}{|c|c|c|c|c|c|c|c|c|c|}
\hline Система & $E_{c}, B$ & $\begin{array}{l}\omega^{\mathrm{e}} \\
\mathrm{eB}\end{array}$ & $E_{N}, B$ & $\varphi, \mathrm{B}$ & $\begin{array}{c}\mathrm{I}_{\max }, \\
\text { eВ } \\
\text { Тип ПАР }\end{array}$ & $\begin{array}{c}\mathrm{I}_{\mathrm{M}(1)} \\
\mathrm{eB}\end{array}$ & $\begin{array}{c}\mathrm{I}_{\mathrm{M}(2)} \\
\mathrm{eB}\end{array}$ & $\begin{array}{c}\mathrm{I}_{\mathrm{M}(3)} \\
\mathrm{eB}\end{array}$ & $\begin{array}{l}\mathrm{I}_{\mathrm{p}} \\
\mathrm{eB}\end{array}$ \\
\hline $\begin{array}{c}\mathrm{Zn}, \\
0,5 \mathrm{M} \\
\mathrm{H}_{2} \mathrm{SO}_{4}\end{array}$ & $-0,76$ & 4,2 & $-0,50$ & $-0,26$ & $\begin{array}{c}\text { 8,4 (I) } \\
\text { 9,4 (II) } \\
\text { ПАВ(K) }\end{array}$ & 7,88 & 7,32 & 7,7 & $\begin{array}{l}8,2 \text { (I) } \\
9,4 \text { (II) }\end{array}$ \\
\hline $\begin{array}{c}\mathrm{Cd}, \\
3 \mathrm{M} \mathrm{H}_{2} \mathrm{SO}_{4}\end{array}$ & $-0,50$ & 4,0 & $-0,70$ & $+0,20$ & $\begin{array}{c}8,3 \\
\text { ПАВ(А) }\end{array}$ & 7,48 & 7,88 & 8,28 & $\begin{array}{l}7,5 \text { (I) } \\
7,7 \text { (II) }\end{array}$ \\
\hline $\begin{array}{c}\mathrm{Fe}, \\
0,5 \mathrm{M} \\
\mathrm{H}_{2} \mathrm{SO}_{4}\end{array}$ & $-0,26$ & 4,7 & $\pm 0,0$ & $-0,26$ & $\begin{array}{c}8,4 \text { (I) } \\
9,4 \text { (II) } \\
\text { ПАВ(К) }\end{array}$ & 8,88 & 8,36 & 7,89 & $\begin{array}{l}7,3 \text { (I) } \\
7,9(\mathrm{II}) \\
9,4 \text { (III) }\end{array}$ \\
\hline $\begin{array}{c}\mathrm{Zn}, 10 \mathrm{M} \\
\mathrm{KOH}\end{array}$ & $-1,20$ & 4,2 & $-0,50$ & $-0,80$ & $\begin{array}{l}9,4 \div 9,5 \\
\text { ПАР (А), } \\
\text { ПАР (M) }\end{array}$ & 7,88 & 6,28 & - & $\begin{array}{l}8,2 \text { (I) } \\
9,4 \text { (II) }\end{array}$ \\
\hline
\end{tabular}

Примітки:

1. Розрахунки потенціалів іонізації $\mathrm{I}_{\mathrm{M}(1),} \mathrm{I}_{\mathrm{M}(2)}, \mathrm{I}_{\mathrm{M}(3)}$ проводили відповідно за рівняннями (12), (13), (15); приймали $z=1$ або $z=-1, \Delta \psi_{1}=0,05$ В або $\Delta \psi_{1}=-0,05$ $\mathrm{B},[5] V_{M / L}^{0}=-0,26 \mathrm{~B}[12-14], \alpha=0,5$.

2. Цифри (I), (II), (III) - перший, другий і третій максимуми на залежностях $\gamma$-I (рис. 3-5) для ПАВ катіонного (К), аніонного (А) чи молекулярного (М) типу, або на залежностях параметрів адсорбції ПАР від значень I, які були отримані в роботі [12$14]$.

Більш складна картина спостерігається при дослідженні впливу органічних сполук на лужну корозію цинку, в умовах якої відома лише незначна кількість ефективних інгібіторів його корозії. Оскільки цинк у розчині $10 \mathrm{M} \mathrm{KOH} \mathrm{має} \mathrm{дуже} \mathrm{негативний} \varphi$-потенціал, можна було очікувати переважну адсорбцію на його поверхні катіонноактивних органічних сполук. Але при корозії цинку у цьому розчині найбільшу ефективність виявляють органічні сполуки аніонного типу, такі, як фенаксол ВIC-15, лінолева кислота, лаурилсульфат натрію, у яких I $=9,3-9,5$ eB. Такі значення потенціалу 
іонізації органічних сполук відповідають резонансному потенціалу цинку, який був отриманий авторами $[12,14]$, в сірчанокислотному розчині, що вказує на вибіркову адсорбцію інгібіторів на поверхні цинку, покритій його оксидом або гідроксидом. Аналогічно, при корозії сплаву МА-8 (рис. 5), поверхня якого покрита оксидом, найбільшу захисну дію у $1 \mathrm{M} \mathrm{H}_{2} \mathrm{SO}_{4}$ мають органічні сполуки аніонного типу, з I = 9,2 - 9,3 еВ, такі, як феноксол ВЧС-15, ДС-10, у яких I = 9,2 - 9,3 еВ. Поряд з цим при його кислотній корозії виявляє також високу ефективність добавка катіонного типу - феніламінопіридин, що свідчить про адсорбцію інгібітору на поверхні металу, позбавленого від оксидів магнію.

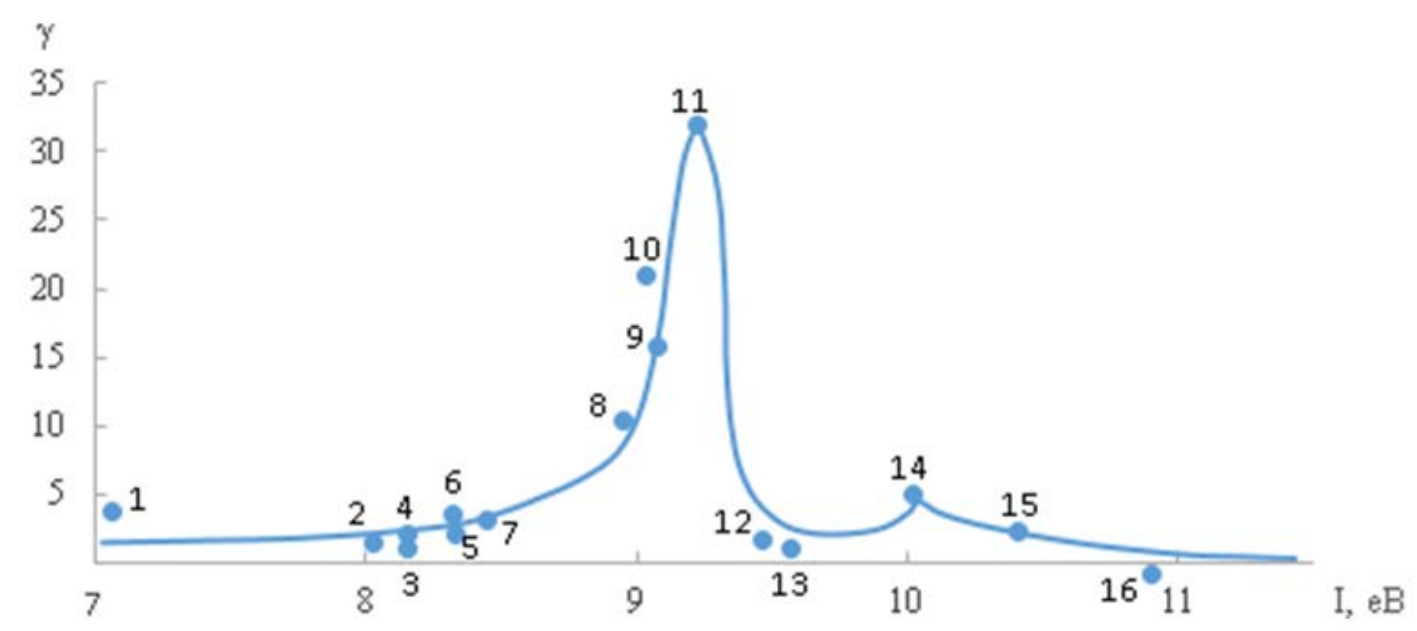

1 - дифеніламін, 2 - ДМТМ, 3 - ТМ, 4 - бензотриазол, 5 - фенол, 6 - катапін, 7 бензотриазол, 8 - синтанол, 9 - феніламінопіридин, 10 - феноксол ВЧС-15, 11 - ДС10, 12 - сульфосаліцилова кислота, 13 - сечовина, 14 - пропіловий спирт, 15 етиловий спирт, 16 - метиловий спирт (концентрація добавок $\left.1 \cdot 10^{-2}{\text { моль } \cdot{ }^{-1}}^{-1}\right)$

Рис. 6. Залежність коефіцієнтів гальмування корозії магнію в $1 \mathrm{M} \mathrm{H}_{2} \mathrm{SO}_{4}$ від потенціалів іонізації органічних сполук

Однак поряд 3 прогнозуванням адсорбції при підборі органічних сполук слід враховувати механізм впливу адсорбованих частинок на кінетику електродних реакцій корозійних процесів.Так, адсорбція заряджених органічних сполук на поверхні металу може призводити до накопичення надлишкових зарядів в металевій обкладці подвійного електричного шару, викликати зміну складу його електролітної обкладки і за рахунок виникнення адсорбційного стрибка потенціалу $\left(\Delta \psi_{1}\right)$, призводити до зміни швидкості 
протікання електродних процесів $[5,21,22]$. Найбільш ефективні катіонноактивні органічні інгібітори корозії цинку, які забезпечують виникнення позитивного адсорбційного стрибка потенціалу $\left(\Delta \psi_{1}>0\right)$, підвищують перенапругу виділення водню на його поверхні, яка протікає із загальмованістю стадії заряду іонів гідроксонію $[5,7,20]$. Навпаки, аніонноактивні органічні сполуки, що переважно адсорбуються на поверхні кадмію, зменшують перенапругу виділення водню за рахунок виникнення негативного адсорбційного стрибка потенціалу $\left(\Delta \psi_{1}<0\right)$. Такий різний вплив адсорбованих частинок на водневу реакцію дозволяє пояснити більш високу захисну дію досліджених інгібіторів при корозії цинку, ніж при кислотної корозії кадмія.

На залізі та вуглецевих сталях процес виділення водню протікає з приблизно однаковою швидкістю стадій розряду та рекомбінації, і для них вплив електричної природи органічних сполук на виділення водню значно нівелюється. Катіонноактивні органічні сполуки за рахунок виникнення при адсорбції позитивного адсорбційного стрибка потенціалу виявляють більшу ніж аніонні захисну дію при кімнатній температурі їх кислотної корозії. Але при підвищених температурах мають більш високу захисну дію похідні тіосечовини, які здатні утворювати із d-металами міцні зв'язки завдяки наявності у атомів сірки неподілених пар електронів.

Крім того, незначний вплив вільних амінів на кислотну корозію цинку та кадмію у значній мірі $\epsilon$ обумовленим протіканням реакцій поверхневої протонізації і ефектів каталітичного видалення водню, характерні переважно для s, p - металів [5, 20]. Так, з аналізу даних [5] витікає, що захисна дія ароматичних амінів, у яких $\mathrm{I}<\mathrm{I}_{\max (\mathrm{I})}$, при однаковій поверхневій активності на ртуті поступово зростає із підвищенням їх значень $\mathrm{pK}_{\mathrm{a}}$. Це пояснюється загальмованістю стадії розряду адсорбованих катіонних форм амінів, константа швидкості якої, згідно трактувань Бренстеда, пропорційна константі їх кислотної дисоціації $K_{a}^{\alpha}(\alpha=0,5)$. Захисна дія похідних піридину, у яких $\mathrm{I}>\mathrm{I}_{\max (\mathrm{I})}$, при підвищенні їх значень $\mathrm{pK}_{\mathrm{a}}$ навпаки зменшується, що пов'язано із 
загальмованістю реакції їх поверхневої протонізації, для якої константа швидкості обернено пропорційна $\mathrm{pK}_{\mathrm{a}}$. При зростанні потенціалів іонізації у межах кожного класу цих органічних сполук (похідні аніліну або піридину) схильність їх до каталітичних ефектів і стимулювання корозії знижується. Отже, при порушенні умов адсорбційної рівноваги, що виникає на поверхні цинку з'являється можливість зворотного переходу електронів від адсорбату до адсорбенту. Це призводить до каталітичного виділення водню в присутності органічних сполук, які схильні до процесів протонізації. Кватернізація атомів нітрогену вуглецевими радикалами виключає можливість протікання реакції протонізації і забезпечує високу захисну дію четвертинних солей піридину при його кислотній корозії.

Для заліза та вуглецевих сталей ефекти каталітичного виділення водню в присутності вільних амінів відіграють значно меншу роль завдяки можливості передачі на їх незаповнені d-орбіталі неподіленої пари електронів атомів нітрогену.

Таким чином, використання адсорбційної моделі, що була запропонована, дозволяє інтерпретувати механізми адсорбції органічних сполук на металах i виявляться доцільним при раціональному підборі інгібіторів корозії металів у водних агресивних середовищах. Комплексне врахування потенціалів іонізації і електричної природи органічних сполук, робіт виходу електрона та $\varphi$ потенціалів металів дає можливість прогнозувати селективну адсорбцію на поверхні металів потенціальних інгібіторів їх корозії. Але при розробці інгібіторів, крім адсорбційних властивостей органічних речовин, необхідно враховувати вплив адсорбованих частинок на реакції корозійних процесів, схильність металів і органічних сполук до реакцій каталітичного виділення водню, наявність на поверхні металів оксидів та гідроксидів та ін.

Із моделі адсорбції органічних сполук на металах витікають шляхи підвищення ефективності захисної дії органічних інгібіторів корозії, які базуються на цілеспрямованій зміні адсорбційних властивостей органічних 
сполук та модифікації поверхневих властивостей металів. До них відносяться наступні:

- цілеспрямований синтез поліфункціональних органічних сполук, схильних до електростатичної та специфічної адсорбції, що можуть виявляти високу захисну дію в широкому діапазоні температур агресивних розчинів;

- використання органічних сполук з електроннодонорними замісниками, які будуть посилювати іiі електронну взаємодію 3 поверхнею металів, та великими за розміром угрупованнями, що спроможні підвищувати захисну дію інгібіторів за рахунок стеричних ефектів;

- $\quad$ кватернізація нітрогенвмісних органічних сполук і пригнічення схильності їх до процесів каталітичного виділення водню, що зазвичай протікають на поверхні s,p-металів;

- використання сумішей органічних сполук з неорганічними аніонами або катіонами - добавками-синергістами, які схильні до зарядної та електронної взаємодії як з органічними сполуками, так і з поверхнею металів;

- модифікування поверхні електродів 3 метою підвищення їх адсорбційної активності за рахунок процесів контактного осадження важких металів, електрохімічного впровадження лужних та лужноземельних металів, утворення гідроксидів та ін.

Інгібітори корозії металів, розроблені співробітниками «КПІ ім. Ігоря Сікорського» [7,20,24], з використанням наведених вище наукових підходів, знайшли практичне застосування при кислотному травленні чорних та кольорових металів (інгібітори серії КПИ, СПХ, СП), їх захисті від кислотної та мікробної корозії у присутності сульфатвідновлюючих бактерій, розробці удосконалених хімічних джерел струму із цинковими та кадмієвими анодами (інгібітори типу ІКС, ІКЩ), комбінованому захисті від корозії вуглецевих сталей $з$ нанесеними на їх поверхню дифузійними покриттями.

\section{3. Висновки}

1. Модель адсорбції органічних сполук на металах, що заснована на уявленнях про утворення комплексів 3 переносом заряду, враховує вплив на протікання адсорбції зарядної та електронної взаємодії між адсорбатом та адсорбентом. Використання цієї моделі $є$ доцільним при інтерпретації 
різних видів адсорбційних процесів та механізмів адсорбції органічних сполук на металах із водних електролітів.

2. Встановлення адсорбційної рівноваги на поверхні металів залежить від ряду фізико-хімічних властивостей адсорбатів та адсорбентів (потенціалів іонізації та електричної природи поверхнево-активних речовин, роботи виходу електрона із металу та його $\varphi$-потенціалу в шкалі Антропова), які необхідно використовувати про моделюванні та прогнозуванні процесів адсорбції на металах.

3. Комплексне використання адсорбційної моделі, що заснована на концепції утворення комплексів 3 переносом заряду, i врахуванням природи агресивного середовища та механізму впливу адсорбованих сполук на часткові реакції корозійних процесів виявляється перспективним при створенні ефективних органічних інгібіторів корозії металів у водних агресивних середовищах.

\section{Література}

[1]. Кузнецов Ю.И. Физико-химические аспекты ингибирования коррозии металлов в водных растворах // Успехи химии. - 2004. - 73, № 1. - С. 79 - 93.

[12]. Кузнецов Ю.И. Современное состояние теории ингибирования коррозии металлов //Ю.И.Кузницов//Защита металлов.-2002.-Т.38, №2.-С.122-131

[3]. Образцов В. Ингибиторы кислотной коррозии стали: Проблемы и перспективы/Фізіко-хімічна механіка матеріалів.-2004.-№4.-С.757-762

[4]. Антропов Л.И., Макушин Е.М., Панасенко В.Ф. Ингибиторы коррозии металлов. - К.; Техника, 1981. - 183 с.

[5]. Антропов Л.И., Погребова И.С. Связь между адсорбцией органических соединений и их влиянием на коррозию металлов в кислых средах //Коррозия и защита от коррозии.-М.:ВИНИТИ АН СССР,1973.- Т.2.Итоги науки.-С.27 112.

[6]. Иванов Е.С. Ингибиторы коррозии металлов в кислых средах. - М.: Металлургия, 1986. - 175 с.

[7]. Погребова I.С. Інгібітори корозії металів. - К.: Хай-Тек пресс, 2012. - 296 c.

[8]. L.I. Antropov, Kinetics of electrode process and null points of metals. New Delhi, 1960, $94 \mathrm{p}$.

[9]. Антропов Л.И. Применение $\varphi$-шкалы потенциалов к проблемам коррозии и защиты металлов // Журнал физической химии. - 1963. - 73, №5. - С. 965 978. 
[10]. Решетников С.Н. Ингибиторы кислотной коррозии металлов. - Л.: Химия, 1986. - 144 с.

[11]. Григорьев В.П. Химическая структура и защитное действие ингибиторов коррозии/ В.П.Григорьев, В.В.Экилек.- Ростов на-Дону:Издательство Ростовского универститета, 1978.-184 с.

[12]. Нечаева Е.А., Куприн В.П. Явление избирательной адсорбции органических веществ на металлах и оксидах // Итоги науки и техники. Сер. Электрохимия. - 1980. - 16, № 8. - С. 1264 - 1268.

[13]. Урбах М.И., Нечаева Е.А. О хемсорбции органических веществ на металлах // Электрохимия. - 1980. - 16, № 8. - С. 1264 - 1268.

[14]. Нечаев Е.А. Хемосорбция органических веществ на оксидах и металлах. - Х.: Высш. школа, 1989. - 144 с.

[15]. Лоренц В. Реакция частичного переноса заряда как элементарный процесс в электрохимических системах // Электрохимия. - 1976. - № 12. - С. $1398-1410$.

[16]. Красильщиков Л.И. Влияние частичного переноса заряда при адсорбции на коррозионные и электродные процессы // Противокоррозионная защита в химической промышленности. - М.: ВНИК, 1985. - С. 24 - 33.

[17]. Ларькин Б.М., Розенфельд И.Л. Корреляция между донорной способностью алифатических аминов и их эффективностью как ингибиторов коррозии по данным квантово-химических расчетов // Защита металлов. - 1976. - 12, № 3. - C. $259-263$

[18]. I.S. Pogrebova, "Using of the HSAB principle for prognosis of the adsorption of the surfactants on the metals", in Proc. $8^{\text {th }}$ Eur. Symp. Corrosion Inhib., Ann. Univ. Ferrara, 1995, Suppl. No 10.

[19]. Погребова И.С. Новые подходы к прогнозированию процессов адсорбции и подбору ингибиторов коррозии металлов // Вопросы химии и хим. технологии. - 1999. - № 1. - С. 265 - 267.

[20]. Погребова І.С. Моделювання процесів адсорбції органічних сполук на металах на основі концепції «жорстких» і «м'яких» кислот та основ//Наукові вісті НТУУ»КПІ--2013.-№6.-С.116-126

[21]. Антропов Л.І. Теоретична електрохімія. - К.: Либідь, 1993. - 540 с.

[22]. Дамаскин Б.Б., Петрий О.А., Батраков В.В. Адсорбция органических соединений на электродах. - М.: Наука, 1968. - 333 с.

[23]. Моисеева Л.С., Е.В.Ступак, Ю.В.Федоров. О связи защитного действия смешаных ингибиторов корозии потенциалами ионизации их компонентов//Защита металлов.-1996.-том 32, №5.-С537-542

[24]. Поргебова I.С., Пилипенко Т.Л., Лоскутова Т.В., Коберник Н.А. Поліфункціональні солі піридину з карбонільними угрупуваннями як інгібітори кислотної та мікробної корозії металів//Проблеми корозії та протикорозійного захисту матеріалів. 2018.- №2.-с250-255 


\section{Chemical and potentiostatic formation of conversion molybadatic coatings on mild steel's surface}

Frolenkova S.V., Motronyuk T.I., Overchenko T.A., Ushchapovskiy D.Yu., Nahorniy A.

National Technical University of Ukraine «Igor Sikorsky Kyiv Polytechnic Institute», Kiev, Peremohy Avenu 37, 03057

Three directions of formation of molybdenum-based coatings on low-carbon steel have been developed: 1 - chemical passivation of steel with the formation of oxide protective films modified with molybdenum compounds; 2 - the restoration of molybdates on the surface of the active steel with the formation of layers of molybdenum dioxide; 3 - the potentiostatic formation of films containing compounds of molybdenum on passive or active steel.

For evaluation of the stability and protective effect of KP, the steel samples, after treatment in molybdenum-containing solutions, were transferred to distilled water or water, measured the potential and evaluated corrosion resistance by massometric method.

Keywords: film, molibdate, conversion coating protective effect, passive or active steel.

\section{Хімічне та потенціостатичне формування конверсійних молібдатних покриттів на маловуглецевій сталі}

Фроленкова С.В., Мотронюк Т.І., Оверченко Т.А., Ущаповський Д.Ю., Нагорний А.

Начіональний Технічний Університет України «Київський політехнічний інститут імені Ігоря Сікорського», м. Київ, Проспект Перемоги 37, 03057 
В сучасному світі все частіше молібденвмісні конверсійні покриття (КП) використовуються замість хроматних, які зазвичай наносять як підшарок під лакофарбні або полімерні покриття, а також як самостійні для тимчасового захисту від атмосферної корозії. Екологічна небезпека технології хроматування спонукала до заміни хроматів на більш екологічно безпечні речовини, такі як трьохзарядний хром, перманганати, молібдати та ванадати. В більшості досліджень визнано, що найбільш перспективними є молібдати, які виявилися ефективними для підвищення корозійної стійкості в атмосфері алюмінію, магнію, цинку та їх сплавів. Але для захисту маловуглецевої сталі, яка $€$ найбільш розповсюдженим матеріалом при виготовленні різноманітних деталей для багатьох галузей промисловості, задача заміни хроматів на даний момент не вирішена взагалі.

Метою даної роботи є дослідження процесів формування захисних плівок на маловуглецевій сталі в ацетатних та боратних розчинах з добавками молібдатіонів. Підгрунтям для вибору ацетатів та боратів як основних компонентів електролітів слугували літературні відомості щодо певних пасивуючих властивостей цих аніонів [1-3].

\section{1. Експериментальна частина}

Розроблено три напрямки нанесення молібденвмісних покриттів на маловуглецеву сталь: 1 - хімічна пасивація сталі 3 утворенням оксидних захисних плівок, модифікованих сполуками молібдену; 2 - відновлення молібдатів на поверхні активної сталі з утворенням шарів діоксиду молібдену; 3 - потенціостатичне формування плівок, що містять сполуки молібдену, на пасивній або активній сталі.

Для оцінки стабільності та захисної дії КП стальні зразки після обробки в молібденвмісних розчинах переносили у дистильовану або водогінну воду, вимірювали потенціал та оцінювали корозійну стійкість масометричним методом. 


\section{2. Результати та їх обговорення}

В першому технологічному режимі самовільна пасивація сталі проявляється в зміщенні потенціалу в позитивному напрямку до величин порядку $+0,1-+0,2$ В (н.в.е.). Зовнішній вигляд поверхні сталі при цьому практично не змінюється, корозія не відбувається. Час обробки поверхні становить 20 - 60 хв. Утворені сірі, інколи зі слабим райдужним відтінком, плівки мають післядію - тимчасово захищають сталь від корозії у воді та в повітряній атмосфері. За даними рентгенівського аналізу плівки містять $2-4$ \% молібдену.

В другому режимі потенціал сталі знаходиться в межах від -0,3 до -0.4 В (н.в.е.), де за рахунок анодної реакції окиснення заліза відбувається процес відновлення розчинних молібдатів до діоксиду молібдену. На поверхні сталі формуються чорні 3 синім відтінком захисні плівки, міцно зчеплені 3 поверхнею сталі. Рекомендована тривалість нанесення покриття становить $5 \div$ 10 хв. Для прискорення процесів відновлення молібдату, в розчин додавали хлорид амонію.

Режим 3 дає можливість управляти складом та властивостями конверсійних покриттів. Зміщення потенціалу в позитивний бік до величини $0,7 \div 0,9 \mathrm{~B}$ обумовлює збільшення товщини та захисної дії пасивної плівки оксиду трьохзарядного заліза, але перешкоджає відновленню молібдату. Зміщення потенціалу в негативний бік до $\mathrm{E}=(-0,7) \div(-0,8)$ В обумовлює прискорення відновлення молібдату до діоксиду молібдену з утворенням фазової плівки 3 одночасним катодним захистом сталі від подальшого розчинення [4].

Потенціал відновлення молібдатів залежить від складу розчину, головним чином від $\mathrm{pH}$. Розрахункові значення рівноважних потенціалів реакцій $[4,5]$

$$
\begin{aligned}
& \mathrm{MoO}_{4}{ }^{2-}+4 \mathrm{H}^{+}+2 \mathrm{e}=\mathrm{MoO}_{2}+2 \mathrm{H}_{2} \mathrm{O} \\
& \mathrm{HMoO}_{4}{ }^{-}+3 \mathrm{H}^{+}+2 \mathrm{e}=\mathrm{MoO}_{2}+2 \mathrm{H}_{2} \mathrm{O}
\end{aligned}
$$

наведені в таблиці (утворення полімерних іонів не враховували).

Заданий сталий потенціал сталі забезпечували за допомогою потенціостата. Досліджено також можливість управління величиною потенціалу шляхом введення в розчин певних добавок та внутрішнього електролізу. Так, добавки 
іонів нітратної кислоти та трьохзарядного заліза сприяють зміщенню потенціалу пасивної сталі в позитивний бік.

Таблиця. Рівноважна концентрація іонів молібдату та потенціали їх відновлення при загальній концентрації молібдену $4,85 \cdot 10^{-3} \mathrm{M}$

\begin{tabular}{|c|c|c|c|c|}
\hline \multirow{2}{*}{$\begin{array}{c}\text { pH } \\
\text { розчину }\end{array}$} & \multirow{2}{*}{$\begin{array}{l}\mathrm{C}_{\mathrm{MoO}_{4}{ }^{2-}} \\
\mathrm{M} \cdot 10^{3}\end{array}$} & \multirow{2}{*}{$\begin{array}{l}\mathrm{C}_{\mathrm{HMoO}^{-}}, \\
\mathrm{M} \cdot 10^{3}\end{array}$} & \multicolumn{2}{|c|}{$\begin{array}{c}\text { Рівноважні потенціали, } \\
\text { В (н.в.е) }\end{array}$} \\
\hline & & & Реакція (1) & Реакція (2) \\
\hline 5,3 & 0,807 & 4,043 & $-0,112$ & $-0,11$ \\
\hline 3,8 & 0,030 & 4,820 & 0,024 & 0,02 \\
\hline
\end{tabular}

Поглиблення пасивного стану досягається також наступними шляхами: утворення на поверхні сталі малорозчинних сполук (добавки катіонів цинку, кальцію, бісмуту, стануму, аніони фосфатів, ацетатів); прискорення реакцій відновлення молібдатів (добавки катіонів амонію, аніонів дігідрофосфатів); формування захисних адсорбційних шарів (аніони органічних кислот, органічні інгібітори).

Зміщення потенціалу сталі до величини, що обумовлює піi катодний захист (технологічний режим 2), досягається зовнішнім контактом стальних зразків 3 цинком в комірці 3 катіонообмінною мембраною (метод внутрішнього електролізу). Сталь занурювали в основний електроліт, а цинк - в фоновий розчин хлориду амонію. При короткому замиканні електродів цинк нав’язує сталі свій негативний потенціал. Величину потенціалу сталі регулювали глибиною занурення, тобто площею цинкового анода. Аноліт поступово збагачується на йони цинку, хоча швидкість розчинення цинку досить мала. При накопиченні великої кількості йонів цинку аноліт можна використовувати для приготування хлористоамонійного електроліту цинкування.

\section{3. Висновки}

При формуванні покриття методом внутрішнього електролізу потенціал сталі мало змінювався в часі. Товщину КП визначали масометричним методом в розрахунку на діоксид молібдену. За одну годину осадження при потенціалі 
$\mathrm{E}=-0,75$ В було отримане покриття товщиною 2,5 мкм. Покриття мало чорний насичений колір, було щільним та міцно зчепленим зі сталевою поверхнею.

Найкращі з точки зору захисної дії КП результати одержано при таких режимах обробки сталі:

1- пасивація сталі при заданому високому позитивному потенціалі (сірі плівки); 2-потенціостатичне формування плівки діоксиду молібдену при високому негативному потенціалі, який обумовлює катодний захист сталі і запобігає підтравленню стальної основи (чорні плівки);

3-двостадійна обробка - пасивація сталі 3 накладанням потенціостатичного відновлення молібдату (чорні, темносині плівки з райдужними відтінками); 4-потенціостатична обробка сталі при потенціалі $-0,15 \div-0.3$ В в такому пасивуючому розчині, де сталь знаходиться в пасивному стані, а молібдати відновлюються, хоча і з невеликою швидкістю (райдужні плівки). Оброблені в подібному режимі стальні зразки переносили у воду і вони залишалися пасивними без ознак корозії впродовж всього терміну випробувань - 168 год.

\section{Літературні посилання}

[1] Lv Jinlong, Liang Tongxiang, 2016. The effect of passivated potential on the passive films formed on pure chromium in borate buffer solution. Surface and Interface Analysis 49 (6).

[2] Donchenko, M.I., Frolenkova, S.V. and Motronyuk, T.I., 2016. The mechanism of mild steel passivation by oxometalates and halogenates in aqueous solutions. Voprosy khimii i khimicheskoi tekhnologii, 2, pp. 26-31.

[3] Frolenkova S.V., Vorobyova V.I., Overchenko T.A., Skiba M.I., 2018. Ecologically safe modified solutions for deposition of conversion coatings on steel. Naukovyi Visnyk NHU, № 6, pp.65-71, ISSN 2071-2227.

[4] Christy, Mary A., Rajendran, S., A Sharmila, A., Devadharshini, K., Sangeetha, P. and Krishnaveni, A., 2015. Corrosion Inhibition by Oxyanions. Int. J. Nano. Corr. Sci. Engg., 2(3), pp. 46-59.

[5] Trela Joanna and Scendo Mieczysław, 2015. Sodium molybdate (VI) as a corrosion inhibitor of carbon steel. Technical Issues, 2, pp. 47-53. 


\title{
Part 4 \\ ELECTROCHEMICAL SENSORS
}

\author{
Розділ 4 \\ ЕЛЕКТРОХІМІЧНІ СЕНСОРИ
}




\title{
Influence of corrosion on percolation of current and mechanical integrity of anodes in oxygen sensors
}

\author{
Buket O.I., Vashchenko O.M. \\ National Technical University of Ukraine "Igor Sikorsky Kyiv Polytechnic Institute”, \\ Peremogy pr.,37,03056, Kyiv, Ukraine
}

The technical realization of scientific research always comes up against the problem of corrosion. This problem often has the following two general technical aspects: the effect of corrosion on the mechanical integrity of an object and the effect of corrosion on the transfer of electric current in the object's body [1]. These aspects acquire some independent significance under the condition of polyphase composite electrodes. Then consider the phenomenon of current percolation through a conductive matrix [2], which prevents the reduction of the cross section of the network of conductors due to their corrosion. In this case, the mechanical integrity and percolation of current do not correlate with each other absolutely exactly. Therefore, such a case, characteristic of porous lead anodes of amperometric sensors [3], requires detailed study. The relevance of the study is substantiated by the importance of the problem of reliability of technical means of monitoring the suitability of air for human breathing, an important component of which are amperometric sensors [4]. The results obtained showed that the magnitude of the corrosion conversion of the mass of the electrode affects the current and strength of the electrodes in full accordance with the geometric parameters of the structural components of the porous electrode. The main parameters are the grain size, the area (or average diameter) of the contact patch of the grains and the relative porosity of the electrode. Therefore, the deep corrosion indicator, as meaningfully closest to the geometry, should adequately assess the effect of corrosion on the reliability of electrodes, taking into account their mechanical integrity and current percolation by their conductive matrix. It is shown that an inversion of the action of crevice corrosion is observed, which results in the preferential oxidation of the metal not in the gap, but opposite the free pore due to current shielding in the electrolyte solution volume, which substantiates the technical possibility and feasibility of using porous pressed electrodes. Without such an inversion, the use of porous pressed electrodes would be fundamentally inexpedient due to the loss of current percolation and mechanical integrity at the slightest anodic oxidation of the electrode material.

Keywords: amperometric oxygen sensor, porous lead anode, corrosion, resource, mechanical integrity, current percolation. 


\title{
Вплив корозії на перколяцію струму і механічну цілісність анодів сенсорів кисню
}

\author{
Букет O.I., Ващенко O.M.
}

Національний технічний університет Украӥни "Київський політехнічний інститут імені Ігоря Сікорського", пр-т Перемоги, 37, 03056 м. Київ, Украӥна

Технічна реалізація наукових розробок завжди наштовхується на проблему корозії. Ця проблема часто має наступні два загально технічні аспекти: вплив корозії на механічну цілісність об'єкту та вплив корозії на перенос електричного струму в тілі об'єкту [1], що особливо характерно для технічної електрохімії. Найчастіше ці аспекти є жорстко взаємопов'язаними. Лише за умови поліфазних композиційних електродів вони набувають деякого самостійного значення. Тоді розглядають явище перколяції струму через електропровідну матрицю [2], якому перешкоджає скорочення перетину мережі провідників внаслідок їх корозії. У цьому випадку механічна цілісність і перколяція струму не корелюють між собою абсолютно точно. Тому такий випадок, характерний для пористих свинцевих анодів амперометричних сенсорів [3], вимагає детальнішого вивчення. Актуальність дослідження обгрунтовується важливістю проблеми надійності технічних засобів моніторингу придатності повітря для дихання людини, важливою складовою яких є амперометричні сенсори [4].

Попередні дослідження підтвердили надійність системи свинець-лужний електроліт в умовах природних концентрацій вуглекислого газу у повітрі як 3 теоретичної точки зору (за термодинамікою електрохімічних процесів), так і експериментально [5]. Назріла потреба визначити надійність іiі технічної реалізації. 


\section{1. Методика експерименту}

Експерименти проводили на електродах розміром $\varnothing 18 \times 8$ мм пресованих 3 гранул свинцю середнім діаметром 1 мм, аналогічних електродам, дослідженим раніше [5]. Вимірювання проводили за звичайною триелектродною схемою в стандартній комірці з комплекту потенціостата ПИ-50-1.1. Дослідні електроди піддавали анодній поляризації у лужному розчині $30 \%$ КОН. Випробування проводили при струмовому навантаженні на електроді від 0,1 до 100 мА. Після пропускання 10 \% від теоретичного ресурсу електрода, його виймали з розчину, промивали, сушили фільтрувальним папером. Зазвичай зусилля на стиснення при експлуатації сенсорів кисню не переважають 5 кг. Тому випробовування на міцність промитих і висушених електродів проводили між двома пласкими керамічними плитками, верхню 3 яких навантажували ємністю 35 л води. Випробовували партії однотипних електродів кількістю від 7 штук.

\section{2. Результати та їх обговорення}

Як і було показано раніше [5], за умови наявності свинцю і його самовільної корозії або примусового анодного окиснення повна карбонізація лужних розчинів не відбувається. Попередні експерименти [3] також показали, що оптимальною пористістю свинцевих анодів є 16 \%. Цій пористості відповідає максимально можлива площа контакту зерен при можливості акумулювати у порах електрода максимальну кількість продуктів анодного окиснення металу [3]. За цієї умови вдається досягти ступеню використання маси свинцю до 25\% і навіть $30 \%$.

Максимально можливий ресурс електрода визначали як такий, що відповідає повній втраті перколяції струму. В описаних умовах експлуатації випробовувані аноди втрачали перколяцію струму при використанні близько 25 \% маси електрода, яка у даних дослідах становила 16,0 г. Витрачений у досліді відносний ресурс $p_{a}$ визначали у відсотках від максимально можливого за законом Фарадея відповідно до рівняння 


$$
p_{a}=\frac{I \cdot \tau \cdot M}{0.25 \cdot m \cdot z \cdot F} \cdot 100 \%
$$

де $\mathrm{M} \mathrm{i} \mathrm{z} \mathrm{-} \mathrm{молярна} \mathrm{маса} \mathrm{і} \mathrm{число} \mathrm{еквівалентів} \mathrm{досліджуваного} \mathrm{металу,} \mathrm{F} \mathrm{-} \mathrm{число}$ Фарадея, $\mathrm{m}$ - маса електрода, 0,15 - максимально можливий ступінь використання маси електрода, I - сила струму випробувань, $\tau$ - тривалість випробувань.

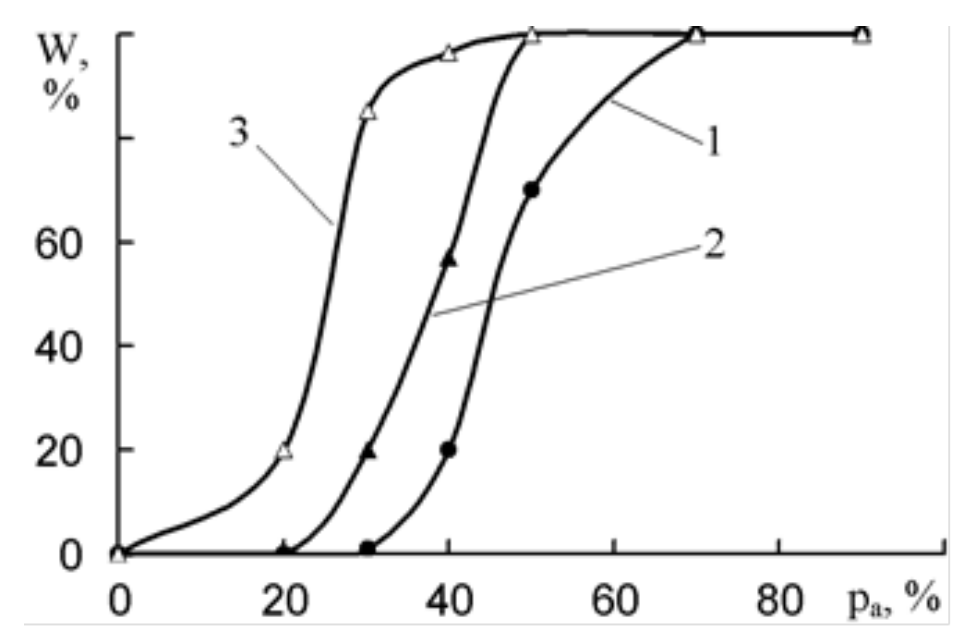

Рис. 1. Залежність вірогідності W втрати міцності пористого свинцевого анода від відносного використання його ресурсу за рівнянням (1), сила анодного струму, мкА: $1-10 ; 2-100 ; 3-1000$.

Вірогідність втрати форми електрода під зусиллям 5 кг за одержаними результатами наведена рис. 1, з якого видно, що випробовування електродів струмами до 10 мкА мало впливає на відмінності у міцності - практично всі електроди руйнуються під дією зусилля 5 кг при використанні 50 \% від максимально можливого ресурсу. Збільшення сили струму веде до переважного окиснення електродів по зовнішній, видимій циліндричній поверхні й призводить до передчасного руйнування. Причина полягала у тому, що зусилля стиснення прикладалося до саме до дисковидних торців електродів, один з яких 
у дослідах був повернений до допоміжного електрода дослідної комірки аналогічно тому, як подібні електроди повернені до протилежного електрода у сенсорних системах. Зерна свинцю у названому торці циліндричного анода

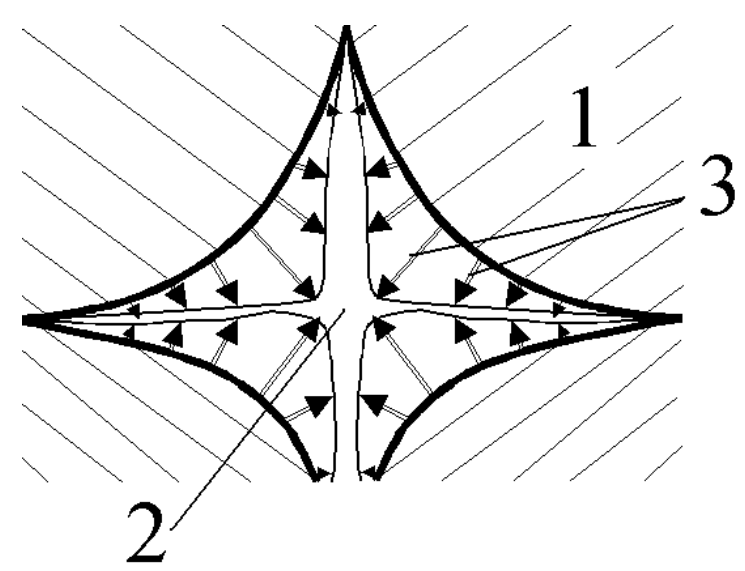

піддавалися найбільш інтенсивному окисненню, наслідком чого була швидка втрата міцності.

Рис. 2. Нерівномірна поляризація поверхні пористого електрода внаслідок взаємного екранування струму в об’ємі розчину електроліту у порі, 1 - метал; 2 - електроліт; 3 - розподіл векторів струмового навантаження

Одержані результати вказують на цілковиту інверсію дії корозії у щілині. Так відомо, що щілинна самовільна корозія 3 кисневою i навіть водневою деполяризацією сприяє анодному окисненню металевого виробу перш за все в малодоступних місцях внаслідок нерівномірної поляризації уповільненим транспортом деполяризатора. Проте в амперометричному сенсорі деполяризатор відновлюється переважно на робочому електроді, внаслідок чого струм у щілині взаємно екранується, як показано на рис. 2. Тому, окиснення зерен свинцю йде переважно навпроти пори, яка $є$ каналом переносу струму по провіднику другого роду. Така інверсія принципово уможливлює експлуатацію пористих пресованих електродів. Інакше всі електроди подібної конструкції виходили $б$ з ладу при використанні першого ж відсотка від теоретичного pecypcy. 
3 цих причин збільшення плями контакту між зернами свинцю внаслідок підвищення зусилля пресування має сприяти збільшенню максимально можливого ресурсу електрода за струмом. Додаткові експерименти показали пропорційне зростання ресурсу міцності - руйнування електродів спостерігається при використанні 70 \% від максимального ресурсу за струмом. Проте одночасно було показано, що при цьому знижується надійність електродів по мірі зменшення їх пористості. Для електродів 3 пористістю менше $20 \%$ іноді виявляється особливий вид руйнування під дією корозії розрив електродів під дією внутрішньопорового тиску продуктів корозії. Випробовування свинцевих електродів, аналогічних описаним до рис. 1, у розчині $30 \% \mathrm{KOH} \mathrm{при} \mathrm{струмі} \mathrm{анодного} \mathrm{окиснення} 500$ мкА показало, що при зниженні пористості електрода від $20 \%$ і нижче росте вірогідність розриву електрода під дією тиску, який створює більший об’єм $\mathrm{PbO}$, утворюваний на місці окисненого свинцю. Тому, як було показано раніше [3], оптимальною пористістю свинцевого електрода є 16 \%, оскільки при вищій пористості максимально можливий ресурс знижується внаслідок зменшення площі плями контакту зерен, а при нижчій пористості максимально можливий ресурс значно переважає здатність пор приймати у себе об’ємні продукти корозії без значної деформації, що викликає передчасний розрив електрода як струмопровідної матриці.

\section{3. Заключення}

3 одержаних результатів можна зробити висновок, що величини корозійного перетворення маси електрода впливають на ресурс електродів за струмом та за міцністю у повній відповідності до геометричних параметрів структурних складових пористого електрода. Визначальними параметрами є розмір зерна, площа (або середній діаметр) плями контакту зерен та відносна пористість електрода. Тому глибинний показник корозії, як змістовно найбільш близький до геометрії, має дозволяти адекватно оцінювати вплив корозії на надійність 
електродів 3 огляду на їх механічну цілісність та перколяцію струму по їх електропровідній матриці. Показано, що спостерігається інверсія дії щілинної корозії, наслідком чого є переважне окиснення металу не в щілині, а навпроти вільної пори внаслідок екранування струму в об’ємі розчину електроліту, що обгрунтовує технічну можливість i доцільність застосування пористих пресованих електродів. Без такої інверсії застосування пористих пресованих електродів було б принципово недоцільним внаслідок втрати перколяції струму й механічної цілісності при найменшому анодному окисненні матеріалу електрода.

\section{Література}

[1] Talbot, D., Talbot, J. (2018). Corrosion Science and Technology. Boca Raton: CRC Press.

[2]SB Aziz, Study of electrical percolation phenomenon from the dielectric and electric modulus analysis, Bulletin of Materials Science, 2015 - Springer.

[3] Амперометричний сенсор для визначення кисню у повітрі; Патент України на корисну модель; № 84847 дата 11.11.2013.

[4]P.Kumar, A.N. Skouloudis, M.Bell, M.Viana, M.C.Carotta, G.Biskos, L.Morawska, Real-time sensors for indoor air monitoring and challenges a head in deploying them to urban buildings, Science of The Total Environment, Volumes 560-561, 2016, Pages 150-159.

[6]O.Vashchenko, O.Buket, Prevention of carbonization in the alkaline electrolyte of oxygen sensor, Promising Materials and Processes in Applied Electrochemistry: Monograph. Kyiv.: KNUTD,2017. - Pages 157-163. 


\section{Part 5 \\ MODERN ELECTROCHEMICAL AND RELATED TECHNOLOGIES}

\section{Розділ 5 \\ СУЧАСНІ ЕЛЕКТРОХІМІЧНІ ТА СПОРІДНЕНІ ТЕХНОЛОГІї}




\title{
Inversion of metal oxide composites structural matrixes
}

\author{
Sakhnenko N.D., Ved' M.V., Karakurkchi A.V., Mayba M.V. \\ National Technical University Kharkiv Polytecnic Institute, 2, Kyrpychova str., \\ Kharkiv, 61002
}

The principles of formal description for the metal-oxide systems with a wide spectrum of application fields, based on electrochemical technologies of synthesis an are offered. The description of the such systems state is proposed to be constructed by the graphs theory, which allows to visualize the nature of transformations and to establish quantitative parameters of dynamics of the indicated processes as the intensity of transitions between individual states. A generalized inversion scheme of a two-component bimetal system is constructed, which takes into account the presence of individual metals, their alloy, two monoxides and a hetero oxide compound. The factors influencing the nature and intensity of transitions between the nodes of the graph are analyzed and an example of inversion of a metal oxide composite structural elements is shown.

Key words: electrochemical synthesis, inversion, metal oxide systems, structural elements, formalization

\section{Інверсія структурних матриць металоксидних композитів}

Сахненко М.Д., Ведь М.В., Каракуркчі Г.В., Майба М.В.

Національний технічний університет «Харківський політехнічний інститут», м. Харків, вул. Кирпичова, 2, 61002

Сучасним трендом хімічного матеріалознавства $є$ створення так званих smart матеріалів 3 невичерпними галузями застосування. Та однією з непересічних проблем, що гальмують впровадження таких матеріалів, $є$ їхня висока собівартість, необхідність залучення прецизійного обладнання та високих технологій, багатостадійність. Означені, та інші чинники, схожі за природою, значно стримують використання таких матеріалів, та, з іншого боку, сприяють 
розвитку новітніх технологій i одержанню нових знань. Одним із шляхів подолання принаймні частини 3 перелічених проблем $\epsilon$ застосування smart матеріалів не в формі консолідованої субстанції, а покривів варійованої товщини, сформованих на поверхні металевих носіїв, що дозволяє досягти суттєвої економії коштовних металів, сплавів та їхніх сполук. Така методологія майже завжди виправдана, оскільки в переважній більшості випадків застосування функціональних матеріалів передбачає роботу лише їх поверхневого шару, тому захисні, діелектричні, каталітичні, високопровідні, резистивні та ін. властивості реалізуються саме в поверхневих шарах, незалежно від ступеню шорсткості. Значною мірою це стосується і всього розмаїття металоксидних систем (MOC) - від монооксидних захисних до композитних і гетерооксидних електрохімічних покривів. Однак погляди на структуро- і фазоутворення в поліметалевих і оксидних системах різняться, що не дозволяє з єдиних позицій здійснювати їх дизайн, а відтак і оптимізацію технологічних процесів виробництва, тому створення узагальненого опису МОС є нагальною потребою сьогодення.

\section{1. Стан проблеми}

В поточний час серед покривів значну роль відіграють композитні матеріали 3 металевою матрицею, до складу яких в ролі другої фази інкорпоровано оксиди - алюмінію, титану, цирконію, та ін. Застосування саме металевої матриці, яку формують на металевій підкладці, має численні переваги $[1,2]$.

Водночас не менш розповсюдженими є і оксидні покриви, головним чином на вентильних металах - титані, цирконії, алюмінії, ніобії, танталі. В деяких галузях промислового виробництва (гетерогенний та фотокаталіз, сенсорні елементи, нано- та мікроелектроніка) до складу таких оксидних покривів включають в ролі легувальних компонентів метали та їхні оксиди, що надає змогу суттєво поліпшувати функціональні властивості таких гетерооксидних композитів [3-5].

Серед практично реалізованих технологій композитних матеріалів i покривів можна виділити численні групи способів, що різняться за принципами 
організації - металургійні, термоконденсаційні, просочування та випалу, полімеризації, золь-гель і т.і. Втім можна виокремити сукупність гальванохімічних методів - катодне осадження, анодне оксидування, зокрема i плазмово-електролітичне, електрофорез та ін., візитівкою яких $\epsilon$ одностадійність, можливість реалізації на серійному обладнанні, високий рівень адаптації до автоматизації та робототехніки, гнучке керування перебігом процесу, висока продуктивність та інші, не менш значущі елементи, які роблять такі технології майже безальтернативними. Відзначимо ще одну, майже не реалізовану можливість таких технологій, - здатність до інтеграції в одному технологічному циклі різних гальванохімічних способів синтезу. Як приклад, наведем реалізований нами при створенні магнітоелектричних наноламінатів технологічний ланцюг, до складу якого входили плазмово-електролітичне оксидування та електрофоретичне осадження [6].

\section{2. Робоча гіпотеза}

Наведені тези є елементами логічного кортежу, що складає підгрунтя до нової парадигми хімічного матеріалознавства в царині створення smart матеріалів - інверсія природи структурних елементів металоксидних композитів за рахунок варіації технологічних засад [7]. Як приклад можна розглядати такі системи, як $\mathrm{Ni}-\mathrm{TiO}_{2}, \mathrm{Ni}-\mathrm{Al}_{2} \mathrm{O}_{3}, \mathrm{Fe}-\mathrm{ZrO}_{2}$ та ін. [8, 9], в яких структурні елементи «матриця» $\mathrm{i}$ «друга фаза» можна інвертувати за рахунок змінення режимів i параметрів електролізу та компонентного складу електролітів. Саме на таких засадах можна докорінно змінювати вміст та співвідношення окремих фаз, формувати наперед задану геометрію поверхні від майже дзеркально блискучої до рівномірно поруватої або 3 високою питомою площею. Системне дослідження інверсії структури металоксидних композитів дозволить одержати нові знання щодо чинників впливу на тонку структуру матеріалів, виявити квантові ефекти в нанорозмірних шарах покривів [10], здійснювати легування таких структур в широких межах варіювання компонентів, а також проводити цільовий пошук високоефективних матеріалів і структур для потреб багатьох галузей промислового комплексу. 


\section{3. Формалізований опис інверсії двохкомпонентних систем}

На наш погляд узагальнену схему інверсії двокомпонентної біметалевої (M1 i M2) системи доцільно надати у вигляді орієнтованого графа, що дозволяє наочно відобразити природу перетворень і встановити кількісні параметри динаміки означених процесів (інтенсивності переходів між окремими станами системи). Запишемо трансформації, які будуть мати місце в такій металоксидній системі, в формі брутто-рівнянь, а окремі фази будемо асоціювати з вузлами графа.

До числа перетворень слід віднести утворення індивідуальних оксидів

$$
\begin{aligned}
& \mathrm{M} 1 \rightarrow(\mathrm{M} 1 \mathrm{Ox}), \\
& \mathrm{M} 2 \rightarrow(\mathrm{M} 2 \mathrm{Oy}),
\end{aligned}
$$

і змішаного оксиду (гетерометалевого оксиду)

$$
(\mathrm{M} 1 \mathrm{M} 2) \rightarrow(\mathrm{M} 1 \mathrm{Ox} \cdot \mathrm{M} 2 \mathrm{Oy})
$$

Крім цього, врахуємо формування біметалевого сплаву (інтеметаліду)

$$
\mathrm{M} 1 \leftrightarrow(\mathrm{M} 1 \mathrm{M} 2) \leftrightarrow \mathrm{M} 2,
$$

а також власне композиту з металевою матрицею варійованої природи

$$
\begin{aligned}
& \mathrm{M} 1 \rightarrow(\mathrm{M} 1 \cdot \mathrm{M} 2 \mathrm{Oy}) \leftarrow(\mathrm{M} 2 \mathrm{Oy}) \\
& \mathrm{M} 2 \rightarrow(\mathrm{M} 2 \cdot \mathrm{M} 1 \mathrm{Ox}) \leftarrow(\mathrm{M} 1 \mathrm{Ox}),
\end{aligned}
$$

Цілком природно, рівняння (1) - (6) відбивають лише сенс формування фаз, але не механізм реакцій, i в кожному конкретному випадку мають бути деталізовані. Так, наприклад, формування гетерооксиду М1Ox·М2Оу можна надати як наслідок перебігу реакцій за маршрутом (3), або ж як результат парціальних перетворень (1) і (2).

3 урахуванням викладеного, вузли графу станів складуть наступні структурні елементи:

$$
\text { (M1), (M2), (M1M2), (M1Ox), (M2Oy), (M1Ox·M2Oy), }
$$


до яких віднесено як індивідуальні метали (M1) i (M2) та їх сплав (інтерметалід) (М1M2), так і монооксиди (M1Ox) і (M2Oy), а також гетерооксид $(\mathrm{M} 1 \mathrm{Ox} \cdot \mathrm{M} 2 \mathrm{Oy})$.

Вочевидь сукупність рівнянь (1) - (6) і відповідні ланки графа, що відображають динаміку переходів між його структурними елементами (7), дозволяють сформувати двовимірний графічний образ в формі циклічної фігури. У той же час називати їі графом певною мірою не зовсім коректно, оскільки в 2D форматі графічний образ матиме ребра, які перетинаються, тоді як за правилами побудови графів така процедура є неприпустимою. Однак цей аспект запропонованої схеми саме і відображає головну ідею - інверсію структурних матриць КЕП, а враховуючи можливість введення ще одного універсального елемента графа - інтермедіата Im, який відповідає сукупності проміжних станів на всіх етапах трансформації металоксидної системи (сплавотворення, формування композитного електрохімічного або гетерооксидного покриву і т.і), узагальнена схема набуває завершеного вигляду

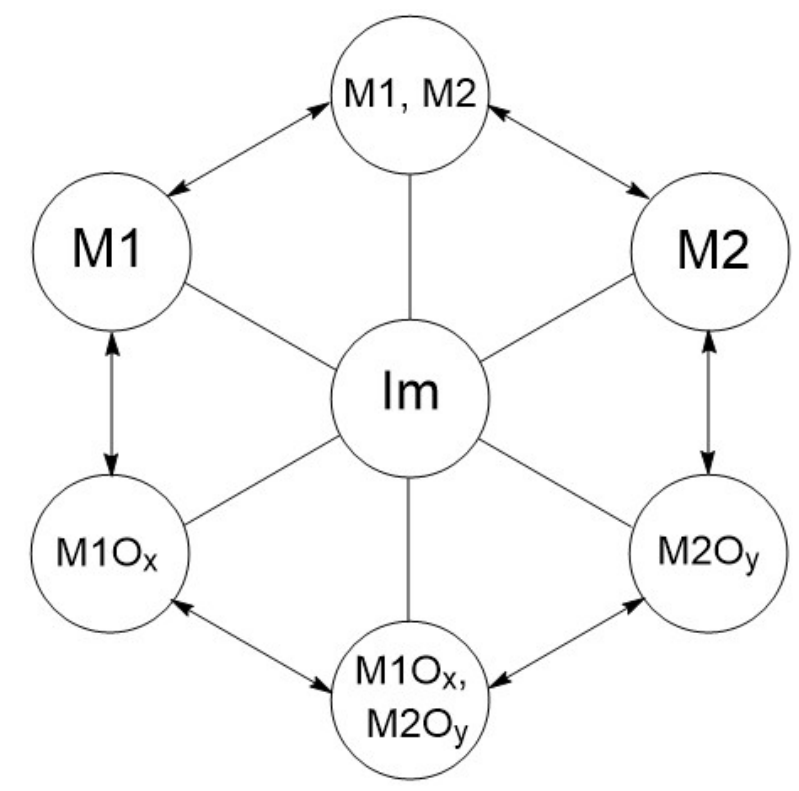

Рис. 1. Граф станів біметалевої металоксидної системи

Інтенсивності переходів між окремими вершинами графа на рис.1. - це саме електрохімічні реакції, швидкості яких обумовлюються значною кількістю чинників (рис.2), серед яких природа, склад і співвідношення компонентів 
електролітів, природа поляризації (анодна, катодна, реверсивна), режим електролізу (стаціонарний, нестаціонарний, імпульсний і т.п.), а також його амплітудні і часові параметри [11]. Саме сукупнісь перелічених та значна кількість інших чинників в підсумку визначають не тільки склад консолідованого матеріалу або покриву, але і його структуру та морфологію, ступінь локалізації окремих фаз, їх розподіл по товщині матеріалу, та врешті решт властивості і галузі практичного застосування. Зрозуміло, що для формалізації поліметалевих тернарних систем, як у [12], візуалізацію в означений спосіб зробити складно, тут в нагоді стане науковий доробок фізичної хімії з топологічного опису багатокомпонентних силікатних систем.

Наведена на рис.1 схема має і глибокий філософський підтекст, оскільки являє собою деяку фізико-хімічну «аватару», як втілення взаємозв'язку i взаємозумовленості процесів 3 їх внутрішнім змістом і красою зовнішнього прояву.

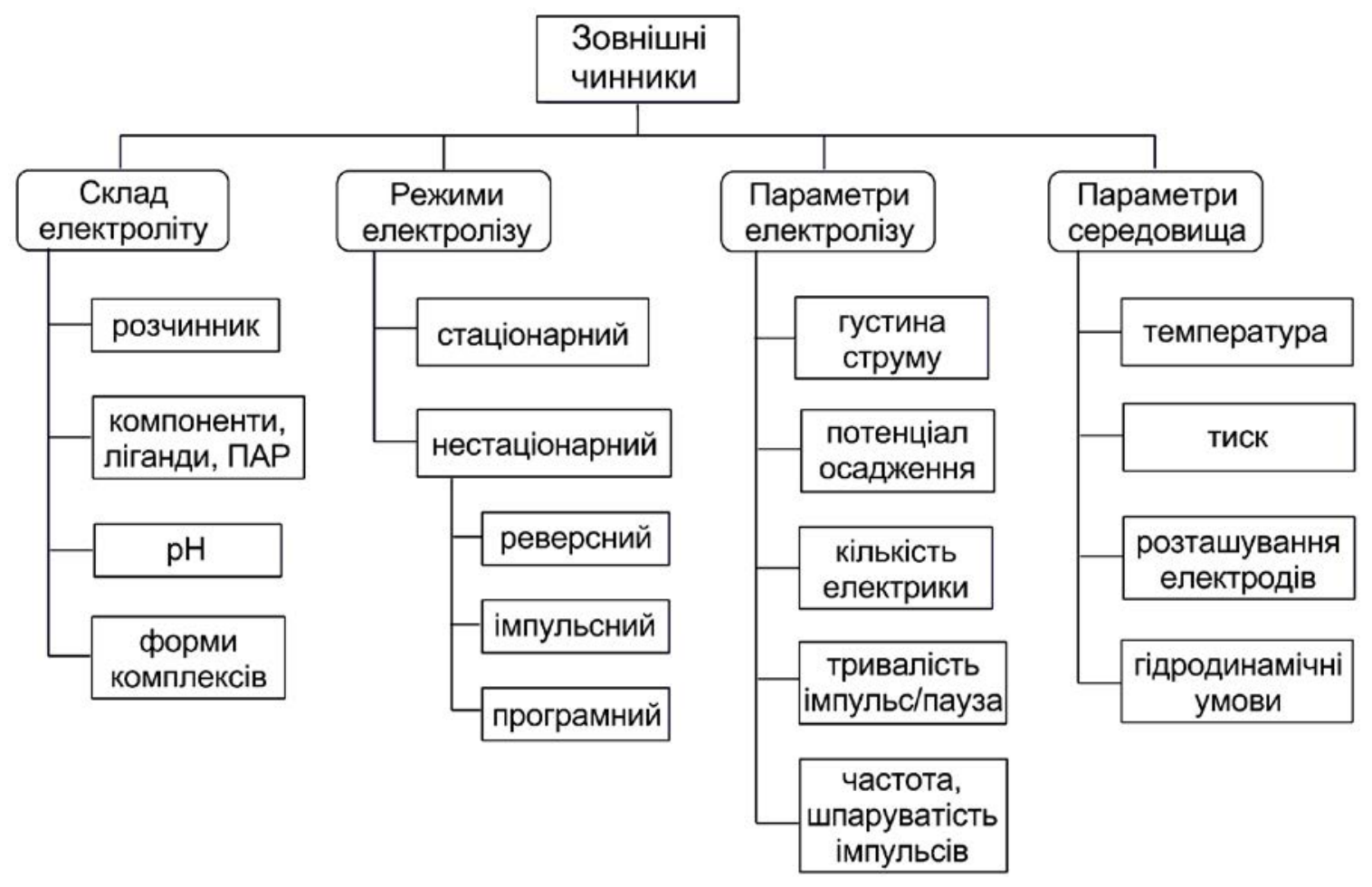

Рис. 2. Зовнішні чинники електролізу

Як приклад реалізації взаємних перетворень в такій біметалічній системі можна навести систему $\mathrm{Ni}-\mathrm{Al}$, для якої, зокрема, утворення сплаву, добре відомого в металургії як ПМ-НЮ50 за ТУ 14-22-101-96, може бути реалізовано 
електролізом в неводних розчинах, формування композитів з металевою та/або оксидною матрицями - широко відомо, а гетерооксидний покрив наносять в режимі плазмово-електролітного оксидування. Так, зокрема, армуванння КЕП 3 нікелевою матрицею оксидом алюмінію підвищує фізико-механічні властивості композиту [13], а інкорпорування нанорозмірних металевих частинок до оксидної матриці підвищує хімічний опір КЕП в лужних середовищах і надає такому покриву каталітичних властивостей.

\section{4. Висновки}

За результатами аналізу інформаційних джерел обгрунтовано доцільність побудови формалізованого опису металоксидних систем з широким спектром галузей застосування, технології синтезу яких мають електрохімічне підгрунтя. Запропоновано опис стану таких систем конструювати із залученням теорії графів, що надає можливість наочно відобразити природу перетворень i встановити кількісні параметри динаміки означених процесів як інтенсивності переходів між окремими станами. Побудовано узагальнену схему інверсії двокомпонентної біметалевої системи, яка враховує присутність індивідуальних металів, їх сплаву (інтерметаліду), двох монооксидів та

гетерооксидної сполуки. Проаналізовано чинники впливу на природу та інтенсивність переходів між вузлами графа та наведено приклад інверсії структурних елементів металоксидного композиту.

\section{Література}

[1]. V.N. Tseluikin, Protection of Metals and Physical Chemistry of Surfaces, 52 (2016) 254.

[2]. M. V. Ved', M. D. Sakhnenko, O. V. Bohoyavlens'ka, T. O. Nenastina, Materials Science, 44 (2008) 79.

[3]. N.D. Sakhnenko, M.V. Ved, A.V. Karakurkchi. Nanoscale Oxide PEO Coatings Forming from Diphosphate Electrolytes. Chapter 38, in: Nanophysics, Nanomaterials, Interface Studies, and Applications, Springer Proceedings in Physics 195. O. Fesenko, L. Yatsenko (Eds.), 2017, 507 
[4]. G.Sh. Yar-Mukhamedova, M.V. Ved', A.V.Karakurkchi and N.D.Sakhnenko, IOP Conf. Series: Materials Science and Engineering 213 (2017) 012020, 6 p.

[5]. A. Karakurkchi, M. Sakhnenko, M. Ved', A. Gorohivskiy, O. Galak, S.Menshov, O. Matykin, in: Promising Materials and Processes in Applied Electrochemistry. Kyiv: KNUTD, 2017, 214.

[6]. Н.Д. Сахненко, М.В. Ведь, М.В. Майба Конверсионные и композиционные покрытия на сплавах титана / Х.: НТУ «ХПИ», 2015. - 176 с.

[7]. М.Д. Сахненко, М.В. Ведь, Г.В. Каракуркчі. ХХ Українська конференція 3 неорганічної хімії : Тези доповідей, Дніпро : ЛІРА, 2018, 142

[8]. Tushar Borkar, Sandip P. Harimkar, Surface \& Coatings Technology 205 (2011) 4124

[9]. E.A. Vasil'eva, A.V. Tsurkan, V.S. Protsenko, and F.I. Danilov, Protection of Metals and Physical Chemistry of Surfaces 52 (2016) 532.

[10]. N.D. Sakhnenko, A.V. Karakurkchi, M.V. Ved, A.S. Gorohivskiy, A.V. Galak, International conference on Nanotechnology and nanomaterials, Book of abstracts. Lviv : Eeurosvit, 2016, 320.

[11]. M.D. Sakhnenko, M.V. Ved', I.Yu. Ermolenko, Yu.K. Hapon, M.O. Kozyar, Mater Sci. 52 (2017) 680

[12]. A. V. Karakurkchi, M. V. Ved', I. Yu. Ermolenko, and N. D. Sakhnenko Surface Engineering and Applied Electrochemistry 52 (2016) 43.

[13]. М.Д. Сахненко, М.В. Ведь, О.О. Овчаренко, Фізико-хімічна механіка матеріалів 53 (2017) 76. 


\title{
Features of properties of PVC compositions filled by graphite
}

\author{
Shariko Ye., Novak D., Plavan V., Bereznenko N. \\ Kiev National University of Technology and Design (KNUTD)
}

The work is devoted to the study of approaches for the creation of composite materials based on polyvinyl chloride with dispersed filler. As a result of the theoretical and experimental studies, the influence of various types of fillers on the structure of composite films was established. The electrophysical and mechanical properties of compositions based on polyvinyl chloride and graphite were analyzed. The influence of the filler content on the properties of composites was analyzed.

Keywords: polyvinyl chloride, graphite, composite, electrophysical properties, mechanical properties.

\section{Особливості властивостей ПВХ композиції, наповненої графітом}

\author{
Шарико С.М, Новак Д.С., Плаван В.П., Березненко Н.М. \\ Київський національний університет технологій та дизайну, м. Київ, \\ Немировича-Данченка, 2, 01011
}

Через високий електричний опір полімери використовуються переважно в електротехніці як ізолятори. В ряді випадків, однак, потрібно, щоб полімери були струмопровідними. Полімерні струмопровідні композиційні матеріали знаходять сьогодні широке використання для виготовлення електронагрівальних елементів, екрануючих та антистатичних покриттів, струмопровідних клеїв, фарб, паст, елементів повітряних фільтрів, у медицині для стимулювання росту кісткових тканин, як антитромбогенні імплантанти [1].

Підвищення струмопровідності можна досягнути введенням $\mathrm{y}$ композиційний матеріал струмопровідних наповнювачів, наприклад металічних порошків, волокон, різних типів технічного вуглецю, графіту, графітових 
волокон. Як зв’язуючий матеріал найбільшого використання одержали фенолформальдегідні, епоксидні, фуранові та деякі інші смоли, які в результаті затвердіння утворюють тривимірні структури, а також деякі термопласти та каучуки. Однак такі полімерні матеріали та методи їх одержання не завжди забезпечують однорідність наповнення і потрібні властивості.

На сьогоднішній день у світовій практиці серед гнучких полімерів домінують полівінілхлоридні (ПВХ) пластикати. Однією 3 основних причин широкого використання ПВХ пластикату $є$ його здатність до модифікації шляхом змішування із цільовими добавками і одержання необхідних властивостей матеріалів для переробки відомими методами (екструзія, вальцювання, каландрування), здатність згасати після винесення із полум’я та ін.

Дослідження залежності величини струму від Т (при швидкості лінійного нагріву зразка 3 K/хв.) [2] вихідного ПВХ показали, що в діапазоні температур 293-385 К на спектрі деполяризації фіксуються максимуми сили струму в області 313 K та $\alpha$-релаксаційного переходу, які відповідають гетерозаряду. Заряд композиційних ПВХ-електретів спадає із збільшенням ступеня наповнення, починаючи $3 \varphi=0,5$ \% об. Це пояснюється тим, що при збільшенні концентрації наповнювача, зменшується об’єм полімерного матеріалу, який підлягає поляризації.

Також в роботі [3] показана можливість створення полімерних композитів на основі ПВХ з різними типами та комбінаціями наповнювачів 3 гнучкими i регульованими електропровідними властивостям.

\section{1. Постановка завдання}

Одним із простих і ефективних способів, який забезпечує композитам нові прогнозовані характеристики, $\epsilon$ введення в полімери наповнювачів різної хімічної природи, форми та розмірів. У струмопровідних полімерних композицій реалізується перколяційний характер залежностей електричних характеристик [4]. У відносно вузькому діапазоні концентрацій електричний опір міняється особливо різко, що пов язано 3 формуванням стійкої струмопровідної решітки наповнювачем [5]. 
Аналізуючи вищесказане була поставлена задача створення сучасних струмопровідних полімерних матеріалів на основі ПВХ з додаванням графіту.

\section{2. Результати досліджень}

Для дослідження використані: емульсійний полівінілхлорид (EПВX) Vinnolit ЕР6854, графіт марки МСМВ (ТВ-17), диоктилфталат.

Створення полімерних композитів включає такі етапи: змішування компонентів композитів, отримання зразків композитів методом спікання у формі. Перемішування компонентів кожного полімерного композиту відбувалось за допомогою верхньопривідної мішалки протягом 5 хвилин. Отриману суміш засипали у циліндричну форму діаметром 26 мм та спікали при температурі $190^{\circ} \mathrm{C}$ і витримували їх протягом 10 хвилин. Після чого зразки виймали з форми. Зразки композитів отримували у вигляді круглих пластинок діаметром 26 мм і товщиною 1,5 мм. Об’ємний вміст наповнювача в композитах варіювався в межах від 1 \% об. до 30 \% об.

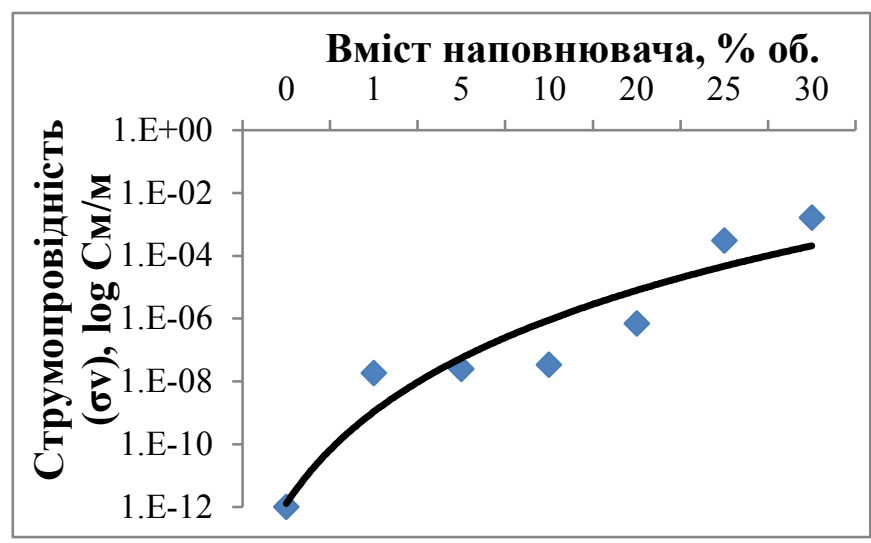

Рис. 1. Залежність струмопровідності від вмісту наповнювача для зразків ПВХ, наповненого графітом.

На рис. 1 представлено залежність струмопровідності при постійному показнику струму та кімнатній температурі $\left(22^{\circ} \mathrm{C}\right)$ від вмісту наповнювача для досліджуваних систем на основі ПВХ і графіту, густина яких становить 1,35

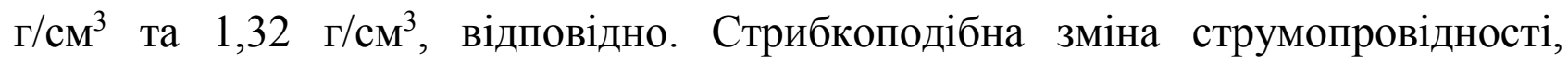
пов'язана 3 явищем перколяції, спостерігається в концентраційному діапазоні 1 - 20 \% об. При вмісті 20 \% об. графіту струмопровідність системи на півтора 
порядки більше, ніж до порога перколяції. Така різка зміна провідності пов'язана 3 дисперсією наповнювача в полімерній матриці та утворенням мережі графітових провідних каналів [6]. Критичний вміст графіту робить можливим перехід електрона крізь ізолюючі прошарки полімеру та сприяє різкому збільшенню провідності.

Суттєвим недоліком дисперсно-наповнених струмопровідних полімерних композитів є нестабільність їх властивостей, яка може бути пов язана з рядом причин, наприклад, нерегульованою зміною структури агрегатів наповнювача. Тому, важливо, щоб такі матеріали мати не тільки задані, а і стабільні струмопровідні та механічні властивості.

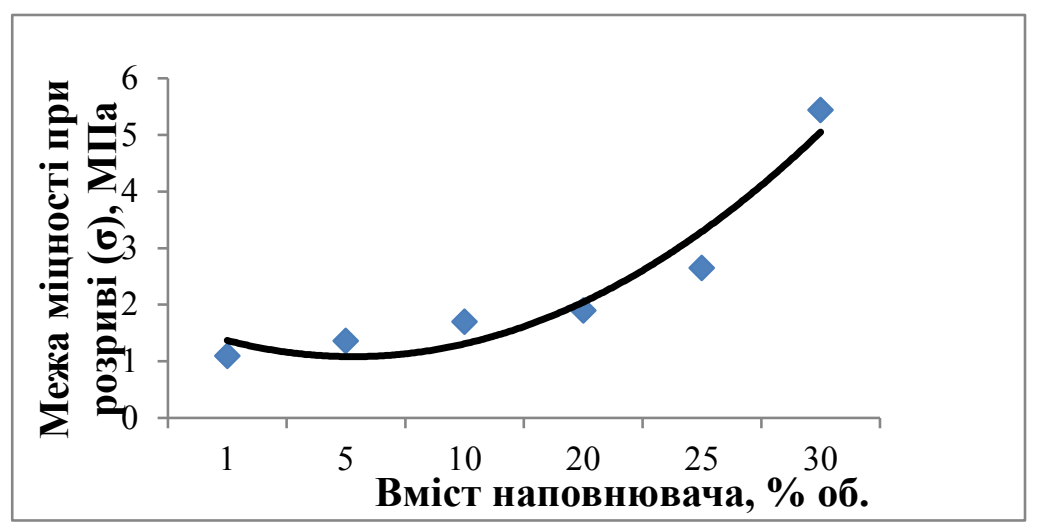

Рис. 2. Залежність межі міцності від вмісту графіту.

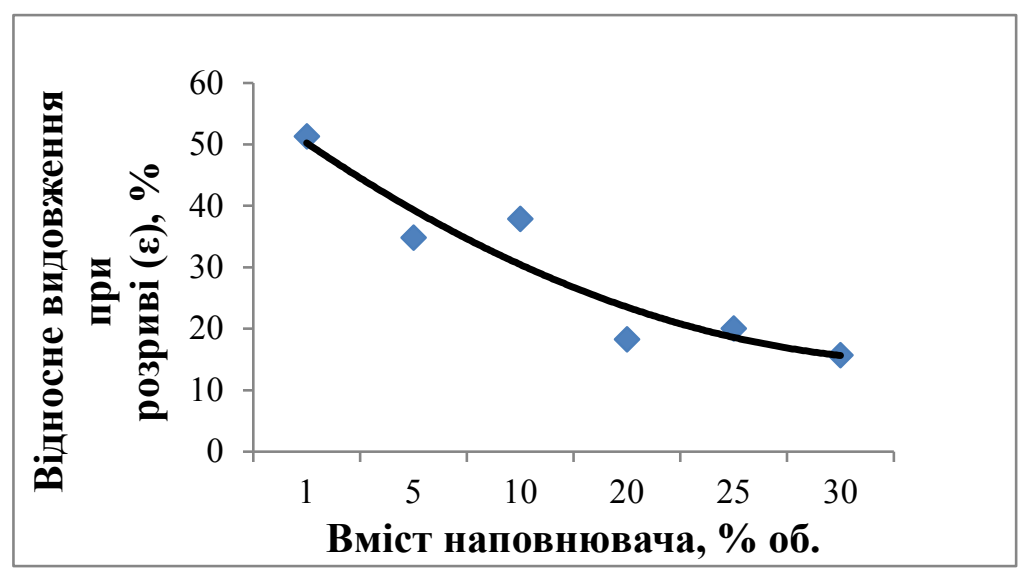

Рис. 3. Залежність відносного видовження від вмісту графіту.

Одержані експериментальні дані наглядно ілюструють тенденцію зростання межі міцності при розриві при введенні до ПВХ графіту. Для композиції 3 
вмістом графіту $30 \%$ об. значення межі міцності при розриві становить 5.5 МПа, тобто спостерігається зростання межі міцності при розриві у 5 разів порівняно $з$ композицією наповненою $1 \%$ об. графіту. Це вказує на те, що в цьому випадку частинки графіту виконують армуючу функцію. Відносне видовження зразків композицій зі збільшенням вмісту графіту до 20 \% об. зменшується від 50 до 18 \%. При подальшому збільшенні вмісту до 30 \% об. цей показник дещо зменшується (до 15 \%). Ми пов'язуємо це явище 3 тим, що збільшується частка наповнювача, який локалізується при кристалізації в невпорядкованих частинах полімеру. Якщо ці частинки великі у порівнянні 3 невпорядкованими ділянками, то вони впливають на ці ділянки всією своєю поверхнею, торкаючись декількох таких областей, а також кристалічних ділянок, на які вони впливають менше. При цьому наповнювач в тому чи іншому ступені взаємодіє з полімером.

\section{3. Висновки}

Визначено залежності межі міцності та відносного подовження при розриві полімерних композиційних матеріалів на основі емульсійного ПВХ Vinnolit ЕР6854 від вмісту графіту марки МСМВ (ТВ-17). Показано, що збільшення концентрації графіту призводить до зменшення показника відносного видовження при розриві композиції, але натомість підвищуються показники межі міцності при розриві та струмопровідності.

\section{Література}

[1] Мамбиш С.Е. Карбонатные наполнители в поливинилхлориде // Пластические массы. - 2008. № 2. - С. 5-10.

[2] Крівцов В.В.Композиційні електрети на основі ПВХ та комплекс їх властивостей: автореф. дис. канд. фіз.-мат. наук: 01.04.19; НАН України. Ін-т хімії високомолек. сполук. - К., 2007. - 20 с.

[3] Куриптя Я.А. Електропровідні полімерні гібридні композити на основі полівінілхлориду / Куриптя Я.А., Савченко Б.М., Шостак Т.С., Новак Д.С., Іскандаров Р.Ш. // Вісник КНУТД. - № 3 (98), 2016. - С. 166 - 172.

[4] Zhang W., Dehghani-Sanij A. A., Blackburn. R. S. Carbon based conductive polymer composites // J. Mater. Sci. 2007. Vol. 42. P. 3408-3418.

[5] Shin S.G. A Study on the Percolation Threshold of Polyethylene Matrix Composites Filled Carbon Powder// Electr. Mater. Lett. 2010. Vol. 6(2). P. 65-70.

[6] Sachdev V.K., Mehra R.M., Mehra N.C., Phys. Stat. Sol. (a), 201 (2004), 2089. 


\title{
Recent developments and perspectives of development of microbial fuel cells in Ukraine
}

\author{
Shchurska K. O., Zubchenko L. S., Galkin O. Yu., Kuzminskiy Ye. V.
}

\begin{abstract}
National Technical University of Ukraine "Igor Sikorsky Kyiv Polytechnic Institute”, Kyiv, pr. Peremogy 37, 03056
\end{abstract}

Microbial fuel cells (MFCs) are devices able to transform chemical energy of organic compound (carbohydrates, fats, proteins, etc.) into electricity (or hydrogen) via electrochemical reactions involving biochemical pathways. MFCs are bioelectrochemical systems that generate electrical current using bacteria. This process is based on the catabolism of organic substances such as glucose, acetate, butyrate or other organic compounds contained in wastewaters. Due to oxidation of the organic compounds, electrons are released, transferred to the anode and delivered to the cathode through an external electrical circuit. MFCs could be defined as devices able to transform chemical energy of organic compounds into electricity via electrochemical reactions involving biochemical pathways [1].

Despite the fact that the idea of using microbial cells for electricity production was put forward by Potter in 1911, the current concept of MFCs design was proposed only in 1977 by the research team of Suzuki Toyu. The idea was picked up and studied later in more detail by Bennetto. They foresaw the possibility of microbial fuel cells using to generate electricity in third world countries. Beginning in the 1980s, Benneto's research helped to understand the process of fuel cell operation. Many scientists still admit his unquestionable authority in resolving this issue [2, 3].

More recently, Dr. Logan's research team of the University of Pennsylvania, which is working on the introduction of MFC in the industry, found that electricity generation is not the only result of MFC work. It turned out that with the addition of electricity to the system, hydrogen is produced on the cathode. In this case, the whole system becomes a microbial electrolysis cell (MECs). As research concepts, MFCs 
and MECs are parts of the group of bioelectrochemical systems (BESs) [1, 3]. A significant number of scientific publications appeared in the last two decades shows that the interest in the use of microbial fuel cells is constantly growing. The scientific teams of the laboratories in the USA, China, Australia and other countries have been engaged in research in the field of optimization of the MFCs during recent years. The objective of this work is to review the current state of research in the field of MFCs in Ukraine as well as to determine the prospects for their further development.

\section{Recent developments in MFCs in Ukraine}

In recent years, the theme of the MFCs has received a new powerful impetus. This is primarily due to growing interest in the production of so-called "green" electricity. Microorganisms are capable to use a wide range of organic substances as a fuel, including a variety of waste; this makes the MFCs very promising for research. Thus, according to the authors of the review article [2], the number of publications about MFCs has rapidly increased over the last decade from 100 publications in 2006 to 1020 in 2016, quoting from 2000 to 32,000, respectively; for MECs: publications from 15 to 280 publications for the same 10 years, quoting from 200 to 5500, respectively. Unfortunately, although this review has about 500 references, nonEnglish publications of Ukrainian scholars are not provided.

Researches in the field of MFCs are conducted at the Department of Environmental Biotechnology and Bioenergy in the National Technical University of Ukraine "Igor Sikorsky Kyiv Polytechnic Institute" led by Professor Kuzminskiy. Researches are conducted in three main directions.

The first one refers to research of hydrogen producing in MECs for wastewater treatment. The rational hydrogen production process parameters were determined. The new three-stage method of anode biofilm formation with high exoelectrogenic ability was developed and constructively executed. Possibility of various organic wastes using as a nutrient medium for hydrogen production was substantiated: the efficiency of organic brewery wastewater compounds that had been pre-treated under anaerobic conditions with hydrogen producing bacteria was $0.02 \mathrm{~g} \mathrm{H}_{2} / \mathrm{g}$ COD (chemical oxygen demand); the efficiency of glycerol conversion to hydrogen was 39 
$\%$; the efficiency of hydrogen production from malting plant wastewaters was $0.01 \mathrm{~g} \mathrm{H}_{2} / \mathrm{g} \mathrm{COD}[4,5]$.

The second direction of the research is devoted to the development of biotechnological method for electricity generation by the association of chemoorganotrophic microorganisms on the substrates of different origin. It was substantiated the rational technological parameters of the exoelectrogenic biofilm formation process and electrical energy generation, in particular, COD is $0.6 \div 0.8$ $\mathrm{gO} / \mathrm{dm}^{3}$, the temperature is $30 \div 35^{\circ} \mathrm{C}$, $\mathrm{pH}$ is $7 \div 8$ units, cultivation modes are periodic (duration is $6 \div 8$ days) or continuous (MFC-bioreactor hydraulic load is $1.1 \div 1.3$ $\mathrm{m}^{3} /\left(\mathrm{m}^{3} \cdot\right.$ day), with specific current density $(12 \div 15) \cdot 10^{-3} \mathrm{~A} / \mathrm{m}^{2}$ at $\left.\mathrm{R}_{\mathrm{ex}}=0,5 \Omega\right)$. The work shows the new technical and technological solutions for the flow microbial fuel cell with mobile electrode blocks for the implementation of the modified selection procedure for exoelectrogens biofilm. Power density of microbial fuel cell is $3.6 \div 7.5 \cdot 10^{-3} \mathrm{~W} / \mathrm{m}^{2}$, and wastewater treatment efficacy was $35 \div 40 \%$ (in values of COD) $[6-8]$.

The third direction of the research is devoted to hydrogen production in the photobioelectrochemical system. The process is investigated in the two-chamber system with protone-exchange membrane and polycrystalline silicon solar cell, as the source of additional energy. The silicon solar fuel cell is chosen due to the structure of its energy levels. While using the sodium acetate as a model substrate for photobioelectrochemical system the maximum process Columbic efficiency reaches $45 \%$ with hydrogen yield $-0.01 \div 0.015 \mathrm{gH}_{2} / \mathrm{gCOD}$. For the model mixture that simulates dairy wastewater maximum hydrogen yield is $0.007 \div 0.01 \mathrm{gH}_{2} / \mathrm{gCOD}$. The Columbic efficiency fluctuates within $32 \div 48 \%$ and depends on the mixture composition and the method of the biofilm formation $[9,10]$.

The process of electric current generating is studied by a group of scientists from the Department of Microbiology at Lviv National Ivan Franko University (Bilyy O., Vasiliev O., Hnatush S., Katernyak S., Maslovska O., Ferensovich Y.P. etc.). They study pure culture of Desulfuromonas Acetoxidans IMV B-7384, which are typical representatives of exoelectrogens. The purpose of their work is to study the 
metabolism of Desulfuromonas acetoxidans in the presence of various compounds in the nutrient medium (like ferrum (III) citrate, fuchsin, methylene blue, etc.). Desulfuromonas acetoxidans IMV B-7384 are highly perspective microorganisms for construction and development of microbial fuel cell technologies aimed for wastewater remediation from transition metal ions. Metal ions catalyze formation of reactive oxygen species that could harmfully affect bacterial cells. Activity of glutathione peroxidase, glutathione-S-transferase and glutathione reductase of $D$. acetoxidans IMV B-7384 bacteria was investigated under the influence of different concentrations of ferric (III) citrate. Enhancement of activity of enzymes of glutathione system confirms their necessary role in antioxidant protection of $D$. acetoxidans IMV B-7384 cells [11].

Unfortunately, there are no other studies in this area in Ukraine. In the country that is energy dependent and has problems with wastewater treatment, there is no research on energy production in the MFCs. Such low interest can be explained by insufficient financing of scientific research in this area, since the study of electricity generation processes in bioelectrochemical systems at this stage involves the use of expensive materials and equipment.

\section{Perspectives of microbial fuel cells development in Ukraine}

Recent studies of aerobic biocathodes, in which oxygen is used as an electron acceptor, have attracted increased interest because of their stable high power output compared to the chemical cathode. It is known that the presence of oxygen suppresses the denitrification. Therefore denitrifying biocathodes are usually considered to be anaerobic. However, a number of microorganisms have recently been isolated from an anaerobic reactor based on its ability to use nitrates as an electron acceptor in air-saturated conditions.

The proposed development of aerobic denitrifying biocathodes for sustainable wastewater treatment and power generation will include the development of the following issues:

- establishment of sufficient electrical contact between the bacteria and electrodes surface; 
- achievement of the appropriate voltage for useful energy obtaining in MFCs;

- avoidance of expensive abiotic catalysts to ensure widespread use;

- increase of the cathodic potential for rising denitrification degree.

Despite all the significant obstacles microbial fuel cell technology has a great future. Firstly, the "fuel" for MFCs is very simple to find, especially now since the problem of wastewater treatment and organic waste utilization is very acute. MFCs technology solves both problems. Secondly, the efficiency of MFCs using can be very high (although so far only theoretically) [2, 3, 12].

\section{Conclusion}

MFCs can be used for fuel production and in bioremediation of different organic wastes. However, this technology is only at the research stage but urgent need for recycling organic wastes, as well as the intensive search for alternative sources of energy, is an important stimulus for large-scale research in the field of MFCs.

\section{References}

[1] B.E. Logan, P. Aelterman, B. Hamelers, R. Rozendal, U. Schroeder, J. Keller, S. Freguia, W. Verstraete, K. Rabaey, Microbial fuel cells: methodology and technology Environ. Sci. Technol. 40 (2006) 5181-5192.

[2] C. Santoro, C. Arbizzani, B. Erable, I. Ieropoulos Microbial fuel cells: From fundamentals to applications. A review, J. Power Sources. 356 (2017) P. 225-244.

[3] Z. Wang, G.D. Mahadevan, Y. Wu, F. Zhao, Progress of air-breathing cathode in microbial fuel cells J. Power Sources 356 (2017) 245-255.

[4] N. B. Golub, K.O. Shchurska, M. V. Trotsenko, Anaerobic treatment of brewary wastewater with simultaneous hydrogen production J. Water Chemistry and Technology 36, 2 (2014) 163-176.

[5] M. Yu. Kozar, K. O. Shchurska, L. A. Sabliy, Ye. Kuzminskiy Malt plant wastewater treatment and biohydrogen production Eastern-European Journal of Enterprise Technologies T. 6, № 66 (2013) 33-36. 
[6] I. A. Samarukha, Yu. S. Bilim, O. A. Mikhaylenko, Methods of formation of biofilm of microorganisms with exoelectrogenic activity Naukovi Visti NTUU KPI 3 (2012) 66-73.

[7] I. A. Samarukha Investigation of the process of nonmediative bioelectrogenesis by association of anaerobic microorganisms. Biotechnological indices Naukovi Visti NTUU KPI №3(77) (2011) 85-89.

[8] I. A. Samarukha Mechanisms of electron transfer to insoluble terminal acceptors in chemoorganotrophic bacteria Ukrainian Biochemical Journal 2 (2014) 90-96.

[9] L. Zubchenko, Photobioelectrochemical hydrogen and electricity production from different organic wastes 2nd ISE Satellite Student Regional Symposium on Electrochemistry «Promising Materials and Processes in Applied Electrochemistry» (2017) 260-266.

[10] L. Zubchenko, Ye. Kuzminskiy Characteristics of biofilm formation process in the bioelectrochemical systems, working in batch-mode of cultivation, Chem. Chem. Technol. 11 №. 1 (2017) 105-110.

[11] O. Maslovska, S. Hnatush, S. Katernyak, The activity of enzymes of glutathione antioxidant system of Desulfuromonas acetoxidans IMV B-7384 under the influence of ferric (III) citrate Visnyk of the Lviv University. Series Biology, 70 (2015) 213-220.

[12] Ye. Kuzminskiy, K. Shchurska, I. Samarukha, G. Lagod, Bioelectrochemical Hydrogen and Electricity Production Theoretical bases, description and modeling of the process Politechnika Lubelska (2013) 102. 


\section{Diffused multi-layer coatings with titanium, chrome, aluminium, car- bon, nitrogen on $\mathrm{Y} 8 \mathrm{~A}$ steel}

Khyzhnyak V. G., Loskutova T.V., Kalashnikov T.Y., Arshuk M.V., Pogrebova I.S.

National Technical University of Ukraine «Igor Sikorsky Kyiv Polytechnic Institute»,37 Peremohy Av., 03056 Kyiv, Ukraine

The influence of barrier layers on the basis of titanium nitride, chromium carbides on phase and chemical composition of multi-component titanium alloys, titanium-chromium coatings of steel U8A is determined. The TiN nitride layer was formed on U8A steel by physical deposition from the gas phase; layer of chromium carbides - by chromium diffusion; some samples had been nitrated and subsequently titanium casted, a layer of TiN was formed on the steel. Barrier layers interfere with the formation of the chemical-thermal treatment of the $\mathrm{Fe}_{\alpha}(\mathrm{Al})$ zone; contribute to the saturation of outer areas of aluminum coating. Microstructural coatings appear in the form of light, light gray stripes; practically nonporous. The highest heat resistance at the test temperature of $1000^{\circ} \mathrm{C}$ for 100 hours showed titanium aluminum chrome coatings with a barrier layer based on TiN. Wear resistance in conditions of slip friction without lubrication of U8A steel with coatings was 1.8 - 4.5 times higher than the initial one after hardening and low temperature (HRC 62).

Key words: protective coatings, U8A steel, barrier layer; nitrides, carbides, nitriding, titanium alloys, physical deposition from the gas phase, micro hardness, heat resistance, wear resistance.

\section{Дифузійні багатошарові покриття за участю титану, хрому, алюмінію, вуглецю, азоту на сталі У8А}

Хижняк В. Г., Лоскутова Т. В., Калашніков Г. Ю., Аршук М.В., Погребова I.С.

Національний технічний університет Украӥни «Київський політехнічний інститут імені Ігоря Сікорського», Київ, пр.Перемоги, 37, корп.№9, 01056

До теперішнього часу використовують різні технології для створення покриттів з метою збільшення експлуатаційних властивостей інструментів із 
сталей та твердих сплавів. Вибір типу покриття для реального інструменту визначається певними властивостями або комбінацією властивостей окремих шарів в зоні сполук : твердість, коефіцієнт тертя, коефіцієнт термічного розширення, адгезійні властивості тощо.

Досвід експлуатації інструментів останніх років показав необхідність присутності в успішних покриттях шарів наступних сполук : карбіду титану $\mathrm{TiC}$, нітриду титану TiN, оксиду $\mathrm{Al}_{2} \mathrm{O}_{3}$ [1-4]. В технології хімічного осадження 3 газової фази при отримані щарів $\mathrm{TiC}, \mathrm{TiN}, \mathrm{Al}_{2} \mathrm{O}_{3}$ використовують хлорид титану $\mathrm{TiCl}_{4}$, хлорид алюмінію $\mathrm{Al}_{2} \mathrm{Cl}_{6}$, водень $\mathrm{H}_{2}$, як газ носій, а також $\mathrm{N}_{2}, \mathrm{CH}_{4}$, $\mathrm{CO}_{2}$. Комбінація шарів сполук дає можливість отримувати покриття з різними переважаючими властивостями. Так, сполука $\mathrm{Al}_{2} \mathrm{O}_{3}$ має серед перерахованих саму високу термічну $\mathrm{i}$ хімічну стабільність. Вільна енергія утворення $\mathrm{Al}_{2} \mathrm{O}_{3}$ становить 378 ккал/моль та 325 ккал/моль відповідно при температурі 298 K та 1000 K; TiN - 74,0 та 58 ккал/моль, TiC - 43,0 та 41 ккал/моль.

Сама висока твердість характерна для сполуки ТіС - 30,0 - 35,0 ГПа; для сполук $\mathrm{TiN}, \mathrm{Al}_{2} \mathrm{O}_{3},-20,0$ ГПа.

Певне розташування шарів сполук визначає властивості покриття. Максимально високу температурну стабільність, хімічну стабільність, стійкість до лункоутворення має покриття 3 наступним розташуванням шарів (від поверхні ) : $\mathrm{Al}_{2} \mathrm{O}_{3}, \mathrm{TiN}, \mathrm{TiC}$. Товщина окремих шарів не перевищує 3,0 - 5,0 мкм. Відомі багатошарові покриття на сталях і твердих сплавах отриманих методами фізичного осадження з газової фази та хіміко-термічної обробки [5 10]. Це покриття на основі карбідів, нітридів, інтерметалідів перехідних металів IV - V груп періодичної системи та алюмінію.

В останні роки знайшли використання комбіновані методи нанесення покриттів, які поєднують, наприклад, азотування 3 наступним дифузійним титануванням, ванадіюванням, хромуванням [10].

Азотування при температурі $540^{\circ} \mathrm{C}$ впродовж 20 годин супроводжується формуванням на сталу У8А шару сполук та зони внутрішнього азотування. Після титанування при температурі $1050^{\circ} \mathrm{C}$ впродовж 4 годин на поверхні 
азотованої сталі У8А формується двошарове покриття. Зовнішній шар - карбід титану ТiC з мікротвердістю 38,6 ГПа, товщиною 14,0 мкм; внутрішній ідентифіковано як сполуку TiN з мікротвердістю 29,0 ГПа і товщиною 3,5 мкм. Бар'єрні функції шару TiN при титануванні азотованої сталі У8А підтверджується значно меншою кількістю заліза ніж в шарі ТіС після звичайного титанування. Крім того, на зовнішній стороні азототитанованих покриттів практично відсутні шари сполук $\mathrm{Fe}_{2} \mathrm{Ti}, \mathrm{FeTi}, \mathrm{Fe}_{2} \mathrm{Ti}_{4} \mathrm{O}$, товщина яких на титанованій сталі У8А може в значній мірі переважати товщину робочого шару $\mathrm{TiC}$.

Можна вважати, що бар'єрний шар TiN буде позитивно впливати на зносо-, жаро-, корозійну стійкість покриттів на сталі У8А. Крім того, можна припустити можливість використання в якості бар'єрних сполук деяких карбідів перехідник металів IV - VI груп періодичної системи при комбінованих методах ХТО.

Відомі дифузійній покриття отримані при багатокомпонентному насиченні сталі У8А із порошкових сумішей за участю перехідних металів та алюмінію [11]. Припущення щодо фазового складу та властивостей покриттів були наступні : карбіди перехідних металів утворені при ХТО визначають твердість, зносостійкість покриттів, сполуки алюмінію - жаростійкість. Ці припущення не були реалізовані на практиці. Встановлено, що на поверхні сталі У8А при титаноалітуванні $\left(1050^{\circ} \mathrm{C} ; 4\right.$ години) в порошкових сумішах утворюється багатошарове покриття. Зовні розташовується шар ТiC, під яким i основою - стовбчасті кристали шару на основу $\alpha$-Fe(Al)[11]. Отримана композиція негативно впливає на зносостійкість в умовах контактної взаємодії. За даних умов можливе продавлення та руйнування шару TiC. Шар $\alpha$-Fe(Al) зовні заблокований шаром $\mathrm{TiC}$, що не дає розчиненому в $\alpha$-Fe алюмінію позитивно вплинути на жаростійкість.

Таким чином, 3 аналізу наведених результатів робіт [10,11] можна зробити висновок щодо необхідності розробки способу нанесення покриттів, 3 бар'єрним шаром, який запобігав би дифузії алюмінію при ХТО в сталь У8А і 
формуванню зони $\alpha-\mathrm{Fe}(\mathrm{Al})$, а при експлуатації гальмував би небажаний перерозподіл елементів між покриттям і основою, покриттям і контртілом.

Як зазначали, експлуатаційні властивості покриттів в умовах тертя ковзання без змащування, дії високих температур визначаються наявністю на зовнішній стороні покриття сполуки $\mathrm{Al}_{2} \mathrm{O}_{3}$. Цілком зрозуміло, що підвищення жаростійкості Ti - Al покриттів є важливою задачею. Жаростійкість сплавів Ті - Al залежить від складу і зростає при збільшенні вмісту алюмінію до 60 - 70\% мас. Бінарні сплави $\mathrm{Ti}$ - Al при значному вмісті алюмінію стають надзвичайно крихкими, що обмежує їх практичне використання. Сплави $\mathrm{Ti}-\mathrm{Al}-\mathrm{Cr}$ за участю фаз Лавеса $\mathrm{Ti}(\mathrm{Al}, \mathrm{Cr})_{2}$ та т-фази $\left(\mathrm{Ti}_{0.25} \mathrm{Al}_{0.67} \mathrm{Cr}_{0.08}\right)$ відзначаються високою жаростійкістю та механічними властивостями $[12,13]$. В першу чергу це сплав, який містить 70 - 75\% т-фази та 25 - 30\% фази Лавеса.

Слід зазначити, що багатокомпонентні покриття на сталі У8А за участю $\mathrm{Ti}, \mathrm{Al}, \mathrm{Cr}$ з бар'єрним шаром в науково-технічній літературі не представлені.

Метою роботи є отримання на поверхні сталі У8А багатошарових покриттів за участю титану, алюмінію, хрому. Встановлення впливу бар'єрних шарів на основі нітриду титану $\mathrm{TiN}$, карбідів хрому $\mathrm{Cr}_{7} \mathrm{C}_{3}, \mathrm{Cr}_{23} \mathrm{C}_{6}$ на фазовий $\mathrm{i}$ хімічний склади, структуру, властивості титаноалітованих та титаноалюмохромованих покриттів на сталі У8А.

\section{1. Експериментальна частина}

В якості об’єкта досліджень було вибрано інструментальну сталь У8А (вміст вуглецю $0,85 \%$ по масі). Азотування проводили в середовищі дисоційованого аміаку (25-35\%) при температурі $540^{\circ} \mathrm{C}$ впродовж 20 годин. Нітрид титану TiN наносили на установці ВУ1Б з титановим катодом методом фізичного осадження з газової фази при температури $560-600^{\circ} \mathrm{C}$ впродовж 25 хвилин. Хромування відбувалось в закритому реакційному просторі за умов зниженого тиску 3 використанням в якості вихідних порошку хрому та чотирихлористого вуглецю $\mathrm{CCl}_{4}$ [14]. Титаноалітування, титаноалюмохромування проводили в контейнерах 3 плавким затвором в суміші порошків $\mathrm{Ti}$ (40\%), $\mathrm{Al}$ (15\%), $\quad \mathrm{NH}_{4} \mathrm{Cl} \quad$ (5\%), $\quad \mathrm{Al}_{2} \mathrm{O}_{3} \quad$ (40\%); 
титаноалюмохромування - Ti (15\%), $\mathrm{Al}$ (15\%), $\mathrm{Cr}$ (25\%), $\mathrm{NH}_{4} \mathrm{Cl}(5 \%), \mathrm{Al}_{2} \mathrm{O}_{3}$ (40\%). Аналіз дифракційних піків, знятих на дифрактрометрі ДРОН УМ-1 виковували за допомогою програми «Powder Cell 2.2.». Хімічний аналіз проводили на електронних мікроскопах «Ieol ISM - 640LV» із спектрометром та «Cam Scan 4D». Мікроструктуру досліджували на мікроскопі Neophot 7, мікротвердість - на приладі ПМТ 3.

\section{2. Результати досліджень та їх обговорення}

Результати досліджень фазового складу, структури, мікротвердості, властивостей отриманих в роботі покриттів наведена в табл. 1,2 рис. 1-6. Результати аналізу сталі У8А 3 покриттями № 1 - 3 (табл. 1) показали, що склад, будова відповідають відомим [11]. На поверхні сталі У8А після азотування формується зона сполук нітридів заліза $\mathrm{Fe}_{4} \mathrm{~N}, \mathrm{Fe}_{2} \mathrm{~N}$ та зона внутрішнього азотування. Крім того зафіксована присутність в покритті оксиду заліза $\mathrm{Fe}_{3} \mathrm{O}_{4}$, що $\epsilon$ типовою складовою покриття після азотування в аміаку.

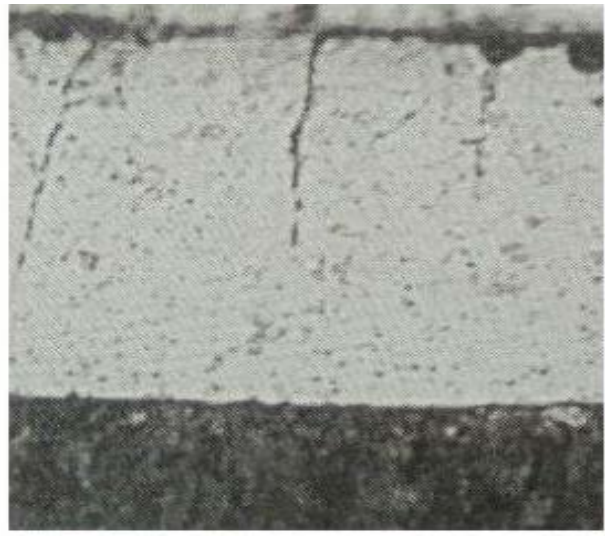

a

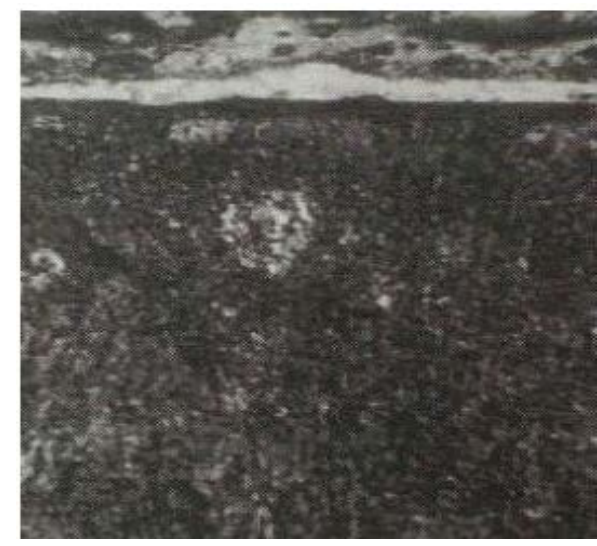

6

Рис. 1. Мікроструктури Ti-Al-Cr сталі У8A (a); Ti-Al-Cr 3 шаром TiN (б), х300; світловий мікроскоп.

При хромуванні сталі У8А в середовищі хлору за умов зниженого тиску формується покриття за участю карбідів $\mathrm{Cr}_{7} \mathrm{C}_{3}, \mathrm{Cr}_{23} \mathrm{C}_{6}$ та $\sigma$-фази. На частину зразків перед титаноалітуванням наносили методом фізичного осадження 3 газової фази покриття товщиною 4,5 - 5,5 мкм на основі сполуки TiN. B світловому мікроскопі, шар сполуки $\mathrm{TiN}$ має жовтувато-золотавий колір, що відповідає нітриду титана близького по складу до стехіометричного. Останнє 
підтверджується рентгенофазовим аналізом, відповідно до якого період гратки TiN становить 0,4239 нм (табл. 1 ).

Таблиця 1. Фазовий склад та характеристики покриттів на сталі У8А

\begin{tabular}{|c|c|c|c|c|c|}
\hline $\begin{array}{c}\text { Покрит- } \\
\text { тя, № }\end{array}$ & $\begin{array}{c}\text { Вид обробки } \\
\mathrm{T}^{0} \mathrm{C}, \text { час }\end{array}$ & $\begin{array}{c}\text { Фазовий } \\
\text { склад }\end{array}$ & $\begin{array}{c}\text { Період кри- } \\
\text { сталічної } \\
\text { гратки, нм }\end{array}$ & $\begin{array}{c}\text { Товщина, } \\
\text { мкм }\end{array}$ & $\begin{array}{c}\text { Мікротвердість, } \\
\text { Гпа }\end{array}$ \\
\hline 1 & $\begin{array}{c}\text { Азотування } \\
\text { 540; 20; }\end{array}$ & $\begin{array}{l}\mathrm{Fe}_{2} \mathrm{~N} \\
\mathrm{Fe}_{4} \mathrm{~N} \\
\mathrm{Fe}_{3} \mathrm{O}_{4}\end{array}$ & $\begin{array}{l}a=0,4799 \\
c=0,4425 \\
a=0,8413\end{array}$ & $\begin{array}{c}8,5 \\
-\end{array}$ & $\begin{array}{c}5,7 \\
7,3 \\
-\end{array}$ \\
\hline 2 & $\begin{array}{l}\text { TiN; фізичне } \\
\text { осадження }\end{array}$ & TiN & 0,4239 & 5,5 & 19,6 \\
\hline 3 & $\begin{array}{c}\text { Хромування } \\
1050 ; 3\end{array}$ & $\begin{array}{c}\text { б-фаза } \\
\mathrm{Cr}_{23} \mathrm{C}_{6} \\
\mathrm{Cr}_{7} \mathrm{C}_{3}\end{array}$ & $\begin{array}{l}\text { a: } 0,8810 \\
\text { c: } 0,5446 \\
a=1,072 \\
a=1,401 \\
c=0,4529\end{array}$ & $\begin{array}{l}6,0 \\
8,5\end{array}$ & $\begin{array}{c}8,5 \\
17,5 \\
16,0\end{array}$ \\
\hline
\end{tabular}

Титаноалітування сталі У8А 3 попередньо нанесеними покриттями супроводжується зміною фазового, хімічного складів, структури поверхні. На азотованій сталі У8А після подальшої ХТО зникає зона сполук нітридів заліза $\mathrm{Fe}_{4} \mathrm{~N}, \mathrm{Fe}_{3} \mathrm{~N}$, змінюється зона внутрішнього азотування. Після титаноалітування азотованої сталі (зразок №4, табл. 2) покриття складається із шарів сполук ТіС, $\mathrm{TiN}, \mathrm{Fe}_{2}(\mathrm{Ti}, \mathrm{Al}), \mathrm{Fe}_{2}(\mathrm{Ti}, \mathrm{Al})_{4} \mathrm{O}, \mathrm{Al}_{2} \mathrm{O}_{3}$. Присутність шару TiN, який зазначив себе як бар'єрний, зумовлює відсутність в покритті шару сполуки $\mathrm{Fe}_{2}(\mathrm{Ti}, \mathrm{Al})$, а також шару $F e \alpha(A l)$, який стабільно існує в звичайних титаноалітованих покриттях під шаром карбідів (рис.1). Всі шари покриттів 4 - 7 (табл.2,3) крім шару TiN в покриттях №5,7 формуються за рахунок екстракції елементів основи до поверхні та їх взаємодії з адсорбованими насичуючими елементами. Цілком зрозуміло, що присутність бар’єрного шару TiN в покритті №5 вже на перших 
етапах титаноалітування гальмує дифузійний потік вуглецю до поверхні. Останнє зумовлює меншу товщину шару ТіС в покриттях №5,7 в порівнянні 3 товщиною шару ТіС в покритті №4 (табл.2,3).

Таблиця 2. Фазовий склад та характеристики покриттів на сталі У8А

\begin{tabular}{|c|c|c|c|c|c|}
\hline $\begin{array}{c}\text { Пок- } \\
\text { риття, } \\
\text { № }\end{array}$ & $\begin{array}{c}\text { Вид обробки } \mathrm{T}^{0} \mathrm{C} \text {, } \\
\text { час }\end{array}$ & Фазовий склад & \begin{tabular}{|} 
Період \\
кристалі- \\
чної гра- \\
тки, нм
\end{tabular} & $\begin{array}{c}\text { Тов- } \\
\text { щина, } \\
\text { мкм }\end{array}$ & $\begin{array}{c}\text { Мікрот- } \\
\text { вер- } \\
\text { дість, } \\
\text { Гпа }\end{array}$ \\
\hline \multirow[t]{5}{*}{4} & Азототитаноаліту- & $\mathrm{Fe}_{2}(\mathrm{Ti}, \mathrm{Al})_{4} \mathrm{O}$ & $a=1,1298$ & 9,5 & 9,5 \\
\hline & вання*; & $\mathrm{Fe}_{2}(\mathrm{Ti}, \mathrm{Al})$ & $a=0,4796$ & 10,0 & 12,1 \\
\hline & азотування, 540;20; & & $b=0,7865$ & & \\
\hline & титаноалітування; & $\mathrm{TiC}$ & 0,4306 & 7,5 & 34,2 \\
\hline & $1050 ; 4$ & TiN & 0,4235 & 6,0 & 20,5 \\
\hline \multirow[t]{3}{*}{5} & Титаноалітування*; & $\mathrm{Fe}_{2}(\mathrm{Ti}, \mathrm{Al})_{4} \mathrm{O}$ & $\mathrm{a}=1,1291$ & 11,5 & 12,0 \\
\hline & сталь 3 шаром TiN & $\mathrm{TiC}$ & $\mathrm{a}=0,4301$ & 6,0 & 36,0 \\
\hline & $\begin{array}{c}\text { титаноалітування; } \\
1050 ; 4\end{array}$ & TiN & $a=0,4238$ & 4,5 & 20,0 \\
\hline
\end{tabular}

* - на поверхні встановлено присутність $\mathrm{Al}_{2} \mathrm{O}_{3}$

Як в же зазначали, в процесі титаноалітування можлива дисоціація певних попередньо нанесених сполук покриття. Відповідно до отриманих результатів в покритті №6 (табл.3) при титаноалітуванні відбувається дисоціація карбіда хрому $\mathrm{Cr}_{7} \mathrm{C}_{3}$, що підтверджуються зменшенням товщини його шару після ХТО. Звільнений з карбіда хрому вуглець взаємодіє з титаном 3 утворенням карбіду $\mathrm{TiC}$, а хром-інтерметалідів. Товщина шару $\mathrm{TiC}$ в покритті №6 (табл. 3) становить 9,0 мкм.

Загальна товщина титаноалітованого покриття на сталі У8А досягає 35,0 - 36,0 мкм; товщина гетерогенної зони на основі інтерметалідів (AlCrTi, TiAl, $\mathrm{Ti}_{3} \mathrm{Al}, \mathrm{Cr}_{2} \mathrm{Ti}$ ) становить 19,5 мкм (покриття №6, табл.3). 
Як зазначали, утворення титаноалюмохромованих покриттів за способом №6 (табл. 3) відбувається при титаноалітуванні сталі У8А з шарами сполук хрому $\mathrm{Cr}_{7} \mathrm{C}_{3}, \mathrm{Cr}_{23} \mathrm{C}_{6}, \sigma$-фази. В роботі запропоновано також спосіб ХТО сталі У8А, який полягає в нанесенні на поверхню шляхом фізичного осадження 3 газової фази шару TiN з наступним титаноалюмохромуванням в порошковій суміші : $\mathrm{Ti}(15 \%), \mathrm{Al}(15 \%), \mathrm{Cr}(25 \%), \mathrm{NH}_{4} \mathrm{Cl}$ (5\%), $\mathrm{Al}_{2} \mathrm{O}_{3}$ (40\% по масі) при температурі $1050^{\circ} \mathrm{C}$ впродовж 4 один. Фазовий склад титаноалюмохромованих покриттів №7 (табл. 3) відрізняється від фазового складу покриття №6 (табл.3). Безпосередньо до основи в покритті №7 (табл.3) примикають шари сполук TiN, TiC, зовні - шари на основі інтерметалідів титану, алюмінію, хрому, заліза. Серед інтерметалідів покриття №7 (табл.3) було ідентифіковано сполуку TiAlCr (фаза Лавеса) з параметрами гратки а $=0,3008, \mathrm{c}=0,8156$ нм. Шар фази Лавеса розташований в центрі зони інтерметалідів.

Зовнішній шар із значним вмістом хрому $\left(\mathrm{Ti}_{12} \mathrm{Al}_{16} \mathrm{Cr}_{50} \mathrm{Fe}_{22}\right)$ вірогідніше за все відповідає сполуці $\mathrm{FeCr}$ ( $\sigma$-фаза), шар біля сполуки $\mathrm{TiC}-\left(\mathrm{Ti}_{30} \mathrm{Al}_{13} \mathrm{Cr}_{9} \mathrm{Fe}_{48}\right)$ інтерметаліду FеTi.

Мікрорентгеноспектральним аналізом був визначений хімічний склад покриттів. Встановлено, що на зовнішній стороні титаноалітованих покриттів №6 (табл. 3) концентрація алюмінію та хрому становить відповідно 8,9-10,9 \% та 13,4 - 13,6 \% по масі. Максимальна концентрація хрому була виявлена в зоні покриття на основі сполуки $\mathrm{TiCr}_{2}-66,4 \%$ мас. Згідно до діаграми стану Ti-Cr$\mathrm{Al}[16,17]$ та отриманих результатів хімічного складу покриттів 6,7(табл.3) виявлені сполуки складу, що відносяться до фаз Лавеса. Шар карбіду титану ТіС в покритті №6 (табл.3), товщина якого становить 6,0 мкм, містить 78,8 - 80,0 \% титану та незначну кількість $0,1-0,2 \%$ алюмінію та $0,2-0,3 \%$ хрому. По мірі просування до основи в покритті в значній мірі зростає концентрація заліза та хрому, падає вміст титану, алюмінію відповідно до 0,1 \% та 0,2 \% по масі.

Розподіл елементів за товщиною титаноалюмохромованих покриттів 3 шаром TiN №7 (табл. 3) на сталі У8А наведено на рис. 2. В зонах покриття, які примикають до основи і складаються з шарів $\mathrm{TiN}, \mathrm{TiC}$ концентрація алюмінію $\mathrm{i}$ 
хрому незначна; становить $0,1-0,6$ \% по масі і не відрізняється від хімічного складу подібних зон в покриттях 4,5. При цьому концентрація хрому на зовнішній стороні покриття №7 (табл.3) досягає 50,0, алюмінія- 14,0\% мас.

Таблиця 3. Фазовий склад та характеристики покриттів за участю хрому на сталі У8А

\begin{tabular}{|c|c|c|c|c|c|}
\hline $\begin{array}{c}\text { Пок- } \\
\text { риття, } \\
\text { № }\end{array}$ & $\begin{array}{c}\text { Вид обробки } \mathrm{T}^{0} \mathrm{C}, \\
\text { час }\end{array}$ & Фазовий склад & $\begin{array}{c}\text { Період } \\
\text { кристалі- } \\
\text { чної гра- } \\
\text { тки, нм }\end{array}$ & $\begin{array}{l}\text { Тов- } \\
\text { щина, } \\
\text { мкм }\end{array}$ & $\begin{array}{c}\text { Мікрот- } \\
\text { вер- } \\
\text { дість, } \\
\text { Гпа }\end{array}$ \\
\hline 6 & $\begin{array}{c}\text { Титаноалітована*; } \\
\text { сталь } 3 \text { шаром } \\
\mathrm{Cr}_{7} \mathrm{C}_{3}, \mathrm{Cr}_{23} \mathrm{C}_{6} ; \\
\sigma-\text { фаза; } \\
\text { хромування; 1050; } \\
3 ; \\
\text { титаноалітування; } \\
1050 ; 4\end{array}$ & $\begin{array}{l}\mathrm{AlCrTi} \\
\mathrm{Cr}_{2} \mathrm{Ti} \\
\mathrm{Ti}_{3} \mathrm{Al} \\
\mathrm{TiC} \\
\sigma-\phi а з а \\
\mathrm{Cr}_{23} \mathrm{C}_{6} \\
\mathrm{Cr}_{7} \mathrm{C}_{3}\end{array}$ & $\begin{array}{l}a=0,5008 \\
a=0,6950 \\
a=0,5801 \\
c=0,4650 \\
a=0,4326 \\
- \\
a=1,0711 \\
a=1,4110 \\
c=0,4530\end{array}$ & $\begin{array}{l}6,0 \\
2,0 \\
7,0 \\
4,0\end{array}$ & $\begin{array}{l}5,8-6,2 \\
6,1- \\
7,0 \\
\quad-\end{array}$ \\
\hline 7 & $\begin{array}{c}\text { Титаноалюмохрому- } \\
\text { вання**, сталь } 3 \text { ша- } \\
\text { ром TiN; } \\
\text { TiN, фізичне оса- } \\
\text { дження; } \\
\text { титаноалюмохрому- } \\
\text { вання } 1050 ; 4 .\end{array}$ & $\begin{array}{c}\sigma \text {-фаза } \\
\mathrm{Ti}_{12} \mathrm{Al}_{16} \mathrm{Cr}_{50} \mathrm{Fe}_{22} \\
\text { TiAlCr } \\
\\
\mathrm{Ti}_{31} \mathrm{Al}_{10} \mathrm{Cr}_{9} \mathrm{Fe}_{50} \\
\mathrm{TiC} \\
\mathrm{TiN}\end{array}$ & $\begin{aligned} &- \\
& a=0,5009 \\
& c=0,8161 \\
& a=0,3984 \\
& a=0,4309 \\
& a=0,4231\end{aligned}$ & $\begin{array}{c}16,0 \\
3,5-4,0 \\
5,0-5,5\end{array}$ & $\begin{array}{l}12,4 \\
30,6 \\
20,4\end{array}$ \\
\hline
\end{tabular}

* - на поверхні встановлено присутність $\mathrm{Al}_{2} \mathrm{O}_{3}$,

** - на поверхні встановлено присутність фази $\mathrm{Cr}_{2} \mathrm{O}_{3}$ 
Відмінність фазового складу та характеру розподілу елементів в покриттях 6, 7 (табл. 3) зумовлені фазовим складом поверхні перед ХТО та складом насичуючого середовища. Джерелом заліза для покриттів 6, 7 (табл. 3) є основа; хрома - для покриття №6 (табл. 3) - карбідохромові покриття; для покриття №7 (табл. 3) - насичуюче джерело; титана, алюмінія для покриттів №6, 7 - насичуюче середовище; азота - в покритті №7 (табл.3) -нітрид TiN. Функції бар’єрного шару в покриттях №6, 7 (табл. 3) виконують відповідно шари карбідів хрому та нітриду титану.

На концентраційній кривій розподілу елементів за товщиною покриття №7 (рис.2) можна виявити присутність азоту поза межами шару нітриду TiN. Вірогідно при ХTO відбувається дисоціація сполуки TiN. Виявлений азот не розчинається в $\mathrm{TiC}$, шар якого безпосередньо примикає до шару $\mathrm{TiN}$, a дифундує до шару зони III (рис.2). Останнє підтверджується значною мікротвердістю сполуки $\mathrm{Ti}_{31} \mathrm{Al}_{10} \mathrm{Cr}_{9} \mathrm{Fe}_{50} 3$ азотом, яка виявляється на 25,0 - 30,0 \% вищою ніж сполуки без азоту, і становить 12,0 - 12,4 ГПа.

Мікротвердість окремих складових покриття змінюється в широкому діапазоні : від мікротвердості шарів карбіду ТiC - 30,6 - 36,5 ГПа, нітриду TiN - 19,6 - 20,5 ГПа, карбідів $\mathrm{Cr}_{7} \mathrm{C}_{3}, \mathrm{Cr}_{23} \mathrm{C}_{6}-17,0$ ГПа, до твердості інтерметалідів, оксидів (табл. 2,3).

Багатокомпонентні покриття, які отримані в роботі, відповідно до мікроструктурного аналізу виявляються у вигляду світлих полос с чіткою границею розподілу покриття-основа (рис.1,2). Мікротріщини, пори в покриттях практично відсутні. Шари нітриду титану TiN в вихідному стану, після титаноалітування, азототитноалітування мають характерний жовтуватозолотавий колір.

Результати проведених при температурі $1000^{\circ} \mathrm{C}$ впродовж 100 годин випробувань підтвердили високу жаростійкість отриманих в роботі покриттів (рис.3). Аналіз літературних джерел [12,18,19] показав, що в умовах безперервного окислення сплавів $\mathrm{Ti}-\mathrm{Al}-\mathrm{Cr}$, на поверхні формується оксидна 
плівка $(\mathrm{Al}, \mathrm{Cr})_{2} \mathrm{O}_{3} 3$ високим опором до окислення. Утворений таким чином шар оксидів визначає жаростійкість покриття при подальших випробуваннях.

Саму високу жаростійкість серед представлених в роботі, проявили покриття № 6,7 (табл. 3). Мікроаналіз поверхні після випробувань показав, що в процесі окислення формується щільна оксидна плівка темно-сірого, майже чорного кольору; сколи, відшарування відсутні. Перевага покриттів № 6,7 над покриттями 4,5 зумовлена формуванням при окисленні якісної захисної плівки $(\mathrm{Al}, \mathrm{Cr})_{2} \mathrm{O}_{3}[12,18,19]$. На поверхні титаноалітованих покриттів за тих же умов окислення формується менш щільна, пухка плівка оксидів $\mathrm{TiO}_{2}$ та $\mathrm{Al}_{2} \mathrm{O}_{3} 3$ незадовільними захисними властивостями $[12,18,19]$.

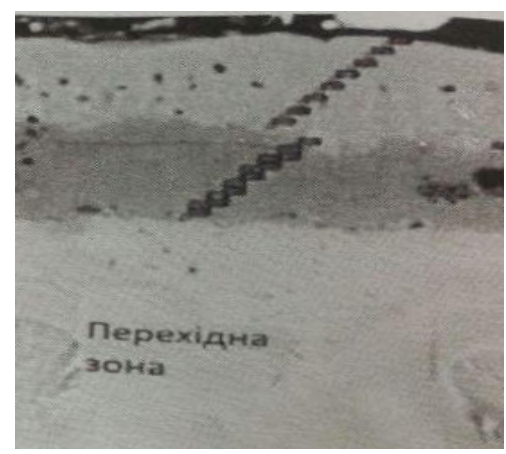

a

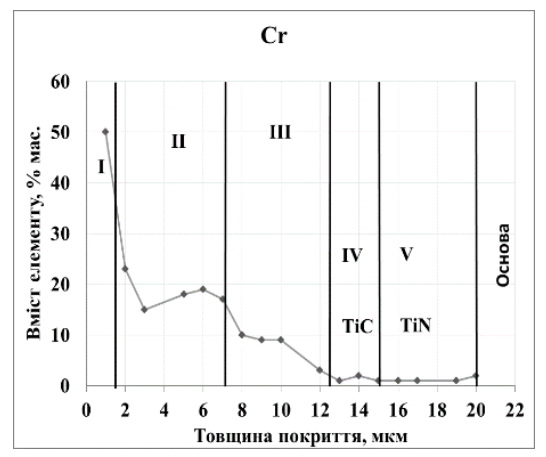

$\Gamma$

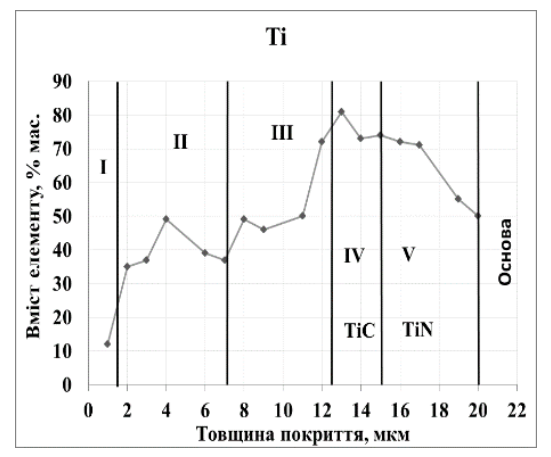

6

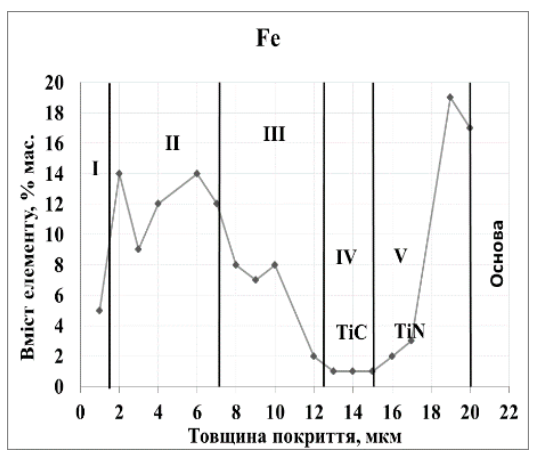

д

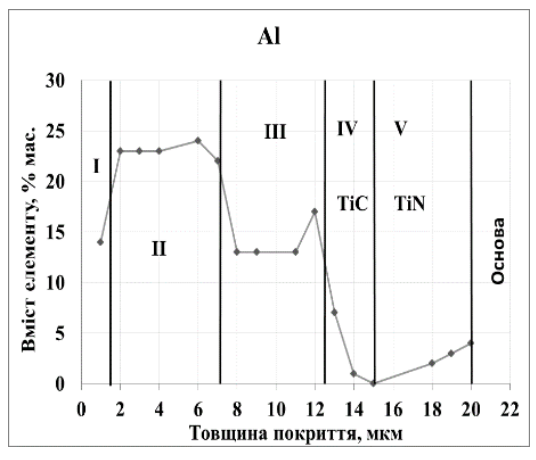

B

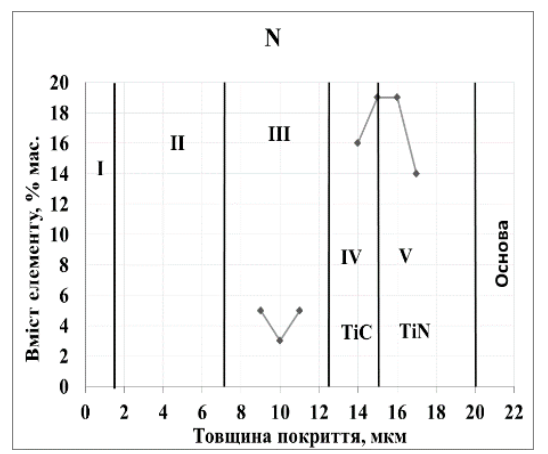

e

Рис. 2. Мікроструктура титаноалюмохромованої сталі У8А з попередньо нанесеним шаром TiN (a - електронний мікроскоп) та розподіл елементів за товщиною покриття; б - Ti, в - Al, г - Cr; д - Fe; e - N; Насичуюча суміш : Ti (15\%); $\mathrm{Cr}(25 \%) ; \mathrm{Al}(15 \%) ; \mathrm{NH}_{4} \mathrm{Cl}(5 \%) ; \mathrm{Al}_{2} \mathrm{O}_{3}(40 \%) ; \mathrm{T}=1050^{\circ} \mathrm{C} ; \mathrm{t}=4$ години; зона I - $\mathrm{Ti}_{12} \mathrm{Al}_{16} \mathrm{Cr}_{50} \mathrm{Fe}_{22} ; \mathrm{II}$ - TiAlCr; III - $\mathrm{Ti}_{31} \mathrm{Al}_{10} \mathrm{Cr}_{9} \mathrm{Fe}_{50}$; IV - Ti(N,O); TiC; V TiN. 
Зносостійкість отриманих в роботі покриттів, для яких величину зносу оцінювали за розмірами лунки тертя, виявилась вищою у 1,8 - 4,5 рази за зносостійкість вихідної сталі (рис. 4). Висока зносостійкість зумовлена будовою та властивостями покриттів, їх високою мікротвердістю та жаростійкістю: наявністю шарів $\mathrm{TiC}$, TiN; інтерметалідів; $\mathrm{Al}_{2} \mathrm{O}_{3}$. Можна вважати, що випробування на зносостійкість за розмірами лунки моделює розвиток процесів тертя в часі $\mathrm{i}$ просторі на відміну від результатів випробувань $з$ притертою поверхнею. Стан, структура, хімічний склад поверхні контакту і поверхні біля лунки наведено на рис. 5, 6, табл.4.

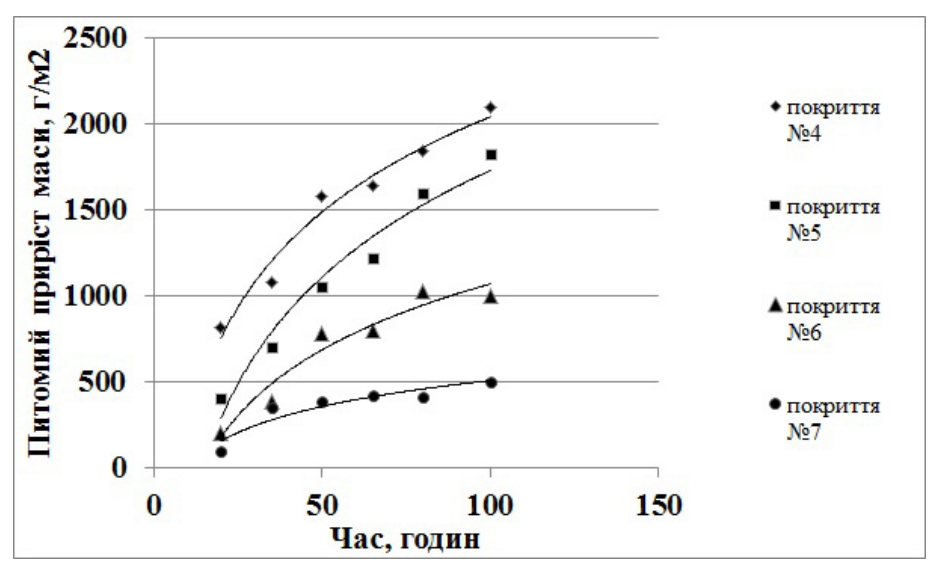

Рис. 3. Кінетичні криві окислення сталі У8А з покриттями, температура $1000^{\circ} \mathrm{C}$, час 100 годин.

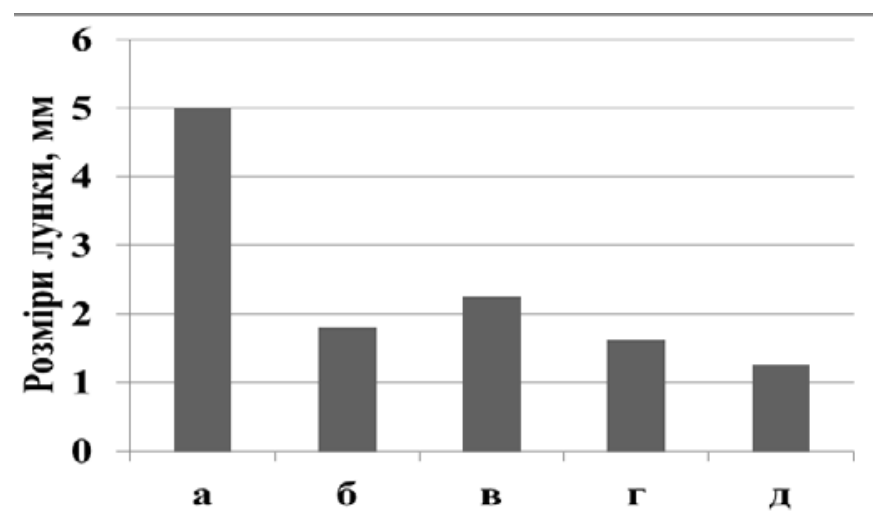

Рис. 4. Зносостійкість сталі У8А з покриттями в умовах тертя козвання без змащування; а - сталь У8А; HRC 61; б - азотування з наступним титаноалітуванням (№4, табл. 2); в - нанесення шару TiN за наступним титаноалітуванням (№5, табл. 2); г - хромування з наступним титаноалітуванням (№6, табл. 3); д - нанесення шару TiN з наступним титаноалюмохромуванням (№7, табл. 3). Швидкість ковзання 5,0 м/с; навантаження 1,5 H; час випробовування 300 c. 
Ділянки 3 максимальною та мінімальною висотою поверхні в області тертя показані на рис.5. Слід зазначити, що розшарувань, відокремлення окремих часток, появи сітки тріщин при випробуванні покриттів № 6, 7 виявлено не було.

Присутність в покриттях біля основи шарів TiC, TiN, шару $\mathrm{Al}_{2} \mathrm{O}_{3}$ на зовнішній стороні сприяє зростанню зносостійкості сталі У8А. Шар оксиду алюмінію $\mathrm{Al}_{2} \mathrm{O}_{3}$, який розташований на зовнішній стороні дифузійної зони, бар'єрний шар $\mathrm{TiN}$ поступаються за мікротвердістю шару карбіду $\mathrm{TiC}$, але суттєво зменшують при терті взаємодію контртіла із сталлю У8А. На поверхні тертя (рис. 5,6) спостерігаються лінії абразивного мікрорізання в напрямку ковзання. В якості абразиву виступають, вірогідніше за все, окремі тверді частки покриття (карбіди, нітриди, оксиди) або контртіла. Крім того в зоні контакту відбуваються процеси пружної, пластичної деформації, руйнування. Поверхня лунки в процесі тертя згладжується.

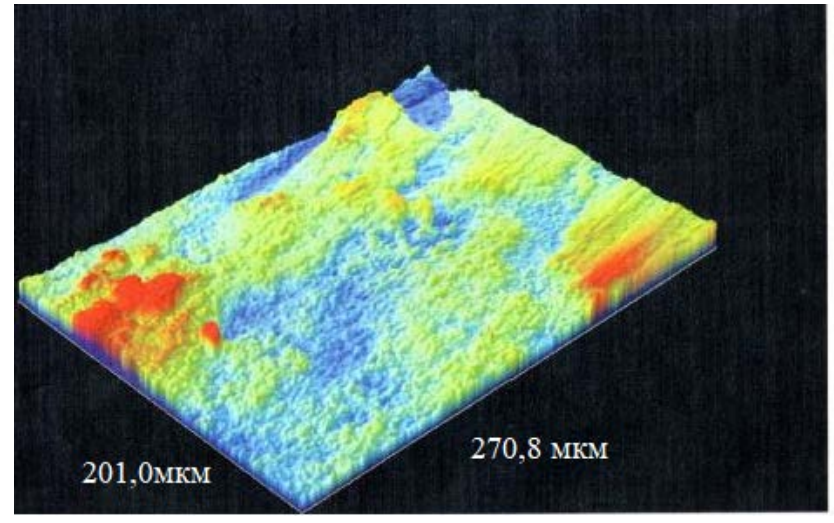

a

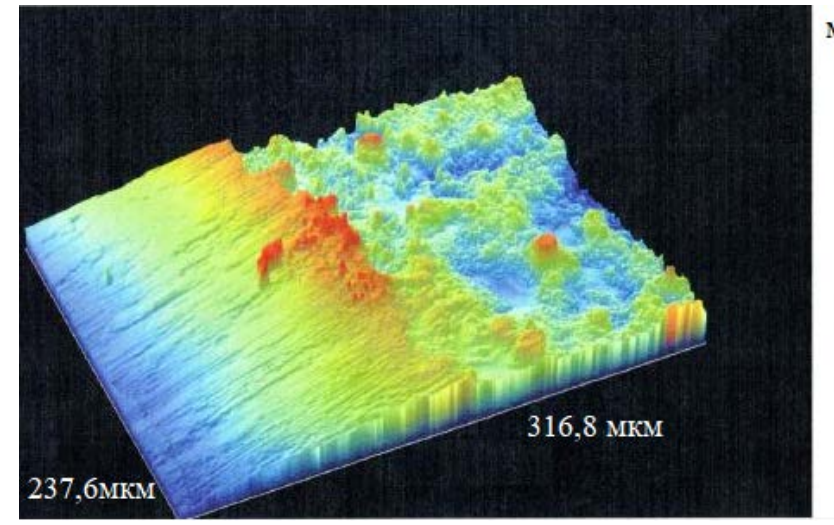

6

Рис. 5. Топографія поверхні тертя сталі У8А з хромотитаноалітованими покриттями 3 шаром TiN (№6, табл. 3) - a; $з$ титанохромоалітованими покриттями 3 шаром TiN (№7, табл. 3) - б; умови тертя: навантаження 1,5 H; швидкість ковзання 5,0 м/с; час випробувань - 300 с.

Аналіз мікроструктури та хімічного складу титаноалюмохромованих покриттів на сталі У8А в області лунки зношування дозволив визначити зони 3 різними особливостями будови (рис.6, табл.4). Зона А - світла зона 3 темними 
вкрапленнями із слідами різання вздовж руху контртіла, відповідає матеріалу основи;. Зона Б - деформоване і частково зруйноване покриття.

Мікрорентгеноспектральним аналізом показано, що сполука спектру №1 в зоні А, №5 в зоні Б відповідає оксиду (Al, $\mathrm{Cr}$ ) ${ }_{2} \mathrm{O}_{3}$ (рис. 6, табл.4). Вказаний оксид сформувався або при ХТО, або в процесі тертя ковзання в контактній зоні, де температура може досягати значних величин, окремі ділянки в зоні Б відповідають сполукам, що входять до складу покриття: TiN, TiC, $\mathrm{Fe}(\mathrm{Ti}, \mathrm{Al})_{4} \mathrm{O}$.

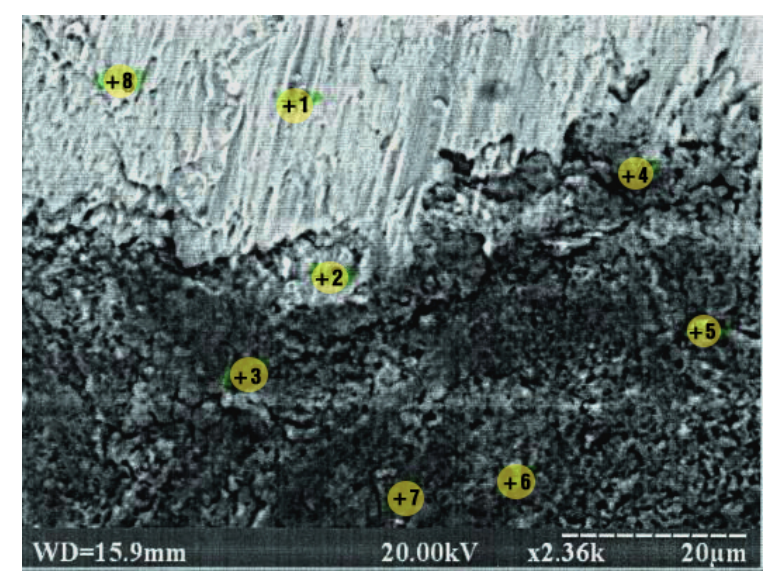

Рис.6. Мікроструктура зони тертя сталі У8А з титаноалюмохромованими покриттями з TiN (№7, табл. 3); навантаження 1,5 H; швидкість ковзання 5,0 м/с; час випробувань - 300 с; (електронний мікроскоп).

Таблиця 4. Розподіл елементів на поверхні лунки зносу титаноалюмохромованого покриття на сталі У8А з шаром TiN.

\begin{tabular}{|c|c|c|c|c|c|c|c|c|}
\hline \multirow[t]{2}{*}{ Зона } & \multirow{2}{*}{$\begin{array}{c}\text { № } \\
\text { спект } \\
\text { ру }\end{array}$} & \multirow{2}{*}{$\begin{array}{c}\text { Фазовий } \\
\text { склад } \\
\text { (можливий) }\end{array}$} & \multicolumn{6}{|c|}{ Вміст елементів, \% мас } \\
\hline & & & $\mathrm{Ti}$ & $\mathrm{Al}$ & $\mathrm{Cr}$ & $\mathrm{Fe}$ & $\mathrm{O}$ & $\mathrm{N}$ \\
\hline \multirow{3}{*}{$\begin{array}{c}\text { А } \\
\text { Основа } \\
\text { сталь } \\
\text { У8А }\end{array}$} & 1 & $(\mathrm{Al}, \mathrm{Cr})_{2} \mathrm{O}_{3}$ & 0,6 & 30,4 & 7,0 & 1,0 & 41,0 & - \\
\hline & 8 & $\begin{array}{l}\mathrm{Fe}_{\alpha}(\mathrm{Cr}, \mathrm{Si}) \\
(\mathrm{Cr}, \mathrm{Fe})_{7} \mathrm{C}_{3}\end{array}$ & 0,1 & 0,3 & 0,5 & основа & - & - \\
\hline & 2 & TiN & основа & 2,5 & 1,5 & 1,0 & - & 15,0 \\
\hline
\end{tabular}




\begin{tabular}{|c|c|l|c|c|c|c|c|c|}
\hline \multirow{2}{*}{$\begin{array}{c}\text { Б } \\
\text { Зона } \\
\text { сполук }\end{array}$} & 3 & $(\mathrm{Al}, \mathrm{Cr})_{2} \mathrm{O}_{3}$ & 1,0 & 25,5 & 9,0 & 1,5 & 63,0 & - \\
\cline { 2 - 9 } & 4 & \multicolumn{1}{|c|}{$\mathrm{TiC}$} & основа & 2,8 & 2,2 & 1,8 & 1,4 & 0,6 \\
\cline { 2 - 9 } & 6 & $\begin{array}{l}(\mathrm{Al}, \mathrm{Cr})_{2} \mathrm{O}_{3} \\
\mathrm{Fe}_{2}(\mathrm{Ti}, \mathrm{Al})_{4} \\
\mathrm{O}\end{array}$ & 0,8 & 28,5 & 8,6 & 2,0 & 40,1 & - \\
\cline { 2 - 9 } & 7 & $\begin{array}{l}\mathrm{Fe}_{2}(\mathrm{Ti}, \mathrm{Al})_{4} \\
\mathrm{O}\end{array}$ & 62,0 & 16,0 & 0,5 & 15,0 & 5,5 & - \\
\hline
\end{tabular}

Отримані і досліджені в роботі багатошарові покриття за участю карбідів хрому, карбіду титану, нітриду титану, інтерметалідів отримані шляхом послідовної реалізації кількох методів насичення : азотування, хромування, фізичного осадження 3 газової фази 3 наступною дифузійною металізацією. Отримані покриття мають високу жаростійкість, зносостійкість та можуть бути перспективними при експлуатації виробів із сталі У8А в умовах дії контактних навантажень, підвищених температур.

\section{3. Висновки:}

1. При багатокомпонентному титаноалітуванні сталі У8А після азотування, 3 шаром TiN, 3 шаром карбідів хрома; при титаноалюмохромуванні сталі 3 шаром TiN на поверхні формуються багатошарові покриття за участю наступних сполук : TiC, $\mathrm{TiN}, \mathrm{Al}_{2} \mathrm{O}_{3}$, інтерметаліди за участю $\mathrm{Ti}, \mathrm{Al}, \mathrm{Cr}, \mathrm{Fe}$. При дифузійній металізації шари карбідів хрома і нітриду титана виконують бар'єрні функції; гальмують проникнення алюмінію в основу i перешкоджаючи таким чином утворення $\mathrm{Fe} \alpha(\mathrm{Al})$.

2. Мікротвердість окремих шарів на сталі У8А наступна: шар $\mathrm{TiC}$ - 30,0 - 36,6; $\mathrm{TiN}-20,0$ - 20,5; шари інтерметалідів - 5,8 - 12,4ГПа.

3. Сама висока жаростійкість при температурі $1000^{\circ} \mathrm{C}$ вподовж 100 годин встановлена для покриттів на сталі У8А за участю нітриду титану TiN i наступного титаноалюмохромування. 
4. Зносостійкість сталі У8А з захисними покриттями в умовах тертя ковзання без змащування зростає в $1,8-4,5$ рази в порівнянні зі стійкістю вихідної сталі (НRC 62).

\section{Література}

[1] L. von Fieandt, T. Larsson, E. Lindahl, O. Backe, M. Boman. Chemical vapor deposition of TiN on transition metal substrates. Surface and Coatings Technology, 334 (2018). - p. 373-383

[2] L. Toller, C. Liu, E. Holmstrom, T. Larsson, S. Norgren, Investigation of cemented carbides with alternative binders after CVD coating, Int. I. Refract. Met. Hard Mater. 2016.

[3] Knotek, F. Loffler and G. Kramer Arc deposition of Ti - C and Ti - C - N using acetylene as a reactive gas. Vacuum / volume 43 / number $5-7$, pages 645 $-648 / 1992$

[4] Deepak G. Bhat and Paul F. Woerner. Coatings for cutting tools. Journal of Metals. V. 38 (Feb. 1986). - p. $68-69$.

[5] H. Riedl, E. Aschauer, C.M. Koller, P. Polcih. Tectural arrangement for hugh temperature oxidation resistant hard coatings. Surf. Coat. Technol., 332. 2017. - p. $80-88$

[6] A. Gilewicz, P. Chielewska, D. Murzynski, E. Dobruchowska, B. Warcholinski. Corrosion resistance of $\mathrm{CrN}$ and $\mathrm{CrCN} / \mathrm{CrN}$ coatings deposited using cathodic are evaporation in Ringers and Hanks solution, Surf. Coat. Technol. 299 (2016). - p. 7 - 14

[7] M. Aghaie-Khafri, F. Fazlalipour. Vanadium carbide coatings on steel deposited by the thermo-reactive diffusion technique. Journal of physics and chemistry of solids, 69 (2008). - p. $2465-2470$.

[8] X.J. Lu, Z.D. Xiang, Formation of chromium nitride on carbon steels by pack cementation process. Surf. Coat. Technol. 300 (2016). - p. 7 - 13.

[9] S. Sen, Wear properties of niobium carbide coatings performed by pack method on AISI steel, Thin solid films. 483 (2015). - p. 152-157. 
[10] Хижняк В.Г., Курило Н.А. Будова та механічні властивості карбідних та нітридних покриттів титану, ванадію та хрому на сталі У8А. Металознавство та обробка металів. - 2007, - №3 - с. 17 - 21.

[11] Химико-термическая обработка металлов и сплавов. Справочник. Борисенок Г.В., Васильев Л.А., Воршинин Л.Г., и др. М. : Металлургия, 1981 $-424 \mathrm{c}$.

[12] Fox-Rabinovich Wilkinson D.S., Veldhuis S.C., Dosbaeva G.K., Weatherly G.C. Oxidation resistance $\mathrm{Ti}-\mathrm{Al}-\mathrm{Cr}$ alloy for protective coating application Intermetallics. - 2006. - 14. - p.189- 197.

[13] Chungan Zhou, Ying Yang, Shengkai Gong, Huibin Xu. Effect of Ti - Al $\mathrm{Cr}$ coatings on the high temperature oxidation behavior of TiAl alloys. Materials Science and Engineering. A307 (2001). - p. $182-187$.

[14] Лоскутова В.Ф., Хижняк В.Г., Погребова І.С., Горбатюк Р.М., Бочар І.Й. Карбідні покриття на сталях і твердих сплавах. Тернопіль : Лілея, 1998. $144 \mathrm{c}$.

[15] Zhuang W., Shen I., Liu Shang L., Du Y., Schuster I.C., Thermodynamic optimization of the $\mathrm{Cr}$ - Ti system, Z. Metallkd., 91, 121 - 127 (2000) (Thermodin., Calculation, 53).

[16] Gupta K.P., The Cr - Ni - Ti system - update, I. Phase equilib, 24 (1), 86 89 (2003) (Equil. Diagram, Review, 7 )

[17] J.K. Lee, M. H. Oh, D.M. Wee, Long-Term oxidation properties of Al - Ti - Cr two-phase alloys as coating materials for TiAl alloys. Intermetallics 10 (2002). - p. $347-352$.

[18] O.M. Barabash, Yu.V. Milman, D.V. Miracle, M.B. Karpets, N.P. Korzhova, T.N. Legkaya, N.M. Mordovets, Yu. N. Podresov, I.V. Voskoboinik. Formation of periodic microstructures involving the $\mathrm{L} 12$ phase in eutectic $\mathrm{Al}-\mathrm{Ti}$ - Cr alloys. Intermetallics 11(2003). p. - $953-962$. 


\title{
The structure of functional coatings of tin-lead alloy on foil glass fiber deposited from the melt
}

\author{
Ushchapovskiy D.Yu., Linyucheva O.V., Motronyuk T.I., Pidvashetsky G.Yu., \\ Zabaluev A.S., Aksonova O.V.
}

National Technical University of Ukraine «Igor Sikorsky Kyiv Polytechnic Institute», Kiev, Peremohy 37, 03056

\begin{abstract}
The structure of functional coatings of tin-lead alloy investigated by XRD and EDX methods. It was established that the composition and structure of $\mathrm{Sn}-\mathrm{Pb}$ coatings are heterogeneous. The coating layer adjacent to the copper base is the intermetal of the approximate composition of $\mathrm{Cu}_{6} \mathrm{Sn}_{5}$. The coating consist of two main phases: the $\alpha$ phase is saturated with lead and the $\beta$-phase is saturated with tin. The multiphase noneutectic composition of the coating may be due to the interaction between the copper base and the mother maturing coating at the temperatures of its deposition.
\end{abstract}

Key words: functional coating, lead-tin alloy, copper base, heterogeneous structure.

\section{Структура функціональних покриттів зі сплаву олово-свинець на фольгованому склотекстоліті, нанесених із розплаву}

\author{
Ущаповський Д.Ю., Лінючева О.В., Мотронюк Т.І., Підвашецький Г.Ю., \\ Забалуєв А.С., Аксьонова О.В. \\ Національний Технічний Університет Украйни «Київський політехнічний \\ інститут імені Ігоря Сікорського
}

Покриття зі сплавів олово-свинець, а зокрема ПОС-61, набули широкого використання у технології виробництва плат друкованого монтажу. Такі покриття називаються фінішними, і наносяться на контактні площадки та металізовані отвори для монтажу радіоелементів методом паяння. Покриття зі сплаву ПОС-61 наносять двома способами - гальванічним та «гарячим» iз розплаву (HASL технологія) $[1,2]$. На даний момент гальванічний спосіб все рідше використовується у промисловості через екологічну небезпечність. 
Нанесення покриттів із розплавів або HASL технологія, через відсутність високотоксичних стічних вод та коротшу тривалість технологічного процесу стає домінуючою. Основним недоліком HASL технології є високий перепад товщини покриття на різних ділянках пласких контактних площадок та, зокрема, наскрізних металізованих отворів [3]. Це унеможливлює монтаж радіоелементів 3 планарними виводами методами групової пайки. Проте для друкованих вузлів із радіоелементами, що монтуються за допомогою штирьових виводів, HASL технологія є найбільш економічно виправданою. 3 точки зору промислового виробництва, актуальною науково-практичною задачею $є$ визначення структури покриттів зі сплаву ПОС-61, отримуваних «гарячим» способом. Особливо важливим це є при валідації тих чи інших методів контролю якості та складу покриттів.

\section{1. Методика досліджень}

Покриття на заготовки друкованих плат наносили за стандартною HASL технологією [2]. Заготовку плати занурювали у розплавлений до $260{ }^{\circ} \mathrm{C}$ припой на час до 2 хв, після чого надлишок припою знімали обдуванням гарячим (290 $\left.300{ }^{\circ} \mathrm{C}\right)$ стисненим повітрям. В якості матеріалу покриття використовували евтектичний припой ПОС-61 повіреного складу, що відповідає ГОСТ 21930-76. Покриття наносили на зразки двостороннього фольгованого склотекстоліту (рис.1 a) та на заготовки однобічного фольгованого склотекстоліту зі сформованими контактним площадками квадратної форми розмірами 5х5 та 10x10 мм² (рис.1 а та б, відповідно).

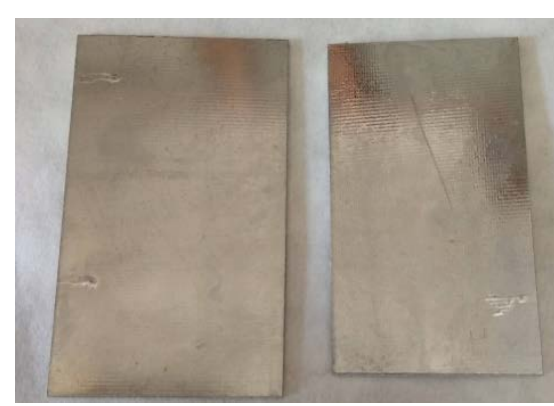

a

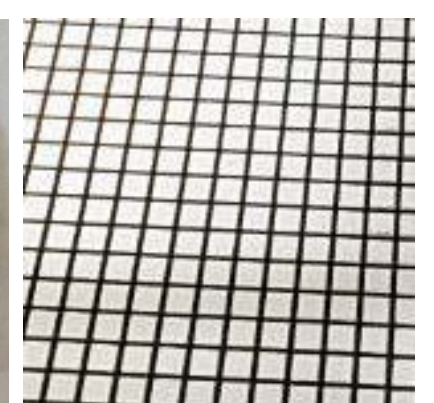

6

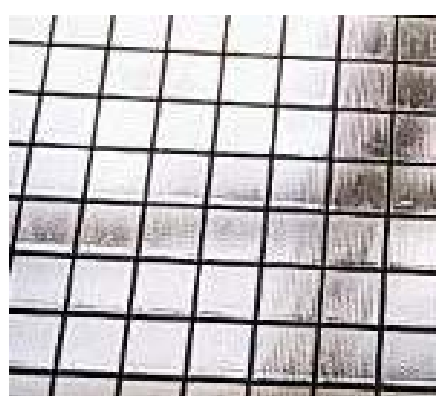

B

Рис.1. Зразки фольгованого склотекстоліту із покриттям олово-свинець. 
Пряме вимірювання масової частки компонентів фінішних покриттів на поверхні заготовок друкованих плат здійснено методом неруйнівного енергодисперсійного рентгенофлуоресцентного аналізу (XRD) без використання еталонів. Дослідження проводились із використанням мультиелементного прецизійного експрес-аналізатора «EXPERT 3L». Аналізатор забезпечує визначення масових часток елементів від $12 \mathrm{Mg}$ до 92U в будь-яких типах сплавів.

Структуру та кількісний склад у поперечному перерізі покриттів досліджували за допомогою металографічних шліфів. Шліфи виготовляли шляхом вирізання характерної ділянки на зразках заготовок друкованих плат 3 подальшим запресовуванням їх у бакелітову основу. Шліфування та полірування здійснювали за стандартною методикою, на шліфувальній установці фірми Buhler 3 використанням абразивних паперових кругів із зернистістю 2500. Дослідження проводились із використанням растрового електронного мікроскопа РЭМ-106И, із вбудованим аналізатором, що давав можливість визначити кількісний склад покриття (EDX методом).

\section{2. Результати та їх обговорення}

Результати визначення складу покриттів зі сплаву олово-свинець нанесених на заготовки фольгованого склотекстоліту (рис.1.а) наведено в табл.1. Не дивлячись на те, що покриття наносили із розплавленого припою ПОС-61, склад покриттів у значній мірі відрізняється від складу вихідного матеріалу. Однак, як видно склад покриттів (табл. 1, зразок №3), які не піддавали дії гарячого стисненого повітря є ближчим до складу вихідного матеріалу.

Надалі були проведені дослідження поперечного перерізу покриттів 3 використанням металографічних шліфів (рис.2.). 
Таблиця 1. Склад покриттів сплавом олово-свинець отриманих із розплаву за даними ЕДРФА аналізу

\begin{tabular}{|c|c|c|c|c|c|c|}
\hline \multicolumn{6}{|c|}{ Вміст мас.\% } \\
\hline Елемент & \multicolumn{2}{|c|}{ Зразок №1 } & \multicolumn{2}{|c|}{ Зразок №2 } & \multicolumn{2}{|c|}{ Зразок №3* } \\
\hline $\mathrm{Sn}$ & 42,58 & 27,04 & 43,11 & 27,07 & 49,74 & 51,11 \\
\hline $\mathrm{Pb}$ & 57,42 & 72,96 & 56,89 & 72,93 & 50,26 & 48,89 \\
\hline
\end{tabular}

* - покриття нанесене без використання завершальної обробки (обдування гарячим стисненим повітрям)

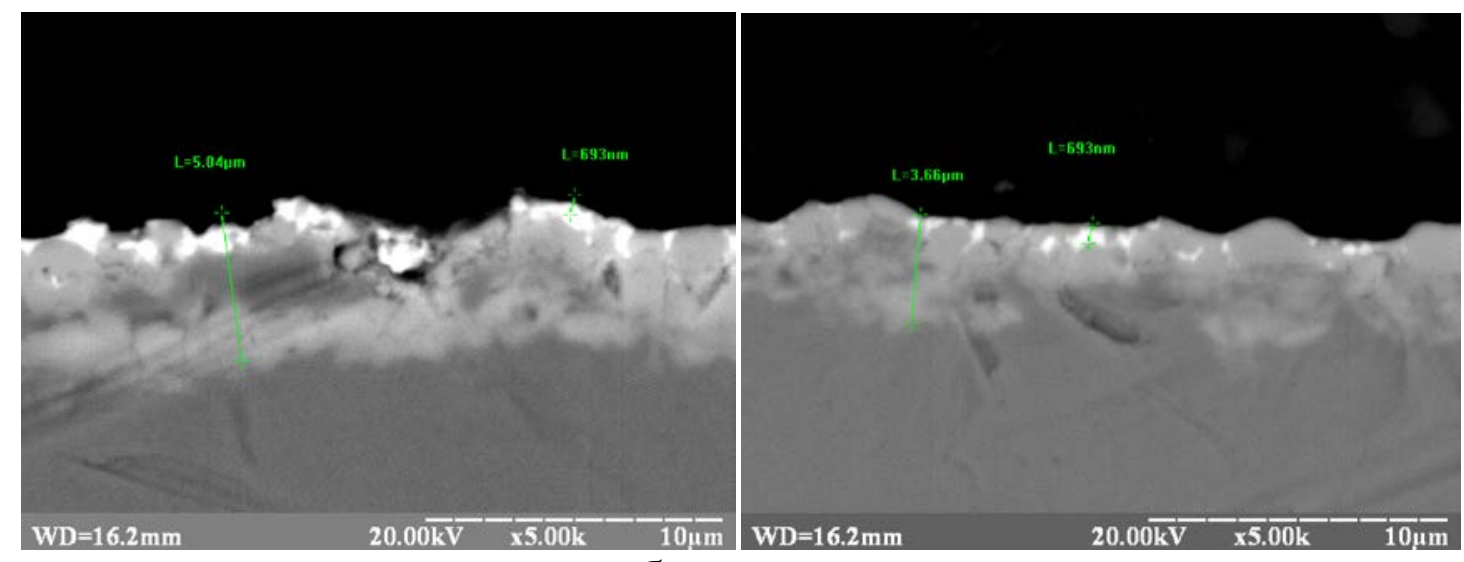

б

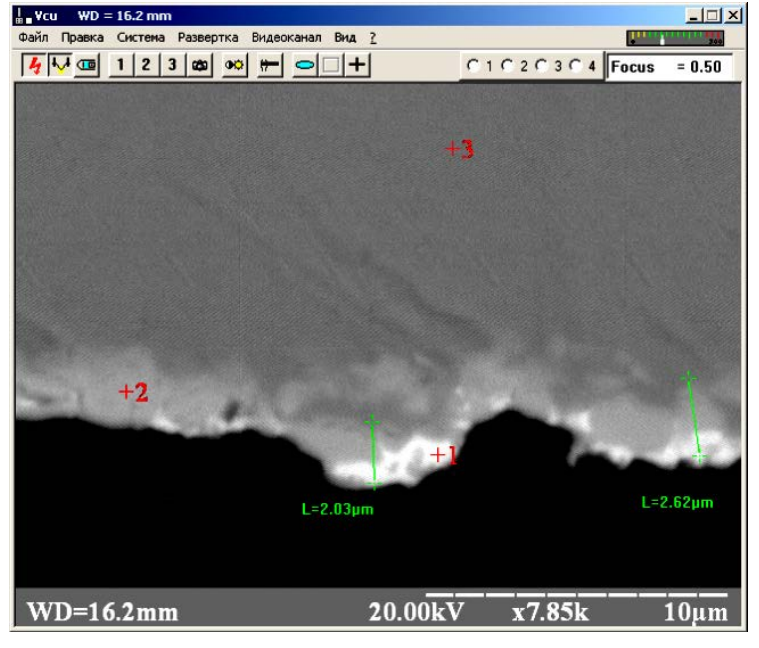

B

Рис. 2. Мікрофотознімки шліфів зразків фольгованого склотекстоліту з покриттям зі сплаву олово-свинець. 


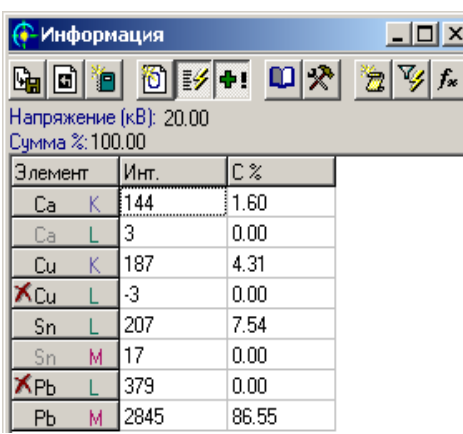

$\mathrm{a}$

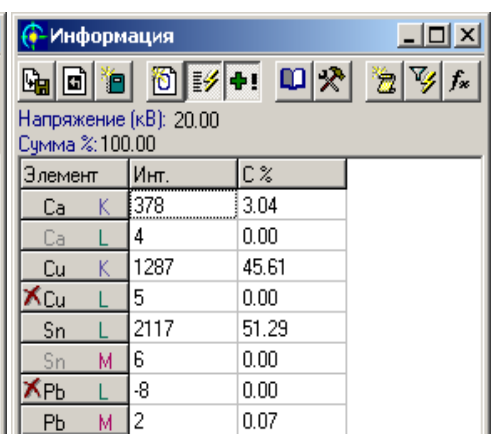

6

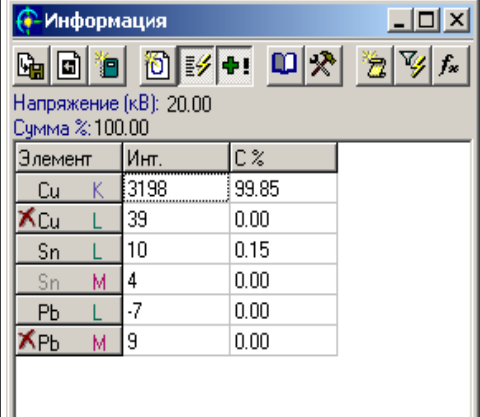

B

Рис. 3. Результати визначення складу зразка у точках позначених на рис.1: a $(+1) ;$ б - $(+2)$; в - $(+3)$.

Як видно $з$ рис.2. покриття дійсно не є гомогенним, спостерігаються дві окремі металічні фази. Аналіз покриття у більш світлій зоні (рис.3, точка +1) показав, що дана фаза містить близько 86,55 \% свинцю, 7,54 \% олова, 4,3 \% міді, у незначній мірі присутній кальцій $(1,6 \%)$. Аналіз покриття у більш темній зоні (рис.3, точка +2 ) показав, що дана фаза містить близько 51,3\% олова та 45,6 \% міді. Точка (рис.3, точка +3) - основа - мідна фольга. Тобто, на зовнішній поверхні покриття нерівномірно розподіляється насичена за свинцем фаза, у глибині покриття ближче до основи (точка +2, рис.2) знаходиться також мідь, що може свідчити про наявність інтерметалідів, які утворилися в наслідок взаємодії розплавленого сплаву з мідною основою склотекстоліту.

Результати дослідження складу покриття на шліфах зразків 3 контактними площадками квадратної форми показали наступне. На контактних площадках розміром 5х5 мм товщина покриття варіюється у межа 2 - 6 мкм (рис.4).

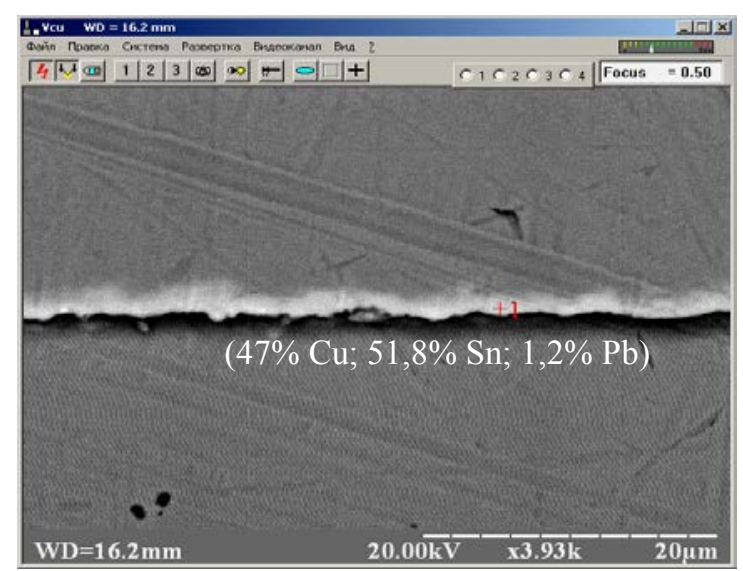

б

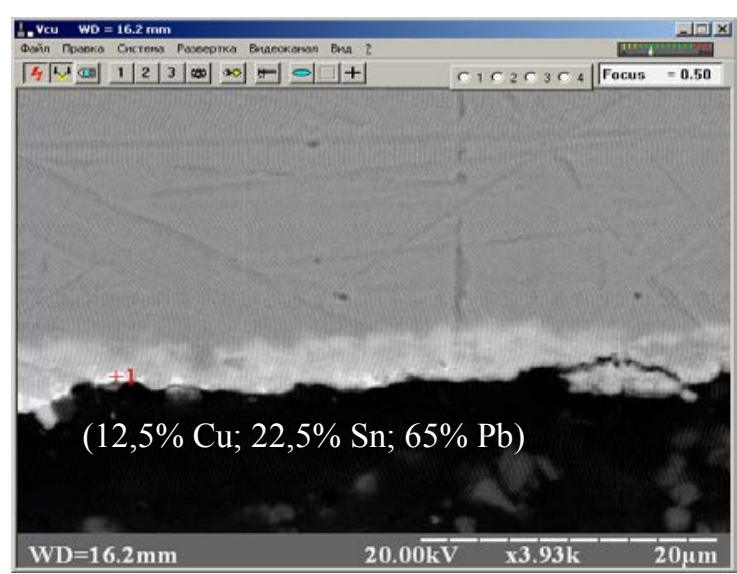

$(12,5 \% \mathrm{Cu} ; 22,5 \% \mathrm{Sn} ; 65 \% \mathrm{~Pb})$

$\mathrm{VD}=16.2 \mathrm{~mm}$

a

Рис. 4. Фотографії шліфів фрагментів контактних площадок розміром 5х5 мм 3 покриттям олово-свинець на верхній (а) та на нижній (б). 
Структура і склад покриття є також неоднорідними. У верхній частині контактної площадки, де покриття має меншу товщину, міститься в основному мідь та олово (рис.4 а). У нижній частині контактної площадки, де товщина покриття є більшою (рис. 4 б) з'являється більше світлих вкраплень, які відповідають наявності переважно свинцевмісної фази, яка концентрується на зовнішній поверхні покриття.

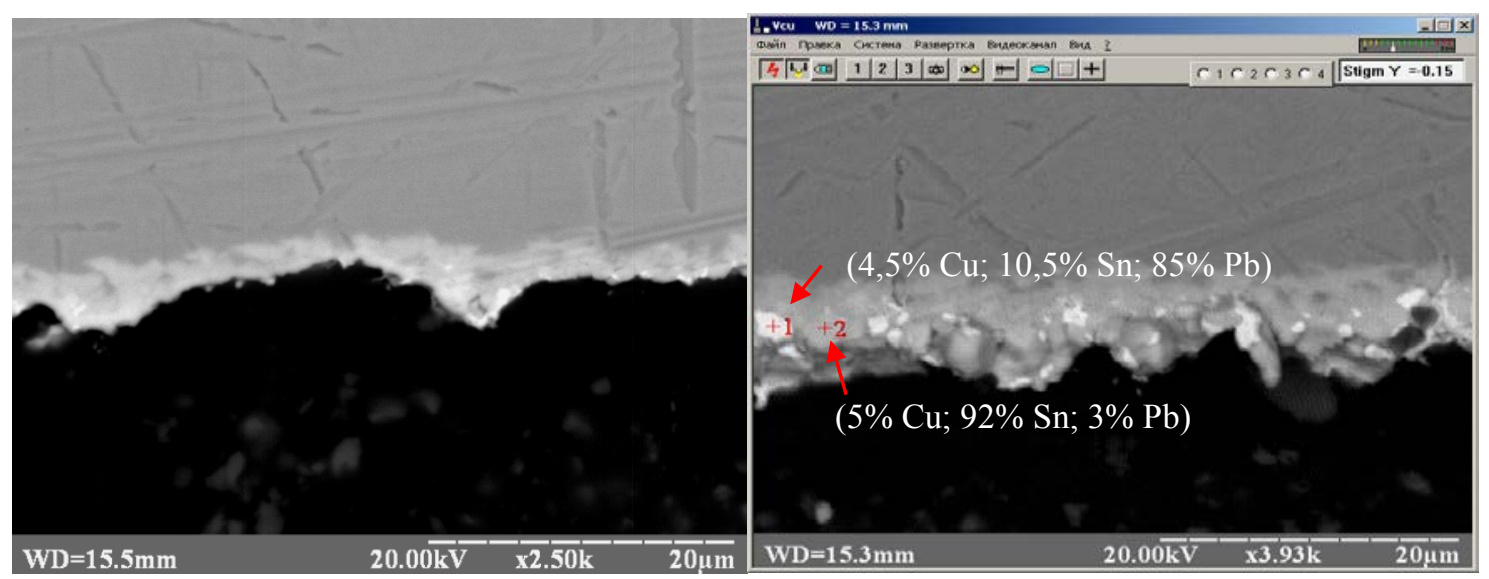

a

6

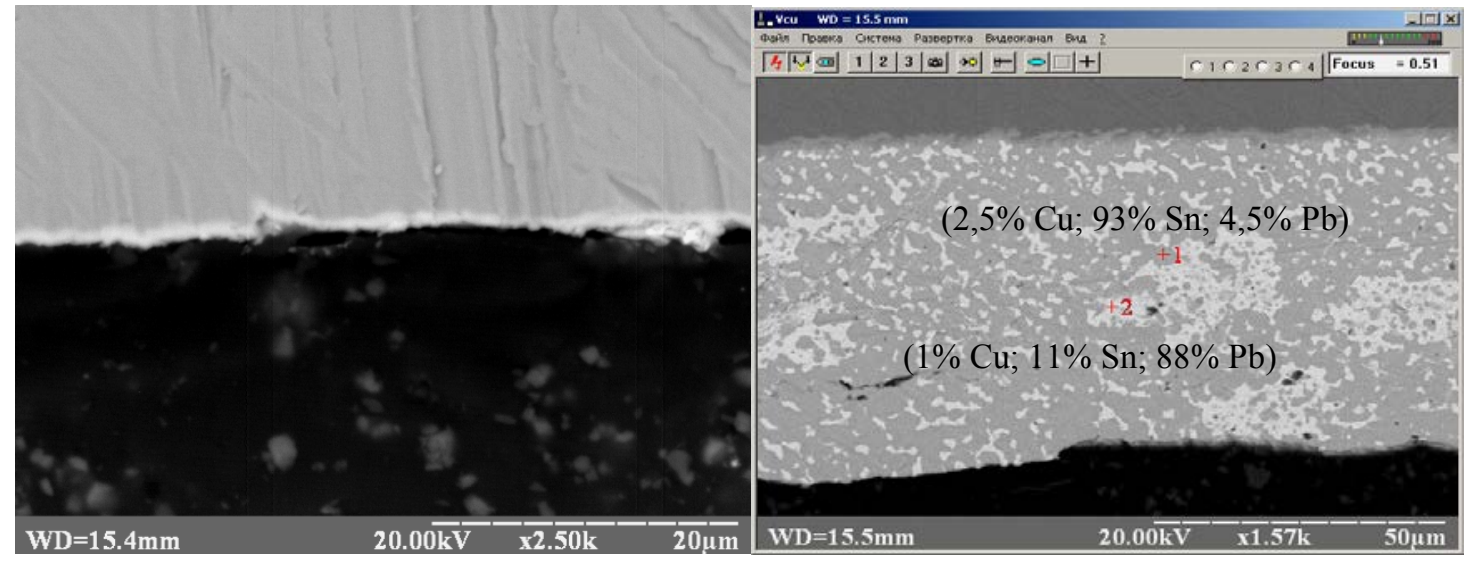

$\Gamma$

Рис. 5. Фотографії шліфів фрагментів контактних площадок розміром 10х10 мм 3 покриттям олово-свинець на верхній (a, в) та на нижній $(б$, г) частинах.

На контактних площадках розміром 10х10 мм товщина покриття варіюється в межах 2 - 80 мкм (рис.5). Товщина покриття 80 мкм відповідає напливу у нижній частині. Як видно з рис.5, чим більшою $є$ товщина покриття, тим більше 3'являється збагаченої на свинець фази і тим ця фаза більш рівномірно розподілена у об'ємі покриття.

Отримані результати пояснюються наступним. Значення температур при 
нанесенні покриттів зі сплаву олово-свинець $\left(200{ }^{\circ} \mathrm{C}\right)$ і при обдуванні гарячим стисненим повітрям $\left(300{ }^{\circ} \mathrm{C}\right)$ та дані діаграми стану $\mathrm{Cu}-\mathrm{Pb}-\mathrm{Sn}$ (рис.6 a) відповідають умовам утворення інтерметаліда $\mathrm{Cu}_{6} \mathrm{Sn}_{5}$, в якому міститься близько 60,5 мас.\% $\mathrm{Sn}$ та 39,5 мас.\% Cu. Визначений склад шару покриття, що прилягає до мідної основи (рис. 2 та рис. 4 а) є близьким до складу інтерметаліда. Тобто, при нанесенні покриття із розплаву дійсно відбувається хімічна взаємодія мідної основи із розплавленим припоєм, яка може інтенсифікуватись при обдуванні покриття гарячим повітрям. Це призводить до зменшення вмісту олова та збільшення вмісту свинцю у об'ємі розплаву біля поверхні мідної основи. Відповідно до (рис. 6 б) у випадку коли вміст свинцю у сплаві стає більшим за евтектичний, структура сплаву стає неоднорідною. У сплаві з'являється багата на свинець $\alpha$-фаза із вмістом свинцю близько 80 мас.\%, яка буде одразу кристалізуватись на поверхні плати (температура кристалізації близько $300{ }^{\circ} \mathrm{C}$ ). Це підтверджують отримані у даній роботі дані (рис. 2 - 5). Після кристалізації багатої на свинець $\alpha$-фази, приповерхневий шар розплаву збіднюється на свинець і може почати викристалізовуватись багата на олово $\beta$-фаза.

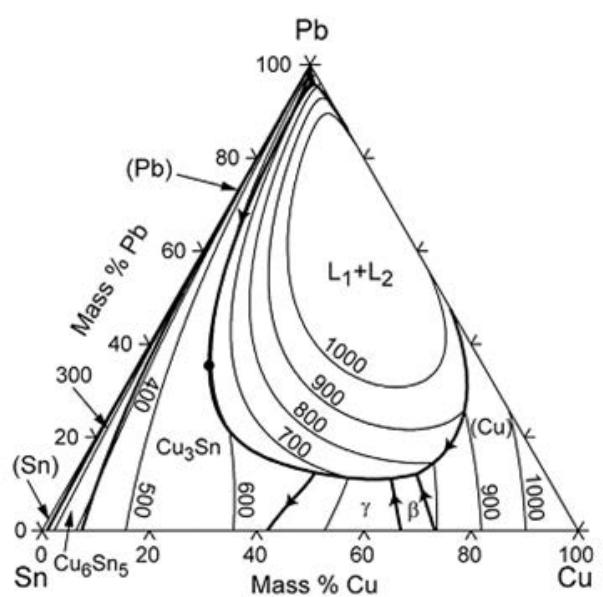

a

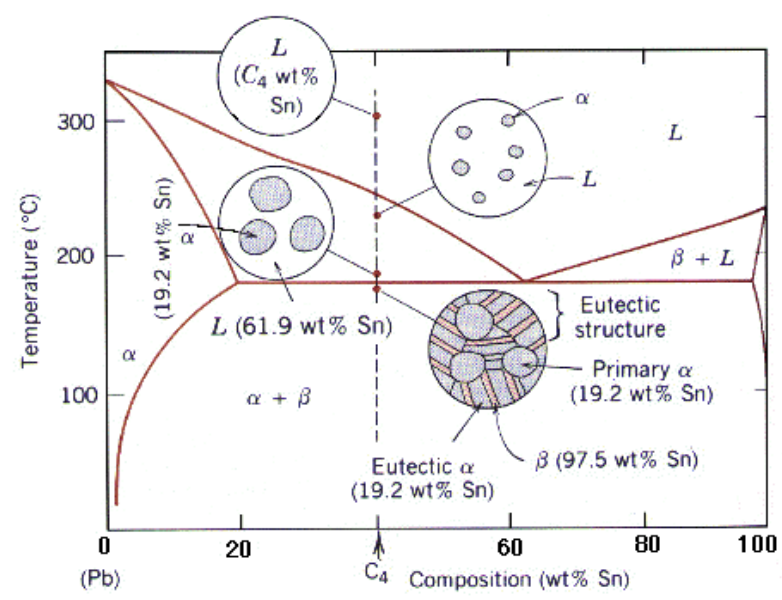

б

Рис. 6. Діаграми стану системи $\mathrm{Cu}-\mathrm{Pb}-\mathrm{Sn}$ (a) [4] та системи $\mathrm{Pb}-\mathrm{Sn}[5,6]$.

Надалі в процесі вилучення заготовки із розплаву (вертикальне витягування), розплавлений сплав під дією власної ваги стікає до нижньої частини контактної площадки, а його надлишок видаляється гарячим повітрям. Таким чином, на 
верхній частині контактної площадки покриття являє собою в основному інтерметалід $\left(\mathrm{Cu}_{6} \mathrm{Sn}_{5}\right) 3$ насиченою на свинець $\alpha$-фазою на поверхні, що підтверджується рис. 4 a, 5 а та 5 в. На нижній частині контактної площадки накопичується гетерофазний сплав, що містить $\alpha$-фазу насичену свинцем та $\beta$ фазу насичену оловом (рис.5 б, г), що узгоджується з даними рис.6 б.

Відповідно до отриманих даних можна зробити висновок щодо валідації обраних методів для визначення усередненого складу досліджених покриттів. Оскільки структура покриття зі сплаву-олово свинець отриманого із розплаву є неоднорідною, методи XRD та EDX, придатні для визначення кількісного складу лише у певній дуже обмеженій області (область фокусу випромінювання). Точне визначення усередненого складу покриття на всій досліджуваній площині $є$ можливим лише 3 використанням кількісного хімічного аналізу.

\section{3. Висновки}

Показано, що зі збільшенням розміру контактних площадок збільшується перепад товщини покриття зі сплаву олово-свинець, нанесеного «гарячим» способом.

Встановлено, що склад та структура покриттів Sn-Pb є неоднорідними. Шар покриття, що прилягає до мідної основи являє собою інтерметалід орієнтовного складу $\mathrm{Cu}_{6} \mathrm{Sn}_{5}$. Основу покриття складають дві фази: $\alpha$-фаза насичена свинцем та $\beta$-фаза насичена оловом. Багатофазний неоднорідний склад покриття може бути зумовлений взаємодією між мідною основою та вихідним матері покриття за температур його нанесення, а також особливостями технологічного процесу.

\section{Література}

[1] А.М. Медведев, Технология производства печатных плат, Техносфера, $2005,300 \mathrm{c}$.

[2] http://www.elinform.ru/articles_68.htm

[3] Шкундина, С., 2011. Электроника. 2, 150.

[4] R. Cayumil, [et all], 2014. Waste Management. 34, 1783.

[5] https://www.slideshare.net/RakeshSingh125/f-phasediagram.

[6]http://sv.rkriz.net/classes/MSE2094_NoteBook/96ClassProj/pics/Pb_Sn.GIF. 


\title{
Electrochemical reduction of benzaldehyde at platinum single crystal surfaces
}

\author{
Bolielyi O. S.
}

\section{Kyiv Polytechnical Institute named by Igor Sikorsky}

\section{Introduction}

Nowadays, catalytic technologies are the object of a great interest for industrial, business and ecological sectors all over the world. It is known that nowadays considerable amount of the heterogeneous catalysis processes include hydrogen, which is mostly produced by steam reforming of various organic compounds e.g. methanol and natural gas. As this process produces incredible amounts of $\mathrm{CO}_{2}$ in contrast to steam reforming, reduction of $\mathrm{CO}_{2}$-emissions from the chemical sector require the $\mathrm{CO}_{2}$ neutral production of hydrogen. This can be achieved by the electrochemical production of hydrogen when the used electricity stems from zeroemission technologies. Hence, heterogeneous hydrogenation would require a hydrogenation plants and an electrolysor. However, it can be more cost effective if the hydrogenation of organic compounds will occur due to electrolysis. In that case there is no more need in hydrogenation plant. This idea motivates scientists to study the mechanisms of electrocatalytic hydrogenation of organic compounds.

In order to study the process of benzaldehyde reduction at platinum single crystal surfaces cyclic voltammetry $(\mathrm{CV})$ experiments were carried out. There were different types of single crystal electrodes used during experiments: $\operatorname{Pt}(111), \operatorname{Pt}(110)$ and $\operatorname{Pt}(100)$.

There were already several papers where reduction of acetaldehyde, acetone and acetophenone were studied $[1,2,3,4,5,6,7]$. Basically, their aim was to study the reduction process of organic compounds at different single crystal electrodes in acidic media and by doing so they could suggest their mechanisms for reduction processes. From these papers the trend of $\mathrm{C}-\mathrm{C}$ bond stability acetaldehyde $<$ acetone $<$ 
acetophenone was acquired. It is interesting to know, where is benzaldehyde placed in this stability trend.

The comparison of the CVs in blank electrolyte and the electrolyte with benzaldehyde showed, that the presence of benzaldehyde suppresses the features of all the single crystals. What exactly is happening is hard to say, however it was suggested that there might be a poisoning reaction occurring at single crystal surfaces. This can be caused by $\mathrm{CO}$ adsorbing at the surface, as well as the phenyl ring from benzaldehyde or the products of its reduction or oxidation. All processes occur due to the cleavage of $\mathrm{C}-\mathrm{C}$ bond in benzaldehyde.

The aim of the experiments is to define whether any processes occurring at the platinum surfaces of electrodes in acidic media in presence of benzaldehyde.

\section{Experimental}

The blank electrolyte was $0.1 \mathrm{M} \mathrm{H}_{2} \mathrm{SO}_{4}$, prepared from MiliQ-water and $\mathrm{H}_{2} \mathrm{SO}_{4}$ (suprapure, Merck). Experiments on benzaldehyde reduction were performed with the blank electrolyte containing $20 \mathrm{mM}$ of benzaldehyde. Benzaldehyde (99.5\%, SigmaAldrich) was used. As it is important to keep the electrolyte cell free from oxygen to prevent unwanted reactions, all solutions were freed from oxygen by purging with $\operatorname{argon}(6.0$, Linde).

All potentials were measured versus a reversible hydrogen electrode (RHE) in contact with the blank electrolyte containing $0.1 \mathrm{M} \mathrm{H}_{2} \mathrm{SO}_{4}$ A platinum wire was used as a counter electrode. Prior to use the counter electrode it was rinsed with MiliQ water followed by annealing.

Cyclic voltammograms were recorded on Iviumstat (Ivium Technologies) and BioLogic VSP-300 (Science Instruments).

There are many different types of single crystals with different atomic orientation. This research was conducted with the use of $\operatorname{Pt}(111), \operatorname{Pt}(110)$ and $\operatorname{Pt}(100)$ single crystal surfaces. Fig. 1 represents the atomic arrangements mentioned above types of single crystal atomic arrangements. Thus, (111) surface has typical hexagonal arrangement of atoms, (100) has square arrangement and (110) has rectangular arrangement of atoms. 
In order to achieve a single crystalline surface, the electrode was prepared by the Clavier method [8]. After flame annealing the crystal was cooled in and atmosphere of $80 \%$ argon and $20 \%$ hydrogen. After a cooling period of $20-30$ s the crystal was dipped in water, saturated with the above-mentioned gas mixture, and transferred to the electrochemical cell.

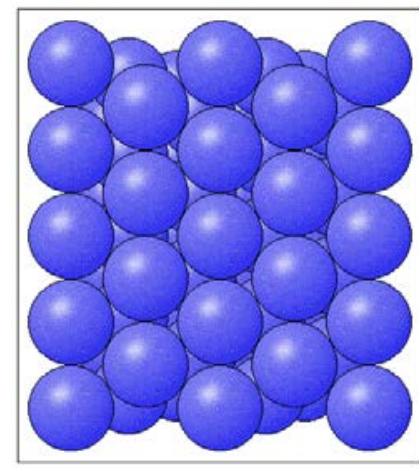

(111)

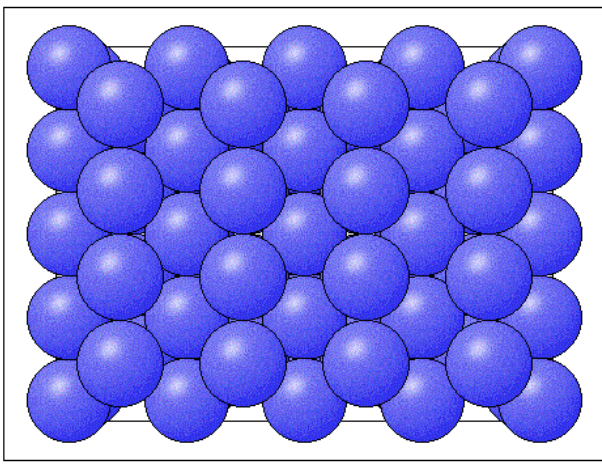

(110)

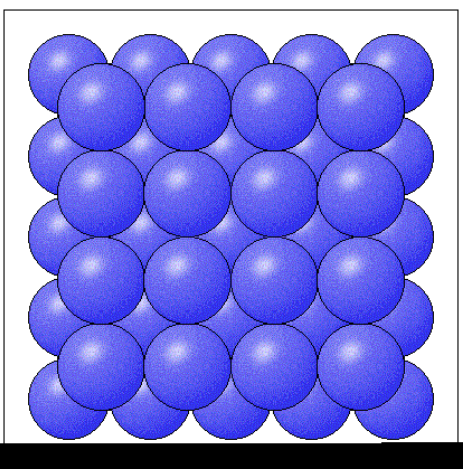

$(100)$

Fig. 1. View from the top at the atomic arrangement of (111), (110) and (100) surfaces

Cyclic voltammetry experiments were conducted with bead type single crystals. The glassware used in experiments was kept in permanganate solution for at least 8 hours. Before using glassware, it was cleaned with solution of sulfuric acid (95-97\%, ACS reagent) and hydrogen peroxide (35\%, Merck) and must be boiled in MiliQ water for at least 3 times. Used sulfuric acid and hydrogen peroxide solution were neutralized before pouring it out into a sink. In order to do this sodium bicarbonate powder (100\%, VWR Chemicals) was used.

\section{Results and discussion}

Fig. 2 compares $\mathrm{CVs}$ obtained in the blank electrolyte of $0.1 \mathrm{M} \mathrm{H}_{2} \mathrm{SO}_{4}$ with those obtained in the electrolyte of $0.1 \mathrm{M} \mathrm{H}_{2} \mathrm{SO}_{4}$ and $0.02 \mathrm{M}$ of benzaldehyde. In the $\mathrm{CV}$ of $\operatorname{Pt}(111)$ obtained in the blank electrolyte adsorption/desorption at the $\operatorname{Pt}(111)$ terraces is observed in the potential range of 0.15 to $0.35 \mathrm{~V}$. In the potential range of 0.0 to $0.15 \mathrm{~V}$ there is a current which corresponds to hydrogen evolution and it is present at all types of single crystals. The typical sulfate spike at $\mathrm{Pt}(111)$ is present at $0.5 \mathrm{~V}$. In contrast, $\mathrm{CV}$ in the electrolyte with benzaldehyde shows that $\mathrm{Pt}(111)$ features were 
suppressed, which means that during the experiment some species were adsorbed at the platinum surface. As these species can no longer be removed by cycling to 0.85 $\mathrm{V}$, they block the surface and fewer amounts of products can be adsorbed in further cycles. The current in the potential region between $0.0 \mathrm{~V}$ and $0.15 \mathrm{~V}$ decreases with the addition of benzaldehyde to the blank solution. This feature indicates, that less hydrogen is evolved and if there is a benzaldehyde reduction, then less species are reduced. Hence, there is something being adsorbed at the $\operatorname{Pt}(111)$ surface in presence of benzaldehyde, that blocks the surface.

We do not observe an oxidation process in the first sweep starting from $0.85 \mathrm{~V}$ going in negative direction. This indicates that benzaldehyde does not oxidize or anything else present in the electrolyte as the oxidation process should already take place in the first sweep.

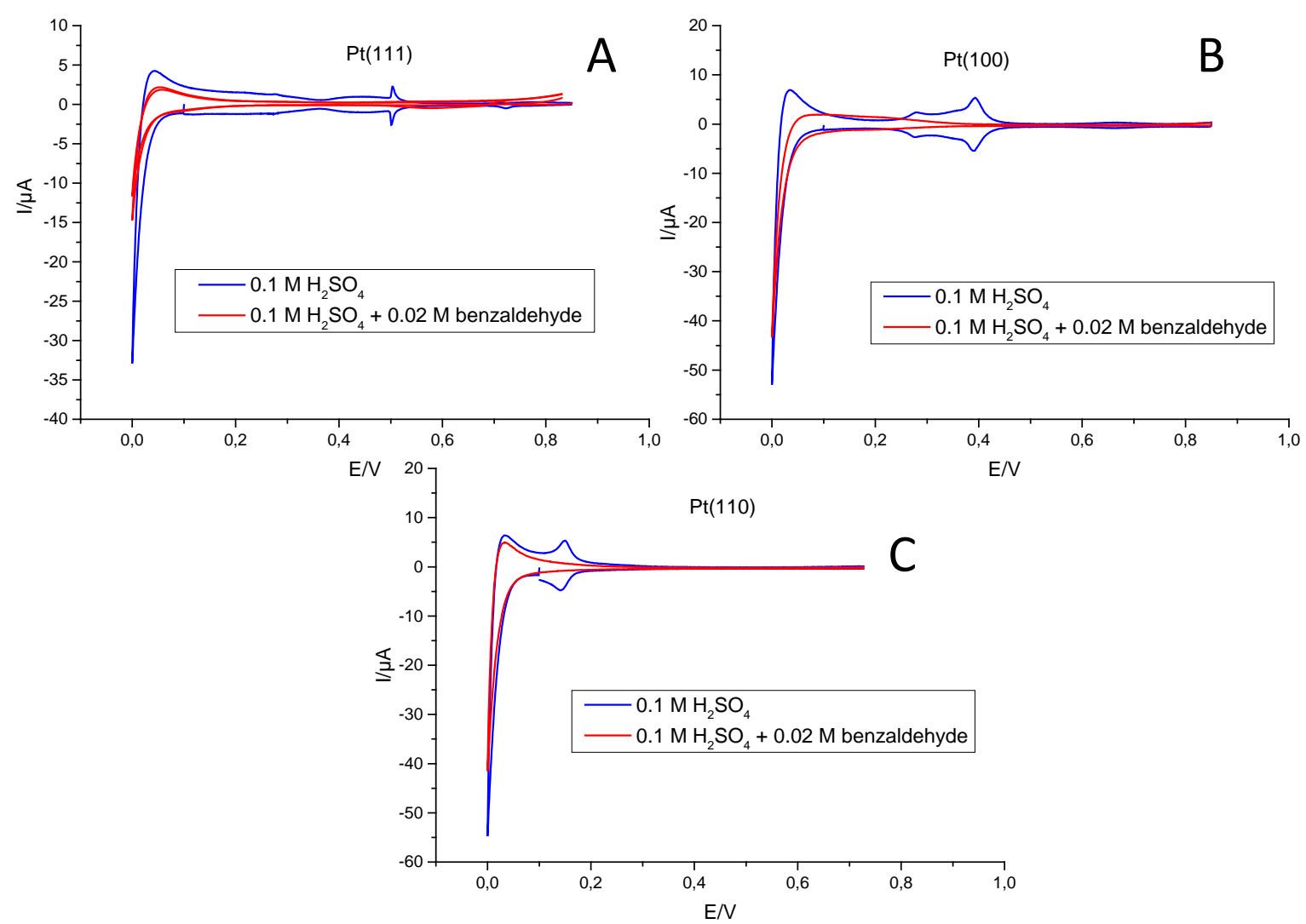

Fig. 2. CVs at different types of platinum single crystal electrodes in blank electrolyte (blue curves) and in solution containing $0.02 \mathrm{M}$ benzaldehyde (red curves). CVs at $\mathrm{Pt}(111)$ (A), Pt (100) (B) and Pt(110) (C) 
There is also a slight current increase at potentials starting from approximately 0.75 $\mathrm{V}$ at positive going sweep, which might indicate an oxidization process. Hence, there is something accumulating at the platinum surface during a cycle and at $0.75 \mathrm{~V}$ it starts to oxidize. This oxidation process might be the $\mathrm{CO}_{\text {ads }}$ being oxidized to $\mathrm{CO}_{2}$, what usually happens at potentials starting from $0.5 \mathrm{~V}$. There can also be some species related to the products of benzaldehyde reduction or oxidation, which adsorb at the platinum surface during a negative going sweep and they start to oxidize at higher potentials. These results are interesting because acetone does not suppress any $\operatorname{Pt}(111)$ features [5]. This means that acetone does not adsorb at the $\operatorname{Pt}(111)$ electrode and it appears to be inactive towards acetone reduction. In case of acetophenone $\operatorname{Pt}(111)$ features are suppressed due to reduction of acetophenone. Hence, there is strong acetophenone adsorption at the $\operatorname{Pt}(111)$ indicating considerable activity of the $\operatorname{Pt}(111)$ electrode for acetophenone reduction.

At the other types of the single crystal surfaces the situation does not change. The $\mathrm{CV}$ at $\mathrm{Pt}(100)$ in the blank electrolyte shows us a typical peak at $0.4 \mathrm{~V}$ indicating hydrogen adsorption at $\mathrm{Pt}(100)$ terraces. At $\mathrm{Pt}(100)$ the current corresponding to hydrogen evolution is observed between $0.0 \mathrm{~V}$ and $0.15 \mathrm{~V}$. With addition of benzaldehyde these processes are suppressed and the current, which corresponds to hydrogen evolution is reduced. The same situation is observed for $\operatorname{Pt}(110)$, where hydrogen adsorption takes place at the potential of $0.15 \mathrm{~V}$. The addition of benzaldehyde to the blank electrolyte leads to the suppression of all reactions at any type of platinum surfaces. This is an indication of the adsorbate presence, which competes with the adsorption of hydrogen at the platinum surfaces. There is only one reduction region at potential range of $0.0 \mathrm{~V}$ to $0.15 \mathrm{~V}$, where reduction of benzaldehyde can take place, or the hydrogen evolution occurs.

In order to see if the electrode can be reactivated specific experiment was conducted. This experiment was aimed to obtain a CV, which consists of 4 cycles in the solution with benzaldehyde at $\mathrm{Pt}(111)$. The first cycle is an ordinary cycle carried out without any changes. At the end of the second cycle the potential was stopped at $0.85 \mathrm{~V}$ for 3 minutes. Cycles number 3 and 4 were also obtained without any 
changes. From the CV data shown at Fig. 3 the current between $0.0 \mathrm{~V}$ and $0.15 \mathrm{~V}$ is reduced in the second cycle compared to the first cycle. The deactivation of the electrode from the first to the second cycle indicates that an adsorbate accumulates at the surface of the $\operatorname{Pt}(111)$ electrode. On the other hand, reactivation of platinum crystal occurs in the third cycle, meaning that some adsorbate was oxidized, while staying at $0.85 \mathrm{~V}$. It results in the increase of a current at the third cycle, meaning that less adsorbate was adsorbed at the third cycle in respect to the second cycle.

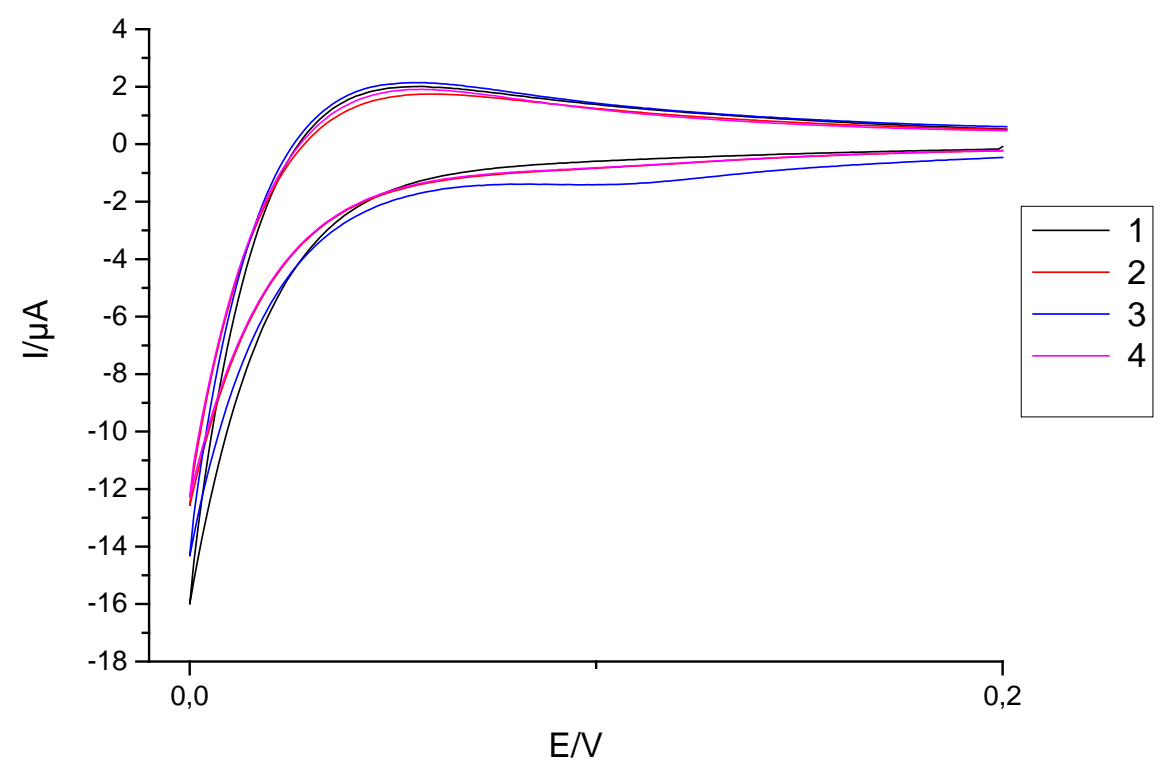

Fig. 3. $\mathrm{CV}$ in the electrolyte containing $0.1 \mathrm{M} \mathrm{H}_{2} \mathrm{SO}_{4}$ and $0.02 \mathrm{M}$ benzaldehyde at $\operatorname{Pt}(111)$. Numbers are the sequence of the cycles

Hence, reactivation happened due to the oxidation process, that was taking place at the second cycle. However, reactivation is not complete, as the current between $0.0 \mathrm{~V}$ and $0.15 \mathrm{~V}$ in the first and the third cycles are different. That might indicate the presence of the species, which were not fully oxidized at $0.85 \mathrm{~V}$ for 3 minutes. Previously it was mentioned that adsorbed $\mathrm{CO}$ is oxidized around $0.5 \mathrm{~V}$. If the adsorbate was only $\mathrm{CO}$ we would expect it to be removed at $0.85 \mathrm{~V}$ already. Hence, there is another fragment of benzaldehyde than $\mathrm{CO}$ accumulates at the $\operatorname{Pt}(111)$, which is more difficult to remove than the CO.

The results of this experiment show that adsorbate is being formed during the process at the platinum surface in solution containing benzaldehyde. The surface of 
platinum single crystal can be reactivated if the potential remains at $0.85 \mathrm{~V}$, but this reactivation is only partial. Some adsorbate remains at the surface of platinum electrode indicating poisoning reaction at $\mathrm{Pt}(111)$.

\section{Conclusions}

The data obtained from CVs indicate that a poisoning reaction leads to deactivation of the platinum single crystal surfaces. However, holding the potential at $0.85 \mathrm{~V}$ for extended periods of time reactivates the single crystal surface partially. Although, from the data obtained it is obvious that there is a poisoning reaction occurring at all types of single crystal surfaces these data are not enough to understand whether the poisoning reaction is adsorption of $\mathrm{CO}$ or the adsorption of species related to benzaldehyde or its products. We can only suggest in correspondence to literature, that $\mathrm{CO}_{\text {ads }}$ species are totally removed from the platinum single crystal surface at potentials higher than $0.5 \mathrm{~V}$. If that is so then the poisoning reaction, which takes place at the platinum single crystals occurs due to the presence of benzaldehyde inside the cell with the electrolyte.

It is also hard to say if benzaldehyde reduction is taking place, so there is no clear evidence for the position of benzaldehyde in stability trend acetaldehyde $<$ acetone $<$ acetophenone. Hence further researches are required to answer this question, as well as to define whether benzaldehyde reduction is taking place at the platinum single crystal surfaces and if so, then which products are formed during the reduction.

\section{Acknowledgements}

I would like to thank my advisors from CASC group in Leiden University M.T.M. Koper and C.J. Bondue for their guidance and help during my internship. 


\section{References}

[1] De Hemptinne, X.; Schunck, K., Electrochemical reduction of acetone. Electrocatalytic activity of platinized platinum. Transactions of the Faraday Society 1969, 65 (0), 591-597.

[2] Bänsch, B.; Härtung, T.; Baltruschat, H.; Heitbaum, J., Reduction and oxidation of adsorbed acetone at platinum electrodes studied by DEMS. Journal of Electroanalytical Chemistry and Interfacial Electrochemistry 1989, 259 (1), 207-215.

[3] Zinola, C. F.; Rodríguez, J. L.; Arévalo, M. C.; Pastor, E., A DEMS study of the electroreduction and oxidation of 3-buten-2-one and 2-butanone adsorbates on platinum in sulphuric solutions. Journal of Electroanalytical Chemistry 1998, 454 (1), 161-172.

[4] Bondue, C. J.; Koper, M. T. M., A mechanistic investigation on the electrochemical reduction of aliphatic ketones, SUBMITED FOR PUBLICATION.

[5] C. J. Bondue, F. Calle-Vallejo, M. C. Figueiredo, M. T. M. Koper, Structuresensitive Selectivity of the Electrochemical Reduction of Aliphatic ketones at platinum Single Crystal Electrode, SUBMITED FOR PUBLICATION.

[6] Lai, S.; Koper, M., Lai, S. C. S. \& Koper, M. T. M. Electro-oxidation of ethanol and acetaldehyde on platinum single-crystal electrodes. Faraday Discuss. 140, 399-416. 2008, 140, 399-416; discussion 417.

[7] Lai, S. C. S.; Koper, M. T. M., The Influence of Surface Structure on Selectivity in the Ethanol Electro-oxidation Reaction on Platinum. The Journal of Physical Chemistry Letters 2010, 1 (7), 1122-1125.

[8] Clavilier, J.; Armand, D.; Sun, S. G.; Petit, M., Electrochemical adsorption behavior of platinum stepped surfaces in sulphuric acid solutions. Journal of Electroanalytical Chemistry and Interfacial Electrochemistry 1986, 205 (1), 267-277. 
Ther mally synthesized $\mathrm{Mn}_{2} \mathrm{O}_{3}, \mathrm{Mn}_{3} \mathrm{O}_{4}$

oxides for anodes of Mg-battery with

Mg-per chlor ate electrolyte based on dimethylfor mamid

\author{
Apostolova R.D., Savchenko A.S. \\ Ukrainian State University of Chemical Technology, Dnipro, Ukraine,
}

Gagarin ave, 8, 49005

According to the literature, nanometer $\mathrm{Mn}_{2} \mathrm{O}_{3}, \mathrm{Mn}_{3} \mathrm{O}_{4}$ oxides, together with nanometer electrically conductive fillers, are capable of providing a high discharge capacity at high rate of discharge in an electrolyte with a narrow window of electrochemical stability in anodes for a magnesium battery. Since the use of nanometer manganese-oxide compounds is associated with a threat to human health, the possibility of using synthesized oxides of $\mathrm{Mn}_{2} \mathrm{O}_{3}, \mathrm{Mn}_{3} \mathrm{O}_{4}$ with a particle size above the submicron level for anodes of magnesium batteries in magnesiumperchlorate electrolyte based on dimethylformamide solvent using impedance spectroscopy was studied with Mg-counterelectrode. Discharge capacity of $\mathrm{Mn}_{2} \mathrm{O}_{3}$, $\mathrm{Mn}_{3} \mathrm{O}_{4}$ with Norit electrically conductive filler equals to $200 \mathrm{mAh} / \mathrm{g}$. The electrolyte used does not provide effective electrochemical conversion of $\mathrm{Mg}$.

Термически синтезированные оксиды $\mathrm{Mn}_{2} \mathrm{O}_{3}, \mathrm{Mn}_{3} \mathrm{O}_{4}$

для анодов Mg-батареи с Mg-перхлоратным электролитом на основе диметилформамида

Апостолова Р.Д., Савченко А.С.

Украинский Государственный Университет Химической Технологии, Днипро, Украина, пр. Гагарина, 8, 49005

\title{
1. Введение
}

Диоксид $\mathrm{MnO}_{2}$ относят к перспективным катодным материалам для магниевой батареи, которая предлагается взамен литиевой как более безопасная, энергоемкая и дешевая. Оксиды марганца $\mathrm{MnO}, \mathrm{Mn}_{2} \mathrm{O}_{3}, \mathrm{Mn}_{3} \mathrm{O}_{4}$ не 
проявляют электрохимической активности в катодах литиевой и магниевой батарей. Совсем недавно обнаружили способность указанных Mn-оксидов к эффективному электрохимическому преобразованию в анодах литиевой и магниевой батарей $[1,2]$. Их высокая разрядная емкость и скоростная способность проявляются при использовании нанометровых частиц активного материала в совокупности с нанометровыми электропроводящими наполнителями. Успех был достигнут при использовании магниевого электролита с Al-фенильным комплексом (APC) на основе эфирных растворителей [3]. АРС-электролит обладает узким окном электрохимической стабильности, и он не пригоден для магниевых батарей с высоко-вольтовыми катодными материалами, предназначенных для замены литиевых батарей. Поиск подходящего электролита для высоко-вольтовых катодных материалов ведут разработчики магниевой батареи.

В данной работе апробировали магний-перхлоратный электролит, основанный на растворителе диметилформамид применительно к оксидам $\mathrm{Mn}_{2} \mathrm{O}_{3}, \mathrm{Mn}_{3} \mathrm{O}_{4}$ и $\mathrm{Mg}$. Поскольку использование нанометровых марганецоксидных соединений сопряжено с угрозой для здоровья человека, в работе изучена возможность использования синтезированных оксидов $\mathrm{Mn}_{2} \mathrm{O}_{3}, \mathrm{Mn}_{3} \mathrm{O}_{4}$ с размером частиц выше субмикронного уровня для анодов магниевых батарей, с применением импедансной спектроскопии.

\section{2. Экспериментальная часть}

Оксиды $\mathrm{Mn}_{2} \mathrm{O}_{3}, \mathrm{Mn}_{3} \mathrm{O}_{4}$ получены термическим разложением $\mathrm{MnO}_{2}$ при $900^{\circ} \mathrm{C}$ с последующим быстрым охлаждением. По данным рентгенофазового анализа, проведенного на установке ДРОН-2, в продукте синтеза содержится смесь оксидов $\mathrm{Mn}_{2} \mathrm{O}_{3}$ (70\%), $\mathrm{Mn}_{3} \mathrm{O}_{4}$ (30\%). Размер кристаллитов - 79,9 нм. Синтезированные оксиды исследовали с магневым противоэлектродом (Mg 96,96) размером $1 \times 1 \mathrm{~cm}$ в электролите 1 моль ${ }^{-1} \mathrm{Mg}\left(\mathrm{ClO}_{4}\right)_{2}$, выдержан над цеолитами $4 \AA$ - (Иодобром,), диметилформамид (ДМФ) - Sigma-Aldrich. Оксиды марганца $\mathrm{Mn}_{2} \mathrm{O}_{3}, \mathrm{Mn}_{3} \mathrm{O}_{4}$ использовали в композиции с электропроводящим наполнителем Norit A SUPRA USP с удельной 
поверхностью $1900 \mathrm{~m}^{2} \cdot \Gamma^{-1}$, успешно апробированным в композиции со шпинелью $\mathrm{LiMn}_{2} \mathrm{O}_{4}$ [4]. Были изготовлены электроды, в составе которых, \%: $\left(\mathrm{Mn}_{2} \mathrm{O}_{3}, \mathrm{Mn}_{3} \mathrm{O}_{4}\right)$ - 80, Norit - 10, фторпластовое связующее Ф4Д - 10. Их сушили при температуре $250^{\circ} \mathrm{C}$ (7-8 ч).

Заряд-разрядные характеристики электродов получены на испытательном стенде с программным обеспечением в гальваностатическом процессе. Импедансные спектры регистрировали и анализировали с использованием программ ZPlot, ZView (Version 2.1 b) в частотном ряду 100 кГц-10 мГц. Два адекватных исследуемых электрода поляризовали с помощью двух магниевых противоэлектродов. Годографы импеданса двух аналогичных противоэлектродов в контакте с электролитом снимали в зависимости от потенциала электродов в квазиравновесных условиях на радиометре VoltaLab PGZ 301.

\section{3. Результаты и их обсуждение}

Напряжение разомкнутой цепи системы композитный $\left(\mathrm{Mn}_{2} \mathrm{O}_{3}, \mathrm{Mn}_{3} \mathrm{O}_{4}\right.$ Norit)-электрод / $\mathrm{Mg}\left(\mathrm{ClO}_{4}\right)_{2}$, ДМФ / $\mathrm{Mg}$ находится в пределах 1,7-1,9 В. Ее разрядный профиль подобен профилю нанометровых оксидов марганца, представленных в литературных источниках. Начальный спад напряжения сменяется протяженным участком вблизи 0,4-0,2 В (Рис.1).

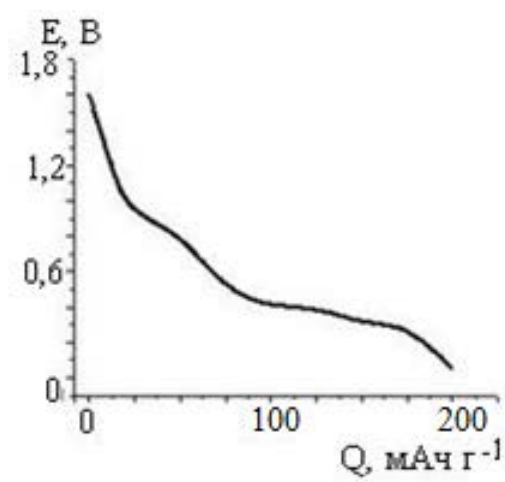

Рис. 1. Стартовая кривая магнезирования ? $\left(\mathrm{Mn}_{2} \mathrm{O}_{3}, \mathrm{Mn}_{3} \mathrm{O}_{4}\right.$, Norit) в магниевом электролите при плотности тока $20 \mathrm{M \kappa A} \cdot \mathrm{cm}^{-2}$.

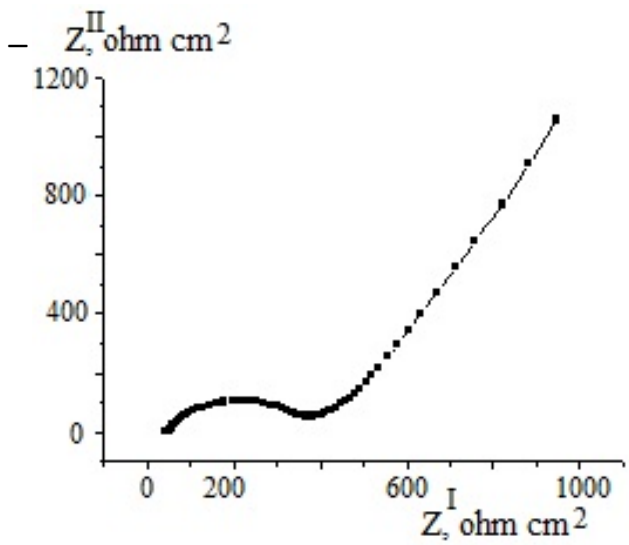

Рис. 2. Годограф импеданса двух электродов $\left(\mathrm{Mn}_{2} \mathrm{O}_{3}, \mathrm{Mn}_{3} \mathrm{O}_{4}\right.$, Norit), разделенных Mg-электролитом. 
Эффективность электрохимического преобразования композитного электрода с магниевым противоэлектродом зависит от трех основных составляющих в числе прочих: Mg-электрода, $\left(\mathrm{Mn}_{2} \mathrm{O}_{3}, \mathrm{Mn}_{3} \mathrm{O}_{4}\right.$, Norit)-электрода и электролита. Для определения их индивидуального участия в процессе магнезирования привлечена импедансная спектроскопия. В импедансных исследованиях проанализированы годографы импеданса композитного и магниевого электродов в контакте с электролитом, а также системы композитный электрод / электролит / магниевый электрод.

Годограф импеданса двух электродов $\left(\mathrm{Mn}_{2} \mathrm{O}_{3}, \mathrm{Mn}_{3} \mathrm{O}_{4}\right.$, Norit), разделенных слоем электролита (1 мм), представляет дугу окружности в высоко-, среднечастотной области, переходящую в линейный шлейф в низкочастотной области (рис. 2). Двухэлектродная система, простая в техничном исполнении, позволяет исключить влияние электрода сравнения, используемого в импедансометрии, изменяющегося в контакте с электролитом. Годограф импеданса двух электродов-аналогов гомогенного состава представляет дугу с параметрами слагаемых двух электродов. В данном случае годограф импеданса является характеристикой $\left(\mathrm{Mn}_{2} \mathrm{O}_{3}, \mathrm{Mn}_{3} \mathrm{O}_{4}\right.$, Norit)-электрода с поверхностью равной двум исследуемым электродам. Нелинейный участок годографа импеданса (Рис. 2) аппроксимируется электрической схемой, в которой последовательно соединяются омическое сопротивление $\mathrm{R}_{0}=20$ Ом $\cdot \mathrm{cm}^{2}$ (отнесенное к сопротивлению электролита) и сопротивление переноса заряда через границу электрод / электролит $\mathrm{R}$, шунтированное емкостью геометрической поверхности раздела С. В исходном состоянии электродов $\mathrm{R}_{1}=175$ Ом $\cdot \mathrm{cm}^{2}, \mathrm{C}_{1}=6,17$ мкФ $\mathrm{cm}^{-2}$, в конце разряда $\mathrm{R}_{1} \geq 500 \mathrm{Oм}^{\circ} \mathrm{cm}^{2}, \mathrm{C}_{1}=4,37$ мкФ $\mathrm{cm}^{-2}$. Индекс 1 относится к параметрам одного электрода.

В годографе импеданса двух магниевых электродов, разделенных слоем электролита в 1 мм, имеется одна большая дуга окружности, траектория которой искажается в низкочастотной области (Рис.3). 
Значение эффективного сопротивления переноса заряда, ограничиваемого барьерным сопротивлением поверхностных эффектов на $\mathrm{Mg}$-электроде, превышает значение $\mathrm{R}_{1}$ композитного электрода на два порядка.

Годограф импеданса системы практически совпадает с годографом импеданса магниевого электрода. Доля участия композитного электрода в сопротивлении переноса заряда системы составляет 2-3\%.

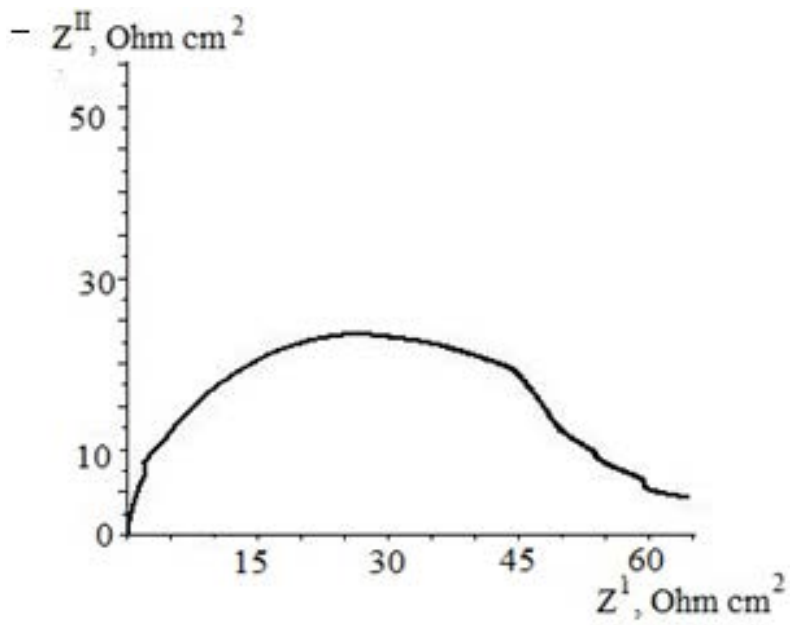

Рис. 3. Годограф импеданса двух Mg-электродов, разделенных электролитом.

\section{4. Заключение}

Известно, что электрохимические характеристики электродного материала зависят от многих факторов, в числе которых один из важнейших способ синтеза материала. В данном исследовании использован традиционный термический способ. Его достоинством является техническая простота изготовления материала. Но к недостаткам относится агломерация частиц синтезируемого материала, возрастающая с повышением температуры. В данном исследовании, оксидам $\mathrm{Mn}_{2} \mathrm{O}_{3}, \mathrm{Mn}_{3} \mathrm{O}_{4}$, термически синтезированным при $900^{\circ} \mathrm{C}$, изначально трудно конкурировать с нанометровыми аналогами, представленными в литературе как перспективные кандидаты в анодные материалы для магниевой батареи, способной заменить литиевую батарею. Кроме того, трудность определяется необходимостью поиска электролита, совместимого в этом случае с синтезированным марганец-оксидным материалом и магнием. 
Полученные результаты термически синтезированного материала показали возможность получения разрядной емкости в магний-перхлоратном электролите, основанном на растворителе диметилформамид, с магниевым противоэлектродом, достигающую 200 мАч/г. Импедансные исследования оксидов $\mathrm{Mn}_{2} \mathrm{O}_{3}, \mathrm{Mn}_{3} \mathrm{O}_{4}$ в контакте с электролитом позволяют оценить его ток обмена по данным сопротивления переноса заряда через поверхность раздела электрод / электролит. Она оценивается порядком $10^{-5} \mathrm{~A} / \mathrm{cm}^{2}$.

Данные импедансной спектроскопии магнивого электрода в контакте с электролитом свидетельствуют о неудовлетворительной совместимости Mg-электрода c Mg-перхлоратным электролитом, основанным на диметилформамиде и ограничивающим потенциальные возможности термически синтезированного электродного материала. Для окончательной оценки пригодности используемого в работе электролита для композиции $\left(\mathrm{Mn}_{2} \mathrm{O}_{3}, \mathrm{Mn}_{3} \mathrm{O}_{4}\right.$, Norit) в аноде магний-ионной батареи необходимы в дальнейшем исследования с подходящим катодным материалом, оптимизированным по массе.

Статья подготовлена в рамках проекта № 42/170790 «Развитие энергоемких источников энергии, основанных на украинских магниевых и марганцевых сырьевых материалах для инновационного приборостроения» при поддержке Министерства Образования и Науки Украины.

\section{Литература}

[1] Yue J., Gu X., Chen L., Wang N., Jiang X., Xu H., Yang J., Qian Y. General synthesis of hollow $\mathrm{MnO}_{2}, \mathrm{Mn}_{3} \mathrm{O}_{4}$ and $\mathrm{MnO}$ nanospheres as superior anode materials for lithium ion batteries. J. Mater. Chem. A, 2014, 2, 17421.

[2] Wang L., Asheim K., Vullum P.E., Svensson A.M., Vullum-Bruer F. SpongeLike Porous Manganese (II,III) Oxide as a Highly Efficient Cathode Material for Rechargeable Magnesium Ion Batteries Chem. Mater., 2016, 28, pp. 6459-6470.

[3] Wang L., Wang Z., Vullum P.E., Selbach S., Svensson A.M., Vullum-Bruer F. Solvent-Controlled Charge Storage Mechanisms of Spinel Oxide Electrodes in Mg Organohaloaluminate Electrolytes. Nano Lett., Just Accepted Manuscript DOI: 10.1021/acs.nanolett.7b03978 Publication Date (Web): 19 Dec 2017 Downloaded from http://pubs.acs.org on December 20, 2017.

[4] Apostolova R., Peskov R., Shembel' E. Features of electrochemical transformations of $\mathrm{LiMn}_{2} \mathrm{O}_{4}$ composition with Norit carbon filler in a model lithium accumulator. Surf. Engineer. Appl. Electrochem., 2015,3, pp.296-303. 
The promising processes and materials have been considered in such key directions of applied electrochemistry as electrochemical power sources, electroplating, corrosion protection, electrochemical sensors, modern electrochemical and related technologies during the last years. A state of art in these key directions of electrochemistry determines a progress in general development of science and engineering of XXI century and promotes to creation of essentially new types of production and technologies. Monograph has been recommended for scientists, lectors, PhD students, engineers and technicians.

Scientific issue

Barsukov Viacheslav Z.

Borysenko Yukiya V.

Khomenko Volodymyr G.

Linyucheva Olga V.

\title{
PROMISING MATERIALS AND PROCESSES IN APPLIED ELECTROCHEMISTRY - 2018
}

\author{
Monograph
}

\author{
Editor N. P. Mazur \\ Resposible person for printing $\mathrm{Yu}$. V. Konovalenko \\ Proofreader N. P. Bilanyuk \\ Computer design N. P. Mazur
}

Printing proof 28.11.2018. Format $60 \times 841 / 16$.

Conditional sheet 16,96. Calculated sheet 13,28. Circulation 300 copies. Order N 674.

KNUTD Instant Printing Department.

Nemirovich-Danchenko Street, 2, Kyiv, 01601, Ukraine.

Certificate ДК № 993, 24.07.2002. 


\begin{abstract}
Розглянуті перспективні процеси та матеріали в таких пріоритетних напрямках прикладної електрохімії, як електрохімічні джерела струму, гальванотехніка, захист від корозії, електрохімічні сенсори, сучасні електрохімічні та споріднені технології. Стан досліджень в цих пріоритетних напрямах електрохімії в значній мірі визначає прогрес у загальному розвитку науки і техніки XXI століття та сприяє створенню принципово нових видів продукції та технологій. Монографрія рекомендована для науковців, викладачів, аспірантів, студентів профрільних ВН3, інженерно-технічних працівників електрохімічних виробництв.
\end{abstract}

Наукове видання

Барсуков В'ячеслав Зіновійович

Борисенко Юлія Володимирівна

Хоменко Володимир Григорович

Лінючева Ольга Володимирівна

\title{
ПЕРСПЕКТИВНІ МАТЕРІАЛИ ТА ПРОЦЕСИ В ПРИКЛАДНІЙ ЕЛЕКТРОХІМІї - 2018
}

\author{
Монографрія
}

\author{
Редактор Н. П. Мазур \\ Відповідальний за поліграфічне видання Ю. В. Коноваленко \\ Коректор Н. П. Біланюк \\ Комп'ютерний дизайн Н. П. Мазур
}

Підп. до друку 28.11.2018 р. Формат 60x84 1/16.

Ум. друк. арк. 16.96. Облік. вид. арк. 13,28. Тираж 300 пр. Зам. 674.

Видавець і виготовлювач Київський національний університет технологій та дизайну. вул. Немировича-Данченка, 2, м. Київ-11, 01011. 